DEPARTMENT OF THE INTERIOR

UNITED STATES GEOLOGICAL SURVEY

GEORGE OTIS SMITH, DIRECTOR

\title{
BULIETIN 442
}

\section{IINERAL. RESOURCES OF ALASKA}

\author{
REPORT ON PROGRESS OF \\ INVESTIGATIONS IN
}

\section{9}

BY

ALFRED H. BROOKS AND OTHERS

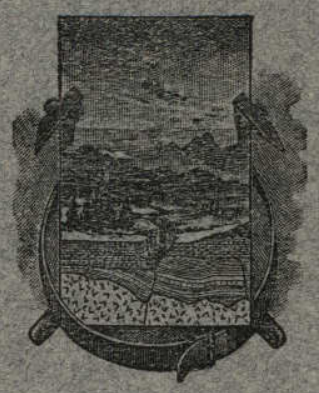

W A SHINGTON

QOVERNMENT PRINTING OFFIOE

1910

From

The Library C metadc304119

WAYNE LOE 


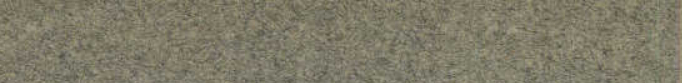


DEPARTMENT OF THE INTERIOR

UNITED STATES GEOLOGICAL SURVEY

GEORGE OTIS SMITH, DIRECTOB

BULLETiN 442

\title{
MINERAL RESOURCES OF ALASKA
}

\author{
REPORT ON PROGRESS OF \\ INVESTIGATIONS IN
}

\section{9}

$\mathbf{B X}$

ALFRED H. BROOKS AND OTHERS

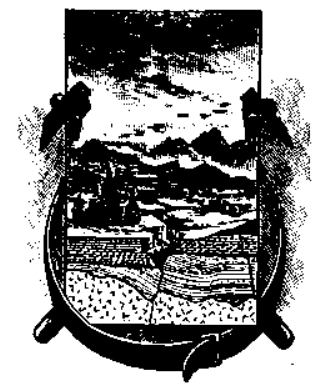

WASHINGTON

GOVERNMENT PRINTING OFEICE

1910

\section{From}

The Library of WAYNE LOEL 



\section{CONTENTS.}

Administrative report, by Alfred II. Brooks..................... 5

The mining industry in 1909, by Alfred H. Brooks.................... 20

Alaska coal and its utilization, by Alfred H. Brooks................ 47

The preparation and use of peat as a fuel, by Charles A. Davis. . . . . . . . . . 101

Mining in southeastern Alaska, by Adolph Knopf. . . . . . . . . . . . . . 133

Occurrence of iron ore near Haines, by Adolph Knopf. . . . . . . . . . . . . 144

Report of water-power reconnaissance in southeastern Alaska, by John C. Hoyt. 147

Mining in the Chitina district, by Fred H. Moffit................. is8

Mining and prospecting on Prince William Sound, in 1909, by U. S. Grant. .. 164

Preliminary report on the mineral resources of the southern part of Kenai

Peninsula, by U. S. Grant and D. F. Higgins. . . . . . . . . . . . . . . 166

Outline of the geology and mineral resources of the Iliamna and Clark Lake

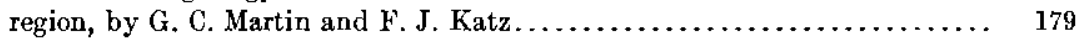

Gold placers of the Mulchatna, by F. J. Katz . . . . . . . . . . . . . . . . . . . . 201

Sketch of the geology of the northeastern part of the Fairbanks quadrangle,

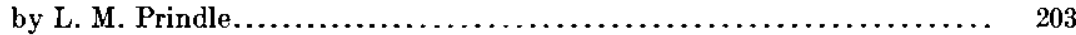

The auriferous quartz veins of the Fairbanks district, by L. M. Prindle...... 210

Placer mining in the Yukon-Tanana region, by C. E. Ellsworth........... 230

Occurrence of wolframite and cassiterite in the gold placers of Deadwood Creek,

Birch Creek district, by Bertrand 1 . Johnson . . . . . . . . . . . . . 246

Water supply of the Yukon-Tanana region, 1909, by C. E. Ellsworth . . . . ... 251

The Koyukuk-Chandalar gold region, by A. G. Maddren. . . . . . . . . . . ... 284

Mineral resources of the Nulato-Council region, by Philip S. Smith and Henry

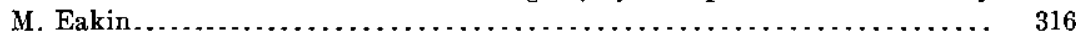

Mining in Seward Peninsula, by Fred F. IIenshaw.................. 353

Water-supply investigations in Seward Peninsula in 1909, by Fred F. Henshaw . 372 


\section{ILLUSTRATIONS.}

Puate I. Map showing relation of Alaska coal fields to transportation routes.... · 52

II. Hydrograph of Porcupine Creek........................... I54

III. Map of southwestern part of Kenai Peninsula .................... 168

IV. Moose Pass and False Creek gold district, Kenai Peninsula......... 172

V. Geologic reconnaissance map of Iliamna and Lake Clark region.... . 184

VI. Geologic sketch map of northeastern part of Fairbanks quadrangle.... 204

VII. Map of Koyukuk-Chandalar region........................... 284

VIII. Map of Nulato-Council region.......................... 316

Fraure 1. Map of southeastern Alaska.......................... 148

2. Hydrograph of Turner River........................... 154

3. Diagrammatic section at Dutton mine.................... 195

4. Geologic sketch map of auriferous lodes, Fairbanks district........ 212

5. Geologic sketch map of Deadwood Creek ................... 247

6. Cross-section of Nulato-Norton Bay region during Cretaceous deposition......................................... 329

7. Sketch map of Alameda Creek.......................... 336

8. Sketch map of Omilak mine............................ 345 


\section{From \\ The Library of \\ WAYNE LOEL}

\section{INVESTIGATION OF MINERAL RESOURCES OF ALASKA IN 1909.}

By Alfred H. Brooks and others.

\section{ADMINISTRATIVE REPORT.}

By Alfred H. Brooks.

\section{PREFACE.}

It has become an established practice of the Geological Survey to issue each year a bulletin in which both the conditions of the mining industry of Alaska and the more important economic results obtained by the investigations during the year are summarized. This volume, the sixth of this series, is, like those previously issued, ${ }^{a}$ intended to serve as a handbook of reference for those who are interested in the mining and mineral resources of the Territory. None of the various papers here included represents final results; they simply outline the general features of the geology and mineral resources of the areas discussed, special emphasis being laid on conclusions that may have an immediate practical bearing on the development of the mining industry.

The rapid progress in prospecting and mining in Alaska makes it necessary to publish the results of geologic surveys as soon as possible, that they may become available to the prospector, mine operator, and engineer. In publishing such preliminary results there is, of course, danger that more exhaustive investigation may show some of the conclusions to be at fault. Those interested in any particular district are, therefore, advised to obtain the complete reports, which are illustrated with maps, photographs, and diagrams, as soon as they are available. It is to be regretted that the publication of the complete reports is usually delayed because of the time required by the laboratory and office work necessary for their preparation and by the elaborate illustrations. Moreover, it frequently happens that,

a Report on progress of investigations of the mineral resources of Alaska, 1904: Bull. U.S. Geol. Survey No. 259, 1905. Iden, 1905: Bull. 284, 1906. Idem, 1906: Bull. 314, 1907. Idem, 1907: Bull. 345, 1908. Idem, 1908: Bull. 379, 1909. 
after the completion of the office work on the results of the survey of an area, a reexamination in detail of part of the district is necessary. Such a reexamination delays the completion of the report, but is fully justified because of the desirability of making the publications as complete statements of the facts and their interpretation as the character of the survey, the conditions of the region, and the progress of the science of applied geology will permit.

This volume is arranged on the same plan as those previously published. First will be presented a general account of the mining industry of Alaska in 1909, which includes the statistical data. This will be followed by nineteen special papers contributed by seventeen authors, which fall into two classes. One class includes the papers of a general character summarizing the mining progress of certain of the most important districts, and these have been prepared by the geologists or engineers who are most familiar with the districts. The other class of papers comprises those that present preliminary accounts of the results of surveys and investigations and are, in fact, progress reports, which will be supplanted by the more complete accounts to be published later.

The summary of the mining conditions throughout the Territory is based on the best information available and is made as complete as possible. For the districts that have been visited during the year by a representative of the Survey, definite information is at hand. It is impossible, however, with the small force available, to visit all parts of the Territory every year. Therefore it is necessary to supplement the information gathered by members of the Survey by data obtained from various sources. As in previous years, the writer has had the cordial cooperation of many Alaskans in the collection of such data. It would be impossible to enumerate all those who have contributed to this work. They include mine operators, territorial officials, officers of banks, transportation companies, and other corporations, as well as many prospectors. Special acknowledgment should, however, be made to the following, some of whom have furnished not only data used for statistical purposes, but also statements on the progress of mining, etc.: James H. Watson, of Valdez; A. K. Beatson, of Latouche; W. H. Hammer, of Sunrise; C. E. Cone, of Knik; R. Blix, of Copper Center; George W. Esterly, of Nizina; Milin Dempsey, of Dempsey; E. R. Brady, of Jack Wade; J. H. Van Zandt, of Fortymile; J. J. Hillard, of Eagle; Ralph Donaldson, of Rampart; V.L. Bevington, of Hot Springs; J. C. Dillew, Falcon Joslin, Fairbanks Banking Company, First National Bank, Washington-Alaska Bank, and Alaska Pacific Express Company, of Fairbanks; E. R. Stevens and R. T. Hirsh, of Nome; C. W. Thornton, of Solomon; Lewis Lloyd, of Shungnak; and G. C. Cole, of Dawson. 
As in previous reports, much attention is given in this volume to the consideration of the gold-placer districts, for placer mining is still the dominating industry of the Territory. In contrast with the previous bulletins, however, more space is here devoted to new fields of possible mineral value. Of this character are reports discussing the mineral resources of the eastern part of Kenai Peninsula, of the Iliamna and Clark lakes region, and of the Norton Bay region. The investigations of these areas have been made possible by the fact that some surveys in more important mining districts are nearing completion, and hence during 1909 a much larger percentage of the funds available could be devoted to reconnaissance and exploratory work. An important feature of the volume is the presentation of the new data obtained by a resurvey of the Koyukuk and Chandalar placer districts. Probably the most important contribution is the paper on the occurrence of auriferous quartz in the Fairbanks region.

The work has embraced investigations of a varied character and has been widely distributed throughout the Territory. Reconnaissance, detailed geologic and topographic surveys, and explorations have been made along with special investigations of the gold, copper, and coal deposits. Data have been obtained on stream flow in the placer and lode districts, some general stratigraphic and geologic studies have been made, and statistics of mineral production have been collected, as well as data on the progress of mining.

Fourteen parties, including 23 technical men and about 30 packers, cooks, etc., have been engaged in Alaskan surveys and investigations during the season of 1909 . In addition, some gage readeprs were employed, who gave only a part of their time to the work. Of the technical men, 12 were geologists, 7 topographers, and 4 engineers. The length of field season for these different parties has varied greatly, but the work was carried on between March and November. Three parties were engaged in geologic work, five in both topographic and geologic surveys, two in topographic surveys, and four in investigating water resources.

The areas covered by geologic explorations (10 or 16 miles to the inch) amount to 6,100 square miles; by geologic reconnaissance surveys ( 4 miles to the inch), 5,500 square miles; by detailed geologic surveys ( 1 mile to the inch), 453 square miles. Much of the time of the geologists was devoted to the investigation of special field problems in the important mining districts, the results of which can not be presented areally. Some 6,190 square miles of topographic exploratory surveys (10 or 16 , miles to the inch), 5,170 square miles of topographic reconnaissance surveys (4 miles to the inch), and 444 square miles of detailed topographic surveys ( 1 mile to the inch) were completed. 
In the Yukon-Tanana region 21 gaging stations have been maintained during the year, furnishing data on the water resources of about 3,000 square miles. In the Seward Peninsula 60 gaging stations have been maintained, yielding data on some 3,600 square miles.

To state the work geographically, three parties were in southeastern Alaska, one in the Copper River basin, one on Prince William Sound and Kenai Peninsula, one in the Matanuska Valley, two in the Iliamna Lake region, three in the Yukon basin, and three in the Seward Peninsula and Norton Bay region.

Among the important results of the year have been the completion of a detailed base map of the most important part of the Matanuska coal field; the completion of a detailed geologic survey of the eastern part of the Chitina copper-bearing belt; and the exploration and survey of large areas in the Iliamna Lake, Norton Bay, and Kenai Peninsula regions. The study of the Berners Bay gold district has been completed. Much new information on the general geology and mineral resources of the Yukon-Tanana region has been obtained, especially regarding the Fairbanks district. The stream-gaging work in the Seward Peninsula and Yukon-Tanana regions has yielded important results on the water available for placer mining.

The following table shows the allotment, including both field and office expenses, of the total appropriation of $\$ 90,000$ to the various districts investigated:

Allotment to Alaskan surveys and investigations in 1909.

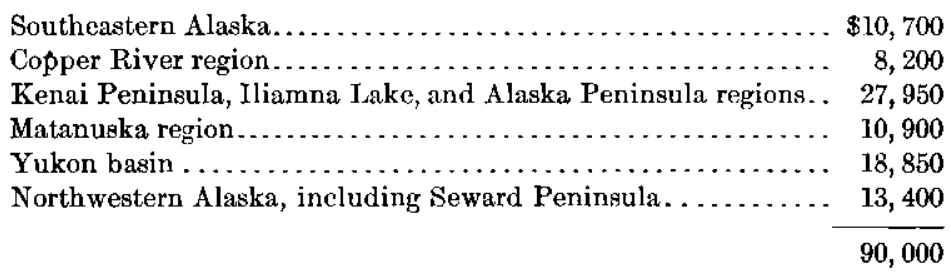

The Alaskan surveys, both geologic and topographic, can be conveniently classed in three grades, in accordance with the refinement with which the field work is carried on, namely, exploratory, reconnaissance, and detailed. What are here termed exploratory surveys embrace all those which yield only very general information as regards topography and geology. Horizontal location in this work is often based purely on foot traverses, and vertical control on aneroid barometer readings. Such work, while it has no permanent value, affords a means of obtaining a general knowledge of the larger geologic and topographic features of a region at a low cost. It also, as a rule, yields sufficiently accurate data regarding mineral resources to make it possible to decide whether a more expensive investigation is justified. The maps resulting from such surveys, which are published on a scale of 10 or 16 miles to the inch, have no geodetic value, but are usually 
accurate enough to guide the occasional prospector and traveler. Where relief is shown by contours the interval is usually 500 or 1,000 feet. Most of the surveys made during the first few years after the Alaskan surveys were begun were of this type. By this means a skeleton of explorations was extended over much of the Territory, which yielded some information with regard to very extensive areas.

The reconnaissance topographic surveys are all based on mensuration accurate to the scale. Both horizontal and vertical control are based on careful instrumental work. It is true, however, that the positions of the resulting maps are sometimes not accurately fixed, owing to the absence of a systematic triangulation scheme. The error in position is, however, usually not sufficient to affect the value of the map for anything but geodetic purposes.

The geologic reconnaissance surveys vary in degree of refinement. Usually they are based on an amount of field work which does not admit of more than a very broad basis of stratigraphic classification. So far as circumstances permit, the attempt is made to keep the field mapping accurate to the scale.

All the geologic and topographic reconnaissance maps are published on a scale of 4 miles to the inch $(1: 250,000)$. The contour interval chosen is generally 200 feet.

Detailed topographic maps have been prepared of only a few of the most important mining districts. These have all been published on a scale of 1 mile to the inch $(1: 62,500)$, with 25,50 , or 100 foot contours. While these detailed maps are thoroughly controlled within themselves as to vertical and horizontal position, yet in those made of areas lying away from tide water the contours are not always referable to a bench mark, the altitude of which is definitely fixed. The same is true also of the horizontal control. Although the geodetic value of the maps is thus impaired, the defects do not curtail their usefulness for engineering purposes.

The detailed geologic maps that have been published are accurate to the scale. Some of them have not gone into so great a degree of refinement in stratigraphic units as the Survey's maps of better-settled districts than Alaska. This is not, however, because the Alaskan geologist has lower standards than he who works in the States, but because the degree of mining development in the Territory, as a rule, does not warrant the expenditure of the additional money which would be necessary to accomplish these great refinements.

In the following table the approximate amount of money devoted to the investigations of each class is indicated. It is not possible always to give the exact figures, as in some cases the same party or even the same man has carried on two different kinds of work; but this statement will help to elucidate a later table which will summarize the complete areal surveys. 
Approximate allotment of Alaskan funds to different kinds of surveys and investigations in 1909 .

Geologic reconnaissance and exploratory surveys......... $\$ 31,800$

Detailed geologic surveys........................ 9,200

Special geologic investigations.................... 2,500

Topographic reconnaissance and exploratory surveys....... 11, 500

Detailed topographic surveys...................... 15, 000

Investigations of water resources. . . . . . . . . . . . . . . . 8,300

Collection of statistics of mineral production............ 1,500

Miscellaneous, including clerical salaries, administration, inspec-

tion, instruments, and office supplies and equipment...... 10,200

Allotment for salaries and field expenses, 1909.

90,000

Scientific and technical salaries...................... $\$ 30,720$

Field expenses, equipment, and supplies............. 50,660

Clerical and other office salaries.................... 8,620

90,000

The following table exhibits the progress of the Alaska investigations and the annual grant of funds since systematic surveys began in 1898. It should be noted that since 1902 a part of the money has each year been spent on special investigations of mineral deposits, the results of which can not be expressed areally.

Progress of surveys in Alaska, 1898-1909.a

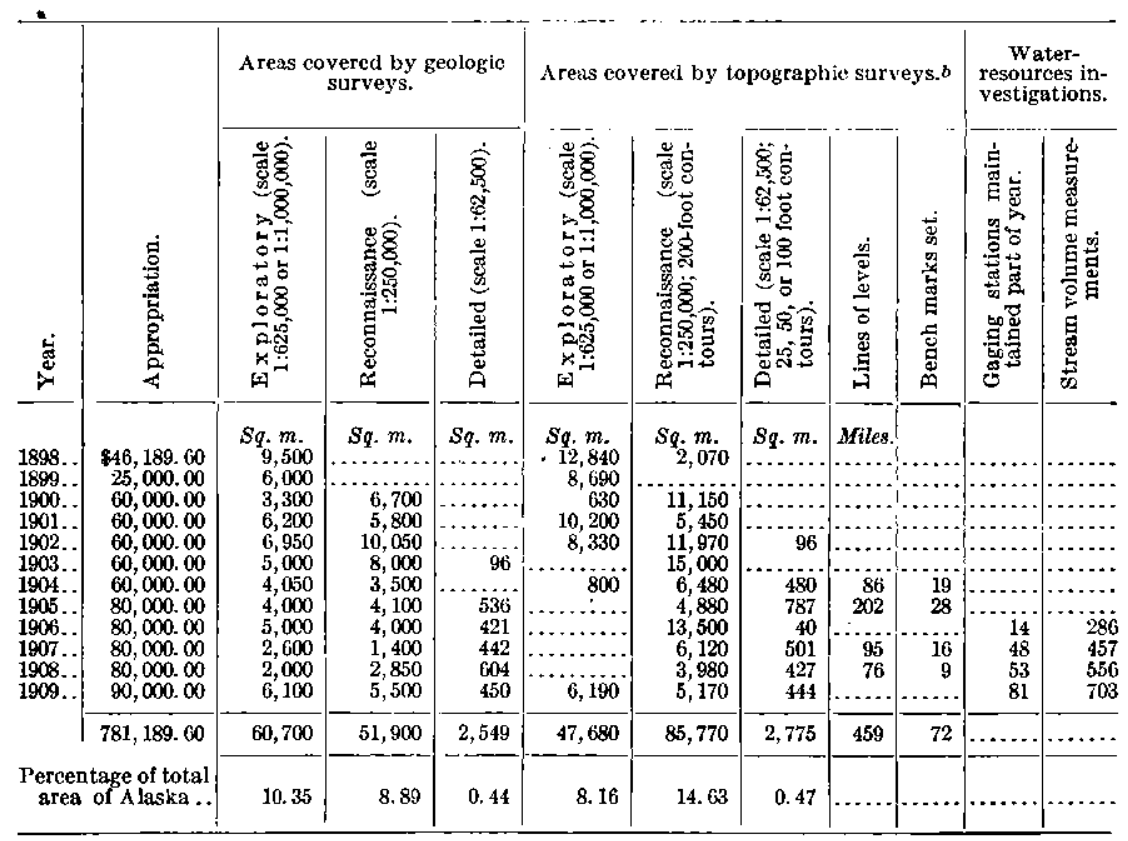

a The areas presented in this table differ somewhat from those previously published. This is due in part to the reclassification of the work and in part to the fact that the areas have been more carefully sealed from the maps than formerly.

$b$ In addition to the above, the International Boundary Survey and the Coast and Geodetic Survey have made surveys of parts of Alaska. 
The exploratory and reconnaissance geologic surveys have covered an area of 112,000 square miles, equal to about 19 per cent of the total area of Alaska. This work has, however, been so distributed as to indicate something of the general geology of at least two-thirds of the Territory. The exploratory and reconnaissance topographic surveys aggregate 133,450 square miles, or about 23 per cent of the total area. Although nearly four-fifths of the Territory is still unsurveyed, yet all the larger geographic features have been blocked out by a system of explorations and reconnaissances. All but two ${ }^{a}$ of the larger rivers have been surveyed. In spite of this progress, there is still at least 100,000 square miles of which geologic and topographic maps are urgently needed.

Detailed surveys have only just been well begun, less than one-half of 1 per cent of the total area having been covered. It will be necessary, however, to survey in detail only the important mining districts, and about 50 per cent of those now known have been covered, but, naturally, with the advance of the mining industry other districts will have to be included in the plans for detailed survey.

\section{GEOGRAPHIC DISTRIBUTION OF INVESTIGATIONS.}

\section{GENERAL WORK.}

The writer left Seattle for Cordova on July 1, 1909, and, going inland over the Copper River route, reached Mr. Moffit's camp (see p. 15), in the Nizina region, on July 17 . About two weeks were spent with Mr. Moffit and Mr. Capps in visiting some of the mineral deposits of the district and in studying the areal geology. On July 24 , in company with Mr. O. Potter, a mining engineer from Houghton, Mich., the writer went overland from the Nizina region to the Copper River crossing, and thence to Tonsina, on the Valdez-Fairbanks trail. Mr. Potter's intimate knowledge of this region made his companionship of great value and mitigated to a certain extent the disagreeableness of traveling on foot through a little-inhabited region during almost continuous rainstorms. From Tonsina Mr. Potter went to Valdez, and the writer traveled inland over the military trail to Fairbanks, which he reached on August 19. Here he met the Prindle party (see p. 15) and spent some days in visiting a few of the more important lode prospects of the district. Later he returned to the coast by way of the White Pass and Yukon route. A week was spent during September in visiting Mr. Bagley and Mr. Knopf in their survey of the Eagle River district.

In the office the writer has given most of his time to administrative and routine work, in which he was aided by R. II. Sargent, who super-

$a$ The Noatak and Colville. An exploration of the Noatak has been made by the Revenuc-Cutter Service; the lower Colville has been mapped by the Geological Survey, and its Keadwaters have been explored by navy oflicers. 
vised the topographic surveys. By order of the Director and in cooperation with Mr. Sargent comprehensive plans for subdivisional surveys of the agricultural and coal lands of Alaska were made and submitted to the Secretary of the Interior.

During the writer's absence in the field E. M. Aten looked after the office routine and also rendered valuable service in the compilation of mineral statistics of Alaska. The little time available for routine duties was devoted by the writer to a continuation of the work on the Mount McKinley report. Some progress was also made in the collection of data for the preparation of a summary report on the mineral resources of Alaska.

W. W. Atwood has, in addition to his work in southwestern Alaska (see p. 18), done some work on a report which will summarize the knowledge of the stratigraphy of the more important coal-bearing rocks of Alaska. The interest in the peat deposits of Alaska awakened by a brief paper on the utilization of this fuel, ${ }^{a}$ which was published last year, seemed to justify a more complete account of the processes involved. Mr. Davis, who is the recognized authority on this subject, has kindly prepared another paper which appears on pages 101-132 of this volume.

In addition to working up the topographic field data, the office force has also devoted some attention to the compilation of special maps. There is a large demand for general maps which shall cover several mining districts. This demand is being met by compiling maps for publication on a scale of 8 miles $(1: 500,000)$ or 16 miles $(1: 1,000,000)$ to the inch. One such map (scale 1:500,000, with 200foot contours) of Seward Peninsula and another of the Koyukuk and Chandalar placer districts have been compiled. It is planned to prepare similar maps of all the most important mining regions of Alaska as fast as circumstances permit and the field data become available. These compilations are being made under the direction of Mr. Sargent.

\section{SOUTHEASTERN ALASKA.}

Adolph Knopf began the study of the geology and mineral resources of the Berners Bay region on May 25 and completed it about a month later. He devoted the rest of the season to carrying similar investigations southeastward along the mineralized belt which connects the Juneau and Berners Bay mining districts. These investigations were carried southward to Eagle River, leaving an unmapped area, the work on which will be completed in 1910 . A total area of 125 square miles was mapped by Mr. Knopf.

In the Berners Bay region Mr. Knopf was hampered in his economic studies by the fact that all the mines were closed. It was therefore

a Davis, C. A., The possible use of peat fuel in Alaska: Bull. U. S. Geol. Survey No. 379, 1909, pp. 63-66. 
impossible to make the exhaustive studies which the importance of the district warrants. In the fall about ten days was devoted by Mr. Knopf to visiting the fields of the most important mining developments, and the results of these investigations are embodied in a report in this volume. (See pp. 133-163.) Mr. Knopf's report on the Berners Bay region has been submitted for publication.

It is to be regretted that the Geological Survey is not able to offer salaries sufficient to hold some mining geologists in the service. For this reason the report of $\mathrm{C}$. W. Wright on the copper deposits of Kasaan Peninsula and Hetta Inlet is still incomplete. Mr. Wright had offers for professional services in Sardinia which he could not afford to refuse, and hence left the Survey before his report was completed. It is expected, however, that he will finish the report this summer.

J. W. Bagley, assisted by R. E. Johnson, began topographic work in the Eagle River district on May 15 and continued, so far as weather conditions permitted, until October 22 . In spite of the exceptionally wet season, an area of 154 square miles was mapped for publication on a scale of 1 mile to the inch, with 50-foot contours. The almost continuous rain or cloudy weather and the heavy timber and underbrush made the detailed survey of this area one of extraordinary difficulty and expense. There still remains about 20 or 30 square miles to survey to connect this area with the region covered by the Juneau special map, and this work will be undertaken in 1910 .

\section{KENAI PENINSULA.}

The gold placers and coal resources of the Kenai Peninsula were investigated by the Geological Survey in 1904, since when the demands for work in other parts of the Territory had prevented further surveys in this district. Meanwhile, as some promising lode deposits had been opened up, the need for further investigation had become more pressing. Therefore U. S. Grant and D. F. Higgins were engaged to extend the reconnaissance surveys in this field.

The party was employed from June 10 to July 9 in supplementing and completing the reconnaissance of Prince William Sound, and from July 9 to September 10 in making a rough topographic survey and geologic investigation of the eastern and southern coast of Kenai Peninsula from Seward to Seldovia. A boat traverse of the shore line was made, and the topography was sketched for 1 to 3 miles inland. Short trips were also made to Moose Pass and False Creek, north of Seward. In all an area of about 600 square miles was covered by the geologic and topographic survey. A brief summary of the economic results of this investigation is presented in this volume (pp. 166-178) and the more complete report is in preparation. 


\section{ILIAMNA AND CLARK LAKES REGION.}

One of the largest regions of southern Alaska that was unsurveyed previous to 1909 lies west of Cook Inlet, including the drainage basins of Tliamna and Clark lakes. The presence of copper and gold deposits in this region has been reported, and a survey was determined upon as part of the general plan to extend the reconnaissance work in new fields so far as circumstances permit.

The field work in this region was a combined topographic and geologic reconnaissance by a party of twelve men in charge of D. C. Witherspoon, topographer. The party landed and began work at Iliamna Bay May 16, 1909. After crossing the mountains to Iliamna village it was divided into two sections. One of these, in charge of Mr. Witherspoon, with F. J. Katz, geologist, consisted of six men and was equipped with a pack train of eight horses. This party traversed the area north of Iliamna and east of Clark Lake. The other party, in charge of G. C. Martin, geologist, with C. E. Griffin as topographer, likewise consisted of six men and was equipped with three Peterboro canoes. This party traversed the shore lines of Hliamna and Clark lakes, mapping as much of the topography and geology as could be reached from the shore, and made an exploratory trip down Kvichak River to Kogiung. Field work for both parties ended at Iliamna Bay on September 28. The topographic surveys of these two parties covered an area of 5,150 square miles, the geologic surveys 3,000 square miles. A brief summary of results is included in this volume (pp. 179-202).

\section{MATANUSKA VALLEY.}

In accordance with the established policy of surveying the more valuable coal fields in detail as soon as circumstances permit, the preparation of the base map of the Matanuska field was undertaken this year. This survey was made by R. H. Sargent, assisted by J. B. Leavitt, who were occupied in it from June 11 to September 18. During this time an area of 196 square miles was covered for publication on a scale of 1 mile to the inch $(1: 62,500)$ with 50 -foot contours.

\section{COPPER RIVER REGION.}

The completion in 1908 of the reconnaissance, surveys ${ }^{a}$ of the two copper belts lying north and south of the Wrangell Mountains paved the way for more detailed investigations. As the southern or Chitina copper belt will be the first one to be developed, it was

a Moflit, F. H., and Maddren, A. G., The mineral resources of the Kotsina-Chitina reglon, Alaska: Bul. U. S. Geol. Survey No. 374, 1909.

Moffit, F. H., and Knopf, Adolph, The mineral resources of the Nabesna-White River district, Alaska: Bull. U. S. Geol. Survey No. 417, 1910 . 
appropriate to begin the detailed investigation in this field. The funds available for this work made it possible to survey only a part of the Chitina belt, and after careful consideration it was decided to take up the work in the Nizina district first. This conclusion was based on three considerations. (1) The information available indicated that the Nizina district afforded the best opportunities for solving the greneral geologic problems relating to the entire copper belt. (2) The mining developments of this part of the district were more extensive than elsewhere in the belt and thus gave better opportunities for observations on the occurrence of the ores and greater promise of soon reaching a productive basis. (3) Investigation of this field made it possible also to cover the Nizina placer district, which had long been productive in a small way and gave promise of a larger output.

A topographic base map of the Nizina district was made by D. C. Witherspoon in 1908, and F. H. Moffit and S. R. Capps devoted the time from July 2 to September 10, 1909, to a detailed study of its geology and mineral resources. During this time an area of 325 square miles was surveyed. This investigation covered only about one-quarter of the Chitina copper belt, but it is believed that the conclusions reached as to the occurrence of the ores will have value to the entire district. If the developments in the Chitina Valley continue, as is anticipated, further detailed surveys should be undertaken.

\section{YUKON-TANANA REGION.}

L. M. Prindle, assisted by B. L. Johnson, continued the geologic mapping in the Yukon-Tanana region, devoting special attention to the study of the auriferous quartz veins in the vicinity of Fairbanks. A preliminary statement of the results of this later study is presented on pages $230-245$ of this report. The geologic mapping of some 2,000 square miles was completed, which practically finishes the reconnaissance work in that part of the Fairbanks quadrangle lying north of the Tanana. A final report on this work is in preparation, an abstract being presented on pages 203-229 of this volume.

Water-resources investigations were continued in the Fairbanks and Circle districts during 1909 by C. E. Ellsworth. Mr. Ellsworth began stream gaging at Fairbanks on April 20 and continued his measurements until September 10. Twenty-one gaging stations and four rainfall stations were maintained and 232 measurements were made. These investigations furnished information regarding the runoff of about 3,000 square miles. A brief statement of results is contained on pages 251-283 of this bulletin. It will take several years more of observations before the average run-off of the various streams can be even approximately determined. 


\section{KOYUKUK AND CHANDALAR DISTRICTS.}

Reconnaissance surveys were made of the Koyukuk and Chandalar placer districts by F. C. Schrader and T. G. Gerdine in 1899. As there has been much progress in mining in this field, a reexamination and an extension of the surveys were undertaken as a part of the plans for 1909. The work was intrusted to A. G. Maddren, who, with one man and two horses, went from Fort Hamlin, on the Yukon, northward to Coldfoot, on the Koyukuk. After investigating the placer deposits in the vicinity of Coldfoot, he continued his journey to the Chandalar district and thence returned to the Yukon. The field work continued from June 25 to September 4, during which about 500 square miles were surveyed geologically and topographically and practically all the important placer localities were visited. A summary of the results is published in this volume (pp. 284-315), and the more complete report is in preparation.

\section{NORTON BAY REGION.}

Previous to 1909 one of the largest unsurveyed areas of the more accessible parts of Alaska was one which lies between the lower part of the Koyukuk and the Yukon at Nulato and Seward Peninsula. The exploration of a part of this field was undertaken last summer by P. S. Smith and H. M. Eakin. The party, including packer and cook, with four horses, left Nulato on June 26 and reached the mouth of the Koyuk, to which some supplies had been sent from Nomk: about three weeks later. The following month the surveys wer' continued to the northeast and to the south, and later the work wa carried westward across the Fish River basin, ending at Council Ser tember 22. The results included a rough exploratory survey of abo: 5,000 square miles and a somewhat more detailed survey of 200 or $30 ;$ square miles.

\section{SEWARD PENINSULA.}

Stream gaging was continued in Seward Peninsula during the sum? mer of 1909 by F. F. Henshaw and G. L. Parker. The field wor began near Nome on June 12 and was continued in the various min ? $^{2 n}$ districts of the peninsula until September 22. A brief summar? results is presented on pages $372-418$ of this report. Mr. Henshit: also engaged in preparing a summary report on the results of stream gaging which has been done in Seward Peninsula during past four years.

\section{COLLECTION OF STATISTICS.}

As in previous years, the statistics of the gold, silver, and $c_{f} .1$. production of Alaska were collected by the writer, assisted by va: 0 members of the field force and by Mr. Aten. Every year a $\mathrm{Yr}_{\mathrm{r}}$ ? percentage of the operators show their interest in this work by:- 
nishing data of production. If funds were available for sending a representative into each district to collect the required information in person, complete and reliable figures could undoubtedly be had. As it is, the work is still largely done by correspondence, and the address list of operators is by no means complete. It is expected, however, that soon every operator in the Territory will report his production, so that accurate totals for each district can be published. Until this is done the figures of production can be only approximate. The attention of all those interested in the advancement of the mining industry of Alaska is directed to the fact that it will be greatly to the advantage of this industry if accurate figures of the gold output of each district are published. Those operators who have hesitated to furnish the desired information for fear it might be used to their disadvantage are reminded of the fact that the Geological Survey has received confidential information from practically every mining corporation in the States for many years and has never been charged with betraying a confidence. The figures furnished are used only to make up totals of districts, and every precaution is taken to prevent their being published in any way to indicate the output of individuals or corporations unless permission has been explicitly granted in writing. Reports are now received from nearly every lode mine in Alaska, but there is still a large percentage of the placer miners who neglect to return the schedules mailed to them. Fortunately there are other, hough less exact, sources of information. The statement of placersold production as presented is, then, based in part on the returns rom operators and in part on data furnished by bankers, express ?mpanies, federal officials, and other residents of Alaska.

\section{PUBLICATIONS ISSUED OR IN PREPARATION.}

There are still unavoidable delays in the issuing of the more elaborate eports after the manuscript has been completed, yet as a rule the ime occupied in publication does not exceed three or four months. Ine cause of delay in the submission of manuscript is the fact that rrly all the Alaskan publications are of the nature of progress rrts, and as every season's field work adds new information there ways a tendency to defer publication until the new data can be srporated. During 1909 the Survey published three bulletins, professional paper, one water-supply paper, and three separate $s$ relating to Alaska. Two other bulletins appeared in the early of 1910 . The complete list is as follows:

REPORTS.

1 resources of Alaska; report on progress of investigations in 1908, by Alfred $\mathrm{H}$. ooks and others. Bulletin 379 .

1e akutat Bay region, Alaska; Physiography and glacial geology, by R. S. Tarr; ceal geology, by R. S. Tarr and B. S. Butler. Professional Paper 64.

$55695-$ Bull. 442-10 22 
Mineral resources of the Kotsina-Chitina region, Alaska, by F. H. Moffit and A. G. Maddren. Bulletin 374.

The Fortymile quadrangle, Yukon-Tanana region, Alaska, by L. M. Prindle. Bulletin 375.

Water-supply investigations in the Yukon-Tanana region, Alaska, 1907 and 1908, by C. C. Covert and C. E. Ellsworth. Water-Supply Paper 228.

The Innoko gold-placer district, Alaska, with accounts of the central Kuskokwim Valley and the Ruby Creek and Gold Hill placers, by A. G. Maddren. Bulletin 410 .

The Nabesna-White River copper region, by F. H. Moffit and Adolph Knopf; including geologic and topographic reconnaissance maps. Bulletin 417.

\section{MAPS ISSUED SEPARATELY.a}

Index map of Alaska showing areas surveyed and published sheets; also includes a list of recent publications.

Fairbanks quadrangle map, scale 1: 250,000 , contour interval 200 feet. Topography by T. G. Gerdine, D. C. Witherspoon, and R. B. Oliver.

Rampart quadrangle map, scale 1: 250,000, contour 1 isterval 200 feet. Topography by D. C. Witherspoon and R. B. Oliver.

The following papers and maps are in various stages of preparation and will be published as soon as circumstances permit, but probably, for the most part, during the year 1910:

Geology and ore deposits of Kasaan Peninsula and Copper Mountain region, Prince of Wales Island, by C. W. Wright, including detailed geologic and topographic maps.

Geology and mineral resources of the Berners Bay region, Alaska, by Adolph Knopf, including detailed topographic and geologic maps.

The Yakutat Bay earthquake of September, 1899, by R. S. Tarr and Lawrence Martin. Professional Paper 69.

Geology and mineral resources of the Nizina district, Alaska, by F. H. Mofht and S. R. Capps, including detailed geologic and topographic map.

The geology and mineral resources of the Prince William Sound region, by U. S. Grant, including geologic reconnaissance map.

The Mount McKinley region, by Alfred $\mathbf{H}$. Brooks and L. M. Prindle, including geologic and topographic reconnaissance maps. Professional Paper 70.

Geology and mineral resources of parts of the Alaska, Peninsula, by W. W. Atwood, including geologic and topographic reconnaissance maps.

Geology and mineral resources of the Fairbanks district, by L. M. Prindle and F. J. Katz, including detailed topographic and geologic maps.

The Fairbanks quadrangle, by L. M. Prindle, including geologic and topographic: reconnaissance maps.

The Koyukuk and Chandalar placer districts, by A. G. Maddren, including geologic: and topographic reconnaissance maps.

Geologic reconnaissance in southeastern Seward Peninsula and Norton Bay-Nulato region, by P.S. Smith and H. M. Eakin.

Geology of the Nome and Grand Central quadrangles, by F. H. Moffit and P. S. Smith; including detailed geologic map.

Geology and mineral resources of the Solomon and Casadepaga quadrangles, by P. S. Smith, including detailed geologic map. Bulletin 433 .

The water supply of Seward Peninsula, by F. F. Henshaw. 


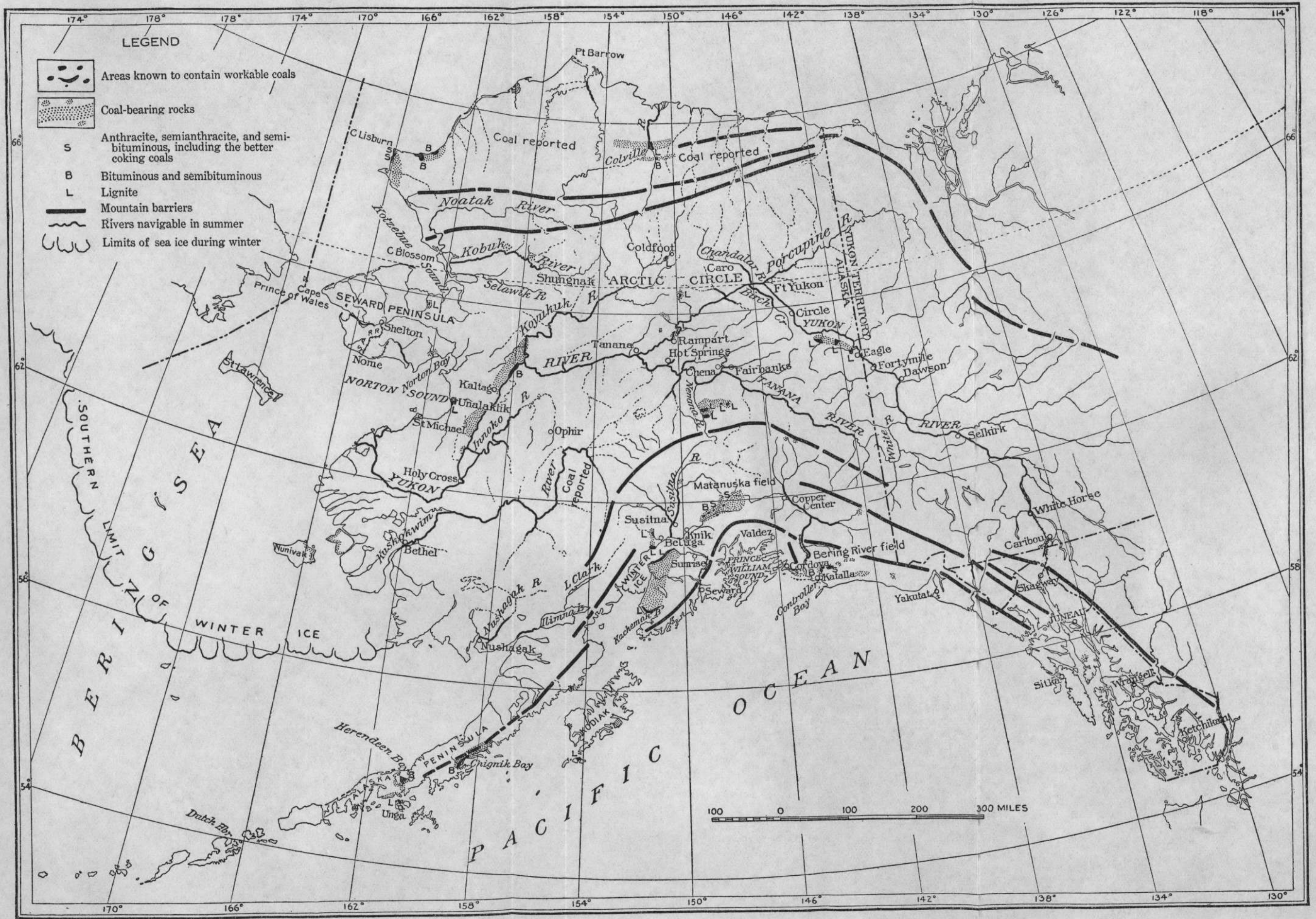

MAP SHOWING RELATION OF ALASKA COAL FIELDS TO TRANSPORTATION ROUTES. 


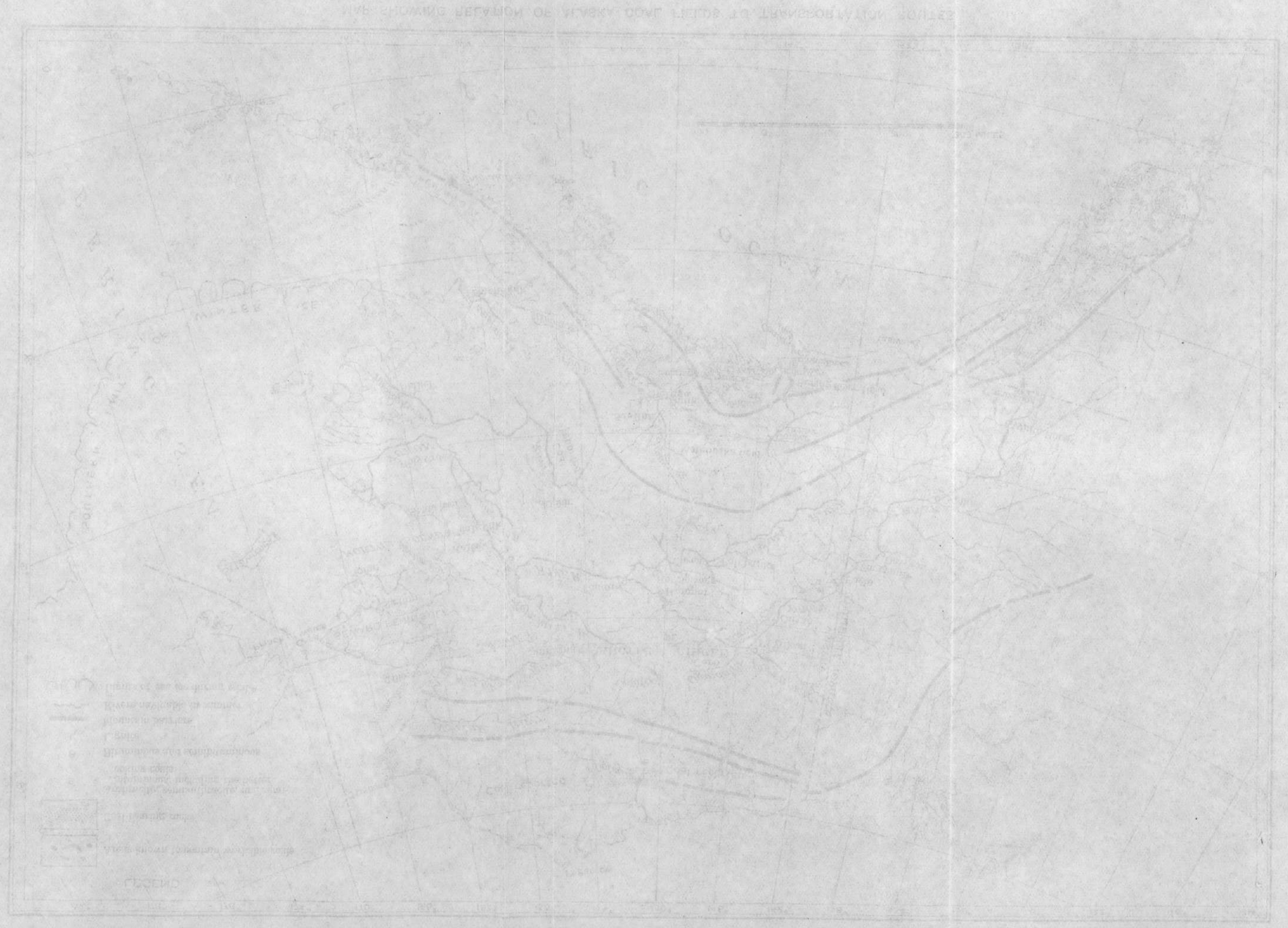


Kasaan special map, Prince of Wales Island, scale 1: 62,500, contour interval 50 feet. Topography by R. H. Sargent, J. W. Bagley, and D. C. Witherspoon.

Copper Mountain special map, Prince of Wales Island, scale 1: 62,500, contour interval 50 feet. Topography by R. H. Sargent.

Nizina special map, Copper River region, scale 1: 62,500, contour interval 100 feet. Topography by D. C. Witherspoon.

Map of Circle quadrangle, scale 1: 250,000 , contour interval 200 feet. Topography by D. C. Witherspoon.

Map of Fortymile quadrangle (new edition), scale 1: 250,000, contour interval 200 feet. Topography by E. C. Barnard.

Map of Seward Peninsula, scale 1: 500,000, contour interval 200 feet. Topography by United States Geological Survey. 


\title{
THE MINING INDUSTRY IN 1909.
}

\author{
By AlFred H. Brooks.
}

\section{INTRODUCTION.}

Gold placer and lode mining in Alaska in 1909 showed marked progress over the previous year both in the amount of actual gold production and in the advances made in preparation for more extensive operations. The copper output was less than in 1908, chiefly because the low price of this metal did not encourage mining, but, nevertheless, considerable prospecting and dead work were accomplished. There was little change in the output of other minerals as compared with previous years except in that of coal, which showed a decline.

In strong contrast to the prosperity prevailing in most of the gold-bearing districts was the condition in the coal fields, where there was not only no industrial advance but in some cases a decided retrogression. This was caused in part by the long delay in the issuance of patents to coal lands, in part by the popular furor which has been raised against all Alaska coal claimants. As a consequence, many who have been earnestly striving to develop the coal fields have become discouraged, and it has become increasingly difficult to find the large amount of eapital necessary to any coal-mining enterprise. Moreover, these conditions have affected other industries more or less dependent on the opening of the coal fields. This is notably true of copper mining and the construction of railways. In short, it may be said that while Alaska's gold mines have had the most prosperous year since 1906, many other mining enterprises have received a check, or even have retrograded. As the conditions which produced this retrogression are not inherent in the mineral resources of the Territory, there is every hope that they may soon be rectified.

There is no doubt that a serious handicap to placer mining is to be found in the present inadequate mineral-land laws. These tend to discourage the bona fide miner and prospector to the advantage of the speculator, whose principal aim is to obtain control of large areas of prospective placer ground without any serious attempt at development.

Those who are familiar with the conditions in this region, so difficult of access, realize that Alaska needs the most generous treatment from 
the people of the United States and their representatives. Every effort should be made to encourage the construction of railroads and wagon roads and the opening of the coal and copper fields. Even in the most favored district the Alaska mine operators are, as a rule, working under great disadvantages as compared with those in the States. Owing to the excessive cost of transportation to inland Alaska, only the richest placers can now be exploited, and the mining of lode gold, copper, and coal is, in many localities, out of the question. The conditions which confront the average Alaskan are similar to those which prevailed in the Western States before the construction of the transcontinental railways.

Alaska is known to have great latent possibilities for the miner, but this mineral wealth has no value except as it be made accessible by railways and wagon roads, and much of it can be developed only by the investment of a large amount of capital for mine equipment. The exaggerated statements which have recently appeared in current literature as to the monetary value of these mineral resources are not only misleading as to fact, but also do harm by leading the people to believe that there is an equity of great immediate value for every citizen of the United States in the undeveloped wilds of Alaska. No one knows how many ounces of gold, pounds of copper, or tons of coal will eventually be won from this extensive territory. In the developed placer districts there is, to be sure, some basis for estimating gold reserves, and the surveyed portions of the coal fields give more definite results. (See p. 52.) These, however, are for the most part minimum estimates and are of value chiefly to the economist in indicating possible sources of metals and fuels for the generations to come. To take such estimates and, without regard to the cost of recovering these minerals, multiply them by the present market value in the centers of population, as has been done, is far from leading to results which have the slightest value.

The gross value of the mineral output is of importance in a discussion of the industry and enables comparisons to be made of one year with another and one district with another. This gross value is far, however, from indicating the net return to the claim owner or operator. While the exploitation of bonanza deposits of gold and copper often yields extraordinary profits, yet in the average enterprise the difference between the cost of extraction of the metal and its value is by no means excessive, considering the uncertainties of this kind of mining. In fact, it is an open question whether a large part of the gold mining of the world has not been done at an actual economic loss. The average profit on bituminous coal mining in the United States is about 10 cents a ton, and although the profit to the Alaska coal operator will undoubtedly be larger eventually, yet competition with other developed fields will prevent its becoming excessive. (See pp. 88-93.) 
In spite of the fact that in 1909 the output of the Seward Peninsula placers decreased nearly 20 per cent and that of the copper mines about 8 per cent, as compared with the previous year, the value of the total mineral production of Alaska in 1909 is estimated at $\$ 21,237,502$, while in 1908 it was $\$ 20,142,272$. In the following table the sources of this wealth, as well as a comparison with the previous year, are presented. It should be noted that the statistics for the gold output are not yet complete and that the figures for the production of coal, gypsum, etc., during 1909 are only estimated.

Mineral production of Alaska, 1908 and 1909.

\begin{tabular}{|c|c|c|c|c|c|c|}
\hline & \multicolumn{2}{|c|}{1908.} & \multicolumn{2}{|c|}{$1909 . a$} & \multicolumn{2}{|c|}{$\begin{array}{l}\text { Increase }(+) \text { or de- } \\
\text { crease }(-)\end{array}$} \\
\hline & Quantity. & Value. & Quantity. & Value. & Quantity. & Value. \\
\hline \multirow[t]{2}{*}{ 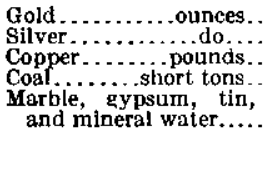 } & $\begin{array}{c}933,290.07 \\
135,672 \\
4,585,362 \\
3,107\end{array}$ & $\begin{array}{r}319,292,818 \\
71,906 \\
605,267 \\
14,810 \\
157,471\end{array}$ & $\begin{array}{c}989,879.06 \\
126,906 \\
4,124,705 \\
2,800\end{array}$ & $\begin{array}{r}\$ 20,463,000 \\
65,991 \\
536,211 \\
12,300 \\
160,000\end{array}$ & $\begin{array}{l}+56,585.99 \\
-\quad 8,766 \\
-460,657 \\
-\quad 307\end{array}$ & $\begin{array}{rr}+ & 1,170,182 \\
- & 5,915 \\
- & 69,056 \\
- & 2,510 \\
+ & 2,529\end{array}$ \\
\hline & $\ldots$ & $20,142,272$ & & $21,237,502$ & & $+1,095,230$ \\
\hline
\end{tabular}

c Preliminary estimates.

Nore.-In the above table copper is valued at 13.1 cents a pound for 1908 and at 13 cents for 1909; silver at 53 cents an ounce for 1908 and at 52 cents for 1909 .

The increase in total value is about one-third from the gold placers and two-thirds from the gold lode mines. With the decrease in output of copper has also come a fall of 2 cents in its value per pound, as compared with 1908. The decrease in coal output is not significant, as coal mining is still confined to a small output of lignite for local consumption. As pointed out, the existing conditions do not encourage the development of coal mines, and Alaska's annual supply of some 100,000 tons is still brought in from a distance at an excessive cost to the consumer. The output of marble, tin, and gypsum is lumped together, as a separate listing might reveal the production of individual properties.

Value of total mineral production of Alaska, 1880-1909.

\begin{tabular}{|c|c|c|c|}
\hline \multicolumn{2}{|c|}{ By years. } & \multicolumn{2}{|l|}{ By substances. } \\
\hline 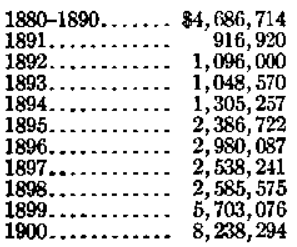 & $\begin{array}{rr}1901 \ldots \ldots & 87,007,398 \\
1902 \ldots \ldots & 8,400,693 \\
1903 \ldots \ldots . & 8,941,614 \\
1904 \ldots \ldots & 9,567,535 \\
1905 \ldots \ldots & 16,478,142 \\
1906 \ldots \ldots & 23,375,008 \\
1907 \ldots \ldots . & 20,847,055 \\
1908 \ldots \ldots & 20,142,272 \\
1909 \ldots \ldots & \text { a } 21,237,502 \\
& \\
& 169,482,675\end{array}$ & 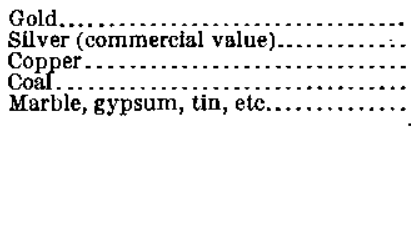 & $\begin{array}{r}\$ 162,686,455 \\
1,184,259 \\
4,800,014 \\
323,189 \\
488,758 \\
169,482,675\end{array}$ \\
\hline
\end{tabular}


The increased lode-gold production came entirely from the Juneau district, though much attention was given to the prospecting of quartz claims in many other districts, notably near the town of Seward, in the Willow Creek basin, and at Fairbanks. Copper mining was continued in the Ketchikan district, where one new mine became a producer in 1909, and on Prince William Sound, while there was much activity shown in the as yet unproductive districts of Copper River. As already stated, the coal-mining industry, if anything, retrograded as compared with 1908. The output of marble and gypsum for 1909 is not yet known, but certainly was no less than in 1908.

All the placer camps except those of Seward Peninsula, where dry weather and other conditions interfered with mining (see pp. 335-354), were prosperous. In the Yukon basin there was a notable increase in the gold output of practically all the placer districts, which more than made up for the decreased production of the Seward Peninsula mines. (See pp. 43-45.) The general movement of prospectors into the Innoko basin and the adjacent parts of the Kuskokwim Valley continued during 1909.

\section{TRANSPORTATION.}

Over $\$ 17,000,000$ worth of manufactured and raw material was shipped from the States to Alaska during the fiscal year ending June 30,1909 . The products returned from Alaska during the same period, including minerals, fish, furs, etc., had a value of over $\$ 30,000,000$. Though no figures are available for the total tonnage represented by this commerce, these values give a measure of its importance. Transportation to and from Alaska ports is, of course, effected by steamer, at relatively low cost. Such of the supplies as are destined for points along the Pacific seaboard (open to navigation throughout the year), including a large percentage of the total tonnage, reach the consumer at relatively reasonable prices. The cost of freight to Bering Sea ports is greater, because the open season for vessels extends only from the last of May to the latter part of October. Very much heavier are the costs of transportation to inland points, reached only by river steamer in summer or long sled journeys in winter. Freight and passenger tariffs vary more or less from year to year, so that the following table will serve to guide the prospective shipper only in a general way, but is presented to indicate the approximate and relative costs of transportation: 
Approximate freight and passenger rates from Seattle to towns in Alaska.

[Based on tariffs of 1907-8.]

\begin{tabular}{|c|c|c|c|c|c|c|c|c|c|c|c|}
\hline \multirow{2}{*}{\multicolumn{2}{|c|}{ Point of destination. }} & \multirow{2}{*}{$\begin{array}{l}\text { Coal, per } \\
\text { ton. }\end{array}$} & \multirow{2}{*}{$\begin{array}{c}\text { General } \\
\text { merchandise, } \\
\text { per ton. }\end{array}$} & \multicolumn{2}{|c|}{ Lumber, per $\mathbf{M}$. } & \multirow{2}{*}{$\begin{array}{l}\text { Machinery, per } \\
\text { ton. }\end{array}$} & \multicolumn{2}{|c|}{ Forage, per ton. } & \multirow{2}{*}{$\begin{array}{l}\text { Horses, per } \\
\text { head. }\end{array}$} & \multicolumn{2}{|c|}{ Passenger rates. } \\
\hline & & & & Rough. & Dressed. & & Hay. & Grain. & & $\begin{array}{l}\text { First } \\
\text { class. }\end{array}$ & $\begin{array}{l}\text { Second } \\
\text { class. }\end{array}$ \\
\hline \multirow{4}{*}{\multicolumn{2}{|c|}{ 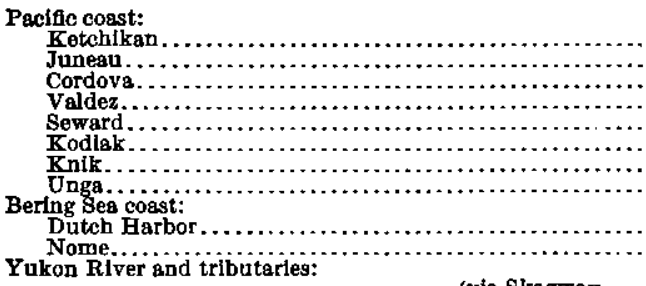 }} & $\begin{array}{r}\$ 5.00 \\
5.00\end{array}$ & $\begin{array}{r}88.00 \\
9.00\end{array}$ & $\begin{array}{r}\$ 7.50-\$ 11.25 \\
7.50-11.25\end{array}$ & $\begin{array}{r}56.50 \\
6.50\end{array}$ & $\begin{array}{r}\$ 8.00-\$ 22.00 \\
9.00-23.00\end{array}$ & $\begin{array}{r}\$ 15.00 \\
15.00\end{array}$ & $\begin{array}{r}89.00 \\
9.00\end{array}$ & $\begin{array}{r}\$ 20.00 \\
20.00\end{array}$ & $\begin{array}{r}\$ 22.00 \\
25.00\end{array}$ & $\begin{array}{r}\$ 14.00 \\
16.00\end{array}$ \\
\hline & & 6.00 & 11.00 & $15.00-18.00$ & $\$ 10.00-13.00$ & $11.00-24.00$ & 15.00 & 11.00 & $\$ 25.00-30.00$ & 45.00 & 25.00 \\
\hline & & $\begin{array}{r}8.00 \\
10.00 \\
10.00\end{array}$ & $\begin{array}{l}14.00 \\
15.00 \\
17.00\end{array}$ & $\begin{array}{l}18.00-21.00 \\
20.00-23.00 \\
20.00-23.00\end{array}$ & $\begin{array}{l}13.00-16.00 \\
16.00-17.00 \\
15.00-19.00\end{array}$ & $\begin{array}{l}14.00-27.00 \\
15.00-28.00 \\
16.00-30.00\end{array}$ & $\begin{array}{l}18.00 \\
19.00 \\
21.00\end{array}$ & $\begin{array}{l}13.00 \\
16.00 \\
17.00\end{array}$ & $\begin{array}{l}25.00-30.00 \\
25.00-30.00 \\
25.00-30.00\end{array}$ & $\begin{array}{l}55.00 \\
55.00 \\
70.00\end{array}$ & $\begin{array}{l}38.00 \\
38.00 \\
47.00\end{array}$ \\
\hline & & $\begin{array}{l}10.00 \\
12.50\end{array}$ & $\begin{array}{l}18.00 \\
15.00\end{array}$ & $\begin{array}{l}20.00-23.00 \\
18.00-27.00\end{array}$ & $16.00-22.00$ & $\begin{array}{l}\text { 17. } 00-31.00 \\
15.00-55.00\end{array}$ & $\begin{array}{l}22.00 \\
22.00\end{array}$ & $\begin{array}{l}18.00 \\
17.00\end{array}$ & $\begin{array}{r}30.00-35.00 \\
75.00\end{array}$ & $\begin{array}{r}90.00 \\
100.00\end{array}$ & $\begin{array}{l}60.00 \\
65.00\end{array}$ \\
\hline \multicolumn{2}{|c|}{ 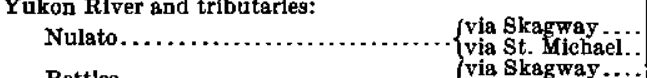 } & $\begin{array}{r}104.00 \\
\cdots\end{array}$ & $\begin{array}{r}147.00 \\
45.00\end{array}$ & 67.50 & 67.50 & $\begin{array}{r}104.00-142.25 \\
45.00-130.50\end{array}$ & $\begin{array}{r}104.00 \\
61.75\end{array}$ & $\begin{array}{r}104.00 \\
45.00\end{array}$ & $110.00 \pm$ & $\begin{array}{l}115.00 \\
102.00\end{array}$ & $\begin{array}{r}90.00 \\
72.00\end{array}$ \\
\hline Bettles $\ldots \ldots \ldots \ldots \ldots \ldots \ldots \ldots \ldots$ & $\left\{\begin{array}{l}\text { via St. Iichaei... } \\
\text { via Skagway .... }\end{array}\right.$ & $\begin{array}{l}85.00 \\
85.00\end{array}$ & $\begin{array}{r}120.00 \\
128.00\end{array}$ & 180.00 & 180.00 & $\begin{array}{r}120.00-205.50 \\
85.00-123.00\end{array}$ & $\begin{array}{r}138.00 \\
85.00\end{array}$ & $\begin{array}{r}120.00 \\
85.00\end{array}$ & & $\begin{array}{l}1+0.00 \\
150.00 \\
106.00\end{array}$ & $\begin{array}{r}125.00 \\
81.00\end{array}$ \\
\hline Tanana.. & ivia St. Michael. & & $55.00-140.50$ & 82.50 & 82.50 & 55. 00-140.00 & 63.25 & 55.00 & .. & 110.00 & 85.65 \\
\hline Failrbanks. & $\left\{\begin{array}{l}\text { via skapway.... } \\
\text { via St. Miehoe } 1 . .\end{array}\right.$ & $\begin{array}{l}78.00 \\
73.00\end{array}$ & $73.00-146.00$ & $\begin{array}{r}53.00 \\
109.50\end{array}$ & $\begin{array}{r}53.00 \\
109.50\end{array}$ & $\begin{array}{r}103.00-180.00 \\
73.00-104.50\end{array}$ & $\begin{array}{l}88.00 \\
83.95\end{array}$ & $\begin{array}{l}83.00 \\
73.00\end{array}$ & & \begin{tabular}{|l|}
125.00 \\
125.00
\end{tabular} & $\begin{array}{l}100.00 \\
100.00\end{array}$ \\
\hline Rampart. & $\{$ via Skagway -... & 83.0 & 124.00 & 8230 & 8230 & 83. $00-120.35$ & 83. 00 & 83.00 & ... & 105.00 & 80.00 \\
\hline & & 79.00 & 114.00 & 82.0 & & & 79.00 & & & & 75.00 \\
\hline & via st. Michael. & & 65.00 & 97.50 & 97.50 & & 74.75 & 65.00 & $88.00 \pm$ & 125.00 & 100.00 \\
\hline Eagle. & $\left\{\begin{array}{l}\text { via skagway.... } \\
\text { via St. Michael.. }\end{array}\right.$ & 75.00 & $\begin{array}{r}108.00 \\
70.00\end{array}$ & 105.00 & 105.00 & $\begin{array}{l}75.00-108.75 \\
70.00-165.50\end{array}$ & $\begin{array}{l}80.00 \\
80.50\end{array}$ & 70.00 & .......... & 130.00 & 105.00 \\
\hline
\end{tabular}


It is not to be supposed that the rates given above are a measure of the total cost of transportation to the Alaska mines, for they represent only a small part of it. Along the Pacific seaboard most of the mining is confined to a zone immediately adjacent to tide water and hence there is little additional charge for transportation. Far different are the conditions in the interior, where most of the mining is 10 to 200 miles distant from the nearest point that can be reached by steamer. The data at hand are insufficient to make possible a complete statement of the cost of transportation in the various inland districts, but the following notes will indicate something of the magnitude of these charges.

Up to 1909 all the supplies for the Copper River region were sledded in winter from Valdez, and much of the freight is still carried by this route, though during the last year the railway from Cordova, supplemented by steamers on Copper River in summer and horse sleds in winter, transported a part of the supplies. The cost of transportation from Valdez varies greatly, but for points along the Fairbanks trail south of the Tanana divide it is estimated to be from $\$ 100$ to $\$ 400$ a ton. Winter freighting to the more distant camps, such as Valdez Creek, Chistochina, and Nabesna, costs from $\$ 500$ to $\$ 700$ a ton. In the past the supplies for the Chitina copper district were all moved during the winter months and were from two to three months on the way. The cost varied from $\$ 100$ to $\$ 600$ a ton, with an average of about $\$ 200$ a ton. It should be noted that the rates quoted apply only to the winter months, when most of the freight is moved. In summer the transportation of emergency supplies by pack horses to the more distant camps costs as high as $\$ 2,000$ a ton.

There is little information at hand in regard to local freight rates in the Cook Inlet and Susitna regions. It is reported that in 1909 the cost of hauling supplies by sleds from the coast to the Yentna district was $\$ 200$ a ton.

In 1909 about 47,000 tons of freight was received at Nome, including merchandise, coal, lumber, and live stock, at a cost of about $\$ 660,000$. The cost of freighting to the mines, by coasting vessels and wagons in summer and by sleds in winter, in different parts of Seward Peninsula varies from about $\$ 80$ to $\$ 200$ a ton in summer and from about $\$ 3$ to $\$ 50$ a ton in winter. It appears that the average price paid for transportation in the peninsula is about $\$ 20$ a ton. On the assumption that half the supplies landed at Nome are for the use of the miners, this will represent an additional freight charge of nearly half a million dollars. The total transportation charge on the supplies of Seward Peninsula will, then, be about $\$ 1,200,000$, or nearly 30 per cent of the value of the entire gold output of the year. 
No exact figures are available in regard to the amount of freight annually shipped to the Alaska portion of the Yukon basin, but it is probably safe to say that this amounts to 30,000 tons and that it costs over $\$ 2,500,000$ to land it at the end of steamboat navigation. The mine freight must then be hauled by wagons or sleds, except at Fairbanks, where there is a railway. It is estimated that this haulage from steamers to mines for the Alaska Yukon costs from $\$ 2,000,000$ to $\$ 2,500,000$ a year. The total annual cost of freight for the Yukon basin is, therefore, probably between $\$ 4,500,000$ and $\$ 5,000,000$, or nearly 50 per cent of the value of the entire gold output. It should be noted that these estimates of the cost of freight do not include any charge for the transportation of fuel, which is included in the similar figures already presented on the commerce of Seward Peninsula. In the Yukon basin practically only wood is used, whereas Seward Peninsula depends almost entirely on coal brought from a distance.

The data at hand seem to justify the conclusion that Alaska's annual expenditure for transportation of supplies and equipment is between $\$ 7,000,000$ and $\$ 8,000,000$. Probably 30 per cent of this represents ocean freights, which must remain a fixed charge, even with the improvement of transportation lines into the interior. It would appear that on 70 per cent of this amount a very material reduction could be brought about by the construction of railroads and wagon roads. A trunk railway into the Yukon, with a freight rate, for example, of 10 cents a ton-mile, should make a saving of at least 50 per cent in the cost of transportation of supplies and equipment to the Yukon camps. It should be noted also that, even were the freight tariffs by river and rail the same, there would be an actual money saving in shipping by rail, because of the losses entailed through the uncertainties and delays of the present system. Fairbanks freight via St. Michael is now from six weeks to two months in transit and can be transported only between about the first of July and the middle of September. Although the comparatively small amount of freight now annually carried into the Yukon basin may not seem to justify a railway, yet if a line were constructed it would give an impetus to mining that would probably soon put the enterprise on a paying basis.

The great tax on the mining industry of Alaska caused by the present system of transportation is strikingly illustrated by the fact that the annual freight bill-much, to be sure, paid indirectly-for every white man, woman, and child living in inland Alaska and on Seward Peninsula is over $\$ 350$. As this figure is based on incomplete data concerning tonnage and on estimates of population it is only approximate, but it at least indicates to what order of magnitude the true figure belongs. If these estimates are correct, the amount paid 
for freight in the placer camps of Alaska is equal to nearly half of the value of the annual gold production. These freight charges are reflected in the high cost of all supplies and of labor.

All of this clearly indicates why only the richest placer ground is being mined and suggests that the present industrial advancement of inland Alaska is small when compared with that which will take place when railway communication with tide water has decreased the cost of operating. While the Yukon and many of its tributaries are navigable, and parts of Copper and Susitna rivers are available for small steamers (see map, Pl. I), yet, as shown, this mode of transportation is both expensive and time consuming. It has served the purposes of the pioneer and has made possible the opening of the richer placer districts without the expenditure of the large amount of capital needed for railways. But gold and copper lode mining, not to mention coal mining, are almost impossible with only the inadequate steamboat service. Even if the rivers were open throughout the year they would be means of communication for only a small part of the mineral-bearing areas and must be supplemented by wagon roads and railways if all the mining districts are to be made productive. As it is, however, the entire water transportation has to be crowded into four months of the year.

The matter presented shows the urgent need of railways for the development of Alaska's resources, yet it can not be denied that the visible tonnage is by no means so large as to assure immediate returns on the capital invested. Present conditions are much the same as those which prevailed before the building of the transcontinental railways, though the routes chosen for the latter for the most part had the advantage over those of the Alaska railways, inasmuch as they traversed extensive areas of arable lands whose products the railways could carry to market. There is much arable land in Alaska, but the present competition with more favored fields will not justify the hope that agricultural products may be exported from the Territory, though its extensive grazing lands may eventually be a source of supply for beef. Therefore these arable lands at present will be of use to settlers only as a local market for their products arises through a population attracted by the mineral wealth. It is to the mines that the proposed railways must look for their tonnage, with every prospect that in time agricultural communities will spring up in the region made accessible. The development of coal mines will certainly yield a large tonnage, but the immediate market for Alaska coal (see pp. 80-95) is not so large as to assure the success of all the railways which are under construction or planned into the two important coal fields. There is every hope that the copper deposits will in time give business to the support of railways, but the actually developed tonnage of ore is relatively small. The latent 
possibilities of the placer fields are also large, but the assured traffic for railways is by no means extensive.

These facts are here cited, not because it is intended to imply that railways can not be made a commercial success in the Territory, but simply to counteract some of the exaggerated statements in current literature of the great profits assured from railway investments. Sufficient progress has been made on several railway projects to insure that some of the coal and copper districts will be developed solely by private initiative. Whether these same railway lines will be pushed on into the little-developed placer districts without public aid is at least an open question. It seems most likely that some form of government guaranty will be necessary before a railway line from the Pacific to the Yukon will be constructed.

While many plans have been formulated for the building of railways in Alaska, most of them have not progressed very far. Interest in railway construction now largely centers in three provinces to be developed-(1) the Copper River basin and the Bering River coal field, (2) Kenai Peninsula and the Susitna and Matanuska basins, (3) the Yukon-Tanana region. Construction work is going on more or less actively in the first two, and various plans have been formulated for a railway to the third. As has been set forth at length ${ }^{a}$ elsewhere, there are three routes of approach to the provinces above indicated. One of these extends from southeastern Alaska, at Lynn Canal, along the inland front of the St. Elias Range and the Tanana Valley. $\Lambda$ preliminary survey has been run along a part of this route. The second line of approach is by way of the Copper River valley, where 100 miles of one railway has been completed and surveys made for several others. The third route is across Kenai Peninsula and up the Susitna and Matanuska; this line has been surveyed and about 70 miles of railway constructed. Much has been said and written about the control of these three "gateways" to Alaska and their relative value as lines of approach. In one sense they are competitive routes, but only if all three of the proposed railways are built through to the Tanana. For practical purposes, however, these lines will be noncompetitive, for it is not likely that all three will be built through so as to intersect. At least, the plea for competitive routes is not a present-day problem. What is needed is railway transportation to the Yukon basin, and then, if business develops, competitive lines may be built.

For the present a line to Copper River will develop one province; the one to the Matanuska and Susitna a second; and one of these or the line from southeastern Alaska the Tanana Valley. Within

a Brooks, Alfred H., Railway routes: Bull. U. S. Geol. Survey No. 284, 1906, pp. 10-17; Railway routes in Alaska: Nat. Geog. Mag., March, 1907, pp. 165-190; The mining industry: Bull. U. S. Geol. Survey No. 379, 1910, pp. 23-25. 
each province competition, if possible, would certainly be desirable by assuring low freight rates. It has been pointed out, however, that the visible tonnage hardly justifies the construction of one trunk line, let alone two. Nevertheless, surveys have been made for competitive lines in each of these provinces. There are three or four location surveys for railways into the Copper River basin, and many more for the development of the Bering River coal field. Competitive lines would, therefore, seem to be assured if the prospective business warrants the investment.

As stated before, actual railway construction work in 1909 was confined to two lines, namely, the Copper River and Northwestern Railway and the Alaska Northern Railway, formerly called the Alaska Central. The Copper River and Northwestern Railway ${ }^{a}$ is a standard-gage line running from Cordova, on Prince William Sound, to Kennicott, in the Chitina Valley. The total distance is 199 miles, of which 102 miles was completed March 25, 1910 . It is expected that the line will be built through to the Chitina by November, 1910. Three crossings of Copper River are made by this line, one at the head of the Delta (bridge completed), one between Childs and Miles glaciers (bridge completed), and a third at the mouth of the Chitina. 'The company reports that it has in contemplation the extension of the line to the Yukon basin, presumably through the pass at the head of Delta River. The distance from the crossing at the Chitina to Fairbanks is about 240 miles. The cost up to the present time has been about $\$ 10,000,000$, and the estimated cost of completion is $\$ 5,000,000$. Surveys have been made for a branch line from the lower Copper River crossing to the Bering River coal field. The route chosen for this branch line is 50 miles in length, with a maximum grade of 0.3 per cent, and the estimated cost is $\$ 2,000,000$.

The Alaska Central Railway, ${ }^{b}$ reorganized in 1909 under the name Alaska Northern Railway, is a standard-gage line projected from its coastal terminal at Seward, on Resurrection Bay, to Turnagain Arm, and thence to Knik, at the head of Cook Inlet (146 miles). The company reports that from this point the railway is to be extended through Broad Pass and on to Fairbanks (457 miles). From Knik a branch line (38 miles) is projected to the Matanuska coal field, with a total distance from Seward of 184 miles. These proposed routes have been surveyed. Plans for branch lines to the Kuskokwim and the Innoko have also been made, but it is not known that these lines have been surveyed yet. The distance from Knik to the Innoko district is about 270 miles. Seventy miles of the road from

\footnotetext{
a Data compiled chiefly from hearings held before the joint committee of Congress investigating the Department of the Interior and the Bureau of Forestry, vol. 3, 1910, pp. 2108-2370.

$\checkmark$ Data from hearings of joint committee, etc., vol. 5, 1910, pp. 3816-3820.
} 
Seward have been completed, bringing the track to the head of Turnagain Arm at a cost of about $\$ 5,000,000$. The company reports that between Seward and the coal field the maximum grade is 2.2 per cent and occurs at only one place. The first and second summits from the coast are reached from tide water at a grade of 2 per cent.

Besides these lines some preliminary work was done in 1909 on a railway from the mouth of Edwardes River, Controller Bay, to the Bering River coal field (27 miles). Surveys were also made of one line from Katalla and another from Kanak Island, both of which extend to the coal field. Apparently no work has been done for the proposed railway line from Valdez to the Chitina copper district, though some additional surveys were made. The project of a railway from Cook Inlet to Iliamna Lake and on to the Kuskokwim also appears not to have been pushed. Besides the projects and railways under construction, as noted above, the White Pass and Yukon Route from Skagway, the Tanana Valley Railway at Fairbanks, the Seward Peninsula Railway and the Council City and Solomon River Railway of Seward Peninsula, and the short line, known as the Yakutat Southern Railway, at Yakutat Bay were operated.

The following table presents the available data regarding the railways of the Territory:

Mileage and terminals of Alaska railways, December 31, 1909.

Southeastern Alaska:

White Pass and Yukon Route, Skagway to White Pass (narrow gage).

Terminal at White Horse, Yukon Territory. Total mileage, 102 miles.. 20.4

Yakutat Southern Railway, Yakutat to Situk River (narrow gage)...... $9 \pm$ Copper River:

Copper River and Northwestern Railway, Cordova to Tiekel (March 25, 1910) (standard gage) ................................... 102.0

(The same company has built a few miles of track at Katalla, where the Alaska Pacific Railway and Terminal Company has also done some work. At Valdez a few miles of track of the Alaska Home Railway were laid in 1907 , and some work was previously done on the Copper River and Northwestern Railway.)

Kenai Peninsula:

Alaska Northern Railway, Seward to a point near head of Turnagain Arm (April 16, 1910) (standard gage) .......................... 70.0 Yukon basin:

Tanana Valley Railway, Fairbanks and Chena to Chatanika (narrow gage).. 46.0 Seward Peninsula:

Seward Peninsula Railway, Nome to Shelton (narrow gage)........... 80.0

Paystreak branch Seward Peninsula Railway (narrow gage)...............

Council City and Solomon River Railway, Council to Penelope Creek

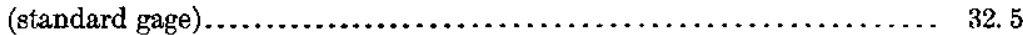

Wild Goose Railway, Council to Ophir Creek (narrow gage).......... 5.0 
Portions of railways in Seward Peninsula are out of repair and not in use.

The construction of railways emphasizes the need of supplementing them by wagon roads and trails. Much has been accomplished in the way of trail and road construction since the Alaska road commission was organized in 1905. At the close of $1909^{a} 720$ miles of wagon road, 421 miles of sled road, and 203 miles of trail had been built and 927 miles of trail had been staked. In addition to this, some trails had been built by private initiative. While some of the mining districts, like those of Nome and Fairbanks, have been rendered fairly accessible by wagon roads, ${ }^{b}$ in many others the conditions of travel are almost as primitive as ever. The total amount of road and trail construction is insignificant by comparison with what is urgently needed.

\section{METAL MINING.}

INTRODUCTION.

In 1909 , as in 1908 , about one-fifth of the gold production came from lode mines and four-fifths from placer mines. As the lode production is increasing far more rapidly than that of the placers, this ratio will not continue indefinitely, but there is no reason to believe that the ratios will change materially for several years. In the foIlowing table the metal production has been distributed as to source. As complete statistical data are not yet at hand, there may be an error of 5 or 10 per cent in these figures.

Sources of gold, silver, and copper in Alaska, 1909.

\begin{tabular}{|c|c|c|c|c|c|c|}
\hline & \multicolumn{2}{|c|}{ Gold. } & \multicolumn{2}{|c|}{ Silver. } & \multicolumn{2}{|c|}{ Copper. } \\
\hline & $\begin{array}{l}\text { Quantity } \\
\text { (fine } \\
\text { ounces). }\end{array}$ & Value. & $\begin{array}{l}\text { Quantity } \\
\text { (fine } \\
\text { ounces). }\end{array}$ & Value. & $\begin{array}{l}\text { Quantity } \\
\text { (pounds). }\end{array}$ & Value. \\
\hline \multirow[t]{2}{*}{$\begin{array}{l}\text { Siliceous orcs.. } \\
\text { Copper ores... } \\
\text { Placers............ }\end{array}$} & $\begin{array}{r}198,693.69 \\
1,6088.61 \\
789,576.76 \\
\end{array}$ & $\begin{array}{r}\$ 4,107,363 \\
33,253 \\
16,323,000 \\
\end{array}$ & $\begin{array}{l}30,118 \\
22,549 \\
74,239 \\
\end{array}$ & $\begin{array}{r}815,661 \\
1,170 \\
38,603\end{array}$ & $4,124,705$ & 8536,211 \\
\hline & $989,879.06$ & $20,463,616$ & 126,906 & $5 \overline{5}, 434$ & $4,124,705$ & 536,211 \\
\hline
\end{tabular}

Gold mining began in Alaska thirty years ago. Its gradual advancement until the first exploitation of the Nome placers in 1899 is reflected in the following table, which exhibits the annual metal production. A second great advance in production was made in 1905, when the Fairbanks district first yielded a large output of gold.

a Richardson, W. P., Annual report of the road commissioners for Alaska, 1909: H. R. Doc. 864, 61st Cong., $2 \mathrm{~d}$ sess.

It should be noted that these roads have been built in part by the funds derived from local taxes. 
The exploitation of the elevated beach lines at Nome and of rich creeks at Fairbanks again brought up the gold output in 1906, since which time it has fluctuated somewhat but has not varied greatly. An abortive attempt at copper mining was made on Prince of Wales Island as early as 1880 , but the systematic exploitation of copper deposits did not begin until 1901, when the Gladhaugh mine on Prince William Sound began shipping ore. The fluctuations in the copper output are due largely to variations in the value of the metal in different years. The silver production is practically all represented by the recovery incidental to mining placer and lode gold.

Production of gold, silver, and copper in Alaska, 1880-1909.

\begin{tabular}{|c|c|c|c|c|c|c|}
\hline \multirow[b]{2}{*}{ Year. } & \multicolumn{2}{|c|}{ Gold. } & \multicolumn{2}{|c|}{ Silver. } & \multicolumn{2}{|c|}{ Copper. } \\
\hline & $\begin{array}{l}\text { Quantity } \\
\text { (fine } \\
\text { ounces). }\end{array}$ & Value. & $\begin{array}{l}\text { Quantity } \\
\text { (fine } \\
\text { ounces). }\end{array}$ & $\begin{array}{l}\text { Commer- } \\
\text { cial value. }\end{array}$ & $\begin{array}{l}\text { Quantity } \\
\text { (pounds). }\end{array}$ & Value. \\
\hline 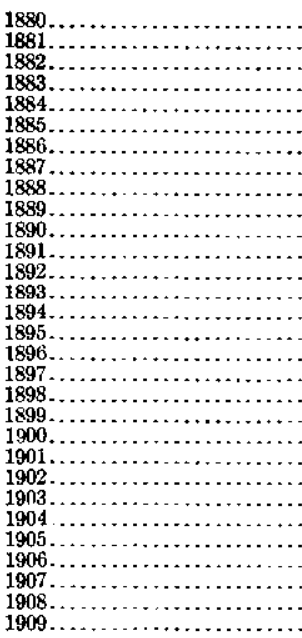 & $\begin{array}{r}968 \\
1,935 \\
7,256 \\
14,566 \\
9,728 \\
14,513 \\
21,575 \\
32,653 \\
41,119 \\
43,538 \\
36,862 \\
43,538 \\
52,245 \\
50,213 \\
61,927 \\
112,642 \\
138,401 \\
118,011 \\
121,760 \\
270,997 \\
395,030 \\
335,369 \\
400,709 \\
420,069 \\
443,115 \\
536,101 \\
1,066,030 \\
936,043 \\
933,290 \\
989,879\end{array}$ & $\begin{array}{r}\$ 20,000 \\
40,000 \\
150,000 \\
301,000 \\
201,000 \\
300,000 \\
446,000 \\
675,000 \\
850,000 \\
900,000 \\
762,000 \\
900,000 \\
1,080,000 \\
1,033,000 \\
1,282,000 \\
2,328,500 \\
2,861,000 \\
2,439,500 \\
2,517,000 \\
5,602,000 \\
8,166,000 \\
6,932,700 \\
8,283,400 \\
8,683,600 \\
9,160,400 \\
15,630,000 \\
22,036,794 \\
19,349,743 \\
19,232,818 \\
20,463,000\end{array}$ & $\begin{array}{r}2,320 \\
8,000 \\
7,500 \\
8,000 \\
8,000 \\
8,400 \\
22,261 \\
67,200 \\
145,300 \\
116,400 \\
92,400 \\
140,100 \\
73,300 \\
47,900 \\
92,000 \\
143,600 \\
198,700 \\
132,174 \\
203,500 \\
149,784 \\
135,672 \\
126,906\end{array}$ & $\begin{array}{r}\$ 11,146 \\
\\
\\
2,181 \\
7,490 \\
6,071 \\
7,920 \\
7,000 \\
6,570 \\
14,257 \\
44,222 \\
99,087 \\
70,741 \\
54,575 \\
84,276 \\
45,494 \\
28,598 \\
48,590 \\
77,843 \\
114,934 \\
80,165 \\
136,345 \\
98,857 \\
71,906 \\
65,991\end{array}$ & $\begin{array}{r}250,000 \\
360,000 \\
1,200,000 \\
2,043,586 \\
4,805,236 \\
5,871,811 \\
6,308,786 \\
4,585,362 \\
4,124,705\end{array}$ & 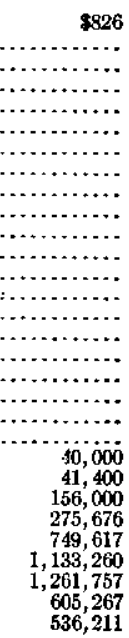 \\
\hline & $7,632,092$ & $162,686,455$ & $1,939,737$ & $1,184,259$ & $29,553,419$ & $4,800,014$ \\
\hline
\end{tabular}

In the following table the total gold production is distributed according to districts, so far as the information at hand will permit. The error in distribution is believed to be less than 10 per cent, and it is hoped in the future to eliminate it altogether. The production from the Pacific coast belt is for the most part from the lode mines of southeastern Alaska but includes also a small placer output, as well as the production from a lode mine on Unga Island. The gold credited to the Cook Inlet and Copper River region is, aside from the output of some small quartz mines in the Susitna basin and on Kenai Peninsula, all from placers and includes the yield of the Nizina, Chistochina, and Sunrise districts and of the productive creeks of the Susitna basin. 
The gold output from Seward Peninsula and the Yukon basin ${ }^{a}$ is nearly all from placers, though there was a small production from some lode prospects in Seward Peninsula and in the Fairbanks district.

Value of gold production of Alaska, with approximate distribution, 1880-1909.

\begin{tabular}{|c|c|c|c|c|c|}
\hline Year. & $\begin{array}{l}\text { Paciflo coast } \\
\text { belt. }\end{array}$ & $\begin{array}{l}\text { Copper } \\
\text { River and } \\
\text { Cook inlet } \\
\text { region. }\end{array}$ & Yukon basin. & $\begin{array}{c}\text { Beward Pe- } \\
\text { ninsula and } \\
\text { northwest- } \\
\text { ern Alaska. }\end{array}$ & Total. \\
\hline 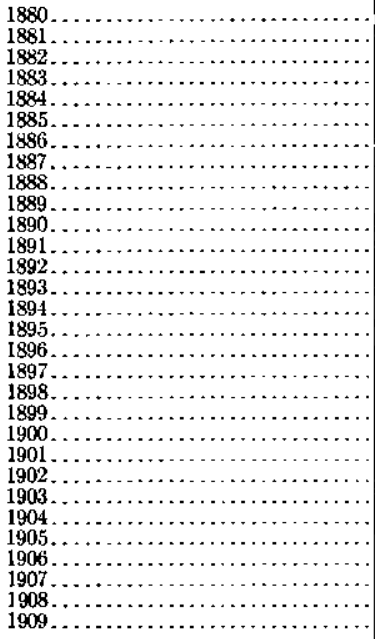 & $\begin{array}{r}320,000 \\
40,000 \\
150,000 \\
300,000 \\
200,000 \\
275,000 \\
416,000 \\
645,000 \\
815,000 \\
860,000 \\
712,000 \\
800,000 \\
970,000 \\
833,000 \\
882,000 \\
1,569,500 \\
1,941,000 \\
1,799,500 \\
1,892,000 \\
2,152,000 \\
2,606,000 \\
2,072,000 \\
2,546,600 \\
2,843,000 \\
3,195,800 \\
3,430,000 \\
3,454,794 \\
2,891,743 \\
3,448,318 \\
4,206,000\end{array}$ & $\begin{array}{r}350,000 \\
120,000 \\
175,000 \\
150,000 \\
150,000 \\
160,000 \\
180,000 \\
375,000 \\
375,000 \\
500,000 \\
500,000 \\
332,000 \\
275,000 \\
401,500 \\
375,000\end{array}$ & $\begin{array}{r}\$ 1,000 \\
1,000 \\
25,000 \\
30,000 \\
30,000 \\
35,000 \\
40,000 \\
50,000 \\
100,000 \\
110,000 \\
200,000 \\
400,000 \\
709,000 \\
800,000 \\
450,000 \\
400,000 \\
500,000 \\
650,000 \\
550,000 \\
800,000 \\
1,000,000 \\
1,300,000 \\
6,900,000 \\
10,750,000 \\
9,183,000 \\
10,323,000 \\
11,580,000\end{array}$ & 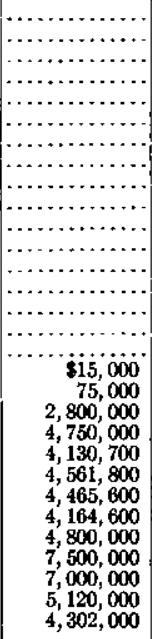 & $\begin{array}{r}\$ 20,000 \\
40,000 \\
150,000 \\
301,000 \\
201,000 \\
300,000 \\
446,000 \\
675,000 \\
850,000 \\
900,000 \\
762,000 \\
900,000 \\
1,080,000 \\
1,033,000 \\
1,282,000 \\
2,328,500 \\
2,861,000 \\
2,439,500 \\
2,517,000 \\
5,602,000 \\
8,166,000 \\
6,932,700 \\
8,283,400 \\
8,683,600 \\
9,160,400 \\
15,630,000 \\
22,036,794 \\
19,349,743 \\
19,292,818 \\
20,463,000\end{array}$ \\
\hline & $47,966,255$ & $4,118,500$ & $56,917,000$ & $53,684,700$ & $162,686,455$ \\
\hline
\end{tabular}

\section{LODES.}

Systematic auriferous lode mining in Alaska began with the opening of the Treadwell mine in 1882 , and since then this industry has made an output of $2,146,551$ fine ounces of gold, valued at $\$ 44,466,698$, and 968,518 fine ounces of silver, with a commercial value of $\$ 594,163$. The total copper production up to the close of 1909 was $29,553,419$ pounds, valued at $\$ 4,800,014$. There has also been a small production of tin, chiefly recovered from placers. Some tungsten and antimony have been produced incidentally to prospecting, and some lead has been recovered from Alaska ores. Other ores, such as magnetite, hematite, and chromite, are known to occur in the Territory but have not been developed on a productive basis.

The year 1909 witnessed a marked advance in the auriferous lode mining industry of the Territory, both in the output of the produc-

$a$ This refers, of course, only to the Alaskan parts of the Yukon basin and does not include the production of the Klondike and other Canadian camps. 
ing mines and in the development of new prospects. Alaska's auriferous lode mines produced during the year 198,693 fine ounces of gold, valued at $\$ 4,107,363$, as compared with an output of $162,411.08$ fine ounces, valued at $\$ 3,357,335$, in 1908 . The increased production came largely from the Juneau district, but new lode prospects were discovered in many parts of the Territory. Noteworthy among the lode developments are those of Fairbanks, of Kenai Peninsula near Seward, and of Willow Creek, in the Susitna basin. Some advance was also made in lode prospecting in Seward Peninsula and in the Chandalar and some of the other Yukon districts.

The development on but few of these newly discovered lodes has gone far enough to permit their being designated as mines. For this reason the number of productive gold lode mines is the same as in 1908, namely, 12. But in addition there are at least a score of prospects that are being systematically developed, some of which have made a small output.

The output of the auriferous lode mines in 1909 is estimated at $1,490,000$ short tons, as compared with 1,477,436 short tons in 1908 . The average value of the gold and silver recovered in 1909 is estimated at $\$ 2.78$ a ton. The low values reflect the domination of the output of the Treadwell group of mines in the total.

Copper mining was less active in 1909 , when seven properties were productive, as compared with nine properties in 1908 . This was due to the discouragement caused by the continued low price of copper. With the opening of the Bonanza mine and others in the Copper River region, together with some on the coast, a large increase in the annual copper production is to be expected within the next two years. In 1909 about 35,000 short tons of copper ore was hoisted, as compared with 51,509 tons in 1908 . The average copper content of the ore in 1909 was about 5.4 per cent, and the gold and silver values were about $\$ 1.15$ a ton.

Most of the important lode districts of Alaska are covered by special reports in this volume and need no discussion here. The region about Juneau continues to be the only important lode-gold producer, but there is every reason to believe that the auriferous lodes of Berners Bay region will soon make a large output. Prince William Sound is known chiefly as a copper producer, yet some promising gold-bearing lodes have been found near its shores. Several of these are being systematically prospected, and at one, near Valdez, a small stamp mill has been installed. A number of auriferous lodes are being systematically developed on Kenai Peninsula, near the town of Seward. The Apollo mine, on Unga Island, has been operated throughout the year, and other properties in the vicinity are being carefully prospected, 
Much work was done on the auriferous quartz veins of the Willow Creek region. Unfortunately, it has been impossible so far for the Survey to investigate these deposits, but the following notes are based on data that are believed to be reliable.

The district lies about 30 miles north of Knik, which is accessible by steamer and with which it is connected by horse trail. According to Paige and Knopf, ${ }^{a}$ Willow Creek follows the contact between a quartz diorite and granite mass on the north and a belt of garnetiferous mica schists and chlorite-albite schist on the south. The placer gold of this district, according to the same authors, ${ }^{b}$ is derived from quartz stringers in the schists. Since they made their examination some auriferous quartz veins have been found in this district, and these are reported to occur chiefly in the granite. This occurrence may be due to the fact that the deformation of the region might open well-defined fissures in the massive granite, while in the schist the stream would produce zones of shattered rock. There is not evidence enough in hand to make a definite statement, but it appears that the placer gold has been derived from the schists, while the gold-quartz veins that have been opened occur chiefly in the granite. The quartz veins carry free gold, iron, arsenopyrite, and possibly chalcopyrite. High gold values, but only very low silver values, are reported. In one deposit free-milling gold quartz was found at the surface and to a depth of 50 feet, where the lode gradually became refractory.

Four companies are said to be doing systematic work in this district. The Gold Bullion Mining Company has a property on Cragie Creek, a northerly tributary of Willow Creek. So far only open-cut mining has been done; but this work, according to W. E. Bertholf, the manager, has uncovered a vein that varies from 18 inches to 5 feet in width and has been traced through several claims. A 2-stamp mill, installed in 1908, was operated for about three weeks in 1909 with favorable returns.

The Alaska Gold Quartz Mining Company has a property on Fishhook Creek, a tributary of the Little Susitna. According to J. S. Carle, the manager, the vein has been followed by an adit tunnel for 140 feet, with a width of 2 to 5 feet. A 3-stamp mill was installed in the summer of 1909 and operated for a part of the season. At 50 feet from the mouth of the tunnel the vein changed from freemilling to base ore, and operations were suspended until a concentrating table could be installed.

The Brooklyn Development Company also has a property in the same district. In the fall of 1909 contracts were let by this com-

a Paige, Sidney, and Knopl, Adolph, Geologic reconnaissance in the Matanuska and Talkeetna basinc, Alaska: Bull. U. S. Geol. Survey No. 327, 1907, p. 10.

o Idem, p. 66 . 
pany to drive a 100-foot tunnel, and a 2-stamp mill was brought to Knik, which will be taken to the claim during the winter. No details were learned regarding the Gold Top Mining Company.

In addition to the work noted above, considerable prospecting was done in the Willow Creek district and in the adjacent regions. Both quartz and copper lodes are reported at various places. This preliminary work on the Willow Creek quartz veins led to a gold production of the value of about $\$ 25,000$, which is a remarkably good record in view of the fact that milling was limited to only a few weeks.

The most important development of auriferous lode mining in the Yukon basin is that of the Fairbanks district. Some promising gold-bearing quartz veins have also been found in the Chandalar district, but not much work has been done on these.

Much interest was excited among mining men by the discovery of auriferous lodes near the northern base of the Alaska Range and in the Bonnifield placer district. These lodes lie about 40 miles south of Fairbanks and can be reached by a direct trail during the winter. In summer they are accessible only by long horse trails, via either the Little Delta or the Nenana. Little information is available regarding this region, as it has not been surveyed. From the reports at hand it appears that there are two types of deposits; to the one belong the auriferous quartz veins of the region, to the other the mineralized zones in a sheared and much altered rhyolite. Only one deposit of the latter type has been reported. This, the Jerome ledge, oceurs on Chute Creek, a tributary of Wood River. It is stated that a mineralized belt of rhyolite has been found which has a width of 250 feet and can be traced a long distance. This is said to carry gold values. Through the courtesy of Mr. R. M: Crawford the writer was able to examine a specimen of this ledge. It is a bluish rock, in which small vitreous quartz and feldspar crystals can be seen. The rock is impregnated throughout by iron pyrite, which probably carries the gold. There is no evidence of secondary quartz veins in the rock, the pyrite being the only evidence of mineralization. The owners report assays of $\$ 5$ in free gold, $\$ 4$ in concentrates. Some very high values have also been found in the rock. A very unpromising looking fragment of rock said to come from this deposit was assayed for the writer by Ledoux $\&$ Co., who reported $\$ 1.03$ in gold and a trace of silver.

The Jerome ledge is well exposed and, the owners claim, has been carefully sampled, with the results given above. An adit tunnel has been driven for some distance and the material passed through a small prospecting mill. If the deposit is as large as reported, it ought to be possible to develop it in spite of its comparatively low values and its difficulty of access. Altered rhyolite of this type has been seen by the writer on Nenana River and appears, there- 
fore, to be widely distributed. If the Jerome ledge proves to be a valuable deposit, other similar rocks of the region should be examined by the prospector. Auriferous quartz veins carrying other metals have also been reported from the Bonnifield district.

The reported development of two ore bodies carrying gold values in the Klondike district near Dawson is a significant fact for the lode miners of the Alaska Yukon. These deposits have been recently described ${ }^{a}$ as follows:

The workings (Lone Star mine) are situated at the head of Victoria Gulch, a tributary of Bonanza Creek. Victoria Gulch is the upstream end of the placer gold on Bonanza Creek, and as the gulch is rich in gold from its mouth to its source it is generally believed that the Lone Star vein was an important aource of the supply of placer gold on Bonanza and on Eldorado creeks. An extension of the lode cuts the latter creek well up toward the end of discovered pay.

The lode was located nine or ten years ago and has always been considered valuable, but unfortunately litigation has prevented its development. The deposit has been described by R. G. McConnell, of the Canadian Geological Survey, as a stockwork paralleling a fissure vein. The hanging wall consists of contorted schist, and the apparent foot wall is made up of solid gray schist, possibly an altered porphyry. Lying next to the foot wall is a lode of quartz 4 feet wide. Between this and the hanging wall there is a body of blue clay fully 10 feet wide on the surface, containing a large percentage of iron pyrite of undetermined value. The trend of the lode is north and south. The stockwork before mentioned is crosscut by this fissure at an angle of about $45^{\circ}$, showing the fissure to be a newer deposit. It consists of contorted ribbon rock containing a fair amount of gold and dips slightly toward the hanging wall of the fissure. This older deposit has been traced for a distance of 400 fect in length; its width has not been determined. An open cut has been run on this deposit at a depth of 20 feet along its general course. This cut shows a stockwork of schist and quartz veins more or less parallel. The trend is southeast. The north and south fissure has been definitely traced for a distance of 1,500 feet. For this distance it carries its width of 4 feet. The clay is also found to continue and maintain its character for this distance. The vein for its whole determined length shows free gold which may be obtained by panning. Twenty tons crushed some years ago as a test gave $\$ 407$ gold, and the many samples taken would indicate its value to be from $\$ 17.50$ to $\$ 20$ per ton free gold. Whatever gold is contained in the concentrate must be added to this. The clay carries small amounts of free gold. The pyrite, of which there is a large percentage, has not yet been properly tested but is known to be valuable.

Two shafts, one 40 and the other 50 feet deep, have been sunk on the vein. These show the ore to be of the same width, character, and value as on the surface. An adit has also been started at a point which will tap the lode at a depth of 100 feet, in a distance of 210 feet; this will be used as a drain for the first level and also for taking out the rock. Toward the end of the season a mill run of 410 hours was made on rock from the stockwork or older deposit, 100 tons of unselected rock being crushed, returning $\$ 1,334$. During the last thirty hours of this run an amalgam trap was used, recovering $3 \frac{1}{2}$ ounces of amalgam, leading those in charge to believe gold has been lost before.

The equipment consists of a 2-stamp Hendy mill placed 200 feet below the level of the open cut and about 300 feet distant, a Challenge ore feeder, Blake crusher and ore bins, 30-horsepower steam boiler, and 20-horsepower horizontal engine, a dynamo and all necessary tools, 3,000 feet of rails, a gravity tram, and self-dumping cars which discharge directly into the ore bins. All necessary buildings have been put up in a sub-

a Lewington, Guy A. R., Quartz mining in the Yukon Territory: Min, and Sci. Press, January 1, 1910, p. 65 . 
stantial manner. It is expected that the mill will be enlarged just as soon as the ore body has been definitely traced and its value established. The small plant now at work will keep development going.

Development work is also well under way on the property of the Dome Quartz Mining Company. This mine is situated on a divide between Lombard and Dominion creeks and is owned principally by Hartman \& Davidson. During the latter part of last winter an adit was started for the purpose of cutting the lodes, of which there are five, at a depth of 600 feet below the outcrop. This adit has always seemed an ill-advised undertaking, on account of the risk and cost. However, nothing succeeds like success. It is now in about 1,000 feet and has tapped two of the veins, which are found to show their full width and value. The other three veins, it is hoped, will be crosscut some time next year. This will require about 500 feet of additional driving. The property is generally believed to be of value. The crosscutting of two lodes at a depth of 600 feet and the finding of 3 feet of ore in each vein with gold that will certainly pay places the property in a most enviable position and is a matter of great satisfaction to all concerned.

The Klondike placer district lies in the eastern extension of the Yukon-Tanana region. So far as known the geologic conditions of the Klondike repeat themselves in the various placer districts of the Yukon-Tanana region. For this reason the definite proof of the occurrence of workable auriferous lodes in the Klondike district points to the conclusion that similar discoveries will be made in the Alaska part of the belt.

But little progress was made in lode mining on Seward Peninsula during 1909. The Hurrah quartz mine was idle during the year, but as the ownership of the property has changed, it seems probable that it will soon again be operated. Some development work was done on the Alaska Chief, a galena deposit located on Lost River. Work was continued at a number of auriferous lode prospects, notably the McAllister, at the head of Nome River. It is reported that systematic work was also done on an auriferous lode prospect near Bluff and on the Slisco antimony property on Hobson Creek. Though the excitement of a few years ago, caused by the discovery at several localities of gold-bearing quartz, has died down, considerable lode prospecting is still going on.

While the low price of copper did not encourage extensive mining of this metal, yet a number of copper mines were operated throughout the year, and in the aggregate considerable development work on copper properties was accomplished. The most important fact bearing on the industry was the continuation of work on the railway which will open the Chitina copper district. As the accompanying reports cover the advancement in all the more important districts-southeastern Alaska, Prince William Sound, and the Chitina region-it will not be necessary here to consider the copper-mining industry at length. In southeastern Alaska one new mine, the Goodro, was put on a productive basis in 1909, and three others-the It, the Mount Andrew, and the Jumbo-were operated throughout the year. Dead 
work was also done on a number of other properties in this district. In Prince William Sound the Bonanza continued its heavy shipments throughout the year. The Standard and Gladhaugh were also productive, and other deposits were systematically developed. Work also continued on a score of properties in various parts of Alaska, including the Nabesna-White River region, Kenai Peninsula, Iliamna Lake, and Seward Peninsula.

\section{TIN.}

Though the output of tin was small, ${ }^{a}$ considerable prospecting was done. Some activity was manifested in the tin region of western Seward Peninsula during the summer of 1909. On Cape Mountain the United States Alaska Tin Mining Company employed a crew of six men, and the tunnel, which at a depth of 266 feet is planned to undercut a quartz vein exposed on the surface, striking $\mathrm{N} .45^{\circ} \mathrm{W}$. (magnetic) and dipping $80^{\circ} \mathrm{N}$., has now been driven approximately 450 feet through hard, solid granite. If the ledge maintains the dip shown in the outcrop, the tunnel must intersect the ore body within a short distance and will afford information as to the character of the vein at this deptl, which will be the greatest yet attained in the entire tin region. On the Bartells property the operations of the season were restricted to the accomplishment of the annual assessment work. The mineral claims of the two companies mentioned above were surveyed for patent during the summer. Some productive work was done on the placer deposits of Buck Creek. At Lost River the main efforts of the season were devoted to the recovery of stream tin occurring on Cassiterite Creek in the vicinity of the tin-bearing dikes. On Brooks Mountain development work was continued on the contactmetamorphic deposits, one of which is known to be stanniferous to some extent, and encouraging results are reported. Stream tin has been reported from a number of creeks in the Yukon basin, and considerable tin is reported in the placers on Sullivan Creek, in the Hot Springs district. On Deadwood Creek, in the Birch Creek district, stream tin occurs in association with wolframite.

\section{GOLD PLACERS.}

\section{INTRODUCTION.}

The placer-gold production of Alaska for 1909 is estimated at $\$ 16,322,000$, as compared with $\$ 15,888,000$ in 1908 . This increase must be credited in great part to districts of the Yukon basin, nearly all of which had a larger production in 1909 than in 1908. On the other hand, the dry weather led to a marked falling off in the placergold output in some other districts. 
Perhaps the most significant fact of the year's operations is the continued activity in installing dredging enterprises. Five dredges were operated in Seward Peninsula throughout the open season, and six more were completed in time to do some work, making eleven dredges, small and large, which were in use during 1909. The results of these enterprises have encouraged many to take up this form of mining, and plans for severgl more dredges have been made. Three dredges were operated in the Fortymile district. Plans were also formulated for dredges at Fairbanks. Some examinations have been made for a dredge on Kenai Peninsula.

The results of the dredging operations at Dawson are of interest to the Alaska mines, as they indicate something of the cost of large enterprises in the Yukon basin. The annual report of the Yukon Gold Company ${ }^{a}$ contains this statement in regard to the dredging operations:

The Yukon country, in 1909, experienced a late spring with a correspondingly late opening of the navigation and mining operations. The seven dredges, the last of which was completed late in 1908, started as early as power was available. The last dredge began operation on June 9, 1909. The dredging season for six out of the seven dredges was $132 \frac{1}{2}$ days as against a normal season of 140 days. The running time of one dredge, No. 5, was curtailed on account of local conditions. The dredges during the season handled $2,381,880$ cubic yards and produced $\$ 1,363,722$ worth of gold. The value per cubic yard was 57.24 cents and the cost 31.94 cents per cubic yard. This cost includes all thawing charges-amounting to 15.45 cents per yard-preliminary stripping operations, and depreciation at the rate of $\$ 2,000$ per month per dredge. As an example of what may be expected in ground entirely thawed, the No. 1 dredge handled in the month of August 100,217 yards at a cost of 9.28 cents per yard.

$\mathrm{It}$ is worthy of note that the actual value per yard of material handled exceeded the estimated value based on examination results by 16.8 per cent. The cost per yard was 6 per cent higher than the estimated cost for the season, but it is less than the estimated average cost for handling the creek deposit by 8.6 per cent. The dredges operated 83.5 per cent of the possible running time.

Less definite data are available regarding the cost of dredging in other parts of this northern field. On Seward Peninsula only unfrozen ground has been dredged, the cost per cubic yard, including overhead charges, being placed at 18 cents. In a region where fuel is so expensive as in Seward Peninsula (coal costs $\$ 20$ a ton) it is not likely that mining men will be encouraged to attempt the thawing of ground for dredging. In parts of the Yukon basin, with a considerable supply of wood and an abundance of lignitic coal, it seems economically possible to dredge frozen ground; at least this method of handling the gravels is being seriously considered. It should be remembered that gravels which run less than, say, $\$ 2$ to the yard can not be mined under present conditions, while such values would be regarded as extraordinarily high in dredging ground.

a Eng. and Min. Jour., March 19, 1910, pp. 602-603. 
SUMMARY OF PLACER MINING BY LOCALITIES.

PACIFIC COAST REgION.

For the purposes of this discussion the Pacific coast region will be made to include not only the seaboard but also the drainage basins tributary to it, including the Copper and Susitna. The placers of this province are estimated to have had in 1909 an output valued at $\$ 490,000$, as compared with $\$ 450,000$ in 1908 .

Southeastern Alaska.-Placer mining was carried on during 1909 in the Porcupine district and on Gold Creek in the Juneau district. In the former district the Porcupine Gold Mining Company completed a bed-rock flume nearly 2,000 feet long, and installed a trolley lift with buckets of $2 \frac{1}{2}$ cubic feet capacity and with automatic dump. The plant installed provides for the piping of the gravels into the buckets at bed rock and lifting them to a hopper that discharges into the sluice boxes. This plant was not finally completed until late in the season, but was then operated. Some smaller operations also were carried on in the district.

Beach mining.-As in previous years there was more or less beach mining along the Pacific shore between Yakutat and Unga Island. This is all done by men working with rockers or small string boxes. The recovery of gold is in many places dependent on weather conditions, for the operations are most profitable after a heavy surf has concentrated the gold in the surface layer of sand. The most important center for this form of mining is at Yakataga, near Controller Bay. Though it is impossible to procure accurate statistics, the entire production of the Pacific seaboard is probably not over $\$ 25,000$ in value.

Copper River region.-The Copper River region includes two placer districts. One of them, the Nizina district, in the upper Chitina, is described by F. H. Moffit in this volume. The Chistochina district, sometimes known as the Chisna, is in the northern part of the Copper basin. It is one of the most inaccessible of the Alaska placer camps, being reached now only by trail from Valdez, a distance of about 250 miles. Winter freight rates have been about $\$ 500$ a ton. Because of these costs it has been possible to exploit only the richest gravels. As a consequence the camp has not attracted many miners. Conditions are improving, both because of the construction of the wagon road to Fairbanks, the route of which passes within 25 miles of the camp, and because of the building of the Copper River and Northwestern Railway, transportation over which will avoid the cost and delays of hauling freight over the Valdez summit. The improvement in the trail has already brought freight rates down to $\$ 300$ a ton. 
It is reported that 24 claims were worked in this district by about 100 men in 1909 , and the total production is estimated to have a value of $\$ 112,000$. Considerable prospecting of bench claims on the lower Chisna was carried on. Some work was also done on a ditch to bring water to these bench claims and on a tunnel intended to tap an old channel on Daisy Creck. As in previous years, most of the gold was taken from Slate and Miller creeks.

Sunrise district.-The placers of the northern part of Kenai Peninsula included in the Sunrise district are being worked, but the gold output is small. Bear, Resurrection, and Canyon creeks are the largest producers. This district is rendered easily accessible by the Alaska Northern Railway, supplemented by a wagon road which has been built by the road commission from Trail Lake to Sunrise and Hope. In view of these facilities, mining costs should be low. A number of plans are being considered for the installation of hydraulic and dredging plants. Because of the presence of large glacial bowlders in many of the gravels, the hydraulic method would appear to commend itself more than dredging. It is possible, however, that the gravels of some of the streams may not contain enough bowlders to seriously interfere with dredging, but it would seem desirable that careful prospecting with a drill be done to determine the character of the material before a dredge is installed.

Cook Inlet.- So far as known the only prospecting in the Cook Inlet region during 1909 was that done on Beluga River. Fine gold has long been known to occur in the alluvium of this stream. In 1902 an attempt was made to mine it with the aid of a hydraulic plant, but this was soon abandoned. Operations in 1909 consisted in prospecting for dredging ground, but the results are not available for publication. This is one of the fields where large glacial bowlders are likely to be found in the alluvium, a fact which should be taken into account in the choice of a method of mining.

Susitna basin.-The Susitna basin can be divided geographically into three districts-Willow Creek, Yentna, and Valdez Creek. The lode deposits of Willow Creek, the center of interest to the miners and prospectors, have already been described. (See p. 35.) There was also some placer mining, notably on Grubstake Gulch, where the hydraulic plant of the Klondike Boston Mining Company is located. The water supply, which is reported to have been abnormally low, is said to have permitted the plant to run for only fortyseven days during the season. One giant is said to have been used.

Some prospecting was done on Metal Creek, a tributary of Knik River. The results are said to have been encouraging and plans for further development have been made.

Valdez Creek is a tributary of the upper Susitna, being about 160 miles by trail from Valdez. Its isolation has made mining costs very 
high. Winter freight rates are $\$ 600$ to $\$ 700$ a ton, while the cost of transportation by pack horse in summer, either from the mouth of Indian Creek, which can be reached by boat up the Susitna, or from Gulkana, on the Copper, is $\$ 2,000$ a ton. In 1909 about 100 men were working in this district on about ten claims, and the gold output has a value between $\$ 50,000$ and $\$ 75,000$. The gravels are thawed, which increases the cost of mining.

The Yentna basin is the most prosperous of the Susitna districts. Winter freight rates from Susitna River are about $\$ 200$ a ton. There were between 120 and 150 miners in this district in 1909, and the gold output is valued at $\$ 100,000$ to $\$ 120,000$. The productive placers occur in two districts. One includes Cache and Peters creeks and their tributaries and the other includes Wagner Creek and some other tributaries of Lake Creek. Plans have been made for installing several hydraulic plants in this district in 1910. There is much auriferous gravel in which the values are too low to permit profitable exploitation by hand methods.

\section{YUEON BASIN.}

General statement.-The Alaska Yukon placer districts had in 1909 the most profitable season since mining first began there, nearly a quarter of a century ago. The estimated value of the gold output is $\$ 11,580,000$, as compared with $\$ 10,323,000$ in 1908 . Progress in mining in most of the important camps of the Yukon is covered by the reports of Mr. Ellsworth and Mr. Maddren in this volume and will need no detailed description here. It is of interest to note that the gold output of the Klondike, in Canada, which had rapidly declined in the last few years, showed a decided increase in 1909 . It is to be expected that all the Alaska camps will eventually pass through the same history-first a very large production, when the richest placers are worked, then a gradual decline, until the introduction of large plants revives mining activity.

While practically all the Alaska Yukon camps made an increased production in 1909 as compared with the previous year, those of the Tanana Valley were the most prosperous. The various districts tributary to the lower Tanana are estimated to have produced gold to the value of over $\$ 10,150,000$. Of this, Fairbanks made an output estimated at $\$ 9,650,000$, as compared with $\$ 9,200,000$ in 1908 . The general prosperity is also indicated by the value of the merchandise shipped to the Tanana Valley from the United States, which was $\$ 2,637,476$ during the fiscal year ending June 30,1909, as compared with a total of $\$ 2,040,628$ for the previous fiscal year.

In spite of this evident prosperity, it can not be denied that the time is rapidly approaching when the gold production of the Fairbanks district will decline unless some radical changes are made in 
mining methods. So far as present methods of exploitation are concerned, many of the richest creeks are nearly worked out. Little appears to have been accomplished in the matter of preparing to mine the gravels of lower gold tenor, though some plans for dredges are under way. Meanwhile, much enterprise has been turned toward the search for auriferous veins, which should yield results assuring permanency to the camp. A lode-mining industry, however, is not likely to develop fast enough to make up for the decreased production of the placers. The Fairbanks miners cculd well follow the lead of those of the Fortymile district, where three large plants are holding up the gold output in spite of the decrease in small operations.

The Haiditarod excitement has hurt the Fairbanks district by drawing away some of the most enterprising operators and also a large percentage of its mine labor. This may lead to a falling off of the gold output in 1910 .

Probably the most important feature of the year's mining industry in the Yukon is the general drift to the Innoko region, for there is in every camp a large class of restless prospectors who are ready for a venture in a new field. The continued increase in gold production of the Koyukuk is worthy of note, though the high costs of operating have prevented a proportionately prosperous community. The continued success of the dredges in the Fortymile district has already been referred to as an important feature of the year's mining.

Bonnifield district. - Considerable more work was done in the Bonnifield district in 1909 than in any previous year. This work in part consisted of mining, but more important were the steps taken to install a large hydraulic plant on Gold King Creek, where there is said to be a large body of auriferous gravels. As a preliminary to this installation a winter sled road was cut through from Fairbanks, a distance of about 40 miles. Considerable work was also accomplished in installation of the plant, which it is expected will be ready for operating in 1910. The gold values of the gravels are said to be low, but there is reported to be ample water for a hydraulic plant. Gold King, Grubstake, and Platt creeks are the chief gold producers of the district. The total gold output in 1909 is estimated to have a value of over $\$ 50,000$.

Kantishna district.-There appears to have been but little mining in the Kantishna district during 1909. The gold output, all of which came from a few small operators, is unknown but probably did not exceed a few thousand dollars in value.

Gold Hill district.-There was renewed activity in the Gold Hill district during 1909. Productive mining appears to have been confined to Mason and Grant creeks, but good prospects were also reported on other streams. In the fall of 1909 twelve claims were being opened on Grant Creek, and the results will probably indicate 
definitely whether the gravels carry values. Placer gold has long been known to occur in this district, ${ }^{a}$ but it has never been carefully prospected.

Innoko district. ${ }^{b}$ - A new movement of population into the Innoko district was brought about by the discovery of gold placers on Otter Creek, a northerly tributary of Haiditarod River, which drains the southern part of the field. Thousands of prospectors and miners flocked into this field during 1909 from all parts of Alaska as well as from points outside of the Territory. The movement promises to become one of the important ones in the history of Alaska. To judge from the best information available, the discovery on Otter Creek does not, in point of either value or extent of deposits, warrant this large influx of prospectors. At the same time it also appears to be true that auriferous gravels are distributed over-a considerable area and that gold in quantities sufficient for profitable exploitation has been found in several widely separated localities. It is probably safe to say that although the district may not be able to support the extensive population it has recently acquired, yet it certainly offers a promising field for the prospector.

High freight rates, absence of trails, and lack of established centers of distribution continue to make the cost of mining and prospecting very high. Travel in summer is chiefly by steamer and small boat up the Innoko from the Yukon. Winter travel is from Kaltag on the Yukon, but some have made the long trip from Cook Inlet through the Alaska Range at Rainy Pass, a distance of about 325 miles. The Kuskokwim route has been little used, chiefly because the mouth of the river is uncharted. The Haiditarod basin has not been visited by any member of the Geological Survey. It is reported that the discovery on Otter Creek consisted in finding a bed of gravel 4 feet thick and 50 to 60 feet wide which carried 7 to 10 cents to the pan. The gold is said to be fairly fine, of a uniform size, and evenly distributed. Most of the gold in 1909 was taken from Gaines and Ophir creeks. The value of the aggregate output of the year is unknown but is variously estimated at $\$ 300,000$ to $\$ 400,000$; that of the 1908 output was less than $\$ 100,000$.

The reports from the Innoko during the last year have been so conflicting that it is impossible to form any just estimate of the actual condition of the mining industry. On the one hand, many have left the new camp, discouraged at the outlook, but on the other, many experienced miners have remained in the country and expressed entire confidence in its future importance. Another year should yield more definite information. A survey of the Innoko district is to be made by the Geological Survey in 1910 .

a Maddren, A. G., The Innoko goldl-placer district, Alaskis: Bull. U. S. Geol. Survey No. 410, 1910, pp. 81-83.

b Maddren, A. G., op. cis. 


\section{KUSKOKWIM BASIN.}

The movement of prospectors brought about first by the discovery of the Kantishna and later by that of the Innoko has led to considerable prospecting in the Kuskokwim basin. Though both placer and lode gold have been reported from many localities, so far as known the only productive mining has been on Tuluksak River, a tributary of the lower Kuskokwim. A few claims in this district were operated in 1908, and it is reported that about 20 men were at work on this stream in 1909 . Good prospects are also reported on the Takotna, a tributary of the Kuskokwim, which heads against the Innoko. In 1908 some good prospects were found on tributaries of Hartman River, which forms a part of the drainage of the south fork of the Kuskokwim. It was estimated that the deposits would yield $\$ 8$ a day to the man, a recovery which, in view of the isolation of the region, hardly justified operations. If a trail were built from Knik to the Innoko, it would pass through this district.

\section{NORTHWESTERN ALASKA.}

Northwestern Alaska, as the term is here used, embraces the placers of the Norton Bay region, Seward Peninsula, and the Kobuk basin. The mining progress in the first two is treated in separate articles in this volume.

With the exception of operations on a few productive claims on Bonanza Creek (Norton Bay) and on some in the Kobuk Valley, all the gold mining of northwestern Alaska is confined to Seward Peninsula. As has been indicated, productive mining on the peninsula received a setback in 1909 as compared with 1908 . On the other hand, considerable dead work was accomplished preparatory to the installation of dredges. In the development of dredging enterprises the Seward Peninsula operators have made more progress than those in any other part of Alaska, and notably so in 1909. It is an open question whether the gold output will again attain the maximum of previous years, and certainly not for some time to come; but the peninsula should with the installation of the dredges now planned, which will make 12 or 15 in all, enter upon an era of steady prosperity. It is not to be expected that such a dry season as that of 1909, which was the chief reason for the decreased gold output, will recur for several years. The fact can not be denied, however, that the records for four years indicate that low-water conditions are normal and high-water conditions abnormal, and that the methods of mining will have to be adjusted to this fact.

The Kobuk Valley continues to support a small placer-mining population. In 1909 claims were worked by 16 men, with a total value of output of about $\$ 16,000$. 'Dahl Creek was the largest producer and Shingnek Creek second; some gold was taken out of Riley Creek. The sluicing season in 1909 was very short, as there was no water after August 1, a fact which materially reduced the production. 


\title{
ALASKA COAL AND ITS UTILIZATION.
}

\author{
By Alfred H. Brooks.
}

\section{INTRODUCTION.}

It is the purpose of this article to present a brief description of the Alaska coal fields and to discuss their availability as a source of fuel and the possible market for their output. Almost all the data used in this compilation are taken from the reports of the Geological Survey. A full list of these publications is appended (pp. 95-100), but it does not seem best to give a specific reference for each statement of fact. It will suffice to state that the writer's own field work in the coal fields has been very slight, and hence the descriptive matter here included must be credited to the many geologists who have investigated Alaska coal resources. Special acknowledgement should, however, be made to George C. Martin, whose reports ${ }^{a}$ have been very freely drawn upon in the preparation of this paper. Mr. Martin has not only personally investigated the two most important fields, but has prepared summary statements of the fuel resources of all Alaska and has discussed the question of markets.

\section{GEOLOGIC DISTRIBUTION OF COAL.}

The geologic age and sequence of the several coal-bearing formations have not been very definitely determined. Detailed surveys have been made only in the Bering River field, where the structure is so complex that the results are far from conclusive. It seems, however, to be pretty well established that nearly all the coals which are of present commercial importance are of Tertiary age, and that a large part belong to the Kenai formation (Eocene).

The oldest coals known in Alaska are some which are of a highgrade bituminous character and occur near and south of Cape Lisburne, on the Arctic Ocean. These are contained in a formation of Mississippian (lower Carboniferous) age, made up of slates and limestones. On the upper Yukon is a series of conglomerates, sandstones,

a Martin, G. C., Markets for Alaska coal: Buli. U. S. Geol. Survey No. 284, 1906, pp. 18-29; Preliminary report on the Matanuska coal field: Bull. U. S. Geol. Survey No. 289, 1906; The A laska coal fields: Bull. U. S. Geol. Survey No. 314, 1907, pp. 40-46; The geology and mineral resources of the Contraller Bay region: Bull. U. S. Geol. Survey No. 335, 1908. 
and shales (Nation River formation) which carries some thin beds of bituminous coals. This formation is Carboniferous and has been provisionally assigned to the Pennsylvanian epoch. The next higher coal-bearing beds are in the Corwin formation, which occurs about 20 miles east of Cape Lisburne. This formation is made up of shales, sandstones, and conglomerates and includes a large number of beds of subbituminous coal. It has been referred to the Jurassic period. A coal-bearing formation of about the same age has been recognized in the Matanuska Valley, northeast of Cook Inlet, but no Jurassic coals are known elsewhere in Alaska. Upper Cretaceous coals have been found in southeastern Alaska, on the Alaska Peninsula, on the lower Yukon, and in the Colville River basin. Except in southeastern Alaska, where only lignite has been found, the Cretaceous coals are chiefly bituminous. Lithologically the Upper Cretaceous rocks vary in different localities, but as a rule they are composed predominatingly of the finer clastic material and limestones.

The Kenai formation (Eocene) is by far the most important of the coal measures. It has been found in large and small areas almost throughout Alaska and nearly everywhere carries some coal. It is typically made up of coarse and fine clastic material, locally with a large percentage of conglomerate. Much of the Kenai can be definitely recognized as of fluviatile origin, and in many places it carries a fresh-water flora. Only on the Alaska Peninsula have marine fossils been found in the formation, and here they are intimately intermingled with plant remains. Much the larger part of the Kenai coal is lignitic, but the high-grade coal of the Matanuska field and possibly part of that of the Bering River field are also of Kenai age. The Bering River coal may be in part of Miocene age; if so, it is the only Miocene coal recognized in Alaska. Some thin beds of lignitic coal that have been found at Yakutat Bay and at various places in the Yukon basin are probably of Pliocene, possibly of Pleistocene age.

The geologic positions of the Alaska coals are summarized in the subjoined table:

Stratigraphic position of Alaska coals.

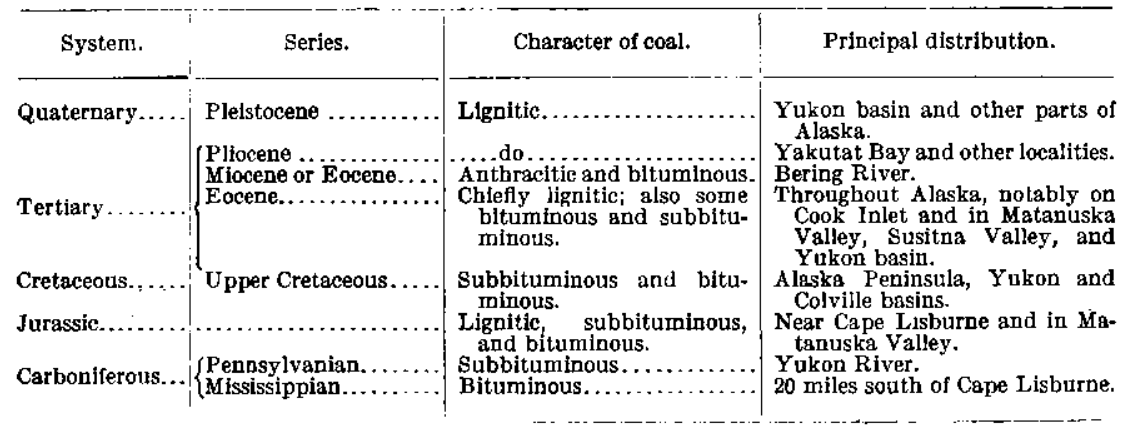




\section{COMPOSITION OF COAL.}

About one-half of the known tonnage of Alaska coal is lignite (see table, p. 54), a little over one-fifth is anthracite and high-grade bituminous coal, and the rest falls into the bituminous and subbituminous classes. It is fair to assume that these ratios will hold for the coals of the areas on which no tonnage estimates are possible.

The anthracite of the Bering River and Matanuska fields is but little below that of Pennsylvania in composition. To judge from the amount of deformation that the rocks in which the beds occur have undergone, it seems probable that much of the anthracite will yield a large amount of slack. It is possible that some of the beds are so crushed as to make it necessary to defer their mining until some method of utilization of the fine coal has been devised. The coals classed as semianthracite are of about the same composition as the Loyalsock or Bernice basin coals of Pennsylvania.

The higher-grade bituminous (semibituminous) coals of the Bering River and Matanuska fields are comparable in composition and heating power with the Georges Creek, New River, and Pocahontas coals of the East. Many of these beds also include a large amount of slack, which may, however, be utilized under boilers or for making coke. The lower-grade Alaska bituminous coals compare favorably in composition with the coals of Japan, Vancouver Island, Washington, and Australia. This is an important point, as these are the fuels with which the Alaskan coal must come into competition.

The following table summarizes the composition of the Alaskan coals:

Analyses of Alaska coals.a

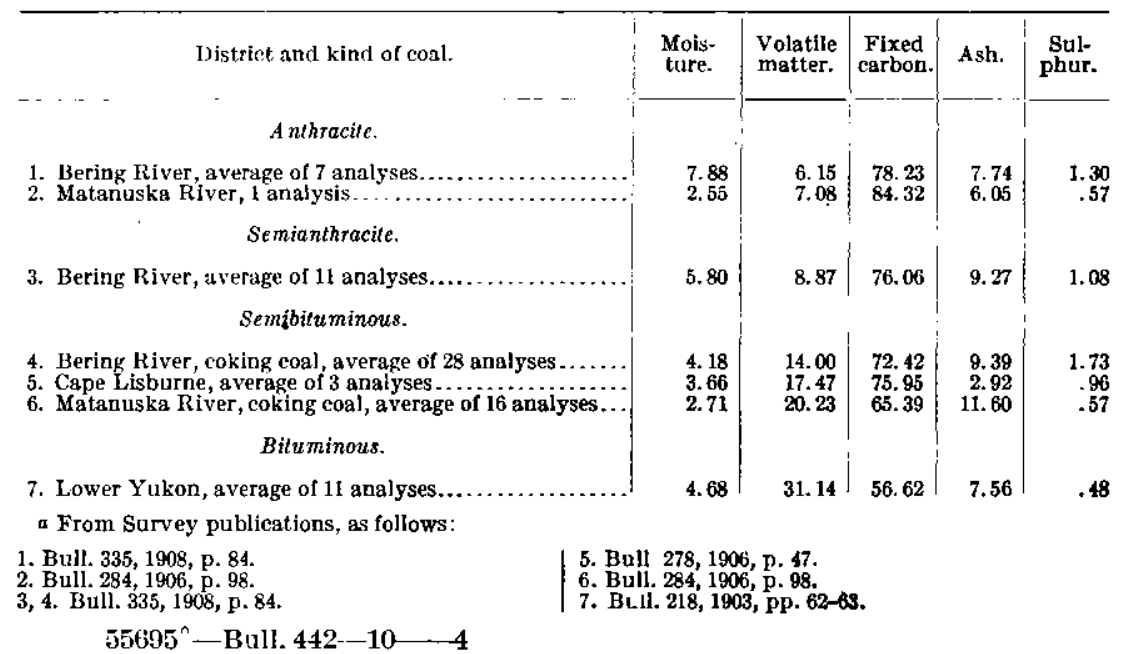


Analyses of Alaska coals $a$ - Continued.

District and kind of coal.

Subbituminous.

8. Matanuska River, sverage of 4 analyses..

9. Cbignik Bay, Alaska Peninsula, average of 4 analyse...

10. Herendeen Bay, Alaska Peninsula, average of 2 analyses.

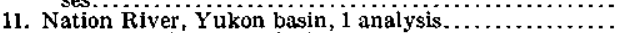

12. Koyukuk River, 1 analysis.

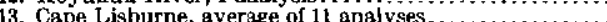

14. Anorturuk River, lanalysis. .

Lignite.

15. Admiralty Island, southeastern Alaska, average of 5 analyses....

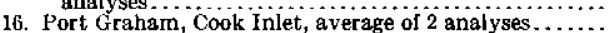

17. Kachemak Bay, Cook Inlet, average of 10 analyses

18. Tyonek and Beluga River, Cook Inlet, average of 5 analyses.

19. Unga Island, Alaska Peninsula region, average of 3 analyses.

20. Kodiak Island, 1 analysis

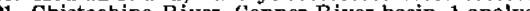

22. Chitistone River, Copper River basin, 1 analysis.

23. Upper Yukon, Canadian, average of 13 analyses.

25. Upper Yukon, Rampart province, average of 6 analyses.

26. Nenans River, Tanana basin, 1 analysis ...................

28 . Wainwright Inlet, northern A laska, 1 analysis . . .......

ж. Colville River, northern Alaska, 1 analysis .............

\begin{tabular}{|c|c|c|c|c|}
\hline $\begin{array}{l}\text { Mois- } \\
\text { ture. }\end{array}$ & $\begin{array}{l}\text { Volatile } \\
\text { matter. }\end{array}$ & $\begin{array}{c}\text { Fixed } \\
\text { carbon. }\end{array}$ & Ash. & $\begin{array}{l}\text { Sul- } \\
\text { phur. }\end{array}$ \\
\hline $\begin{array}{l}6.56 \\
6.98\end{array}$ & $\begin{array}{l}35.43 \\
30.89\end{array}$ & $\begin{array}{l}49.44 \\
42.88\end{array}$ & $\begin{array}{r}8.57 \\
19.29\end{array}$ & $\begin{array}{l}0.37 \\
1.50\end{array}$ \\
\hline $\begin{array}{l}7.75 \\
1.39 \\
4.47 \\
9.35 \\
6.85\end{array}$ & $\begin{array}{l}32.83 \\
40.02 \\
34.32 \\
38.01 \\
36.39\end{array}$ & $\begin{array}{l}50.06 \\
55.55 \\
48.26 \\
47.19 \\
43.38\end{array}$ & $\begin{array}{r}9.26 \\
3.04 \\
12.95 \\
5.45 \\
13.38\end{array}$ & $\begin{array}{r}.36 \\
2.98 \\
. .35 \\
.35\end{array}$ \\
\hline $\begin{array}{r}1.97 \\
18.41 \\
20.46\end{array}$ & $\begin{array}{l}37.84 \\
38.10 \\
38.77\end{array}$ & $\begin{array}{l}35.18 \\
35.79 \\
35.56\end{array}$ & $\begin{array}{r}24.23 \\
7.69 \\
10.25\end{array}$ & $\begin{array}{l}.57 \\
.40 \\
.35\end{array}$ \\
\hline 21.50 & 37.28 & 30.60 & 10.63 & .57 \\
\hline $\begin{array}{r}19.09 \\
12.31 \\
15.91 \\
1.65 \\
13.08 \\
10.45 \\
11.42 \\
13.02 \\
37.73 \\
10.65 \\
11.50\end{array}$ & $\begin{array}{l}39.39 \\
51.48 \\
60.35 \\
51.50 \\
39.88 \\
41.81 \\
41.15 \\
48.81 \\
24.14 \\
42.99 \\
30.33\end{array}$ & $\begin{array}{l}26.84 \\
33.80 \\
19.46 \\
40.75 \\
39.28 \\
40.49 \\
36.95 \\
32.40 \\
29.27 \\
42.94 \\
30.27\end{array}$ & $\begin{array}{r}16.83 \\
2.41 \\
4.28 \\
6.10 \\
7.72 \\
7.27 \\
10.48 \\
5.77 \\
8.86 \\
3.42 \\
27.90\end{array}$ & $\begin{array}{r}1.26 \\
1.30 \\
.33 \\
.16 \\
.62 \\
.50\end{array}$ \\
\hline
\end{tabular}

a From Survey publications, as follows:

8. Bull. 284, 1906, p. 98.

9. 10. Bull. 379,1909, p. 146 .

11, 12. Bull. 218, 1903, p. 62 .

13. Bull. 278,1906 , p. 4 .

14. Prof. Paper 20, 1904, p. 114

15. Bull. 284,1906, p. $2 \%$,

16, 17. Bull. 259, 1905, p. 170; Bull. 379, 1909, p. 126.

18. Bull. 379,1909 , v. 126 .

19. Bull. 259, 1905, p. 170; Bull. 379, 1909, p 14 î.

20. Bull. 259, 1905, p. 1 i50.

21. Prof. Paper 41, 1906, p. 124.

22. Idem, p. 125 .

23. Bull. 218, 1903, pp. 61-62.

24. Idem, $p .63$.

25, 26 . Idem, p. 62

27. Bull. 379 , 1909 , p. 363 .

28, 20. Prof. Pader 20, 1904, p. 114.

\section{AREAS OF COAL LANDS AND COAL FIELDS.}

As only about one-fifth of Alaska has been surveyed geologically, it is evident that any estimate of the area of the coal fields serves only as a measure of the minimum area. With these limitations on the accuracy of the figures the total known coal fields include an area of about 12,667 square miles. It is not impossible that future surveys may prove that the coal fields embrace many times this area. The figures indicate the number of square miles of land which are underlain by the coal-bearing formations. If, however, the estimate is made to cover only the area of actually proved coal lands, namely, those which are known to be underlain by coal beds of a quality and thickness and at a depth that make mining practicable, the figures are only 1,202 square miles. In other words, only about one-tenth of the area of the coal fields is sufficiently well known to be classified as coal land. This is due to the fact that detailed surveys are often necessary to establish the presence or absence of commercial beds of coal. It should be noted that in the above classification only quality, quantity, and depth of coal are taken into account. It is clear that 
so far as development is concerned the accessibility of the coal and the possibility of marketing it are just as important as the factors mentioned above in designating commercially valuable coal lands. For example, some of the best coals have no value because they can not be marketed under any demand that can now be foreseen. It is evident, therefore, that the figures presented above have little practical import. They will serve the economist only by indicating the minimum coal-bearing areas which may in the generations to come be drawn upon for fuel.

The general distribution of coal areas in Alaska is presented in the subjoined table, which was compiled by Mr. Martin in 1908. Since this table was compiled some surveys have been made which modify some of the figures presented. As the figures are a mere approximation, however, and as nearly every season's field work yields results bearing on these areas it is impossible to publish an estimate which will have lasting value. It therefore seems best to leave the table as it stands until information is available which will permit more accurate estimates to be made.

Estimate of areas of Alaskia coal fields.

[In square tiniles.]

\begin{tabular}{|c|c|c|}
\hline - & $\begin{array}{l}\text { Coal lands } \\
\text { (areas be- } \\
\text { lieved to } \\
\text { be under- } \\
\text { lain by } \\
\text { workable } \\
\text { coal). }\end{array}$ & \begin{tabular}{|l} 
Coal fields \\
(supposed \\
areas un- \\
derlain by \\
coal-bear- \\
ing rocks).
\end{tabular} \\
\hline 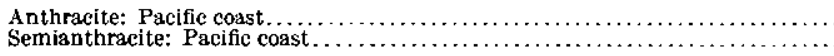 & $\begin{array}{r}25.8 \\
7.2\end{array}$ & 620 \\
\hline $\begin{array}{l}\text { Semibituminous: } \\
\quad \text { Pacific coast } \ldots \ldots \ldots \ldots \ldots \ldots \\
\text { Aretic slope } \ldots \ldots \ldots \ldots \ldots\end{array}$ & $\begin{array}{l}35.8 \\
14.2\end{array}$ & $\cdots$ \\
\hline $\begin{array}{l}\text { Total semibituminous ............. } \\
\text { Total high-grade } . . . . . . . \ldots \ldots \ldots\end{array}$ & $\begin{array}{l}50.0 \\
83.0\end{array}$ & $\cdots \cdots$ \\
\hline $\begin{array}{l}\text { Bituminous: } \\
\quad \text { Pacific coast } \ldots \ldots \ldots \ldots \ldots \ldots \ldots \ldots \ldots \ldots \ldots \\
\quad \text { Interior region. } \ldots \ldots \ldots \ldots \ldots \ldots \ldots \ldots\end{array}$ & $\begin{array}{r}2.0 \\
162.0\end{array}$ & $\begin{array}{r}900 \\
2,475\end{array}$ \\
\hline Total bituminous. & 164.0 & 3,375 \\
\hline 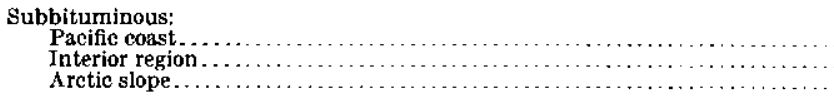 & $\begin{array}{r}49.7 \\
6.0 \\
205.0\end{array}$ & $\begin{array}{r}657 \\
15 \\
1,323\end{array}$ \\
\hline Total subbituminous. & 260.7 & 1,995 \\
\hline 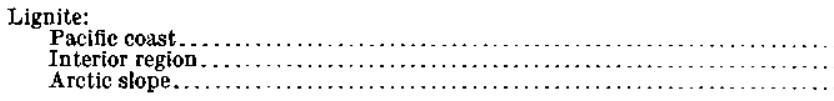 & $\begin{array}{r}337.0 \\
264.5 \\
93.0\end{array}$ & $\begin{array}{l}2,938 \\
2,003 \\
1,736\end{array}$ \\
\hline Total lignite.. & 694.5 & 6,677 \\
\hline 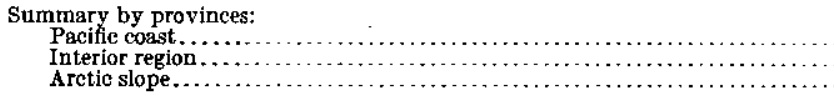 & $\begin{array}{r}457.5 \\
432.5 \\
312.2\end{array}$ & $\begin{array}{l}5,115 \\
4,493 \\
3,059\end{array}$ \\
\hline & I, 202.2 & 12,667 \\
\hline
\end{tabular}


The incompleteness of these figures can best be illustrated by some examples. The Bering River field may be extended into the mountains and have many times its present known area. If the entire eastern and western extensions of the Matanuska Valley are underlain by coal beds, as may be the case, the actual area of this field is many times that used in the present estimate. In the Cook Inlet and Susitna regions the estimates for area are based on a coal field of 30 to 40 square miles. As a matter of fact, it is not improbable that the whole Cook Inlet-Susitna depression may be underlain by coalbearing rocks at no depth prohibitive of mining. If such is the case, this coal field might possibly embrace 10,000 to 20,000 square miles. There is also good reason to believe that the area of the coal fields of the Arctic slope far exceeds that of all the rest of the Alaskan fields.

The accompanying map ( $\mathrm{Pl}$. I) shows the distribution of the coal, together with symbols indicating its quality. The areas believed to be underlain by workable coal beds are marked in black on the map, and the areas of the coal fields, so far as they are known, are indicated by stippling. Under the first of these two symbols are included only areas in which there is a reasonable degree of certainty that commercial coal bedsoccur; the second indicates what is known of theprobable extension of the coal fields, and hence defines the areas worthy of prospecting. It should be noted that this mapping does not by any means have the same value throughout the Territory, for in some portions it is based on geologic surveys of a high degree of refinement, in others only on hasty observations made during a rapid exploration.

\section{TONNAGE ESTIMATES.}

Estimates of Alaska's coal resources, expressed in tonnage, were prepared for the Conservation Commission. ${ }^{a}$ Although these figures are of some value to the economist, inasmuch as they serve to indicate the minimum quantity of fuel which Alaska can furnish, yet they do not show the ultimate coal resources of the Territory. The estimates have little bearing on the questions here under consideration, but as they have recently received wide publicity and have to some extent been misinterpreted, it seems best to repeat them and to discuss briefly their significance.

The facts already presented which militate against an accurate statement of the area of Alaska coal lands apply with still greater force to estimates of tonnage. Of the 1,202 square miles classed as coal land, less than one-quarter has been surveyed in sufficient detail to yield any quantitative data whatever. Even where such surveys have been made, a large factor of uncertainty is introduced either by the folded and faulted condition of the coal beds or by the lack of

a Rept. Nat. Conserv. Comm., Senate Doc. 676, 60th Cong., 2d sess., vol. 3, p. 581: reprinted in Bull. U. S. Geol. Survey No. 394, 1909, p. 182. 
definite knowledge regarding sequence of strata. There must, therefore, be a very large element of uncertainty in the tonnage estimates for even the 300 to 400 square miles of surveyed coal fields. Moreover, in Alaska there are almost no data available from private sources, such as the results of extensive mining or prospecting operations, which form an important element in the estimates made of the coal resources of the States.

The estimates of tonnage given below were made by Mr. Martin on the following basis:

1. No beds less than 3 feet thick were assumed to be workable or contributed to the tonnage.

2. The depth of workability was assumed to be 3,000 feet for the highest-grade coal (anthracite, semianthracite, semibituminous); 2,000 feet for the better bituminous and subbituminous coals, such as those on the lower Yukon, at Cape Lisburne, and on Matanuska River; and 1,000 feet for the poorer subbituminous coals and all the lignites.

3. The tonnage was computed by the formula Tonnage $=$ area of bed to limit of workability (square miles) $\times$ thickness (inches) $\times$ specific gravity $\times 72,600$.

4. The specific gravity was assumed to be 1.30 for lignite, 1.35 for bituminous, and 1.38 for the high-grade coals.

5. Bering River field: A certain percentage of the coal-bearing rocks is shown by the average sections to consist of workable coal beds; this percentage of the computed bulk of rock to the limit of workability gave the estimated tonnage.

6. Nenana field: As for Bering River, with the necessary change for percentage of coal in rocks.

7. Matanuska field: Each bed was estimated separately according to its average thickness, length on a safe assumption of continuity, and width on the dip to the limit of workable depth.

8. Lisburne field: The Corwin district was computed like the Matanuska, the length of the beds being assumed to be the distance from the shore to the edge of the mapped area. The Beaufort district was assumed to have one-half the tonnage per square mile of the Corwin district.

9. Yukon field: Each bed was figured as in the Matanuska, but the beds were not assumed to extend more than a mile in each direction from the mine or prospect where they had been exposed, except in the Washington-Bonanza district, where a continuity of 50 miles on the strike was assumed.

10. Cook Inlet field: Computed as for the Matanuska.

11. All the other fields were computed on the basis of a most conservative estimate of thickness of coal underlying the field and an area believed to be a safe minimum. In none of the fields was the 
coal assumed to go beyond points where it is shown to exist by reliable information from members of the Survey. The areas used in making the last class of estimates are consequently very small and are possibly subject to an immense extension in the light of subsequent information.

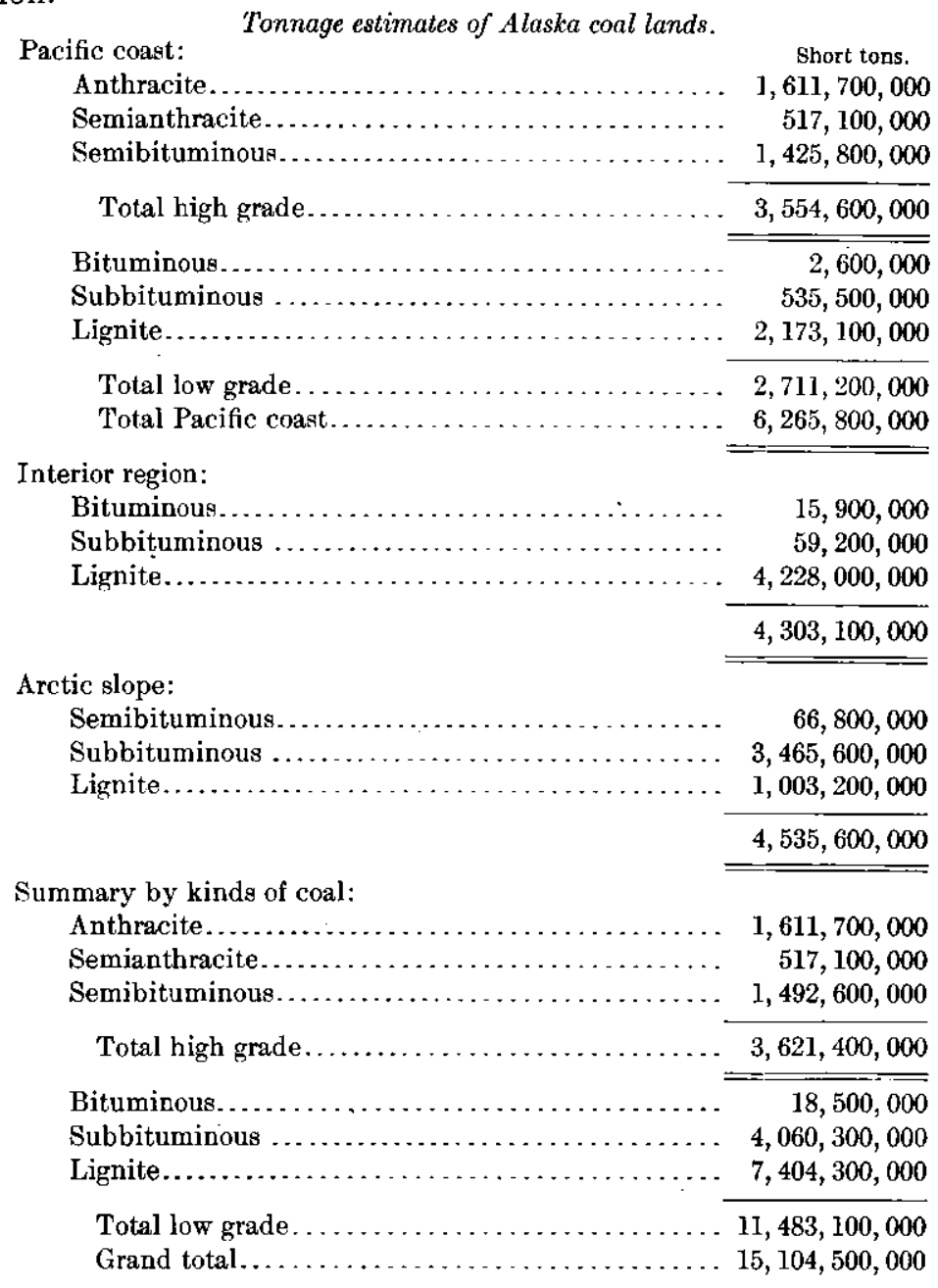

In making these estimates the attempt has been made to err on the conservative side, and thus they represent minimum rather than maximum figures in each case. This may account for the fact that they indicate an average of 20,000 tons to the acre on the Alaska coal lands, as compared with 32,000 tons to the acre in the coal fields of the western public-land States. On the other hand, with the same data for any particular area, the coal estimates of the federal geologist will usually exceed those made by the mining engineer for private interests. The reason for this lies in the fact that the geolo- 
gist includes in his estimate all the coal beds of a certain thickness and to a certain depth, for it is his purpose to present figures which shall approximate at least the ultimate coal resources of the district under examination. The mining engineer, on the other hand, is not interested in the ultimate coal recovery but is charged with the duty of estimating the quantity of coal which is either immediately available or can be mined under conditions that will soon arrive. For example, a number of engineers have roughly approximated the coal of the Bering River field at 500,000,000 tons, and these figures have been widely quoted. This estimate, however, includes only the coal lying above water level which can be mined without hoisting. The tonnage estimate of the Geological Survey is many times this figure, because it includes all the coal lying within 3,000 feet of the surface. It should therefore be borne in mind that the two classes of estimates are made with very different purposes and do not admit of direct comparison.

In considering the above table it must be remembered that these estimates cover only the 1,202 square miles of coal lands, namely, that part of the coal fields which, with a reasonable degree of certainty, is believed to be underlain by workable coal beds. No allowance whatever is made for the remainder of the 12,667 square miles, which are mapped as coal fields. The possibilities of finding coal in the unsurveyed districts are also ignored. Evidently, therefore, if the same acre tonnage holds throughout the coal fields, these estimates should be multiplied by ten. Again, the discovery of new coal fields will add to the tonnage. It is therefore probably safe to say that the minimum estimate of Alaska's coal resources should be placed at $150,000,000,000$ tons and that the actual tonnage may be many times that amount. These figures indicate coal resources far in excess of the original coal supply of Pennsylvania. It must be remembered, however, that over half the Alaska coal is lignite, while all of the Pennsylvania coal is of a high grade.

\section{THE COAL FIELDS.}

\section{SOUTHEASTERN ALASKA.}

Though Tertiary (or possibly Upper Cretaceous) coal-bearing terranes are known to cover a considerable area in the southern part of Admiralty Island and are also found on adjacent islands, the included coals appear to have no present importance. These beds are from a few inches to 2 or 3 feet in thickness, and the coal, so far as known, is all of a low-grade lignitic character. A little mining has been done, however, and it is possible that coal may be discovered which could find a local market. 
BERING RIVER FIELD.

One of the two Alaskan fields containing the largest known amount of high-grade coal lies about 25 miles northeast of the indentation of the southern shore line of Alaska called Controller Bay. The field is drained by Bering River, from which it received its name. ${ }^{a}$ The surveyed parts of the Bering River field embrace about 22 square miles underlain by anthracite and about 28 square miles underlain by semibituminous and semianthracite coal.

The workable coal beds in this field are from 3 to 25 feet thick, but through local swellings a much higher maximum thickness is attained. They are included in a great series of sandstones and shale of Tertiary age (Miocene?), which are intensely folded and much faulted. In quality the coals vary from an anthracite, with 84 per cent of fixed carbon, to a semibituminous, with 74 per cent of fixed carbon. (See pp. 49-50.) The field includes some coking coal. The excessive deformation of the strata has led to the crushing of much of the coal. Very little work has been done in this field, so it is impossible to state the physical condition of the coal below the surface, but it seems likely that many beds will be found to contain a large amount of slack.

The coal-bearing rocks of the Bering River field trend to the northeast into the unsurveyed high ranges, where it is probable that there may be other extensive areas. There is also some fragmentary evidence that coal occurs along the seaward face of the mountains east of the Bering River field. Prospectors report the discovery of coal between Controller Bay and Yakataga. There is also said to be coal on the southwest slope of Mount St. Elias, about 100 miles east of Controller Bay. Mr. Broke, one of a party of mountaineers who attempted the ascent of Mount St. Elias in 1888, makes a number of references to the occurrence of coal in his book ${ }^{b}$ which gives an account of the expedition. One locality referred to by him appears to lie northwest of the Yahtse Valley and well up on the slope of the mountains. Another is in the Karr Hills, which are described as being made up of sandstone with great beds of coal. One bed is mentioned which is 6 to 8 feet in thickness, and the coal is said to have been burned in the camp fire. All these facts suggest at least that there may be other coal fields in this region besides that of Bering River. Therefore the areas given above only have value in giving a minimum, for it may prove that the surveyed field is but a small fraction of the total. At the same time it should be noted that, on account of the expense of development, any coal occurring

a It is sometimes called the Controller Bay field and sometimes the Katalla field.

b Broke, George, With sack and stock in Alaska, London, 1890, pp. 86, 91. 
in the high ranges is not likely to be made available until the more accessible fields approach exhaustion or until coal commands a much higher price than it does now.

\section{COPPER RIVER REGION.}

Lignitic coal has been discovered at several places in the Copper River basin, but in no great quantities. It is known to occur in the Chitina Valley and also in the Chistochina basin. It is also quite probable that the same coal-bearing beds may occur underneath the heavy covering of glacial gravels and silts. These coals are all believed to belong to the Eocene (Kenai formation). There is little hope of the development of a coal-mining industry in this province, as the fuel is of a poor quality and the beds are not thick. It is possible, however, that some may in time have value for local use.

\section{COOK INLET.}

Coal-bearing Tertiary rocks are widely distributed in the Cook Inlet region. They are in most places but little disturbed, though locally considerably folded and faulted. The largest areas of coalbearing rocks in this field occupy the western part of Kenai Peninsula, and are in part buried under a cover of Quaternary gravels. It is not impossible that the entire Cook Inlet depression may be underlain by these coal-bearing formations. It seems probable that the coal reserves in the Cook Inlet region are very large, for the area of the coal field is estimated at 2,565 square miles.

The best-known part of this field lies adjacent to Kachemak Bay on the north, where 2,000 to 3,000 feet of coal-bearing rocks are exposed. These rocks probably contain an aggregate thickness of over 60 feet of workable lignitic coal beds, the thickest of which reaches about 7 feet. Lignite in workable seams has also been found at Port Graham and Tyonek. The coal thus far found in Kenai Peninsula is all lignite, though but little search has been made, except along the shore line. It is possible that higher-grade coals may occur along the mountain front, where greater deformation may have taken place.

Though Kenai Peninsula was the scene of the earliest coal-mining venture in Alaska (1854), yet the product of the industry has amounted to only a few thousand tons. Coal has been mined at Port Graham, on Kachemak Bay, and near Tyonek. The accessibility of the coal to tide water and the undisturbed condition of the beds make for cheap mining and transportation. With improvement in methods for the utilization of lignites, fuel from this field might yet become a competitor with the fuels of a higher grade. Under present conditions 
of utilization, however, this coal can hardly be expected to compete with that of the Bering River and Matanuska fields, except in a very local market.

\section{MATANUSKA FIELD.}

The Matanuska coal field shares with that of Bering River the preeminence in the present fuel situation in the Territory. This field lies about 25 miles from tide water at Knik Arm, a northerly embayment of Cook Inlet. As, however, Cook Inlet is frozen during the winter months, the distance to tide water must be measured to the east side of Kenai Peninsula, about 184 miles. ${ }^{a}$

The known commercially valuable coals of the Matanuska are included in folded and faulted rocks of Tertiary (Eocene?) age, including shales, sandstones, and conglomerates aggregating 3,000 feet in thickness. Coals are also known to occur in a Jurassic formation which is extensively developed in the upper Matanuska basin. These Jurassic coals appear to be chiefly lignitic but may include some of higher grade. Their commercial importance has not been established.

The Tertiary coal-bearing series has been traced for 50 to 60 miles along the Matanuska Valley, but much of it is buried under a heavy blanket of Quaternary gravels. The bituminous coal, which seems to form the main body, appears to pass into a lignite at the west end of the field, while there is some evidence that the same coal is represented by an anthracite near the east end of the belt of Tertiary rocks. This anthracite may, however, belong to the older coal-bearing formation.

The commercial coals of the Matanuska field vary from a subbituminous to a semibituminous, and there is also some anthracite, but of this less is known. It is evident from the facts in hand that there is a large amount of high-grade bituminous coal in this district. The beds vary from 5 to 30 feet in thickness.

So far as at present known, the total area underlain by commercial seams aggregates 46.5 square miles. As much of the field is covered, however, and as it has not been surveyed in detail, the coal-bearing area is probably much larger. The total area of what may prove to be coal-bearing rocks is approximated at 900 square miles.

A railway is in construction which will lead to the opening of this field, and this should result in the development of the high-grade fuels. The lignites of the western part of the Matanuska field will not bear shipment to a distance in competition with those of higher fuel value.

\section{SUSITNA BASIN.}

Lignitic coal-bearing rocks have been found in small and widely separated areas in the Susitna basin. There is some evidence that in the lower Susitna Valley there are extensive deposits of this for-

a Possibly a summer port of shipment could be established on Knik Arm, 60 miles from the coal field. 
mation, now buried underneath a heavy cover of glacial gravels and silts. In any event lignitic coal is known to occur on both margins of the valley. According to reports of prospectors it is best developed along the eastern slope, where there is a belt of Tertiary sediments, which appear to be coextensive with those of the Matanuska Valley. The same rocks occur at the mouth of the Chulitna, where there are beds of lignite from 6 inches to 6 feet in thickness. Under conditions which can now be foreseen these coals are not likely to have value except for local use. It is not impossible, however, that there may be many thousand square miles in this region which are underlain by coal-bearing rocks; if so, this province is an important element in the ultimate fuel resources of Alaska.

\section{ALASKA PENINSULA REGION.}

Coal has been found both in Upper Cretaceous and in Eocene formations in the Alaska Peninsula. The developed coals occur in three separate fields-Herendeen Bay, Chignik, and Unga Islandand include both lignitic and bituminous varieties. In addition, lignitic coals have been found in other parts of the peninsula. These coals occur in beds which are either practically horizontal, as at Unga, or thrown into open folds with some faulting, as in the Herendeen Bay and Chignik fields. The proved bituminous coal lands of the peninsula include an area of about 30 square miles; the known area of the bituminous coal-bearing formations is about 90 square miles. The known areas of the lignite-bearing formation amount to about 60 square miles. These figures are, however, not significant, as but a small fraction of the total area of the peninsula has been surveyed. It is quite possible that the total area of the coal fields may amount to many hundred square miles.

In Herendeen Bay field the commercial coal beds measure 2 to 5 feet in thickness, but in the Chignik field they are somewhat thinner. On Unga Island lignite coal beds up to about 3 feet in thickness have been found. Coal has been mined for many years at Chignik, and some has been taken out at Herendeen Bay for local use, but the total output of the peninsula does not exceed 20,000 tons. These coal fields are all readily accessible from good harbors and will form one of the early available fuel assets of the Territory when the demand for coals of this grade warrants their exploitation.

\section{YUKON REGION.}

The coals of the Yukon, including some bituminous and subbituminous, together with a large amount of lignite, are for the most part of Tertiary (Eocene?) age. Some of the bituminous coals are probably Upper Cretaceous. There are also some thin coal beds in the 
Carboniferous rocks of the Yukon, but these appear to be of no commercial value. The Tertiary lignitic coal beds typically occur in association with conglomerates, sandstones, and shales, usually only little deformed but in places much folded and faulted. The bituminous coals, which are confined to the lower Yukon, occur with finer sediments that have been gently folded and somewhat faulted.

The lignitic coal occurs in beds up to 20 feet in thickness; the bituminous is in beds from 2 to 3 feet thick, and such comparatively thin seams have not encouraged exploitation, especially as they appear not to have much continuity. Therefore, in spite of the high price of mineral fuel in this central region there has been but a small production, and that chiefly for the use of the Yukon River steamers, many of which now, however, burn California petroleum.

Coal-bearing beds are so widely distributed in the Yukon region that it will not be feasible to give an account of all the occurrences. The three largest fields are (1) the Nulato region, (2) the Nenana region of the lower Tanana Valley, (3) the Washington and Coal Creek belt of the upper Yukon. Of these the Nulato field contains the best coal, while the Nenana is the most extensive and has the thickest beds. The total area known to be underlain by coal in the entire Yukon region is about 260 square miles; the coal fields may embrace 2,000 square miles or more.

The Nenana field, being the largest, merits a little more detailed description. It lies 20 to 40 miles south of Tanana River, between Nenana and Delta rivers. It is included in a formation (Eocene) from 500 to 1,800 feet in thickness, which is for the most part only slightly deformed but in places considerably faulted. The coals, which are all of lignitic character, vary from a few inches to 20 feet in thickness. One measured section on Healy Fork showed 60 feet of coal. The total area known to be underlain by coal is 66 square miles, but the coal-bearing strata are exposed in an area of 600 square miles and are known to extend eastward into an unsurveyed area. The Nenana field therefore must include a very large amount of coal.

Some of the lignitic coals of the upper Yukon should eventually find a local market when the scant supply of accessible timber approaches exhaustion. There is a constantly increasing demand for power in the placer districts, and this can only be met either by developing water powers, which are not extensive, or by utilizing the coals. The low fuel values and the cost of transportation of these coals may lead to their transformation into electric power at the mines, to be transmitted to the placer camps. Some of the lignite fields are near enough to the placer fields to permit such utilization. 


\section{KUSKOKWIM BASIN AND BERING SEA COAST.}

Lignitic coal beds have been reported to occur at various places in the lower Kuskokwim basin, but most of these appear to be too thin and too low in grade to have any commercial value. Similar coal beds occur on the Bering Sea coast near the mouth of the Kuskokwim and on Nunivak, but little is known about them.

It has only recently been brought to the attention of the writer by W. E. Priestley ${ }^{a}$ that coal also occurs on the upper Kuskokwim. It appears that this coal formation covers considerable area and that some of the beds are very thick. A specimen of the coal collected by Mr. Priestley shows it to be a good grade of lignite.

\section{SEWARD PENINSULA.}

The known coal-bearing areas of Seward Peninsula do not exceed a few square miles. The rocks are probably of Eocene age, and the coal is of a low grade. This coal, however, is important because it can probably be utilized locally to furnish power for mining purposes, instead of the higher-grade coals that are now being brought in from outside sources. There is a little coal in the southeastern part of the peninsula, but it is not believed to be in commercially valuable beds. The important coals are those of Chicago Creek, lying in the northeastern part of the peninsula. Here a lignitic coal bed has been opened which is over 80 feet in thickness, with only a few thin partings of bone and shale. Two small coal mines are being operated in this district, and their product is marketed at the near-by placer camps and is competing with higher-grade fuels transported from a distance. In considering the value of this coal it should be noted that most of Seward Peninsula is without timber, and that all mining operations must therefore depend on imported fuels or draw on this local supply of lignite.

\section{NORTHERN ALASKA.}

Geographically the known coal fields of northern Alaska fall into three groups--those of (1) Cape Lisburne, (2) the Colville basin, (3) Wainwright Inlet. Coal has also been found on Kobuk River and is reported to occur between these areas, as well as east of Colville River. The Cape Lisburne field includes the Corwin and Cape Beaufort districts.

Three coal-bearing formations are recognized in this northern field-(1) the Carboniferous Lisburne formation (Mississippian?), made up of slates, shales, and limestones, with some high-grade

a Mr. Priestley made a winter trip from the Innoko to Seward in 1909 . In the course of his journey he explored the basin of Big River, a southerly tributary of the Kuskokwim near the forks, where he found the coal. 
bituminous coals, and having a thickness of 500 feet or more; (2) the Jurassic Corwin formation, including at least 15,000 feet of shales, sandstones, and conglomerates and containing a large number of subbituminous coal beds; (3) the Tertiary Kenai formation (?), made up of conglomerates, sandstones, and shales, with lignitic coal seams. The two lower formations are closely folded and faulted; the Tertiary beds are, as a rule, only little disturbed.

In areal extent, quantity, and quality of coal the Cape Lisburne field is the most important in northern Alaska. It includes the highgrade bituminous coal of Carboniferous age (Cape Beaufort district), which varies from 1 to 5 feet in thickness. An area of 14 square miles is known to be underlain by this coal, but the actual size of the besin is probably much larger. In the Corwin district, embracing the subbituminous Jurassic coals, there are beds up to 12 feet in thickness. The actual area known to be underlain by commercial coal beds in this district is over 200 square miles, while the coal-bearing formation, as roughly outlined, embraces over 1,200 square miles. This is the most extensive coal deposit which has been found in Alaska.

The total area in northern Alaska known to be underlain by coal aggregates 302 square miles, and the coal fields, roughly outlined from the data in hand, include some 3,000 square miles. The scant evidence available points to the conclusion that a survey of this northern region will show very large coal fields in this part of Alaska.

A little coal mining for local use has been carried on in the bituminous field near Cape Lisburne and in the lignitic field of Wainwright Inlet, but the region as a whole is practically untouched. It is certain that there will be no extensive mining in this northern field for many generations to come. These coals appear to be too inaccessible to invite exploitation, except for the local use of whalers and natives, under any demands that can now be foreseen. The chief difficulties in attempting to ship out this coal by vessels are, first, the lack of harbors, and, second, the fact that the open season for navigation is less than two months.

\section{MINING DEVELOPMENTS.}

Though something has been known of Alaska coal for more than sixty years, the amount of actual mining has been insignificant. The total production since the Territory was acquired from Russia is less than 50,000 tons. This is all the more significant because during this time more than a million and a half tons of coal have been shipped to Alaska, all but about 20 per cent of which was brought from foreign fields.

The following table shows the annual coal production since 1897 and an estimate of the output between 1888 and 1897. A little coal was mined previous to 1884 by the crews of vessels that ran short 
of fuel, but this probably did not aggregate more than a few hundred tons. The total output of coal previous to 1889 , including that mined by the Russians, was probably less than 10,000 tons.

Production of coal in Alaska, 1888-1909.

\begin{tabular}{|c|c|c|c|c|c|}
\hline Year. & $\begin{array}{l}\text { Amount } \\
\text { (short } \\
\text { tons). }\end{array}$ & Value. & Year. & $\begin{array}{l}\text { A mount } \\
\text { (short } \\
\text { tons). }\end{array}$ & Value. \\
\hline \multirow[t]{2}{*}{ 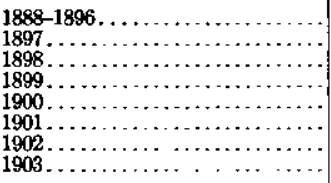 } & \multirow[t]{2}{*}{$\begin{array}{l}6,000 \\
2,000 \\
1,000 \\
1,200 \\
1,200 \\
1,300 \\
2,212 \\
1,447\end{array}$} & \multirow[t]{2}{*}{$\left.\begin{array}{r}\$ 84,000 \\
28,000 \\
14,000 \\
16,800 \\
16,800 \\
15,600 \\
19,048 \\
9,782\end{array}\right\}$} & \multirow[t]{2}{*}{ 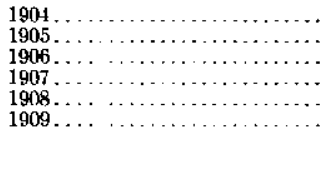 } & $\begin{array}{r}1,694 \\
3,774 \\
5,541 \\
10,139 \\
3,107 \\
2,800\end{array}$ & $\begin{array}{l}\$ 7,225 \\
13,250 \\
17,974 \\
53,600 \\
14,810 \\
12,300\end{array}$ \\
\hline & & & & 43,414 & 323,189 \\
\hline
\end{tabular}

Note.-The production for $1888-1896$ is estimated on the best data obtainable. The figures for 1897 to 1908 are based for the most part on data supplied by operators; those for 1909 on preliminary estimates.

Several of the first explorers of the Alaska coast noted the presence of coal on Cook Inlet, where, too, the first attempts at mining were made. In 1854 an American company ${ }^{a}$ under a Russian charter opened a coal mine at Port Graham, on Cook Inlet, and this mine continued to supply Russian steamers with fuel until the transfer of the Territory. The demand for fuel due to the rapid increase in the population of California was the first incentive to a systematic search for coal in Alaska. In the early seventies coal lands were staked on Unga Island, and during the next thirty years a number of companies were organized for the purpose of exploiting the coal of Cook Inlet and the Alaska Peninsula region. Up to 1896, however, nothing notable was accomplished either in mining or in prospecting, though some mining had been done at Kachemak Bay, Chignik, and Herendeen Bay, on Admiralty Island, and along Yukon River. Coal mining lagged in Alaska chiefly because the Pacific coast markets were supplied from the rapidly developing fields of Washington, California, and Vancouver Island.

It appears to have been about 1896 that the Bering River field first attracted the notice of prospectors, and about two years later the Matanuska field was also found. By 1901 prospectors had begun to recognize the importance of these two fields. It was not, however, until after the examination and reports by the Geological Survey (1904-1908) that the public outside of Alaska began to realize that these fields contained a large quantity of high-grade fuel.

Meanwhile the exodus to Alaska which took place from 1897 to 1900 , because of the placer-gold discoveries, had much increased the local demand for fuel. Several mines were then opened on the Yukon, intended to supply coal to river steamers. Most of these enterprises were abandoned when petroleum engines were substi- 
tuted for coal burners in 1902. An enterprise which had for its purpose the shipping of coal to Nome from the Cape Lisburne fields was equally unsuccessful. More important was the opening of a coal mine on Chicago Creek, in the northeastern part of Seward Peninsula. This mine began to supply the neighboring placer camps with fuel in 1903 and has been in operation every winter since that time. A second mine was opened in 1909. These enterprises indicate the value of the lignite deposits for local industries. Mining in a small way has also continued to the present day at several localities on the Pacific seaboard, and more intermittently on the Yukon and at Cape Lisburne. In 1906-7 a few thousand tons of coal was mined on Bering Lake, being used in the railway construction work of the vicinity. This is the only mining that has been done in either of the two most important coal fields.

Two influences have held back the development of the Bering River and Matanuska fields. One was the advances made in the California oil districts, and the other the unfortunate conditions existing in regard to the laws under which Alaska coal lands can be taken up.

During the decade ending with the year 1908 the annual output of the California oil fields increased from about 2,500,000. to nearly $45,000,000$ barrels. As probably 80 per cent of this petroleum is used for fuel in the Pacific coast States, it has to a corresponding extent decreased the demand for coal.

A far more serious handicap has been the coal-land laws. Though laws intended to enable the individual to obtain title to coal lands have been on the statute books for the last decade, not a single acre of land has yet (July 1, 1910) gone to patent. It is therefore not surprising that progress has been checked in the coal fields and that many who would undertake their development have become discouraged.

The first act, passed June 6, 1900, simply extended to Alaska the provisions of the coal-land laws in the United States. This law was ineffective, for it provided that only subdivided lands could be taken up, and there were then no land surveys in Alaska. The matter was rectified by the act of April 28, 1904, ${ }^{a}$ which permitted unsurveyed lands to be entered and the surveys to be made at the expense of the entrymen. Unfortunately, the law provided that only tracts of 160 acres could be taken up, and no recognition was given to the fact that it was impracticable to develop an isolated coal field requiring the expenditure of a large amount of money by such small units. Many claims were staked, however, and surveys were made for patents. It was recognized by everybody familiar with the condi-

a A complete statement of the Alaska cual-land situation is contained in the testimony of Frederick Dennet, Commissioner of the General Land Office, in hearings before the Committee to Investigate the Interior Department and Forest Service, vol. 5, 1910, pp. 4298-4391. 
tions that after patent was obtained these claims would be combined in tracts large enough to assure successful mining operations. No one experienced in mining would, of course, consider it feasible to open a coal field on the basis of single 160-acre tracts. The claims for the most part were handled in groups, for which one agent represented the several different owners. Unfortunately, a strict interpretation of the statute raised the question whether even a tacit understanding between claim owners to combine after patents had been obtained was not illegal. Remedial legislation was sought and enacted in the statute of May 28, 1908. This law ${ }^{a}$ permitted the consolidation of claims staked previous to November $12,1906,{ }^{b}$ in tracts of 2,560 acres. One clause of this law invalidated the title if any individual or corporation at any time in the future owned any interest whatsoever, directly or indirectly, in more than one tract. The purpose of this clause was to prevent the monopolization of coal fields; its immediate effect was to discourage capital. It was felt by many that this clause might lead to forfeiture of title through the accidents of inheritance or might even be used by the unscrupulous in blackmailing. It would appear that land taken up under this law might at any time be forfeited to the Government through the action of any individual who, innocently or otherwise, obtained interest in more than one coal company. Such a title was felt to be too insecure

- to warrant the large investments needed for mining developments.

The net result of all this is that no titles to coal lands have been passed. Meanwhile, a popular clamor has been raised indiscriminately against all Alaska coal claimants. The practice of locating coal lands through power of attorney, which is strictly legal and universally accepted in all mining law, has been confused with the so-called "dummy entrymen" practice, which is illegal. It is true that many of the coal-land claimants are nonresidents, yet this is necessarily so, for the man who has tho means necessary to provide for a survey, payments to the Government, and the development work on a claim required before patent is issued usually does not follow the vocation of a prospector. The difference between the mining of coal and the mining of placer gold has not always been recognized. A placer claim may yield a profit to the prospector who has but a supply of provisions and a few simple tools, but as a necessary preliminary to coal mining at least several thousand dollars must be expended on each claim. Even after the money necessary to patent has been spent, no profit from mining can accrue until sufficient capital has been invested to provide equipment and transportation facilities. These explanations, obvious to every coal miner,

a See opinion of the $\Lambda$ ttorney-General, dated June 12, 1909, expressed in letter to the Secretary of the Interior, Senate Doc. 248, 61st Cong., 2d sess., 1010.

$\checkmark$ All coal lands of Alaski have been withdrawn from location and entry since November $12,1906$.

$5 \overline{0} 695^{\circ}-$ Bull. $442-10-5$ 
are made here because an idea seems prevalent that any individual prospector, after staking a coal claim, can proceed to develop it at a profit as he might a gold placer.

\section{GEOGRAPHIC CONTROL OF THE DEVELOPMENT OF THE COAL FIELDS.}

Two great series of ranges, ${ }^{a}$ the Pacific mountam system on the south and west and the Rocky Mountain system on the north and east, traverse Alaska and divide it into three general geographic provinces. The southernmost of these provinces, here called the Pacific slope, is divided from a second province, called the central region, by a series of snow-covered ranges. This central region is separated from the third province, called the Arctic slope, by a second mountain barrier. The Pacific slope provine includes the watersheds of all the streams flowing into the Pacific Ocean, and therefore a considerable part of the southern mountain system. The Pacific seaboard, except for the upper part of Cook Inlet, is open to navigation throughout the year. (See Pl. I.) A number of transverse valleys and low passes break the continuity of the southern mountain barrier and thus afford routes of approach to the central region. Yukon and Kuskokwim rivers, which drain the central region, are, together with their tributaries, navigable for thousands of miles, but only for the summer months. The Arctic slope is accessible along its seaboard only for a part of the summer. While the mountains which bound it on the south are broken by many passes, railway connection with an open port on the Pacific will not be commercially practicable under any conditions that can now be foreseen. Evidently, then, geographic and climatic conditions have a dominating control of the utilization of Alaska's mineral fuel. In considering the use of Alaska's coal it is therefore necessary to take into account the distribution of the fields with reference to these conditions. By this means it can be determined which coals are available for present use and which are locked up by natural conditions until such time in the future as the price of fuel may make it commercially possible to bring them to market.

It is evident that the coals of the Pacific slope province are at present of most importance. These include the lignitic or bituminous coals of southeastern Alaska, Cook Inlet, the Susitna basin, and the Alaska Peninsula, as well as the high-grade fuels of the Bering River and Matanuska fields. About 40 per cent both of the area known to be underlain by coal and of the estimated area of the total coal fields of the Territory falls in this province. It includes also at least 90 per cent of the known bituminous and higher-grade coals of the Ter- 
ritory. In considering this percentage of total coal area it should be noted that this is the best-known part of Alaska, and there is, therefore, less likelihood of future discoveries of coal in this province than in the less explored districts of central and northern Alaska. However, as over 50 per cent of this province is geologically almost unknown there is every reason to believe that future surveys may lead to the discovery of other coal-bearing areas.

The central province includes some bituminous and subbituminous coals on the lower Yukon, besides more extensive areas of a lignitic coal-bearing formation in the upper Yukon basin, notably in the Nenana basin and near the coast line of Bering Sea and elsewhere. About 35 per cent of the total known coal-bearing area falls in this province, and about 36 per cent of the estimated coal fields. At least 80 per cent of the central province, however, is almost unknown, so it is likely that further discoveries of coal will there be made. With this province should be grouped some coal reported to have been discovered in the upper Kuskokwim basin.

The northern region includes the bituminous and subbituminous coals near Cape Lisburne, as well as lignitic and bituminous coalbearing rocks in the Colville basin and the lignitic coal of Wainwright Inlet. These fields aggregate about 24 per cent of the total of the Territory; and the area known to be underlain by coal forms about 25 per cent of the total. These percentages of total areas are very large considering the fact that only about 10 per cent of the entire province has been studied geologically. There is every reason to believe that very extensive coal fields exist in this part of Alaska.

The coals of the Arctic slope lie north of the Arctic Circle and are not available for export under any demand that can now be foreseen. To transport these coals to any large market, unless during the brief open season of navigation, would necessitate the construction of a thousand miles of railway, much of it through a region without resources. This is, of course, commercially impracticable. Some of these northern fields can find a very restricted local market along the seaboard in supplying whalers and other vessels. It may be possible to supply the Nome market from the Cape Lisburne field, but attempts to do this in the past have not met financial success. These northern fields for the most are of no present commercial importance and must be regarded solely as forming a part of the ultimate coal resources of the world.

Much of the coal of the central province is almost equally unavailable for export under present methods of utilization. It is chiefly lignite and is, therefore, not suitable for transportation to the seaboard, a distance of 400 to 600 miles. In the absence of extensive forests these coals will in time, however, have great value for local consumption. The estimated $4,000,000,000$ tons of this coal, aside 
from any additional discoveries in the central region, will supply any probable local demand, especially considering the fact that the extensive peat deposits of the region are also a possible source of fuel.

It has been shown that the coal fields of northern and inland Alaska have no value except for local use. There remains, therefore, only the coals of the Pacific slope for which an export coal trade can be expected to develop. The known coal lands within these fields contain, according to the estimates (p. 54), over 6,000,000,000 tons of coal, of which $3,500,000,000$ tons is of high grade. If the same ratio between tonnage and area holds in the unsurveyed fields, these figures should be multiplied by 10 . It is probably safe to say that these fields contain 50 to 60 billion tons of coal and possibly much more.

The Cook Inlet fields, as well as those of the Alaska Peninsula, lie on or close to tide water and, indeed, for the most part have good harbors, which are ice free throughout the year. These fields are admirably located as regards transportation; but unfortunately their coal is for the most part not of a quality to assure successful competition with other coals tributary to the Pacific Ocean. A few mines have been opened and have found a small local market; but the attempts at export have not met with success. Considering the comparatively high cost of mining and the expense of export on account of lack of return freight, it is not to be expected that these coals can for the present compete in the west-coast market.

On the other hand, the Bering River and Matanuska fields furnish the only known source of high-grade fuels near either the eastern or the western shore of the Pacific Ocean, unless such fuels may be had from the inland coal fields of China. They have, therefore, a great importance to industries of the Pacific coast. From them must come the high-grade steaming and coking coals and anthracite needed by the growing population of the Pacific seaboard States. Unless they are utilized the manufacturing and smelting industries and the navy must depend largely on foreign fuels, except as coal may be brought around Cape Horn or until after the completion of the Panama Canal. Alaska's own need for high-grade coal can be supplied only from these two fields, unless it is furnished by such foreign fuel as is transported for a thousand miles or more.

Railway construction is necessary before the Bering River and Matanuska coals can be brought to tide water. (See pp. 73-76.) The lack of railways is one of the causes which has delayed the development of these coals, as a large investment of capital is necessary before any returns can be expected. Moreover, it increases the cost of the product and places the coal at a corresponding disadvantage with that of such fields as those of Vancouver Island, New South Wales, and some of China and Japan. 


\section{COST OF MINING AND MARKETING.}

GENERAL CONSIDERATIONS.

With regard to operating costs and markets Alaskan coal fields may be divided into two groups. One includes the lignitic and other coals of inland and northern Alaska which have no value for export and can be mined only for local use. The other includes those coals which lie near enough to the open ports of the Pacific to warrant the belief that they may be mined for export from the Territory. Mining costs are not all-important to the fields of the first group, whose product will not be marketed in competition with that of fields more favorably situated; in other words, the selling price will be determined entirely by the local demand and supply. The cost of mining in these isolated fields will depend on their location, the labor supply, etc., and needs no special consideration here. .

On the other hand, the price at which the coals of the Pacific slope can be mined and marketed is of prime importance. Their product, outside of, say, 120,000 tons, ${ }^{a}$ which will more than supply the present local needs, must seek a market in the Pacific coast States, where it will be in direct competition with the coals of British Columbia, Washington, and even Japan and Australia. As the export of the lignitic coals, even from the fields which are on tide water, does not seem commercially feasible under the present demands for fuel, these need not here be considered, and the whole question of mining costs resolves itself into a consideration of those in the Bering and Matanuska fields.

Coal mining in the fields of the Pacific slope of Alaska presents no problems which have not been solved elsewhere. This is equally true of transportation, for no serious physical obstacles have to be overcome in building railways from the coal fields to open ports. The whole question of placing Alaska coal on the market in competition with that from other fields depends, then, on relative cost of production. This, of course, means not only the cost of actual mine operations, but also the interest and other overhead charges. These costs will, for a time at least, be greater than those for mining and marketing coal in the States similarly located with reference to water transportation and distance from points of consumption. It is certain that until a large industry is established the miners' wages will be higher than in the States. With the influx of a permanent mining population, however, wages will gradually adjust themselves and there is no reason why they should continue on a much higher scale than, for example, in the coal fields of Washington or Montana. It is a significan fact that in 1909 the wages of miners 
in the lode distriets along the Alaska seaboard averaged only about 10 per cent higher than those of coal miners in the State of Washington. Mr. Storrs, ${ }^{a}$ a well-known mining engineer, estimates the cost of miners' wages in the Bering River field at 82 per cent of the total cost of mining coal, including the overhead charges. This is only about 6 per cent higher than the average percentage for the coal fields of Washington and Montana. There can be no doubt, however, that pioneer operators will have to stand a high charge for labor until conditions have adjusted themselves. When continuous employment is assured in the Bering River and Matanuska fields economic laws should act to make the wage scale about the same as in Washington. This is evident from the fact that after the railways necessary to coal development have been constructed a miner can be transported from Puget Sound to the Alaskan fields in a few days and at no great cost.

What has been said of labor is also true of supplies and material. In the early stages of development these will be expensive, but the improvement of means of transportation and the general industrial advancement will lower this cost. When the coal fields have been opened on a large scale, supplies and material should be had at the same cost as in the States plus the ocean and railway freight charges, which ought to be low.

The initial expense of installation of mining plants and transportation systems will be large as compared with similar enterprises in the coal fields of the Western States. There are no data which will make it possible to express definitely the ratio of costs between a mining plant in Alaska and one in the States. Probably most engineers would regard it as unsafe to estimate the increased cost in $\Lambda$ laska as less than 20 per cent, and possibly it would be as much as 50 per cent. As a consequence of the larger initial investment, interest charges will be higher than for plants of the same size in more accessible regions. This interest will remain a fixed charge against the cost of mining during the life of the plant, and will not be subject to reduction by improvements of economic conditions, as will the cost of labor and supplies.

In spite of their northern latitude, the climate ${ }^{b}$ in these fields is no more severe than in some of the productive fields in the States. In fact, it can be definitely stated that mining operations will be but little hampered by the climatic conditions. It is possible, however, that snowslides may have to be guarded against in some localities,

a Storrs, A. H., Report on the Cunningham coal lanis and Bering River coal field, November, 1907: Hearings before Joint Comm. to investigate Interior Dept. and Forest Scrvice, March 26, 1910, pp. 2326-2345.

$b$ The annual precipitation in the Bering River field probably between 120 and 140 inches; in the Matanuska feld, about 25 to 40 inches. In the Bering River field the average temperature during the three winter months is about $30^{\circ} \mathrm{F}$; during the summer months, about $51^{\circ} \mathrm{F}$. The records in the Matanuska field are very imperfect, but the summer temperature is higher and the winter temperature lower than in the Bering River field. 
and the excessive rainfall of the Bering River field may interfere somewhat with outdoor work. The operating costs of the railways tapping these two fields will be enhanced by the heavy snows in and along the front of the coastal ranges, which probably average 8 to 12 feet annually.

\section{BERING RIVER AND MATANUSKA FIELDS.}

To forecast the probable market for the Bering and Matanuska coal it will be necessary to make an estimate of the cost per ton delivered at point of consumption. It has been shown that although if either of these two fields were on a productive basis a considerable local market could be found for the output, yet in view of the heavy investment necessary in railways and equipment this local demand would not be sufficient to assure commercial success to the enterprise. In other words, the coal must be delivered in the markets outside of Alaska in competition with that of other fields. Mining and transportation costs are therefore of vital interest to the industry.

The subject of costs is so complex and there are so few reliable data bearing on it that any estimate at present must be regarded as little more than an approximation. Probably no two mining engineers would agree on an estimate of the cost of mining a ton of coal in Alaska and delivering it in the west-coast market.

It is therefore with much hesitancy that the writer presents figures which are based largely on an office study of the problem and to which exception will undoubtedly be taken by men who have had a large practical experience in coal-mining operations. A full statement of the basis of the figures will be given, so that the reader may put his own interpretation on them, and it is hoped that they will at least serve as an approximation. It can not be too strongly emphasized, however, that a difference of, say, 10 cents in the cost of delivering a ton of coal at the point of consumption may mean the difference between success and failure. In other words, the operator under the strong competitive conditions which will exist may have to content himself with as low a profit as 10 cents a ton, the approximate average on bituminous coal mining in the States.

As there has been practically no mining of Alaska's high-grade coals, there is little exact information on which to base estimates of operating costs. Therefore the only way to arrive at such costs is to estimate them on the experience gained in the developed fields of the States. It will simplify this discussion to limit it chiefly to the Bering River field, which is better known than the Matanuska field. The conditions in both fields are in many ways similar except as regards distance to tide water. If anything, the Matanuska field will probably have a little advantage in the actual cost of mining, for its coal beds seem to be somewhat less disturbed than those of the 
Bering River field. This will, however, be more than offset by the extra railway haul, amounting to about 130 miles. The Matanuska field, again, appears to have the advantage in having a greater percentage of high-grade coking coal, an important matter where there is liable to be a large proportion of slack, which has far less value than lump coal, unless it can be utilized for making coke.

The cost of mining the Bering River coal will probably be greater than that of mining in the Washington fields, which averages about $\$ 1.90$ a ton, including labor, supplies, and all fixed charges. According to the census figures of 1902, the cost of coal mining in Washington varied from an average of $\$ 1.26$ a ton in the Roslyn field to $\$ 2.16$ a ton in the Carbon River field. The maximum and minimum costs, of course, lie above and below these figures, which are averages of districts. These figures are based on statistics gathered eight years ago, and since that time there may have been some improvements in methods of mining and economies by reason of larger operations. On the other hand, wages have increased about 25 per cent and there has also been an increase in the cost of supplies. It is not likely, therefore, that total mining costs have materially changed.

The difference in mining costs between the Roslyn and Carbon River fields appears to be largely due to the disturbed condition of the beds in the latter. It is also chargeable to the fact that the operations in the Roslyn field are on a larger scale than those in the Carbon River field. Many of the coal beds in the Bering River field may be as much folded and faulted as those in the Carbon River field, and hence it does not seem probable that the cost of mining will be very different except as influenced by the price of labor and supplies. Therefore it will probably not be safe to place the cost of mining, including fixed charges, in the Bering River field at less than $\$ 2$ a ton. It is true, however, that in the Bering River, as in other fields, there are some coal beds which can be mined for much less than others, and this price is intended to represent an average.

It is of interest to note that Mr. Storrs in the report cited estimates the cost of mining in the Bering River field, including all fixed charges, at $\$ 1.93$ to $\$ 1.96$ a ton. Stephen Birch, on the other hand, in his testimony before the joint committee, estimated the cost of mining at $\$ 1.75$ a ton, and it appears that he also included in this all fixed charges. In presenting the case of Alaska coal miners before the Interior Department, Falcon Joslin ${ }^{a}$ placed the cost of mining at $\$ 2$ a ton. The consensus of opinion, therefore, seems to be that the coal can be mined at a cost between $\$ 1.75$ and $\$ 2$ a ton.

It would be of interest to compare these figures with the cost of mining in the Vancouver Island collieries. Unfortunately no state-

a Senate Doc. 248, 61st Cong., 2d sess., 1910, p. 200. 
ments of the cost of mining in these fields have been published. The writer has been advised, however, that the cost is between $\$ 2$ and $\$ 2.50$ a ton. It is probable that these estimates include something for transportation, though this item probably does not exceed 10 or 20 cents. These costs seem abnormally high, as the wage scale is somewhat lower than that of the Washington fields and the coals are certainly less disturbed than those of the Carbon River district.

This estimate of $\$ 2$ a ton refers to the bituminous coal and is intended to include all operating expenses, such as labor and supplies, as well as interest and other overhead charges. Anthracite mining, including breaking and sizing, will probably be more expensive. Finlay ${ }^{a}$ has estimated the cost of anthracite mining in Pennsylvania at $\$ 1.29$ a ton for run-of-mine coal and at $\$ 1.93$ a ton for coal actually marketed. Cf this amount about 40 cents represents the cost of breaking the coal after it is mined. The average cost of bituminous-coal mining in Pennsylvania is estimated by Finlay at $\$ 1.03$ a ton. In other words, in Pennsylvania the anthracite costs about 60 per cent more per ton f. o. b. than the bituminous coal.

These ratios between the cost of bituminous and that of anthracite mining are not likely to hold in the Bering River field. It is true, however, that the anthracite coal occurs in the most complexly folded part of the field, and that the cost of mining, including sizing, will therefore probably average higher than that for the bituminous coal. It is evident that the percentage of culm will be an important factor in anthracite mining. The slack coal can in part be used as fuel at the mine, but this will not consume more than 10 per cent of the gross output. Unless, therefore, some market can be made for the culm by briquetting or otherwise it will be wasted and thereby increase the cost of the coal actually marketed.

The cost of transportation, the second large item, is even more difficult to determine than that of mining. Transportation cost can be conveniently divided into three items-(1) railway rate to tide water, including loading charges; (2) ocean freight ${ }^{b}$ to Puget Sound or other ports; (3) unloading charges. For the purpose of this discussion only the Bering River field will here be considered, but the same figures should apply to the Matanuska field by adding the additional amount necessary for the longer railway haul. There are two general projects for reaching the Bering River field by railway; one contemplates the extension of a branch line from the nearest point on the Copper River and Northwestern Railway to the coal field, using Cordova as a terminal. The mileage of such a railway by the shortest route, via Lake Charlotte, would be about 58

a Finlay, J. R., The cost of mining, New York, 1909, pp. 77-78.

b It has been noted that there is some market for the coal in $\Lambda$ laska, but not sufficient to warrant development on a large scale. 
miles, ${ }^{a}$ of which 25 would be the branch line and 33 over the main line already constructed. The other plan is to build directly from Controller Bay, a distance of some 27 miles to the coal field. For the purpose of this discussion the cost of shipment via the longer route will be emphasized, as giving probably a maximum cost. It should be noted, however, that the longer railway haul to Cordova may in part be offset by the additional investment necessary for providing terminal facilities at Controller Bay. Recent soundings by the Coast Survey, ${ }^{b}$ however, have revealed a deep-water channel extending into Controller Bay between Wingham and Kanak islands. This channel is protected from the ocean by Kayak, Kanak, and Wingham islands and Okalee spit. It has been said by some who are opposed to the route that during some of the winter months slush and ice might interfere with the shipping. Be this as it may, it remains to be proved that any disadvantages are sufficiently serious to offset the 30 miles extra haul to Cordova. In any event the possibilities of shipment through Controller Bay must be taken into account in estimating the costs of transportation.

In attempting to estimate the cost of this 58 miles railway haul to Cordova, many difficulties are encountered. One unknown factor is the tonnage which should be assured. Obviously a large tonnage will reduce the cost per ton-mile. Most of the available figures on cost of railway transportation of coal are for lines which handle many millions of tons annually. The average cost on bituminous coal in the States is about 7 mills per ton-mile, but this figure is clearly not applicable to a short line like that under discussion, with a comparatively small tonnage and heavy operating expenses. It would be equally misleading to use the maximum freight rates per ton-mile in the States, which are as high as 3 to 4 cents. Another uncertain factor in considering the Cordova route is the question how to proportion the charge between the main line and the coal branch, and hence to determine whether the expense of the bridge across Copper River must be a charge on the coal tonnage.

As at best, however, the figures can only be approximate, it will serve the purpose of this discussion if certain assumptions are made. It will be assumed that during the first ten years after the railway is completed an average of $1,000,000$ tons of coal will be hauled over the railway annually. Furthermore, it will be assumed that the cost over the branch line, which must be supported by the coal traffic, will be 2 cents a ton-mile and over the main line 1 cent a ton-mile. This will give an average of 1.43 cents a ton-mile for the entire distance, or 83 cents for the railway charge to Cordova. As these estimates are only approximate, the railway haul including the loading 
at Cordova will be put in round numbers at 85 cents. If Controller Bay is used as a harbor and is available for use the entire year, the same rates per ton-mile will make the cost of haulage to tide water 54 cents, to which should be added say 12 cents ${ }^{a}$ a ton for extra charges on loading, because of the more expensive ocean terminal.

The freight rate to Seattle is assumed to be 85 cents a ton. This is probably low for a production of only $1,000,000$ tons, for it can be obtained only by providing a fleet of colliers. The distance from Seattle to Controller Bay is about 1,200 miles; to Cordova about 1,350 miles. Freight rates on iron ore from the head of Lake Superior to Ohio ports, a distance of about 1,000 miles, varied from 75 cents a ton in 1907 to 65 cents in 1909 . On the lakes the ore carriers are laid up about four months in the year, whereas the Pacific ports of Alaska are open throughout the year. Moreover, the lake ore carriers have the delay of passing through the St. Marys canal. On the other hand, they carry down annually nearly $40,000,000$ tons of freight and also have return cargoes of several million tons. The freight on coal from the Nova Scotia fields to New England ports, a distance of 800 to 900 miles, is 75 cents a ton. Alaska coal carriers could not count on any return freight. Therefore a freight rate of 85 cents a ton is probably not too high. The charges for unloading are assumed to be 15 cents a ton.

These estimates have included only the profit on the transportation and not that of the coal-mine operator. The average profit in bituminous-coal mining in the States is about 10 cents a ton. Considering that Alaska is a new and undeveloped field it is not likely that capital would be attracted by so low a profit; this is therefore here estimated at 25 cents a ton.

Estimated cost per ton of mining and shipping Bering River coal.

\begin{tabular}{|c|c|c|}
\hline . & $\begin{array}{c}\text { Via Con- } \\
\text { troller } \\
\text { Bay. }\end{array}$ & $\begin{array}{l}\text { Vla Cor- } \\
\text { dova. }\end{array}$ \\
\hline \multirow[t]{2}{*}{ 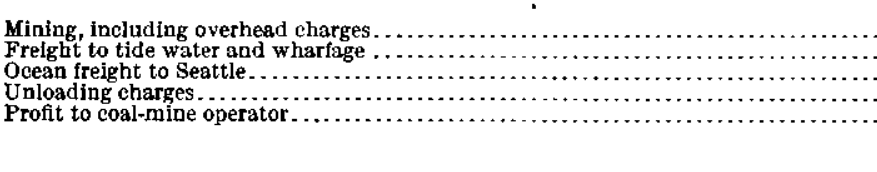 } & $\begin{array}{r}82.00 \\
.66 \\
.85 \\
.15 \\
.25\end{array}$ & $\begin{array}{r}82.00 \\
.85 \\
.85 \\
.15 \\
.25\end{array}$ \\
\hline & 3.91 & 4.10 \\
\hline
\end{tabular}

If the Matanuska coal proves cheaper to mine, as may be the case because it appears to be less folded and faulted, a corresponding saving should be made. On the other hand, the railway haul is some 125 to 160 miles longer than that from the Bering River

a This figure is obtained by estimating the cost of the terminal at Controller Bay as $\$ 1,000,000$. The Interest charges on this amount at 5 per cent would be $\$ 50,000$. The cost of upkeep and depreciation in value are assumed to amount to 7 per cent, or $\$ 70,000$, making $\$ 120,000$ in all, or 12 cents a ton on a million tons of coal. 
field, and this item, even at a much lower rate than has here been considered, will add considerably to the cost of coal at tide water. It is probably conservative to add at least $\$ 1$ a ton for the cost of the Matanuska coal delivered at Puget Sound. ${ }^{a}$ It has been shown that the cost of mining and preparing anthracite for the market will be greater than for the bituminous coal. If this assumption is correct the Bering River anthracite might be put, delivered at Seattle, at a cost of, say, $\$ 5$ a ton.

According to the above figures the Bering River bituminous coal should be delivered at the wharf in Seattle at $\$ 3.91$ to $\$ 4.10$ a ton and the anthracite from the same field for, say, $\$ 5$. The Matanuska bituminous coal might be delivered at Seattle for $\$ 5 .^{a}$ These coals can probably be delivered at Oregon and California ports at an additional cost of not more than 50 cents a ton.

These figures are based on an assumed annual shipment of $1,000,000$ tons. It does not seem likely that the long haul from the Matanuska field could be profitably maintained at the low mile-tonnage rates here used, unless the amount of coal shipped were very much larger or the railway were maintained by other business. If two competitive roads are constructed in the Bering River coal field the freight rate might be less than that here used. On the other hand, an annual business of 1,000,000 tons could hardly support two railways, let alone three. This explanation is made so that the writer may not be credited with the opinion that the haulage of a million tons of coal can support several hundred miles of railway. A million tons has been used as a convenient figure and because it seems the maximum of coal which the present west-coast market can absorb. (See pp. 94-95.)

With the increase in population and the industrial advancement of the Pacific coast province there will be a constantly growing market for the high-grade fuels which Alaska can supply. It is to be expected that this demand will so increase that in time thrce railways can be profitably maintained. When this time comes, competition will bring about economies in transportation and possibly in mining, which will in turn extend the market for this coal. The percentage of slack coal produced which is less valuable for steam and unfit for domestic use is another important element to consider in this connection. This slack coal could be used for making coke if there were sufficient market for the output. If, however, the slack is in any sense a waste product, it might enhance the cost of the salable coal to the point of seriously curtailing the market. A determination of the percentage of fine coal can be made only after actual mining has begun, and even then it is likely to vary from place to place and from bed to bed.

a If a summer terminal can be established on Knik Arm (see p. 58) transportation charges will be less. 


\section{VALUE OF AIAASKA COAL LANDS.}

Though the valuation of the Alaska coal lands is rather outside the scope of this article, yet it will be briefly considered, both because it has recently attracted widespread interest and because it is a subject about which many misconceptions are current. The broad economic fact of the ultimate value to future generations of all the Alaska coal fields is not open to argument. At some distant time in the future, when the more accessible coals approach exhaustion, all the Alaska coal beds, no matter how remote or difficult of access, will have value, unless by that time some other source of energy finds utilization. This wide-reaching problem of economics has, however, but little bearing on the present monetary value of the coal lands. The term value as here used is intended to mean the highest present purchase price on which there will be a reasonable certainty of obtaining returns by the profit realized from the sale of the product of mining.

Many factors must be taken into account to estimate the money value of a given body of coal. Perhaps the most important of these is geographic position. If a coal field can not be made accessible by railway or steamer under present commercial conditions it has only a future or speculative value. The time when this coal can be economically brought to market may be so far distant that no individual or corporation can afford to purchase the coal lands, and then the field can be said to have no monetary value, though it must be taken into account by the economist who is considering ultimate fuel resources. Such a coal field must be classed simply as an asset of mankind, valuable at some distant time in the future when the more accessible coal fields are exhausted. It is probably safe to say that only under very exceptional conditions would a corporation purchase coal lands that could not be developed in less than a century. For example, there are known to be very extensive coal fields in northern Alaska beyond the Aretic Circle. Though these fields include some high-grade coals, they can hardly be said to have any present monetary value.

The same principle applies to coal beds either too thin or lying too deep for commercial recovery under any demands that can $l e$ foreseen. In estimating the value of Alas... a c $c$ al land the a erage engineer will probably disregard any coal bed less t'lan 2 feet in thickness, and also heavily discount any bed more than 2,000 feet in de? th. Such coal beds, though they will eventually be mined, have no present monetary value, and yet must be included in estimating the tonnage of the ultimate coal reserves.

It is self-evident that the quality of the coal is an important factor in the valuation. It often costs as much to mine a lignite as a 
bituminous coal, and yet the end product may be worth only twothirds or half as much. On the other hand, if there is no competition with fuels of better grade, the lignites may sell at a price sufficiently high to assure a profit. $\Lambda$ s, however, much the larger part of the coal production of the world is consumed at or near tide water, high-grade fuels are usually transported at comparatively low cost. The improvements in gas-producer engines may eventually bring up the value of lignites by making them more available as a source of power. It is conceivable that such progress might even depress the value of bituminous coals by bringing them into competition with the more abundant lignites.

Under quality of coal must be considered not only composition and purity, which determine heat units, but also physical character. For example, there may be beds of high-grade coal in some of the Alaska fields that are so crushed as to be of little value at present. When, however, at some distant time in the future the demand for coal on the west coast has become greater than the uncrushed beds can be made to supply, even the crushed coal beds may be exploited for use under boilers or in making coke or briquets. Ilere again the crushed coal beds, though they may have no immediate money value, form a part of the ultimate fuel resources.

Cost of mining is of course one of the important elements in the valuation of a coal bed. Geographic isolation will increase costs in the early years of the development of a field because of the high price of labor, supplies, etc., but with the larger operations these costs are in time usually reduced. A far more important element in the cost of mining the coal is inherent in the character of the deposit. Complex folding very materially increases the cost of mining. Thickness of beds is also important, for the cheapest mining is done within certain limits, above and below which the cost is increased. The character of roof and floor may also have an appreciable influence on operating costs. Among many other factors the presence or absence of gas is important, as is also the position of the coal relative to the surface and the presence of ground water, for the hoisting of coal and the pumping of water add materially to the cost of production.

The market for the coal is another important element in determining value. Coal lands for whose product there is an unlimited market-other conditions being equal-will have a higher value than those for which a market must be developed. If it will take ten years, say, to develop a market for the coal of a particular field, it is self-evident that this element will discount the present money value of the land.

Coal lands purchased at a certain price must, of course, carry the compound interest charges and taxes until such time as returns can be 
had from the product of mining. In other words, an acre of coal land held undeveloped for any period will, at the end of that time, represent not only the amount originally invested, but also the interest charges on that investment. ${ }^{a}$ This can be best illustrated by an example. Suppose that coal lands are purchased at $\$ 10$ an acre ${ }^{b}$ and held without development for one liundred years. Then, compounding the interest annually at 5 per cent, the lands at the end of the century will represent an investment of $\$ 2,634$ an acre, plus any taxes that may have been paid, with the interest thereon.

On applying the above consideration to Alaska fields it is found that probably the coal representing over half the known tonnage value will not be available for use until some distant time in the future and therefore can not be said to have any present monetary value. This includes most of the coal of the Arctic slope and over half that in the interior region.

Of the rest, it can be said of the lignites that their value is not high. Those lying on the Pacific seaboard must come into direct competition with better grades of coal, except in a very local market. The lignites of the interior can be mined and transported only at high cost, and hence their value under present conditions is very low. It remains to consider the value of the high-grade coals of the Bering River and Matanuska fields. Private coal lands are ordinarily sold by the acre, and in the past often little consideration has been given to the quantity of coal they contain. In the best practice now, however, the quantity of coal is estimated before a valuation is placed on the land. ${ }^{\circ}$ In other words, the coal is estimated at so much a ton in the ground. Those unfamiliar with coal mining find it hard to understand why the value of a ton of coal in the ground should be so very small a fraction of its market price to the consumer. They lose sight of the facts that the coal in the ground is the raw material which the miner by his labor manufactures and the railway company transports, and that, as a rule, before the coal reaches the consumer several different individuals or corporations must have made a profit out of it.

The writer ${ }^{d}$ has roughly estimated the accessible coal of the Bering and Matanuska fields as having a value of half a cent a ton in the ground. Exception has been taken to this valuation, but chiefly on the part of those who have given little consideration to the matter and who think of the value of coal in terms of its retail price to the consumer. To these persons a valuation of half a cent appears another way of expressing the thought that these lands have no value at all. This is, however, far from being the case, for half a cent

a It is assumed that there are no surface values to the land that can afford any returns.

b This is the present price fixed by law at which public coal lands in Alaska, more than 15 miles from a railway, are sold.

c Ashley, George H., The valuation of public coal lands: Bull. U. S. Geol. Survey, No. 424, 1910,

$d$ Hearings before Joint Comm. to investigate Interior Dept. and Forest Service, 1910, p. 2845. 
a ton is higher than the value of most of the eastern coal lands, ${ }^{a}$ in spite of the fact that they are close to the centers of population and hence to markets. In fact, in some of the well-developed eastern fields good bituminous coal has recently sold for as low as onethirteenth of a cent a ton in the ground.

If this ton value is transposed to a basis of so much per acre, it will admit more readily of comparisons. Few tonnage estimates have been made on the Bering River and Matanuska coal fields, but the best information available indicates that these lands will yield between 10,000 and 100,000 tons to the acre. This means that some of the lands will yield only 10,000 tons of coal to the acre; others may yield as much as 100,000 tons. Multiplying this acre tonnage by half a cent (the estimated value of the coal in the ground) indicates that these lands are worth from $\$ 50$ to $\$ 500$ an acre. Such values are far above the average of the bituminous-coal lands in the United States. Although the lands containing the coking coals of Pennsylvania have sold for $\$ 800$ to $\$ 2,000$ an acre, ${ }^{b}$ in the other Appalachian fields the average values are $\$ 10$ to $\$ 386$, in the central fields $\$ 10$ to $\$ 200$, and in the Rocky Mountain fields $\$ 10$ to $\$ 500 .^{c}$ It is evident, therefore, that the valuation of half a cent a ton for coal in the ground, far from being too low, is higher than the average in the States, and it is at least an open question whether purchasers at this rate could be found.

\section{MARKET.}

\section{INTRODUCTION.}

The possible markets for Alaska coal are, first, within the Territory itself, where, except for Seward Peninsula, ${ }^{d}$ it can effectually shut out the imported fuels; second, in the Pacific States and Territories. It is improbable that, under the estimated cost of mining (see pp. 69-76), the Alaska coal can compete in foreign markets.

The present Alaska market can not support the large coal-mining industry which will be necessary to assure economic operations. Consequently Alaska coal will have to invade fields already supplied from other sources and come into direct competition with that which is mined in more accessible and more favored regions. It therefore becomes pertinent to this argument to inquire into the coal trade and, so far as possible, to present figures of consumption and prices.

The west coast is now chiefly supplied from the Washington and British Columbia fields. The fields of California, Oregon, and the

a Comprare Bull. U. S. Geol. Survey No. 424.

$b$ See Bull. 424.

c The ririces quoted are based on actual sales of private lands.

a This refers to the bituminous coals of the Pacific slope, for experience has shown that the lignitic ccals of the northeastern part of Seward Peninsula can compete with the imported fuels. 
Rocky Mountains also supply some coal, as do those of New South Wales, Australia. Anthracite is brought from Pennsylvania, and during the last few years the Pacific fleet has been supplied from the New River and Pocahontas fields of West Virginia. Belgian coal in the form of coke also finds its way to the Pacific coast, and in some years there has been a considerable importation of Japanese and British coals. It would appear at first sight, therefore, that the market is under strong competition, especially in view of the large consumption of fuel oils. As a matter of fact, the price of coal on the coast, except in some portions of the area in close proximity to the domestic fields, has always been very high. The reasons for these conditions are too complex to permit analysis here. It appears, however, that the Washington fields supply not much more than enough for the markets of the State, and that the foreign coals dominate the California market. An important change will take place when the eastern coals reach the Pacific through the Panama Canal.

The statistics of coal and coke production annually published by E. W. Parker ${ }^{a}$ leave nothing to be desired. The annual importations of coal are stated in the reports of the Bureau of Statistics. ${ }^{b}$ For the local consumption of coal, far less reliable data are available. Mr. Parker's reports, which also deal with the general conditions of the coal trade, give much information, which the writer has supplemented by data gathered from trade journals, consular reports, and publications of boards of trade and state mine inspectors. These are the bases for the figures of coal consumption presented in the tables to follow, which are believed to be sufficiently accurate for the purposes of this discussion.

The production of the California oil fields during the last decade has been the controlling factor in the coal trade of the Pacific seaboard. Coal consumption has increased somewhat, yet not in anything like the ratio of the petroleum consumption. It is roughly estimated that 80 per cent of the California oil is used as fuel in the Pacific coast States and Territories. On expressing this fuel oil in the equivalent amount of coal, it is found that in 1908 the fuel-oil consumption was equal to nearly $12,000,000$ tons of coal, compared with a total coal consumption of only about 4,500,000 tons. If it were not for the oil, there would apparently be a market for three or four times as much coal as is now used, though it is of course true that cheap fuel oil has stimulated certain industries which might not have developed if dependent on coal.

a Annual volume, Mineral resources of the United States, publisbed by U. S. Geol. Survey.

8 Austin, O. P., Foreign commerce and navigation of the United States, annual volume.

$55695^{\circ}-$ Bull. $442-10 \longrightarrow 6$ 
The following table is an attempt to estimate the consumption of mineral fuels in the Pacific coast States and Territories. For convenience of comparison the oil and coke are expressed in their equivalent of coal.

Estimated consumption of mineral fuels in Pacific coast States and Territories, 1899 to 1908, expressed in short tons of coal.

\begin{tabular}{|c|c|c|c|c|c|c|c|c|}
\hline \multirow[b]{2}{*}{ Year. } & \multirow[b]{2}{*}{$\begin{array}{l}\text { Petro- } \\
\text { leum.a }\end{array}$} & \multirow[b]{2}{*}{ Coke.b } & \multicolumn{4}{|c|}{ Coal. } & \multirow[b]{2}{*}{$\begin{array}{l}\text { Total coal } \\
\text { and coke. }\end{array}$} & \multirow[b]{2}{*}{$\begin{array}{l}\text { Grand } \\
\text { total. }\end{array}$} \\
\hline & & & Domestic. & Imported. & Total. & $\begin{array}{c}\text { Percent- } \\
\text { age of } \\
\text { domestic } \\
\text { coal. }\end{array}$ & & \\
\hline \multirow[t]{2}{*}{$\begin{array}{l}1899 \ldots \ldots \\
1900 \ldots \ldots \\
1901 \ldots \ldots \\
1902 \ldots \ldots \\
1903 \ldots \ldots \\
1904 \ldots \ldots \\
1905 \ldots \ldots \\
1906 \ldots \ldots \\
1907 \ldots \ldots \\
1908 \ldots \ldots\end{array}$} & $\begin{array}{r}704,000 \\
1,153,000 \\
2,343,000 \\
3,729,000 \\
6,501,000 \\
5,929,000 \\
9,580,000 \\
8,826,293 \\
10,610,000 \\
11,961,000\end{array}$ & $\begin{array}{l}109,528 \\
137,675 \\
116,886 \\
195,379 \\
209,651 \\
185,275 \\
218,852 \\
426,664 \\
196,020 \\
197,122 \\
\end{array}$ & $\begin{array}{l}2,620,690 \\
2,983,480 \\
3,052,585 \\
3,130,990 \\
3,744,225 \\
3,642,839 \\
3,356,600 \\
3,617,653 \\
4,237,638 \\
3,645,612\end{array}$ & $\begin{array}{r}954,784 \\
1,107,336 \\
1,260,056 \\
1,233,762 \\
925,960 \\
1,011,582 \\
806,329 \\
809,979 \\
1,129,533 \\
923,533\end{array}$ & $\begin{array}{l}3,575,474 \\
4,090,816 \\
\mathbf{4}, 312,641 \\
\mathbf{4}, 364,752 \\
\mathbf{4 , 6 7 0 , 1 8 5} \\
\mathbf{4 , 6 5 4 , 4 2 1} \\
\mathbf{4}, 162,929 \\
\mathbf{4}, 427,632 \\
5,367,171 \\
4,569,145\end{array}$ & $\begin{array}{l}73+ \\
73- \\
71- \\
72- \\
80+ \\
78+ \\
81- \\
82- \\
79- \\
80-\end{array}$ & $\begin{array}{l}3,685,002 \\
4,228,491 \\
4,429,527 \\
4,560,131 \\
4,879,836 \\
4,839,696 \\
4,381,781 \\
4,854,296 \\
5,563,191 \\
4,766,267\end{array}$ & $\begin{array}{r}4,389,002 \\
5,381,491 \\
6,772,527 \\
8,289,131 \\
11,380,836 \\
10,768,696 \\
13,961,781 \\
13,680,589 \\
16,173,191 \\
16,727,267 \\
\end{array}$ \\
\hline & $61,336,293$ & $1,993,052$ & $34,032,312$ & $10,162,854$ & $44,195,166$ & $77+$ & $46,188,218$ & $107,524,511$ \\
\hline
\end{tabular}

$a$ Equivalent of estimated consumption of California petroleum used as fuel ( 3 barrels $=1$ ton of coal).

$b$ Equivalent of coke produced and imported.

During the ten years 1899 to 1908 , according to the foregoing table, the ratios of mineral fuel consumption were as follows: Coal, 41.1 per cent; coke, 1.9 per cent; fuel oil, 57 per cent. Of the coal 77 per cent was from domestic sources, and of this the Washington fields supplied about 85 per cent. British Columbia supplied about 50 per cent of the foreign coal and Australia about 20 per cent.

\section{COAL CONSUMPTION IN THE PACIFIC STATES AND TERRITORIES.}

It is the purpose of this section to discuss the coal consumption in several of the States and Territories which are believed to offer possible markets for Alaska coal. The Hawaiian coal consumption is not stated separately, though included in the above totals, for, except that used by the navy, it amounts to little. The coal consumption of the Philippine Islands will also not be discussed, for the coal fields of the islands appear to be ample for local needs, ${ }^{a}$ and even if these were insufficient, the comparatively close proximity of the coal fields of Japan, Australia, and China would probably prevent the Alaska coal from competing in this market.

a Smith, Warren D., The coal resources of the Philippine Islands: Econ. Geology, vol. 4, 1909, pp. 224-238. 
Coal consumption of Alaska, by sources, 1899 to 1908, in short tons.

\begin{tabular}{|c|c|c|c|c|c|c|c|}
\hline \multirow{2}{*}{ Year. } & \multicolumn{2}{|c|}{$\begin{array}{l}\text { Imported from States, } \\
\text { chlefly from Wash- } \\
\text { ington. }\end{array}$} & \multirow{2}{*}{$\begin{array}{l}\text { Produced } \\
\text { in Alaska, } \\
\text { chiefly sub- } \\
\text { bituminous } \\
\text { and lignite. }\end{array}$} & \multirow{2}{*}{$\begin{array}{l}\text { Total do- } \\
\text { mestic. }\end{array}$} & \multirow{2}{*}{$\begin{array}{l}\text { Total for- } \\
\text { eign coal, } \\
\text { chiedy bi- } \\
\text { tuminous } \\
\text { from Brit- } \\
\text { ish Colum- } \\
\text { bia. }\end{array}$} & \multirow{2}{*}{$\begin{array}{l}\text { Total coal } \\
\text { consumed. }\end{array}$} & \multirow{2}{*}{$\begin{array}{l}\text { Percentage } \\
\text { of domestic } \\
\text { coal. }\end{array}$} \\
\hline & $\begin{array}{l}\text { Bitumi- } \\
\text { nous. }\end{array}$ & $\begin{array}{l}\text { Anthra- } \\
\text { cite. }\end{array}$ & & & & & \\
\hline \multirow[t]{2}{*}{$\begin{array}{l}1899 \ldots \ldots \ldots \\
1900 \ldots \ldots \\
1901 \ldots \ldots \\
1902 \ldots \ldots \ldots \\
1903 \ldots \ldots \ldots \\
1904 \ldots \ldots \\
1905 \ldots \ldots \ldots \\
1906 \ldots \ldots \ldots \\
1907 \ldots \ldots \ldots\end{array}$} & $\begin{array}{r}\text { a } 10,000 \\
15,048 \\
\text { a } 24,000 \\
\text { a } 40,000 \\
64,625 \\
36,689 \\
67,707 \\
68,900 \\
45,130 \\
23,402 \\
\end{array}$ & $\begin{array}{r}\cdots \\
\cdots \\
\cdots \\
633 \\
1,116 \\
491 \\
\end{array}$ & $\begin{array}{r}1,200 \\
1,200 \\
1,300 \\
2,212 \\
1,447 \\
1,694 \\
3,774 \\
5,541 \\
10,139 \\
3,107 \\
\end{array}$ & $\begin{array}{l}11,200 \\
16,248 \\
25,300 \\
42,212 \\
66,073 \\
38,383 \\
71,487 \\
75,034 \\
56,385 \\
27,000 \\
\end{array}$ & $\begin{array}{r}50,120 \\
56,623 \\
77,674 \\
68,363 \\
60,605 \\
76,815 \\
72,567 \\
47,590 \\
\text { b } 88,596 \\
\text { c } 72,831 \\
\end{array}$ & $\begin{array}{r}61,320 \\
72,871 \\
102,974 \\
110,575 \\
126,678 \\
115,198 \\
144,054 \\
122,624 \\
144,981 \\
99,831 \\
\end{array}$ & $\begin{array}{l}18.26 \\
22.30 \\
24.58 \\
38.18 \\
52.16 \\
33.32 \\
49.63 \\
61.19 \\
38.89 \\
27.05\end{array}$ \\
\hline & 394,561 & 2,147 & 31,614 & 429,322 & 671,784 & $1,101,106$ & 38.99 \\
\hline
\end{tabular}

$a$ Estimated.

b Fiscal year ending June 30, 1907.

c Fiscal year ending June 30, 1908.

Alaska coal consumption has fluctuated greatly, as shown in the above table. This has been due, in part, to the lack of settled conditions in the placer fields. The great number of small plants in operation on the elevated beaches near Nome accounts somewhat for the large coal consumption of certain years. Railway construction, the amount of which has varied, also increases the consumption of coal. On the other hand, the amount of coal used by the canneries and lode mines along the Pacific seaboard steadily increased until 1908, when the Treadwell group of mines substituted oil-burning for coal-burning engines.

In 1908 about 30,000 tons of coal was consumed on Seward Péninsula, amounting to about 30 per cent of the total. It is by no means certain that the coal of the Bering River and Matanuska fields could compete in the Seward Peninsula market with that from other sources. These fields would have little advantage in distance of transportation to the Nome market over those of the Washington and Vancouver Island fields. If, however, the demand for coal in Seward Peninsula should increase, it might be worth while to consider the possibilities of supplying it from the Alaska Peninsula, only 700 miles distant from Nome.

In addition to the coal, Alaska is also a large consumer of fuel oil, as is shown in the following table. This oil is shipped to all settled parts of the Territory, including the interior and Seward Peninsula. It is used by many small mining plants in Seward Peninsula, by the Yukon River steamers, and very extensively for launches and small vessels throughout the seaboard. 
Shipments of petroleum to Alaska, 1902 to 1908.

\begin{tabular}{|c|c|c|c|}
\hline Period. & Crude pet & roleum. & Naphthas. \\
\hline 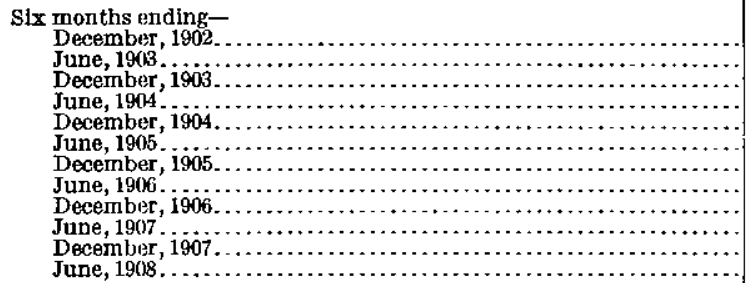 & $\begin{array}{r}\text { Gallons. } \\
21,000 \\
840,000 \\
1,008,000 \\
1,008,400 \\
1,008,030 \\
1,780,326 \\
935,060 \\
11,428,000 \\
1,260,100 \\
2,545,200 \\
6,558,500 \\
3,852,940\end{array}$ & $\begin{array}{r}\text { Barrels. } \\
500 \\
20,000 \\
24,000 \\
24,010 \\
24,001 \\
42,389 \\
22,263 \\
34,002 \\
30,000 \\
60,600 \\
156,155 \\
91,736\end{array}$ & $\begin{array}{r}\text { Gallons. } \\
60,358 \\
210,147 \\
84,776 \\
231,658 \\
106,623 \\
499,196 \\
214,300 \\
361,681 \\
219,297 \\
354,210 \\
282,671 \\
599,959\end{array}$ \\
\hline
\end{tabular}

The coal consumption of the State of Washington has probably less bearing on the question of markets for Alaska coal, because in this State there would be very strong competition with the local fields. At the same time the Alaska coal is of so much higher grade than the average of that from Washington fields that for some purposes it would dominate the market, provided it could be sold at competitive prices, considering the relative fuel values. This is particularly true of the coal used for ocean vessels.

Estimated coal consumption of Washington and Oregon, by sources, 1899 to 1908, in short tons.

\begin{tabular}{|c|c|c|c|c|c|c|c|c|}
\hline \multirow[b]{2}{*}{ Year. } & \multicolumn{2}{|c|}{ Domestic. } & \multicolumn{2}{|c|}{ Foreign. } & \multirow[b]{2}{*}{$\begin{array}{c}\text { Total } \\
\text { domestic. }\end{array}$} & \multirow[b]{2}{*}{$\begin{array}{c}\text { Total } \\
\text { foreign. }\end{array}$} & \multirow[b]{2}{*}{$\begin{array}{l}\text { Grand } \\
\text { total. }\end{array}$} & \multirow[b]{2}{*}{$\begin{array}{l}\text { Percent- } \\
\text { age of } \\
\text { domestic. }\end{array}$} \\
\hline & $\begin{array}{l}\text { Washing- } \\
\text { ton and } \\
\text { Oregon } \\
\text { fields. }\end{array}$ & $\begin{array}{c}\text { Other } \\
\text { domestic } \\
\text { flelds. }\end{array}$ & $\begin{array}{l}\text { Imported } \\
\text { at Pacific } \\
\text { coast } \\
\text { ports. }\end{array}$ & $\begin{array}{c}\text { Estimated } \\
\text { consump- } \\
\text { tion of } \\
\text { Canadian } \\
\text { coal in } \\
\text { eastern } \\
\text { Washing- } \\
\text { ton. }\end{array}$ & & & & \\
\hline \multirow[t]{2}{*}{$\begin{array}{l}1899 \ldots \ldots \\
1900 \ldots \ldots \\
1901 \ldots \ldots \\
1902 \ldots \ldots \\
1903 \ldots \ldots \\
1904 \ldots \ldots \\
1905 \ldots \ldots \\
1906 . \ldots \ldots \\
1907 \ldots \ldots \\
1908 \ldots \ldots\end{array}$} & $\begin{array}{l}1,390,474 \\
1,766,083 \\
1,896,245 \\
2,256,766 \\
2,747,272 \\
2,803,93 \\
2,640,755 \\
3,112,904 \\
3,569,774 \\
3,024,256\end{array}$ & $\begin{array}{r}2,000 \\
500 \\
200 \\
300 \\
300 \\
200 \\
200 \\
300 \\
300 \\
300\end{array}$ & $\begin{array}{r}19,477 \\
20,976 \\
16,744 \\
39,116 \\
41,010 \\
51,170 \\
33,433 \\
69,685 \\
99,245 \\
157,704\end{array}$ & $\begin{array}{r}21,000 \\
12,000 \\
16,000 \\
62,000 \\
39,000 \\
73,000 \\
69,000 \\
113,000 \\
109,000 \\
164,000\end{array}$ & $\begin{array}{l}1,392,474 \\
1,766,583 \\
1,896,445 \\
2,287,066 \\
2,747,572 \\
2,804,137 \\
2,640,955 \\
3,113,204 \\
3,570,074 \\
3,024,556\end{array}$ & $\begin{array}{r}40,477 \\
32,976 \\
32,744 \\
101,116 \\
80,010 \\
124,170 \\
102,433 \\
182,685 \\
208,245 \\
321,704\end{array}$ & $\begin{array}{l}1,432,951 \\
1,799,559 \\
1,929,189 \\
2,388,182 \\
2,827,582 \\
2,928,307 \\
2,743,388 \\
3,295,889 \\
3,778,319 \\
3,346,260\end{array}$ & $\begin{array}{l}97 \\
99 \\
88 \\
96 \\
97 \\
96 \\
96 \\
94 \\
94 \\
90\end{array}$ \\
\hline & $25,238,466$ & 4,600 & 548,560 & 678,000 & $25,243,066$ & $1,226,560$ & $26,469,626$ & 95 \\
\hline
\end{tabular}


The California market, although, as indicated in the following table, one of apparently strong competitive conditions, yet seems to afford one of the best outlets for Alaska coal. Possible competition with eastern coals in this market after the completion of the Panama Canal is discussed on pages 91-92.

Coal consumption of California, by sources, 1899 to 1908, in short tons.

\begin{tabular}{|c|c|c|c|c|c|c|c|c|}
\hline Year. & California & a. $\begin{array}{c}\text { Oregor } \\
\text { timat }\end{array}$ & & $\begin{array}{r}\text { Was } \\
\text { to }\end{array}$ & & $\begin{array}{l}\text { Rocky } \\
\text { Mountein } \\
\text { States (es- } \\
\text { timated). }\end{array}$ & $\begin{array}{l}\text { Eastern } \\
\text { States.a }\end{array}$ & $\begin{array}{l}\text { Total do- } \\
\text { mestic. }\end{array}$ \\
\hline \multirow[t]{2}{*}{ 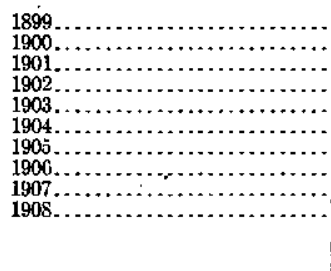 } & $\begin{array}{r}160,615 \\
171,708 \\
151,079 \\
84,984 \\
104,673 \\
78,888 \\
77,050 \\
25,290 \\
13,950 \\
18,755\end{array}$ & \multicolumn{2}{|c|}{$\begin{array}{l}70,000 \\
43,000 \\
48,000 \\
38,000 \\
61,000 \\
71,000 \\
79,000 \\
42,000 \\
26,000 \\
24,000\end{array}$} & \multicolumn{2}{|c|}{$\begin{array}{r}627,450 \\
668,642 \\
674,391 \\
374,595 \\
384,645 \\
321,376 \\
166,445 \\
110,670 \\
87,346 \\
29,426\end{array}$} & $\begin{array}{l}320,000 \\
280,000 \\
230,000 \\
280,000 \\
370,000 \\
300,000 \\
310,000 \\
340,000 \\
400,000 \\
350,000\end{array}$ & $\begin{array}{r}38,951 \\
17,319 \\
27,370 \\
24,133 \\
13,262 \\
29,055 \\
11,663 \\
11,455 \\
83,883 \\
171,875\end{array}$ & $\begin{array}{r}1,217,016 \\
1,180,669 \\
\mathbf{1}, 130,840 \\
801,712 \\
\mathbf{9 3 3}, 580 \\
800,319 \\
644,158 \\
529,415 \\
611,179 \\
594,056\end{array}$ \\
\hline & 886,992 & \multicolumn{2}{|c|}{502,000} & \multicolumn{2}{|c|}{$3,444,986$} & $3,180,000$ & 428,966 & $8,442,944$ \\
\hline Year. & $\begin{array}{c}\text { British } \\
\text { Colum- } \\
\text { bia. }\end{array}$ & Australia. & & & Japan. & $\begin{array}{c}\text { Total for- } \\
\text { eign. }\end{array}$ & Total. & $\begin{array}{l}\text { Percent- } \\
\text { age of } \\
\text { domestic. }\end{array}$ \\
\hline \multirow[t]{2}{*}{ 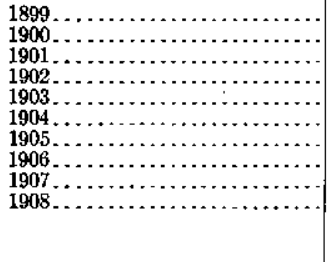 } & $\begin{array}{l}623,133 \\
766,917 \\
710,330 \\
591,732 \\
289,890 \\
335,137 \\
348,515 \\
311,099 \\
205,956 \\
167,415\end{array}$ & $\begin{array}{r}139,333 \\
178,563 \\
175,959 \\
197,328 \\
276,186 \\
148,409 \\
85,031 \\
72,638 \\
387,740 \\
228,174\end{array}$ & & $\begin{array}{l}263 \\
999 \\
270 \\
221 \\
735 \\
730 \\
087 \\
215 \\
582 \\
110\end{array}$ & $\begin{array}{r}8,458 \\
11,398 \\
7,852 \\
19,378 \\
15,350 \\
88,213 \\
54,810 \\
21,546 \\
83,405 \\
21,285\end{array}$ & \begin{tabular}{l|r}
8 & 864,187 \\
8 & $1,010,977$ \\
2 & 946,411 \\
8 & 907,659 \\
0 & 646,501 \\
3 & 638,089 \\
0 & 553,443 \\
6 & 442,498 \\
5 & 695,683 \\
5 & 431,984
\end{tabular} & $\begin{array}{l}2,081,203 \\
2,191,646 \\
2,07,251 \\
1,709,371 \\
1,580,081 \\
1,438,408 \\
1,197,601 \\
971,913 \\
1,306,862 \\
1,026,040\end{array}$ & $\begin{array}{l}58 \\
54 \\
54 \\
41 \\
50\end{array}$ \\
\hline & $4,350,124$ & $1,889,361$ & & 252 & 331,695 & \begin{tabular}{l|l}
5 & $7,137,432$
\end{tabular} & $15,580,376$ & 54 \\
\hline
\end{tabular}

a Chiefly blacksmith and anthracite coal, but including, since 1907, considerable coal used by the navy.

The consumption of coke forms a very important feature of the possible market for Alaska coal. As already indicated, both the Matanuska and Bering River fields include a considerable amount of good coking coals. It has also been shown that some of the beds are likely to yield a large percentage of slack, and if this can be marketed in the form of coke it will form an important element in economic mining. The following table indicates that the coke consumption in this region has fluctuated greatly, but on the whole has increased during the last decade. Vancouver Island supplies most of the imported coke, but some metallurgical processes requiring coke of a high grade utilize Belgian coke. 
Consumption of coke in Pacific States and Territories, by sources, 1898 to 1908, in short tons.

\begin{tabular}{|c|c|c|c|c|c|c|c|c|}
\hline \multirow{2}{*}{ Year. } & \multicolumn{5}{|c|}{$\begin{array}{l}\text { Imported from British Columbia, United Kingdom, } \\
\text { and Belgium. }\end{array}$} & \multirow{2}{*}{$\begin{array}{l}\text { Total coke } \\
\text { imported. }\end{array}$} & \multirow{2}{*}{$\begin{array}{l}\text { Manufac- } \\
\text { tured frond } \\
\text { Washing. } \\
\text { ton col. }\end{array}$} & \multirow{2}{*}{$\begin{array}{l}\text { Total coke } \\
\text { consumed } \\
\text { on Pacific } \\
\text { coast. }\end{array}$} \\
\hline & California. & Oregon. & $\begin{array}{l}\text { Washing- } \\
\text { ton. }\end{array}$ & Hawaii. & Alaska. & & & \\
\hline $\begin{array}{l}1898 \ldots \\
1899 \ldots \\
1900 \ldots \\
1901 \ldots \\
1902 \ldots \\
1903 \ldots \\
1904 \ldots \\
1905 \ldots \\
1906 \ldots \\
1907 \ldots \\
1908 \ldots\end{array}$ & $\begin{array}{l}40,011 \\
53,075 \\
39,968 \\
36,596 \\
58,547 \\
78,337 \\
69,520 \\
81,624 \\
77,207 \\
66,933 \\
80,874\end{array}$ & $\begin{array}{r}442 \\
1,006 \\
440 \\
290 \\
1,416 \\
1,749 \\
4,309 \\
5,484 \\
2,768 \\
2,772 \\
4,712\end{array}$ & $\begin{array}{r}13 \\
1,176 \\
1,615 \\
6,209 \\
25,062 \\
9,324 \\
76 \\
277 \\
221 \\
972 \\
1,590\end{array}$ & $\begin{array}{r}50 \\
668 \\
204 \\
146 \\
672 \\
392 \\
446 \\
1,080\end{array}$ & $\begin{array}{r}15 \\
53 \\
22 \\
49 \\
1 \\
8,543 \\
3,314 \\
31\end{array}$ & $\begin{array}{r}40,466 \\
55,257 \\
42,023 \\
43,166 \\
85,746 \\
89,636 \\
74,100 \\
88,058 \\
230,326 \\
74,437 \\
88,287\end{array}$ & $\begin{array}{l}30,197 \\
33,372 \\
33,387 \\
49,197 \\
40,305 \\
45,623 \\
45,432 \\
53,137 \\
45,642 \\
52,028 \\
38,889\end{array}$ & $\begin{array}{r}70,663 \\
88,629 \\
75,410 \\
92,363 \\
126,051 \\
135,259 \\
119,, 532 \\
141,195 \\
275,968 \\
126,465 \\
127,176\end{array}$ \\
\hline & 682,692 & 25,388 & 46,535 & 3,664 & 12,028 & 911,502 & 467,209 & $1,378,711$ \\
\hline
\end{tabular}

The consumption of anthracite has been small, chiefly on account of its high price. This market, at least, there is little question that the Alaska field will control. Even after the Panama Canal is completed, it is not likely that Pennsylvania anthracite can compete with that from Alaska.

Anthracite consumption of Pacific coast States and Alaska, 1899 to 1908, in short tons.

\begin{tabular}{|c|c|c|c|c|c|c|}
\hline \multirow{2}{*}{ Year. } & \multicolumn{2}{|c|}{ California. } & \multicolumn{2}{|c|}{ Washington and Oregon. } & \multirow{2}{*}{$\begin{array}{c}\text { Alaska, } \\
\text { domestic } \\
\text { and } \\
\text { foreign. }\end{array}$} & \multirow{2}{*}{ Total. } \\
\hline & $\begin{array}{c}\text { Domestic } \\
\text { (estimated) }\end{array}$ & Foreign. & $\begin{array}{c}\text { Domestic } \\
\text { (estimated). }\end{array}$ & Foreign. & & \\
\hline \multirow[t]{2}{*}{ 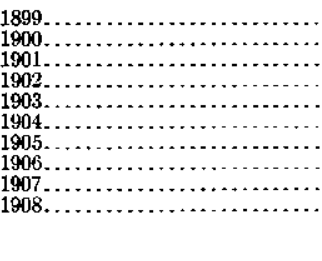 } & $\begin{array}{l}9,368 \\
3,400 \\
5,400 \\
4,800 \\
2,600 \\
3,000 \\
2,000 \\
2,000 \\
2,000\end{array}$ & $\begin{array}{r}6,138 \\
22,543 \\
65,417 \\
37,156 \\
19,206 \\
21,175\end{array}$ & $\begin{array}{r}2,000 \\
500 \\
200 \\
\cdots \\
\cdots \\
\cdots \\
\cdots \\
\cdots \\
\cdots \\
\cdots\end{array}$ & $\begin{array}{r}468 \\
\cdots 320 \\
543 \\
6,170 \\
6,944 \\
3,532 \\
6,647 \\
6,717\end{array}$ & $\begin{aligned} & \cdots \ldots . . \\
& \cdots \ldots \\
& \cdots \ldots \\
& 22 \\
& 17 \\
& 340 \\
& 1,144 \\
& 491\end{aligned}$ & $\begin{array}{r}11,836 \\
3,900 \\
5,600 \\
5,120 \\
9,303 \\
31,713 \\
72,378 \\
43,028 \\
28,997 \\
30,383\end{array}$ \\
\hline & 34,568 & 171,635 & 2,700 & 31,341 & 2,014 & 242,258 \\
\hline
\end{tabular}

PRICE OF COAL ON PACIFIC COAST.

Except in a few districts, the price of coal in the Pacific seaboard States and Territories fluctuates so greatly that it is very difficult to make any general statements which will be of value. For a number of years, however, there has been an upward tendency in coal prices in nearly all parts of the province. In general, it is true that the coal consumer has paid exorbitant prices for fuel. This is especially true in California, where competition with fuel oil seems to have demoralized the coal trade and prevented stable conditions on which business could be built up. 
The average price for run-of-mine coal at the pit's mouth during 1908 was $\$ 2.21$ per short ton in Washington, $\$ 2.74$ in Oregon, $\$ 2.93$ in California, and $\$ 4.83$ in Alaska. ${ }^{a}$ These figures, of course, do not indicate the cost to the consumer. To arrive at the price paid by the consumer it would be necessary to add transponation charges and profit for handling the coal. Moreover, a large percentage of the coal consumed in California is obtained from foreign sources.

The Vancouver Island coal sells, delivered at tide water, at $\$ 3.50$ to $\$ 4.50$ a gross ton. Transportation charges are about 75 cents to Seattle, and greater to California points, in addition to which there are the unloading charges and the duty of 40 cents a ton. Recently quoted Seattle wholesale prices are as follows: House or lump coal, $\$ 5$; nut coal, $\$ 3.75$; screenings, $\$ 2.25$ a long ton. In California coal retails at $\$ 6$ to $\$ 18$ a gross ton, depending on point of consumption and quality of coal. The high cost of fuel on the Pacific seaboard is strikingly illustrated when comparison is made between the prices quoted above and those of coals on the Atlantic coast. For example, during 1908 the average wholesale price of bituminous coal in New York City varied from about $\$ 2.20$ to $\$ 2.60$ a gross ton. ${ }^{b}$ This was for coal of a much better grade than any sold on the west coast. At the same time the wholesale price for anthracite varied from about $\$ 1.50$ to $\$ 5$, according to its size.

Along the Pacific seaboard of Alaska the retail price of coal has varied from about $\$ 8$ to $\$ 15$ and at Nome from $\$ 18$ to $\$ 25$ a ton. Practically no coal is imported into the interior except a little used for blacksmithing purposes, on which the freight alone wotld be $\$ 75$ a ton. To these prices for coal in Alaska must be add ${ }^{\text {? }}$ the local transportation charges, which may amount to more than the original cost of the coal.

The comparisons of prices are far from satisfactory, as in some cases only wholesale and in others only retail prices are available. Moreover, the quality of the coal is not always definitely stated. A better index to coal prices is afforded by those on bunker coal. The following table has been compiled from the reports of the Bureau of Statistics and gives the cost of coal f. o. b. at various ports.

a Parker, E. W., Mineral Resources U. S. for 1908, pt. 2, U. S. Geol. Survey, 1909, pp. 95, 100, 15 j-186. DIdem, pp. $67-72$. 
Quantities in gross tons and average prices per ton of bunker coal supplied to vessels at Pacific coast ports, 1905 to 1909.

\begin{tabular}{|c|c|c|c|c|c|c|c|c|c|c|}
\hline & \multicolumn{2}{|c|}{1905.} & \multicolumn{2}{|c|}{1906.} & \multicolumn{2}{|c|}{1907.} & \multicolumn{2}{|c|}{1908.} & \multicolumn{2}{|c|}{1909.} \\
\hline & $\begin{array}{l}\text { Quan- } \\
\text { tity. }\end{array}$ & $\begin{array}{l}\text { Aver- } \\
\text { age } \\
\text { price. }\end{array}$ & $\begin{array}{l}\text { Quan- } \\
\text { tity. }\end{array}$ & $\begin{array}{c}\text { Aver- } \\
\text { age } \\
\text { price. }\end{array}$ & $\begin{array}{l}\text { Quan- } \\
\text { tity. }\end{array}$ & $\begin{array}{l}\text { Aver- } \\
\text { age } \\
\text { price. }\end{array}$ & $\begin{array}{l}\text { Quan- } \\
\text { tity. }\end{array}$ & $\begin{array}{l}\text { Aver- } \\
\text { age } \\
\text { price. }\end{array}$ & $\begin{array}{l}\text { Quan- } \\
\text { tity. }\end{array}$ & $\begin{array}{l}\text { Aver- } \\
\text { age } \\
\text { price. }\end{array}$ \\
\hline \multirow{10}{*}{ 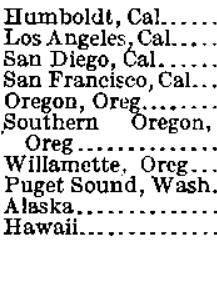 } & 742 & 88.00 & 790 & $\$ 7.79$ & 890 & $\$ 7.80$ & 690 & $\$ 8.00$ & 616 & $\$ 8.00$ \\
\hline & $\begin{array}{r}186 \\
3,511\end{array}$ & $\begin{array}{l}9.86 \\
7.25\end{array}$ & 4 & 7.25 & $\begin{array}{r}261 \\
5,059\end{array}$ & $\begin{array}{r}13.02 \\
6.90\end{array}$ & 9 & 59 & & 7. \\
\hline & 111,871 & 5.75 & 273,960 & 6.04 & 232,856 & 7.04 & 196,274 & $\begin{array}{l}6.47 \\
6.45\end{array}$ & 157,622 & 6. \\
\hline & & & & & & & & & 120 & 8. 7 \\
\hline & 17,664 & & 8,577 & & & & & & & \\
\hline & 5,984 & $\begin{array}{l}5.00 \\
5.29\end{array}$ & $\begin{array}{l}0,01 \\
4,270\end{array}$ & $\begin{array}{l}5.14 \\
5.42\end{array}$ & $\begin{array}{r}1,004 \\
6,040\end{array}$ & $\begin{array}{l}0.00 \\
6.06\end{array}$ & $\begin{array}{r}14,100 \\
5,123\end{array}$ & $\begin{array}{l}8.12 \\
6.92\end{array}$ & $\begin{array}{r}13,066 \\
2,373\end{array}$ & $\begin{array}{l}2.76 \\
5.77\end{array}$ \\
\hline & 355,542 & 3.01 & 492,246 & 3.00 & 661,662 & 3.70 & 339,869 & 4.00 & 363,004 & 4.00 \\
\hline & 14,830 & 10.88 & 14,166 & 11.33 & 17,719 & 12.15 & 16,127 & 11.67 & 13,401 & 11.62 \\
\hline & & & & ....... & & $\ldots \ldots$ & 5,115 & 7.80 & 5,755 & 7.85 \\
\hline & 510,330 & 4. 21 & 798,985 & 4.23 & 937,919 & 4.73 & 583,325 & 5.13 & 564,047 & 4. 89 \\
\hline
\end{tabular}

It is probably safe to use the above table as showing the average wholesale price of coal in the Pacific coast towns. This indicates that in 1909 the average price per ton at California ports was about $\$ 7.25$, at Oregon ports $\$ 5.79$, at Puget Sound ports about $\$ 4$, at Alaska ports about $\$ 11.62$, and in Hawaii $\$ 7.85$. The average for the Pacific coast outside of Alaska and Hawaii was $\$ 5.68$, or more than double the average price on the Atlantic seaboard.

Special grades of coal which come from the East command fancy prices--blacksmithing coal $\$ 11$ to $\$ 12$ and anthracite $\$ 15$ to $\$ 20$ a ton. In 1908 the average price of Washington coke at the ovens was $\$ 5.48 .^{a}$ The average value of the coke produced at the Vancouver Island ovens in the same year is placed at $\$ 6$ a ton. ${ }^{b}$ The following prices for coke in the Pacific coast States have been collected from various sources and are sufficiently accurate to serve as approximations: San Francisco, furnace coke $\$ 8$ to $\$ 10$, gas coke $\$ 7$ to $\$ 8$; Portland, Oreg., and Washington coke $\$ 7$, Belgian coke ${ }^{c} \$ 10$ to $\$ 11$.

\section{COMPETITION BETWEEN ALASKA COAL AND OTHER FUELS.}

It has been shown (pp. 82-86) that the Pacific coast States and Territories now use annually about $4,500,000$ tons of coal, besides some 200,000 tons consumed as coke; also that there has been no marked increase in coal consumption during the last five years, because the increased demand for fuel due to larger population, the depletion of the forests in some districts, and general industrial progress has been met by the petroleum output of the California field.

During the five years that the coal consumption has remained the same the use of fuel in this territory has increased about 70 per cent.

a Mineral Resources U. S. for 1908, pt. 2, U. S. Geol. Survey, 1909, p. 277.

b Rept. Minister of Mines, British Columbia, 1908, p. J11.

$c$ Coke pays a duty of 20 per cent ad valorem. 
Therefore, it is the production of fuel oil which will in large measure control the market for coal. Though the productive areas are constantly being extended, it is only a matter of time when some of the pools will show a decline in output. The history of the longer developed eastern fields makes it fair to assume that the California oil pools will not show anything like the same rate of increase in output during the next decade that they have in the last decade. If this proves to be the case, a much larger use of coal is to be expected. It is therefore reasonable to suppose that in the future California petroleum will be far less of a competitor with Alaska coal than it would be were this coal now on the market.

In this connection it should be noted that some petroleum has been found in Alaska, ${ }^{a}$ and while there has been practically no production, it is not impossible that commercial pools may be found. Oil seepages occur on the west shore of Cook Inlet, on the east side of the Alaska Peninsula, and on Controller Bay, all close to tide water and hence offering possibilities of cheap development.

Coke undergoes little direct competition with fuel oil. While there has been no marked increase in coke consumption for a number of years, yet such an increase is soon to be expected. Copper smelting on the west coast, notably in Alaska, when the Copper River district has been rendered accessible by railway, will undoubtedly increase the demand for coke. More important, however, to the coal miners are the advances made in the iron industry. Iron smelting has only recently been begun on a large scale in this province, but the plant now established on Puget Sound is undoubtedly the forerunner of others to follow. The raw materials are available, for iron occurs in a number of districts, and Alaska can supply the coke. Moreover, the market for iron is growing rapidly. It is estimated that the Pacific coast even now uses annually more than a million tons of raw and manufactured iron, nearly all of which is brought from the East or imported. If this iron were smelted on the Pacific seaboard, it would afford a market for, say, 2,000,000 tons of coking coal.

The present consumption of anthracite in this province is almost insignificant, being but about 30,000 . tons annually. (See p. 86.) If, however, Alaska anthracite can be delivered at Pacific ports at, say, $\$ 5$ a ton (p. 76), making its price to the consumer less than he is now paying for low-grade bituminous coals, a considerable market should be developed. It will probably take some time, however, to accustom the people to the use of anthracite. The annual per capita consumption of anthracite in the Northeastern States aver-

a Martin, G. C., The petroleum fields of the Pacific coast of Alaska: Bult. U. S. Geol. Survey No. 250, 1905; Notes on the petroleum fields of Alaska: Bull. U. S. Geol. Survey No. 259, 1905, pp. 128-139; Geology and mineral resources of the Controller Bay region, Alaska: 13ull. U. S. Geol. Survey No. 335, 1908, pp. ]12-130. 
ages about 2 tons. This is, of course, much larger than it will ever be on the west coast, because of the difference in climate. In Virginia, however, which has a mild climate and where wood is largely used for domestic fuel, the annual per capita anthracite consumption in $1899^{a}$ was two-tenths of a ton. This will serve as a rough measure of the possible future anthracite market in the Pacific coast States.

The following tables, compiled chiefly by Mr. Martin, ${ }^{b}$ indicate the composition of the coals with which Alaska fields may come into competition:

Average composition of coal from countries bordering the Pacific Ocean.

\begin{tabular}{|c|c|c|c|c|c|}
\hline District and kind of coal. & $\begin{array}{l}\text { Mois- } \\
\text { ture. }\end{array}$ & $\begin{array}{c}\text { Vola- } \\
\text { tile } \\
\text { matter. }\end{array}$ & $\begin{array}{l}\text { Fixed } \\
\text { carbon. }\end{array}$ & Ash. & $\begin{array}{l}\text { Sul- } \\
\text { phur. }\end{array}$ \\
\hline $\begin{array}{l}\text { Crows Nest Pass, British Columbia, average of } 10 \text { analyses c } d \ldots \\
\text { Vancouver Island, British Columbia, Comox, average of } 9\end{array}$ & 1.09 & 21.07 & 70.54 & 7.29 & 0.37 \\
\hline 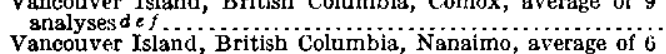 & 1.18 & 28.41 & 62.91 & 7.49 & 1.54 \\
\hline analyses deg & 2. 12 & 34.07 & 55.94 & 7.93 & \\
\hline Washington, Wilkeson, average of 7 ana & .92 & 27.15 & 82 & 10.11 & \\
\hline Washing ton, Cokedale, average of 3 analyses $h j$. & 1.27 & 28.04 & 62.30 & 8. 39 & \\
\hline Washington, Blue Canyon, a & 1.62 & 32.63 & 60.47 & 5. 28 & 53 \\
\hline Washington, Carbonado, average of 15 analyses $i k \ldots$ & 1.67 & 33. 11 & 56.74 & 8.48 & \\
\hline Washingtion, Rosly & 2.68 & 34.37 & 52.75 & 9.87 & \\
\hline Washington, Franklin, average of 5 a & 3.22 & 35.40 & 53.82 & 7.55 & \\
\hline Washington, Renton, average of 10 analyses $i j$. & 4. 48 & 36.01 & 51.17 & 8.23 & \\
\hline Washington, Newcastle, average of 5 analyses $\mathrm{h} i$ & 7.51 & 37.69 & & & \\
\hline Washington, Black Diamond, averago of 4 analyses $i$ & 4.44 & 40.50 & 51.73 & 3.33 & \\
\hline Oregon, Coos Bay, average of 4 analyses $h$. & 10. 41 & 46.15 & 36.85 & 6.59 & 1.02 \\
\hline California, average of 10 malyses $l$. & 11.32 & 45. 09 & 35 & 7.68 & \\
\hline $\begin{array}{l}\text { Colorado-New Mexico, Durango-Gallup fedd, average of } 2 \\
\text { analyses } m\end{array}$ & 10.48 & 41.10 & & & \\
\hline average of 8 analyses $n$ & 2.62 & 42.49 & 07 & 4.82 & .92 \\
\hline es (Cebu), a & 14.00 & 31. 08 & & 4.85 & \\
\hline Philippires (Batan), average of 5 analyses $0 . . . \ldots \ldots . . . .$. & 13.57 & 36.91 & 44.92 & 4. 60 & \\
\hline New South Wales, southern, average of 21 analyses $p$. & .97 & 23.10 & 56.26 & 10.67 & .46 \\
\hline New South Wales, western, average of 13 analyses $p$. & 1.87 & 31.49 & 52.61 & 14.03 & .63 \\
\hline $\begin{array}{l}\text { New South wales, northern, average of } 77 \text { analyses } p . . \\
\text { New Zealand, bituminous coal, average of } 23 \text { analyses } q \text {. }\end{array}$ & $\begin{array}{l}1.92 \\
3.18\end{array}$ & $\begin{array}{l}35.09 \\
40.84\end{array}$ & $\begin{array}{l}54.08 \\
53.13\end{array}$ & $\begin{array}{l}8.91 \\
2.85\end{array}$ & $\begin{array}{r}.54 \\
2.87\end{array}$ \\
\hline & & & & & \\
\hline
\end{tabular}

a Stoek, H. H., The Pennsylvania anthracite coal feld: Twenty-second $A$ nn. Rept. U. S. Geol. Survey, pt. 3,1902, p. 103 .

b Martin, G. C., Geology and mineral resources of the Controller Bay region, Alaska: Bull. U. S. Geol. Survey No. 335, 1908 , p. 111.

c Ann. Rept. Geol. Survey Canada, vol. 3, pt. 2, 1887-88, pp. 12T-15T.

d Ann. Rept. Minister of Mines, British Columbia, for 1902, p. 262 II.

e Ann. Rept. Geol. Survey Canada, 1872-73, pp. $76-78$.

$f$ Ann. Rept. Geol. Survey Canada, $1876-77$, p. 468

$g$ Ann, Rept. Geol. Survey Canada, 1882-1884, p. 37M

$h$ Twenty-second Ann. Rept. U. S. Geol. Survey, pt. 3, 1902, pp. 490, 501, 510.

Ann. Rept. Washington Geol. Survey, vol. 2, 1902, p. 270.

fRept. State Inspector of Mines, Washington, 1901-2.

$k$ Ann. Rept. Washington Geol. Survey, vol. 1, 1901, Pls. XXV, XXVII

$l$ Geology of California, vol. 3, p. 48.

$m$ The Durango-Gallup field: Bull. U. S. Geol. Survey No. 316, 1907, pp. 421-423.

$n$ Outlines of the geology of Japan, Imperial Geol. Survey, Japan, 1902, p. 190.

o The coal measures of the Philippines: Report to the United States military governor in the Philippines, War Department, 1901, pn. 178-181, 256-259.

p Mineral resources of New Suuth Wales, 1901, pp. 324-348.

$q$ Report on analyses of New Zealand coals, Mines Dept. New Zealand, 1907, pp. 6-7. 
Average composition of some eastern coals.

\begin{tabular}{|c|c|c|c|c|c|c|}
\hline District and kind of coal. & $\begin{array}{l}\text { Mois- } \\
\text { ture. }\end{array}$ & $\begin{array}{l}\text { Vola- } \\
\text { tile } \\
\text { matter. }\end{array}$ & $\begin{array}{c}\text { Fixed } \\
\text { carbon. }\end{array}$ & Ash. & $\begin{array}{c}\text { Sul- } \\
\text { phur. }\end{array}$ & Remarks. \\
\hline $\begin{array}{l}\text { Pennsylvania, anthracite, average of } 9 \text { analyses } a \text {. } \\
\text { Loyalsock, Pa., semianthracite, average of } 4\end{array}$ & $\begin{array}{l}3.39 \\
1.49\end{array}$ & $\begin{array}{r}3.81 \\
11.07\end{array}$ & $\begin{array}{l}83.79 \\
78.88\end{array}$ & $\begin{array}{l}8.42 \\
7.69\end{array}$ & $\begin{array}{r}0.59 \\
.86\end{array}$ & $\begin{array}{l}\text { Domestic coal. } \\
\text { Do. }\end{array}$ \\
\hline $\begin{array}{l}\text { Pocahontas, W. Va., semibituminous, average } \\
\text { of } 38 \text { analyses. } b\end{array}$ & .73 & 17.43 & 77.71 & 4. 63 & .62 & $\begin{array}{l}\text { Steam and cokin }{ }_{c}^{\prime \prime} \\
\text { coal. }\end{array}$ \\
\hline $\begin{array}{l}\text { Georges Creek, Md., semibituminous, average of } \\
53 \text { analyses. } \boldsymbol{c}\end{array}$ & .70 & 18.81 & 72.96 & 7.26 & 1.01 & Steam coal. \\
\hline $\begin{array}{l}\text { Connellsville, Pa., bitumlnous, average of } 3 \\
\text { analyses.d }\end{array}$ & 1.07 & 32.70 & 60.28 & 5.95 & .81 & Coking cosi. \\
\hline $\begin{array}{l}\text { Falrmont, W. Va., bituminous, average of } 63 \\
\text { analyses. } e\end{array}$ & .75 & 38.16 & 54.63 & 6.45 & 2.30 & $\begin{array}{l}\text { Cokingf and } \\
\text { steam coal. }\end{array}$ \\
\hline
\end{tabular}

a Ann. Rept. Geol. Survey Pennsylvania, 1885, pp. 313, 318.

$b$ Rept. Geol. Survey West Virginia, vol. 2, 1903, pp. 695, 696, 700.

c Rept. Maryland Geol. Survey, vol. 5, 1906, pp. 631-633.

d Rept. Geol. Survey Pennsylvania, vol. MM 1879, pp. 21-22.

e Rept. Geol. Survey West Virginia, vol. 2,1903 , p. 209.

$f$ The phosphorus in these analyses ranges from 0.0019 to 0.037 , averaging 0.0117 .

The California coal so far produced has been entirely lignitic, but there are some bituminous coals in the State which will some time supply, in part at least, the local market. The extent of these fields is not such as to lead to the belief that they will afford serious competition with the Alaska coal. Oregon also has no very extensive coal fields, nor is the coal of a high grade.

The coals located east of the Cascades in the State of Washington are at some disadvantage in the coast market compared with those from Alaska, both because of their inferior quality and because of the long railway haul. There are some higher-grade coals in the western part of the State which are close to tide water. These, though they may dominate in the Seattle market, are not abundant enough to warrant the belief that they will be able to furnish any considerable part of the increased demand for fuel on the west coast. Therefore, while the Washington coal may be a serious competitor with Alaska coal in the present market, it is at least an open question whether this competition will be more than local in the future.

It is estimated that California annually consumes 300,000 to 400,000 tons (see table, p. 85) of coal from the Rocky Mountain fields. This comes chiefly from New Mexico and seems to be largely used for domestic fuel. It appears that, because of the long railway haul and the comparatively inferior quality of this coal, it is not likely to stand competition with the Alaska coal in the coast towns of California.

Probably a more serious matter to the future market for the Alaska coal is the possible competition with the fuels of the Appalachian fields after the completion of the Panama Canal. Unlike the other coals likely to reach the Pacific market, the Appalachian fuel is of the same high quality as that of the Bering River and Matanuska fields. 
High-grade bituminous coal is now being delivered on shipboard at Atlantic coast ports at a cost of $\$ 2$ a long ton. Emory R. Johnson ${ }^{a}$ has estimated the cost of shipping coal from the Atlantic to the Pacific seaboard by way of the Panama Canal to be $\$ 2.45$ a ton, including canal tollage. This would indicate that eastern coal might be delivered at San Francisco at about $\$ 4.60$ a ton, ${ }^{b}$ while it has been estimated (p. 76) that Alaska coal could be delivered at the same port for $\$ 4.50$. As the error in the estimates is probably greater than the difference between the two figures, it seems as if there might be strong competition in this market between the Appalachian and the Alaskan coals.

Of the foreign competing fields those of Vancouver Island are nearest and have a higher-grade coal (see p. 90) than any others. They are, moreover, close to tide water, and the cost of mining should be less than in the Alaska fields. It appears from the best information available that the Vancouver Island collieries have been making a profit of $\$ 1$ to $\$ 1.50$ a ton, which is, of course, excessive. It is probable that under strong competition with Alaska fields the Vancouver Island operators may have to content themselves with a much smaller profit and be forced to introduce economies in mining and transportation. It is conceivable that under such conditions the Comox and Nanaimo coals might be delivered at Pacific ports at $\$ 3.50$ a ton. ${ }^{c}$ By allowing for the difference in fuel value, this would be the equivalent of $\$ 4.50$ for Alaska coal. The local demand for the Vancouver Island coal will, however, be much greater when the Grand Trunk Pacific Railway is completed, and it may be that this domestic market will absorb the entire product of these collieries.

The New South Wales coal fields of Australia will probably continue to be competitors in the west-coast market, as they are to-day. (See table, p. 69.) Some of these fields lie close to tide water, and it has been estimated that their coal can be delivered on shipboard for $\$ 1.78$ a ton. ${ }^{d}$ With the cheap return freight rates offered by vessels

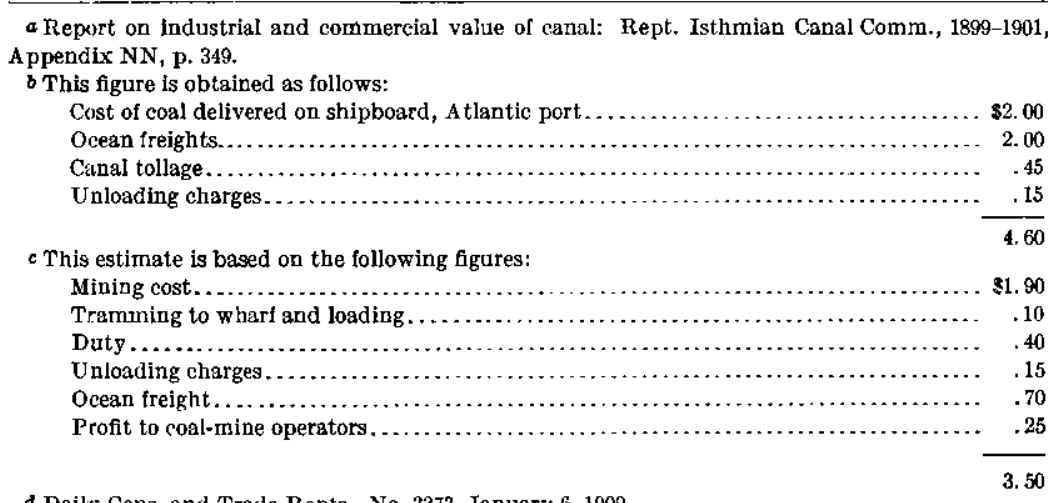

d Daily Cons, and Trade Repts, No. 3373, January 6, 1909. 
carrying wheat to Australia, the New South Wales coal may be nble to compete with Alaska coals in the California market. If we assume, however, that Alaska coal can be delivered in California ports at $\$ 4.50$ a ton, the Australian coals, which are of inferior quality, would have to be delivered at about $\$ 3.30$ a ton.

New Zealand also includes some bituminous fields whose fuels are of about the same grade (see p. 90) as those of New South Wales. Though there are extensive deposits of lignite ${ }^{a}$ in New Zealand, the bituminous coals ${ }^{b}$ do not appear to be in sufficient quantity to justify the opinion that they will ever be an important element in the west-coast market.

Of the other countries bordering on the Pacific, China has the most extensive coal reserves. ${ }^{c}$ The best Chinese coals as well as the most extensive fields lie inland. There is little probability that coals from China will be transported across the Pacific and come into competition with the Alaska fuels. The coal reserves of Japan ${ }^{d}$ are not important either as to quantity or quality and little or no competition is to be expected from this source. The west coast of South America, too, has no great coal supply.e So far as known there are no important coal deposits in Central America or near the west coast of Mexico. In considering the coal market the possibilities of finding petroleum in these countries should be kept in mind. Peru, Chile, and other South American countries now annually consume several million tons of imported coal valued at $\$ 7$ to $\$ 10$ a ton, which is brought chiefly from Great Britain, ${ }^{f}$ with some from Australia and a little from the Appalachian fields of the eastern United States. At first sight the South American countries would seem to furnish a promising market for Alaska coal. This coal, however, because of the distances of transportation, will have little or no advantage as compared with those of other fields, even if the first cost of mining were the same. For example, the distance from the Alaska fields to Valparaiso is about 7,000 nautical miles, compared with a distance of about 8,600 nautical miles from the English and 6,200 miles from the Australian fields. Moreover, on the completion of the Panama Canal, coal can be shipped from the Atlantic ports to Valparaiso by a water route only about 4,400 miles in length. It is not likely that under such conditions the Alaska coal could compete with that from the Appalachian fields.

a Hall, Edward, The coal felds of Great Britain. London, 1905, pp. 348-352.

$b$ There is also some anthracite.

$c$ Willis, Bailey, Mineral resources of China: Econ. Geology, vol. 3, 1908, pp. 1-36, 118-133.

$d$ Outline of the geology of Japan, Imperial Geol. Survey of Japan, Tokyo, 1902, pp. 188-208.

e Brough, Bennett H., Coal resources of the world: Final Rept. Royal Comm. on Coal Supply, pt. 11, appendix 6, London, 1905. Borlkjof, Z. C., The coal deposits of Peru: Eng, and Min. Jour., December 25, 1809.

$f$ Daily Cons. and Trade Repts., No. 3617, November 23, 1909. 
PRESENT MARKET FOR AIASKA COAL.

The above review of the Pacific coal markets indicates that the outlook for the Alaska coal is very favorable. However, the prospective Alaska coal producer is more vitally interested in the immediate market that he can count on. This is, of course, difficult to forecast, and in any event depends largely on the price at which Alaska coal can be mined and delivered. (See p. 76.) There is, however, a comparatively small local market which, because of its geographic position, the Alaskan coals will practically control. There is another part of the coal used in the Pacific market for which the Alaska coal will have a decided advantage over competing fuels. This includes that used by the navy, the blacksmithing coal and anthracite, a large part of the coal used for making coke, and some of that used by shipping. Then there is the larger market, chiefly in California, in which the Alaska coals will be under about equal competitive conditions with those from other regions. The following table sets forth an estimate of the tonnage required for these various uses:

Present estimated market for Alaska coal

\begin{tabular}{|c|c|}
\hline WIthout competition. & Tons. \\
\hline Local railways. . & 50,000 \\
\hline Local towns.. & 20,000 \\
\hline $\begin{array}{l}\text { Local mines...... } \\
\text { Local smelters.... }\end{array}$ & 10,000 \\
\hline \multirow[t]{2}{*}{ 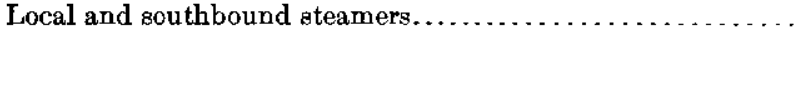 } & 30,000 \\
\hline & 120,000 \\
\hline \multicolumn{2}{|l|}{ Under competition strongly favoring Alasiza coal. } \\
\hline United States Navy... & 150,000 \\
\hline Blacksmith coal........ & 25,000 \\
\hline Anthracite...$\ldots \ldots \ldots \ldots \ldots \ldots \ldots \ldots \ldots \ldots$ & 50,000 \\
\hline Coking coal (estimated at one-half of that now used)... & 100,000 \\
\hline \multirow[t]{2}{*}{ Northbound steamers to Alaska Pacific ports. .............. } & 25,000 \\
\hline & 350,000 \\
\hline \multicolumn{2}{|l|}{ Under competitive conditions about even. } \\
\hline Seward Peninsula, Alas & 25,000 \\
\hline Coking coal (one-half that now used) $\ldots \ldots \ldots \ldots \ldots \ldots \ldots$ & 100,000 \\
\hline 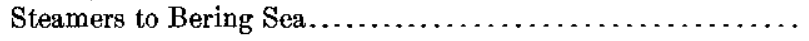 & 25,000 \\
\hline 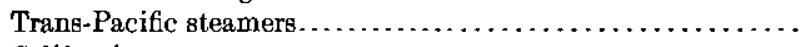 & 250,000 \\
\hline \multirow{2}{*}{ California ports.................. } & 600,000 \\
\hline & $1,000,000$ \\
\hline
\end{tabular}

The first section of this table needs no explanation except to state that the estimates are believed to be conservative. It has been assumed in the second section that the consumption of coal by the Pacific fleet will continue at about the same that it has in the last few years; also that, if the Alaska anthracite were mined near the market, 
at least twice the quantity now used could be sold. It is also assumed that at least half the coking coal now used would come from Alaska. The remainder of the present consumption of coking coal has been put in the third section of the table, in which it was also assumed that the Alaska coal, because of its lighl grade, would become a competitor for the shipping trade. Finally, it is assumed that Alaska fields would compete for one-half of the coal used at present in California. It is fair to assume that the Alaska fuels would find market for at least half the quantity indicated in this section of the table.

These estimates, though they are little more than guesses, will perhaps show to what degree of magnitude the true figures belong. They indicate that at present there is market for some half a million tons, with little competition, and that there is another market for, say, a million tons more, in which the Alaska coal will have at least equal chances with that from other fields. In other words, there appears to be a present market for about $1,000,000$ tons of the better qualities of Alaska coal. The total of the table represents less than a third of the total coal consumption on the Pacific coast. The data which have been presented in earlier sections of this paper will guide those interested in drawing their own conclusions as to how rapidly the market for Alaska coal is likely to grow.

\section{BIBLIOGRAPHY.}

The following list of publications is believed to include all those by members of the United States Geological Survey in which references of any importance are made to Alaska coal. It includes official publications as well as those printed privately. Only those marked with an asterisk ${ }^{*}$ ) deal principally with coal; the others contain only minor references to production and occurrence of coal or descriptions of coal-bearing formations. The arrangement is, first, geographic, and within each group chronologic. Survey publications marked with a dagger $(\dagger)$ are out of stock but may be consulted at the larger public libraries.

During the last few years periodical literature has contained many references to Alaska coal. The more important of these are noted in a supplementary list, which is not intended to be complete. It comprises only such publications by others than members of the Survey as are believed may be of special value to those who are interested in Alaska coal. For the sake of historic interest a few older publications are, however, included in this list.

Publications by members of United States Geological Survey on coal in Alaska, 188s-1910.

General.

Coal, by Albert Williams, jr.: Mineral Resources U. S. for 1883-84, U. S. Geol. Survey, 1885, pp. 17-18.†

Coal, by Charles A. Ashburner: Mineral Resources U. S. for 1885, U. S. Geol. Survey, 1886 , p. $14 . \dagger$ 
Coal, by Charles A. Ashburner: Mineral Resources U. S. for 1888, U. S. Geol. Survey, 1890, pp. $214-216 . \dagger$

The Neocene of North America, by W. H. Dall and G. D. Harris: Bull. U. S. Geol. Survey No. 84, 1892, pp. 232-268.†

Coal, by E. W. Parker: Mineral Resources U. S. for I891, U. S. Geol. Survey, 1893, pp. 209-210.†

* Report on coal and lignite of Alaska, by W. H. Dall: Seventeenth Ann. Rept. U. S. Geol. Survey, pt. I, 1896, pp. 763-906. $\dagger$

Account of an investigation of the gold and coal deposits of southeastern Alaska: Seventeenth Ann. Rept. U. S. Geol. Survey, pt. 1, 1896, pp. 56-59.†

Coal, by E. W. Parker: Mineral Resources U. S. for 1896, U. S. Geol. Survey, 1897, p. $469 . \dagger$

Coal, by E. W. Parker: Mineral Resources U. S. for 1897, U. S. Geol. Survey, 1898, p. $385 . \dagger$

Alaska and its mineral resources, by S. F. Emmons: Nat. Geog. Mag., vol. 9, 1898, pp. 170-172.

Map of Alaska showing known gold-bearing rocks, with descriptive text, containing sketches of the geography, geology, and gold deposits and routes to the gold fields, by S. F. Emmons; a special publication of the U. S. Geol. Survey, 1898, pp. $39-44 . \dagger$

*The ccal resources of Alaska, by Alfred H. Brooks: Twenty-second Ann. Rept. U. S. Geol. Survey, pt. 3, 1902, pp. 515-571.

The mining industry in Alaska, by Alfred H. Brooks: Eng. and Min. Jour., vol. 77, 1904, pp. 75-78. Reprint in Mineral Industry, 1903, New York, 1904, pp. 420-428.

*The production of coal in 1904, by Alfred H. Brooks: Mineral Resources U. S. for 1904, U. S. Geol. Survey, 1905, pp. 112-114 (of separate), 452-454 (of complete volume). $\dagger$

The investigation of Alaska's mineral wealth, by Alfred H. Brooks: Trans. Am. Inst. Min. Eng., Lake Superior meeting, September, 1904, pp. 1-20. Reprint in Bull. Am. Geog. Soc., vol. 37, 1905, pp. 26-40. Reprint in appendix to Rept. Governor Dist. Alaska, 1904, pp. 95-105.

Alaska, by A.lfred H. Brooks: Eng. and Min. Jour., vol. 79, 1905, pp. 16-17.

The mineral resources of Alaska, by Alfred H. Brooks: Proc. Am. Min. Congress, eighth annual session, El Paso, November, 1905, pp. 194-214.

*The outlook for coal mining in A laska, by Alfred H. Brooks: Trans. Am. Inst. Min. Eng., vol. 36, 1906, pp. 489-507.

The mining industry in 1905, by Alfred H. Brooks: Bull. U. S. Geol. Survey No. 284, 1906, p. 9.

The geography and geology of Alaska, by Alfred H. Brooks: Prof. Paper U. S. Geol. Survey No. $45,1906,327 \mathrm{pp}$.

The geologic gurvey of Alaska, by Alfred H. Brooks: Pop. Sci. Monthly, vol. 69, January, 1906, pp. 42-54.

Preliminary report of fuel-testing plant, by J. A. Holmes: Bull. U. S. Geol. Survey No. 290,1906 , pp. 229-231.†

Markets for Alaska coal, by G. C. Martin: Bull. U. S. Geol. Survey No. 284, 1906, pp. $18-29 . \dagger$

The production of coal in 1905, by E. W. Parker: Mineral Resources U. S. for 1905, U. S. Geol. Survey, 1906, pp. 548-549 (pp. 100-101 of separate).†

*Statement by Alfred H. Brooks: Hearing before the Committee on Public Landa, Coal Lands, and Coal Land Laws of the United States, House of Representatives, January 11, 1907.

*The Alaska coal fields, by George C. Martin: Bull. U. S. Geol. Survey No. 314, 1907, pp. 40-46.†

*History and prospective utilization of the Alaeka coal fields, by George C. Martin: Proc. Coal Mining Inst. America, 1907. 
Coal, by E. W. Parker: Mineral Resources U. S. for 1906, U. S. Geol. Survey, 1907, pp. 572, 590,649-650.†

Alaska and its mineral resources, by Alfred H. Brooks: Proc. Am. Min. Congress, eleventh annual session, Pittsburg, December, 1908, pp. 258-268.

The mining industry in 1907, by Alfred H. Brooks: Bull. U. S. Geol. Survey No. 345, 1908 , pp. 30-53.

Coal, by E. W. Parker: Mineral Resources U. S. for 1907, U. S. Geol. Survey, 1908, pp. $94-96 . \dagger$

The mining industry in 1908, by Alfred H. Brooks: Bull. U. S. Geol. Survey No. 379, 1909 , pp. 21-62.

The mineral resources of Alaska, by Alfred H. Brooks: Bull. U. S. Geol. Survey No. 394,1909 , pp. $72-78$.

*Coal, by Alfred H. Brooks: Mineral Resources U. S. for 1908, U. S. Geol. Survey, 1909 , pp. 94-96.†

The Alaska of to-day, by Alfred H. Brooks: Am. Review of Reviews, vol. 40, July, 1909 , pp. 49-62.

Testimony of Alfred $\mathrm{H}$. Brooks: Hearinge Comm. to investigate Interior Dept. and Forest Service, vol. 4, 1910, pp. 2830-2847, 2874-2918, 2974-2978.

\section{Sontheastern Alaska.}

Economic developments in southeastern Alaska, by F. E. and C. W. Wright: Bull. U. S. Geol. Survey No. 259, 1905, pp. 56-57.†

${ }^{*}$ A reconnaissance of Admiralty Island, Alaska, by C. W. Wright: Bull. U. S. Geol. Survey No, 287, 1907, pp. 151-I54

\section{Bering River, Prince Willam Sound, Copper Rlver reglon.}

The extreme southeastern coast; the coast from Lynn Canal to Prince William Sound, by G. H. Eldridge: Maps and descriptions of routes of exploration in Alakka in 1898 , a special publication of the U. S. Geol. Survey, 1899, pp. 101-104. $\dagger$

Report on Prince William Sound and the Copper River region, by F. C. Schrader: Maps and descriptions of routes of exploration in Alaska in 1898, a special publication of the U. S. Geol. Survey, 1899, p. 61.†

The mineral resources of the Mount Wrangell district, Alaska, by W. C. Mendenhall and F. C. Schrader: Prof. Paper U. S. Geol. Survey No. 15, 1903, pp. 66-68.

Petroleum fields of Alaska and the Bering River coal fields, by George C. Martin: Bull. U. S. Geol. Survey No. 225, 1904, pp. 365-382.†

Petroleum fields of the Pacific coast of Alaska, with an account of the Bering River coal deposits, by George C. Martin: Bull. U. S. Geol. Survey No. 250, 1905, 64 pp.†

The Bering River coal field, by George C. Martin: Bull. U. S. Geol. Survey No. 259, 1905, pp. 140-150.†

Geology of the central Copper River region, by W. C. Mendenhall: Prof. Paper U. S. Geol. Survey No. 41, 1905, pp. 123-125.

The distribution and character of the Bering River coal, by George C. Martin: Bull. U. S. Geol. Survey No. 284, 1906, pp. 65-77.

The Yakutat Bay region, by R. S. Tarr: Bull. U. S. Geol. Survey No. 284, 1906, pp. 63-64.

Petroleum at Controller Bay, by George C. Martin: Bull. U. S. Geol. Survey No. 314, 1907, pp. 89-103.†

* Geology and mineral resources of the Controller Bay region, Alaska, by George C. Martin: Bull. U. S. Geol. Survey No. 335, 1908, p. 141. Reprint in message from the President of the United States transmitting, in response to Senate resolution No. 112, of December 21, 1909, original statement of charges made to the President by L. R. Glavis, together with other statements, letters, and records: Senate Doc. 248, 61st Cong., $2 \mathrm{~d}$ sess.

$55695^{\circ}-$ Bull. $442-10-7$ 
Mineral resources of the Nabesna-White River district, by F. H. Moffit and Adolph Knopf: Bull. U. S. Geol. Survey No. 379, 1909, pp. 161-180.

Mineral resources of the Kotsina-Chitina region, Alaska, by F. H. Moffit and A. G. Maddren: Bull. U. S. Geol. Survey No. 374, 1909, 102 pp.

The Yakutat Bay region, Alaska, by Ralph S. Tarr and Bert S. Butler: Prof. Paper U. S. Geol. Survey No. 64, 1909, pp. 168-169.

Mineral resources of the Nabesna-White River region, by F. H. Moffit and Adolph Knopf: Bull. U. S. Geol. Survey No. 417, 1910, p. 61.

Cook Inlet, Matanuska, and Susitna reglon.

A reconnaiseance from Resurrection Bay to the Tanana River, Alaska, in 1898, by W. C. Mendenhall: Twentieth Ann. Rept. U. S. Geol. Survey, pt. 7, 1900, p. 324. $\dagger$ The Susitna drainage area, by G. H. Eldridge: Maps and descriptions of routes of exploration in Alaska in 1898, a special publication of the U. S. Geol. Survey, 1899 , p. 112.†

Report of the Susitna expedition, by G. H. Eldridge and Robert Muldrow: Maps and descriptions of routes of exploration in Alaska in 1898, a special publication of the U. S. Geol. Survey, 1899, pp. 22-24. $\dagger$

Report on the region between Resurrection Bay and the Tanana River, by W. C. Mendenhall: Maps and descriptions of routes of exploration in Alaska in 1898, a apecial publication of the U. S. Geol. Survey, 1899, p. 48.†

The Kenai Peninsula, by W. C. Mendenhall: Maps and descriptions of routes of exploration in Alaska in 1898, a special publication of the U. S. Geol. Survey, 1899, pp. $109-110 . \dagger$

A reconraissance in the Susitna Basin and adjacent territory, Alaska, in 1898, by G. H. Eldridge: Twentieth Ann. Rept. U. S. Geol. Survey, pt. 7, 1900, pp. 1-29.†

*Preliminary statement on the Matanuska coal field, by George C. Martin: Bull. U. S. Geol. Survey No. 284, 1906, pp. 88-100.†

*A reconnaissance of the Matanuska coal field, $\Lambda$ laska, in 1905, by George C. Martin: Bull. U. S. Geol. Survey No. 289, 1906, 36 pp.†

*Coal fields of the Kachemak Bay region, by R. W. Stone: Bull. U. S. Geol. Survey No. 277,1906 , pp. $53-73$.

*A reconnaissance in the Matanuska and Talkeetna basins, by Sidney Paige and Adolph Knopf: Bull. U. S. Geol. Survey No. 314, 1907, pp. 104-125.

*Geologic reconnaissance in the Matanuska and Talkeetna basins, Alaska, by Sidney Paige and Adolph Knopf: Bull. U. S. Geol. Survey No. 327, 1907.

*The Mount McKinley region, Alaska, by Alfred H. Brooks: Prof. Paper U. S. Geol. Survey No. 70 (in preparation).

\section{Alaska Peninsula and Aleutian Islands.}

The Kodiak Islands, the Alaska Peninsula, and the Aleutian Islands, by W. C. Mendenhall: Maps and descriptions of routes of exploration in Alaska in 1898, a special publication of the U. S. Geol. Survey, 1899, pp. 113-117. $\dagger$

A reconnaissance in southwestern Alaska in 1898, by J. E. Spurr: Twentieth Ann. Rept. U. S. Geol. Survey, pt. 7, 1900, pp. 262-264.†

Mesozoic section on Cook Inlet and Alaska Peninsula, by T. W. Stanton and G. C. Martin: Bull. Geol. Soc. America, vol. 16, 1905, pp. 408-409.

*Coal resources of southwestern Alaska, by R. W. Stone: Bull. U. S. Geol. Survey No. 259, 1905, pp. 151-171. $\dagger$

*The Herendeen Bay coal field, by Sidney Paige: Bull. U. S. Geol. Survey No. 284, 1906, pp. 101-108.

*Mineral resources of southwestern Alaska, by W. W. Atwood: Bull. U. S. Geol. Survey No. 379, 1909, pp. 108-152.

*Geology and mineral resources of parts of Alaska Peninsula, by W. W. Atwood: Bnll. U. S. Geol. Sưrvey No. - (in preparation). 
Yukon and Knskokwim region.

Geology of the Yukon gold diatrict, Alaska, by J. E. Spurr: Eighteenth Ann. Rept. U. S. Geol. Survey, pt. 3, 1898, pp. 380-382. $\dagger$

Report of the Fortymile expedition, by E. C. Barnard: Maps and descriptions of routes of exploration in Alaska in 1898, a special publication of the U. S. Geol. Survey, 1899, p. 81.†

The Yukon district, by Alfred H. Brooks: Maps and descriptions of routes of exploration in Alaska in 1898, a special publication of the U. S. Geol. Survey, 1899, p. 95. $\dagger$

A reconnaissance from Pyramid Harbor to Eagle City, Alaska, by Alfred H. Brooks: Twenty-first Ann. Rept. U. S. Geol. Survey, pt. 2, 1900, pp. 382-383. $\dagger$

Report on the White River-Tanana expedition, by A. J. Peters and A. H: Brooks: Maps and descriptions of routes of exploration in Alaska in 1898, a special publication of the U. S. Geol. Survey, 1899, p. 71.†

Report of the Kuskokwim expedition, by J. E. Spurr and W. S. Post: Maps and descriptions of routes of exploration in Alaska in 1898, a special publication of the U. S. Geol. Survey, 1899, p. 36.†

Preliminary report on a reconnaissance along the Chandlar and Koyukuk rivers, Alaska, in 1899, by F. C. Schrader: Twenty-first Ann. Rept. U. S. Geol. Survey, pt. 2, 1900, pp. 485-486.†

Geology and mineral resources of a portion of the Copper River district, Alaska, by F. C. Schrader and Arthur C. Spencer, a special publication of the U. S. Geol. Survey, 1901, pp. 91-92.†

* Coal resources of the Yukon basin, Alaska, by A. J. Collier: Bull. U. S. Geol. Survey No. 213,1903 , pp. 276-283.†

* The coal resources of the Yukon, Alaska, by A. J. Collier: Bull. U. S. Geol. Survey No. 218, 1903, 71 pp. $\dagger$

The Bonnifield and Kantishna regions, by L. M. Prindle: Bull. U. S. Geol. Survey No. 314, 1907, pp. 205-226.†

The Fairbanks and Rampart quadrangles, Yukon-Tanana region, Alaska, by L. M. Prindle: Bull. U. S. Geol. Survey No. 337, 1908, p. 24.

The Fortymile quadrangle, by L. M. Prindle: Bull. U. S. Geol. Survey No. 375, 1909, p. 23.

The Innoko gold-placer district, Alaska, by A. G. Maddren: Bull. U. S. Geol. Survey No. 410,1910 , pp. 45,56 , and 57 .

\section{Seward Penlnsula.}

A reconnaissance in the Norton Bay region, Alaska, in 1900, by W. C. Mendenhall: Reconnaissances in the Cape Nome and Norton Bay regions, Alaska, in 1900, a special publication of the U. S. Geol. Survey, 1901, pp. 214-215.

The Kotzebue placer-gold field of Seward Peninsula, Alaska, by F. H. Moffit: Bull. U. S. Geol. Survey No. 225 , 1904, p. $80 . \dagger$

The Fairhaven gold placers, Seward Peninsula, Alaska, by F. H. Moffit: Bull. U. S. Geol. Survey No. 247, 1905, p. 67.

Investigation of the mineral deposits of Seward Peninsula, by Philip S. Smith: Bull. U. S. Geol. Survey No. 345, 1908, pp. 249-250.†

Mining in the Fairhaven precinct, by F. F. Henshaw: Bull. U. S. Geol. Survey No. 379,1909 , pp. 355-369.

\section{Northern Alaska.}

Reconnaissance from Fort Hamlin to Kotzebue Sound, Alaska, by way of Dall, Kanuti, Allen, and Kowak rivers, by W. C. Mendenhall: Prof. Paper U. S. Geol. Survey No. 10, 1902, p. 49.

*The coal fields of Cape Lisburne, Alaska, by A. J. Collier: Am. Geologist, vol. 34, 1904, pp. 401-402. 
A reconnaissance in northern Alaska, across the Rocky Mountains, along Koyukuk, John, Anaktuvuk, and Colville rivers and the Arctic coast to Cape Lisburne, 1901, by F. C. Schrader: Prof. Paper U. S. Geol. Survey No. 20, 1904, 139 pp. $\dagger$

*Coal fields of the Cape Lisburne region, by A. J. Collier: Bull. U. S. Geol. Survey No. 259,1905 , pp. 172-185.†

${ }^{*}$ Geology and coal resources of Cape Lisburne region, Alaska, by A. J. Collier: Bull. U. S. Geol. Survey No. 278, 1906, 54 pp.†

Miscellaneous publications relating to Alaska coal.

Alaska, its population, industries, and resources, by Ivan Petroff: Tenth Census U. S., vol. 8,1882 , p. 87 .

Analyses of coals and lignites of the Northwest, by F. A. Gooch: Tenth Census U. S., vol. 15, 1886, pp. 788-789.

Population and resources of Alaska, by Robert P. Porter: Eleventh Census U. S., 1893.

The coal fields of Cook Inlet, Alaska, U. S. A., and the Pacific coast, by John Kirsopp, jr.: Trans. Inst. Min. Eng. (England), vol. 21, 1901, pp. 536-559.

The Kayak coal and oil fields of Alaska, by P. C. Stoese: Min. and Sci. Press, vol. 87,1903, p. 65.

Report on the Matanuska coal field, by William Griffith, 1906, 40 pp., 8 mape, and many other illustrations.

Kinds and occurrence of anthracite coal, by William Griffith: Min. Mag., vol. 13, No. 3, 1906, pp. 219-220.

Conservation and Alaskan coal lands, by H. Foster Bain: Min. and Sci. Prese, vol. 100,1910 , pp. $185-188$.

Controller Bay coal fields, by George W. Evans: Mines and Minerale, vol. 30, 1910, pp. 449-453.

The Alaska coal cases, by H. V. Winchell: Eng. and Min. Jour., vol. 89, 1910, pp. 860-863. 


\title{
THE PREPARATION AND USE OF PEAT AS FUEL.
}

\author{
By Charles A. Davis.
}

\section{INTRODUCTION.}

The need of a supply of good and easily obtained fuel is more paramount in Alaska than in most other countries, and although coal and wood are so abundant and so readily procured in many parts of the Territory that the fuel question may be said to be solved already, there are many places where neither can be had except at high prices. In such localities the very generally distributed peat deposits may be made available for furnishing both heat and power by proper methods of preparation. Some of these methods are so simple that they can be applied by anyone without the aid of machinery, a fact which makes them especially useful to prospectors and other isolated individuals and to small communities remote from the coast or from transportation routes; other methods can be used only where large capital is to be had. It may be assumed that peat will not be prepared and used for fuel in places where high-grade coal can be obtained at satisfactory prices, although this is by no means an established fact. The regions where coal of good quality may be found are discussed in another place (pp. 47-62).

\section{GENERAL DISCUSSION.}

\section{PEAT DESCRIBED.}

Peat is made up of the remains of dead plants of many kinds, in a partly decayed and more or less disintegrated state. It is the light-brown, dark-brown, or nearly black soil found in wet places, such as bogs, swamps, and margins of ponds and lakes, or, in the tundra region, covering the entire surface of the country. It is known by various names besides peat, such as muck, turf, or, colloquially in parts of Alaska, "tundra," although the last term is, strictly speaking, applicable only to the plains on which lies the coarse, silty, turfy peat thus designated.

After it has been dug and dried, peat may vary from light yellowish brown to nearly black in color and from coarsely fibrous, loosetextured, turfy material to that which is very fine grained or even structureless. The upper layers of peat deposits in the far north 
are generally lighter in color and coarser and more fibrous in texture than those below; in more southern regions the top layers are frequently blacker and more completely decomposed than those toward the bottom of the deposit.

In the wet condition, before digging, peat is darker in color than when dry and contains from 70 to 90 per cent of water, or more, according to drainage and other conditions existing in the deposit.

\section{CONDITIONS FAVORING THE FORMATION OF PEAT.}

It is probable that where the climate is so cold that the ground is always frozen, below a thin surface layer of growing plants, as in the Yukon basin and northern Alaska generally, all the changes produced by decay cease after vegetable matter is included in the frozen mass. Such changes as occur, therefore, must take place in the relatively short time before a given layer of plant remains has been buried far enough below the surface to escape summer thawing. Generally this would mean that most of the softer and more delicate parts of plants would be preserved with the more resistant parts, and in this way a deposit of peat would be built up more rapidly than would be supposed from the character and density of the vegetation forming the surface growth. On the other'hand, peat thus formed lacks compactness, density, and weight, and requires thorough grinding to make an easily transported and durable fuel. In regions where the climate is cool or cold and moist and where both air and ground water are at constantly low temperatures, but where the ground water is not perennially frozen, the processes of decay and disintegration go on very slowly in masses of plant débris; hence in high latitudes peat is widely distributed and may accumulate to a greater or less extent wherever plants grow.

In dryer regions and in those having high summer temperatures peat is formed only in areas where the ground water rises above or near the surface-that is, in ponds and swamps, for in such places only are found the two important essentials for the preservation of vegetable matter, namely, exclusion of air and uniformly low soil temperatures.

The plants ehiefly concerned in the formation of peat in the far north, to judge from the few specimens seen, seem to be such as are found growing on the surface of the deposits at the present time, comprising mosses (mainly sphagnum), low shrubs, and herbs. In warmer latitudes water plants and certain water-loving grasslike plants growing in wet places are important peat formers and, together with some kinds of shrubs and trees, build up deposits of peat by their growth and partial decay wherever drainage conditions permit. 


\section{PEAT a VARIABLe sUbstance.}

From the foregoing statements it is plain that the peat deposits of one region may be quite different from those of another in structure and in the quality of the material of which they are composed. It is also true that marked variations may be found in different deposits in the same region and even in different parts of the same deposit; in fact it is the general rule that the peat in different layers of a bog varies in structure, degree of decomposition, chemical composition, ash content, and other features. The black or dark-colored kinds make better and more durable fuel; the fibrous brown or lightcolored types serve best where quick, hot fires are required, or for kindling, and are less desirable as general fuel unless given thorough grinding in some form of peat machine to destroy the fibrous character of the material and render it solid and compact.

\section{ASH CONTENT.}

If peat is very high in ash, its fuel value is low, and the ash content may be so high that the material will not pay, in heat units, for the work of getting it ready to burn. Roughly stated, the heating value of peat decreases about 1 per cent for each 1 per cent increase in the ash, but if the ash percentage remains below 20 there are many exceptions to this statement. With increase in ash above 20 per cent, the decrease in heating value is marked. In Europe it is customary to consider all peats with more than this proportion of no commercial value for fuel. Locally, in the absence of better fuels, such material could be used, however, either for heating and other domestic purposes, or in the generation of power by firing under boilers or in gas producers.

The ash in a sample of peat may be determined roughly by burning a small thoroughly dried block of the material to be tested in a tin can or cup, the bulk of the ash in proportion to that of the original block indicating the relative amount of ash. It should be remembered, however, that the ash of peat is very light and bulky compared with that of coal. If means of weighing are at hand, the percentage of ash can easily be obtained. The can or cup is weighed before and after putting the peat into it, the difference being the weight of the peat; after the peat has been burned the can is w eighed again, and this weight, minus that of the can, is the weight of the ash. The percentage of ash can then be found by dividing the weight of the ash by that of the peat and multiplying by 100 .

It is generally possible to tell by inspection whether peat has a large percentage of ash. The mineral matter that it contains is brought to it either by the wind, as dust, or by water, as floating mud 
or as dissolved matter, which may reach the deposit from streams, rain rills, or springs. Peat which becomes gray or contains rusty or whitish spots on drying, or which is gritty when ground between the teeth, or is greenish or grayish when wet usually contains much ash.

\section{DISTRIBUTION OF PEAT IN ALASKA.}

The cool, moist climate of the greater part of Alaska favors the formation of peat because the remains of such vegetation as grows are preserved under climatic conditions and accumulate as peat beds.

In the mild southeastern parts of the Territory, along the Pacific coast, the growth of plants is luxuriant, and forests, with a dense undergrowth of shrubs and herbs, and in many places carpeted with mosses, cover the lowlands and slopes. Beneath such forest growth, beds of peat of considerable thickness have been observed where streams have cut into them, and it is reasonable to expect that they may be found in similar places away from streams.

In the dryer southwestern part of the Territory, although there are no forests, shrubs, grasslike herbs, and mosses cover the plains, the floors of valleys, and the greater part of the mountain slopes with a dense growth and build deposits of considerable thickness by the accumulation of their remains.

In southern Alaska many beds of peat having a thickness of 15 to 20 feet have been noted, and although they have not been tested the peat was apparently of good fuel value.

In the central and northern sections of Alaska, where there is less rainfall than in the parts already discussed, but where the lower average temperature keeps the air very moist and prevents evaporation, the ground is in general fully covered by grasslike plants, chiefly sedges, and by mosses which form a loose spongy turf.

On the treeless low plains, the tundra bordering the Arctic Ocean and Bering Sea, the turf-forming plants are especially abundant, growing on a frozen substratum composed of their own remains and ice. In some places along the Arctic Ocean, where the sea is now encroaching on the tundra, peat beds rising 8 to 10 feet above sea level receive the impact of the storm waves, while peat in the form of bowlders or finer material strews the beach or makes it up entirely, covering the shore with a stratum of water-soaked mush. In these parts of the Territory the subsoil is always frozen, and the turf, except in the dryest times, is saturated with water, so that decay is retarded or entirely prevented. On the other hand, growing plants get the moisture they need to make luxuriant growth, so that peat is very generally formed and is of widespread occurrence. In places in these regions beds of peat that were 30 to 40 feet deep have been exposed by natural agencies. 
It seems evident that peat beds of workable extent are to be found in most parts of the Territory. As to quality of these deposits, little can be said. It is known that the surface material is very fibrous and poorly decomposed, and it is quite probable that the lower parts of the deeper beds will give material that is much more compact and better for fuel.

\section{METHODS OF ESTIMATING AND WORKING PEAT DEPOSITS.}

\section{INTRODUCTION.}

The principal consideration in prospecting peat deposits in so thinly settled a region as Alaska is that of an assured market near at hand; the area and depth of the peat are of much less consequence. The depth may be determined by boring or digging holes; these should be near enough together to show whether there is enough material of good quality to make an attempt to work it a commercial possibility. The least area that can be exploited successfully depends on several factors, such as the method of manufacture, the depth and quality of the peat, the amount available, the competition of other and better fuel, and the capital to be invested in the plant for its utilization.

The quantity of fuel obtainable from a given peat bed may be estimated roughly as 200 tons of air-dried product per acre for each foot in depth. For dense, heavy, dark-colored kinds of peat the amount will be more than this, and for very fibrous, mossy, light-brown types it may be somewhat less. The quantity of fuel that may be obtained for a power or lighting plant from even a small and rather shallow peat deposit is very considerable, as may be illustrated by the fact that in Sweden a producer-gas plant for generating electricity has been built at a bog having an area of about 35 acres and an average depth of 5 feet, which, it has been estimated, will furnish a full supply of fuel for thirty years. The quantity of fuel contained in this deposit is estimated at 44,500 tons, or 330 tons an acre for each foot in depth, indicating that it is unusually well decomposed and dense. From this and similar facts it may be deduced that small areas of rather shallow peat beds may be utilized to advantage to produce from 1,200 to 1,500 tons of fuel a year for many years, and that, if the plant is equipped with the best types of machinery and worked by modern methods, the cost of production will be low enough so that the income from the enterprise will be satisfactory.

For the most successful manufacture of raw peat into fuel it should have such physical properties that it can readily be put into a form in which it is easy to handle and use without excessive loss; it should not be very high in ash, nor too fibrous or woody to be readily reduced to a pulp by properly designed, simple, and easily operated machinery. 
DRAINAGE.

It is the practice in Europe, where peat is dug extensively for fuel by hand, to drain the bogs carefully before they are worked. Aside from the greater convenience in digging which this practice insures, it frees the peat from water to some extent, although not so much as would be thought at first, because of the water-holding properties of the peat. If, however, the water in the peat averages 90 per cent in the undrained condition and draining reduces it to 80 per cent, the weight of water in the peat, and consequently the waste, will be reduced 50 per cent. If the land is to be drained, the bog should first be surveyed and levels taken to find the fall of the land and the distance and fall to the nearest main watercourse. The removal of the peat should begin at the lowest part or outlet end of the deposit and proceed toward the higher parts. This will make draining a relatively simple matter, and will reduce it to the smallest amount possible; it will also, by keeping the parts still unworked wet, protect them from fires.

THA WING.

Where the peat is frozen, as it usually is in the regions of Alaska where it is most likely to be utilized as fuel, the protecting top layers of growing vegetation, the mat or turf of moss and mingled grasslike plants, should be stripped from considerable areas, in order that the underlying more thoroughly decomposed material may thaw out. Gravels and sands are reported to thaw to a depth of 10 to 12 feet in a season, but it is unlikely that peat will thaw so readily, on account of its poor conducting power, and if it can be worked for a few feet in the ordinary way described below this is all that can be expected.

If the peat does not thaw quickly enough, it can be cut or quarried into small blocks by the use of suitable tools, and, after thawing, these can be cut in to bricks or blocks of the right size for fuel and exposed to the air until dried, or the blocks can be treated and dried by the processes outlined below, in which case they should not be allowed to dry much while thawing.

The material stripped from the surface of the peat, when dry, makes excellent bedding for horses, packing material, or insulating material for covering steam or water pipes laid underground, or for filling in between the walls of buildings to keep the cold from penetrating. When used for insulating it should be as dry as possible.

\section{THE PLANT.}

CHARACTER.

The kind and extent of the permanent plant will be determined largely by the method of preparation chosen, by the extent of the proposed operations, and by the capital available. 
No buildings will be required for making cut peat beyond the rough sheds needed to protect the product from the weather after it has been dried and to protect the tools.

If machine peat is to be made, the only buildings needed will be light, cheap, wooden structures for the protection of the boiler, engine, pulping machine, and the stored product. The buildings may be of the cheapest and simplest construction consistent with durability for the expected lifetime of the plant.

Recent European practice and the most advanced construction in the United States favors small, cheap, compact, portable plants, which dig, grind, and lay or spread out the peat as a continuous operation, engine, boiler, and other machinery all being mounted on a platform on wheels or rollers. Such plants are automobile, and either run on movable tracks or have special broad wheels that enable them to move slowly over the surface of the bog. These plants need no housing, as they are built with removable iron or wooden sides and a stout roof. Increased output, where such plants are used, is obtained by adding new units. The possible output is from 1 to 10 tons of salable peat a day with one or two men, according to the power of the engine employed.

If the plant is designed to produce peat briquets, it must have strong and durable buildings, on account of the weight and size of the necessary driers, boilers, engines, and presses used in any form of the briquetting process, and the storage pockets must be thoroughly protected against the weather on account of the ease with which the product absorbs water.

The producer-gas plant for utilizing peat fuel needs about the same construction as a steam-boiler plant, but the buildings need not be so large for an equivalent development of horsepower.

\section{LOCATION ANI PLAN.}

If the plant is to be a permanent and stationary one, its main buildings should be placed so that the raw, wet peat will have to be moved the shortest possible average distance to reach the machinery by which it is to be treated and the finished material after treatment can be quickly transported to and from the drying and storage grounds. At the same time, account must be taken of the means of getting the product to market easily and at small expense. It should be remembered in this connection that the dry, finished salable product is the cheapest to transport, because there is no waste to it; therefore the finished fuel can be moved a longer distance without loss than the fresh, water-laden raw peat. Still it is evident that the selection of the place where the building is to be located must be more or less affected by its nearness to a town or to favorable drying grounds, etc. The laying out of the plant, the location of machinery in the building, 
and the placing of drying grounds in relation to the buildings must all be carefully planned, so that the necessary processes of treatment may become, so far as possible, automatic, needing the smallest amount of attention and labor. In general, every place where machinery can be substituted for hand labor should be considered, and, if feasible, the machinery put in place.

\section{MACHINERY.}

The choice of machinery is of necessity governed by the kind of product sought. Except for the production of cut peat on a small scale, machinery of some kind is essential. Before buying machinery it is very desirable that the investor should thoroughly acquaint himself with the progress in making peat fuel that has been made in Europe during the last century. This can be done by carefully reading one or more of the excellent manuals of peat utilization noted in the list of publications at the end of this paper.

It is much better to take advantage of the experiments and experience of the practical men who have been at work on the problems of peat-fuel production for more than a century and who have embodied their experience in methods of production that have been fully worked out and proved on a practical basis than it is to attempt to devise new machinery and processes or to adopt untried methods or machines invented by men without experience. An advantage is gained by examining carefully German books on this important subject, because in these will be found records of many unsuccessful peat-fuel machines. The prospective inventor of similar devices may find that his very plan has been tried long ago by experienced men and found useless for commercial purposes. If new methods are to be tried, they should be understood to be such, and not made the basis of a commercial plant, from which immediate financial returns are expected.

\section{PEAT FUEL.}

\section{INTRODUCTION.}

Peat has never been used much as fuel in America, although for many years small amounts have been produced in Canada and in the northern and northeastern parts of the United States, either by experimental factories or by individuals who have prepared small quantities for their own use. Many of the more extensive developments have been conspicuous failures. A few have reached completion, but none have attained their theoretical output; that is, none have made and sold at a profit the amount of peat fuel which the promoters of the plan estimated for a season's production and which the investors had a right to expect. 
In none of this experimental work has the cause of failure been directly traceable to the peculiar properties of the peat itself. In some plants too little capital was available to handle the enterprise properly; in others machinery was installed which had not been thoroughly tested before it was adopted; others were placed in charge of enthusiastic but inexperienced men; and still others were unable to obtain proper and cheap transportation for their products and hence could not market them.

Unlike coal and other fuels on the market, peat needs special treatment, including drying, before it can be used for fuel. As it is dug from the undrained deposit it contains from 85 to 95 per cent of water, and drainage rarely lowers the amount below 80 per cent. That is, a short ton of wet peat may have only 100 pounds of dry, burnable matter and rarely will contain more than 400 pounds. In the wet condition it is entirely unburnable and the various ways in which it is prepared for use or market consist principally in methods for ridding it of water quickly and cheaply and for increasing its fuel efficiency and transportability. The following brief discussion considers these methods in the order of simplicity and amount of capital required for equipment, as well as prospective usefulness under Alaskan conditions. In this discussion the matters of location, markets, means of transportation, and other factors which would be pertinent for regions of denser population and long-established trade in fuels, over well-developed routes, can be omitted, as it is assumed that any use made of peat in Alaska, for some time at least, will be local.

\section{CUT PEAT.}

The simplest and most ancient form of preparation of peat for fuel still in use in Ireland, Sweden, and many other parts of Europe where peat is used for domestic purposes, is to cut it from the bog in the form of blocks. This is done with some special form of spade, the type in use in many parts of Europe being made by welding a narrow, sharp lug at right angles to the point of the blade of a long, narrow spade; this is called in England a slane. As fast as cut, the blocks are laid on the cleared surface of the bog, near the opening, and after a few turnings become partly dry; they are then loosely stacked for further drying and storage.

This form of peat fuel is entirely dependent on the structure of the peat for its texture, compactness, and efficiency. As it can be cut only from the drained parts of peat beds, it is usually bulky, is easily broken and crumbled, and burns freely but with considerable waste. On the other hand, the cost of production is small, and little equipment is required besides sheds for storing and possibly for drying the finished product. The cost of making cut peat ready for the market in 
Europe varies, according to a recent writer, ${ }^{a}$ from about 50 cents to as much as $\$ 1.75$ a ton of air-dried peat. These considerable differences are apparently caused by differences in the methods used and the efficiency and price of labor. The size of the bricks into which the peat is cut depends on the climate, the compactness and state of decomposition of the peat, and the uses to which the bricks are to be put. Allowance must be made for shrinkage of about one-quarter to one-half in the size of the bricks, in drying; bricks of fibrous, turfy, poorly decomposed material would need to be of larger size than those of more compact and well-rotted peat. If cut too small, the bricks are costly to handle, burn too quickly, and break too readily. If made too large, however, they do not dry out quickly or thoroughly and are burned with diffieulty.

The bricks are sometimes cut vertically from the beds and sometimes horizontally, depending on the compactness of the peat. In general, the best results will be obtained by making horizontal cuts from a trench, as this brings the long axis of the bricks parallel with the bedding of the peat.

In northern Europe the top turf is removed from a space as wide as the length to be given the bricks, then vertical cuts are made the length of the spade at the proper distance from the working trench, and horizontal cuts are made with the slane to form the bricks and lift them from the bed. By using a broad spade, with properly spaced lugs, two or three bricks can be cut and lifted at a time.

In those parts of Alaska where the peat beds are frozen and do not thaw out readily on being stripped of their overlying covering of moss, special methods of quarrying the frozen material by the use of saws and axes may be necessary. Thawing in the parts of the peat beds that are being worked may be hastened by cutting trenches near enough together so that the peat between them will be warmed by the air from the sides as well as from the top. It is probable also that the frozen peat may be removed in slabs of considerable size by separating it along the more fibrous layers formed by certain kinds of plant remains, and after these slabs are thawed they can be cut up into bricks. If the peat is to be macerated, it may be dug with pick and shovel and, after thawing, thrown into the peat machine, before it has dried very much.

For Alaskan conditions it is doubtful if the bricks, when cut, should exceed 12 by 6 by 3 inches, and it may be possible that in the moister and cooler parts of the Territory smaller bricks will give more satisfactory results, because drying will be more rapid and more thorough; experiment will determine the proper size for each locality.

\footnotetext{
1908.

a Nystrom, E., Peat and lignite, their manufacture and uses in Europe: Canada Dept. Mines, Ottawa,
} 
It is clearly an advantage to cut as large bricks as it is possible to dry thoroughly, on account of the larger output thus obtained with the same number of cuts and the increased ease of handling during drying.

After cutting, the bricks are laid out on the edge of the cutting trench until they are dry enough to be handled, and are then piled up into small heaps by placing several together on end or cob fashion, or into small conical or pyramidal open piles, the bricks being so placed that the air can readily circulate between them. When well dried they are stacked loosely in large piles and protected from rain by some form of rough roof.

The work of preparing peat for fuel in this way should be begun as early as possible in the spring, so that advantage may be taken of the favorable drying conditions existing in spring and early summer.

So far as can be judged, this type of peat fuel is not adapted for large production in this country on account of the high cost of the necessary labor. It can be used by individuals or by small, isolated communities, such as trading and military posts, mission stations, or mines, where need arises, but especially in those districts away from the seacoast where wood is scarce or at seacoast localities that are remote from wood and coal supplies. The fact that a large part of the fuel used for heating and cooking by the people of Iceland, northern Russia, Finland, Sweden, Denmark, Ireland, and some other parts of Europe is peat which has no other preparation than that above described plainly indicates that climatic conditions need not prohibit its manufacture and use in Alaska.

\section{MACHINE PEAT.}

As the need arose for a fuel better than cut peat, in a more durable and transportable form, efforts were made to improve the texture and other qualities by treatment which rendered the material more compact. The earliest and the simplest process to be used consisted in adding water to the peat as dug, thoroughly kneading it by the trampling of men or animals, either in holes in the peat bed itself or in wooden or metal troughs sometimes 10 feet or more long. The resulting wet pulp is shoveled into molds, or, after being spread in a layer 5 to 8 inches thick over a portion of the bog that has been cleared for the purpose it is marked off into bricks, which separate from one another as contraction due to drying takes place. As soon as they are dry enough the bricks are turned, then piled and treated exactly like cut peat.

The name machine peat is given to all forms of the product made by grinding, mixing, or macerating the wet peat as it comes from the beds, so that it becomes less fibrous. In the process the included 
coarse material is broken up, and probably also some of the cellular structure of the peat is destroyed. Certain colloidal or gluelike substances released or developed during the grinding act to cement the material and, as they are insoluble in water when dry, render the whole mass more or less waterproof.

A distinction is sometimes made between the product obtained by grinding peat to which sufficient water has been added to reduce the whole to a watery pulp and drying the resulting slurry or semifluid mass in molds laid on the ground, and that made by macerating the peat about as it is dug, or with only a slight admixture of water, and forming it into bricks of any desired size by cutting up the long prism of thoroughly ground peat as it issues from the orifice of the grinding machine. The bricks resulting from the latter method are sufficiently firm to retain their form when they come from the machine and are dried by exposure to the air on covered racks, or on the ground without cover.

The crude process of macerating the peat by trampling it in troughs or openings in the bog is not adapted to any but the most primitive conditions, or to places where it is necessary to have the fuel and where better appliances, requiring the development of power, can not be obtained. The process is also open to the objection that a good deal of manual labor is needed in spreading the peat and handling it on the drying grounds.

In Europe this method of making peat fuel seems to be confined largely to small and isolated communities, and it is emphasized here only because it may be used in such places in Alaska where no other fuel can be had at equivalent cost. In European districts and plants where peat production is large such inefficient and simple methods have been abandoned for those depending on machines, the output of which is sometimes also called condensed, machine-formed, or pressed peat. The last name is something of a misnomer, however, for only enough pressure is exerted upon the peat by the machinery to force it from the outlet in a stiff, pasty condition. In the United States the term "wet process" has been applied to distinguish it from briquetting, in which the peat is dried artificially before shaping it by pressure.

So far as shown by many entirely trustworthy reports the machine process is the only successful method of making fuel for general purposes from peat now in use in Europe, and for that reason it merits a somewhat full discussion here, especially as it is generally applicable to all types of peat and requires but a relatively small outlay of capital to establish a well-equipped plant and but little experience and power to run it.

The essential part of such a plant is the peat machine, of which many patterns are now on the market. Some excellent models of 
these machines have been designed and are built to order in the United States. In its simplest form the peat machine is very similar to the clay pug mill of the brickmaker, and both brick and tile mills have been used in this country with peat of certain types for making peat fuel. The specially designed peat machine, however, consists of a vertical or horizontal cast-iron body, with a hopper attached above it, in which revolve one or two knife-armed shafts. These are provided also with spirally arranged flanges for moving the peat forward to the grinding knives and advancing it to the outlet after grinding. In some machines the edges of the screw flanges are sharp and work against knives set firmly in the cast-iron walls of the body of the machine. Others have both fixed and revolving knives combined with screw flanges.

The main object of the whole construction is to thoroughly cut up, crush, and grind all the constituents of all types of peat into a homogeneous, pasty mass, without clogging or braaking the machine. The machine that will make uniformly compact, tough bricks from any type of peat, but especially from fibrous material, rapidly and continuously, without excessive consumption of power, is the one best adapted to Alaska peats. The most successful peat machines are of very heavy construction and have adjustable knives, so that any kind of peat can be ground, and all parts subject to clogging and wear are easily accessible. The heavy construction is necessary because of the stumps and other woody matter, as well as stones, often found in peat beds.

Machines of foreign make may be had of all sizes and capacities, from those which can be run by a single horse and with the help of a few men have a capacity of 3 tons or more of air-dried fuel per working day up to those which require a considerable force of men, powerful engines, and auxiliary machinery for excavating and handling the product and have an estimated capacity of 50 tons or more of finished material per day of ten hours.

For detailed descriptions of the types of machines of this class made by many European manufacturers and for reports as to their efficiency the reader is referred to the excellent accounts by Nystrom ${ }^{a}$ and to the catalogues of American and European manufacturers of peat machinery.

Besides the peat machine, the equipment for making pressed peat consists of small cars, trucks, and other machinery for moving the product to the drying grounds and storage sheds and, at most plants, for carrying the raw peat from the bog to the peat machine.

The larger peat machines are usually provided with some form of mechanical elevator, which takes the peat to the hopper from the car,

a Nystrom, E., Peat and lignite, their manufacture and uses in Europe: Canada Dept. Mines, Ottawa, 1908.

$55695^{\circ}-$ Bull. $442-10--8$ 
or from the top of the bog, or possibly from the bottom of the excavation, the arrangement being dependent on the location of the machine relative to the excavations.

The machine itself may be mounted directly on rails or on a movable platform by the side of the excavation, and follow the digging, thus saving the expense of moving the wet peat to some fixed point of grinding. In case this plan is adopted, the cleared part of the bog may be used for a drying ground, and only the dry material need be taken from the bog, a plan which saves the cost of transporting the large amount of water contained in the wet peat. 'To this equipment must generally be added, under the economic conditions found in America, some form of power digging machine suitable for getting out from the bog each day as much peat as the machine can properly grind. Failure to do this involves the necessity of having a large force of men digging peat, as it is estimated that practically ten times the weight of material produced must be dug - that is, 500 tons, or about 400 cubic yards, for an average daily production of 50 tons. The form of digging machinery is apparently immaterial, so long as it is efficient and adapted to the conditions under which it must be used. In Europe the chain-and-bucket digger has been used with success. The ordinary steam shovel, the bucket or dipper dredge, and similar forms of steam excavators have been tried, and recently the centrifugal pump has been used for digging very wet peat, which, after excavation, is forced or floated to the machine. As such devices as those mentioned are of doubtful utility under conditions known to exist in parts of Alaska, where it may be especially desirable to make machine peat, the conditions under which operations are to be carried on in a particular locality must be thoroughly studied before any of these digging devices is chosen. It is not unlikely that in many places none of them can be used, in which case special methods should be developed, as, if some provision is not made, the producing part of the plant is likely to be in operation only a part of the time. Sufficient drying ground and storage room must also be laid out and made ready for any contingency, or again the plant will be idle at times when everything else is favorable for production.

The requirements for making the ordinary machine type of fuel from peat are, therefore, (1) a deposit of good peat; (2) some form of peat machine; (3) machinery for digging the peat; (4) adequate ground space and pallets, or short wooden boards, on which to dry the peat, and enough room for storage; (5) tramways and cars, or mechanical carriers of some description, for transporting the peat to and from the grinding plant, the drying grounds, and the storage bins. The cost of this outfit, exclusive of the land, naturally will vary widely according to the estimated productive capacity of the plant, the number and quality of the buildings erected, and the amount and 
kind of accessory machinery provided. The cost for a 5 -ton plant will be not far from $\$ 1,000$; one which will produce from 50 to 60 tons of finished peat fuel a day will probably cost from $\$ 8,000$ to $\$ 10,000$, if economy is used in laying out and constructing the buildings. These prices are for the eastern part of the United States, and to them must be added the cost of transporting the machinery to the locality where it is to be used. This cost, with other items that must be taken into account, will mean an increase of at least 50 per cent for most parts of Alaska. The capital needed to run the plant during its first season must be added to this sum.

Small, compact, and efficient machines of simple and strong construction and with a capacity of 5 to 20 tons of finished fuel daily seem best adapted to the conditions existing in those parts of $\Lambda$ laska where peat is most likely to be used as fuel. This is especially true until more is learned about the chances of success of an entirely new type of fuel of which the prospective consumers know little of the heating value and other qualities of the raw material and nothing of the final product. The capacity of a small plant can be increased at any time by duplicating the essential machinery. It is far easier, in any case, to be successful with a small, thoroughly equipped plant, turning out a finished and attractive looking form of fuel, than with one only partly fitted out with a highly efficient peat machine, the rest of the equipment being inadequate to run it.

In this connection it may be said that in the last two years there have been brought out in both Europe and the United States small portable peat plants designed to move about on the surface of the peat bog by their own power, and, while moving, to dig, grind, and spread the peat, very little manual labor being required. One of these, designed and used in Germany, runs on a movable track placed beside the trench from which the peat is dug. The machine digs the peat on one side and elevates it to the pug mill, where it is ground and formed into bricks, which are spread on the bog surface in orderly fashion on the side of the track opposite the opening, the whole plant moving along the track as the work progresses. This machine is operated by a single man, the power for digging, grinding the peat, and spreading it, as well as moving it, being supplied by a gasoline engine, although steam could be used. The daily output is the equivalent of 10 tons of dry fuel.

A similar portable plant of about the same capacity, designed and built in this country, is independent of track, being mounted on broad wheels and a movable roller platform, which is a part of the plant. The digging is done from the rear end of the machine as it moves slowly forward, and the peat as it is dug is elevated to the grinding mill, from which it falls through a spout into a spreading and marking device that forms it into a sheet of uniform thickness on the surface of 
the bog and marks it with parallel cuts lengthwise, so that on crosscutting it rectangular blocks or bricks will be formed. The machine is also designed to turn the blocks up into windrows as they dry. This plant is operated by a single man, or in larger sizes two may be required. The motive power is a gasoline or steam engine. The German plant has been thoroughly tested, and the American plant will be used during the summer of 1910 in a number of places.

The cost of production of machine peat is generally estimated in the United States, somewhat optimistically perhaps, at not over $\$ 1$ a ton of air-dried fuel. This estimate is doubtless fair, if only the cost of labor is taken into account, as in Europe the labor cost generally falls below 75 cents a ton, but when loading, managerial, interest, maintenance, and amortization charges and the cost of the peat are properly apportioned the cost will be found to exceed $\$ 1.50$, and unless unusual skill in management is shown will probably approximate $\$ 2$ a ton. From this statement it may be possible to estimate the cost of the same material under the conditions existing in different localities in Alaska where it may be desirable to attempt the manufacture of machine peat.

At present it is impossible to forecast the prices at which peat can be sold in Alaska. The little that has been produced in the United States has been eagerly bought at high prices for domestic use, and more has been demanded after it has been tried. Its theoretical fuel value is greater than that of good wood and from five-eighths to fiveninths that of good coal, hence its selling price should be intermediate between that of wood and coal in the communities where it is produced.

An objection often made to this method of preparing peat is that production must be confined to the season of no frosts, as freezing prevents the wet machine peat from properly compacting and drying hard; moreover, rainy or very humid weather checks operations entirely, because the peat will not dry out of doors in such weather. These conditions necessitate the suspension of work altogether during the winter and give irregular employment to the force and plant at all seasons; they also reduce the theoretical output. The same objections are valid, however, in many other successfully conducted industries, some of which require much larger capital for equipment. They therefore seem no certain bar to success in this new industry, which will, in Alaska, have a season of production quite as long as that in other regions where peat is the only fuel and where the fuel supply for the entire year is prepared and stored during short humid or even rainy summers. In Sweden the peat-gathering season ends about the 20th of August in most years.

Artificial drying by some simple and direct method after the bricks have been formed is the ideal sought by many inventors to replace 
the uncertainties and limitations which the present system of air drying imposes upon production, but no one has yet been able to overcome the fact that it takes more heat to dry a ton of wet peat as it comes from the bog or the peat machine than can be obtained from the fuel which the process yields. To this cost for fuel must be added all the charges for producing the material which is dried. Moreover, during the drying process the bricks crack and check, their value being thus seriously impaired. It seems possible, however, that by utilizing waste heat in very efficient driers peat from which a considerable amount of water has already escaped may be dried sufficiently by artificial treatment to be stored, and that the limit of the season of production may be thus extended. Aside from the peculiar properties of the peat, the cost of the additional treatment and handling, as well as of extra equipment, must be taken into account, as these must be paid for by the material recovered.

It is evident, therefore, that the problem is complicated and can be attacked only by trained and experienced men if it is to be brought to a successful issue. Successful artificial drying, in any event, will be accomplished only by utilizing what would otherwise be waste fuel and heat. It appears certain that no attempts should be made to dry machine peat artificially in Alaska until it is clearly shown that air drying can not be successfully used, and that there is in some locality a demand for this kind of fuel great enough to justify the costly installation that must be made to have the process even technically a success.

\section{BRIQUETTED PEAT.}

In Europe, where lignite and poor grades of coal have long been successfully briquetted and sold in large quantities, the attempt to briquet peat was made early in the development of the briquetting industry. In this form peat makes an efficient and easily transported fuel and commands a ready sale, at good prices, for domestic use, because of its cleanliness, ease of handling, and other good qualities. The briquets are of uniform size and of cylindrical, ovoid, prismatic, or other shape. Generally, although not invariably, they burn more slowly than peat prepared by the processes previously described.

In preparing the peat for briquetting, cut peat or pressed peat is air dried to about 40 or 50 per cent of moisture, then ground and screened and artificially dried to about 15 per cent of moisture; it is then conveyed to the briquetting press or stored. An improved method of air drying is in use near London, Ontario, where, instead of digging, grinding, and pulverizing the peat, as is generaily done in Europe, the surface of the cleared bog is very lightly barrowed, and after an hour or more of exposure to the sun and wind the air-dried dust is collected by a special machine, constructed on the principle of the exhaust carpet cleaners and operated electrically from a track 
laid on the surface of the bog. As only the dry dust is picked up by the collector, the material reaches the storage bins with not more than 30 per cent of moisture. It is afterward pulverized still finer and dried to about 15 per cent of moisture in its passage to the briquetting press.

All forms of air drying out of doors are open to the objections that have already been stated, and more attempts have been made to produce driers for the production of peat briquets than can be recorded here. Nearly every principle applicable to the construction of machinery of this type has been tried, and as yet none has been found able to meet the need satisfactorily, so that the peat can be dug, ground, dried, pulverized, and briquetted without the intervention of a period of exposure to the air and the sun's heat. This has been the aim of all manufacturers of peat fuel, and especially of inventors, since the briquetting press was introduced, but whether they have tried driers alone or combinations of presses for squeezing out part of the water, with driers of almost every conceivable type, using direct heat, steam heat, or electric devices, all have been discarded after a time, because of the cost of maintenance as compared with the value of the output; in other words, they have failed to pay operating expenses and a profit. This failure may be attributed, beyond any doubt, to the small value of the product and the small quantity of salable material obtained as compared with the raw peat treated, as shown in the table below:

Weight of water removed at 10 per cent stages from 1 ton of peat as excavated from the bog (90 per cent water) in drying to 10 per cent of water.

\begin{tabular}{|c|c|c|c|c|c|}
\hline $\begin{array}{l}\text { Percent- } \\
\text { age of } \\
\text { water in } \\
\text { the peat. }\end{array}$ & $\begin{array}{l}\text { Dry peat } \\
\text { content. }\end{array}$ & $\begin{array}{l}\text { Water } \\
\text { content. }\end{array}$ & $\begin{array}{l}\text { Weight of } \\
\text { water re- } \\
\text { moved for } \\
\text { each } 10 \text { per } \\
\text { cent re- } \\
\text { duction. }\end{array}$ & $\begin{array}{l}\text { Weight of } \\
\text { material } \\
\text { obtained } \\
\text { for each } 10 \\
\text { per cent } \\
\text { reduction. }\end{array}$ & $\begin{array}{c}\text { Total } \\
\text { weight of } \\
\text { water } \\
\text { evapo- } \\
\text { rated. }\end{array}$ \\
\hline $\begin{array}{l}90 \\
80 \\
70 \\
60 \\
50 \\
40 \\
30 \\
20 \\
10\end{array}$ & $\begin{array}{r}\text { Pounds. } \\
200 \\
200 \\
200 \\
200 \\
200 \\
200 \\
200 \\
200 \\
200\end{array}$ & $\begin{array}{c}\text { Pounds. } \\
1,800 \\
800 \\
466.7 \\
300 \\
200 \\
133.3 \\
85.7 \\
50 \\
22.2\end{array}$ & $\begin{array}{c}\text { Pounds. } \\
\text { i,000 } \\
333.3 \\
166.7 \\
100 \\
66.7 \\
47.6 \\
35.7 \\
27.8\end{array}$ & $\begin{array}{c}\text { Pounds. } \\
2,000 \\
1,000 \\
666.7 \\
500 \\
400 \\
333.3 \\
285.7 \\
250 \\
222.2\end{array}$ & $\begin{array}{c}\text { Pounds. } \\
\cdots 1,000 \\
1,333.3 \\
1,500 \\
1,600 \\
1,666.7 \\
1,714.3 \\
1,750 \\
1,777.8\end{array}$ \\
\hline
\end{tabular}

The most recently advertised artificial drying plant for preparing peat for briquetting has been developed in the United States. It is described as a series of large hollow rolls revolving at different rates of speed and heated by exhaust steam from the engine which runs them. The peat, in the form of a thin paste, is passed between the rolls and formed into a sheet of dry pulp, after which it is disintegrated and pressed into briquets, of any desired size and shape. 
The cost of briquetting plants is six to ten times greater than that of plants of the types previously mentioned, probably involving a minimum expenditure of not less than $\$ 50,000$ for the complete equipment, with buildings, necessary driers, engines, digging, and other appliances, and a single briquetting press with a capacity of about 50 tons in twenty-four hours. This unit is mentioned because it is apparently as small as has been considered practicable for commercial purposes. The estimate is based on the quotations of German manufacturers of tried machinery and is likely to be exceeded in actual construction; it certainly will be if untried processes are adopted and newly invented machinery is installed. The greatly increased cost of the plant over that required for the manufacture of machine peat is easily understood in view of the need for heavier and more complicated machinery and for a much greater amount of it, together with the larger and more powerful boilers and engines required, all of which entail heavier and more substantial construction of buildings.

In 1903 F. H. Mason, ${ }^{a}$ then United States consul-general in Berlin, published the following estimate of the cost of a peat-briquetting plant, equipped with European machinery, for artificial drying, with an estimated output of 50 tons of briquets a day:

Estimated cost of 50-ton peat-briquetting plant.

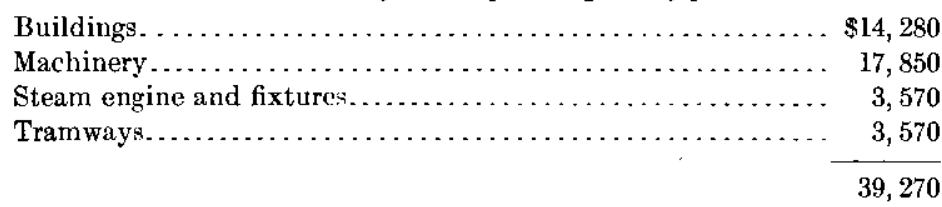

Later estimates increase rather than diminish this sum, and it is doubtful if, when duties, higher price of labor, and other necessary charges are added, such a plant could be constructed in Alaska within the estimate first given $(\$ 50,000)$.

If, however, the system of drying the peat on the bog is adopted, a certain undetermined deduction may be made, as a part of the drying machinery will not be needed. It may be said also that by increasing the surface from which air-dried material is collected and the number of collectors, a sufficient amount of peat dust may be gathered and stored to supply the briquetting press during unfavorable weather and even through the winter. If this is done, weatherproof storage houses of large capacity and of durable construction will have to be added to the equipment.

I $t$ is apparent also that if the price of production given for machine peat is a just approximation, that for briquetted peat must be increased at least by the interest charges on the greater investment required 
and by the maintenance and other expenses of running the more complicated and powerful machinery. Besides this, the added cost of artificial drying and of grinding and briquetting must be taken into account. It will hardly be possible, therefore, to make peat briquets with any machinery now on the European market for less than $\$ 3$ a ton, and even this is scarcely feasible, except under very favorable conditions. What can be done with American machinery now in the process of development remains to be seen. The Canadian processes mentioned above have not yet reached the stage where their inventors consider them fully perfected, although they are in operation on a factory scale; no figures relative to them can be quoted.

The fuel efficiency of briquetted peat should be at least one-third greater than that of machine peat of the same origin to warrant the added cost of production given above. Actually the increase in efficiency, as given by Nystrom, is only about 15 per cent. It is therefore apparent from business considerations that the increased cost of the plant and the more complicated machinery and processes necessary to make peat briquets are not justified, especially as the cost of production is more likely to be 50 per cent greater than it is to be 33 per cent. Peat is somewhat more transportable in the form of briquets than in any other form because it is less bulky, and it might have a somewhat greater sale on this account, but not in proportion to the increase in cost of manufacture. The present state of the attempts at cornmercial production of peat briquets is such that the installation of a plant for this purpose in Alaska should be undertaken only after the most careful examination of European and American developments in this direction to find out whether they could be used as desired. In any case only the densest and purest deposits of peat, and those of large extent, should be considered suitable for briquetting operations.

Electric processes of preparing peat for briquetting have been announced at various times and extensively advertised. They have been based on the supposition that the cell structure of the plant remains in the peat would be destroyed by the passage of electric currents, after which the water could be removed by pressure. None of these processes has yet been commercially successful, and the theory on which they are based is of very doubtful value, as there is no evidence that the cellular structure will be in any way affected by the passage of the electric currents used.

\section{PEAT POWDER.}

Peat in the form of fine powder, burned under a blast in a specially constructed burner, makes a very efficient fuel. The process of preparation is simple. The peat is cut or dug from the bog and, after being left on the surface through the winter to disintegrate, is gath- 
ered in a partly air-dried condition, dried artificially, and then pulverized. The resulting powder is dark colored, nonabsorbent, and very nearly as heavy as coal.

In firing with peat powder no smoke is developed, because the supply of air can be adjusted so that combustion is complete and rapid. The firing can be so regulated and controlled by the engine, after proper connections are made, that it becomes almost or quite automatic. In fact, peat used in this way burns and yields results like a gas. This is especially illustrated by the ease with which the temperature of the flame is regulated and by the possibility of getting oxidizing and reducing flames at will by changing the quantity of air supplied to the flame.

The temperatures obtained and held by properly built peat-powder burners are sufficient to melt glass, iron, steel, and other metals, and the use of peat fuel of this type for burning brick and lime could be widely extended in regions where peat is abundant. The vacuum collector, already mentioned, which takes the peat from the bog in the form of air-dried powder, should have special application to this product for fuel purposes, if it has sufficient capacity to warrant its use. With it the cost of gathering, completing the drying, and pulverizing should not exceed $\$ 2$ a ton for the product ready for the market under conditions as they exist over most of the United States, and the cost of a well-equipped plant will be much less than for one intended for any type of briquetting.

\section{PEAT COKE AND CHARCOAL.}

A step further in the process of increasing the fuel value of peat and of rendering it more transportable is to convert it into coke or charcoal. The present method of coking peat is to make bricks of the peat to be converted into charcoal, using any of the types of peat machines developed for making machine peat and, after drying these bricks as thoroughly as possible by exposure to the air, inclose them in gastight retorts heated from the outside. The gases driven off from the peat when heated in such retorts are, so far as possible, condensed and redistilled, and in this way a number of valuable byproducts are recovered. These substances are practically identical with those obtained from the destructive distillation of wood in charcoal making by modern methods. They consist of (a) methyl or wood alcohol, ammonia or anmonium sulphate, and acetic acid or acetate of lime, which are obtained by treating the tar water or lighter distillates; and (b) illuminating oils, lubricating oils, paraffin wax, phenol (creosote oil and carbolic acid), and asphalt, which are obtained from the tar. The noncondensable gases are combustible and may be used in heating the retorts and in running the engines which furnish the motive power of the plant. 
The most fully developed and most successful of the processes of coking peat, and apparently the only one which has reached the commercial stage, is that devised by Martin Ziegler and represented in Europe by three large and successful plants, two in Germany and one in Russia. By this method the peat is dug and formed into bricks by peat machines and air dried exactly as if it were to be sold as machine peat. The peat bricks are then stacked in vertical castiron retorts with fire-brick lining, provided with air-tight openings for removing the finished coke and recharging with peat, and with flues for the escape of the gases formed. The retorts are surrounded by a double fire-brick wall with flue spaces between, through which the combustion gases pass. These gases are further used by conducting them to driers, where the peat is dried before introducing it into the ovens.

At the beginning of the process fires are started in fire boxes at the base of the retorts, but when the coking is well under way the lighter and uncondensable gases are conducted to the fire boxes and furnish all the heat needed. The condensable gases are drawn by fans to the special recovery plant and there redistilled, a part of the necessary heat coming from that of the combustion gases and a part being waste heat from the coking retorts. As fast as a charge is sufficiently coked it is drawn off at the bottom into air-tight receivers in which the coke cools. At about the same time a fresh quantity of peat is put into the top of the retort, through box openings provided for the purpose, thus making the process continuous.

The products of this treatment are peat coke and peat half coke, the latter not so thoroughly coked as the former, so that not all the heavy volatile constituents are driven off. The peat coke is black, heavy, and hard, gives a metallic note when struck, is as strong as good charcoal, and is adapted to all the uses of charcoal, especially to the smelting and refining of metals. The half coke is less dense and burns with a long, clear flame, making excellent fuel for use under boilers and for steam production generally.

For making peat coke of good quality the peat should be thoroughly ground and dried and should be low in ash and other impurities. For the half coke poorer grades of peat with considerable ash may be used.

The amount of coke obtainable from peat of good quality- that is, peat which contains less than 8 per cent of ash, which is free from coarse fibrous or woody material, and which, when machined, dries into hard, tough blocks by the Ziegler process-is from 30 to 33 per cent, and of peat half coke (or peat coke No. 2) from 45 to 50 per cent of the weight of the dry peat used. A considerable portion of the remainder is recoverable as by-products, which are, it is claimed, sufficiently valuable to pay a considerable part, if not all, of the cost of production, leaving the peat coke as profit. 
The coking plants are built on the unit system, a single retort or, better, two retorts, with the accessory mechanism and recovery plant, constituting a unit. The cost of a unit with two retorts is about $\$ 50,000$, and in it about 50 tons of air-dried peat could be coked daily, with a resulting product of $16 \frac{1}{2}$ tons of coke or nearly 23 tons of half coke. The cost of production and of the recovery of by-products for the unit with one or two retorts is high compared with that for a larger number, as about the same general equipment, supervision, and number of men are necessary in either plant.

The cost of producing peat coke, including digging, machining, and drying the peat, expenses of maintenance, etc., under conditions existing in America is estimated to be from $\$ 3$ to $\$ 3.50$ a ton for small plants and considerably less for large ones, if the by-products are recovered and sold at current market prices. For Alaska these prices would be considerably increased, as labor costs so much more and there would be no market for the chemical by-products. Without the sale of such materials it is doubtful if the coke could be made at a profit, except on a very small scale for use in metallurgical operations requiring charcoal, as peat coke can replace charcoal in all its uses, including the making of charcoal iron and steel and the refining of other metals. Powdered peat charcoal is also used in hardening steel and in the manufacture of calcium carbide. As a fuel it is reported to be, and in all respects should be, equal to hard-wood charcoal.

As yet no attempt to manufacture peat coke by the Ziegler process has been made in the United States. A few small ovens have-been erected for making peat charcoal on an experimental scale, but so far as has appeared these ovens have not been sufficiently well equipped to get beyond an early stage of experimentation, and it can not be foretold whether peat coke and charcoal can be profitably made here or not. The matter is still more uncertain for Alaska, for it is not even known that peat of the right sort for making peat coke can be found there in large enough deposits to justify the erection of a suitable plant for making it.

\section{GAS FROM PEAT.}

When peat is heated in a closed retort or away from the air, large volumes of gas are given off. This gas is inflammable, burning with a bright flame, which develops much heat. In fact, its production gives the long, bright flames which characterize a peat fire when the fuel is thoroughly air dried.

The gas from any fuel-charcoal, coal, coke, wood, or peat-is generated on a commercial scale in some form of gas producer, commonly a vertical hollow furnace, with a grate at the bottom and an air-tight device for supplying fuel at the top, so that it may be operated 
continuously. Gas producers for the development of illuminating gas are not here considered, as those in which "power gas," for use in internal-combustion gas engines, and fuel gas are made are of more special interest in this discussion.

An old type of power gas producer still in general use is known as the "suction producer" and supplies gas directly to the engine, which develops its charge and draws it from the producer, as needed, by the suction of its own piston stroke. Producers of this kind are restricted to the use of anthracite, charcoal, and other fuels without bituminous matter, unless some very efficient form of tar extractor is used, as the tars and similar substances from bituminous fuels would be carried over into the engine as gases and, condensing there, would clog up the valves and other working parts.

A second type is the pressure producer, which is so constructed that steam and air blasts cause the gas to be produced from the fuel under slight pressure. It can thus be stored under pressure in a suitable container until used, and as its production does not depend on the suction stroke of the engine, it can be cleansed on its way to the container before it is supplied to the engine. Gas producers of this kind, therefore, are adapted to the use of bituminous coal, lignite, and peat, and when used with such materials are provided with special attachments for cleansing the gas of ash and the condensable volatile matter, the gas being forced through these attachments as it is sent to the container. This type of producer was designed for large plants and until recently was run chiefly on anthracite.

A third form of power gas producer is the down-draft type, in which the tarry products of distillation of the fuel are converted into permanent gases. This type seems to have been most satisfactory for use with peat abroad. The hot gases containing the volatilized tars and similar materials are drawn by exhaust fans from the top of the producer through the fuel bed, where the hydrocarbons are decomposed in contact with the hot carbon into simple, permanent gases, which are then cleansed and supplied to the engines.

Gas producers for using peat as a source of power gas have been made by several European manufacturers of gas engines. They have been for several years in successful operation in Sweden and Germany, and new plants are yearly added to the list.

The producer gas obtained from peat is large in quantity, as much as 48,000 cubic feet per ton of water-free peat substance, having a heat value of 152 British thermal units per cubic foot, being reported. ${ }^{a}$

The calorific value of producer gas from peat varies considerably, like that of producer gas from coal and other fuels, the variations depending on the quality of the peat, the amount of air and steam

a Nystrom, E., Peat and lignite: thelr manufacture in Europe, Canada Dept. Mines, Ottawa, 1908, p. 227 . 
introduced into the producer, and the type of producer. Nystrom gives the results of carefully conducted European tests to determine the calorific value of producer gas from peat as follows:

Calorific value of producer gas from peat.

[ Britlsh thermal unit per cubic foot.]

From a Koerting gas producer at Skabersjo, Sweden, specially constructed for using peat. Average of ten analyses made by testing commission. Peat used had 32 per cent moisture.............. 132

From a Luther gas producer, built for using peat at Ofenfabrik Koefner, Nymphenburg............................ 114

From a Mond producer of the type used for bituminous coal at Stock-

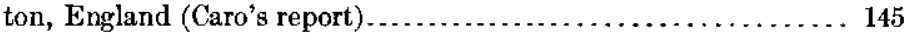

From a Mond producer at Winnirgton, England (Caro's report) . . . 152

In this country very few records of experiments with peat in gas producers have been published. Of these experiments, the two made in 1905 and 1906 at the fuel-testing plant of the United States Geo$\operatorname{logical}_{\text {Survey }}{ }^{a}$ at St. Louis, Mo., are of importance chiefly because they were made in a large pressure, producer constructed for anthracite coal and not for bituminous fuels. As in one of these experiments the amount of peat used was too small for a full-test run, they must be considered as incomplete. In the first test the gas obtained was made from air-dried machine peat from a point near Halifax, Mass., and its average calorific value was 166 British thermal units per cubic foot. The second test was one of fifty hours' duration, using air-dried machine peat obtained near Orlando, Fla., the average calorific value of the gas being 175 British thermal units per cubic foot. These values are about the same as those of the producer gas obtained from bituminous coal in tests made at the St. Louis testing plant during the same year, in the same gas producer, and by the same corps of testing engineers.

Calorific value of producer gas from bituminous coal.

[ British thertnal units per cubie foot.]

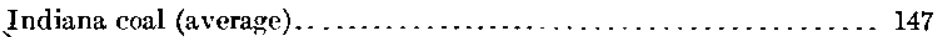

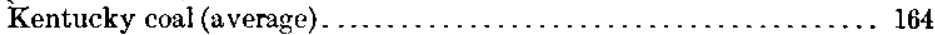

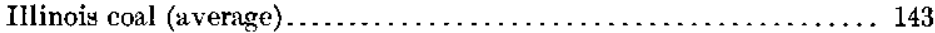

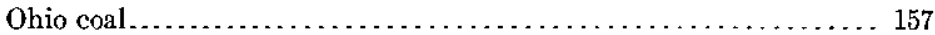

Pennsylvania coal.................................... 142

Virginia coal..................................... 157

North Dakota lignite............................ 161

In the 50 tests from which the foregoing figures were obtained the gas in only five showed a greater calorific value than that of the Massachusetts peat; and the value of the Florida peat was surpassed in but one test on coal, and that only by a single British thermal unit. 
These comparisons show that the two samples of American peat and the foreign peats referred to above were as good fuel for the gas producer, so far as quality of the gas is concerned, as the coals used in the tests cited. It should also be noted that while air-dried machine peat was used in the producer tests at the fuel-testing plant, it is quite possible to use peat with 30 to 40 per cent of moisture and in lumps of any size or shape, as dug from the bog, for manufacturing producer gas.

Another significant feature of the tests cited above is the fact that the single full-test run made with peat as fuel in the gas producer gave a greater horsepower than that obtained from the best of the coal used in the boiler tests. The same result was obtained in the shorter run on Massachusetts peat and more recently has been confirmed by tests made by the United States Geological Survey at Pittsburg, Pa., with a down-draft gas producer designed for bituninous coal. In one of these more recent tests the peat used was from North Carolina and contained nearly 29 per cent of ash, yet gas was obtained of good quality and in sufficient quantity to run the gas engine that formed a part of the testing plant with its full load in a satisfactory manner. The energy of the fuel was converted into electric current and a commercial electric horsepower per hour was developed from about 4 pounds of the peat as fired-that is, with more than 28 per cent ash and 15 per cent of moisture.

Too much stress must not be placed on these few test runs, but it seems safe to conclude that the value of peat as a fuel is greatly increased when it is converted into power gas in a gas producer, and that, in the tests cited, under rigid conditions, the peat, with a fuel ratio to bituminous coal of $1: 1.8$, gave more power when gasified and used in a gas engine than an equal weight of coal used as fuel under a steam boiler. Apparently, therefore, the ideal way in which to use peat fuel for power purposes is to convert it into producer gas and use it in the gas engine, and that this can be successfully done has been demonstrated by a number of commercial operations abroad.

The cost of installing a plant with gas producers and gas engines is as yet somewhat greater than that of equipping with steam boilers and engines of the same horsepower, but these differences are decreasing. On the other hand, the cost of operating and maintaining the producer plant is about one-half that of the steam plant, ${ }^{a}$ because a smaller amount of fuel, of much poorer quality, and a smaller firing force are required.

The weight of dry peat required per electric horsepower per hour, as shown by the available records of experiments, averages from 2 to 3 pounds, and the gas obtained from the producer may be somewhat 
richer in hydrogen and lower in nitrogen than that from coal, although the hydrogen content would naturally depend on the degree to which the free hydrogen developed was consumed in the producer.

The principle governing the use of peat in gas producers as a source of power gas for use in gas engines may be applied to the production of fuel gas, ${ }^{a}$ and in that form the energy of the peat may be economically and satisfactorily converted into heat units for firing steam boilers, ceramic kilns (brick, tile, pottery, etc.), lime and cement kilns, metallurgical furnaces, f॰rges, foundries, and steel, muffle, glass, oreroasting, and similar furnaces. ${ }^{b}$ It is probable also that producer gas generated from peat could be used for fuel to thaw gravels in placer mining in those parts of Alaska where thawing is necessary. The gas could be generated for this purpose in pressure producers built without the more complicated scrubbing devices necessary to purify the gas for gas engines, and stored in simple gas holders, from which it could be piped to the places where it is to be used and burned in blast burners attached to suitable lengths of flexible hose. As producer gas is rich in carbon monoxide, a colorless, odorless, and very poisonous gas, care to prevent leakage would be necessary in all confined places, like pits and tunnels.

Illuminating, retort, or bench gas made by heating peat in closed retorts or ovens heated from the outside until all the gaseous matter is driven off could be used for the same purposes as producer gas. It is also possible to develop both kinds of gas at one operation by using the waste heat from gas producers to coke peat in closed chambers or retorts placed in such relation to the gas producers that the hot producer gas can be forced through them. This process has been used in the Kiegler coking plants before mentioned and is practicable at least in large operations.

The chief difficulties in utilizing peat for gas production in Alaska are those attendant upon the production of the peat in sufficient quantities for fuel and the transportation of the necessary materials for construction to the places where they are to be erected. These difficulties, however, are no greater than some that have been overcome in other lines of construction in mining operations. The first step in such development should probably be to test thoroughly the feasibility of producing the peat fuel. It now seems probable that, if it is found that this can be done, the product, even though very crude, can be very economically used in gas producers either for fuel or for the production of power.

Peat fuel, in proper form, is especially valuable for metallurgical work, being as a rule much lower in sulphur than coal or coke. Peat 
that has been subjected to salt or brackish water, however, seems to be an exception to this rule and may contain considerable sulphur, some of which appears in the gases produced from it.

The producer in which peat is to be converted into producer gas for any of the purposes indicated above must be designed to meet the peculiar requirements of the fuel and to care for the considerable amounts of tar and other condensable matter that will be liberated as the gasification proceeds. The form of the kilns or furnaces in which the gas is to be burned and the metbod of firing them will also have to conform to the requirements of a gaseous fuel, and men will doubtless have to be specially trained to get the best practical results. In general, the attempt to develop plants for utilizing gas as fuel should be left to trained experts in gas firing and to concerns with large capital, because much experimental work usually needs to be done before such processes and the plants using them attain anything like their theoretical efficiency in actual practice. It may be said, however, that in individual plants nearly all the uses suggested as possible for producer gas as fuel have been tried on a commercial scale, either in Europe or in the United States, in some cases with marked success, and there seems no doubt that peat gas can be produced for any of these purposes very cheaply with a properly designed and well-constructed producer.

\section{USE OF PEAT FOR FUEL IN ALASKA.}

At Nome and along the tundra in that region the coarse, fibrous turfy peat is sometimes used for fuel under boilers, and occasionally for heating, by those who, being natives of northern Europe, are familiar with its use. At St. Michael for two seasons some peat has been prepared under direction of the quartermaster, Lieut. Philip Remington, by cutting it out in blocks and drying in the air. The first season, apparently because of insufficient drying, the material that was gathered burned very slowly and without the evolution of much heat, but by making the blocks smaller and drying more thoroughly this difficulty was obviated and a peat fuel of good quality prepared.

The following is a fuel analysis of this material on the moisture-free basis:

$$
\text { Analysis of peat fuel prepared at St. Michael. }
$$

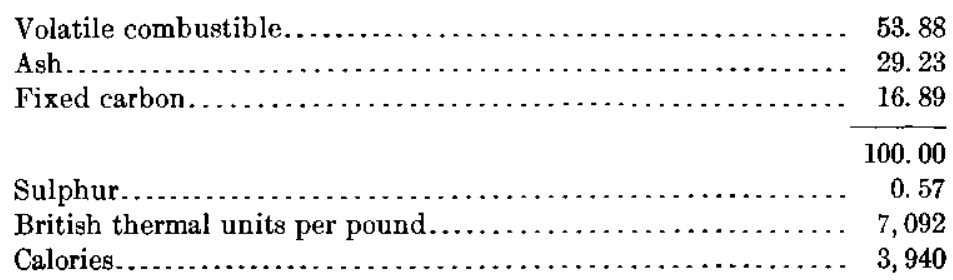


The peat from which the analysis was made consisted largely of the poorly decomposed remains of grasslike plants and mosses and was light in weight. The high percentage of ash reduces the fuel value, but it still is somewhat more than one-half that of the best coal. These facts plainly indicate that, with thorough drying, the peat can be used at least as an emergency fuel in lieu of something better.

\section{CONCLUSIONS.}

But little has been said in this discussion relative to the value of peat as compared with coal and wood. Peat has a theoretical heating value ranging from five-ninths to five-eighths or more of that of good bituminous coal. It may be said, however, that the range of British thermal units in any considerable number of coal samples from different fields, or from different mines in the same field, is rather large. Thus in the tests made at the fuel-testing plant at St. Louis ${ }^{a}$ the thermal value in a variety of bituminous coals from the eastern and central coal fields of the United States ranged from 9,360 British thermal units per pound for the poorest reported to 14,674 British thermal units for the best, while the few samples of lignite tested had a range from 6,739 to 7,603 British thermal units per pound.

The average calorific or heating value of 36 samples of coal from various parts of Alaska, collected and analyzed by the United States Geological Survey, is 12,800 British thermal units per pound, the highest giving 15,200 and the lowest 8,894 British thermal units, all calculated on the moisture-free basis. The lignites and subbituminous coals of the Yukon, the lignites of Chicago Creek and Seward Peninsula, and the subbituminous coals and lignites of northern Alaska would all lie below the average given above in heating value, as most of the 36 samples includerl in the list mentioned were pure bituminous coals. The heating values of such coals generally lie between 6,000 and 11,500 British thermal units. On the same basis peat ranges from less than 6,000 to 10,865 British thermal units, the higher figure being obtained from a peat sample from Florida. Turfy peat from the tundra at St. Michael gave 7,092 British thermal units per pound.

Under test conditions in Europe, in comparison with steam coal of good quality, peat when fired under boilers has been found to have about the ratio stated above-namely, a ton of good peat is worth about five-ninths of a ton of good coal. Under the usual methods of firing, however, there is likely to be a greater loss of heat units from the coal than from the peat, especially if the latter is in the form of air-dried machine peat. The peat does not clinker or give off any 
volatile matter in the form of black smoke; it burns up completely, leaving only a powdery, light ash, which is small in bulk compared with the original fuel; it makes a good fuel bed in the furnace and burns with a long, bright, clear flame, without smoke or sulphurous gases, so that neither flues, grates, nor boiler plates are corroded or clogged. In burning peat it is of advantage not to stir the fire, which causes the fuel to break up and drop through the grate, or to give it too much draft, for then it burns with too great intensity. If, however, the attempt is made to burn cut peat in too large pieces before the material is thoroughly dry, very little flame or heat will be obtained and a smoldering smoky fire is the result, even with good draft. The water in the fuel absorbs the heat as fast as generated, and the fuel mass is kept at too low a temperature to maintain active combustion until the greater part of the moisture is converted into steam. The remedy for such a condition is to cut the peat into smaller pieces and dry these as much as possible before putting them into the furnace. When the interior of the peat mass is moist to the touch, the percentage of moisture is too high to give a brisk fire. In a horizontal furnace the fresh fuel can be dried by throwing it well back of the fire and subjecting for a time to the heat of the outgoing gases, after which it may be spread over the grate. In Europe the step grate is often used where peat is fired under large boilers.

As domestic fuel, machine peat is clean, can be made to burn slowly or rapidly, as desired, by regulating the drafts, is very easily handled, and is so efficient that it commands a ready sale at good prices to all who have had opportunity to try it. The poorer grades, those that are very fibrous and full of ash, are not so good but have their value where other fuel is scarce and high in price.

It would seem, therefore, that there is a good field for the preparation and use of peat in many parts of Alaska, where it is to be found in abundance and of fair or good quality. A small peat deposit will furnish fuel to a community of some size for a long time, if proper methods are taken to develop it. The principal points to be borne in mind in such exploitation are that the simplest equipment which is well designed to produce the desired quantity of a salable form of fuel is the one most likely to be successful, and that every added process of handling adds many times to the first cost of equipment and to the difficulties of producing an article which can be sold at a price sufficient to pay the cost of preparation.

It also seems probable, from present knowledge, that large peat deposits will be most efficiently and satisfactorily utilized by converting the peat into producer gas and using the gas for power to run gas engines, which, in turn, may be employed for manufacturing or for the generation of electricity. The production of gas may have 
added value where the form of the producer is such that at least the ammonia generated by gasifying the peat may be saved and sold as a by-product. This process, however, may not be feasible in small plants, for the installation and cost of maintenance are higher in proportion for small than for large units. For all plants requiring the use of more than 150 horsepower the use of producer gas to be furnished from peat fuel should be taken under serious consideration where peat beds are available.

Peat fuel is well adapted for burning bricks, lime, and cement, either as machine peat, peat powder, or as a source of producer gas, and for general power purposes and various metallurgical operations, when fired in the form of gas or coke. $\Lambda$ very important use is for heating and cooking purposes in small and isolated communities.

\section{SELECT BIBLIOGRAPHY OF WORKS ON PEAT.}

Bastin, E. S., and Davis, C. A. Peat deposits of Maine. Bull. U. S. Geol. Survey, No. $376,1909$.

Bjorling, P. R., and Gissing, F. T. Peat, its use and manufacture. London, 1908.

Carter, W. E. H. Peat fuel, its manufacture and uses. Rept. Ontario Bur. Mines for 1903, Toronto, 1904.

Dana, S. L. Muck manual, 1842.

Davis, C. A. Origin, distribution, and uses of peat in Michigan. Ann. Rept. Michigan Geol. Survey, 1906.

FrüH, J. Torf und Dopplerit. 1883.

Frü̈, J., and Schroetter, ('. Die Moore der Schweiz mit Berücksichtigung der gesamten Moorfrage. 13eitr. geol. Schweiz, geotech. Ser. 3, Bern, 1904. (A very comprehengive treatise on the peat deposits of Switzerland, and a discussion of the general distribution of peat deposits over the earth. Has a very extensive bibliography.)

Gissing, F. T. Commercial peat, its uses and possibilities. London, 1909.

Hausoing, A. Handbuch der Torfgewinnung und Torfverwertung, 2d ed. P. Parey, Berlin, 1904.

Honm Es, J. A. Preliminary report on the operations of the fuel-testing plant of the United States Geological Survey at St. Louis, Mo. Bull. U. S. Geol. Survey No. 290, 1906.

Johnson, S. W. Peat and ita uses. New York, 1866.

Journal of the American Peat Society, quarterly, Toledo, Obio.

Koller, T. Die Torfindustrie. Wien, 1898.

LeavitT, T. H. Facts about peat. Boston, 1867. Reprinted, Boston, 1904.

McFarlane, T. Moss manure. Bull. Lab. Inland Rev. Dept. Canada, No. 97, Ottawa, 1904.

Nystrom, E. Peat and lignite, their manufacture and uses in Europe. Canada Dept. Mines, Ottawa, 1908.

Parmalee, C. W., and MacCourt, W. E. A report on the peat deposits of northern New Jersey. Ann. Rept. State Geologist New Jersey for 1905, Trenton, 1906. (Has many analyses and a bibliography.)

Parsons, A. L. Peat, its formation, uses, and occurrence in New York. Twentythird Ann. Rept. State Geologist; Fifty-seventh Ann. Rept. State Museum,

- Albany, 1904. (Has many analyses and a bibliography.) 
RIEs, H. Uses of peat and its occurrence in New York. Twenty-first Ann. Rept. State Geologist, Albany, 1903. (Has many analyses and bibliography.)

SAVAGE, T. E. A preliminary report on the peat resources of Iowa. Bull. Iowa Geol. Survey No. 2, Des Moines, 1905.

Shaler, N. S. Fluviatile swamps of New England. Am. Jour. Sci., 3d ser., vol. 33, 1887.

Fresh-water morasses of the United States. Tenth Ann. Rept. U. S. Geol. Survey, pt. 1, 1890.

Origin, distribution, and commercial value of peat deposits. Sixteenth Ann. Rept. U. S. Geol. Survey, pt. 4, 1895.

Peat and swamp soils. Twelfth Ann. Rept. U. S. Geol. Survey, 1891.

Swamps of the United States. Science, vol. 7, 1886.

TAYLOR, A. E. Peat deposits of northern Indiana. Thirty-first Ann. Rept. Indiana Dept. Geol. and Nat. Res., Indianapolis, 1906. 


\title{
MINING IN SOUTHEASTERN ALASKA.
}

\author{
By ADOLPH KNopf.
}

\section{INTRODUCTION.}

The condition of the mining industry of southeastern Alaska during 1909, gaged by the production of gold, silver, and copper, remained substantially the same as in 1908 . But in other respects the year marked a considerable advance. The main line of development consisted in the initiation of large enterprises designed to exploit extensive low-grade ore bodies and in the continuous improvement in the power-producing facilities of the large mines already in operation, notably at the Treadwell group and at the Perseverance mine. The final settlement of the protracted litigation that involved a large number of valuable properties at Berners Bay will allow the deve]opment of that important district. The building of the government trail from Juneau to Eagle River and the new strikes at Auk Bay have served to stimulate the interest of the prospector in the Juneau gold belt. All these facts point to a considerable activity during 1910.

\section{GOLD MINES AND PROSPECTS.}

\section{PRODUCTION.}

The following table gives the tonnage of gold ore mined in southeastern Alaska in 1907 and 1908 and its content of precious metals. According to preliminary estimates, the production for 1909 was about 20 per cent greater than that for 1908 .

Production of gold ore in southeastern Alaska.

\begin{tabular}{|c|c|c|c|c|c|c|}
\hline \multirow{2}{*}{ Year. } & \multirow{2}{*}{ Ore mined. } & \multicolumn{2}{|c|}{ Gold. } & \multicolumn{2}{|c|}{ Sllver. } & \multirow{2}{*}{$\begin{array}{l}\text { Average } \\
\text { value } \\
\text { per ton. }\end{array}$} \\
\hline & & A mount. & Value. & A mount. & Value. & \\
\hline $\begin{array}{l}1907 . \\
1908 .\end{array}$ & $\begin{array}{c}\text { Tons. } \\
1,206,639 \\
1,475,516\end{array}$ & $\begin{array}{l}\text { Ounces. } \\
132,300 \\
161,975\end{array}$ & $\begin{array}{r}\$ 2,734,885 \\
3,348,312\end{array}$ & $\begin{array}{r}\text { Ounces. } \\
22,20.3 \\
31,834\end{array}$ & $\begin{array}{r}814,653 \\
16,872\end{array}$ & $\begin{array}{r}82.28 \\
2.28\end{array}$ \\
\hline
\end{tabular}




\section{JUNEAU DISTRICT.}

DOUGLAS ISLAND.

The only productive properties on Douglas Island are the four mines of the Treadwell group. A large proportion of the gold in the ore milled is locked up in the sulphurets, amounting to as much as 46 per cent in the concentrates of the Alaska-Treadwell mine, and investigations, which have now been in progress for some time, were therefore instituted to devise a method of recovery that would render shipment of the sulphurets to the smelter at Tacoma unnecessary. The investigations, involving a process of tube milling to 200-mesh, followed by amalgamation and cyanidation, have now reached the stage of an experimental 10-ton plant. Two buildings large enough for the installation of a 100-ton plant have been constructed.

The cost of power is being steadily reduced from year to year. A central power plant to generate electric power is under construction, and two steam turbines, direct connected to two 750-kilowatt generator units, will be installed. The water rights on Sheep Creek were acquired and the water will be used to generate hydro-electric energy, which will be transmitted across Gastineau Channel by cable. The Ready Bullion dam, which is designed to furnish 500 horsepower for the Mexican and Ready Bullion mills, is nearing completion and will have a storage capacity of seventy days.

At the Alaska-Treadwell, which is the deepest mine of the Treadwell group, the shaft has been sunk a distance of 300 feet and a station cut out at the 1,800-foot level. From the shaft station on the 1,450foot level, which is at that point 181 feet in the foot-wall country rock of the lode, the main crosscut has been driven to the hanging wall of the ore body and the ore has been developed by drifts and raises. The ore on the 1,450-foot level has been found to be as good as or even better than any other in the history of the mine. The ore mined during the year came principally from the 1,050-foot, 1,250foot, and 1,450-foot levels, and in part from the higher levels.

The main shaft of the Seven Hundred Foot mine has now attained a total depth of 1,303 feet. Shaft stations were cut at the 1,050 -foot and 1,250-foot levels and connect with the corresponding levels of the Treadwell mine.

At the Alaska-Mexican mine the shaft has been sunk 330 feet deeper, giving it a depth of approximately 1,450 feet, and ore was partly developed on the 1,210-foot level. The ore sent to the mill during the year was derived principally from the 990-foot level.

The Ready Bullion shaft has now been sunk a distance of 1,985 feet along the incline. The ore milled during the year was taken mainly from the 1,350-foot and 1,500-foot levels. Shaft stations have 
been cut on the 1,650-foot and 1,800-foot levels, and ore has been partly developed on the 1,650-foot level.

At Nevada Creek the Alaska Treasure Consolidated Mines Company employed a force of 25 men in driving a double-track tunnel 3,000 feet long to undercut an ore body at a depth of 700 feet. The deposit exposed on the surface is described by Spencer ${ }^{a}$ as a mineralized greenstone cut by veinlets of albite, accompanied by pyrite, galena, sphalerite, and chalcopyrite.

\section{GOLD CREEK MINES.}

The two mines operating on Gold Creek are situated on the slopes surrounding Silverbow Basin at the head of the stream. They are working on large low-grade deposits consisting mainly of black slate that is cut by short irregular stringers and veins of quartz carrying sufficient values to make ore of the whole mass of slate and quartz.

Operations for the season were commenced at the Perseverance mine on May 28. A crew of 80 men was employed, and the 100 stamps were kept dropping during the summer and fall months. The main development work has consisted in extending the stopes 500 feet along the trend of the lode, and this work will be continued during the winter months. An increase of the power facilities has been under contemplation for a number of years, and some progress toward this end has been accomplished during the last year. A producer-gas power plant has been partly installed on the shore of Gastineau Channel, and poles for the electric transmission line have been put in place.

Mining was resumed at the Alaska-Juneau mine, the mainland. property controlled by the management of the Treadwell group, early in June. Thirty men were employed, and the 30-stamp mill was kept in continuous operation. About 4,000 tons of ore were milled per month. The ore was extracted partly from open pits and partly from a "glory hole." The practice of sorting the ore, whereever feasible, was begun this year, and the mill returns show that the value of the ore was thereby doubled over that of previous years.

The Ebner and Hallam properties were taken over by a holding company known as the California and Nevada Copper Company. Several men were employed on surface work, such as the construction of trails and the stripping of ore bodies. Thorough sampling to serve as a guide to future development was in progress during the latter half of the year.

At the Nowell placer, in Silverbow Basin, mining was carried on by a lessee employing a force of six men. The large amount of bowlders and a long tail race with insufficient grade to dispose of the tailings hampered the profitable exploitation of the placer. 


\section{BERNERS BAY REGION.}

GENERAI STATEMENT.

The term Berners Bay region is usually applied to the long tapering peninsula lying between Berners Bay and Lynn Canal. This peninsula is the most important mining region north of Juneau: The geologic features have been briefly described by Spencer, ${ }^{a}$ whose studies were of a hasty reconnaissance character. The writer was engaged during a part of the summer of 1909 in a detailed study of the geology of the region and the new facts elicited by that investigation are believed to deserve presentation here in summary form. A detailed report is in preparation.

\section{GEOLOGY.}

A formation consisting preponderantly of slates and graywackes occupies the largest part of the Berners Bay area. Some metamorphosed andesites (greenstones) and quartz porphyry schists are associated with it, but are of negligible importance. The slates are mainly black clay slates but include some of green and, to a less extent, some of red color. The graywackes are intimately interstratified with the slates in beds ranging from a few inches to 8 feet in thickness and are commonly gray or greenish gray. They are roughly schistose and in the thicker beds nearly massive.

These rocks have been profoundly folded and closely compressed, and the axes of folding have also been acutely folded and in places pitch vertically. In consequence of this severe folding of the axes it happens that at many places closely adjacent strata show an angular discordance of strike. Ordinarily this would be taken to indicate a fault of some magnitude, but in the shore cliffs, where the geologic relations are perfectly exposed, that feature can be seen to be due to the vertical attitude of appressed folds. Subsequent to the complex folding of the rocks a cleavage was induced in them, commonly coinciding with the stratification and trending N. $75^{\circ} \mathrm{W}$. (magnetic). In places, such as in the arches of folds standing on edge, the cleavage trends conspicuously across the bedding.

Some fossil leaves were found embedded in the slates on the east side of Berners Bay and were submitted to F. H. Knowlton for determination. He reports that they indicate a Jurassic or Lower Cretaceous age, with the probability in favor of their being Jurassic.

A series of ancient lavas, mainly of basaltic character, form a belt trending northwest from Berners River to Lynn Canal. They make up the mountainous mass known as the Lions Head and the pre-

a Speneer, A. C., The Juneau gold belt, Alaska: Bull. U.S. Geol. Survey No. 287, 1906, pp. 134-13̈7. 
cipitous peaks flanking Iynn Canal. Brown, red, and greenish blue are the prevailing colors of these old volcanic rocks. They are conspicuously spotted with greenish-yellow amygdules of epidote, and as this is their most prominent feature, they might be called epidotic amygdaloids. Sporadically the amygdules carry a small amount of chalcopyrite.

Some rhyolite dikes and sills are associated with the amygdaloids, in places cutting across the bedding and in places lying between the volcanic sheets. They range in thickness from a few feet to 100 feet. They are dense-textured rocks of light color and weather white on exposed surfaces.

The granular intrusive rocks are represented mainly by diorites. The most important of these, because the larger number of the valuable ore bodies so far discovered lie within the area underlain by it, is a grayish rock composed of plagioclase feldspar, hornblende, and biotite and ranging in texture from rather finely granular to coarsely granular. This rock occupies the drainage basin of Johnson Creek and the upper part of that of Sherman Creek. A small area of heavy, dark, nearly black rock, composed mainly of hornblende, is associated with this variety of diorite near Berners River.

The northeastern portion of the Berners Bay region is composed of a quartz diorite gneiss having a marked tabular structure parallel to that of the cleavage of the slates and graywackes. Mineralogically the gneiss corresponds closely to the diorite already described, but it differs from that rock in having a gneissic or schistose structure and an invariably fresher appearance. The quartz diorite gneiss is undoubtedly the earlier intrusive, but its component minerals have not been subjected to attack and destruction by vein-forming solutions, and to this immunity it owes its contrast to the diorite that incloses the main ore bodies. Near its contact with the andesites the gneiss takes on a peculiar appearance. Numerous white feldspars are embedded in a black foliated groundmass consisting of biotite and hornblende. Farther from the contact the amount of biotite diminishes and the rock assumes a more normal aspect. It maintains its petrographic character and gneissic structure for many miles to the southeast.

ORE DEPOSITS.

The ore bodies of commercial value are deposits of gold ore. They have been classified by Spencer into three varieties, on the basis of their mode of occurrence in the country rock. These three varieties are (1) fissure veins, (2) stockworks or fracture zones in the diorite, and (3) lodes occurring along the contacts of intrusive bodies of diorite. To these might be added a fourth variety-stringer lodes 
in slate. Although no ore bodies of demonstrated value have so far been discovered in the slates, there is no inherent improbability of the existence of paying lodes. An enormous amount of quartz veining has affected the slates and graywackes, but it must be confessed that the amount of metallization visible is nearly insignificant.

\section{MINES AND PROSPECTS.}

Mining activity, other than a small amount of prospecting, was at a standstill in the Berners Bay region during 1909. The final settlement of the litigation in which many of the properties near Comet have been involved for a number of years seems to be assured, and a period of large development work and productivity may be expected in the immediate future. The Jualin mine, on Johnson Creek, has been idle during the year. It is stated that during 1910 a shaft is to be sunk in the hanging-wall country rock of the lode, and the levels below the working tunnel are to be unwatered.

The developments in the Berners Bay mining region up to 1906 were described by Wright, ${ }^{a}$ and as no changes have taken place since that date, repetition here is unnecessary.

In the mining belt extending southward from Berners Bay to Juneau the Eagle River mine continued to be the only productive property. The 20 -stamp mill was kept operating during the greater part of the year and a large amount of underground development work was done. The ore extracted came mainly from level 1, which is the working tunnel of the mine. During the year a tunnel has been commenced 485 feet below level 1 and is projected to crosscut the ore-bearing zone at this increased depth.

At the head of Canyon Creek, a tributary of Cowee Creek, development work was continued on the E Pluribus Unum and other claims. It is planned to sled in a small prospector's mill during the spring of 1910. This will be used to crush the ore mined from a rich shoot on the surface and will thus assist in the preliminary development of the property.

On Peterson Creek work was continued during the year on the Prairie and contiguous claims, mainly in the construction of trails.

Considerable excitement was created locally in the early part of the spring by the discovery of quartz stringers carrying free gold in the vicinity of Auk Bay. Many locations were made and some work was done. Prospecting is carried on under difficulties, inasmuch as the region is covered with a heavy mat of moss and vegetation. Exposures of rock are almost lacking, and owing to the small amount of development work accomplished little can as yet be said of the value of the new discoveries.

a Wright, C. W., Lode mining in southeastern Alaska: Bull. U. S. Geol. Survey No. 284, 1906, pp. 32-34. 
A large number of prospects are scattered along the mineral belt between Juneau and Berners Bay, but on most of them little more was done than the fulfillment of the annual assessment requirements.

Little interest was manifested during the year in the prospects located on the southern extension of the Juneau gold belt. The Crystal mine, at Port Snettisham, continues to be the only productive property. A crew of ten men was employed and the 5-stamp mill was steadily operated.

Some work has been done on a prospect known as the Lost Charlie Ross, which is situated 8 miles up Whiting River at an altitude of about 3,000 feet. This locality is well back in the great granitic mass that forms the core of the Coast Range. The ore body is reported to be $4 \frac{1}{2}$ feet thick and 100 feet long and consists of quartz-carrying galena, arsenopyrite, sphalerite, and pyrite. The distribution of the minerals is said to be bunchy. An assay of a streak of solid mineral 11 inches wide on the foot wall of the deposit gave a return of $\$ 21.60$ in gold and 50 ounces in silver to the ton and 40 per cent of lead. A tunnel which is planned to undercut the ore body at a depth of 150 feet has been driven for a distance of 70 feet.

Developments have continued during the year at Limestone Inlet, and some new work has been undertaken near Bishop Point, at the entrance of Taku Inlet.

\section{SITKA MINING DISTRICT.}

Active operations continued during the year on the De Groff and Mills properties, on the west coast of Chichagof Island. At the De Groff mine the capacity of the milling plant, which consisted of four stamps, was enlarged by the addition of an edge-runner mill. Some difficulty was encountered in the separation of the gold from the ore on account of failure to amalgamate, but sea water was substituted in the batteries and a high extraction was obtained.

\section{KETCHIKAN MINING DISTRICT.}

Near Hollis, on Twelvemile Arm, a 5-stamp mill, built so that an additional battery of five stamps can readily be added, was installed on the Julia claim, on Harris Creek. A dam has been built and sufficient water power to run the property was developed. A depth of 170 feet on the vein has been attained and enough ore is said to have been blocked out to pay for the installation of the plant and for further exploration work.

Iittle interest was taken during the year in other gold prospects in the Ketchikan district, the principal mining activity in the district concerning itself chiefly with copper properties in which the gold values are only incidental. 


\section{COPPER MINES AND PROSPECTS.}

\section{GENERAI STATEMENT.}

The financial depression of 1907 and the severe fall in the price of metals dealt a heavy blow to the copper-mining industry of southeastern Alaska, and a notable curtailment in the production immediately ensued. It is, however, an exceedingly encouraging feature that in spite of those handicaps a number of prospects have since that time entered the ranks of producing mines. During 1909 ore was shipped from four mines, all of which are situated on Prince of Wales Island, in the Ketchikan mining district.

Most of the copper mines and prospects of southeastern Alaska are located on primary deposits of contact-metamorphic origin, commonly situated near the contact of limestone with intrusive dioritic rocks. The ore occurs in highly irregular masses and lenses embedded in the limestone and consists of auriferous chalcopyrite associated with iron oxides and sulphides, calcite, and various silicates, principally andradite garnet. On account of the erratic distribution of ore in these deposits, a large amount of exploration work is necessary to keep development in advance of extraction. They form a type of ore body that is comparatively rare in other parts of the world as a commercial producer of copper. They do not conform in shape or other peculiarities to the commonly accepted ideas concerning lodes and prove puzzling features to those engaged in their exploitation. The greatest depth attained upon them in the Ketchikan district is approximately 250 feet. It is therefore interesting to learn that on Texada Island, in the Gulf of Georgia, a copper deposit of this type is being profitably mined at a depth of 1,000 feet.

\section{PRODUCTION.}

The production of copper ore in southeastern Alaska during 1907 and 1908 is shown in the subjoined table. The output for 1909 , as shown by preliminary estimates, is about 10 per cent less than that for 1908 .

Production of copper ore in southeastern Alaska.

\begin{tabular}{|c|c|c|c|c|c|c|c|c|}
\hline \multirow{2}{*}{ Year. } & \multirow{2}{*}{$\begin{array}{c}\text { Ore } \\
\text { mined. }\end{array}$} & \multicolumn{2}{|c|}{ Copper. } & \multicolumn{2}{|c|}{ Gold. } & \multicolumn{2}{|c|}{ Silver. } & \multirow{2}{*}{$\begin{array}{l}\text { Average } \\
\text { value } \\
\text { per ton. }\end{array}$} \\
\hline & & Amount. & Value. & A mount. & Value. & Amount. & Value. & \\
\hline $\begin{array}{l}1907 . \\
1908 .\end{array}$ & $\begin{array}{l}\text { Tons. } \\
79,982 \\
43,215\end{array}$ & $\begin{array}{l}\text { Pounds. } \\
4,758,814 \\
3,260,399\end{array}$ & $\begin{array}{r}\$ 951,761 \\
430,372\end{array}$ & $\begin{array}{r}\text { Ounces. } \\
3,384 \\
2,213\end{array}$ & $\begin{array}{r}\$ 69,960 \\
46,310\end{array}$ & $\begin{array}{r}\text { Ounces. } \\
44,196 \\
24,648\end{array}$ & $\begin{array}{r}829,143 \\
13,0 f 33\end{array}$ & $\begin{array}{r}\$ 13.14 \\
11.10\end{array}$ \\
\hline
\end{tabular}


KETCHIKAN MINING DISTRICT.

\section{KASAAN PENINSUla.}

Early in $\Lambda$ pril work was commenced on the Goodro mine, which is situated half a mile from the head of a tidal slough known as the Salt Chuck, at the upper end of Kasaan Bay. A wharf, ore bins, 3,850 feet of tram (in part gravity and in part horse tram), and bunk houses were constructed and the shipment of ore was commenced. The ore is lightered out of the Salt Chuck on barges at ligh tide and loaded upon a dismantled sailing vessel lying at the head of Kasaan Bay. When laden with 2,000 to 3,000 tons of ore, the hulk is towed to the smelters at Ladysmith or Tacoma.

The ore consists of a heavy green dioritic rock containing much biotite and, as the main copper-bearing mineral, scattered particles of bornite, with which are associated sporadic blebs of chalcocite and chalcopyrite. This deposit is unlike any other yet discovered in southeastern Alaska. A force of 22 men was employed, and approximately 35 tons of ore was mined daily. The ore was derived partly from an open cut 15 feet high and 30 feet wide on the apex of the deposit and partly from a large chamber stoped out at the end of a tunnel 90 feet long, driven 94 feet below the outcrop. The ore obtained from the lower level is said to run 2 per cent ligher in copper than that from the surface cut; the difference may be due to the greater prevalence of the richer sulphide-chalcocite-in the lower level.

The It mine, at which active development work commenced in 1908 , has been a steady producer during 1909 , and development and exploration work have been continued. A compressor plant has been installed on the beach and a gasoline hoist has been installed in the 'adit level. An incline was put down here and approximately 250 feet of development work has been done on the level 50 feet below the adit level. Two ore bodies were encountered and 50 tons of ore and waste are hoisted daily. The ore is sorted and a product comparatively high in copper and gold is shipped to the smelter at Ladysmith, on Vancouver Island.

The Mount Andrew mine, which was formerly worked under a lease held by the Brittania Smelting Company, has resumed operations under the management of the proprietary corporation, the Mount Andrew Iron and Copper Company. $\Lambda$ crew of 25 men was employed. Work was commenced in March and a daily output of 50 tons of shipping ore was maintained. During the winter months only such ore as is extracted in the development work will be shipped. Exploration has been continued on the working level and large reserves, 
carrying $2 \frac{1}{2}$ per cent of copper, have been developed, but only the ore running 4 per cent is extracted at present. An incline from the working level has been sunk 100 feet; at 68 feet drifts have been run in both directions and are planned to crosscut the ore body known as No. 4, which was a large rich mass of ore continuous from the surface down.

The Mamie and Stevenstown mines, which adjoin the Mount Andrew property on the northeast, and the smelter at Hadley were idle during 1909.

The Rush \& Brown mine was not operated, but late in the year some ore was shipped that had been broken in previous years.

\section{HETTA INLET.}

The Jumbo mine, the property of the Alaska Inclustrial Company, is the only mine on Hetta Inlet from which ore was being shipped during 1909. The ore consists of chalcopyrite in a gangue of wellcrystallized garnet and calcite, with which are associated in extremely variable amounts pyrrhotite, pyrite, molyblenite, specular hematite, epidote, and other silicates. According to the present developments the ore-bearing zone, in which masses of ore are scattered in a highly erratic manner, is approximately 500 feet long, 500 feet wide, and of unknown depth. During 1909 considerable ore was extracted between level 2 and the surface. On level 4 , which is 262 feet below level 2, the drifts now aggregate 800 feet, and a raise of 127 feet has been put through to level 3 . With the completion of this raise, level 4 , whose portal is situated just behind the upper terminal of the aerial tramway, became the main working level of the mine. Considerable ore has also been encountered on this level, but owing to the nature of contact-metamorphic deposits the actual tonnage can not be computed in advance of extraction.

Eight claims, situated a short distance northwest of the Jumbo mine, were leased by the Alaska Industrial Company to the Tyee Copper Company. The cupriferous magnetite bodies adjoining the diorite contact were prospected by a combination of diamond drilling, tunneling, and careful plotting of the surface geology. Nine holes aggregating 700 feet were put down. In one of the tunnels, which is situated at an altitude of 2,000 feet, a body of chalcopyrite-pyrrhotitegarnet ore 10 feet thick was encountered.

At the varióus other mines and prospects situated in the vicinity of Hetta Inlet no important developments are to be recorded. 
OTHER PROPERTIES.

The Niblack mine, on the east coast of Prince of Wrales Island, owing to litigation, has been idle during the year. The machinery has been sold by the lessees and removed.

At Seal Bay, on the south end of Gravina Island, 700 feet of the projected 2,000-foot tunnel have been driven on the War Eagle property. This tunnel was started late in the summer of 1908 and is expected to crosscut certain ore bodies that are exposed on the surface.

A small amount of development work is reported to have been done on the Veta group, at Mallard Bay, near the south end of Prince of Wales Island. The deposit, which carries values in copper and gold, is said to be 20 feet wide, though not all of this width is of sufficient grade to make ore. A depth of 30 feet has been attained on the lode and 78 feet of drifts and crosseuts have been driven.

It is reported that three men were employed during the summer on the Yellowstone group of claims, at Sea Otter Harbor, on the west coast of Dall Island. They are said to have succeeded in uncovering a number of parallel lodes of auriferous chalcopyrite-pyrrhotite ore at an altitude of 2,400 feet.

\section{CONCLUSIONS.}

The principal mineral resources of southeastern Alaska are gold, silver, copper, marble, and gypsum. Of these, silver is obtained as an incident to the production of gold. The output of gold is maintained chiefly by the Juneau district and owing to the preponderant production of the Treadwell group of mines far exceeds that of the other metals in value. Copper is produced in the Ketchikan district only. Some gold is associated with the copper ores, averaging $\mathbf{4 0}$ cents per unit of copper. 


\section{THE OCCURRENCE OF IRON ORE NEAR HAINES.}

\section{By Adolph Knopf.}

\section{INTRODUCTION.}

Deposits of iron ore of commercial value have recently been reported to occur near Haines, in southeastern Alaska. The writer spent one day in July, 1909, in examining them, and the results of that examination are embodied in the following notes.

Iron ores have as yet attracted little attention as possible mineral resources of Alaska. Some deposits on Prince of Wales Island, in the Ketchikan district, form, perhaps, an exception to this statement. The economic features of these ores have recently been discussed by C. W. Wright, ${ }^{a}$ who states that "at the copper mines of Prince of Wales Island a considerable tonnage of magnetite, carrying from 0.5 to 1.5 per cent of copper, has been developed which can not be profitably mined as a copper ore. However, if there were a market for the iron in these ores the copper could be readily separated mechanically and the deposits mined with profit."

The recent installation of a steel plant and small blast furnace near Port Townsend, in Washington, and the successful inauguration of electric smelting in Shasta County, Cal., are industrial developments likely to stimulate interest in all possible sources of iron ore along the Pacific coast.

Haines is situated in latitude $59^{\circ}$ north, on Portage Cove, a small embayment of Chilkoot Inlet, the eastern channel at the head of Lynn Canal. Steamers plying the inside passage between Seattle and Skagway call regularly at Haines.

\section{GEOLOGIC FEATURES.}

The rocks outcropping in the vicinity of Haines are coarsely crystalline diorites and gabbros, which represent various modifications of a single intrusive mass of deep-seated origin. They are particularly well exposed along the shores of Chilkoot Inlet from Battery Point, 4 miles south of Haines, to a point 2 miles north of Haines, 
where they come into contact with a series of greenstones. Extending northwestward, they form the mountainous ridge lying between Chilkoot and Chilkat inlets.

The rock mass exposed along the shore north of Haines is a remarkable occurrence geologically. Specimens collected from the finesttextured portions show a rock composed of a coarsely crystalline aggregate of feldspar, hornblende, and pyroxene, throughout which are scattered some visible grains of magnetite. The dark minerals (the hornblende and pyroxene) make up half the bulk of the rock. When examined microscopically the rock is found to consist of an allotriomorphic granular assemblage of plagioclase feldspar (bytownite), hornblende, and augite. Magnetite and apatite are present as accessory constituents in unusually large amounts. From this normal type of rock, which would be termed a gabbro, abrupt variations in texture and mineral composition are encountered. In places the cliffs for hundreds of feet are composed solidly of formless hornblende individuals 6 inches long by 3 inches broad. Commonly this hornblende rock contains more or less grayish-green augite admixed with it and is ramified by coarse white feldspathic dikelets or blotched by masses of gabbro. In places it even forms a breccia cemented by such material. Locally the hornblendite contains numerous lumps and particles of magnetite, which can easily be recognized by the characteristic bluish tarnish that they assume upon weathered surfaces. At no point along the shore, however, has the segregation of magnetite proceeded far enough to yield a solid body of iron ore, or even a body of ore of commercial grade.

Near Fort Seward, which is situated just west of Haines, the rock exposed consists of a coarsely granular aggregate of pyroxene, hornblende, and black mica (biotite). Mica-bearing modifications of the gabbro occur at other points farther inland and have led to some prospecting for mica deposits. It is to be noted, however, that the black iron mica (biotite), in contradistinction to the other two micas, muscovite and phlogopite, has little commercial value.

On the northwestern extension of this belt of basic plutonic rocks carrying disseminated magnetite is situated the property of the Alaska Iron and Steel Company. The work done here consists of a tunnel approximately 100 feet long, situated at an altitude of 300 feet, 2 miles distant from Haines by a well-built government road. The rocks occurring in the vicinity of the mouth of the tunnel are poorly exposed on account of the thick growth of vegetation. On the dump occur a variety of hornblende-augite rocks. One of the most striking types consists of a rock in which large lustrous crystals of black hornblende are embedded in a finely granular matrix of grayish-green pyroxene. From this sort of rock there are variations in $55695^{\circ}-$ Bull, $442-10-10$ 
structure and granularity, and some of these carry appreciable quantities of magnetite.

The magnetite-bearing facies constitute the ore rock. In the most favorable specimens a maximum content of 30 per cent of magnetite, or, roughly, 20 per cent of metallic iron, is attained, but the existence of an ore body of this grade has not yet been demonstrated. The magnetite in the ore rock occurs as particles one-eighth to onefourth inch in diameter scattered through a granular matrix of pyroxene and hornblende. Owing to the metallic-like reflections from cross-fractured hornblende the eye is prone to overestimate the magnetite content of the ore. When examined under the microscope the ore shows, in addition to the features already described, a small amount of apatite, indicating a certain content of phosphorus.

Some of the material was submitted to the chemical laboratory of the Geological Survey for determination of its titanium content. The coarse particles were separated magnetically, ground to 100mesh, and the magnetite again removed magnetically. Chase Palmer reports that the product contains 3.91 per cent of $\mathrm{TiO}_{2}$. This determination therefore indicat $s$ that the concentrated iron-ore product is not likely to contain prohibitive quantities of titanium.

\section{CONCLUSIONS.}

The iron ore occurring near Haines consists of primary magnetite sparsely disseminated in a basic igneous rock composed of pyroxene and hornblende. An ore of this character would require fine crushing and concentration. A study of producing iron-ore properties where the adoption of such processes was necessary will therefore furnish valuable data for an analysis of the commercial possibilities of the Alaskan iron-ore deposits. Many factors enter into the problem, but hardly need discussion at this time. At Lyon Mountain, N. Y., where crushing, drying, and electromagnetic concentration are necessary, the lowest-grade iron ore treated contains 34 per cent of metallic iron. ${ }^{a}$ This is far above that of the highest-grade rock so far found at Haines. Geologically it is possible that richer bodies of magnetite may occur as segregations in the basic granular rocks that form the ridge extending northwestward from Haines. A magnetic survey of the area underlain by these rocks would undoubtedly prove a quicker and more economical way to test this possibility than the driving of expensive prospect tunnels. 


\section{A WATER-POWER RECONNAISSANCE IN SOUTHEASTERN ALASKA.}

Ву Јонм С. Ноут.

\section{INTRODUCTION.}

The territory covered by this report (see fig. 1) includes that portion of southeastern Alaska extending southward from White Pass for a distance of about 350 miles. Detailed investigations of waterpower resources were made in three districts of this area-Ketchikan, Juneau, and Skagway. Data were also obtained at Sitka and other points and from conversation with persons familiar with the country.

From Ketchikan the plants of the local power company, the New England Fish Company, and the Metlakatla Fish Company, at Beaver Falls and Sulzer, were visited. The undeveloped possibilities at Hadley, Kasaan Bay, Cholmondeley Sound, Georges Arm, Carroll Inlet, Unuk River, and about Sulzer were investigated also.

From Juneau the developments of the Treadwell Company on Douglas Island, of the Perseverance and other companies in Silverbow Basin, and of the Amalga Company at Eagle River were visited. The conditions in Taku Inlet, including Turner Lake, were investigated and information was obtained in regard to Endicott River and the streams between Juneau and Eagle River.

At Skagway the local power plant and the plant of the Chilkat Fish Company were visited, and a trip was made over White Pass and another to Haines, from which the Porcupine Creek district was visited.

At Sitka data were obtained in regard to Chichagof Island in Klag Bay.

\section{GENERAL TOPOGRAPHIC FEATURES.}

Southeastern Alaska comprises a narrow strip of mainland and a series of islands separated from one another by a network of channels and straits. Both the mainland and the islands are indented with many bays, fiords, and inlets, which, with the other natural conditions, practically cut off all travel except by boat.

With the exception of small areas of flat lands along the larger rivers and at places along the coast, the entire area is mountainous. 
The mountains rise abruptly from the shore line and reach a maximum elevation varying from 4,000 feet in the southern part of the area to 7,000 feet in the northern part. Owing to this topography, the streams, with the exception of a few of the larger rivers which come through the mountains from the interior, have small and precipitous

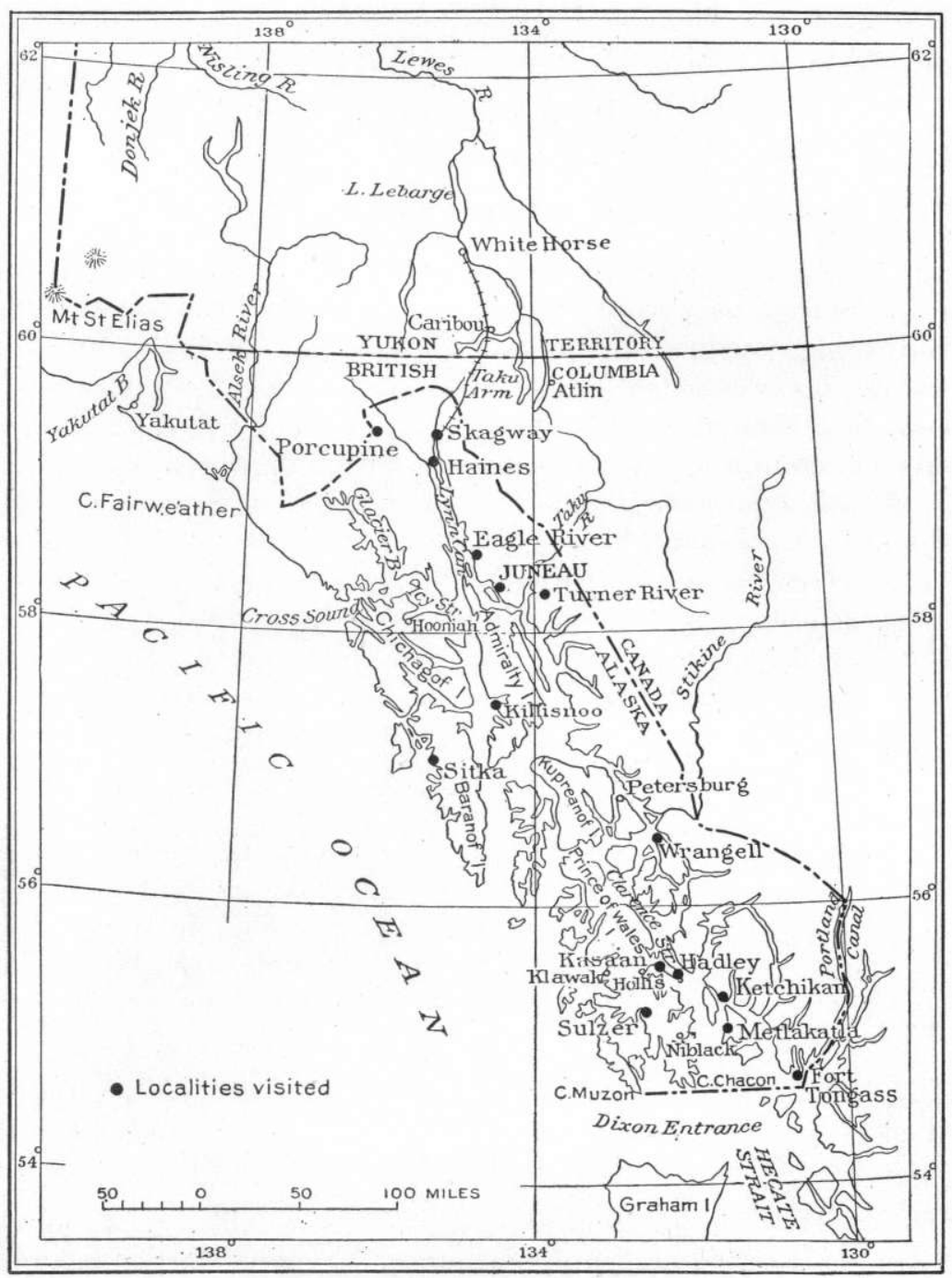

Figure 1.-Map of southeastern Alaska.

drainage areas. Their courses are short and they have a large fall; in fact, many of the streams are made of a series of cataracts.

In the northern part of the area most of the streams head in the glaciers which cover a large portion of the country. In the lower southern part of the area many of the streams head in small lakes 
which occur a short distance back from the shore line in the hanging valleys that are characteristic of this area. Most of the streams flowing from these lakes are precipitous, and many of them empty into the ocean with a cataract at the shore line. These lakes afford excellent opportunities for storage, as the topography near them is such that a dam can usually be constructed for raising their water level. The most successful powers already developed depend on such storage during a large part of the year, and further development in this region will depend on the availability of such lakes.

\section{GEOLOGY.}

In general there is over the underlying rock of the country but a small depth of soil; hence the facilities for ground-water storage are exceedingly scanty. The underlying rock of the islands and of the mainland up to the foothills is limestone, slate, and schist; in the remainder of the area it is granite.

At the mouths of some of the larger rivers there are alluvial flats and glacial deposits, but the coast is, except in a few places, rocky and steep.

\section{CLIMATE.}

As shown in the following tables, the climate is similar to that of the extreme northwestern part of the United States. The last frosts occur not much later than the 1st of May and the first frosts do not come until early in September. The number of growing days, therefore, averages about 180 .

The winter temperature ranges from $10^{\circ}$ to $20^{\circ}$ above zero; the summer temperature ranges from $70^{\circ}$ to $80^{\circ}$, with occasional extremes between $85^{\circ}$ and $90^{\circ}$.

Precipitation varies considerably in different portions of the area. Along the west coast and in the area along Dixon Entrance, which is exposed to the direct winds from the Pacific, it is rather high, ranging from 130 inches a year at Fort Tongass to 88 inches at Juneau. In passing inland it decreases and at Skagway is only 21 inches.

A disagreeable feature of the country is the large number of rainy days, which averages about 200, except in the vicinity of Skagway, where it is less than 100. With few exceptions the rains are gentle and mostly in the form of mist. Notwithstanding the great precipitation, it dries off quickly after showers, a fact which indicates that the humidity is low. 
Temperature and precipitation in southeastern Alaska.a

\begin{tabular}{|c|c|c|c|c|c|c|c|c|}
\hline \multirow{3}{*}{ Month. } & \multicolumn{4}{|c|}{$\begin{array}{l}\text { Fort Tongass (1 year, } b 16 \text { months- } \\
\text { June, } 1868 \text {, to Eeptember, } 1870 \text { ). }\end{array}$} & \multicolumn{4}{|c|}{$\begin{array}{l}\text { Fort Wrangell (2 years, } 40 \text { months- } \\
\text { May, 1868, to August, 1882). }\end{array}$} \\
\hline & \multicolumn{2}{|c|}{ Temperature } & \multicolumn{2}{|c|}{ Precipitation. } & \multicolumn{2}{|c|}{$\begin{array}{c}\text { Temperature } \\
\left({ }^{6} \text { F.). }\right.\end{array}$} & \multicolumn{2}{|c|}{ Precipitation. } \\
\hline & $\begin{array}{l}\text { Maxi- } \\
\text { mum. }\end{array}$ & $\begin{array}{l}\text { Mini- } \\
\text { mum. }\end{array}$ & Inches. & $\begin{array}{c}\text { Number } \\
\text { of days } \\
\text { over } 0.01 \\
\text { inch. }\end{array}$ & $\begin{array}{l}\text { Maxi- } \\
\text { mum. }\end{array}$ & $\begin{array}{l}\text { Mini- } \\
\text { mum: }\end{array}$ & Inches. & $\begin{array}{c}\text { Number } \\
\text { of days } \\
\text { over } 0.01 \\
\text { inch. }\end{array}$ \\
\hline \multirow[t]{2}{*}{ 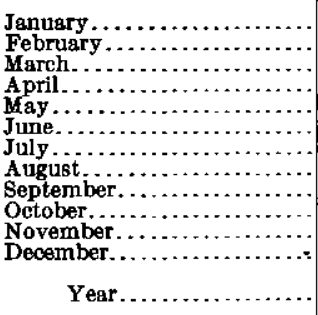 } & $\begin{array}{l}47 \\
45 \\
59 \\
60 \\
70 \\
75 \\
91 \\
81 \\
67 \\
58 \\
51 \\
47\end{array}$ & $\begin{array}{r}6 \\
23 \\
-2 \\
33 \\
38 \\
43 \\
52 \\
47 \\
38 \\
37 \\
32 \\
24\end{array}$ & $\begin{array}{r}12.92 \\
10.79 \\
8.21 \\
9.57 \\
7.70 \\
6.66 \\
10.58 \\
6.71 \\
17.66 \\
14.11 \\
15.46 \\
13.33\end{array}$ & $\begin{array}{r}18.5 \\
21.5 \\
17.5 \\
19.0 \\
15.5 \\
10.3 \\
16.6 \\
9.6 \\
19.3 \\
20.0 \\
27.0 \\
19.0\end{array}$ & $\begin{array}{l}47 \\
58 \\
54 \\
64 \\
78 \\
86 \\
82 \\
84 \\
73 \\
67 \\
53 \\
52\end{array}$ & $\begin{array}{r}-4 \\
2 \\
-10 \\
24 \\
35 \\
38 \\
44 \\
43 \\
38 \\
31 \\
4 \\
-3\end{array}$ & $\begin{array}{l}\text { 6. } 07 \\
8.11 \\
2.89 \\
4.11 \\
3.71 \\
3.56 \\
3.69 \\
3.07 \\
6.63 \\
7.36 \\
11.27 \\
10.41\end{array}$ & $\begin{array}{l}17.6 \\
20.0 \\
12.6 \\
16.6 \\
18.6 \\
13.7 \\
15.8 \\
14.3 \\
17.2 \\
13.2 \\
17.8 \\
22.5\end{array}$ \\
\hline & & & 133. 10 & 213.8 & & & 70.88 & 199.9 \\
\hline \multirow{3}{*}{ Month. } & \multicolumn{4}{|c|}{$\begin{array}{c}\text { Killsnoo (16 years, } 43 \text { months-May, } \\
1881 \text {, to December, } 1902 \text { ). }\end{array}$} & \multicolumn{4}{|c|}{$\begin{array}{c}\text { Juneau (2 years, } 39 \text { months--June, } \\
1881 \text {, to Fehruary, 1897.) }\end{array}$} \\
\hline & \multicolumn{2}{|c|}{ Temperature } & \multicolumn{2}{|c|}{ Precipitation. } & \multicolumn{2}{|c|}{$\begin{array}{l}\text { Temperature } \\
\left({ }^{\mathrm{F}} \mathrm{F} .\right) \text {. }\end{array}$} & \multicolumn{2}{|c|}{ Precipitation. } \\
\hline & $\begin{array}{l}\text { Maxi- } \\
\text { mum. }\end{array}$ & $\begin{array}{l}\text { Mini- } \\
\text { mum. }\end{array}$ & Inches. & $\begin{array}{c}\text { Number } \\
\text { of days } \\
\text { over } 0.01 \\
\text { inch. }\end{array}$ & $\begin{array}{l}\text { Maxi- } \\
\text { mum. }\end{array}$ & $\begin{array}{l}\text { Minl- } \\
\text { mum. }\end{array}$ & Inches. & $\begin{array}{c}\text { Number } \\
\text { of days } \\
\text { over } 0.01 \\
\text { inch. }\end{array}$ \\
\hline 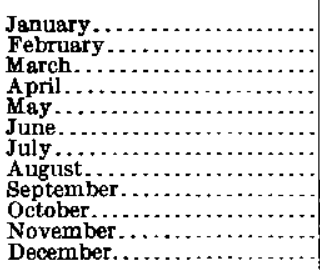 & $\begin{array}{l}52 \\
50 \\
52 \\
633 \\
76 \\
76 \\
84 \\
81 \\
69 \\
60 \\
53 \\
54\end{array}$ & $\begin{array}{r}-2 \\
-10 \\
-2 \\
15 \\
24 \\
33 \\
38 \\
36 \\
27 \\
25 \\
1 \\
1\end{array}$ & $\begin{array}{l}5.98 \\
\text { 4. } 96 \\
4.04 \\
3.50 \\
3.38 \\
2.36 \\
4.19 \\
4.90 \\
7.79 \\
7.92 \\
5.16 \\
4.81\end{array}$ & \begin{tabular}{r|}
18.0 \\
14.9 \\
15.0 \\
11.0 \\
11.3 \\
9.9 \\
11.7 \\
16.5 \\
19.3 \\
22.3 \\
16.9 \\
17.6
\end{tabular} & $\begin{array}{l}50 \\
50 \\
50 \\
63 \\
71 \\
82 \\
88 \\
82 \\
85 \\
66 \\
60 \\
45\end{array}$ & $\begin{array}{r}-4 \\
-4 \\
10 \\
13 \\
26 \\
38 ? \\
38 \\
38 \\
31 \\
20 \\
-1 \\
1\end{array}$ & $\begin{array}{r}10.61 \\
4.85 \\
6.62 \\
5.25 \\
7.36 \\
4.99 \\
5.59 \\
7.53 \\
12.19 \\
10.05 \\
10.47 \\
8.10\end{array}$ & $\begin{array}{l}18.1 \\
11.2 \\
18.7 \\
15.0 \\
16.7 \\
14.6 \\
15.5 \\
15.6 \\
18.4 \\
19.8 \\
18.4 \\
19.8\end{array}$ \\
\hline Year. & & & 58.97 & 185.4 & & & 93.06 & 201.8 \\
\hline
\end{tabular}

a Brooks, A. H., Geography and geology of Alaska: Prof. Paper U. S. Geol. Survey No. 45, 1906, pp. $158-170$.

$b$ The'records were not continuous, and the number of years given indicates simply the number of (c):tinuous twelve-month periods covered. 
Temperature and precipitation in southeastern Alaska-Continued.

\begin{tabular}{|c|c|c|c|c|c|c|c|c|}
\hline \multirow{3}{*}{ Month. } & \multicolumn{4}{|c|}{$\begin{array}{l}\text { Skagway (31 months-November, } \\
\text { 1898, to December, 1902). }\end{array}$} & \multicolumn{4}{|c|}{$\begin{array}{l}\text { Sitka (17 years, } 44 \text { months-Novem- } \\
\text { ber, } 1867 \text {, to December, } 1902 \text { ). }\end{array}$} \\
\hline & \multicolumn{2}{|c|}{ Temperature } & \multicolumn{2}{|c|}{ Precipitation. } & \multicolumn{2}{|c|}{$\begin{array}{l}\text { Temperature } \\
\left({ }^{*} \mathrm{~F} .\right)\end{array}$} & \multicolumn{2}{|c|}{ Precipitation. } \\
\hline & $\begin{array}{l}\text { Maxi- } \\
\text { muml. }\end{array}$ & $\begin{array}{l}\text { Mint- } \\
\text { mum. }\end{array}$ & Inches. & $\begin{array}{l}\text { Number } \\
\text { of days } \\
\text { over } 0.01 \\
\text { inch. }\end{array}$ & $\begin{array}{l}\text { Maxi- } \\
\text { mum. }\end{array}$ & $\begin{array}{l}\text { Mini- } \\
\text { murn. }\end{array}$ & Inches. & $\begin{array}{c}\text { Number } \\
\text { of days } \\
\text { over } 0.01 \\
\text { inch. }\end{array}$ \\
\hline 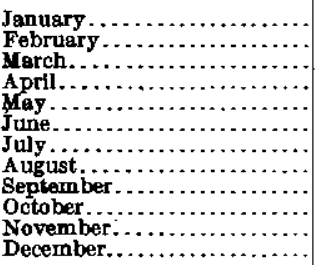 & $\begin{array}{l}42 \\
44 \\
63 \\
61 \\
79 \\
80 \\
92 \\
80 \\
76 \\
60 \\
51 \\
57\end{array}$ & $\begin{array}{r}-4 \\
-9 \\
-10 \\
16 \\
25 \\
34 \\
39 \\
32 \\
30 \\
16 \\
7 \\
-4\end{array}$ & $\begin{array}{r}0.90 \\
.57 \\
.64 \\
2.39 \\
.77 \\
.60 \\
1.73 \\
1.51 \\
3.47 \\
3.22 \\
2.17 \\
3.78\end{array}$ & $\begin{array}{r}7.5 \\
2.5 \\
3.0 \\
10.5 \\
4.7 \\
5.0 \\
5.7 \\
8.5 \\
13.5 \\
12.0 \\
8.0 \\
11.7\end{array}$ & $\begin{array}{l}51 \\
54 \\
65 \\
70 \\
80 \\
80 \\
87 \\
82 \\
74 \\
67 \\
59 \\
59\end{array}$ & $\begin{array}{r}-2 \\
-3 \\
-1 \\
19 \\
28 \\
33 \\
35 \\
39 \\
32 \\
25 \\
5 \\
7\end{array}$ & $\begin{array}{r}12.17 \\
7.47 \\
6.70 \\
5.61 \\
4.11 \\
3.31 \\
3.55 \\
5.84 \\
9.67 \\
11.96 \\
9.80 \\
7.88\end{array}$ & $\begin{array}{l}16.8 \\
15.9 \\
18.0 \\
16.2 \\
16.1 \\
13.6 \\
14.9 \\
16.8 \\
19.5 \\
21.7 \\
19.5 \\
18.9\end{array}$ \\
\hline Year..... & & 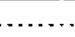 & 21. 75 & 92.6 & $\ldots \ldots \ldots$ & $\ldots \ldots \ldots$ & 88.10 & 207.9 \\
\hline
\end{tabular}

Dates of freezing in southeastern Alaskn. ${ }^{a}$

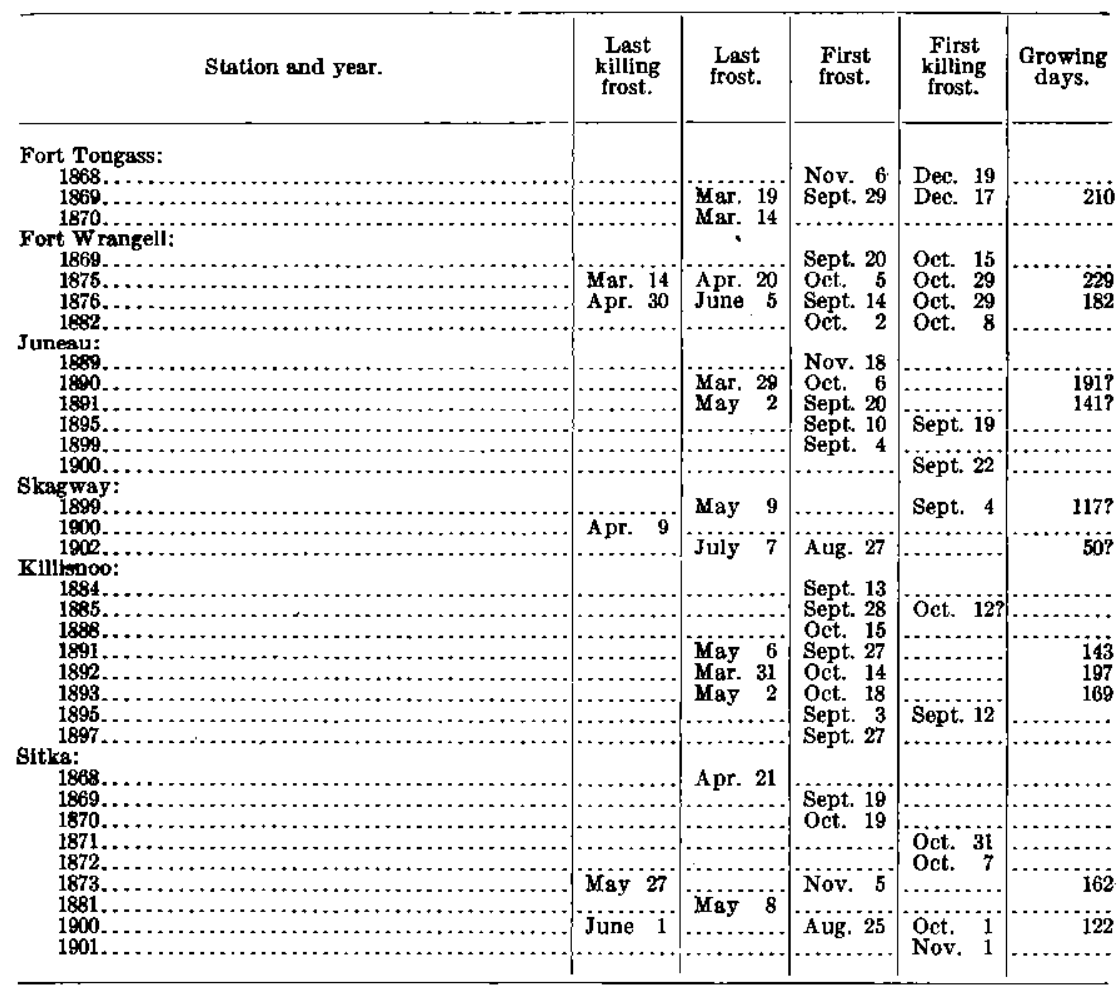

a Brooks, A. H., Geography and geology of Alaska: Prof. Paper U. S. Geol. Survey No. 45, 1906, pp. 171-172. 


\section{VEGETATION.}

Owing to the mild temperature, the long days in summer, and the heavy precipitation, the vegetation in southeastern Alaska is very luxuriant. Except where the soil is too shallow or the slopes too rocky, the whole area is covered with dense forests of spruce, cedar, and hemlock, and is in the national forests. Among this timber there is a heavy undergrowth of devils club, berries, and other small plants. In the southern part of the area trees vary in diameter up to 6 feet and grow up the slopes to the mountain tops. Toward the north the size of the trees diminishes, the undergrowth is not so heavy, and the timber does not extend to the top of the mountains, which are either small or glacier covered.

Much of the forest is overmature and defective timber is common, but in coves and gullies for several miles back from the coast there are many fine stands of spruce and cedar which have never been injured by fire or cutting.

The logging practice now in vogue takes only the best spruce trees which can be felled into the water or on slopes where they can be skidded in by hand. Of course it is difficult to $\log$ in a mountainous country, but much timber can be logged in southeastern Alaska with no more difficulty than attends many operations in the Pacific Coast States, if modern methods are introduced.

So far only the spruce has been used for saw timber, but both spruce and hemlock are undoubtedly good pulp woods. The few sawmills now operating in southeastern Alaska obtain their timber from the national forests, but the supply of timber is much greater than is required by local needs. The Forest Service is desirous of increasing the timber sales, and the presen price of stumpage is low-only $\$ 1$ a thousand board feet. Full information on this subject can be obtained from the forest supervisor at Ketchikan.

Aside from the native growth, garden truck, berries, and the hardy grains and grasses can be raised in all parts of this area. Strawberries, raspberries, and huckleberries grow both wild and cultivated and are of most excellent quality. Grasses and grains are difficult to harvest and cure owing to the large amount of rain.

The areas suitable for agriculture are small and are expensive to bring under cultivation. Agriculture is carried on with difficulty on account of the swampy condition of the ground, which is hard to work with horses unless well drained. 


\section{GENERAL CONDITIONS OF RUN-OFF.}

The run-off from the streams in this area results principally from direct rainfall, melting snow, and melting glaciers. In view of the large rainfall, the excellent forest cover, and the glacial areas, the general deduction would be that this section should have many large streams with an abundant and well-sustained run-off. This, however, is not the case, as the catchment areas are small and, although the total yield per square mile is considerable, the streams are not large and they fluctuate very rapidly.

The forest effects are principally offset by the steep slopes and shallow soil, which afford but little ground storage. The streams respond very quickly to the rainfall and their volume drops with equal quickness as soon as it ceases to rain. Frequently they are reduced from a maximum to a minimum flow within a few days. This is illustrated in the hydrograph (PI. II) of Porcupine Creek near Haines, in the northern part of the area. This strean has a drainage basin of 34 square miles and heads in a large glacial area.

In many places, owing to the steep slopes, there are no well-defined streams but instead the water runs down the mountain side in many small channels, some on the surface and others between the soil and the rock. In some of the developments the water is obtained by contour ditches which bring the water together from these streams.

Most of the large glaciers terminate at elevations but little above sea level and are therefore practically of small value as a source of water supply for the development of power. The smaller glaciers are beneficial only during the summer inonths, as their water is cut off early in the fall by the frosts. It is probable that many of the extreme variations in the glacier-fed streams are due to the making and breaking of ice jams which raise and hold back the water.

The streams which head in lakes have a much better sustained flow and are practically the only ones in the area which are of much value for power, as any large development must depend on storage both for the winter months and during dry parts of the summer.

The principal defect in the water supply, so far as the production of power is concerned, is the extreme low flow during the winter months. On the smaller streams, which have no storage, there is practically no flow in winter, and even on the streams having lake storage the flow is extremely low, as shown in the records for Turner River (fig. 2), which empties into Taku Inlet near Juneau. This stream has a drainage area of 66 square miles and heads in Turner Lake, which offers excellent facilities for storage. A portion of the area is also covered with glaciers. The scantiness of the winter flow is due largely to the meager amount of storage capacity in the ground, which freezes to bed rock, thus holding back the water. 


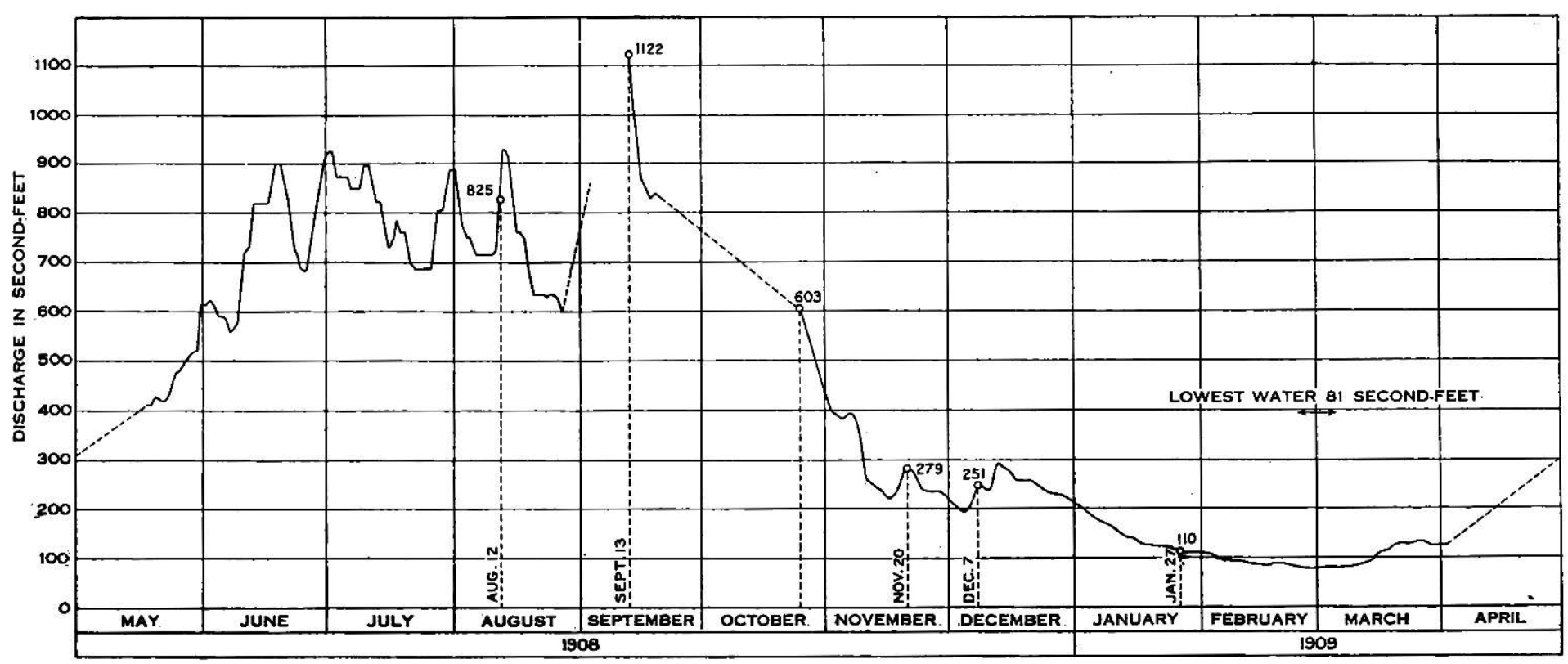

FIGURE 2.-Hydrograph of Turner River. From records furnished by the Alaska Treadwell Gold Mining Company. 


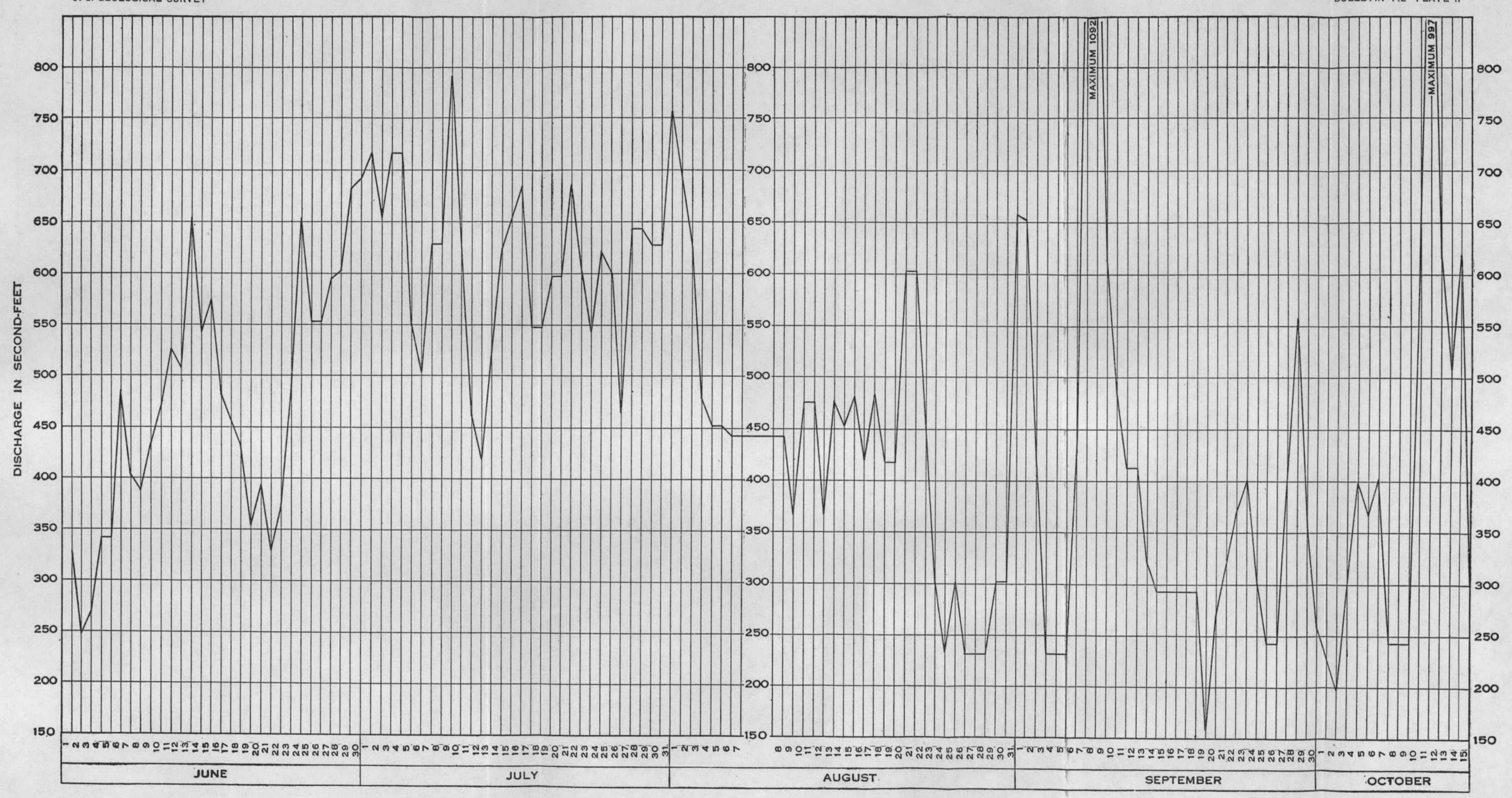




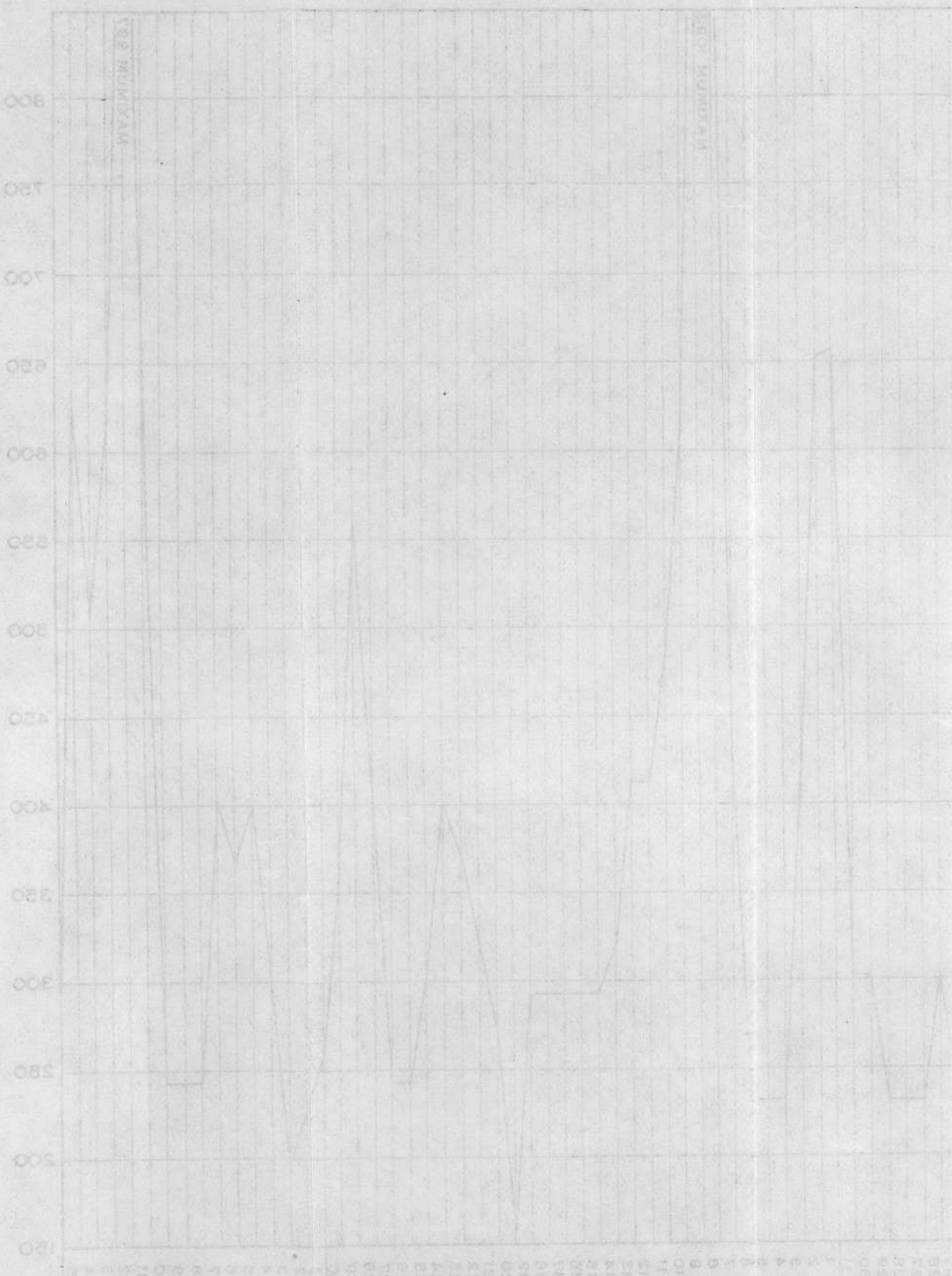




\section{INDUSTRIAL CONDITIONS.}

With the exception of a few towns along the shore and scattered mining camps and fisheries, soltheastern Alaska is very sparsely settled. The only ready means of transportation is by boat. Aside from the regular steamers which run from Seattle and other ports, each town has a local service connecting it with adjoining towns and camps by gasoline launches.

There are practically no roads and the country back from the shorw line is almost inaccessible. The building of government roads. which is now under way, will be a great help to the development of the country.

The two well-developed industries are fishing and mining. The larger part of the fishing is for the salmon canneries. An icing plant has just been established at Ketchikan. The mines are principally quartz mines yielding gold and copper.

Next to fishing and mining comes lumbering, which at present is but little developed and is confined to shingle mills and a few small sawmills that meet the local demands. Agriculture, owing to the small amount of suitable land available, will always be of very minor importance.

The success and future development of both the mining and the lumbering interests depend wholly on their ability to get cheap power. Most of the mines so far opened have been in the Juneau belt and are in ore of low grade, large amounts of which must be cheaply handled in order to make them profitable. The best paying mines owe their successful operation to the presence of cheap power in their immediate vicinity, and their future development will depend on the procuring of further cheap power. This is a vital question with the older companies, and they are investigating every possible source of power. The fishing industry demands only a small amount of power during the canning season. This can readily be obtained at small expense in the vicinity of the plants.

In developing the timber resources it will be possible to produce cheap steam power by the use of sawmill waste as fuel. The ultimate development, however, for both lumber and pulp will be through the establishment of mills at accessible power sites.

The future development of electro-chemical processes may open a new industry for this region. In its present stage, however, there is no field in Alaska for this industry.

Practically the whole area here considered is included in the Tongass National Forest; therefore the conditions governing the national forests will, in a large measure, regulate the development of the timber and other resources of this country. 


\section{POWER POSSIBILITIES.}

As shown in the subjoined table, there were 102 water wheels in southeastern Alaska in 1908, developing 16,319 horsepower. This table is based on a special water-power census taken by the United States Census Bureau, and the amounts are made up from statements received from power owners in the various sections. These figures have not been verified, but it is believed that they are somewhat large, as they probably give the maximum development, and this can be maintained only during a 'small portion of the year. Most of the plants have but little power during the winter months.

In considering the development of the water powers in southeastern Alaska the possibility of developing power from lignite and coal deposits in that region must be taken into account. When these deposits are opened fuel will probably be available at a comparatively low cost on account of the ease of water transportation, and steam power may be produced much more cheaply and will be more reliable than the water power.

A great drawback to water-power development in this region is the difficulty of transmission. The country, as already stated, is cut by numerous channels, has a rough topography, and is covered with dense forests. Therefore transmission lines are difficult and expensive to construct, and this practically prohibits development at sites where the power can not be utilized at the point of development. In view of these difliculties, the possibilities at the present time for large power development in southeastern Alaska are not great, and such projects should be closely scrutinized as to their feasibility both from an engineer's standpoint and from that of an investor.

The opening of new mining districts and the development of the timber interests in this region will create a more widely distributed demand for power and enable the utilization of sites which at the present time can not be considered as available. $\Lambda$ s already stated, the success of any large water-power development, to be run during the entire year, will depend on the possibility of arlequate storage. The meager topographic data available indicate that there are probably many lakes throughout the region which will offer excellent storage facilities. 
Developed water power in Alaska, 1908.

\begin{tabular}{|c|c|c|c|c|}
\hline Owner. & Location of plant. & $\begin{array}{l}\text { Number } \\
\text { of wheels. }\end{array}$ & $\begin{array}{l}\text { Horse- } \\
\text { power. }\end{array}$ & Character of industry. \\
\hline 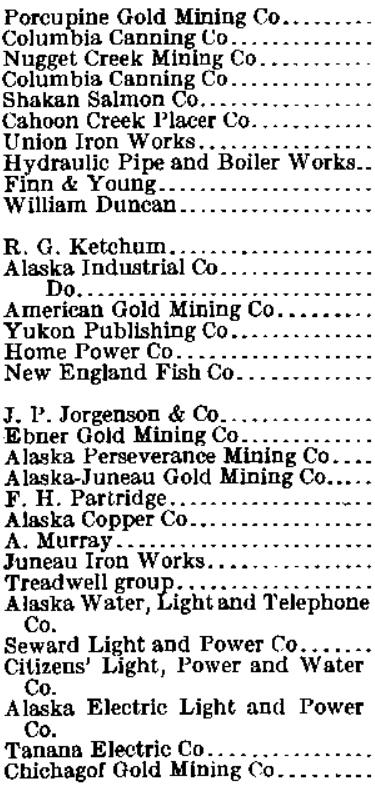 & 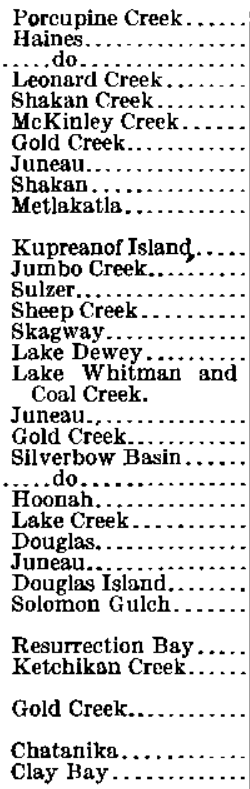 & $\begin{array}{l}2 \\
3 \\
2 \\
3 \\
4 \\
2 \\
1 \\
1 \\
1 \\
2 \\
1 \\
1 \\
1 \\
3 \\
1 \\
1 \\
2 \\
1 \\
4 \\
8 \\
2 \\
2 \\
4 \\
2 \\
1 \\
37 \\
1 \\
1 \\
2 \\
5 \\
1 \\
1\end{array}$ & $\begin{array}{r}50 \\
70 \\
24 \\
25 \\
150 \\
100 \\
8 \\
8 \\
25 \\
53 \\
50 \\
150 \\
30 \\
80 \\
3 \\
125 \\
1,100 \\
\\
25 \\
4,000 \\
880 \\
500 \\
15 \\
300 \\
5 \\
6 \\
6,297 \\
350 \\
150 \\
240 \\
1,000 \\
500 \\
150\end{array}$ & $\begin{array}{l}\text { Placer mining. } \\
\text { Cannery. } \\
\text { Mining. } \\
\text { Sulmon cannery. } \\
\text { Do. } \\
\text { Placer mining. } \\
\text { Machine shop. } \\
\text { Pipe and boiler works. } \\
\text { Sawmill and salmon } \\
\text { cannery. } \\
\text { Barrel factory. } \\
\text { Mining. } \\
\text { Do. } \\
\text { Newspaper. } \\
\text { Light and power. } \\
\text { Fish freezing and Ice } \\
\text { making. } \\
\text { Lumber. } \\
\text { Quartz mining. } \\
\text { Mining. } \\
\text { Do. } \\
\text { Sawnill. } \\
\text { Smelter and sawmill. } \\
\text { Wood turning, etc. } \\
\text { General repairs. } \\
\text { Gold mining. } \\
\text { Light and power. } \\
\text { Do. } \\
\text { Do. } \\
\text { Do. } \\
\text { Do. } \\
\text { Do. } \\
\text { Dong }\end{array}$ \\
\hline & & 102 & 16,319 & \\
\hline
\end{tabular}




\title{
MINING IN THE CHITINA DISTRICT.
}

\author{
By Fred H. Moffit.
}

\section{INTRODUCTION.}

The year of 1909 was one of expectation and preparation in the Chitina district. The subject of greatest interest to those concerned with the copper resources there was progress in the construction of the new railroad up Copper River from Cordova, and all work on the copper prospects, as well as all plans for future work, were influenced by the hope of railroad communication with the coast and a consequent great saving of time and expense in freighting within the next year and a half. As was indicated by the quantity of supplies sent in over the trail from Valdez in the early part of the year, the number of men employed in the copper belt was smaller than in several previous years. On the other hand, operations on the gold-bearing gravels of Chititu and Dan creeks in the eastern part of the district were carried on in about the same manner as in the two years immediately preceding. The execution of one or two projects requiring the use of heavy machinery was postponed till the time when the cost of installation shall be less, and development work in general was interrupted in some degree or was pushed less vigorously than in previous years. This lessening of activity was not wholly and perhaps not even principally due to the cause mentioned, for both development work and prospecting were greatly influenced by the uncertainty of the copper market and the difficulty of obtaining money for developing copper mines while this condition continues.

Construction work on the Copper River and Northwestern Railway was stopped during the winter of $1908-9$, but was begun again in the spring as soon as weather permitted. The steel work of the lower bridge over Copper River was completed early in the summer and work on the piers of the next bridge between Childs Glacier and the foot of Miles Glacier Lake was started. These piers and the abutments are now completed and ready for the steel structure, which was to be put in place in the spring of 1910 . While the piers and bridge are under construction supplies and material for the work above Abercrombie Rapids are ferried across the lower end of the lake on a barge. Ferry slips connected with the railroad were 
built and a small steamboat was launched on the lake to tow a barge on which two cars were carried. During most of the summer a passenger train was run from Cordova to Miles Lake each day, and "camp 55," at the head of Abercrombie Rapids, could then be reached by the ferry and construction trains. At the end of September the track had been laid to "mile 72," but no attempt was made to carry either passengers or freight, except workmen and needed supplies, beyond the rapids. At that time engineering and construction parties were stationed along Copper River from the rapids to the mouth of the Chitina, and the engineers in charge expected to have the rails laid as far as Tiekel River, about 100 miles from Cordova, before work was interrupted by winter weather. Soundings were made for the piers of the third bridge over Copper River just below the mouth of Kotsina River, but between the mouths of the Chitina and the Kennicott grading was not commenced, although the right of way is cleared and ready for the work. It is reported that early in November the track had been pushed forward to "mile 89." Three small steamboats were built for distributing supplies to the men at work above the rapids and for operating the ferry over Miles Glacier Lake, thus making four boats now in use on the river. These boats have difficulty in navigating certain stretches of Copper River in times of high water, particularly when a strong wind is blowing, and although they are of light draft do not attempt to go up Chitina River after the water begins to fall in the latter part of August or early in September.

There can be no question that the building of this railroad is the most important undertaking now being carried on in the Copper River region, and that its completion means more for the future of the district than can be estimated. Development of the copper prospects is impossible until a means of handling the ore and procuring supplies is provided. Another most desirable result to be brought about by the railroad is that the various prospects will shortly be compelled to stand on their individual merits as producers of copper, and the investing public will be able to learn which have value and which have not, and further what place this district is to take among copper-producing camps.

\section{COPPER.}

The following descriptions are not presented as a complete report of copper-mining operations in the Chitina Valley in 1909. During the summer a detailed geologic study was made of the area represented on the Nizina special map (see p. 15), an area that includes the Bonanza mine and the gold placers of Chititu and Dan creeks. The properties within the limits of this area were examined, but none of those west of Kennicott River were visited, and such facts 
as are given concerning them were obtained either from the owners or from others who had been on the prospects. Most of the claims and the occurrence of the copper have been described in a recent Survey publication, ${ }^{a}$ and it is not desirable to repeat that description here.

The Bonanza mine, on the east side of Kennicott Glacier, is in every way the most important copper deposit yet discovered in the Chitina Valley. When the property was visited in 1907 the development work consisted of two tunnels crosscutting the ore body, a winze in the ore in the longer tunnel, and a drift from the bottom of the winze along the ore body. The total length of the tunnels and drift was 340 feet. The winze was 33 feet deep. Since that time a second tunnel has been started 78 feet lower than the longer tunnel and an upraise made connecting with the winze. A body of glance was exposed in the raise and the ore taken out was sacked for shipment. The tramway for carrying ore from the mine to the ore bunkers at the mouth of National Creek, which was begun in 1908, was completed in 1909 and put into operation about the end of August. It is approximately 3 miles long and is divided by an angle station, at a point a little less than halfway down from the loading station, into what are virtually two independent tramways, but, of course, there is no interruption in the descent of the buckets. The difference in elevation of the loading and delivery stations is 4,000 feet and the carrying capacity is 100 tons a day. At the close of the season the buckets were all removed from the cables after 130 tons of ore had been sent down to furnish power for bringing up provisions and fuel for use during the winter. There still remains some construction work to be done, such as the building of ore bunkers and quarters for men, but the completion of the tramway puts the Bonanza mine into a position to produce and ship ore as soon as railroad communication with the coast is established.

About half a mile northeast of the Bonanza mine and across the ridge separating Bonanza Creek from one of the small western tributaries of McCarthy Creek are the claims of the Houghton Alaska Exploration Company and of the Mother Lode Company. These claims are on a fault zone that was traced in a direction N. $30^{\circ} \mathrm{E}$. from the Bonanza mine for a distance of 1 mile. The copper minerals exposed here are high in the Chitistone limestone, at least 1,000 feet above the top of the greenstone. Chalcocite is the prevailing copper mineral and is associated with considerable azurite, an oxidation product of the chalcocite. The claims of the Houghton company have gone to patent, but the others had not at the time they were visited in 1909 . The development work on these various claims con-

\footnotetext{
a Moffit, F. If., and Maddren, A. G., Mineral resources of the Kotsina-Chitlna reglon, Alaska: Bull.
} U. S. Geol. Survey No. 374, 1909. 
sists of several short tunnels and a number of open cuts. Considerable importance, aside from the value of the copper they may produce, attaches to the deposits here, because they are the first proof that the copper-bearing solutions reached so high a stratigraphic position above their source in the greenstone.

Other development work done within the area of the Nizina special map was that of the United Alaska Copper Exploration Company on property, including the Westover claim, situated on Dan Creek and on Chitistone River, and that done along the limestone-greenstone contact from McCarthy Creek to Nizina River on a series of claims held under private ownership.

Prospecting and development operations were carried on in the Chitina Valley in a number of places outside of the Nizina district. Among such operations was the work of the Alaska-Kotsina Copper Company on Kotsina River, of the Great Northern Development Company on Kotsina River and at Iron Mountain and Copper Mountain, of the Hubbard Elliott Copper Mines Development Company on Elliott Creek, and of the Alaska Consolidated Copper Company on Nugget Creek. Work was done also on Kluvesna Creek, Kuskulana, Chokosna, and Lakina rivers and Hidden Creek. Most of this was for the purpose of testing ground or was done as assessment work and did not have for its object the exploitation of an ore body. It is therefore of a more or less temporary character.

The Alaska-Kotsina Copper Company devoted a considerable part of the summer to the development of the claims known as the Hubbard group. The ore was deposited along a well-marked fault plane and has been exposed in several open cuts made in previous years. This year a tunnel was started to cut the lode at quarter depth, but had not been completed when the season closed.

The operations of the Great Northern Development Company were largely of a prospecting character. This company owns a large number of claims scattered along the copper belt as far east as Kennicott Glacier and has expended much money in testing its ground. Among the claims on which work has been done those of Copper Mountain are regarded as most promising.

The work of the Alaska Consolidated Copper Company on Nugget Creek resembles that of the Alaska-Kotsina Copper Company at the head of Kotsina River. In order to determine whether the vein exposed in the tunnel and shaft of the Valdez claim continued down along the fault in which it is found, a second tunnel was started below the old one, but it was not completed at the end of the season.

$55695^{\circ}-$ Bull. $442-10-11$ 
GOLD.

Placer mining on Chititu and Dan creeks was seriously interrupted by unusual weather conditions, and in consequence the gold production fell below that of last year. The winter of 1908-9 was characterized by extraordinary cold and a small snowfall. Overflows took place frequently on the streams and ice formed to a greater thickness than had ever been known there before. In places the ice did not melt till early in July, and sluicing, therefore, could not begin till much later than is customary. Furthermore, twice during the summer high water destroyed the dams and filled in the pits and sluice boxes, so that in all about twenty-six days of the working season were lost.

The hydraulic plant of the Nizina Mines Company was moved in the spring from the place where work was stopped the previous year to a claim higher on the creek, because ice filled the old pit and the whole width of the creek bottom besides, and it was certain that the gravels would not be exposed till late in the season. Yet in spite of unusual difficulties a creditable showing was made in the amount of gravel handled and encouragement was afforded by the proof that the value of the gold in the gravel had not been overestimated.

The hydraulic plant at the mouth of Rex Gulch belonging to Frank Kernan continued operations from the point where work had ceased the previous fall. This plant also was delayed in its earlier work by lateness of the season, but perhaps suffered less from high water during the summer than the property below it.

The placer-mining operations on Dan Creek and the tributary Copper Creek differed little from those of the last two or three years. Preparations were begun by the Dan Creek Mining Company in 1908 for the installation of a hydraulic plant on the lower part of Dan Creek, but it was finally decided to postpone the erection of this plant for a year or two till the completion of the railroad shall make it possible to decrease the very large part of first cost that results from the expense of freighting. There was therefore no attempt to do much more than the work necessary to hold the ground.

Placer mining was carried on in the Copper Creek valley chiefly at or just below the mouth of Rader Gulch, yet some mining was done on Idaho Gulch and on the head of Copper Creek near the mouth of Seattle Gulch. The work was all done with pick and shovel. Twelve or fourteen men were employed on Copper Creek during the summer, but owing to the cost of mining and the fact that the richest of the known gold-bearing gravels had already been sluiced the profits were not great. Experience has not shown the gravels of Copper Creek to equal in value the part of Dan Creek below the canyon, though it is hard to explain why there should be this difference and also why little or no fine gold is found on Dan Creek. 


\section{GEOLOGIC INVESTIGATIONS.}

Detailed mapping of the geologic formations of the Nizina district was begun in July, 1909, and completed early in September. For this survey the topographic map made by D. C. Witherspoon in 1908 was used as a base in the field work. This map represents an area of about 300 square miles and includes most of the Nizina River drainage basin below Chitistone River. Inasmuch as reconnaissance geologic maps of the region had been made in previous years and the principal formations and their distribution were already known in a general way, the work of mapping the boundaries was less difficult than it otherwise would have been.

The more careful study of the summer of 1909 showed the necessity of changing some of the ideas formerly held concerning the thickness and distribution of the Jurassic conglomerate, sandstone, and shale known as the Kennicott formation. It was found that both thickness and areal distribution were greater than had been supposed and that part of the shale areas which until this time have been thought to be Triassic are in fact Jurassic. The economic importance of the Jurassic rocks-the Kennicott formation-lies in the fact that they are the source from which the placer gold of Chititu and Dan creeks was derived. Numerous veinlets of gold-bearing quartz are found in fractures and joint planes of the shales and there is little doubt that they are an adequate source of supply for the gold now concentrated in the creeks, for an enormous quantity of the shales has been removed by erosion. Few of the veinlets exceed an inch or two in thickness, and many of them are no thicker than a sheet of paper or cardboard. Another discovery of interest is that the native copper of Chititu Creek and with little doubt the silver also are derived in part from a source in the Nikolai greenstone, either about the head of Young Creek or higher in the Chitina Valley, and in part from the greenstone of Dan Creek and the upper Nizina, and that it has been transported to its present location by glacial ice. Most of the placer copper of Dan Creek is unquestionably derived from rocks within the greenstone area of the Dan and Copper Creek valleys, but a small proportion of it may have come from a source to the north in the Nizina Valley. The facts concerning the copper in Chititu Creek suggest the desirability of prospecting for copper in the region about the head of Young Creek and eastward in the valley of Chitina River. Some prospecting has been done there, but the region is harder to reach than most of the rest of Chitina Valley and the search for copper has not been thorough. 


\title{
MINING AND PROSPECTING ON PRINCE WILLIAM SOUND IN $1909 .{ }^{a}$
}

\author{
By U. S. Grant.
}

The year 1909 showed less activity in mining and prospecting on Prince William Sound than the previous year. On many of the unpatented properties little was accomplished in addition to the necessary assessment work, although active prospecting was carried on in a few localities. Little ore was shipped from the district until August, but in that and later months there was more activity in mining, so that the total copper production from Prince William Sound for the year 1909 is approximately equal to the production for 1908.

At the Ellamar mine, at the town of Ellamar, most of the work in 1909 was devoted to the construction of a dam to exclude the sea from the ore body, which outcrops at and below the level of high tide. It is expected that with the protection afforded by this dam most of the ore between the surface and the 100-foot level can be removed.

At the Bonanza mine, on Latouche Island, the first half of the year was devoted to further exploration in the lower level, which resulted in the discovery of more ore, and to the removal of part of the mine dump, so that the ore between the quarry floor and the upper level could be economically mined. Later in the year a considerable quantity of ore so situated was mined and shipped.

The Galena Bay Mining Company continued its tunnel on the north slope of Copper Mountain to a total length of about 1,800 feet, and then did some diamond drilling near the breast of the tunnel. The drills penetrated a body of ore about 30 feet in thickness some 200 feet from the breast of the tunnel. Further drilling was done on the Sunnyside claim, about 3,000 feet from the mouth of the Galena tunnel, on the west sicle of Vesuvius Valley. ${ }^{b}$

a In the progress report for 1908 (Buljetin $379, \mathrm{pp} .87-96$ ) is a summary statement concerning recent mining and prospecting on Prince William Sound, accompanied by a map (Pl. IV) showing the locations of the various properties. In that paper is also a list of Survey publications dealing with this district. $A$ more detailed report, entitled "Geology and mineral resources of Prince William Sound, Alaska," is in preparation to be issued as a bulletin of the Survey.

$b$ Information from R. C. Bogue. 
At Landlocked Bay the Standard Copper Mines Company and the Three Man Mining Company did considerable development work, and the latter company constructed an ore bunker at the beach and mined a few hundred tons of ore.

Near Cordova and Orca prospecting was done on several claims, and especially at the Head-of-the-Bay mine, owned by the CordovaTacoma Copper Company. This prospect is 2 miles east of the head of Cordova Bay and the ore lies close to the contact of a diorite mass with the country rock, graywacke, and slate. The Cordova Copper Company exhibited at the Alaska-Yukon exposition some large pieces of native copper from its Fleming Spit prospect.

On Knight Island there was much less prospecting than in 1907 and 1908, though work was done on several properties, especially those owned by Bettels and by Rua (Copper Bullion claims).

On Latouche Island not much work was done outside of the Bonanza mine, but the Latouche Copper Mining Company added a steam boiler and an air compressor to its equipment.

The Cliff Gold Mining Company erected a 5-stamp mill on the north shore of Port Valdez just east of Shoup Bay, where some goldbearing quartz veins have been discovered in the slates and graywackes of the Valdez group. This ore is reported to be free milling and some of it to be very rich.

Prospecting for gold was carried on just northwest of McKinley Lake, which is about 20 miles east of Cordova, and some encouraging finds have been reported. On one of these prospects a 2-stamp mill was erected in $1909 .^{a}$ 


\title{
PRELIMINARY REPORT ON THE MINERAL RESOURCES OF THE SOUTHERN PART OF KENAI PENINSULA.
}

\author{
By U. S. Grant and D. F. Higgins.
}

\section{INTRODUCTION.}

During the summer of 1909 the authors were commissioned to carry on a general geologic reconnaissance of the southern part of Kenai Peninsula. About two months were devoted to a study of the shore line between Seward and Seldovia. (See p. 13.) All mineral prospects of which knowledge was obtained were visited and a few trips were made back from the coast, including one to Moose Pass and False Creek, north of Seward.

Contributions to the geology of Kenai Peninsula have been made by Mendenhall; $;^{a}$ by Gilbert; ${ }^{b}$ by Emerson, Palache, and Ulrich; ${ }^{c}$ by Stanton and Martin; ${ }^{d}$ by Brooks ${ }^{e}$ by Moffit; ${ }^{f}$ by Stone; $g$ by Grant and IIiggins $;^{h}$ and by Atwood. ${ }^{i}$ A more extended report than the present is in course of preparation.

\section{GEOLOGY.}

The rocks of the coast of the southern part of Kenai Peninsula from Prince William Sound westward to Kachemak Bay may be separated into four divisions, as follows: (1) A division of highly folded slates to which the name Sunrise "series" has been applied; (2) a division of cherts, tuffs, and greenstones, with graywackes, slates, and limestones; (3) a division of stratified tuffs, with cherts, slates, limestones, and basic igneous rocks; (4) a division of sandstones, shales, and lignite. These are named in order from east to

a Mendenhall, W. C., A reconnaissance from Resurrection Bay to the Tanana River, Alaska, in 1898: Twentieth Ann. Rept. U. S. Geol. Survey, pt. $\mathbf{i}, 1900$, pp. $26 \bar{j}-340$.

$b$ Gilbert, G. K., Harriman Alaska Expedition, vol. 3, 1904.

c Emerson, B. K., Palache, Charles, and Ulrich, E. O., Idem, vol, 4, 1904.

¿Stanton, T. W., and Martin, G. C., Mesozoic section on Cook Inlet and Alaskan Peninsula: Bull. Geol. Soc. America, vol. 16, 1905, pp. 391-410.

e Brooks, A. H., The geography and geology of Alaska: Prof. Paper U. S. Geol. Survey No. 45, 1906.

$f$ Moffit, F. H., Gold fields of the Turnagain Arm region: Bull. U. S. Geol. Survey No. 277, 1906, pp. 7-52. $\sigma$ Stone, R. W., Coal fields of the Kachemak Bay region: Idem, pp. 53-73.

$h$ Grant, U. S., and Higgins, D. F., Notes on the geology and mineral prospects in the vicinity of Seward, Kenal Peninsula: Bull. U. S. Geol. Survey No. 379, 1909, pp. 98-107.

$i$ Atwood, W. W., Mineral resources of southwestern Alaska: Idem, pp. 108-152. 
west, and this order is also probably the order of age, the oldest being on the east.

The Sunrise "series" occupies the coast from Prince William Sound westward to the west side of Nuka Island Passage. Smaller areas perhaps occur farther west. The rocks are essentially slates and graywackes, with minor amounts of quartzites and conglomerates. In only one place- between Resurrection Bay and Day Harbor-are there surface igneous rocks and here are the ellipsoidal greenstones so characteristic of the Orca group on Prince William Sound. The slates and graywackes of the Sunrise "series" probably include at least two unconformable formations of very similar lithology. On Nuka Bay an apparent unconformity with a basal conglomerate has been observed in this "series." The age of the Sunrise "series" is not known with certainty. The only fossils found in these rocks in the southern part of Kenai Peninsula were obtained at Nuka Bay. These fossils were worm tubes (Terebellina palachei Ulrich $)^{a}$ similar to those found on Yakutat Bay, on Prince William Sound, and on Kodiak Island. At the last-named locality other fossils also occur and Ulrich ${ }^{b}$ refers them most probably to the Lower Jurassic.

The Sunrise "series" is intruded by several masses of granite, which is usually a coarse-grained biotite granite. A large mass of granite extends from Hive and Rugged islands, in Resurrection Bay, westward to and beyond Aialik Bay and makes up much of the headlands on both sides of the southern half of this bay and all the adjacent islands. Another large granite mass makes up Pye Islands and the adjacent mainland.

The next group of rocks consists essentially of cherts, tuffs, and greenstones (locally ellipsoidal in structure), with less amounts of graywackes, slates, and limestones. These rocks extend, with the exception of possible areas of Sunrise "series," from Nuka Island Passage westward to and beyond Port Chatham. The Chugach Islands are made up of these rocks, whose western border passes through Port Graham and Seldovia Bay, and they occur on the southeast side of Kachemak Bay. These cherts and tuffs are much folded, are abundantly intruded by dikes of fine-grained granitic rocks, and, where they are in close proximity to the next group of rocks on Port Graham and Port Chatham, are highly metamorphosed. The relation of these cherts and tuffs to the Sunrise "series" is not definitely known, but they are clearly older than the next series of stratified tuffs. Stanton and Martin ${ }^{c}$ and Moffit ${ }^{d}$ refer these cherts

a Determined by T. W. Stanton.

b Ulrich, E. O., Harriman Alaska Expedition, vol. 4, 1904, p. 132.

c Stanton, T. W., and Martin, G. C., Bull. Geol. Soc. America, vol. 16, 1905, p. 393.

${ }^{d}$ Moflit, F. H., Bull. U. S. Geol. Survey No. 277, 1906, p. 20. 
and tuffs most probably to the Triassic, which seems to be the youngest age possible for them.

The group of stratified tuffs, with which are cherts, slates, limestones, and basic surface igneous rocks, forms the coast line from Dogsalmon Bay (near Port Chatham) northward to Seldovia Bay, except for small areas of the Kenai formation. The general dip of these rocks is westward and they.are much less folded and much less intruded by acidic dikes than the rocks last described. These tuffs contain a considerable fauna which has been referred to the Lower Jurassic. The field work of the present season disclosed a series of cherts and black limestones near the base of this tuff formation. In the limestones are pelecypods of the genus Halobia ( $H$. sp. related to $H$. superba Mojsisovics), a genus which is characteristic of the Triassic. ${ }^{a}$

The uppermost series of rocks, known as the Kenai formation (Eocene series of the Tertiary), is little altered and little folded. It consists of sandstones, shales, and coal (lignite) beds, occupies isolated areas along the coast line from Port Graham northward to and beyond Seldovia Bay, and is extensively developed on the northwest side of Kachemak Bay and to the west and north on the west shore of Cook Inlet.

\section{MINERAL PROSPECTS.}

IRON.

The similarity in lithology of much of Kenai Peninsula and the Lake Superior iron district is marked. In both places there are great thicknesses of graywackes and slates, as well as cherts and greenstones. The greenstones are to a considerable extent ellipsoidal in structure and are closely associated with the cherts. The cherts on Kenai Peninsula are usually gray to black in color and only here and there reddish. On a small island near the west end of Port Dick a small amount of reddish jasperoidal material and some hematite in veinlets were found in connection with these ellipsoidal greenstones. This is the only occurrence of iron ore noted in the district, with the exception of chromic iron ore, which is found at Red Mountain, southeast of Seldovia, and at Port Chatham. These occurrences are described below.

RED MOUNTAIN.

James Linder, J. T. Ballan, and Bruce Markle have staked a number of chromic-iron claims (No. 23 on Pl. III) on Red Mountain, which is a prominent peak, probably over 3,000 feet in altitude, lying about 7 miles southeast of the town of Seldovia. This moun- 


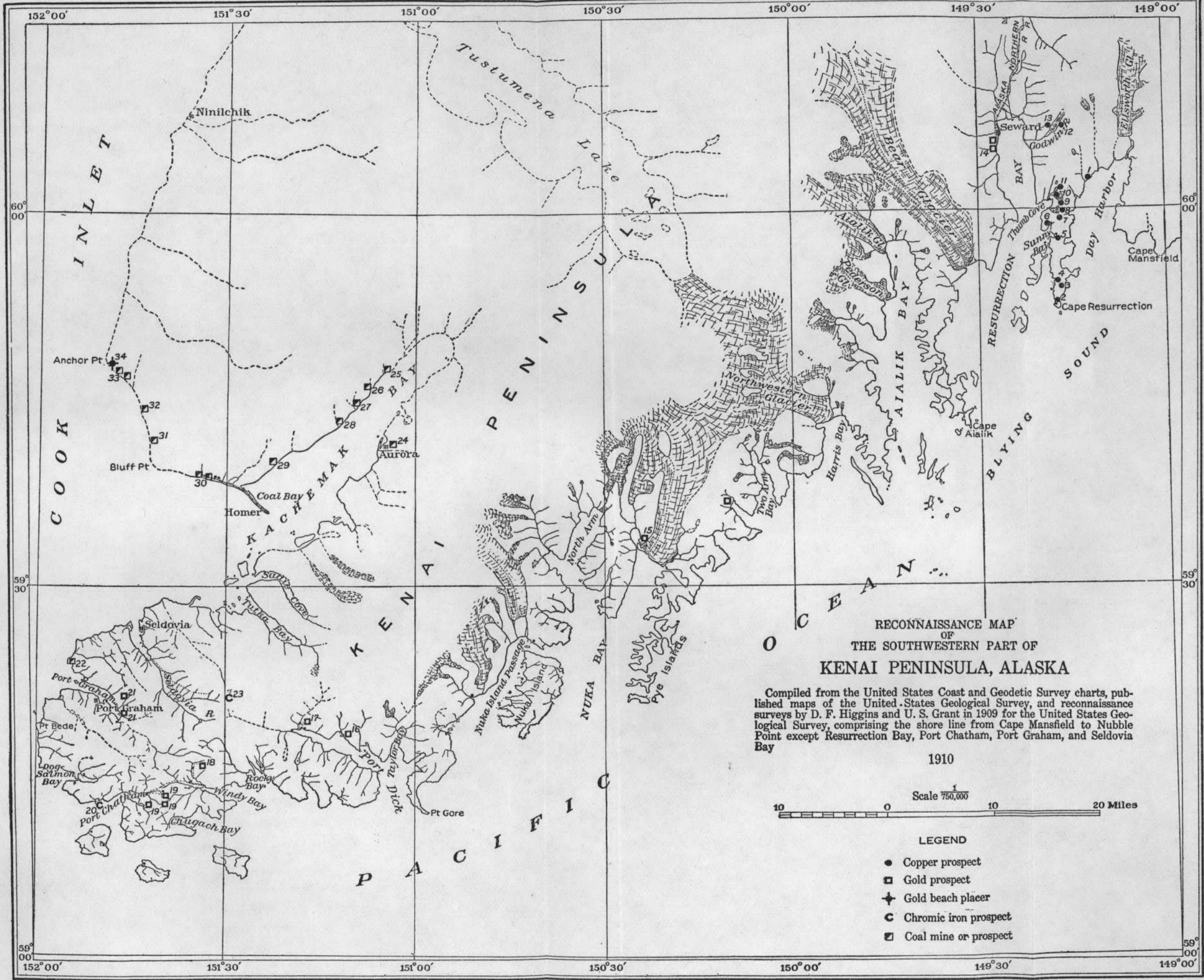

18.

18. Mills and Trimb

20. Anderson

22. Whiley
22. Linder and Ballan

24. Markle
Reynolds-Alaska
Development Co

25. Falls Creek

7. Cottonwood
8urtis

29. Bradley Cook Inlet Coal Field Co.

31. Bluff Point
Diamond Creek

34. Anchor Point 


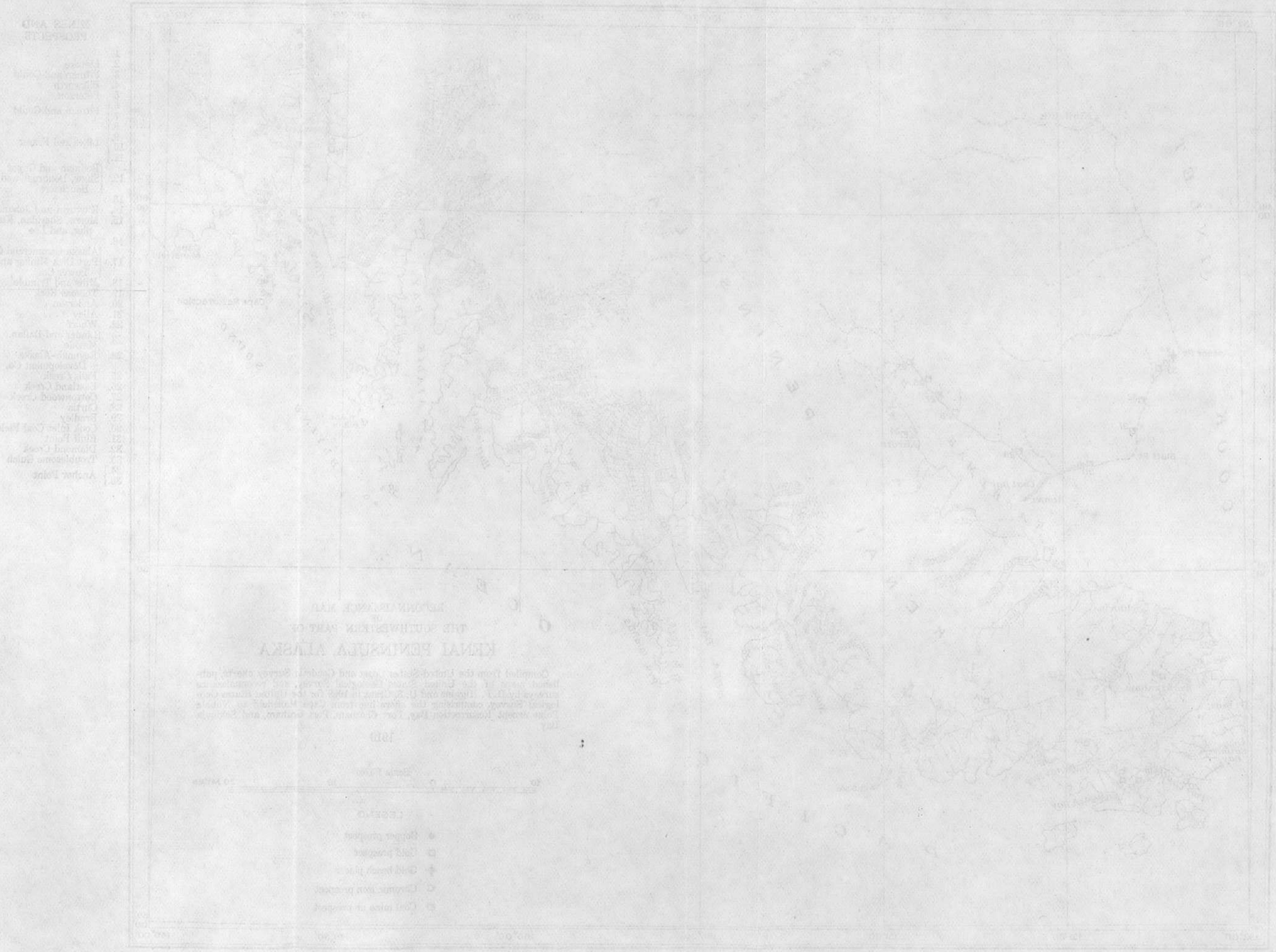


tain is noticeable from several positions along the coast because of its light terra-cotta color and the scarcity of vegetation on its upper slopes. The country rocks are the cherts and tuffs of possibly Triassic age, while the mountain itself is composed of a mass of finegrained peridotite of the variety dunite, a basic igneous rock composed essentially of olivine. This igneous rock occupies an approximately circular area about 2 miles in diameter. In certain places the dunite carries narrow bands of a coarser-grained rock composed of augite and olivine in varying proportions. The dunite itself contains small grains of chromite, and in places these are abundant and are segregated into bands, some of which are made up practically of chromite alone. These chromite bands are of varying thickness, from a fraction of an inch to a foot. Usually they are 1 to 3 inches thick. In one place a zone of 20 feet of country rock was so well supplied with these chromite bands that about one-fifth of this thickness of 20 feet was chromite. Exposures were not sufficient to allow this zone to be traced more than a few rods. An analysis of this chromic iron ore is reported as follows:

Analysis of chromic iron ore.

[By C. E. Bogardus.]

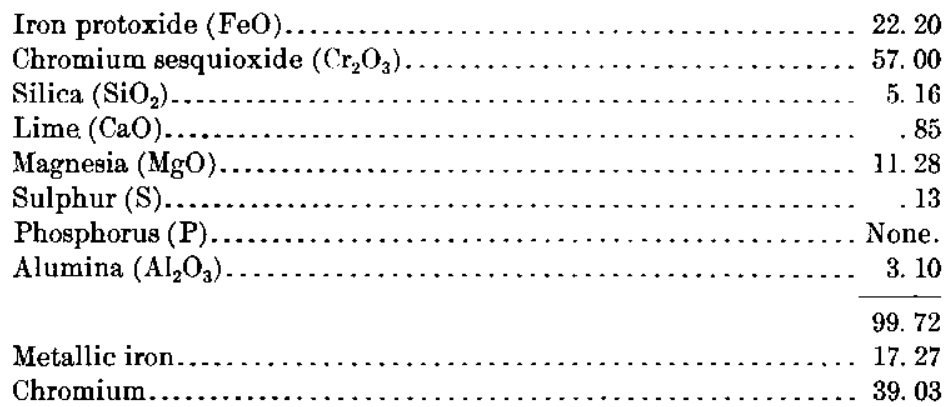

PORT CHATHAM.

The peninsula called Claim Point, on the north side of the entrance to Port Chatham, is composed of peridotite, and the same rock occurs on the mainland just north of this peninsula. On this point William and Charles Anderson have staked chromic-iron claims. The mineral chromite occurs in small amounts in the peridotite and in one place on the east shore of Claim Point fairly pure chromite occurs in bands and veinlike forms in the peridotite. The veins have a general northwesterly strike and $\operatorname{dip} 50^{\circ} \mathrm{SW}$. There is 3 to 10 feet of peridotite well seamed by chromite bands, so that about a quarter of this thickness is chromite. The largest single band noted was 10 inches thick. 


\section{COPPER.}

The copper prospects near Seward are on the east side of Resurrection Bay; they were visited in 1908, and descriptions of them have been published. ${ }^{a}$ As little work has been done on these prospects since the summer of 1908 , they were not visited in 1909 . It is reported that the tunnel on the Fairview claims (No. 3 on Pl. III) has been extended to a length of 25 feet, cutting 6 feet of ore, and that the breast of the tunnel is still in ore. Work is progressing on the Feather Bed claims (No. 8 on Pl. III) about 2,000 feet above sea level, and a trail has been constructed from Safety Cove, on Day Harbor, to these claims.

At the water's edge on the northwest side of Day Harbor, about 4 miles southwest of the head of this bay, a small amount of work has been done on a prospect (No. 1 on Pl. III) which is along a shear zone between gabbro and peridotite. This zone is 4 feet thick and contains some gabbro-pegmatite (a coarse-grained aggregate of plagioclase feldspar and augite), which carries pyrrhotite, pyrite, and possibly a small amount of chalcopyrite.

GOLD.

\section{INTRODUCTION.}

The gold prospects of the northern part of Kenai Peninsula have been described by Moffit. ${ }^{b}$ The work of the summer of 1909 did not include the district investigated by him except for certain points about Kenai Lake and Moose Pass, where there was considerable activity in prospecting for gold. These localities are described below, and descriptions are also given of gold prospects near the southern coast of Kenai Peninsula, especially at Port Dick, Windy Bay, and Port Chatham.

The gold prospects (No. 13 on Pl. III) just south of the Seward town site $^{c}$ were not worked during the summer, and it is stated that no work was done on the gold prospects at Aurora (No. 24 on Pl. III), on the southeast side of Kachemak Bay.

F. P. Skee and John Lechner, of Seward, report a gold prospect, on which little work has been done, about 5 miles west of Resurrection Bay, on the creek whose mouth is at Lowell Point.

Mining and prospecting for placer gold have been carried on at many points in the northern part of Kenai Peninsula, ${ }^{d}$ more or less work has been done about Tustumena and Kenai lakes, and sporadic

a Grant, U. S., and Higgins, D. F., Notes on the geology and mineral prospects in the vicinity of Seward, Kenai Peninsula: Bull. U. S. Geol. Survey No. 379, 1909, pp. 98-107.

$b$ Moffit, F. H., Gold fields of the Turnagain Arm region: Bull. U. S. Geol. Survey No. 277, 1906, pp. 5-72.

c Grant, U. S., and Higgins, D. F., Notes on the geology and mineral prospects in the vicinity of Seward, Kena1 Península: Bull. U. S. Geol, Survey No. 379, 1909, p. 107.

d Moffit, F. H., loc. cit. 
prospecting has been carried on south of these lakes. Lately, however, no serious prospecting for placer gold has been reported south of latitude $60^{\circ}$ except at Anchor Point, on the west side of Cook Inlet, of which Atwood ${ }^{a}$ reports as follows:

During the summer of 1906 a few miners were at work on the Anchor Point beach placers, using rockers or small sluice boxes, and they reported that they were making "fair wages." The gold which they obtained was very fine and the deposit exceedingly shallow, making it necessary to move frequently to different parts of the beach.

MOOSE PASS.

The present center of interest in the Moose Pass gold district lies on the headwaters of Quartz Creek, about 10 miles northwest of Upper Trail Lake. (See Pl. IV.) Leaving the Alaska Central Railway at mile 29, at the lower end of Upper Trail Lake, the traveler to the district goes along the lake to its west end and up Moose Creek through Moose Pass. Thence the route leads over a low divide by Fairman Lake to Quartz Creek, and up Quartz Creek to Slate and Summit creeks. The district might more fitly be termed the Summit Creek district, in view of its nearness to this stream.

Along this route, over which a government road is now being constructed, there is a singular absence of rock exposures. Outcrops are plentiful only on the higher and more rugged mountain slopes. However, such information as could be gained shows that all the territory from Upper Trail Lake to Summit Creek is underlain by closely folded and sheared slates and graywackes. The strike of these rocks is about $\mathrm{N} .10^{\circ} \mathrm{E}$., or about parallel to the axis of the Quartz Creek valley. The dips are high. The whole district, with the possible exception of the highest peaks, has been glaciated.

At the time this region was visited (July, 1909) the property of Gilpatrick, Sprague, and Byers, locally known as the John C. Gilpatrick claims, was the most extensively developed in the district. Upon this property are five cuts or test pits, the principal one of which is a shallow cut across the main lead on the south side of the crest of the divide between Slate and Summit ereeks. This opening shows 6 feet of auriferous quartz west of $10 \frac{1}{2}$ feet of fine-grained greenish-gray rock. The country rock is slate and graywacke. The quartz is iron stained and shows small quantities of native gold, galena, pyrite, and arsenopyrite. A gold telluride (sylvanite or calaverite) is probably also present, but no decisive test for tellurium could be made. Mr. Gilpatrick, however, has roasted some of this quartz and says that there is good evidence of the presence of a telluride.

The greenish-tinted rock noted above is a dike along which is the quartz vein. At this cut the dike rock is in direct contact with the

a Atwood, W. W., Mineral resources of southwestern Alaska: Bull. U. S. Geol. Survey No. 379, 1909, pp. 147-148. 
graywacke on the east side, but no metamorphic action on the sediments was noticeable. A microscopic examination of this dike rock shows that it is a fine-grained aggregate of plagioclase, quartz, mica, and probably orthoclase, with scattered crystals of arsenopyrite. The mica is the result of the alteration of the feldspars and is of a very light-green color, which gives this tint to the rock. Veinlets of coarsergrained fresher acidic plagioclase (soda-lime feldspar) traverse the rock in irregular directions.

Two other openings on this vein and dike are to the south of this one, toward Slate Creek. Lining up these cuts gives the strike of the vein and dike as $\mathrm{N} .15^{\circ} \mathrm{W}$. magnetic, or $\mathrm{N} .10^{\circ} \mathrm{E}$. true. On the nose and about 150 feet below the top of the ridge between Slate and Summit creeks Mr. Gilpatrick has uncovered a 16-inch vein of quartz in slate which pans free gold in considerable amount. Just over the crest of the ridge on the north side, a short distance east of the line of strike of the main vein, is another cut on a quartz vein. This vein is 40 inches wide in sheared graywacke and strikes N. $60^{\circ} \mathrm{W}$, magnetic, dipping about vertically. The quartz of this vein shows free gold very plainly to the eye, also galena and arsenopyrite. Mr. Gilpatrick thinks that these two quartz exposures are on the same vein, which is an offshoot from the main lead. The smaller vein is about on the strike of the larger one.

South of the property across Slate Creek and on the strike of the main vein William Fairman and John C. Madsen have staked several claims and opened two cuts on the vein. David Gaydon has done some work on the same vein on claims adjoining Fairman and Madsen's on the south. Specimens from these two properties shown by Gaydon and Madsen are of the light grayish green dike rock and quartz containing galena, arsenopyrite, and possibly a telluride. A small cut has been opened on the vein near the crest of the first mountain north of Summit Creek. Mr. Gilpatrick reported that native gold was found at that place. Mr. Gaydon and Bert Higgins reported that this vein had been traced north across the mountains on approximately the same strike to Pass Creek, distant about 6 miles from Summit Creek.

About $1 \frac{1}{2}$ miles down Quartz Creek from the Moose Pass trail Fairman and Madsen have opened a considerable placer prospect in the gravels of the flood plain of Quartz Creek. Hand sluicing little more than "makes wages," they say, but the ground might pay well with proper machinery for washing the gravel and for handling the bowlders. The many terraces in this district have never been prospected. At two or three points below the prospect these men have discovered small quartz veins which carry gold in graywacke and slate. No assays of these veins are at hand. 


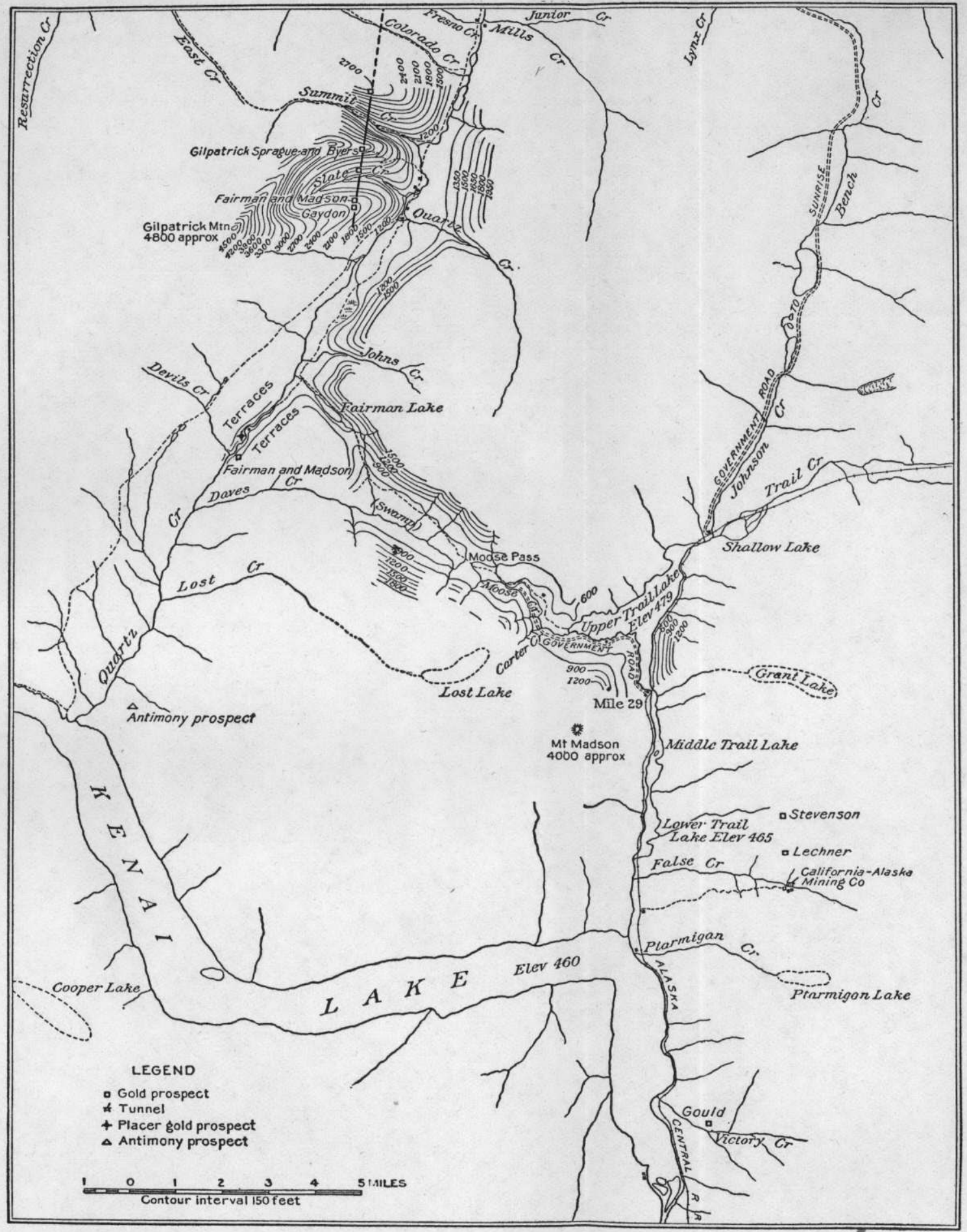

MOOSE PASS AND FALSE CREEK GOLD DISTRICT, KENAI PENINSULA. 



\section{KENAI I.AKE.}

The California-Alaska Mining Company is developing a gold property, known locally as the Skee and Lechner claims, on False Creek, 4 miles east of the south end of the southermost of the Trail Lakes. (See Pl. IV.) The country rock here is slate and graywacke, highly folded. The vein which is being worked is 1 to 4 feet thick, strikes N. $57^{\circ} \mathrm{E}$., and is vertical. The vein material is white quartz, carrying a little arsenopyrite, galena, native gold, and minute quantities of other metallic minerals. Telluride of gold has been reported from this vein, but tests made on the material collected here failed to show any telluride. The vein is crossed by a 12-foot zone of rusty rock in which is arsenopyrite, and the same mineral occurs in small crystals in the country rock immediately adjoining the vein. This locality is about 1,600 feet above sea level. The development work consists of a tunnel 75 feet in length, with two winzes 12 and 40 feet in depth and several strippings. Two arrastres, each 12 feet in diameter, are being installed and were nearly finished at the time of visit, July 16. A Ford rock crusher and an air compressor are also in course of transit from the railroad to the camp. The machinery is to be run by water power from False Creek, which flows past the mouth of the tunnel. It is said that 40 tons of ore, running about $\$ 35$ a ton in gold, has been shipped from this place.

Just north of the property of the California-Alaska Mining Company and about 1,100 feet higher, John Lechner has a prospect which, as far as uncovered, shows a quartz vein 1 to 4 feet in width, striking N. $48^{\circ} \mathrm{W}$. and dipping $65^{\circ} \mathrm{NE}$. This vein contains a little arsenopyrite, galena, and native gold.

About a mile still farther north, on the northern slope of the same mountain, C. E. and $J$. W. Stephenson have some claims. About a mile east of Kenai Lake and near Victory Creek some claims have been staked by A. C. Gould. Both of these groups of claims are reported to be on quartz veins, similar to those described above, cutting slates and graywackes.

\section{TWO ARM BAY.}

On the east side of the east arm of Two Arm Bay there are a few small quartz veins in the graywacke and slate, and in one place there is a zone 4 to 8 feet wide of fractured rock, the fractures being filled by quartz. J. J. Bettels reports that an assay from one of these veins showed no gold. Near the head of this arm of the bay are a few granite dikes cutting the graywacke and slate, and Mr. Bettels reports that an assay across one of these dikes gave $\$ 1.80$ in gold.

On the mountain at the head of the west arm of Two Arm Bay John Kusturin and Gus Johanson have staked nine claims on three 
quartz veins which are reported to be similar veins from 2 to 6 feet in thickness. One of these (No. 14 on PI. III), on the southern flank of the mountain, was examined. The vein strikes $\mathrm{N} .27^{\circ} \mathrm{E}$. and dips $40^{\circ} \mathrm{W}$. This vein is 71 inches thick, the upper 27 inches being quartz and rock, while the rest of the vein is practically all quartz carrying small quantities of pyrite, chalcopyrite, and graphite. Iittle work; except for some small strippings, has been done on these prospects.

\section{NUKA BAY.}

On Nuka Bay Daniel Morris, James Sheridan, George W. Kuppler, and John II. Lee have staked claims at three points. One is on the flat at the west side of the front of McCarty Glacier (No. 15 on Pl. III), at the head of the eastern arm of Nuka Bay. Here are a number of pieces, the largest 5 feet in diameter, of "float" quartz carrying chalcopyrite, but no vein has been found in place. Another point is near the center of the west side of the central or northern arm of Nuka Bay. Here the slates and graywackes are cut by three dikes of very fine-grained granite. The dikes strike N. $35^{\circ} \mathrm{W}$. and dip $80^{\circ} \mathrm{S}$. They are, from north to south, 8,25 , and 35 feet in width. The granite is rusty weathering and contains disseminated pyrrhotite and pyrite.

A broken quartz vein in slates has been uncovered by the men named above near the south point of the first ridge west of the west side of McCarty Glacier. The prospect is about 300 yards from the ice as it was in July, 1909. The vein is 4 to 5 feet wide, striking with the schistosity of the surrounding rock, about north and south, and dipping steeply west. Numerous bands of shattered quartz and partings of slaty and chloritic material are in the vein, indicating deformation of the rock since the vein was formed. Small amounts of pyrite and considerable rusty stain may be seen at the surface, but the vein was opened for only 2 or 3 feet.

\section{PORT DICK.}

North of the head of the western arm of Port Dick there has been considerable prospecting for gold in the last few years. Much of this work was undertaken by the Alaska Commercial Company and later by the Port Dick Mining and Power Company. The former company did most of its work in 1899 and the latter from 1904 to 1907. The work done is about three-fourths of a mile north of tide water and from 200 to 1,200 feet above the sea (No. 17 on Pl. III). Five mules, left here in the fall of 1907 , have passed two winters without care or protection, except for the shelter of a barn, and were in good condition in August, 1909.

The country rocks about the head of the west arm of Port Dick are slates, graywackes, flints, tuffs, and greenstones. Acidic dikes, 
mainly of fine-grained biotite granite, are common, especially on the north side of the arm, where the country rock is largely graywacke, considerably recrystallized. The veins prospected are in the main nearly vertical quartz veins, which cut both the granite and the graywacke. The prospects examined are described below.

Some 200 feet above tide, on the east side of the stream which flows southwestward and enters the west end of the west arm of Port Dick, is a tunnel 140 feet in length. This is along a vein which strikes N. $54^{\circ}$ W. and $\operatorname{dips} 75^{\circ}$ to $85^{\circ} \mathrm{N}$. The wall rock is hardened graywacke. The vein is 6 to 20 inches in width and has veinlets parallel to the main vein, so that there is a maximum thickness of 24 inches of quartz, the average being about 15 inches. In the quartz of the vein is a large amount of arsenopyrite and small amounts of chalcopyrite and pyrite. The arsenopyrite and quartz are arranged so as to give the vein a distinctly banded structure, and in places there are thicknesses of 1 to 3 inches of this sulphide.

Some 300 feet higher than the last and about 500 feet to the south is another tunnel 310 feet long. This is along a quartz vein which varies in direction, but has a general strike of $\mathrm{N} .64^{\circ} \mathrm{W}$. and a dip of $75^{\circ} \mathrm{N}$. to $80^{\circ} \mathrm{S}$. This vein branches a little, but in general is a welldefined vein 12 to 40 inches thick, averaging 24 inches. It is very similar to the one described above, but has a little less arsenopyrite, carries a little pyrrhotite and sphalerite, and has small fractures filled by calcite. The wall rock is a fine-grained biotite granite.

One-third of a mile farther south and 300 feet still higher is another vein, 6 to 12 inches thick, carrying pyrrhotite and chalcopyrite. The strike is $\mathrm{N} .69^{\circ} \mathrm{W}$. and the dip $83^{\circ} \mathrm{S}$. The wall rock is fine-grained biotite granite.

Farther south and about 1,200 feet above tide is a tunnel 240 feet in length, running N. $61^{\circ} \mathrm{E}$. The rock cut is granite and hardened graywacke. At 25 feet from the breast this tunnel cuts a quartz vein 6 to 12 inches thick. This vein strikes N. $59^{\circ} \mathrm{W}$. and dips $80^{\circ} \mathrm{N}$. and has been followed 65 feet in a branch tunnel. Aside from quartz this vein contains arsenopyrite, chalcopyrite, and pyrite.

At the water's edge on the north side of the western arm of Port Dick, near the supply house, the flints have been irregularly fractured and partly impregnated by pyrrhotite and chalcopyrite. A similar phenomenon occurs about 4 miles to the east (No. 16 on Pl. III), also at the water's edge and on the north side of the arm. A small amount of excaration has been done at each of these localities.

\section{WINDY BAY.}

About $2 \frac{1}{2}$ miles north of the west end of the western arm of Windy Bay Sanford J. Mills and A. J. Trimble have done some prospecting on several quartz veins which contain arsenopyrite, chalcopyrite, and 
pyrite (No. 18 on Pl. III). These can frequently be recognized at some distance by the brownish gossan which has developed on their outcrops. These veins are reported to contain gold, silver, copper, and nickel. Those examined by us were about a foot in width and contained the minerals noted above. The country rocks are graywackes, flints, limestones, tuffs, and greenstones cut by acidic dikes. In one place there is a zone 30 to 50 feet in width, made up of reddish decaying acidic dike rock which has been much fractured by recent movements and which contains some quartz veinlets. This zone has a general north-south direction and dips $60^{\circ}$ to $70^{\circ} \mathrm{W}$. Along both sides of the zone the rock is decayed to a limonitic clay. Several small openings have been made in this zone, especially on its sides.

\section{PORT CHATHAM.}

About the head of Port Chatham some prospecting has been done, mainly by Thomas Rock (No. 19 on Pl. III). The country rocks here are flints, tuffs, and graywackes, cut by granitic dikes. About 2 miles east of the head of the northeasterly arm of Port Chatham, on the south side of the main valley and some 450 feet above tide water, the contact between graywacke and a fine-grained biotite granite dike has been uncovered. The dike rock is decayed and has been fractured, the fractures being healed by quartz veinlets. Along the actual contact is a clay selvage one-half inch in thickness. About a fourth of a mile northeast of this prospect and 150 feet higher is an opening, 10 feet long, on a quartz vein' which is 22 to 28 inches in width. The vein strikes $\mathrm{N}: 19^{\circ} \mathrm{W}$. and dips $60^{\circ} \mathrm{N}$.; it carries arsenopyrite, chalcopyrite, pyrrhotite, and a little sphalerite. The country rock is a hardened graywacke. Higher up the hill to the south what appears to be the same vein has been uncovered in two places, where the width is 36 and 44 inches. Here the vein cuts a fine-grained granitic dike rock.

About a mile southwest of Cone Mountain, on the west wall of a cirque which contains a small lake, are some rusty zones crossing the tuffs and flints. A little work, at an altitude of about 2,000 feet, has been done on one of these zones which is 5 feet thick. These zones are fractured parts of the rock, the fractures being healed by quartz and calcite and minor quantities of sulphides.

On the coast between Port Chatham and Port Graham, about 3 miles south of Flat Islets, is a marked brown-weathering zone in tuffs, which are impregnated by pyrite. This zone is irregular and in places is 15 feet wide. No work has been done here.

PORT GRAHAM.

On Port Graham very little prospecting has been done, though a few claims have been staked. One of these is a few rods south of the steamboat wharf, one is on the north shore of the port near its 
east end, and another is in a gulch about 3 miles directly east of the wharf and a mile or more from tide water. The last two claims (No. 21 on Pl. III) are owned by J. W. Alley, and are located on rustyweathering fractured areas in the country rock (cherts). The fractures are filled by quartz veinlets. An assay from one of these localities is said to have shown $\$ 6$ to the ton in gold.

\section{SUMMARY.}

The prospects along the coast of the southern part of Kenai Peninsula are in quartz veins of rather moderate size, so far as known. They contain arsenopyrite and chalcopyrite, locally with small amounts of pyrite, pyrrhotite, and sphalerite. These veins are very similar to a quartz-arsenopyrite vein found on the western part of Prince William Sound, which carries good values in gold. ${ }^{a}$ Samples were taken across several of these quartz veins in the southern part of Kenai Peninsula, care being taken to get average samples of the most promising and most typical veins. The results of these assays are given in the accompanying table, Nos. 1 to 4 being from clearly defined quartz veins and Nos. 5 to 8 being from brecciated mineralized zones. The results of these assays, especially when the small size of the veins is taken into consideration, is not encouraging. There is still, however, the possibility that larger and richer veins may occur in this coast district.

The gold prospects in the Moose Pass and Kenai Lake districts are in quartz veins cutting the graywackes and slates of the Sunrise "series" of rocks. At Moose Pass one vein lies between these sediments and a fine-grained acidic dike rock. Average samples across some of the veins in these districts were collected and assays were made from these samples. The results of these assays are shown in Nos. 9 to 12 of the accompanying table. No. 13 is from the acidic dike rock mentioned above.

Assays of gold-bearing veins in Kenai Peninsula.

By W. H. Coghill and D. F. Higgins.]

\begin{tabular}{|c|c|c|c|}
\hline & $\begin{array}{c}\text { Ounces of } \\
\text { gold per } \\
\text { ton. }\end{array}$ & $\begin{array}{l}\text { Ounces of } \\
\text { silver per } \\
\text { ton. }\end{array}$ & $\begin{array}{l}\text { Value per } \\
\text { ton.b }\end{array}$ \\
\hline 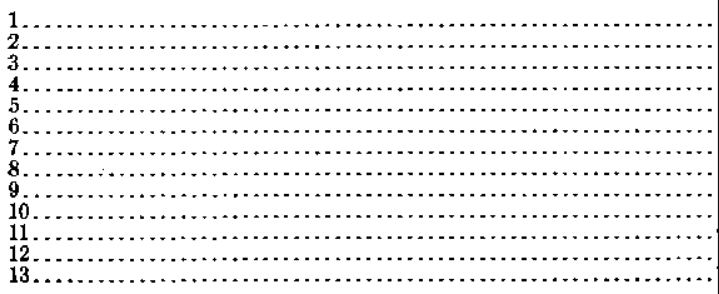 & $\begin{array}{r}0.04 \\
.06 \\
.12 \\
.04 \\
.02 \\
.08 \\
.02 \\
.06 \\
.70 \\
2.44 \\
2.74 \\
.38 \\
.02\end{array}$ & $\begin{array}{r}\text { Trace. } \\
0.94 \\
\text { Trace. } \\
.76 \\
\text { Trace. } \\
\text { Trace. } \\
\text { Trace. } \\
1.14 \\
1.10 \\
.56 \\
.66 \\
.62 \\
\text { Trace. }\end{array}$ & $\begin{array}{r}\$ 0.82 \\
1.71 \\
2.48 \\
1.20 \\
.41 \\
1.65 \\
.41 \\
1.84 \\
15.02 \\
50.71 \\
56.97 \\
8.16 \\
.50\end{array}$ \\
\hline
\end{tabular}

a Grant, U. S., Gold on Prince William Sound: Bull. U. S. Geol. Survey No. 379, 1909, p. 97.

b Gold at \$20.67 per ounce; silver at $\$ 0.50$ per ounce.

$55695^{\circ}$ \%-Bull. 442-10-12 
Assays much higher in gold than those here given have been reported, and many samples show considerable free gold. It should be noted, however, that single assays of samples of free-milling gold ore do not always give accurate information concerning the average gold content of a vein. The average content can be determined by a considerable series of assays of samples taken across the vein at different points. The work thus far done on the prospects in the Moose Pass and Kenai Lake districts and the assays which have been made show the presence of gold ore of sufficient richness for economic mining. The extent of these gold-bearing veins and the tonnage which is available have not been ascertained. Sufficient is known, however, to encourage careful and systematic prospecting of the veins described and also to encourage a search for similar veins in the same general district.

\section{SILVER.}

No silver prospects have been reported from the southern part of Kenai Peninsula. Such silver as is known is found in connection with gold, and assays from the gold prospects show silver running up to 1.14 ounces to the ton of ore. It is probable that small amounts of silver occur in the copper ores, but no assays of these ores are available.

\section{ANTIMONY.}

John Lyengholm, Isaac Hargood, and Lars Larson report an antimony prospect near Kenai Lake north of Seward. The prospect is about three-fourths of a mile from that lake and about 1 mile east of Quartz Creek. (See Pl. IV.) The country rock is slate cut by a dike 6 to 8 feet thick. The specimens shown us from this prospect are of a fine-grained sheared gray acidic rock in which are stringers and disseminated particles of stibnite (sulphide of antimony).

\section{COAL.}

The coal fields of the Kachemak Bay region have been described by Stone ${ }^{a}$ and later by Atwood. ${ }^{b}$ Little development work has been done on the coal (lignite) of this region, except at Port Graham, since the report by Stone. During the summer of $1909 \mathrm{~J}$. W. Whorf mined coal from the north shore of Port Graham just east of Cape Danger (No. 22 on Pl. III). From this place coal was obtained for local use and for some of the steamboats plying these waters, and shipments were made to Seward and to Prince William Sound ports. The coal was taken from a shallow shaft, from a tunnel, and from cuts made in the beach below the high-tide mark. At the time of visit the shaft and tunnel were closed and little information was obtained additional to that given by Stone. ${ }^{c}$ Aside from this work at Port Graham we did not learn of any work having been done on the coals on the east side of Cook Inlet in 1909.

a Stone, R. W., Coal fields of the Kachemak Bay region: Bull. U. S. Geol. Survey No. 277, 1906, pp. 53-73.

b Atwood, W. W., Bull. U. S. Geol. Survey No. 379, 1909, pp. 121-124.

c Op. cit., pp. 66-68. 


\title{
OUTLINE OF THE GEOLOGY AND MINERAL RESOURCES OF THE ILIAMNA AND CLARK LAKES REGION.
}

\author{
By G. C. Martin and F. J. Katz.
}

\section{INTRODUCTION.}

LOCATION.

The region described in this report covers an area of about 4,900 square miles, situated in southwestern Alaska, west of the southern half of Cook Inlet and north of the Alaska Peninsula. It comprises the greater part of the drainage basin of Kvichak River, which is the outlet of Iliamna and Clark lakes, and of the streams flowing into Cook Inlet from the west, south of and including Tuxedni Bay. It lies between the parallels of $59^{\circ}$ and $60^{\circ} 30^{\prime}$ north latitude and the meridians of $152^{\circ} 30^{\prime}$ and $157^{\circ}$ west longitude.

\section{GEOGRAPHIC FEATURES.}

Most of the northeastern part of this region lies within the Chigmit Mountains and consists of high, rugged mountain masses with narrow intervening valleys. The general elevation of these mountains is from 4,000 to 6,000 feet, although many peaks near the north end of Clark Lake are 7,000 feet high, and the highest peak of the whole district is Mount Iliamna, between 9,000 and 10,000 feet.

At Iliamna Bay the mountains extend eastward to the waters of Cook Inlet. Both north and south of this point a belt of foothills and lowlands from 2 to 10 miles in width reaches from the edge of the high mountains to the shore of the inlet. Much of the coast is deeply embayed, Tuxedni Bay, Iniskin Bay, and Iliamna Bay extending into the high mountains, while the other bays have their heads in the foothill belt. Iliamna and Bear bays head at well-known low passes through the mountains, and there are reported to be passable routes through the mountains from Tuxedni Bay and the southwest arm of Kamishak Bay.

The western part of the region lies in the valleys of the lower ends of Iliamna and Clark lakes and consists of broad gravel-covered flats with numerous isolated hills and groups of hills distributed irregularly through them. At the west end of Mliamna Lake the 
valley opens out into the wide coastal plain of Bering Sea. A broad, low pass at the head of Chulitna River leads into the Mulchanna Valley, which is a region of flats and low rounded hills.

Iliamna Lake lies in the south-central part of the region. It is about 80 miles long and in general from 8 to 20 miles wide. It is about 50 feet above tide and drains through Kvichak River into Bristol Bay. Lake Clark, in the northern part of the region, is about 52 miles long and from 1 to 4 miles wide. It is about 220 feet above tide and is tributary to Iliamna Lake through Sixmile Lake and Newhalen River. Kontrashibuna Lake, tributary to Lake Clark from the east through the river of the same name, ${ }^{a}$ is at an elevation of about 560 feet above tide. Upper and Lower Tazimina lakes, which are about 650 feet above tide, drain through Tazimina River into Sixmile Lake. Meadow and Moose lakes lie at an elevation of about 600 feet above tide, on the headwaters of Copper River, which flows into Iliamna Lake at the head of Intricate Bay. Kakonak Lake, about 260 feet above tide, drains through Kakonak River into Iliamna Lake at the head of Kakonak Bay. Hundreds of smaller lakes are distributed over the whole western part of the region.

The largest stream of this region is Kvichak River, which flows from Iliamna Lake into Bristol Bay. Its length from the outlet of the lake to Koggiung is about 62 miles. In the upper half of its course it has a current of 3 to 6 miles an hour. The lower half of its course is tidal, the water being of considerable depth even at low tide. The river is navigated by cannery steamers for about 22 miles above Koggiung, and by launches and Columbia River boats (when favored by strong west winds) for its entire length.

Newhalen River, the second stream of the area in size, has about half the volume of the Kvichak and is about 23 miles in length. For the upper 11 miles of its course it can be navigated by canoes and poling boats. Rapids and reported falls make even canoe navigation impossible for the lower 12 miles. These rapids are avoided by a 5 -mile portage.

\section{CLIMATE AND VEGETATION.}

This region has abundant precipitation, though not as much as the ocean coast. The early summer months are frequently favored with long intervals of clear weather. Similar conditions are said to exist also during part of the winter. It was noticed during the summer of 1909 that cloudiness and precipitation were much greater in the high mountains at the upper ends of Iliamna and Clark lakes and in the Aleutian Range than in the broad valleys of the lower ends of the lakes. In the summers of 1903 and 1904 cloudiness and rain 
were far less at the head of Kamishak Bay than on the mountainous parts of the coast both north and south of that point.

This region is also believed to have a colder winter and a warmer summer temperature than the open coast, in this respect also being intermediate between the coast and the interior.

Iliamna Lake is usually frozen from late in December till late in May. The snow usually leaves the low ground between April 1 and May 1, remaining in the pass between Iliamna Bay and Iliamna village till June. Some snow may be expected in September, but the ground is not permanently covered at low altitudes till several months later. Winter temperatures range from $40^{\circ}$ to $-30^{\circ} \mathrm{F}$.

Spruce forests extend throughout the lowland areas north of Iniskin Bay, in the valley of Lake Clark, and along the shores of Iliamna Lake east of longitude $155^{\circ} \mathrm{W}$. The south shore of Iliamna Lake between longitude $115^{\circ} \mathrm{W}$. and the outlet of the lake and most of the Kvichak Valley has only small scattered areas of spruce. Birch is practically coextensive with the spruce, except possibly on Cook Inlet. The north shore of Iliamna Iake between Newhalen and Kvichak rivers has no trees except cottonwoods. The same condition exists on the west coast of Cook Inlet south of Iniskin Bay and over the greater part of the Alaska Peninsula.

Throughout the region the higher lands, above an elevation of 800 to 1,200 feet, are bare of all vegetation, except moss, grass, and small bushes.

The spruce forests mentioned above contain good timber only locally. They are everywhere interspersed with open grassy meadows, bare ridges and hilltops, treeless swamps, and patches of alders and willows. Much of the spruce is, moreover, very small and is worthless, save for firewood. None of the forest is commercially timber land. The best of it would supply good lumber for barely more than the slight present local needs. The supply of material suitable for mine timber is, however, probably adequate to any local demands that are likely to arise.

A rank growth of grass is present in all parts of the region, especially where the timber has been burned. Abundant horse feed can be found throughout the greater part of the region from about June 1 to October 1 .

Large areas of "reindeer moss" are present throughout most of the region, the low hills south of Iliamna Lake having an especial abundance of it.

\section{SETTLEMENTS AND TRANSPORTATION ROUTES.}

The largest settlement and the chief trading point for this entire region is Iliamna village, situated on Iliamna River, 4 miles above its mouth and 12 miles from Iliamna Bay. This village has a United 
States commissioner, a government school, and three stores. A government reindeer station has been located at the head of Kakonak Bay since the spring of 1905 . The other villages, which are inhabited permanently only by natives, include Kakonak, on the south shore of Iliamna Lake, 12 miles west of the head of Kakonak Bay; Newhalen, near the mouth of Newhalen River; Nondalton, on the west shore of Sixmile Lake, and Kaskanak, on Kvichak River, about 10 miles below Iliamna Lake. There are several cabins belonging to prospectors and traders at Iliamna and Cottonwood bays, but these are occupied only when a steamer is expected or when freight is being moved from the coast. Numerous prospectors' camps and cabins are scattered throughout the district.

There are two well-traveled routes into this region-one from the east by way of Iliamna Bay and the other from the west by way of Koggiung. The steamers from Seattle to Prince William Sound and Cook Inlet, and also the local steamers from Valdez westward and from Seldovia and Port Graham to the upper Cook Inlet ports, will land at Iliamna Bay whenever weather permits and sufficient business warrants it. Iliamna Bay is about one day's sail from Seward or six to twelve days from Seattle. A boat usually calls about once a month from May to October, inclusive, and occasionally during the winter.

A good horse trail leads from the head of Iliamna Bay to Iliamna village, a distance of about 12 miles. This trail crosses a 900 -foot summit 3 miles west of Iliamna Bay. Another trail leads from the head of Cottonwood Bay to Iliamna village, a distance of about 20 miles, crossing three summits at elevations of about $1,700,1,500$, and 1,975 feet, at distances of $4,5 \frac{1}{2}$, and 15 miles from Cottonwood Bay, descending to 1,400 and 600 feet between the summits. A good wagon road has been built for the first 2 miles and from the fifth to the fourteenth mile, or as far as the Dutton copper prospects. These trails can generally be used by horses from June 1 to November 1 . Dogs are used during the rest of the year.

From Iliamna village all parts of Iliamna Lake and Kvichak River can be reached in boats, there being several large sailboats and a gasoline launch at the village. Horses can also be taken from Iliamna village throughout the greater part of the region, except in the high mountains. The shores of Clark Lake are impassable for horses east of longitude $154^{\circ} \mathrm{W}$.

Bristol Bay is visited by cannery vessels about May 1 and by a passenger steamer from Valdez once a month in June, July, August, and September. Part of the supplies for the stores at Iliamna village are brought in by this route, which has the advantage of being all water and avoiding the portage from Iliamna Bay to the village. 
Iliamna Lake can also be reached by a portage from the head of Kamishak Bay to the head of Kakonak Bay. This route is said to be an easy one, the pass being low. It is, however, not much used except by natives, because of the difficulty of having supplies landed on this uncharted part of the coast.

Many of the supplies for Lake Clark and the Mulchatna country west of it are taken in from Iliamna village by dogs in the winter. Summer transportation to Lake Clark may be accomplished either with horses or by boats to a point on the shore of Iliamna Lake 4 miles east of Newhalen River, thence by a 5-mile portage to Newhalen River above the lower rapids, and thence by boat up to Newhalen. Native packers are usually available at this portage.

The Mulchatna country can be reached from Lake Clark by boats up Chulitna River to a short portage at the head of Swan River or up Chulitna and Koksetna rivers to a point near the headwaters of the higher eastern tributaries of the Mulchatna. Horses could also be used in this district.

Prospecting has been carried on in a small way over the greater part of this region and in the adjacent Mulchatna region since 1898. The most active operations were from 1903 to 1906 and will be described at length under the heading "Mineral resources."

\section{GEOLOGY.}

\section{GENERAL FEATURES.}

The region here described covers the south end and parts of the east and west sides of the Chigmit Mountains, the north end of the Aleutian Range, an intermediate region lying between these two ranges, and parts of the Cook Inlet and Bristol Bay regions on the east and west sides. It consequently includes parts of several geographic and geologic subprovinces, the general features of which will be briefly reviewed. The geologic subprovinces which this area includes, or into which it extends, are the Cook Inlet basin on the east, the Chigmit Mountains west of it, the Alaska Peninsula in the southern part, the Bering Sea coastal plain in the western part, and the Iliamna Basin in a central position between the last three. (See Pl. V.)

\section{DESCRIPTION OF THE ROCKS.}

GENERAJ, SEQUENCE.

The rocks of this region include a great variety of sedimentary, metamorphic, intrusive, and volcanic types. At no locality is there a geologic section showing the complete stratigraphic sequence. The complex structure and the general absence of fossils throughout all 
but the eastern part of the area make correlation and the establishment of a complete geologic section rather difficult and subject to doubt. The following table shows what is now believed to be the probable geologic sequence:

General section of rocks in the Iliamna and Clark lakes region.

\begin{tabular}{|c|c|c|}
\hline Age. & Lithologic character. & Areal distribution. \\
\hline Quaternary. & $\begin{array}{l}\text { Beach and flood-plain deposits, terrace } \\
\text { gravels, and glacial till. }\end{array}$ & Entire region. \\
\hline \multirow{2}{*}{ Tertiary. } & $\begin{array}{l}\text { Basaltic flows and tuffs with some in- } \\
\text { terbedded sandstone. }\end{array}$ & Ilianna Lake. \\
\hline & Shale, sandstone, and conglomerate. & Cook Inlet. \\
\hline Upper Jurassic. & $\begin{array}{l}\text { Shale, sandstone, conglomerate, arkose, } \\
\text { and tuff, with interbedded andesitic } \\
\text { flows. }\end{array}$ & Cook Inlet. \\
\hline Middle Jurassic. & Sandstone, shale, and conglomerate. & Cook Inlet. \\
\hline $\begin{array}{l}\text { Middle or Lower Juras- } \\
\text { sic. }\end{array}$ & Granite, quartz diorite, etc. & Chigmit Mountains. \\
\hline Lower Jurassic or older. & $\begin{array}{l}\text { Rhyolitic and andesitic porphyries } \\
\text { and tuffs. }\end{array}$ & $\begin{array}{l}\text { Cook Inlet, Iliamna Lake, Clark Lake, } \\
\text { east of Clark Lake. }\end{array}$ \\
\hline Upper Triassie. & Chert, shale, and limestone. & Cook Inlet. \\
\hline \multirow{2}{*}{ Trjassic or older. } & Tuffaceous greenstones. & $\begin{array}{l}\text { Iliamna Bay, Pile Bay, Kakhonak Bay, } \\
\text { Clark Lake. }\end{array}$ \\
\hline & Limestone. & $\begin{array}{l}\text { Iljamna Lake, Iliamna Bay, south of } \\
\text { Iliamna village (?). }\end{array}$ \\
\hline Late Paleozoic. & Slate and chert. & $\begin{array}{l}\text { Iliamna Bay, Clark Lake, east of Clark } \\
\text { Lake. }\end{array}$ \\
\hline \multirow{2}{*}{ Paleozoic. } & Limestone and calcareous schist. & Clark Lake, south of Iliamna village (?). \\
\hline & $\begin{array}{l}\text { Gneiss, mica schist, and quartzite, with } \\
\text { some crystalline marble. }\end{array}$ & $\begin{array}{l}\text { West of Iliamna Bay, south of Iliamna } \\
\text { village, Clark Lake. }\end{array}$ \\
\hline
\end{tabular}

METAMORPHIC ROCKS.

GNEISS, SCHIST, AND QUARTZITE.

The oldest rocks of this region are metamorphosed sediments now appearing as gneisses, mica schists, quartzites, and crystalline limestone. These rocks occupy two districts, one being in the mountains between Iliamna and Pile bays and the other in the valley of Lake Clark from Kontrashibuna Lake northward to the mountains west of Tlikakila River. 


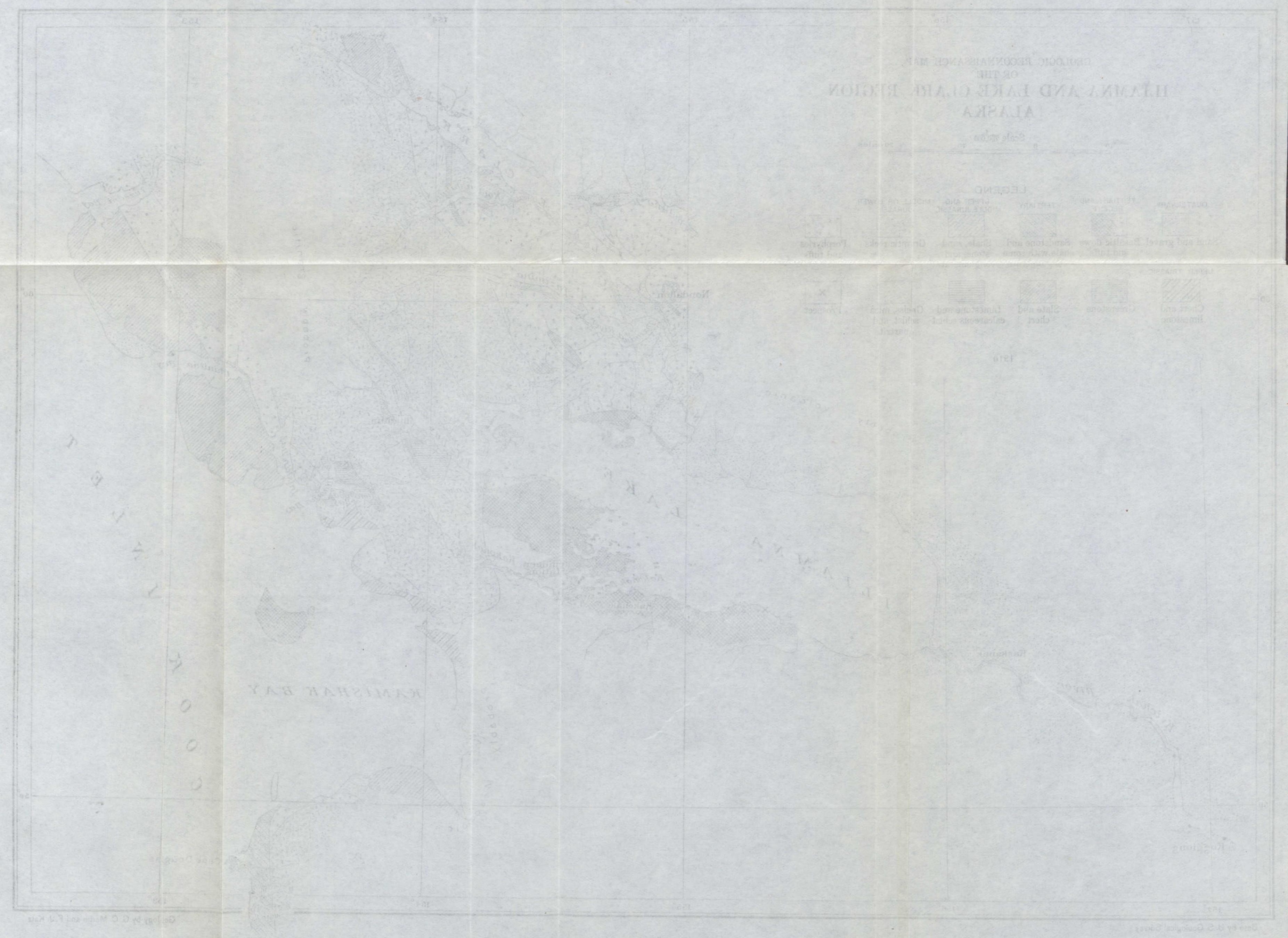


The rocks of the district west of Iliamna Bay include hornblende and biotite gneiss of moderately fine to coarse grain, coarse crystalline marble, quartzite, and mica and chlorite schists. The marble is known to occupy two small areas within the area of the gneiss, 2 miles west of Iliamna and Cottonwood bays, on the trails to Iliamna village. These may be lenses, but are believed to be small detached areas of a larger mass, having undetermined structural and stratigraphic relationships to the neighboring gneiss.

The metamorphic rocks of Lake Clark consist of quartzite, mica schist, calcareous schist, and crystalline limestone. These are believed to be separable into an older series of quartzite and mica schist and a younger series of ealcareous schists and limestones. The quartzite and schist occupy the mountain west of the lower half of Kontrashibuna Lake, being bounded on the east by limestone and on the west and south by much younger volcanic rocks. Another area of schist is on the northwest side of Lake Clark from 3 to 5 miles south of the mouth of Tlikakila River. This is believed to be continuous with the other area. This area apparently has limestone on each side of it, the probable relation being anticlinal structure and limestone overlying the schist.

The schist and quartzite of Lake Clark are, in the absence of evidence to the contrary, considered equivalent to the somewhat similar metamorphic rocks west of Iliamna Bay.

\section{LIMESTONE AND CALCAREOUS SCHIST.}

The limestone and calcareous schist which apparently overlie the mica schist and quartzite on Lake Clark have already been mentioned. These rocks have an apparent thickness of many hundred feet, but the complexity of folding is such that the actual thickness can not be determined. They are predominantly calcareous throughout, and pure limestone beds contribute to a large proportion of the thickness. Their separation from the presumably underlying siliceous rocks is made wholly on the basis of their calcareous character, neither unconformity nor difference in degree of metamorphism having been detected.

Another area of limestone, possibly much younger than that just described, appears on the north shore of Iliamna Lake about 3 miles west of Chekok River. This limestone differs from that on Lake Clark in not being associated with schists and in being much less metamorphosed. This is a fine-grained blue limestone with a considerable amount of bituminous matter. It has been much shattered and crushed, the fractures being healed by the deposition of fine-grained white calcite. Otherwise it has not been much altered, there having been little recrystallization of the noncrushed fragments except along 
the lodes and no observed development of secondary silicates. The areally associated rocks are masses of fine-grained basic igneous rocks on both the east and the west sides and unconformably overlying tuffaceous beds on the south.

The limestone of this locality is of especial interest and importance, because it has yielded most of the fossils which have been found in this area. This fauna consists chiefly of corals and indicates that the limestone is Triassic.

Another area of limestone extends from a locality near the northwest side of Meadow Lake northward to the valley of lliamna River. This limestone is bordered on the east by schists and on the west by altered basic igneous rocks. Several masses of schist occur within the limestone, but whether they are interbedded or were brought in by structural disturbances is not known. The latter origin is believed to be the more probable. This limestone is somewhat more altered than that on the north shore of Iliamna Lake, but decidedly less so than that on Lake Clark. In its relation to the schist it resembles the latter, although there is here a strong suggestion of greater alteration of the schist than of the limestone and presumably of an important time break between their dates of deposition.

On the south shore of Iliamna Bay, about halfway between the mouth of the bay and Cottonwood Bay, is a large mass of limestone, which is so complexly folded that no idea of its thickness may be obtained. It is white and blue, fine grained, much shattered, the fractures being healed with calcite, and very slightly altered, save by this crushing and healing. In all this it resembles the limestone on Iliamna Lake, as it does also in the presence of a coral fauna. The fauna is, however, meager and can not be definitely correlated with that from Iliamna Lake, although the suggrestion of identity from the combined lithologic similarity, degree of alteration, and presence of roughly similar corals is strong. The associated rocks are amygdaloidal basaltic tuffs of indeterminate relationship on the west side and younger granitic intrusive rocks on the east.

SLATE AND CHERT.

A belt of black slate, with a few thin beds of limestone and quartzite and possibly some schist or phyllite along the western margin, lies along the face of the mountains west of Cottonwood Bay. These beds are many hundred and possibly several thousand feet thick. Gneiss and schist border the slate on its west side and greenstone on its east side. The gneiss is overthrust or overfolded upon the slate, which in turn bears the same structural relationship to the greenstone.

Slates with much associated chert and aitered igneous rocks, and with several thin beds of limestone, were seen on either side of Lake 
Clark just above the mouth of Tlikakila River. These rocks differ from the slates of Cottonwood Bay in being less altered and in the presence of associated cherts and igneous rocks. A granite mass which is intrusive into the slate, lies east of it, while on the west also is granite upon which the slate is overthrust.

Cherts and slates were also seen at three localities within the area between Kontrashibuna Lake and Iliamna Lake. At each of these localities the rock consists of very fine grained black slates, argillites, or graywackes, and banded white, gray, and dark-colored cherts or very fine grained quartzitic rocks. The cleavage in the slates is only imperfectly developed. These rocks are all minutely crumpled and no evidence could be obtained as to their thickness and age. The adjacent rocks are all volcanic, and from their slight degree of alteration are evidently much younger than the slates, which they are believed to overlie uncomformably, burying them except in the areas noted above and probably in other small undetected areas.

\section{GREENSTONE.}

Altered volcanic rocks here grouped under the name greenstone occur at several places within this region. Considerable diversity of character exists among them, but they possess in common a number of features-the presence of original basic igneous material; such a degree of alteration that the original character of that material can not in general be determined; original banding or secondary schistosity, or both; and superficial similarity in color, texture, and general physical appearance.

A belt of these rocks extends across the heads of Iliamna and Cottonwood bays. The original material was here probably a finegrained basic volcanic rock including considerable tuff and chert. It now contains much secondary epidote and near the head of Iliamna Bay exhibits considerable schistosity, probably due to local shearing. These rocks are in contact with a belt of slates west of them which are evidently older, being more altered, but which are overthrust or overfolded upon them. The rock adjacent to the greenstone on the east is younger intrusive granite.

A large area of greenstone occupies the mountain between the mouth of Iliamna River and Meadow Lake. The original rock was in part diabase and diorite, although tuffaceous beds were recognized on the shore of Iliamna Lake and pyroxenite occurs near the crest of the mountain. The entire mass is now much altered through the development of secondary minerals but without notable schistosity. These rocks lie immediately west of a belt of limestone, evidently being younger than the limestone, though it is not known whether the contact represents uncomformity or intrusion. Granite is intrusive into the greenstone on the shore of Iliamna Lake. 
A small area of schistose amphibolite of indeterminate origin lies along the contact between granite and rhyolites near the mouth of Pile Bay. It is much more altered than any of the greenstones above described, being essentially a schist.

Somewhat similar green schist (probably chloritic schist) occurs on the south shore of Kakonak Bay near its head. The neighboring rocks are much younger altered volcanic rocks, which are believed to be unconformable above it and here locally cut through by erosion.

Schistose greenstone was also seen on the west shore of Lake Clark opposite the mouth of Currant Creek.

\section{UNALTERED MESOZOIC ROCKS.}

The shore of Cook Inlet from Tuxedni Bay to the head of Kamishak Bay, except at the heads of some of the deeper bays, is occupied by a thick series of unaltered Mesozoic sediments. These beds form a section with which the rocks of the Iliamna Lake region must be compared and in terms of which the age references must be in large part expressed. It is consequently important to describe this section somewhat in detail, although it lies largely outside the proper geographic limits of this paper.

\section{OPPER TRIASSIC CHERTS.}

The lowest known member of the unaltered Mesozoic sediments exposed on the west shore of Cook Inlet comprises a series of black, green, and dark-red chert with subordinate amounts of shale and limestone. These rocks are well exposed on Bear Cove and Bear Bay At the former place the thickness probably exceeds 2,000 feet, although the beds are so disturbed that no accurate measurement has been made. The shales and limestones at these localities carry Pseudomonotis subcircularis and Halobia superba, which show the age of the rocks to be Upper Triassic.

These beds extend northward in an apparently continuous belt from Bear Bay to the south shore of Cottonwood Bay, near its head. At this locality several hundred feet of chert is exposed in the cliffs just east of the low pass leading southward to Bear Cove.

In the lower part of the section at Bear Cove there are large amounts of fine-grained green igneous rock, intimately but obscurely associated with the chert. It is somewhat doubtful whether this rock is intrusive or interbedded. It is somewhat altered, especially in the development of epidote, and resembles in a way the greenstone at the head of Cottonwood Bay.

\section{LOWER JURASSIC (?) PORPHYRIES AND TUFFS.}

Overlying the chert on the south shore of Cottonwood Bay is a thick series of volcanic beds which includes both flows and tuffs. Amygdaloidal basalt and volcanic agglomerates are among the more 
characteristic rocks of this series. Similar rocks were seen on the north shore of Iliamna Bay, where they include fine-grained green and gray felsitic rocks and tuffs, in part cherty, invaded by large dikes of quartz-feldspar porphyry; and also on the south shore of Bear Cove where quartz porphyry tuff, andesite, and andesitic and rhyolitic agglomerates are present. The belt also extends northward from Iliamna Bay, being exposed on the west and north shores of Iniskin Bay, where basalt, gabbro, and tuff are present; near the head of Chinitna Bay, where it includes olivine basalt and tuff; and on the upper arm of Tuxedni Bay, where quartz porphyry, augite andesite tuff, and quartz porphyry tuff were seen.

These rocks accord fairly well in their relation with the Upper Triassic chert, as also in general lithologic character with the Lower Jurassic tuffs, which are exposed on Seldovia Bay and Port Graham. These beds were referred by Stanton to the Lower Jurassic on the basis of the fauna obtained at Seldovia.

No Lower Jurassic faunas have been found west of Cook Inlet, but the volcanic beds on the west shore of Cook Inlet, described above, and also those near Iliamna and Clark lakes, to be described later, may possibly be correlated with the Lower Jurassic rocks of Seldovia on the evidence of similar lithology and sequence.

The shore of Iliamna Iake from a point near the mouth of Pile Bay, 15 miles below the head of the lake, to a point 27 miles below the head of the lake, is composed of quartz latite and quartz latite tuff. The same rocks occur near the head of Kakonak Bay and along the south shore from 4 miles west to 7 miles west of Kakonak village and from 25 miles east to 19 miles east of the outlet of the lake. These rocks show considerable difference in lithologic character from the volcanic rocks already described as occurring on Iliamna Bay and elsewhere on the west coast of Cook Inlet. They appear, however, to correspond with those rocks in general relation to the neighboring rocks, although definite evidence of their age and relations is almost lacking. The same statements apply concerning their relation to the rocks described below.

Large areas around Lower Tazimina Lake and thence northward to Lake Clark are underlain by a group of rocks of porphyritic texture, ranging in composition from acidic rhyolites through quartz porphyries, trachytes, and mica andesites to intermediate hornblende andesites. Associated with these are tuffs, some composed of angular fragments of porphyry embedded in either a felsite or a porphyry base, or again in a fine fragmental base, and others composed chiefly of fine feldspar crystals and fragments in a finely comminuted base. The relation of these rocks to one another seems to be that of a succession of products of volcanic eruption: The various types, in so far as any structures are discernible, seem to lie in successive or 
alternating belts. This is particularly well shown on and near the mountain 8 miles north of the mouth of Chekok River, where a similar order of succession is encountered on the southeast and north sides. About 5 miles south of Tanalian Point there are porphyries distinctly interbedded with tuffs, the whole formation there having a minimum observed thickness of 2,000 feet, with a uniform strike of N. $65^{\circ} \mathrm{W}$. (magnetic) and a dip of $25^{\circ} \mathrm{NE}$. All these rocks are indurated but are internally undeformed and are altered only by weathering processes.

Fine-grained granular rocks occupy an area extending northward from the head of Lower Tazimina Lake for about 4 miles. These rocks are of very fine grain, of light color, locally with porphyritic texture, and in many places miarolitic. They show considerable variation in appearance and the distribution of the different types of rock suggests a series of thick flows in approximately horizontal position. These rocks should probably be considered part of the porphyry and tuff formation, rather than be grouped with the neighboring granites. They have about the same range in composition as the porphyries and tuffs and, though granitic, they are generally also fine-grained porphyritic and miarolitic in texture, indicating crystallization under slight pressures, perhaps of thick flows at the surface. They seem to have the same bedded-flow distribution as the porphyries and tuffs, which they adjoin directly on the north and west.

\section{MIDDLE JURASSIC BEDS.}

The lowest known member of the Middle Jurassic of southwestern Alaska consists of at least 1,100 feet of sandstone and shale with a few thin beds of conglomerate and limestone. These beds are well exposed on the south shore of Tuxedni and Chinitna bays and on the east shore of Iniskin Bay. Their abundant and characteristic fauna is regarded by Stanton as indicating that they include at least part of the Lower Oolite or Middle Jurassic. At Iniskin Bay they rest unconformably upon beds of greenish basalt. Beds of somewhat similar lithologic character and with the same fauna have been found in the upper end of the Matanuska Valley and in the Alaska Range.

These beds are overlain conformably by a higher but lithologically and faunally distinct member of the Middle Jurassic, consisting of 1,300 to 2,400 feet of shale with subordinate amounts of sandstone and limestone. These beds are typically exposed on the north shore of Chinitna Bay, and are also known in a continuous belt extending from that place parallel to the shore of Cook Inlet northward to Tuxedni Bay and southward to Iniskin Bay. Detailed sections at Chisik Island, Oil Bay, and Iniskin Bay on Cook Inlet and at Cold 
Bay on the Alaska Peninsula have been described. The rocks are also known to occur in the upper Matanuska Valley. These beds carry a characteristic marine fauna, marked by the presence of various species of Cadoceras and by other associated forms. It is regarded by Stanton as the equivalent of the Callovian, which belongs at the base of the Upper or at the top of the Middle Jurassic. These two members of the Middle Jurassic have previously been grouped as the Enochkin formation.

\section{UPPER JURASSIC BEDS.}

The Middle Jurassic shales just described are overlain on Chisik Island and on the east shore of Iniskin Bay by a varying thickness (probabily 100 to 300 feet) of predominantly coarse conglomerate consisting of pebbles of granite (more rarely other crystalline rocks) in an andesitic tuffaceous matrix. This bed is probably of very local development, not having been definitely recognized elsewhere in this region, except possibly on the east shore of Oil Bay. Its age is determined within approximate limits by the presence of Middle Jurassic faunas below it and of Upper Jurassic faunas above. In lithologic character (presence of andesitic tuffs) it is more nearly related to the rocks bearing the latter than to those bearing the former fauna, and hence it may be most reasonably interpreted as the basal conglomerate of the Upper Jurassic. A conglomerate of similar lithology, at about the same stratigraphic position, occurs in the upper Matanuska Valley.

The beds which overlie the conglomerate just described, or in its absence rest upon the uppermost shales of the Middle Jurassic, consist of about 5,000 feet of shale, sandstone, arkose, andesitic tuff, and conglomerate. Some andesitic flows are also probably present. These rocks are the equivalent of the Naknek formation of Spurr, the type locality of which is on the shores of Naknek Lake, Alaska Peninsula, where the beds on which the original description was based consist largely of granitic arkose and conglomerate. These beds extend from Naknek Lake over a broad area in the vicinity of Katmai, Cold Bay, and Becharof Lake, and also occupy the shore of Cook Inlet from Tuxedni Bay to Iniskin Bay and much of the shore from a point near the mouth of Iliamna Bay to the south shore of Kamishak Bay. They carry a marine fauna characterized by the presence of Aucella pallasi and Cardioceras, on the basis of which they have been correlated with beds in the Matanuska and Copper River valleys and on the west end of the Alaska Peninsula, and which show their relation with rocks carrying Upper Jurassic faunas in California, in the Black Hills, in Russia, and throughout the European boreal region. 
GRANITIC ROCKS.

Granitic rocks of considerable diversity of character, including granites of various kinds and quartz diorite, occupy the greater part of the area of the Chigmit Mountains from the head of Bear Bay northward beyond the head of Lake Clark and Tuxedni Bay. The rocks probably constitute one large, continuous area, with many smaller ones along its margins. Several of these were seen on Lake Clark. The margin of another mass was observed on the northern flank of Mount Douglas. This is probably the north end of a large mass in the Aleutian Range, which is in all probability widely detached areally from the Chigmit Mountain mass, although it is doubtless closely related in lithologic character and period of intrusion.

The granitic rocks are known to cut all the rocks described above, except the Upper and Middle Jurassic rocks of the coast of Cook Inlet. This relation, together with the presence in the Upper Jurassic and probably also Middle Jurassic conglomerates of pebbles of granitic rocks similar to these, points strongly to the late Lower Jurassic or early Middle Jurassic as the date of intrusion.

TERTIARY ROCKS.

SEDIMENTARY BEDS.

Shale, sandstone, and conglomerate of Tertiary age were observed in one small area on the north slope of Chinitna Bay and covering larger areas in the vicinity of Cape Douglas. The character of the exposures did not permit an estimate of the thickness of the beds in either district. Fragmentary fossil leaves were found, but neither they nor the character and sequence of the rocks are sufficient to warrant detailed correlation with the Tertiary (Kenai) beds so well exposed on the east coast of Cook Inlet. The recognized species all occur in the Kenai flora, and there is no doubt of the general equivalence.

\section{BASALTIC FLOWS AND TUFFS.}

Most of the shores of Iliamna Lake below the large islands at the mouth of Pile Bay, except those covered by sand and gravel, are made of basaltic rocks, including effusive sheets, tuffs, and probably some intrusive dikes and sills. A few thin beds of sandstone and shale were observed. These rocks cap all the high hills northeast of Intricate Bay, descending westward and reaching the lake shore just north of the end of the peninsula north of Intricate Bay. The basaltic rocks of this part of the area have a gentle westward dip, but are otherwise not folded. The islands of Intricate and Kakonak bays and the peninsula between them are likewise composed of basalt and basaltic tuffs, the basalt being prominently exposed in flat mesa caps where horizontal and in monoclinal strike ridges where steeply 
inclined. At most of the exposures the basalt shows the typical vertical columnar jointing characteristic of such sheets. Basaltic sheets also cap the high hills between Kakonak Bay and Kakonak Lake, many of the lower ridges being of conglomerate or conglomeratic tuff. The latter rock is also to be seen on some of the shores of Kakonak Bay. These basic volcanic rocks, with some interbedded conglomerate, form the greater part of the south shore of Iliamna Lake from Kakonak Bay to a point about 25 miles east of the outlet of the lake. A few small outcrops protrude through the sands and gravels at scattered localities from this place to the mouth of Newhalen River, from which to the cape at the west side of Chekok Bay the shores and islands are composed entirely of these rocks, except on the low beaches. Similar basalts and tuffs cap the high hills west of Newhalen River and Sixmile Lake. Basaltic masses, probably dikes or sills, occur at scattered points along the west shore of Lake Clark as far north as the head of Chulitna Bay.

Basalts, probably to be correlated with those already described, cap a group of high hills north of Chekok Bay and the low hill on the east side of Lake Clark, about 7 miles northeast of Tanalian Point.

These basaltic rocks are considered much younger than the rhyolitic and andesitic lavas and tuffs already described. They are mostly unconformable upon the more acidic volcanic rocks, though in part intrusive into them. The sandstones that are probably at the base of the basaltic rocks have yielded a few fossil plan's, which have been referred to the Tertiary.

Small porphyry dikes, which cut all the other rocks, were seen on the shores of Iliamna Bay. They are younger than the granite and possibly belong to the Tertiary period of intrusion.

\section{QUATERNARY DEPOSITS.}

The Quaternary deposits of this region include the flood-plain and delta deposits on the present streams; beach and lagoon deposits on the shores of Cook Inlet and of the lakes; terrace deposits, which are best developed around the lower ends of Iliamna and Clark lakes; a rather small amount of glacial till; and the lava and ash of the active volcanoes.

\section{MINERAL RESOURCES AND MINING DEVELOPMENT.}

\section{INTRODUCTION.}

During the last decade prospectors have located in this region lode claims of copper, silver, and gold, placer-gold claims, and petroleum claims. On some of these development work has been begun. One group of copper claims has been entered for patent. On many of the 
claims, however, not even bona fide "assessment work" has been done. In justice to the prospectors it should be said that the district's remoteness from usual lines of travel in Alaska, the earlier scarcity of supplies, and the unreliable transportation service have held back the development. Only brief descriptions of the claims visited in 1909 by the Survey party and of those about which reliable reports were obtained will be attempted here. Each claim or group of claims discussed is taken up in the order of geographic occurrence westward and northward from Iliamna Bay.

\section{LODES.}

\section{DESCRIPTION OF CLAIMS.}

Several lode claims have been staked on or near the shores of Iliamna Bay. One of these is on Diamond Point, near the entrance to Cottonwood Bay. The country rock is granite, locally intruded by small dikes of porphyry, with the contact of a large mass of greenstone several hundred feet away. The supposed ore body consists of a shattered and much weathered zone 4 to 12 feet wide on Iliamna Bay and apparently 100 feet or more wide on Cottonwood Bay, in which the granite is thoroughly erushed and impregnated with narrow veins and stringers of pyrite. No other sulphides were recognized and no authentic information could be procured concerning assay values, although it was rumored that $\$ 2$ a ton in gold had been obtained.

Other claims have been staked on the south shore of Iliamna Bay near its mouth. These claims were not examined, but the shore of the bay here is formed of limestone and igneous rocks, some of which were seen to be locally fractured and impregnated with pyrite.

The Keyes prospects are on the Copper Kingr group of claims, located by the late Charles M. Keyes in 1905. At the time they were visited by the Survey party snow covered much of the property, but two prospect holes were found on the Black Prince claim, about $1 \frac{1}{3}$ miles west of the head of Iliamma Bay and one-third mile south of the main trail to Iliamna village, at an elevation of 1,000 to 1,500 feet, near the contact of hornblende granite and greenstone. The surface exposures consisted of irregular, nonpersistent masses of garnet rock and crystalline limestone, the latter having a maximum observed thickness of about 20 feet. The garnet rock is cut by smaller veins of quartz and epidote. The ore body exposed in one of the prospect openings is magnetite impregnated with chalcopyrite. The other prospect opening was filled with snow.

The Dutton prospects are about $9_{5}^{3}$ miles west-northwest from the head of Cottonwood Bay, and 6 miles southwest of Iliamna village. A good 14-mile trail on easy grade, about three-fourths of which has 
been made into a wagon road, has been built from Cottonwood Bay to the prospects as a part of the development work on the property. The prospects are also reached by a steeper 6-mile trail from Iliamna village. The region is one of bold relief, and the neighboring mountain peaks rise abruptly from elevations near sea level to about 4,000 feet. The prospects lie along the flank of one of the higher peaks and extend from a point in a col on the Iliamna village trail, at an elevation of 1,900 feet, about $2 \frac{1}{2}$ miles southwestward to an elevation of approximately 1,200 feet.

The property was located in 1902 by George W. Dutton, Silas J. Goodro, and Pierce Thomas. It is controlled by the Dutton Mining Company, which conducted active development work during 1904 and 1905 and more or less desultory work since then. The property has been developed by the construction of 11 miles of wagon road and 3 miles of trail from Cottonwood Bay, two houses, two barns, and a blacksmith shop. Three short adits and a shallow shaft with 46 feet of drift, all of which were blocked at the time of the visit by the Survey party, and numerous surface cuts comprise the actual mining work. A considerable amount of mining machinery and building materials and equipment for a smelter lie scattered along the road all the way from Cottonwood Bay to the prospect. The claims have been surveyed and entered for patent, which, it is reported, the owners expected to procure in the winter of 1909-10.

The claims lie along the northwest side of a limestone belt. On the northwest are greenstones (probably altered diorites and more basic rocks), and on the east are quartzitic slates and gneisses. (See fig. 3.) The mineralized zone; averaging 200 feet in width and locally 300 feet, is partly in the greenstone, but chiefly in the limestone, and contains chalcopyrite, pyrite, garnet,

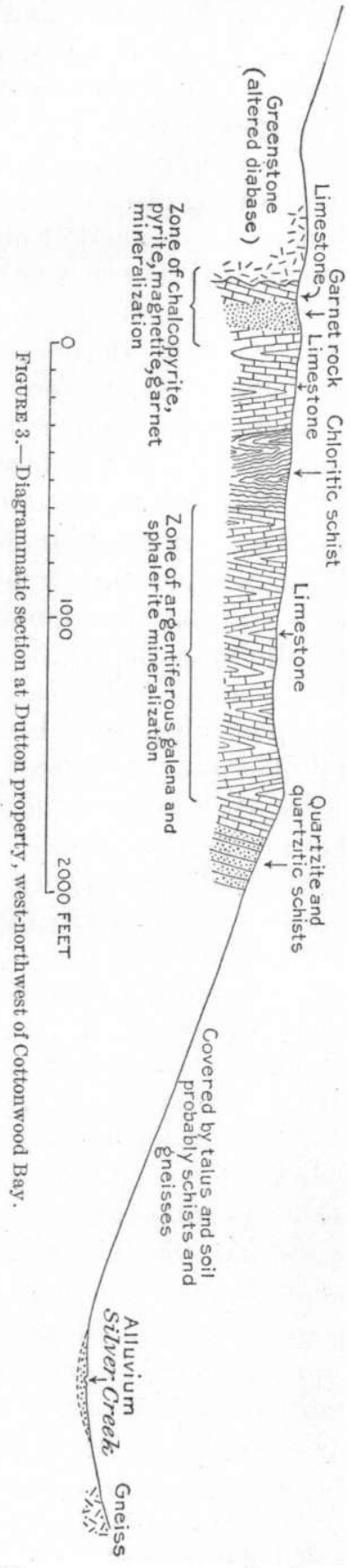
magnetite, calcite, quartz, and amphibole, and lesser amounts of other minerals. There are local developments, in considerable bandlike 
masses paralleling the strike of the limestone and the mineralized zone, of nearly pure garnet rock and magnetite rock and of garnet-magnetite rock. Iron oxides and copper carbonate are the only secondary minerals noted. They are unimportant, and rarely constitute more than a thin film. Glaciation has almost entirely removed whatever gossan there may once have been.

The average values in the ores, as reported by those in charge of the Dutton properties in 1909, are 4 to 6 per cent of copper and 2 ounces of silver and $\$ 1.50$ in gold to the ton. Lead values are unusual, though it is said that at one opening 6 per cent of lead with 9 per cent of copper was found on the east side of the ore zone. It is asserted that one drift at a depth of about 27 feet developed 46 feet of ore containing $13 \frac{1}{2}$ per cent of copper.

There is no timber on the claims. Logs may be brought by an easy trail from the forested region 6 or 8 miles to the southwest. The prospects are situated about 9 miles from the outlet of several small lakes lying about 500 feet above and draining into Iliamna Lake. It is possible that a hydro-electric power installation here would assist, during the summer months at least, the working of these claims.

Adjoining the Dutton properties on the east are the claims of W. E. and E. Duryea. These are on the limestone, and hence the group of prospects is locally spoken of collectively as the "lime belt." The discovery and first locations were made in 1905. The development work consists of a house, trails, a number of shallow pits or shafts, and two adits about 300 feet in combined length. One of these adits was opened on a gulch about 500 feet below a surface prospect, in the expectation of cutting the vein. It had not, at the time of the visit, been driven far enough. The other, begun a short distance below a vein shown in a shallow surface opening, has reached what is regarded as the foot wall of the lode. Further development during 1909 was hindered by lack of powder and other supplies.

The limestone has been cut nearly at right angles to its strike by many small, nearly vertical, dikes, of which 27 were seen which had widths of 3 feet or less. Several larger dikes and irregular masses were also observed, most of which are parallel to the strike of the limestone. In a number of places on the bare limestone surface small chunks and nodules of black manganiferous iron oxide have been found, and wherever these localities have been explored by test pits argentiferous galena-sphalerite lodes have been found along fissures in the limestone. Near the eastern margin of the limestone there seems to be indicated, by patches of manganiferous gossan and by test pits, a more or less persistent mineralization through a distance of 5,000 feet on a fissured zone in the limestone, striking about $20^{\circ}$ east of north (magnetic) and standing approximately vertical. A cliff in the tributary gulch of Silver Creek crosses this zone 
and exposes, through a height of 50 feet or more, much oxidized ledge matter. The width of this mineralized zone on the Silver Bell claim is estimated by the owners at 75 feet. The distribution of other showings on the surface and in test pits would seem to indicate that there has been mineralization along various fractures or fracture zones.

Values as reported by the owners for selected samples are as follows: On the Silver Bell claim, gold $\$ 20$, silver 195 ounces, lead 35 per cent, and zinc 15 to 20 per cent; on the Ida G. claim, gold 3 ounces, silver 196 ounces; on the War Eagle claim, silver 80 ounces, lead 50 per cent. The black manganiferous gossan carries from 2 to 5 or 6 ounces of silver to the ton.

Other silver lode claims have been staked for a distance of $1 \frac{1}{2}$ miles southwest from the Duryea prospects, but no work has been done on them.

The Durand prospect, on Success No. 1 and No. 2 claims, is about a mile from the shore of Pile Bay and $2 \frac{1}{2}$ miles below the mouth of Iliamna River, at an elevation of about 1,000 feet. It is about 3 miles northwest of the Dutton prospect. The ore body is a 10-foot quartz vein, striking $\mathrm{N} .80^{\circ} \mathrm{E}$. (magnetic) and dipping $45^{\circ} \mathrm{NE}$, in schistose greenstone. The vein contains rather uniformly disseminated masses of chalcopyrite and pyrite. The hanging wall is impregnated with pyrite for 4 feet from the vein. The development work comprises a cabin, about a mile of trail, and two shallow prospect pits.

About 2 miles north of the shore of Knutson Bay, on Iliamna Isake, is the Knutson prospect, which was not visited by the Survey party. It is reported to be a quartz vein in granite, bearing copper minerals and gold and silver. The only development work reported is a cabin on Iliamna Lake, a trail to the claim, and a shallow pit.

The Millet copper prospect, on the north shore of Iliamna Lake, is about 25 miles west of Iliamna village and 15 miles east of Newhalen River. The ledge runs N. $35^{\circ} \mathrm{W}$. to N. $40^{\circ} \mathrm{W}$. (magnetic) up a low knoll from a point near the head of a small bight. In $1906 \mathrm{O}$. B. Millet staked four claims along this ledge. The development work includes a house, a blacksmith shop, a trail along the lode, seven open crosscuts from 22 to 42 feet long and averaging 4 or 5 feet in depth, and a shaft 16 feet deep. The prospect is on a dense bluishwhite crystalline limestone and parallels the contact of a dark finegrained trap or altered basaltic rock. This contact is not exposed, and therefore its nature is not known. Near the lake shore there is a thin capping of tuffs and porphyritic flows covering both basalt and limestone. The surface indication which led to the discovery is a weathered and deeply iron-stained limestone with limonite, both very slightly copper stained. The ledge has been traced for 3,500 feet, is 22 to 42 feet wide, and consists of dark-blue crystalline limestone, 
much shattered and broken, at intervals of 1 to 8 or 10 feet by shear zones having a trend $\mathrm{N} .35^{\circ}$ to $45^{\circ} \mathrm{W}$. (magnetic), and dipping from $75^{\circ} \mathrm{NE}$. to vertical. The walls are shattered crystalline limestone, whitish to gray-blue, healed by white calcite seams. The mineralization is in stringers a fraction of an inch to 10 feet in thickness, some of which are of pyrite and chalcopyrite and others of calcite and quartz, with black oxidized iron and copper minerals. The surface of the ore stringers shows limonite and black oxidized iron, copper minerals, and copper carbonates. Complete oxidation is limited to the surface and cracks or fracture zones in the sulphide bodies, where it extends downward 2 or 3 , rarely 7 or 8 , feet. Mr. Millet reports that a picked sample assays gold $\$ 2$ to the ton and copper 10 per cent. An estimate, somewhat unreliable because of the black weathering products which mask both country rock and ore in the old faces of the cut, makes the entire sulphide content of the ledge at least 5 per cent. Not much large timber is available on the claims, but large spruce is abundant about 15 miles farther east on the lake.

The Aukney claim (staked, according to the location notice, by S. A. Aukney October 16, 1908) is situated on the south shore of Iliamna Lake, 23 miles from the outlet of the lake. The rocks as exposed in the lake cliffs consist of tuffaceous and cherty beds striking northeast, parallel to the shore, and dipping from vertical to $75^{\circ} \mathrm{SE}$. They contain much fine disseminated pyrite, which where oxidized give them a bright-yellow stain. No sulphides other than pyrite could be recognized visually and nothing is known as to what precious metals they may contain. The only work done on the claim is a little blasting on the face of the cliff.

The Hardenberg prospect lies on Kasna Creek at an elevation of 2,200 to 2,300 feet, about $1 \frac{1}{2}$ miles from the south shore of Kontrashibuna Lake. It is about 10 miles from Tanalian Point, on Lake Clark, whence it is reached by trail and boat. The claims were staked in 1906 by Charles Brooks and C. von Hardenberg. No development work has been done except the building of a house and a cache on the lake and a trail from them to the prospect. The ledge is in a limestone and approximately parallel to its strike-about north (magnetic). The contacts of the mineralized body with the limestone are masked by slide and soil. Within a zone about 75 feet wide are various bands, some of specular hematite with a little quartz and chalcopyrite; others of micaceous specular hematite, chalcopyrite, quartz, and calcite in a hard gray gangue composed in part of an amphibole; and still other small irregular stringers of chalcopyrite, pyrite, and quartz-all in a much shattered dense limestone. There is very little oxidized material, probably because the region has been thoroughly scoured by glaciation. In the absence of exploratory tunnels, shafts, etc., and because of the masking talus and soil it is difficult to make out the relations of the mineralized bands or to 
estimate their proportions. There appear to be two hematite bands, 7 to 10 feet thick, and three or four zones of similar width which contain chalcopyrite with other minerals. Perhaps the total chalcopyrite aggregates 8 per cent of the mass and may be locally segregated in bodies large and rich enough to constitute ore.

This prospect is about 40 miles from Iliamna Bay and now is accessible only by a roundabout route through Iliamna and Clark lakes. Its development, therefore, is sure to be retarded. A timber supply more than sufficient for development purposes exists immediately below the prospect. Water rights and a power site have been staked by some of the men interested in the property at the falls of Kontrashibuna River, the outlet of Kontrashibuna Lake, 8 miles from the prospect. There is a fall of 60 feet here and a large flow during the summer months, so that sufficient power might be developed to assist materially in the working of the claims. There is another fall on the river entering the head of Kontrashibuna Lake.

It is reported that on the north side of Kontrashibuna Lake another copper prospect has been staked.

SUMMARY.

To speak broadly, it may be said that three classes of ore occurrence have been found in this region-deposits in limestones at or near the contact of igneous rocks; quartz veins in granites and greenstones, some of which are associated with porphyry dikes; and pyritized fracture zones in various rocks, some of which are healed by quartz.

The most promising of the present locations are on deposits of the first-named class. Although generalization regarding ore occurrence in the region is hardly warranted by what is known of the few prospects so far located, yet it is perhaps indicated that the limestone belts, especially along their contacts with igneous rocks, will be the more fruitful fields for prospecting. The larger of the known copper deposits are restricted to the limestones, which have not been found to have a very wide distribution, but they have not been prospected throughout their known extent. The silver-bearing lead and zinc lode south of Iliamna village, another promising prospect, is also in the limestone. It seems probable, from such meager data as are at hand, that the mineralization of the limestones is genetically related to the intrusion of igneous rocks, probably diorites, now altered to greenstones.

- The Iliamna region offers to the prospector the advantages of accessibility, good exposures, a fair timber supply, and water power. Transportation within the region is no more seriously handicapped than in many other parts of Alaska. There appears to have been less prospecting than might be expected, for the region offers certain facilities and attractions for that pursuit. Though not along any 
of the usual lines of travel in Alaska, the district is easily accessible and supplies are readily obtainable. The region lies in the border land of the forests and the tundras and is without the thick mantle of plant growth of either province in areas of their more characteristic development. Consequently travel is comparatively easy and rock exposures are good and abundant. There is sufficient timber in the valleys for building, mining, and fuel during the prospecting and early stages of development. Water powers, especially in the Newhalen, Kontrashibuna, Tazimina, Copper, and Kakonak river basins, invite development and application to mining. Except for the localities directly on the shores of Cook Inlet or Iliamna Lake, transportation of supplies and mining products would encounter the difficulties of a mountainous country. However, the experience with the Iliamna and Dutton trails indicates that conditions are favorable for the maintenance of wagon roads. A preliminary survey of a railroad from Iliamna Bay to the Kuskokwim has been made across this region. Such a railroad would serve as a trunk line from which the several prospects could be reached by wagon road or branch railroads without excessive grades. Transportation at present is effected chiefly by small boats on Iliamna and Clark lakes. Supplies are brought from Iliamna Bay to the village by packing on horses or natives or by sledding in the winter. Some are brought from Bristol Bay by gasoline launches. Between Iliamna and Clark lakes there is a 5-mile portage, which is accomplished by native packers.

If this region reaches the productive stage of development, fuel will have to be brought in.

\section{PLACER DEPOSITS.}

There has been some desultory effort to prospect placers on the streams tributary to Lake Clark from the north. From Caribou Creek, a northeasterly tributary of Chulitna River, fine gold but no pay is reported. On the headwaters of Kijik River the alluvium of Kellet Creek and Ingersol, Lincoln, and Franklin gulches is reported to be auriferous. On Portage Creek, entering Lake Clark about 35 miles above the outlet and heading against the streams just mentioned, one man, now dead, is said to have done considerable work. He took out about $\$ 40$, all coarse gold. The alluvium was found to be about 12 feet deep and composed chiefly of large glacial bowlders.

\section{PETROLEUM.}

The lowlands on the coast of Cook Inlet, especially between Chinitna and Iniskin bays, have been extensively staked as petroleum land and several wells have been drilled. The geology and indications of petroleum in this district have been already described. ${ }^{a}$ No drilling has been done since 1906 and the oil camps are now abandoned. 


\title{
GOLD PLACERS OF THE MULCHATNA. ${ }^{\circ}$
}

\author{
By F. J. Katz.
}

Introduction.-Mulchatna River lies between the Clark-Iliamna Lake basin and the Kuskokwim Valley. Its headwaters rise in the mountains north and northeast of Lake Clark (the Tordillo Mountains of Spurr), opposite the south fork of Kuskokwim River. Three main branches, known as the Big, the Middle, and the Small Mulchatna, flow southwestward to a point about 25 miles north of the west end of Lake Clark, where they unite to form the main Mulchatna. Thence the stream receiving one important tributary, the Koktalee or Kaktul, continues about 60 miles to the southwest, to its confluence with the Tikchik from the northwest. Below this point the river, known as the Nushagak, takes a soutliwesterly and westerly course for 90 miles to Bristol Bay, on Bering Sea. Above the forks of the Mulchatna the country is mountainous with moderate relief; below the forks it is low, with broad gravel-covered; pond-dotted plains and detached hills or mountains.

Routes and supply points. - Canoes can be taken from Bristol Bay up to the Koktalee and, it is reported, to the forks of the Mulchatna, and even beyond in high water. The usual route, however, is from Iliamna, generally from Iliamna Bay, on Cook Inlet, by portage trail to Iliamna village, thence by boat to Newhalen River and Lake Clark. From Lake Clark the trail is either overland from Portage Bay or by boat up Chulitna River, and thence overland. From Koggiung on to Bristol Bay another boat route ascends the Krichak and crosses Iliamna Lake. There are boats and boatmen for hire at Koggiung, at Iliamna, and on Lake Clark, and pack animals and natives are available for work on the portages. At Iliamna supplies of all kinds can be purchased and the local traders have stocked caches with provisions on Lake Clark and on the Mulchatna. It is reported that the trails are good, and on the whole the region is more accessible than others in Alaska which have received more attention. However, steamboat service to Bristol Bay and Iliamna Bay has been irregular.

a The Mulchatna region has not been visited by Survey parties. The notes here given were obtained from prospectors and others met during the summer of 1909 on Clark and Illamna lakes. 
It is not known how many men have from time to time visited the Mulchatna. Sixteen were there during the summer of 1909, and six of them planned to remain during the winter. Others were coming in at the time the Survey party was leaving Iliamna. In the fall those interested organized the Mulchatna mining precinct and elected Thomas Hanmore recorder, though there is and has been a United States commissioner, with headquarters and recording office at Iliamna, whose district includes the Mulchatna.

Prospects.--On the Mulchatna, from the Koktalee up, and on the Koktalee also, fine flour gold is found on all the river bars. Bed rock has not yet been prospected along these larger streams on account of ground water. Only summer work has been attempted so far and as yet no permanent ground frost has been encountered. It is claimed that after May 15 no thawing is required. Above the forks of the Mulchatna, particularly on the middle fork, the gold so far found is coarser and pay is said to be present. Some of the smaller tributaries carry coarse gold. On one of them two men this summer opened a hole and took out about $\$ 8$ worth of coarse gold.

The prospecting so far has been confined to the present stream beds. The pay is practically all on bed rock, which is reported by the prospectors to be chiefly slate. The gravels prospected are generally from 4 to 12 feet deep; one hole is 16 feet deep.

Water is plentiful and grades are sufficient for sluicing. Timber is abundant on all the streams. 


\title{
SKETCH OF THE GEOLOGY OF THE NORTHEASTERN PART OF THE FAIRBANKS QUADRANGLE.
}

\author{
By L. M. Prindele. ${ }^{a}$
}

\section{INTRODUCTORY STATEMENT.}

The area included in the Geological Survey's map of the Fairbanks quadrangle is delimited by meridians 146 and 150 and parallels 66 and 64 . The Fairbanks gold-placer district is in the eastern part of this area. During the season of 1908 a Survey party was engaged in making a detailed geologic map of the Fairbanks district and during 1909 geologic investigations were carried north of the Fairbanks district and westwarl to Rampart. The results of these trips, together with those of previous trips, are being assembled for a geologic map of the entire quadrangle. A portion of the quadrangle, including the Fairbanks district and extensive areas to the north and west, is shown on the accompanying geologic sketch map (Pl. VI). From the presence of the Fairbanks district in the southeastern part of the area covered by this sketch map and of the Birch Creek district extending into the northeastern part of it the attention of prospectors has frequently been directed toward this area as a favorable one for prospecting. Although no other rich placers have yet been discovered than those of the Fairbanks and Birch Creek districts, there are outside of these well-known areas several widely separated localities at which auriferous gravels have been found and some attempts are being made to mine these deposits. There is also a small amount of quartz prospecting in progress.

The following preliminary report is designed to state briefly only what appear to be the main geographic and geologic facts regarding this area northwest of the Fairbanks district and west of the Birch Creek district, and to emphasize especially the contrast between the highly metamorphosed rocks of the eastern and southeastern portions of the area and the less metamorphosed rocks of the northwestern portion, and also the distribution of the granitic rocks.

These features are particularly worthy of attention from the viewpoint of the prospector from the fact that the gold-producing districts of Birch Creek and Fairbanks lie in the schists characterizing 
the southeastern portion, while the quartzites, limestones, slates, and other rocks of the northwestern portion have proved up to the present time practically nonproductive.

\section{GEOGRAPHIC SKETCH.}

There is a strong contrast between the type of topography characteristic of the Birch Creek and Fairbanks districts and intermediate areas and that toward the west. A few miles west of the headwaters of the Chatanika the country becomes of greater and more varied relief. A large part of the northeastern quarter of the Fairbanks quadrangle is made up of groups of bare rocky hills and ridges. The ridges in general trend northeast and southwest. The most conspicuous group of ridges and the one that dominates the area is the White Mountains. These limestone ridges for a distance of about 30 miles are conspicuous alike by color, angularity, and relief. Narrow, serrate ridge lines and steep slopes are characteristic. There are several isolated groups of hills east of the White Mountains that are likewise prominent features, and the position of these is indicated on the map by the areas represented as occupied by granite. This topographic diversity and the contrast with the areas to the east are due primarily to differences in the kind of bed rock.

The country southeast of the White Mountains, between them and the Chatanika, is made up of even-topped ridges with long, broad lateral spurs that separate wide, shallow valleys. Both ridges and valleys are largely covered with small spruce. Between the White Mountains and the Yukon Flats there is a space of about 20 miles occupied by bare, even-topped ridges trending northeast and southwest to east and west. The most prominent of the ridges in the area covered by the map are 4,000 to 5,000 feet above sea level and a few points in the area exceed 5,000 feet. The valleys are for the most part deeply cut and the bed of Beaver Creek in the northwestern part of the area is about 1,000 feet above sea level.

In general terms, then, the White Mountains, formed largely of limestone, and the group of hills formed of intrusive granite constitute the highest parts of the area and are surrounded by prevailingly even-topped ridges at altitudes of 2,500 to 3,000 feet above sea level.

The entire area has been closely dissected by numerous streams and the valleys are mostly narrow and deep. Chatanika and Beaver rivers are the most important streams. The Chatanika, in a part of its course, outlines roughly the western limit of the Fairbanks district. Beaver Creek drains most of the area and is the largest stream. It is easily fordable on foot in the portion of its course above the point where it loops round the southwestern portion of the White Mountains, but before leaving the hills to enter the Yukon Flats it becomes a stream several hundred feet in width. 


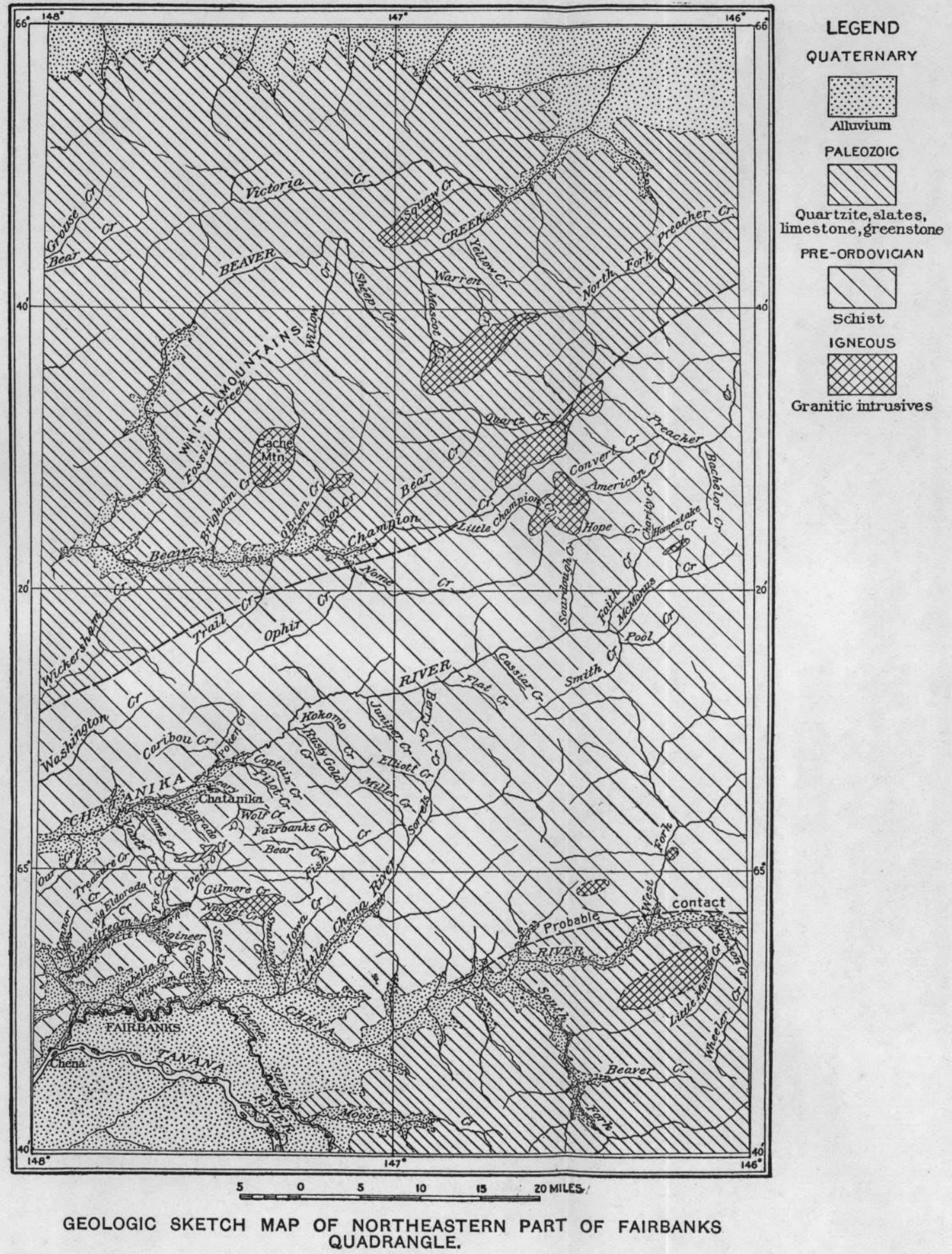



The timber resources of most of the area are meager. Most of the ridges are bare of timber and the timber line is approximately at 2,500 feet. Spruce, poplar, and birch, with some tamarack near the Tanana, are the kinds most common, and spruce is predominant. The proportion of timber increases toward the Tanana, and in some of the valleys near that river there is abundance. There is some timber suitable for mining purposes in parts of the stream flats of the larger streams throughout the area and spruce timber is available in most of the valleys, at least on the sunward-facing slopes. In many places in the smaller valleys the best and largest timber is to be found near the upper limit of growth, the conditions near the stream being less favorable. Small spruce suitable for fuel purposes is abundant.

\section{GEOLOGIC SKETCH.}

General statement.-The rocks of the area are separable into two general groups. One of these groups is composed predominantly of highly metamorphosed rocks of sedimentary origin, with some limestone and metamorphosed igneous rocks. These are all regarded provisionally as of pre-Ordovician age. The other group is composed of a heterogeneous complex of closely folded slates, cherts, conglomerates, greenstones, and limestones, in which, as determined on the basis of paleontologic evidence, there are rocks of Ordovician, Silurian, Devonian, and Carboniferous age. For the sake of brevity these two groups will be termed simply pre-Ordovician and Paleozoic, though the pre-Ordovician rocks may include some of Paleozoic age. There is a transition in metamorphism in passing from the pre-Ordovician rocks to the Paleozoic rocks and locally the latter also have become schistose. The general strike of both these groups is northeast and southwest and the contact line between them is approximately as shown on the map. There is a small area of slightly consolidated sandstone and conglomerate in the Fairbanks district which is probably of Tertiary age. The unconsolidated alluvial deposits include silt, sand, and gravel and are separable into bench deposits and deposits of the present streams. There is a considerable amount of igneous material in the Paleozoic rocks, largely of volcanic origin. Granitic intrusive rocks are common and the areas occupied by them are shown on the map.

Metamorphic rocks.-The contact line shown on the map as running northeast and southwest separates the predominantly highly metamorphosed rocks of the southeastern part of the area from rocks that are for the most part less metamorphosed. From the fact that the metamorphic rocks have proved more productive of placer gold in the Yukon-Tanana region than the others, this contact line possesses also an economic value, the quartzite, slate, and limestone areas being generally less favorable for prospecting. 
The schists are predominantly quartzite schist and quartz-mica schist. There are some quartzites but slightly altered and there are some schists so extremely metamorphosed that their origin is in doubt. The group comprises also carbonaceous, garnetiferous, and hornblendic schists and crystalline limestone. The schists are mostly thin bedded and of rather uniform composition over wide areas. Along the trail from the Birch Creek district to the Fairbanks district these are the only rocks observable. They occupy also large areas eastward to the international boundary. The strike ranges from northeast-southwest to northwest-southeast. They are much folded and closely appressed recumbent folds are common. In many places the folds are in a nearly horizontal position and the beds in these areas present the appearance of horizontality. In places porphyritic granites have been so highly metamorphosed along with the schists that they are not easily separable from the schists, into which they were intruded before the metamorphism of the region took place.

Quartz veins are common in the schists, and in some areas, particularly in the Fairbanks district, the schists have suffered an extensive brecciation. As a result of this brecciation a large amount of quartz has been introduced. In that area also there is a considerable proportion of iron pyrites, which by its alteration discolors large areas of the schists.

Paleozoic rocks.-The rocks regarded as Paleozoic include many varieties of quartzite, mostly feldspathic, with gray, purple, and green slates, cherts, conglomerates, tuff, and volcanic rocks mostly altered to greenstone and limestone. Fossils found in the White Mountains have been determined as Ordovician, Silurian, and Devonian, and some found in the ridges overlooking the Yukon Flats have been determined as Carboniferous (Pennsylvanian). The Ordovician fossils of the White Mountains occur in a conglomerate at the base of the limestone and also in the limestone itself. Higher in the limestone Silurian and Devonian fossils have been found. The conglomerate underlying the limestone contains, along with abundant volcanic material, numerous chert pebbles and some beds of the conglomerate close to the limestone are composed of coarse feldspathic sandstone. The succession has apparently been approximately as follows: Feldspathic quartzites with interbedded gray, purple, green, and black slates and cherts; conglomerate; volcanic flows and breccias with Ordovician fossils near the top; limestone with Ordovician, Silurian, and Devonian fossils and interbedded greenstones and quartzites; gray, greenish, and black shaly slates with Pennsylvanian fossils. The relations between the Carboniferous and underlying beds have not been observed. The Paleozoic rocks southeast of the White Mountains are predominantly feldspathic quartzites, in some places with chert pebbles, and slates; in the White Mountains, cherts, con- 
glomerate, greenstone, and limestone; northwest of these mountains fragmental rocks (partly volcanic, partly with chert pebbles), slates, quartzites, and limestones.

The Paleozoic rocks are at most localities very closely folded; they have in places become schistose and locally have been intensely sheared.

Tertiary (?) rocks.-There is a small patch of loosely consolidated sandstone and conglomerates in the Fairbanks district. The underlying rock of a portion of this deposit at least is a basaltic flow. Carbonized plant remains occur in the sandstone, but the material collected was indeterminable. These rocks resemble the Kenai formation of other areas and provisionally they have been referred to the Tertiary. There is some evidence also that Tertiary rocks are present in a portion of the northern part of the area east of the point where Beaver Creek enters the Yukon flats.

Quaternary deposits.-As a result of the shifting of the shore line which has taken place through changes either in the level of the land itself or in the sea level with reference to the land, benches have been formed in the drainage basins throughout most of the Yukon-Tanana region, and upon the lower benches, as high as 500 feet above the level of the present streams, alluvial deposits have been left. These unconsolidated deposits consist of silt, sand, and gravel, and are separable into bench deposits and those of the present streams.

Benching is prominently developed about the White Mountains up to a level of about 4,000 feet above the sea, and the lower benches, those more directly related to present drainage lines, are occupied by alluvial deposits. In the southwestern part of the area, in the Tolovana flats, there are extensive silt deposits and it is probable that these are due, in part at least, to lacustrine conditions. The deposits of the present valleys have been investigated in detail in the Fairbanks district and found to have a thickness in places of over 300 feet. These deposits are for the most part, under present climatic conditions, permanently frozen.

Granitic rocks.--The distribution of the intrusive granitic rocks (with the exception of dikes too small to appear) is shown on the map (Pl. VI). As a rule the larger masses are oriented with their longer diameters approximately parallel with the strike of the rocks into which they have been intruded. Most of the areas are topographically prominent. The most common type is porphyritic biotite granite, the coarsest of which has feldspars up to 2 inches in diameter. Quartz diorite occurs in the Fairbanks district and to a small extent basic types are present in the Beaver Creek areas. Small dikes are common in the Fairbanks district, some of them being composed only of quartz and feldspar, but most of them are granite porpliyry or somewhat more basic in composition. Several small areas of granite 
porphyry occur near the head of Homestake Creek, and at one locality gold has been found in the bed rock in the contact region between this rock and the schist. Although tourmaline is uncommon in the Fairbanks district it is a very common constituent of the granites in the Beaver Creek area, particularly the mass at the head of Hope Creek. Fluorite is found also in the marginal portion of this mass and in the schist, where veins containing fluorite and iron pyrites occur; one of these veins is reported to carry values in gold.

All these granite areas in the Beaver Creek country, so far as observed; are surrounded by a zone up to about 1,000 feet or more wide, in which the schists show more or less contact effect of the intrusion. The schists have been indurated and have, from the alteration of iron pyrites, acquired a reddish color that renders the contact area visible at a distance. Here and there the development of andalusite was noted.

Iron pyrites, mostly limonitized, was observed also in the marginal portion of some of the granite masses, particularly the one at the head of Bear Creek. On the east side of the mass the decomposed granite contains a considerable portion of limonitized iron pyrites to a distance of several hundred feet from the margins. A sample of the decomposed granite taken for assay contained 83 cents to the ton in gold.

\section{MINING DEVELOPMENT.}

Outside of the territory covered by Plate VI, the areas where most work has been done on the auriferous gravels are the valleys of Washington Creek, of Faith Creek and its tributaries, of Preacher Creek and its tributaries, and of Victoria Creek. The conditions on Washington Creek are similar to those of the Fairbanks district. The creek is being more or less prospected and some pay has been reported. The upper part of the valley of Faith Creek has been investigated with the view of working the ground by the hydraulic method.

The most work during 1909 was being done on Bachelor Creek, a tributary of Preacher Creek, where plans were under way for working ground by the hydraulic method. A ditch was being constructed and part of the equipment was already on the ground. The bed rock at this locality is principally schist, including quartz-mica, quartzitic, and carbonaceous schist. An intrusive mass of granite porphyry 75 feet thick was observed traversing the schist in a direction parallel to its structure $\left(\mathrm{N} .60^{\circ} \mathrm{E}\right.$.), and the same kind of rock occurs on the west slope and also at the head of the valley. The gravels are composed predominantly of schist, with a considerable proportion of vein quartz and some granite porphyry. They are reported to average 7 to 8 feet in thickness and to be unfrozen in the 
bed of the stream. Bench gravels about 20 feet thick lie on a low bench on the east side of the valley.

Gold is found in place in the valley of Homestake Creek along the contact of the intrusive granite porphyry with the schist, and such contacts probably form one source, at least, for the placer gold found in this area.

All the areas thus far considered are within the schist. The valley of Victoria Creek was the occasion of a stampede in 1905, but not sufficient gold was found to pay for working.

In view of the available information it seems that the localities in the vicinity of the granitic rocks are the most favorable localities for prospecting.

$55695^{\circ}-$ Bull. $442-10-14$ 


\title{
AURIFEROUIS QUARTZ VEINS IN THE FAIRBANKS DISTRICT. ${ }^{a}$
}

\author{
By L. M. Prindle.
}

\section{INTRODUCTORY STATEMENT.}

The geographic location of the Fairbanks district in central Alaska is now so well known as to require but little description. Its longitude is $148^{\circ}$ west and its latitude ( $65^{\circ}$ north) is such as to render the climatic factor important in the consideration of mining problems.

The most noteworthy feature in the economic development of the Fairbanks gold-placer district during $1908-9$ has been the discovery of auriferous quartz veins. The discoveries of 1908 in the valley of Chatham Creek and in Skoogy Gulch were followed during 1909 by similar discoveries at several other localities. In view of the fact that quartz prospecting in the Fairbanks district is rendered unusually difficult by the moss, talus, and alluvial deposits that conceal the greatest part of the bed rock under a mantle most of which is permanently frozen, the results attained during the short period since quartz prospecting began are indicative of a rather widespread distribution of gold in quartz veins, particularly in the drainage areas of streams whose valleys have proved productive of placer gold.

As these ore deposits have been but recently discovered and as only a small amount of work has been done on them, this description is by no means a definitive statement of the occurrence of gold in bed rock in the Fairbanks district, but rather a brief summary of what seem to be the most important geologic facts involved in the occurrence of the gold-quartz veins and the bearing of these facts on the quantitative problems of the miner.

The expression of the geologic facts in their topographic relations was rendered possible by the completion of the Fairbanks special

a This description is based on the observations made by L. M. Prindle and F. J. Katz during detailed geologic work in the Fairbanks district in 1908; on the results obtained by L. M. Prindle and B. L. Johnson in the course of a brief visit to most of the localities during 1909, incidental to the mapping of the areal geology of the Fairbanks quadrangle; and on the work of $A$. H. Brooks, who also made a brief visit to these localities during 1909 . In the field and office work and in the preparation of this report the writer bas had the assistance of B. L. Johnson. 
map by the Geological Survey in 1907 on a scale of $1: 62,500$, or about 1 mile to the inch, with a contour interval of 25 feet. This map was used as a base by the Survey party that was engaged in 1908 in a detailed study of the geology and mining developments of the district. The result of this work, together with a more detailed account of the gold-quartz discoveries, will be embodied in a report that is now in preparation. To illustrate the present paper the accompanying sketch map (fig. 4), embracing most of the localities in which gold-quartz veins have been found, has been prepared. The relation of this area to the larger area of which it forms a part is shown on the geologic sketch map of the northeastern part of the Fairbanks quadrangle (Pl. VI).

\section{GEOGRAPHIC SKETCH.}

The surface of the Fairbanks district is made up of riclges and valleys and a small portion of the extensive flats of Tanana Fiver. The ridge and valley feature is a type that has a wide distribution throughout the Yukon-Tanana region. The main characteristic is one of uniformity, both of ridge and of valley. The relief in the Fairbanks district is not great, being embraced in the difference of altitude between the highest parts of the ridges, about 2,700 feet above sea level, and the Tanana Flats, about 500 feet above sea level. The ridge level breaks off rather abruptly to that of the Tanana Flats. The ridges are flat-topped, broad, bulky, and very uniform in height, and have an average elevation above sea level of about 2,500 feet. They slope unsymmetrically to the valleys on either side. In most of the ridges one slope is rather steep, with a grade up to about $20^{\circ}$. The other slope is gradual and merges into a gently sloping valley floor. The balance of ridge and valley development is such that the valleys are approximately counterparts of the ridges.

The valleys lie at levels of about 2,000 feet or more vertically below the ridges. They are narrowly $V$-shaped and symmetrically developed in cross section near their heads, but become open and increasingly unsymmetrical downstream until a valley floor is developed from a few hundred feet to a mile or more wide. The stream is as a rule close to the steeper side of the valley, where it occupies a comparatively narrow flat. From the edge of the stream flat opposite the steeper ridge slope the valley floor, although in some places nearly flat, in most places rises gradually to form a long sloping surface that becomes a dominant feature in this area. Owing to the fact that in such slopes, some of which are several hundred feet back from the stream flats, lie most of the gravels that have proved productive of placer gold, these portions of the valleys are characterized by the greatest amount of mining development. 


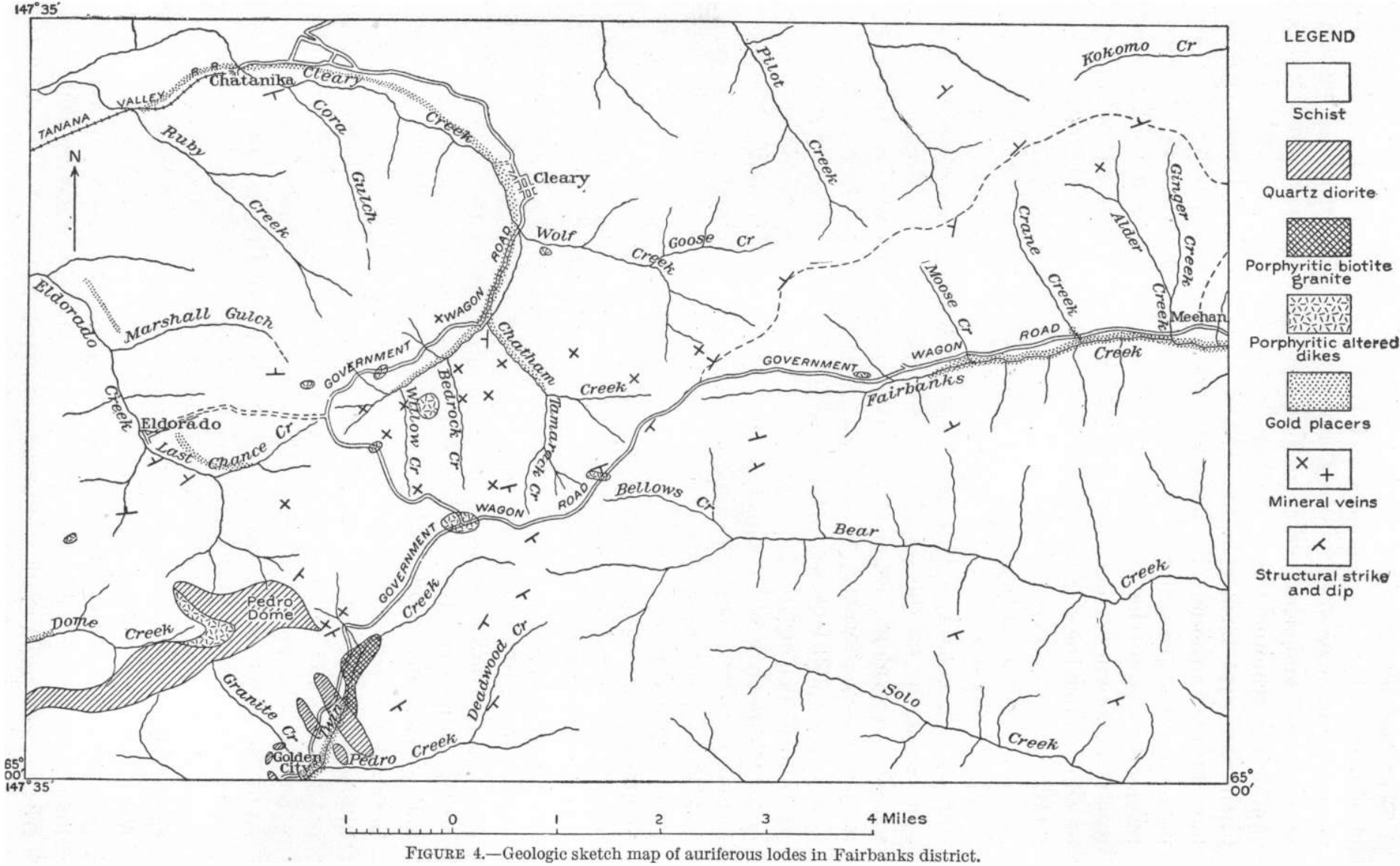


The general trend of the ridges, although obscured by the absence of marked differences in relief and by the presence of numerous lateral spurs more or less equivalent in amplitude to the main ridges, is northeast and southwest, parallel with the main drainage lines. The most prominent ridge is that separating the Chatanika and Chena drainage basins, and in this ridge most of the streams that have proved productive of placer gold have their origin. Most of these streams are small and flow directly or indirectly to the Chatanika on the northwest, to the Chena on the southeast (both southwestward-flowing streams about 30 miles apart), and to the Tanana, which touches the southwestern edge of the ridge country.

The water supply, being to a great extent of local origin, is largely dependent on local topographic and climatic conditions. The topographic uniformity entails uniformity of process in the disposal of the rainfall. The streams head at about the same level, and at homologous positions in the valleys of equal streams there are approximately equivalent amounts of water. Inasmuch as the permanently frozen character of much of the ground to depths that probably exceed 300 feet is favorable to a rapid run-off, the dependence on rainfall is very direct, and in dry seasons the supply of water becomes much less than the amount required by the processes of mining that have hitherto been employed.

Although the prolonged low temperatures of winter leave conditions that prevail throughout the year, yet the long days of the short summers give opportunity for the growth of an abundant vegetation. Spruce and birch have proved sufficient up to the present time for the requirements of mining. The hillsides of the valleys that have proved productive of placer gold have been stripped bare, however, and the quantity of timber still available for the purposes of mining or for use as fuel is being rapidly depleted. Grass grows abundantly on the deforested areas, and there are areas along the larger streams and on the lower slopes facing the Tanana Valley and adjacent portions of the Tanana Flats that are suitable for the growth of the numerous agricultural products that can be raised in abundance.

Owing to the long winters, the working season during the summer is limited to a period of, at most, about one hundred and fifty days, from the latter part of April to the middle of September, although underground work may be carried on throughout the year; nearly all work dependent on water supply is confined to the open period, and with the frequent inadequacy of the water supply during this period the opportunity for summer work is still further abridged.

In the absence of a railroad to the coast the problem of transportation continues to be largely a function of the natural conditions. The region must still receive its supplies by the circuitous river route, either by way of Dawson and the upper river or by way of 
St. Michael and the lower river. The opening of river navigation in the spring, about the middle of May, and its close in the fall, at dates ranging from about October 13 to as late, exceptionally, as November 23 , are two factors that enter largely into the consideration of all business enterprises in this portion of Alaska. Even with the advantage of telegraphic communication with the port cities of the west coast of the United States and notwithstanding efforts by the transportation companies to forward all shipments to their destination before the freeze, supplies can frequently not be shipped in time to reach the district during the open season, so that their shipment is held up until the following season, or they may be delayed in the course of shipment by the freezing of the rivers. In either case extra expense is involved. Supplies for the Fairbanks district are brought by steamer to Chena and Fairbanks and transported by wagon road or railroad to the localities of present economic importance, all of which are within about 30 miles of Fairbanks. The freight rates on ordinary supplies from the coast ports of the States to Fairbanks ave about $\$ 75$ a ton.

The conditions of transportation, although permitting abundance of supplies during the summer, have up to the present time entailed a dearth of supplies during the latter part of the winter and the early spring. These communities are therefore in a condition of economic strain which will probably continue so long as they must depend on means of transportation that are available only during the short summers.

\section{GEOLOGIC SKETCH.}

The predominant bed rock of the area is schist like that of most of the eastern portion of the Yukon-Tanana region. There is a small amount of metamorphic intrusive granitic rock, a few small areas and rather abundant dikes of unmetamorphosed intrusive granitic rocks, and a small proportion of comparatively recent basalt, a part of which may be of volcanic origin.

A large proportion of the area is covered with alluvial deposits. The occurrence of abundant placer gold in these deposits has brought the district to a position of economic importance, and the extensive operations of placer mining have rendered available for observation and study a considerable body of these deposits. They have been found to have a thickness in places of over 300 feet and to be for the most part more or less permanently frozen. These deposits and the superficial covering of moss, timber, and other vegetation conceal so much of the underlying bed rock that only a small portion is accessible to study.

The rocks of the metamorphic formation are in general siliceous and characterized by their glistening appearance, due to the content 
of mica. While quartz-mica schist and quartzite schist are the most common members, there are also rather massive coarse and fine quartzites, carbonaceous schists and quartzites, lenticular masses of crystalline limestone interbedded with the schists, garnetiferous mica schists, amphibole schists, green eclogitic rocks containing a large proportion of garnets and rutile, a small amount of schist containing andalusite, and a little staurolite schist. A small amount of intrusive porphyritic granite has undergone metamorphism along with the schists and thus become a member of this metamorphic formation. These rocks, while differing in degree of metamorphism, have apparently all been subjected to the same metamorphic processes. The general strike of the structure is northeast and southwest. The rocks have been folded to a high degree, and in some places the folds have been overturned to a nearly horizontal position, and have been in part so closely crumpled or cleaved that the primary structures are obscured. These rocks have been intruded by a considerable quantity of igneous material, which has added to the metamorphism and to the complexity of structure. They have also undergone an extensive shattering and local brecciation which are in part most probably directly referable to the igneous intrusive rocks and in part indirectly referable to the interaction between the intrusive and the invaded rocks in the effort toward mutual adjustment under the action of general deformational processes subsequent to intrusion.

The rocks of sedimentary origin play in the main but a passive part in the geologic history of the region, but the igneous rocks, although occupying quantitatively but a small portion of the area, are of significant importance from the fact that they form an active element in the lithologic system involved. They have the power of exerting an influence both mechanical and chemical on rocks remote from their vicinity, and furthermore they may furnish avenues for the transmission in solution of deep-lying materials toward the earth's surface.

The study of the igneous phenomena, apart from its importance in the geologic history, derives special importance from the fact that the mineralization of the region is most probably to be referred more or less directly to the igneous rocks.

The granitic and related igneous rocks of the area intrude the schists. They were forced into the schists in a molten condition at a considerable depth below the contemporaneous surface of the earth, a depth measurable probably by at least several thousands of feet. Since their intrusion they have become part of the present surface by the wearing away and removal by erosion of the rocks under which they were formerly buried. The evidence of their intrusive character is found in the presence of dikes cutting the schists, of inclusions of schist in the marginal portion of the igneous rocks, and 
of some contact metamorphism. The evidence of consolidation under a considerable cover is found in the necessity of such a cover to give an opportunity under conditions of slow cooling for the igneous material to attain the degree of crystallinity that these rocks possess, some of them being comparatively coarse grained porphyritic granites.

The unmetamorphosed intrusive rocks occur as masses of $\mathfrak{a}$ few square miles in area, most of them longer in a northeast-southwest direction, parallel with the general structure of the region, and as small dikes that have a rather wide distribution throughout the Fairbanks district. The material that forms these masses includes quartz diorite, the rock of Pedro Dome; porphyritic biotite granite, which is present on Twin Creek and forms the largest intrusive mass of the district outside of and east of the area shown on the map (fig. 4); altered dikes of granite porphry and quartz diorite porphyry; and persilicic dikes. From the facts available it appears that these intrusive masses are the product of one general period of intrusion; that they were not, however, contemporaneous, but closely sequent, and that the sequence has been in general quartz diorite, porphyritic biotite granite, and persilicic dikes.

The form of the intrusive masses available for study and the material composing them give but partial information as to the apparatus of intrusion and the products of intrusive activities. The materials constituting the rocks at the present time do not express the complete composition of the molten material from which they have crystallized, nor is the present composition necessarily the same as that immediately subsequent to crystallization. The present composition of the rocks, although predominantly that due to the original crystallization, is secondarily that resulting from a more or less complete adjustment to the long sequence of differing conditions that have since prevailed. The period immediately subsequent to intrusion is a critical period, as regards both the igneous rocks themselves and their environment. Besides the important mechanical effects of intrusion, a large amount of material is given off at the time of intrusion and subsequent thereto that is fraught with possibilities for fundamental changes both in the igneous rocks themselves and in the rocks into which they have been intruded. This material finally, as an aqueous solution more or less rich in dissolved substances, may invade not only the igneous rocks but a large volume of the rocks inclosing the intrusive masses and may introduce thus in many places a large amount of material that is more or less directly the product of the igneous action and take into solution minerals already present. The conditions pass from those that in general favor solution to those that in general favor deposition, and the end result in the rocks is the increase in the proportions of some of the minerals that were present before intrusion and the deposition of new minerals. One of the most 
common minerals added to the surrounding rocks through the action of granitic intrusives is quartz. Deposits of metallic compounds or of metals may also be formed.

The intrusive process under deep-lying conditions is a tremendous energizing influence. In the investigation of the intrusive rocks of an area, therefore, the problem is presented of evaluating, so far as possible, the igneous influence and assigning it to its appropriate position with reference to the general deformational and metamorphic forces to which an area like that under consideration has been subjected. If, in addition to the ordinary products of intrusion, ore deposits have been formed, the problem may become of economic importance. Although it may be comparatively easy to map the areas of the igneous rocks themselves, it is difficult to demarcate the areas that have been subject to the action of the influential concomitants and after-products of intrusion or to designate the materials resulting directly from the igneous process. While, therefore, an ore deposit may not be directly referable to the igneous rocks, the assemblage of facts may be sufficient to bring the possibility of such an origin well within the range of probability.

The rocks in the Fairbanks district exhibit structures due in part to sedimentation, in part to deformation, and in part most probably to intrusion. The mineral composition of the rocks is due in part to sedimentation, in part to metamorphism, and in part to the igneous intrusions. The problem, therefore, is complex, and the facts at present available are insufficient to permit definite statements as to the origin of structures or minerals.

Apart from the jointing, close folding, crumpling, minor faulting, and cleavage that the rocks have undergone, the schists, some of the quartz veins, and some of the igneous rocks have been more or less shattered and brecciated over areas of considerable extent. These phenomena are in places most intensified in the immediate vicinity of intrusive rocks, but are exhibited very commonly far beyond the limits of the visible igneous rocks. Although much more widespread in occurrence than the igneous rocks and due partly, perhaps, to general deformation, the largest part of the shattering and brecciation is regarded as having resulted more or less directly from intrusive action on a body of material predominantly so siliceous as to be particularly susceptible to such fracturing. Although the schists have probably been subject to this process at different periods, the largest part of the fracturing is believed to have been closely sequent upon the latest exhibition of intrusive action. The reason for this belief consists in the facts that the quartz diorite of Pedro Dome has undergone a small amount of fracturing and that the persilicic dikes, which were subsequent in origin to the intrusive mass of Pedro Dome and which belong apparently to the latest stage of the intrusion of plu- 
tonic rocks, have been in places intensely brecciated and then silicified and sericitized by the after-products of intrusive action. The shattering of the rocks is regarded as particularly important with reference to the occurrence of ore deposits, in that it has furthered and perhaps been largely the cause of the distribution of gold and metallic compounds within the range of accessibility.

\section{QUARTZ VEINS.}

Although only the northeastern part of the Fairbanks district is shown on the accompanying map (fig. 4), with the quartz prospects that had been found there up to the fall of 1909, auriferous quartz has been reported as far to the southwest as the valley of Ester Creek, and the distribution of gold in quartz veins, so far as it has been indicated by the discoveries of 1909 , is roughly outlined by the distribution of the gold placers. The localities that have proved most productive of placer gold lie in a belt of country about 35 miles long from northeast to southwest and 15 miles wide. The placers are not uniformly distributed throughout this area, the most productive of them being confined to a few of the many valleys. The richest quartz veins that have been found are located near the heads of valleys that have proved large producers of placer gold. While this may be due in part to the fact that there has been more incentive to prospect such valleys for quartz veins, it is believed to represent more or less accurately the distribution of the most highly metallized areas.

The bed-rock gold of the Fairbanks district occurs predominantly in association with quartz veins, and therefore the geographic and geologic distribution of quartz veins, their dimensions, the minerals found in association with quartz, and the physical and chemical alteration of the quartz veins since their formation are all matters of significance.

As far back as 1905 considerable work was done in prospecting for auriferous quartz, especially in the vicinity of Pedro Dome, but no discoveries were made at that time of sufficient importance to stimulate interest in quartz prospecting. It was not till 1909 that, through the work of prospectors, the quartz veins were open to observation, and as yet only their superficial portions have become accessible.

Quartz veins are found throughout the Yukon-Tanana region, ranging in age from pre-Ordovician to Upper Cretaceous. In a particular area, therefore, like the Fairbanks district, there are quartz veins that have been formed most probably at widely separated periods, and, although it may be possible to fix the relative age of some of them with more or less certainty as previous to the general folding of the region and to regard others as being related to a period 
of intrusion, there may be present a considerable proportion of quartz veins showing no recognizable evidence of their period of formation.

The quartz veins after their formation have not been exempt from the deformational processes to which the inclosing rocks have been subjected, but, according to their age, have undergone more or less folding, minor faulting, or brecciation. Slickensided surfaces of the vein quartz attest the motion that has taken place, and that some of the motion has been subsequent to the deposition of gold is shown by the fact that gold has been observed rubbed into slickensided surfaces of quartz in a direction parallel with that of movement. The amount of local faulting to which the veins have been subjected has apparently been considerable. Through this process some of the auriferous quartz veins have in places become discontinuous. Where such has been the case and where the recovery of the vein is sought the direction and angle of the dip of the slickensided surfaces and the direction of the grooves upon them should be carefully scrutinized, as such facts may throw light on the direction in which work should be undertaken to find the continuation of the vein.

Besides the changes already noted there has been in some places a reintroduction of quartz, and the present quartz veins embody the results of a sequence of events, one of which, at least for some of the veins, has been the introduction of gold and sulphides. The portions of the veins at present visible have undergone the processes of weathering and erosion, which have brought about changes in the vein to considerable depths-changes that have gone progressively deeper as the upper portions of the veins have been removed by erosion.

Besides the simple fissure veins crosscutting the schists there are in places shear zones of country rock containing parallel or anastomosing veinlets of quartz, in many places surrounding brecciated portions of the schist, and other areas in which irregular masses of altered and brecciated igneous rock have become permeated with secondary quartz that occurs not as well-defined veins but rather as spongy masses.

The greatest number of auriferous veins that have been found up to the present time are adjacent to the main ridge running northeast from Pedro Dome for a distance of about 10 miles in the drainage areas of Pedro, Cleary, and Fairbanks creeks. The quartz veins that have been found to be auriferous range in thickness from small stringers to veins 12 to 15 feet thick. The general strike of the veins is northeast and southwest, a direction about parallel with the general strike of the country rock. The dips are mainly vertical. The veins are in places parallel with the structure of the schists and in places they crosscut the schists. The deposition of quartz, in some places auriferous, has been common along the joint planes of the schists. The vein quartz of the productive veins has as a rule a 
milky, opaque white color. There is a considerable quantity of gray, glassy, barren quartz referred to commonly by the miners as kidney quartz or bull quartz. The latest deposit of quartz in the productive veins is locally transparent and is present partly as crystals. These crystals are sometimes found projecting into masses of compact granular stibnite that has been deposited subsequently to the quartz.

Quartz is by far the most abundant vein material. A small amount of orthoclase is found in some of the veins, mostly kaolinized, however, and a little micaceous mineral, probably sericite. At one locality small stringers of quartz containing fresh albite were observed. Calcite veins are not common, and those observed are small stringers in calcareous bands in the schist, along with associated sulphides.

The proportion of tourmaline in the Fairbanks district is small. It has been observed in the mica schist and andalusite schist at a few localities. At one locality it occurs in the schist at the margin of an auriferous quartz vein, where it is embedded in colorless mica associated with iron pyrites and arsenopyrite.

\section{METALLIZATTON.}

The metallic compounds and metals that have thus far been observed in the bed rock are iron pyrites, limonite, stibnite, arsenopyrite, galena, sphalerite, and gold. Minerals present in the stream gravels that have apparently been derived from similar veins are cassiterite (which is rather abundant), wolframite, and bismuth, small pieces of the last having been found intergrown with gold.

Iron pyrites is perhaps more abundant than any other sulphide. It occurs in the granitic rocks, in the quartz veins, and in the schists. In the marginal portion of the coarse porphyritic biotite granite of Twin Creek it is in places particularly abundant, occurring as crusts of crystals of pyritohedral habit along the joint planes of the granite and embedded in the granite. The pyrite is almost entirely altered to limonite and the superficial portion of the granite has become a mass of loose material. Similar conditions prevail southeast of the area shown on the map on Hill Creek, a small tributary of Gilmore Creek. A small amount of placer gold found at the head of Hill Creek has been derived apparently from such pyritized granite. Dikes composed almost entirely of quartz and feldspar occur near the head of Engineer Creck (also outside the area of the map), containing crystals of altered pyrites. Small pyritohedrons of altered iron pyrites occur also in dikes of sericitized granite porphyry and marginal to such dikes, in close association with stibnite. In this case the alteration has been to iron carbonate. Small crystalline masses of fresh iron pyrites have been found in association with galena and sphalerite and calcite stringers. 
While the pyritized granite assayed for the Survey failed to reveal more than traces of gold, the conditions on Hill Creek are such that the gold found there has been derived from the granite. The limonitized pyrites of quartz veins in Skoogy Gulch has been found to contain visible gold embedded in the limonite.

Besides the altered pyrite of the veins above mentioned, there is in the brecciated schists, in quartz veins throughout the district, and in some of the altered igneous dikes a large proportion of limonite, which renders conspicuous the minutest fractures by the pronounced discoloration resulting from the presence of the ferruginous material. The wide extent of this discoloration in the Fairbanks district is an index of the large amount of ferruginous matter involved.

Stibnite (bisulphide of antimony) was common in the concentrates from the placers in the early days of mining in the Fairbanks district and was afterward found in place in the bed rock at several localities in widely different parts of the district. It occurs in place here and there in the drainage area of Cleary Creek and together with arsenopyrite accompanies the gold in the richest of the quartz veins. It has been found as narrow stringers composed almost entirely of massive stibnite crosscutting quartzite schist or forming a network of stibnite veins between fragments of brecciated schist; in veins of quartz and stibnite, where the massive stibnite occupies the spaces left between quartz erystals; and as fine needle-like crystals or small crystalline groups along with some fresh, clear quartz areas in more or less fractured quartz veins. At one locality stibnite was found in close association with a sericitized dike of granite porphyry. The schist had not only been intruded by the dike, but had apparently been fractured by it. Stibnite has been deposited on the surface of the dike and occurs as small veins and lenticular masses up to several pounds in weight in the schist. The stibnite at this locality is apparently in close genetic association with the granite porphyry. Assays of the stibnite have not shown a gold content of over $\$ 1$ to the ton.

Arsenopyrite occurs massive in veins a few inches thick in the schist, associated with quartz; as crystals in some of the altered granite porphyry dikes; and as crystals and crystalline groups in some of the rich gold-quartz veins, associated with stibnite and gold. At one locality massive arsenopyrite was found associated with massive stibnite, galena, and quartz. The arsenopyrite is easily distinguishable from the stibnite by the lighter gray color and greater hardness.

Galena is less common than the other sulphides, but has been found in the bed rock in association with sphalerite and calcite veins at one place and with stibnite and arsenopyrite at another. A small amount of sphalerite is present with arsenopyrite, stibnite, and gold in the 
richest quartz veins. It has been found rather abundantly also at two localities in calcareous bands in the schist, associated with iron pyrites and stibnite.

The occurrence of bismuth intergrown with gold has been noted. Small grains composed of these two metals have been found in the concentrates from the placers on Gilmore Creek and in the upper valley of Fish Creek, both in areas of schist and granitic intrusive rocks.

Cassiterite is a common constituent of the concentrates from the placers of several creeks, where its most common associates are garnet and rutile. Wolframite has been observed in the concentrates from two localities.

Much of the gold of the quartz veins is free and visible, occurring as small flakes and grains. It has been observed embedded in limonitized crystals of iron pyrites and also in the midst of clear quartz with no admixture of ferruginous matter. Its most common associates in the richest veins are stibnite and arsenopyrite, with a little iron pyrites and sphalerite. Tellurium ores have been reported, but material tested in the laboratory of the Survey from several localities showed no trace of tellurium. Where the gold occurs in the quartz with sulphide there is a rather even distribution of these minerals throughout the portion of the vein containing them. In places a foot or more of wall rock each side of a vein has been found to be auriferous. While the richest ore is that in which abundant stibnite and arsenopyrite are associated with the quartz, veins composed of the sulphides alone have been found to carry but little gold. Values found in the rock showing specks of free gold are naturally high and help to raise the average values over a wilth of several feet in some places to about $\$ 50$ a ton. A specimen assayed for the Survey contained $\$ 1,033.50$ in gold and 11.50 ounces of silver to the ton. The value of the vein gold has been reported to be $\$ 17.50$ an ounce.

Gold has been deposited in quartz veins from solution. The process of deposition is one in which many factors have been involved. The recognition of the factors involved, the apportionment to each of its appropriate share in the process, and the determination of the relative period of deposition are problems that are difficult and only partly understood. The process and the sequence of events have to be inferred from the kinds and relations to each other of the products that are found in the veins at the present time.

The introduction of gold into the quartz veins in the Fairbanks district, so far as is indicated by the facts at present available, has been an event closely related to the introduction of the sulphides. That the introduction of the sulphides has been, to some extent, at least, independent of the introduction of quartz is shown by the presence of small veins of stibnite crosscutting the schists or cementing fragments of brecciated schist. The introduction of the sul- 
phides has been probably one of the last events in the history of vein deposition, an event during which some quartz, a little mica, gold, and sulphides were deposited, partly in quartz veins already formed and partiy in the form of new veins, some of which are veins of solid stibnite. The deposition in the veins already formed seems to have been either conformable to the preexisting quartz or unconformable to such quartz in spaces resulting from more or less shattering before the deposition of the gold and sulphides. The facts seem to point to the latter supposition as being more expressive of the truth.

The sequence of events may have been somewhat as follows: At about the close of intrusive activity, after the intrusion of dikes of granite porphyry and persilicic granitic dikes with related quartz veins containing a small proportion of alkali feldspar like that of the persilicic granitic dikes, there was an introduction of further products of intrusive activity, solutions in part auriferous. Through the activity of these after-products of the intrusive process some of the dikes have been sericitized with a little alteration of iron pyrite to iron carbonate, and from these solutions have been deposited gold and sulphides. The occurrence of tourmaline in close association with iron pyrite and arsenopyrite at one locality seems to show one phase of the process.

The facts indicate a close relation between the gold and the sulphides and the reference of both to a genetic relationship with the igneous rocks. The period of metallization was probably the close of the Mesozoic.

\section{DESCRIPTION OF LOCALITIES.}

The localities where most of the quartz prospecting has been done are Skoogy Gulch, Bedrock Creek, the ridge between Bedrock and Chatham creeks, Chatham Creek, Willow Creek, the ridge at the head of Wolf Creek, and the ridge at the head of Alder Creek.

The prospects in Skoogy Gulch, including the North Star, Centre Star, S. S., and other locations, are all in schist close to intrusive rocks. The quartz diorite of Pedro Dome and the porphyritic biotite granite of Twin Creek are separated on the west side of Skongy Gulch by only a few hundred feet of schist. The presence of fragments of the lioritic rock penetrated by small dikes of the granitic rock indicates the still closer relationship of the two intrusives. The rock in which the mining developments have been carried out is quartzite schist and quartz-mica schist, striking northeast. The rock is somewhat metamorphosed by the contact influence of the intrusive rocks, an influence shown by the presence of a large amount of biotite and some andalusite. While some of the schist is very micaceous, much of it is a dense blocky quartzite schist. 
A small granitic dike about half an inch thick in one of the tunnels shows the closeness of the igneous influence.

Auriferous quartz veins are reported to have been traced on this slope of Skoogy Gulch for 500 to 800 feet. At one locality where surface prospecting in 1908 had discovered an auriferous stringer about 4 inches thick, together with several smaller auriferous stringers, some of them along the joint planes of the schist, a shaft about 65 feet deep and a tunnel about 200 feet long had revealed in 1909 a considerable number of stringers, some of them barren and some of them carrying high values.

The vein regarded as the main lode strikes northwest and is said to average about 3 feet in thickness. Several hundred feet farther in the same direction a shaft has been sunk on a vein 10 to 12 feet thick which carries values.

The marginal portion of the porphyritic granite contains in places a large amount of iron pyrites in the granite itself and along the joint planes. Iron pyrites occur similarly along the joint planes of the schist at the locality of the auriferous quartz veins. The granite contains also some pegmatitic quartz and feldspar, occurring as feldspathic veins in quartz and quartz veins in feldspar; in some of these veins both margins are feldspar and the middle is quartz. The quartz present in these granitic products is gray and glassy. In the quartz veins that have been opened there is a similar gray glassy quartz and this is apparently barren. The auriferous quartz is grayish white and opaque. The veins of both the barren quartz and the auriferous quartz contain a small amount of feldspar. This is mostly kaolinized, but so far as determinable is like that of the pegmatitic granite dikes above mentioned. Cavities studded with quartz crystals are rather common in the quartz. Limonitized crystals of iron pyrites are common in the auriferous is quartz. The gold occurs partly in visible form embedded either in the limonitized crystals of pyrite or in the quartz. The auriferous quartz contains a large number of microscopic liquid inclusions and so far as observed has been more or less shattered. Although it is possible that the auriferous pyrite and free gold were deposited synchronously with the quartz, it seems more probable that the deposition of gold was subsequent to a shattering of the quartz and synchronous with the deposition of pyrite along the joint planes in the schist and porphyritic granite.

Auriferous quartz has been reported also from the east side of Skoogy Gulch, where limonitized iron pyrites occurs along the joint planes of the schist and where there are also numerous small quartz stringers. High on the eastern slope of Skoogy Gulch a prospect has revealed stringers composed of quartz and arsenopyrite parallel to the structure of the schist. 
At a location known as the Free Gold, on the east slope of the valley of Bedrock Creek near the mouth, rich ore hins been discovered. The schist bed rock is traversed by quartz stringers and one main quartz vein from a few inches to nearly 3 feet in thickness, averaging about 20 inches. This vain is reported to have been traced for about 800 feet on the surface and to have been found auriferous throughout that distance. A tunnel had been driven along the vein for about 90 feet, and at a point along the strike of the vein about 800 feet uphill from the tunnel a shaft had been sunk on the vein to a depth of 50 feet. The portion of the vein exposed at the end of the tunnel is about 50 feet below the surface. The strike of the vein ranges from N. $75^{\circ}$ W. to N. $65^{\circ} \mathrm{E}$. It is in general northeast, with a dip of about $60^{\circ} \mathrm{SE}$. The quartz has been more or less shattered and is slickensided and at one place in the tunnel the vein was lost for a short distance by local faulting. The quartz is grayish white and opaque. It is in part compact and in part of rather open texture, with quartz crystals partly individualized. There are a few grains of kaolinized feldspar and a little colorless mica seattered through the quartz. Mnch of the gold present is visible and is partly in close assoriation with sulphides. The most abundant sulphides are stibnite and arsenopyrite, but iron pyrites and sphalerite are also present. The gold and sulphides, together with some quartz, have apparently been introduced together at a period subsequent to the formation of much of the quartz. The stibnite and arsenopyrite occur mostly as independent crystals or groups of crystals and the gold is partly granular. The portions of the vein rich in sulphides form an evenly granular finegrained mass of quartz with the two predominant sulphides and free gold. These sulphide-rich portions are in places sharply demarcated from the rest of the vein but in other places grade into quartz with only a small proportion of sulphides. The proportion of gold is greater in the sulphide-rich portions of the vein. Part of the gold is so intimately associated with the sulphides that after the ore rich in sulphides is roasted gold appears on the surface as globules.

At two other localities on the east slope of the Bedrock Valley, one of them, the Wyoming Ledge, about 2,000 feet above the mouth of the creek, and the other, the Emma, near the head of the creek, similar auriferous quartz was being prospected. At the Emma the quartz vein had been exposed by a shaft abovt 40 feet deep. The strike, nearly east and west, and the dip, high to the southeast, show approximate parallelism with the vein at the Free Gold, already described. The vein ranges from a few inches to about 16 inches in thickness and is about parallel with the structure of the schist. The quartz and mineral association are similar to those of the vein already described. The schist at this locality has been much brecciated and the fragments have been cemented by quartz.

$55695^{\circ}-$ Bull. $442-10--15$ 
On the ridge between the head of Bedrock Creek and the head of Tamarack Creek there is a small mineralized mass interbedded in the schists, containing some quartz, galena, iron pyrites, arsenopyrite, and stibnite.

Chatham Creek was a good producer of placer gold for about 1 mile above its mouth. Gold quartz and sulphides have been found at several localities in the Chatham Valley either within or just above the portion of the valley where placer gold was found. A small quartz stringer carrying free gold was discovered at the upper end of the productive gravels in 1908. The Pioneer Quartz Mining (ompany has done considerable work at this locality. A shaft was sunk near the creek to a depth of 24 feet, when water was encountered. A second shaft was sunk about 100 feet farther up the east slope of the valley to a depth of about 85 feet on a vein about 3 feet thick, striking northeast and southwest. This vein was found to intersect the smaller vein at nearly right angles. At the intersection the smaller vein, it is reported, follows the main vein for a short distance and then penetrates the country rock. The smaller vein is said to range from 4 inches to 2 feet 6 inches in thickness. Both veins carry free gold, but in the smaller vein there is considerable stibnite and arsenopyrite, with some sphalerite and iron pyrites. The distribution of the sulphides is irregular, but in the portion of the vein where they occur they are for the most part rather evenly distributed through the quartz. They show a slight tendency in some places, however, to form small seams in the quartz. Pieces of free gold have been reported in the quartz, ranging in value up to 25 cents.

The Butler tunnel site was located on the west side of Chatham Creek opposite " 3 a. Chatham," in October, 1908. At a level 150 feet above the creek a tunnel was driven southwest for about 90 feet. At 50 feet from the mouth of the tunnel a shear zone was encountered about 6 feet thick, striking northwest nearly at right angles with the strike of the schists. The operators drifted northwest and then sunk on the shear zone, which was found to dip from $45^{\circ}$ to $70^{\circ} \mathrm{SW}$., to a depth of 150 feet, where the thickness was about the same as in the tunnel. Later a raise was put in above the winze, connecting it with the surface. The second level is about 100 feet below the first and extends along the vein for about 40 feet on each side of the shaft. The mica schist of the shear zone was found to be impregnated with sulphides, chiefly iron pyrites and arsenopyrite, with some galena, sphalerite, and stibnite. These sulphides also occur in the numerous quartz veins that penetrate the shear zone. Free gold is found in the upper, more oxidized portions of the mineralized zone, but it is reported that in the less decomposed, lower portions of the lode the values are in the sulphides. A noteworthy feature is the occurrence 
of tourmaline needles in the mica schist close to the contact of schist and quartz veins and in close association with iron pyrites and arsenopyrite.

At several other localities in the Chatham Valley auriferous quartz has been found, as well as veins of stibnite, and more or less development work has been done.

On the old wagon road between Bedrock and Chatham creeks, in line with the rich ore occurrences near the mouth of Bedrock Creek and those just described, the shattered schist contains considerable stibnite and some gold. A Keystone drill was used for prospecting during the winter of 1908-9 and prospects were found over a width of about 200 feet. During the summer of 1909 the ground was being prospected by trenehing.

On the east side of Willow Creek, about 1,000 feet above the mouth, work was just being commenced by the Willow Creek-Tolovana Mining (ompany on quartz stringers that had been found to be auriferous. The schist was traversed by a number of small parallel stringers striking $\mathrm{N} .75^{\circ} \mathrm{E}$. and ranging from less than 1 inch up to about 3 inches in thickness. Gold was visible in several of these stringers. One minute vein at this locality was found to be composed of quartz and fresh albite.

There are several other localities in the upper Cleary Valley where sulphides and some gold have been found.

Near the head of Wolf Creek, on the Willie claim, 4 to 5 feet of ferruginous quartz and mineralized schist have been exposed from which gold can be panned. The strike is N. $50^{\circ} \mathrm{E}$. and the dip $80^{\circ} \mathrm{SE}$. It is reported that the deposit has been traced by float along this strike for about 1,000 feet.

At the head of Alder Creek, a tributary of Fairbanks Creek, at the McCarthy property, including the Lime, Lemon, and North Star claims, is a vertical quartz vein striking about N. $40^{\circ} \mathrm{E}$. and 12 to 13 feet wide. A tunnel has been driven parallel to the vein for about 120 feet and the lode has been crosscut at a depth of 50 feet. Along the margin of the vein and along the horses of schist that are found in it there is considerable mineralization, and some values are reported. Two other similar large quartz ledges parallel the one described, but had not been opened in 1909 . The vein quartz of these localities is much fractured and the mineral-bearing solutions have apparently been introduced subsequent to the fracturing.

There is apparently a zone in which auriferous quartz veins are particularly abundant, extending northeastward from the head of Cleary Creek across the Willow, Bedrock, and Chatham valleys and on into the ridge at the head of Wolf and Fairbanks creeks. Its extension to the southwest is indicated by the discovery of some auriferous quartz near the head of Big Eldorado Creek. 
Besides the localities above described, others have been reported that are outside the areas visited, and throughout the Fairbanks district a large number of quartz and tunnel-site locations have been made.

\section{METHODS OF PROSPECTING.}

Prospecting for quartz in the Fairbanks district is rendered particularly difficult by the fact that the broken bed rock is for the most part deeply buried under a permanently frozen cover. The process of prospecting employed is that used so extensively in Oregon and California by the pocket hunters, and many of the auriferous veins in the Fairbanks district lave been discovered by men conversant with this process. Prospect holes a few feet in depth at intervals up to 20 feet or more are lug along a hillside where auriferous quartz is suspected. When, by panning the material, colors are found, the same process is employed in tracing the colors up the slope to their origin in the bed rock. Proximity to the vein is indicated by increase in the size and number of colors and their deeper position in the overburclen. Trenches are then dug until the vein is revealed. Subsequent operations in the Fairbanks district, where the veins are liable to change in direction and where they have in places become discontinuous by local faulting, should be confined to the vein. $\Lambda$ practice particularly to be avoided is the driving of long tunnels to intercept the rein at points where its existence has not been demonstraterl. In an area of schist like that of the Fairbanks district, where there has been extensive deformation at different periods and where some of the deformation has taken place subsequent to goll deposition, it is especially advisable to confine development to the vein itself, to trace its extent on the surface, and if the surface extent justifies further operations to sink upon it or to tunnel along it, according to conditions.

To facilitate the work of testing ore that was being discovered during 1908 and 1909 the business men of Fairbanks raised by subscription a sufficient sum for the construction of a stamp mill. A local firm built a 3-stamp gravity mill out of the material available, with stamps weighing 275 pounds each and working 80 to 90 drops a minute. The capacity of the mill ranges from 3 to 5 tons in twentyfour hours. The ore tested at the mill has run from $\$ 25$ to $\$ 200$ a ton of free gold, with an average of about $\$ 50$ a ton. The cost of mining and milling combined, including freight from mine to mill, is about $\$ 50$ a ton.

\section{SUMMARY.}

The bed rock of this district is predominantly schist, regarded as pre-Ordovician in age. The granitic rocks are intrusive and therefore later than the schists. The age of intrusion, although not definitely 
known, is believed to have been Mesozoic, approximately that of partly similar intrusives in the Rampart region which cut Paleozoic and Upper Cretaceous rocks. Quartz veins have been formed at different periods and a part of them have apparently resulted from the intrusions.

The deposition of golıl and sulphides has been for the most part, at least, subsequent to the greatest part of the quartz of the quartz veins, and the ore-bearing solutions have been admitted in part after a fracturing of the veins. There is a close relation between the gold and the sulphides. The most common sulphides are stibnite, arsenopyrite, and iron pyrites. Small rich veins and larger veins with lower values have been found. Local faulting has taken place since the deposition of the grold, and this fact must be borne in mind in opening the veins. The deeply covered bed rock and local faulting render the process of prospecting expensive. In addition to the natural difficulties there are those imposed by the high transportation rates on all supplies, so that prospecting for quartz in the Fairbanks district is an undertaking requiring considerable capital.

The work accomplished in 1908 and 1909 was of the nature of prospecting. Small dumps of ore were accumulating at the openings of several tunnels and a few tons at each dump had been sacked awaiting shipment to the mill. Only the superficial portions of the ore had been exposed and insufficient work had been done to determine with definiteness changes in the character or value of ore with depth. In a few places a decrease in the amount of free gold had been noted. It is very probable that the eroded upper portions of these veins were much richer in free gold than the portions at present exposed and that these upper portions, enriched by long-continued weathering, furnished the bulk of the grold for the deeply buried productive gravels of the present valleys. It is probable also that the proportion of free gold diminishes with increasing depth. It has been demonstrated that there are many veins which carry gold. It is possible that the rich placers have had a multiple origin in the bed rock and that the gold has been distributed through a large number of small veins rather than concentrated locally into large bodies of ore, and the facts indicate that this is in part, at least, the case. It has been demonstrated further that there are veins worth the work hitherto expended on them--veins that possess such dimensions and values as to merit sufficient work to determine their possibilities. 


\title{
PLACER MINING IN THE YUKON-TANANA REGION.
}

\author{
By C. E. Ellsworth.
}

\section{INTRODUCTION.}

During the mining season of 1909 the writer was engaged in an investigation of the water resources of the Fairbanks, Birch Creek, Rampart, Hot Springs, and Salchaket placer districts of the YukonTanana region. (See p. 15.) Incidental to this work, some notes were made on the mining developments which came under his observation, but the data collected were more or less fragmentary, for only a small percentage of the plants in operation were actually visited. In the preparation of this report these data have been supplemented by information furnished by other members of the Survey, as well as by residents of the district, including United States commissioners, mine operators, and others too numerous to mention individually. The statistics of production are based on the reports furnished to the Survey by operators, supplemented by statements of banks, express companies, and deputy collectors. (See pp. 16-17.)

\section{FAIRBANKS DISTRICT.}

\section{MINING CONDITIONS.}

General statement.-Notwithstanding the fact that the richest pay streaks of many of the creeks in the Fairbanks district have been practically worked out, the value of the production for 1909, estimated at $\$ 9,650,000$, was the largest since the discovery of gold in this district in 1902. Aside from the lode prospecting described in detail by L. M. Prindle (pp. 210-229), there were no new developments of importance. The large production was due mainly to the further tracing of the pay streaks already known, the most notable of which is that of Engineer Creek.

It has been estimated that over 100 steam-hoisting plants were operated in the Fairbanks district in 1909 and probably about 3,000 men were employed in mining. No marked improvements were made in the methods of mining, but a more careful supervision of work by mine owners is gradually leading to more economical exploitation. A noteworthy feature is the increased use of both steam 
and horse scrapers in handling the gravels and tailings: A shortage of staples before the opening of navigation in the spring of 1909 caused such excessively high prices that several operators were compelled to discontinue work. With few exceptions the wages continued at the same rates as in 1908 , namely, $\$ 5$ a day and board. Most of the plants worked two shifts daily, of ten hours each.

Owing to the limitations put on mining by the present operating costs only the richest pay streaks are mined, and many of these have been exhausted. It is probable that there are few open-cut operations in the Fairbanks district where the recovered values are less than $\$ 1$ to the cubic yard, and the average cost of drift mining is about $\$ 3.50$ a cubic yard. There is known to be a very large amount of gravel carrying lower values, but it can not be profitably mined until radical changes in mining methods are introduced. Relatively little attention has been given by operators to the problem of recovering these lower values. It is safe to say that the conditions are not favorable to hydraulic mining. This is largely due to the fact that in most places it will not be commercially possible to obtain water under sufficient head, but also to the depths of the deposits and the low stream gradients.

Although some of the ground may be too deep for dredging, much of it could probably be economically handled by such means if cheap enough power could be obtained; and if the overlying muck of the deep ground could be removed by water such ground might be made suitable for dredging, but the difficulty of obtaining water under pressure has already been mentioned and can not be too thoroughly emphasized. Cursory investigations have been made relative to the possibilities of developing electricity by water power for operating dredges, pumping water, etc., but no real advance has yet been made. The extensive coal deposits in the northern foothills of the Alaska Range have been described by Prindle ${ }^{a}$ and a consideration of their possibilities as a means of developing electricity to be transmitted to the Fairbanks mines seems worthy of careful thought.

Dredging frozen ground is impracticable and the cost of thawing about doubles the expense. Thawing by the use of water under head has been introduced in the Klondike region, and this method is said to be cheaper than any other heretofore devised. ${ }^{b}$ The strict application of this method would be impracticable in the Fairbanks district because of the large amount of water under pressure required, but a modification of such means might be practical.

Much of this field has reached the stage where further developments will require a large amount of capital. It appears as if the

a Prindle, L. M., The Bonnifield and Kantishna regions: Bull. U. S. Geol. Survey No. 314, 1906; pp. 221-226; see also Brooks, A. H., The mining Industry in 1908: Bull. U. S. Geol. Survey No. 379, 1909 , p. 47.

b Op. cit., p. 41. 
quantity of gold-bearing gravels, the comparative accessibility of the creeks by railway and wagon roads, and the established commercial conditions justify investigation by engineers experienced in placer mining. Only on the results of such an investigation, probably supplemented by some preliminary experimentation, can the most economic methods of exploitation be determined.

Goldstream Creek and tributaries.-The productive area in the Goldstream basin has been largely increased and this area leads the Fairbanks district in output for the year 1909. Rich deposits have been located on the left bank of Goldstream Creek, and the chances of further discoveries in this valley are promising.

The main valley for about 4 miles below Gilmore Creek is thickly dotted with steam plants, many of which are of large capacity. The principal producing tributaries of Goldstream in 1909 were Engineer, Pedro, and Gilmore creeks. Several very rich claims were located on Engineer Creek during the year and it was probably the leading creek in the Fairbanks district for the season in gold output. Pedro and Gilmore creeks were mined extensively for nearly their entire length. A small amount of mining was also done above claim "No. 7 above," on Fox Creek.

Chatanika River and tributaries.-Dome Creek was probably the second in gold output for the season. The rich pay streaks of the upper part of the creek are about worked out, but prospecting along the lower course has met with success. The status of work on Vault Creek is sinilar to that on Dome Creek, in that the pay streak has been traced well into the Chatanika Flats.

Considerable mining was done on Treasure Creek, but much difficulty was experienced from underground water, and as a consequence mining on some very rich ground was abandoned.

While no doubt Cleary Creek has passed its prime as a gold producer, the extensive work now being done near the mouth in the flats of the Chatanika bears evidence that a considerable output for several years may be expected. The local water supply was found to be inadequate and during the early summer of 1909 a ditch was constructed which diverts water from Chatanika River above Pilot Creek. It follows the south side of the valley through the center of the town of Chatanika and passes beneath the railroad tracks near the depot. If in the future the demand for water for mining along lower Dome and Vault creeks should warrant the expense of construction, the ditch will probably be extended to those localities. An ample supply of water is available for suci purposes. There was considerable winter mining on upper Cleary Creek in 1909, but only two mines were being operated above Discovery claim during the summer. It was reported that an underground reservoir which has handicapped work on claims Nos. 8, 9, and 10 below Discovery has 
been drained by a tunnel. Claims Nos. 4 and 5 below, which have been under litigation for several years, will probably be worked during 1910 , and as they are known to be rich the production of the creek should be considerably augmented by their output. On Chatham Creek several mines were operated; on Wolf Creck work was confined to prospecting from which encouraging results were reported.

During the last two years there has been much mining in the Chatanika Valley along the extension of the pay streaks of the various tributary creeks. On the lower part of Cleary Creek, where its valley opens out into the flats of the Chatanika, the pay streak appears to split up and has been difficult to trace. This may also hold true of the gold-bearing gravels of the lower part of other streams, such as Dome and Vault creeks. These conditions make it difficult to prospect in these flats, for, in the absence of topographic relief, there is little to guide the search of the miner. A large amount of prospecting is therefore necessary. As the gravels average 100 feet in thickness and the cost of sinking shafts to this depth is estimated at $\$ 10$ a foot, it will be seen that the initial expense in this part of the field before any returns can be expected may be very large.

The finding of some rich gravels on Little Eldorado Creek led to a large amount of expensive prospecting during the winter of 1908-9. No extensive pay streaks were traced, hence the miners who had done the prospecting suffered considerable loss. Several claims, however, were productive, but the output did not warrant the village of no small proportions which quickly sprang up near the railroad on this creek, and in consequence it was nearly deserted later in the season.

The considerable development work which has been done on Charity Creek during the last few years was not continued in 1909.

Fish Creek and tributaries.- - Though Fairbanks Creek presented no very prosperous appearance in 1909 the value of the production was about $\$ 500,000$. Most of the work was below I)iscovery claim. Several of the small tributaries of Fairbanks Creek from the north have been found to carry gold. Current reports indicate that a dredging enterprise on Fairbanks Creek was in contemplation. The gravels on the upper part of the creek are from 9 to 15 feet in depth, with 3 to 5 feet of overlying muck, and such an enterprise seems to be warranted.

Some gold was taken from the Fish Creek valley above the mouth of Fairbanks Creek and a little prospecting was done on Bear Creek.

Cripple Creek and tributaries.-Extensive operations have been conducted on Esther Creek in the past, but the close of the 1909 season marked the completion of work on several of the richer claims. 
Ready Bullion Creek has contributed largely toward the production from this basin and some gold has been taken from Cripple Creek. A little work was also reported to have been done on St. Patrick's Creek. Winter sluicing by the use of warm water, which was commenced on Esther Creek in 1907-8, was not extensively practiced in 1909. Only two plants are known to have sluiced continuously during the winter in the Yukon-Tanana region, one on Esther Creek and one on Fairbanks Creek. Winter work is, however, said by some to be cheaper than to wait until spring and rehandle the gravel. The water is collected in the settling basin, where it is warmed by the exhaust from the engine. It is then pumped to the sluice and returned to be settled and used again.

Washington Creek.-Washington Creek, which has been staked for nearly its entire length, so far has not been productive. Very little has been clone aside from the required assessment work.

\section{PRODUCTION.}

The estimated annual and total value of the gold production in this district since its discovery in 1903 is given below:

Value of production of gold from the Fairbanks district.

\begin{tabular}{|c|c|c|c|}
\hline $1903 \ldots \ldots \ldots$ & $\$ 40,000$ & 1908. & $\$ 9,200,000$ \\
\hline $1904 \ldots \ldots \ldots \ldots \ldots \ldots$ & 600,000 & 1909. & $9,650,000$ \\
\hline $1905 \ldots \ldots \ldots \ldots \ldots \ldots \ldots$ & $4,000,000$ & & $40,490,000$ \\
\hline $1906 \ldots \ldots \ldots \ldots \ldots \ldots \ldots$ & $9,000,000$ & & \\
\hline $1907 \ldots \ldots \ldots \ldots \ldots \ldots$ & $8,000,000$ & & \\
\hline
\end{tabular}

\section{CIRCLE JISTRICT.}

\section{MINING CONDITIONS.}

General statement.-No new strikes were made in the Circle district during 1909. With the exception of hydraulicking on Eagle and Mammoth creeks the mines were worked in the same general manner as in the past, by drifting in the winter and open-cut methods in the summer. Suflicient data are not at hand to determine what proportion of the total production was due to winter or summer work, but there is no doubt that the summer output exceeded that of the winter.

The wireless station which was installed at Circle in 1908 has been found a great convenience as a means of communication with the "outside," as well as with the other mining sections of Alaska. A telephone line from (ircle to the creeks is still under consideration. The need of it is never questioned, but the necessary initiative seems to be lacking. The government road was completed nearly to the Central House, which makes a total of about 34 miles already constructed. It was planned to build several miles more during 
the summer, but owing to a rather wet season, particularly during the early part, construction was greatly handicapped. There is a decided need for a good summer road as far as the Miller House, with a branch to Dearlwood (reek. This would do much to reduce the cost of mining in this field. The value of the road already completed is shown by the fact that, although the season of 1909 was fully as unfavorable for travel as any other for several years, practically all the supplies taken to Deadwood Creek during the summer were moved on wagons, for this method was found cheaper, even with only the light loads that could be hauled, than to use pack horses, as has been done in the past. A few trips with wagons were also made as far as the Miller House.

Mastodon Creek.-Mastodon (reek still continues to be the largest producer of the district. The prevailing method of summer work is to remove the overburden by water and shovel the pay gravels into sluice boxes. There was some mining for nearly the entire length of the creek, but the most important operations were near the mouth.

An attempt has been made to work the ground on the creek more systematically by a combination of interests, but as yet little has been accomplished toward that end. While many of the richer deposits have been mined out, it is believed that the aggregate of the values left in the tailings and undeveloped portions is sufficient to warrant exploitation by dredges or large-scale methods.

Deadwood and Switch creeks.-Deadwood Creek, which comes second in production, was mined by methods similar to those used on Mastodon Creek.

During the winter of $1908-9$ seventeen claims were being worked on Deadwood (reek and eight or nine on Switch (reek, and their output for that period is variously estimated from $\$ 25,000$ to $\$ 60,000$. Nuggets valued at $\$ 41, \$ 31$, and $\$ 23$ were found, and several $\$ 8$ to $\$ 10$ nuggets were picked up. Most of the gold is much finer. The rougher and coarser gold is found near the hearls of the creeks. The miners receive $\$ 16$ an ounce for the gold.

The lower part of the creek, after it merges into the ('rooked ('reek flats, has been under consideration as suitable dredging ground for several years and has been prospeeted with that object in view, but the results are not known. There has also been some talk of hydraulicking below Switch ('reek. Daily records of stream flow were kept on Deadwood (reek just above Switch (reek during the last season. (See p. 269.) They show that possibly cluring the period covered by the records sufficient water was available, but in order to obtain a working head it might be necessary to divert the water so far above as to make the supply insufficient luring periods of drought. Nevertheless it does not seem improbable that such an enterprise might 
be successful, and it is recommended that an effort be made to obtain as complete records of stream flow as possible. If capital is to be interested, these records will be the first information called for and they will require the most time to obtain satisfactorily.

Mammoth Creek.-Mammoth (reek, which is formed by the junction of Mastodon and Independence creeks, meanders through a broad gravelly flood plain. Fine gold is said to be distributed rather uniformly throughout the gravel, which is, however, of too low a tenor to pay to work by the usual hand methods. A steam shovel was installed on the creek in 1903 , but does not seem to have proved a paying enterprise. During the summer of 1908 a ditch was constructed from a point on Bonanza ('reek about 3 miles above the mouth along the right banks of Bonanza and Porcupine creeks to a point on the left side of Mammoth ('reek a short distance below the Miller House. The length of this part is 6 miles, the grade 5 feet to the mile, and the bottom width 7 feet. In 1909 this ditch was being extended around the spur between Bonanza and Porcupine creeks for 4 miles, with an intake on Porcupine Creek at an elevation of 2,350 feet, about 4 miles above the mouth of Bonanza Creek.

Considerable difficulty was experienced during the season with the ditch constructed in 1908, owing to the thawing of ground ice and seepage through the loose rock soil. The ditch was built along the hillside, and as the ice in the bottom thawed the water followed the line of thaw until often it finally escaped to the surface below the lower bank. Unless these underground channels were soon discovered and moss was tamped into the openings in the bottom of the ditch, they rapidly wore larger and frequently only a few hours were required before the whole outside bank of the clitch near the break was ground-sluiced away. In many places where the bottom of the ditch was impervious the outer bank, which is mostly in fill, settled and slid, and if allowed to fall below the water level the overflowing water did considerable damage if not immediately stopped. Moss sod was generally used for repair work. In repairing the large breaks the bottom and sides were built up with soil and then lined with sod. Moss was thoroughly tamped into all holes and crevices in the bottom and then puddled with clay. In repairing the settling bank the sod was eut in rectangular strips and successive layers were placed and tamped as the settling proceederl. In some places this settling and rebuilding continued to such an extent that very little, if any, of the original fill could be seen. At the end of the season the ditch presented an excellent example of construction and will probably be cheaply maintained in the future. The plan is to extend the ditch eventually to a point opposite Mastodon ('reek.

The water supplied by this system will be used to hydraulic Mammoth Creek valley for its entire length from Mastodon to Porcupine 
Creek. A working head of 500 feet will be available, although at present only about 300 feet is utilized. The water is taken from a ditch in a flume down the hillside to a point about 200 feet below, where it is dumped into a pressure box at the pipe intake.

Mammoth Creek has a very low grade, and in order to overcome this difficulty a plant was installed which is novel in Alaska, but is identical in principle to the one installed on Eagle Creek in 1908. The general plan of operation is as follows: First, a bed-rock drain is excavated to dispose of the water in the cut and to carry away the overlying muck, which is hydraulicked off from the gravels to be handled by the first set-up. $\Lambda$ ('hannel is then ground-sluiced back of and above the cut and opposite the hydraulic giants. In this channel substantially constructed sluice boxes (with block riffles), similar in design to those ordinarily used in hydraulicking, are set up with a grade elepending on the character of the gravels to be washed. $\Lambda$ sheet-iron back stop about 10 feet high is then erected back of and against the boxes. The auriferous gravels are driven directly by the water from the nozales of the giants against the back stop, from which they drop into the sluice boxes.' A gravel incline is formed in front of the boxes by the stream of water as soon as operations are begun, and for this reason the force of the moving gravel is not expended against the sides of the boxes. The water for transporting and washing the gravel, after it is dropped into the boxes, is diverted from the creek about 1 mile above and carried in a ditch to the head of the sluice and after passing through is carried away in the bed-rock drain. The tailings which accumulate at the end of the sluice are "piped" back out of the way by a separate giant set up at any convenient place. It is not ordinarily necessary tooperate this giant continuously. The frequency with which the tailings have to be moved depends on the dumping room at the end of the boxes and the rate at which the gravel is being moved. This process does, however, require a quantity of water which should be taken into account in considering the supply necessary for such a system.

This method is especially adapted to working creek deposits with medium depths of gravel, where the slope of the bed rock is insufficient to permit the removal of the tailings by gravity. It has several advantages over elevators. The initial expense is less and the water required is less. No such heavy parts are required, which is an important item, especially in the more remote districts, where transportation is always expensive and often uncertain. The cost of set-ups is not as great and the chances of delay incident to repairs and replacement of parts are no greater than in ordinary hydraulicking.

Eaqle Creek.-Eagle Creek, which is formed by the two fcrks, Mastodon and Miller, rises opposite the headwaters of Mammoth 
Creek. It is the extreme head tributary of the North Fork of Birch Creek, and with the exception of its southern fork, Mastodon, is the only tributary of this fork of Birch Creek on which gold has been discovered in sufficient quantities to pay to work by the methods now in vogue. It has been a large producer in the past and has been worked mainly by drifting in winter, but this method has been displaced by others that are more economical. A hydraulic plant, similar to the one on Mammoth (reek, alrealy described, was in operation during practically the entire season of 1909 . The operators were favored with more than the average rainfall and its distribution was such that the water supply was kept fairly constant. This system of elevating gravels which is the first of its kind to be installed in Alaska, is said to be an entire success.

In addition to the above operations on Eagle Creek one claim was worked on Mastodon Fork throughout the season by open-cut and piek and shovel methods.

Miller and Independence crecks.-Mlining on Miller and Independence creeks during 1909 was of about the same extent as in previous years. Four or five claims on each creek were mined by open-cut methods by two or three men to the claim.

Harrison Creek and tributaries. - Several claims were prospected on the North Fork of Harrison Creek during the summer, and it was reported that some profits were made by open-cut and sluice-box methods. Considerable bodies of auriferous gravel are known to occur on the main creek as well as on the north and south forks, and they are reported to be suitable for hydraulicking. A recent attempt has been made to procure an option on a large number of claims on the creek with a view of installing machinery, and it was rumored that active work was commenced during the latter part of the summer of 1909, but nothing definite is known concerning the project. The first hydraulic plant of the Circle district was installed on the North Fork of Harrison Creek in 1905 and an elevator was used to raise the gravel, but the design did not prove to be suited to the conditions and the water supply was inadequate the greater part of the time. Below the junction of the two forks, however, the location seems to be favorable for obtaining a good water supply under an ample working head by a relatively short ditch line. It is possible that the methods now in use on Mammoth and Eagle creeks could be advantageoulsy used here.

Preacher Creek and tributaries.-Bachelor Creek, which is tributary to Preacher Creek from the south about 10 miles from the head, was the scene of considerable mining activity during the summer of 1909. A ditch was in process of construction along the left bank with the intake a short distance below Costa Fork. The grade of the creek was found to be about 70 feet to the mile, and a hydraulic 
elevator will be installed to raise the gravels. The gravel deposits are shallow and bed rock is exposed at many places along the creek bottom.

Preacher Creek is said to carry considerable bodies of low-grade gravel near the mouth of Bachelor Creek and they may eventually be worked on a large scale. Loper Creek, which joins Preacher Creek about 20 miles below Bachelor Creek, from the same side, is also known to carry gold and has been prospected for several years in a small way.

Woodchopper Creek.-No information is available concerning the details of mining on Woodchopper Creek, but the total value of the gold output for 1909 was reported at approximately $\$ 20,000$.

\section{PRODUCTION.}

From the scattered reports received, the total value of production in the Circle district for 1909 is estimated at $\$ 225,000$, which shows an increase of $\$ 50,000$ over that of 1908 , probably due chiefly to a better water supply, although a general trend toward working ground in a more economical and expeditious manner is noticeably in progress in this district.

The estimated annual and total value of gold production in this district since its discovery in 1894 is given in the following table:

Value of production of gold from Circle district.

\begin{tabular}{|c|c|c|}
\hline$\$ 10,000$ & $1903 .$. & 200,000 \\
\hline$\ldots 150,000$ & 1904. & 200,000 \\
\hline $1896 \ldots \ldots \ldots \ldots \ldots \ldots \ldots \ldots, 000$ & $1905 \ldots$ & 200,000 \\
\hline 500,000 & $1906 \ldots$ & 300,000 \\
\hline .. 400,000 & $190 \bar{\tau} .$. & 200,000 \\
\hline $1899 \ldots \ldots \ldots \ldots \ldots \ldots \ldots \ldots .250,000$ & $1908 .$. & 175,000 \\
\hline $1900 \ldots \ldots \ldots \ldots \ldots \ldots \ldots \ldots \ldots \ldots \ldots, 250,000$ & I909.. & 225,000 \\
\hline $\begin{array}{l}1901 \ldots \ldots \ldots \ldots \ldots \ldots \ldots \ldots \\
1902 \ldots \ldots \ldots \ldots \ldots\end{array} 200,000$ & & 60,000 \\
\hline
\end{tabular}

\section{RAMPART DISTRICT.}

\section{MINING CONDITIONS.}

General statement.-The Minook-Baker Creek divide roughly separates the Rampart and Hot Springs districts. Until the last two or three years the term Rampart district signified the area now included in both sections, but the rapid increase in production on the south side of the divide warrants the distinction now generally made.

No new enterprises were begun in the Rampart district in 1909. The considerable prospecting which was carried on during the winter of 1908-9 failed to show any new placer areas of importance.

Little Minook Creek.-Little Minook Creek, which still leads in production, has now reached the point where cheaper and more 
systematic methods of mining will have to be adopted. There is said to be some very rich ground to be worked, which is too deep for open cutting with the present water supply as now used and which can not be worked by drifting because of thawed gravel and underground water channels, which on being tapped soon flood the drift. That part of the creek bed lying below claim "No. 9 above" will no doubt eventually come under the control of one company and be systematically open cut. Some desultory investigations have been made as to the possibilities of obtaining an auxiliary water supply, but the problem is difficult of solution and it would not be surprising if it had to be abandoned and the local supply be made to do as well as possible. It seems proper to remark here that the feasibility of the various plans which have been suggested could be definitely decided once for all by a small expense in surveys, provided the aggregate value of the gold to be obtained thereby is as accurately known as is stated. From 20 to 30 men were mining on the creek during the winter. The gravel was hoisted by windlass. During the summer of 1909 the number of men employed was considerably less. Three automatic dams were operated, when the water supply would permit, to remove the overburden and concentrate the values, which were then shoveled into sluice boxes. During the periods of extreme low water they were very unsatisfactory, the seepage through and about them being about equal to the discharge of the stream. A good wagon road, connecting with the government road at the mouth of the creek, was built by the miners along the right bank as far as "No. 9 above."

Hunter Creek and tributaries.-On IIunter Creek several small dumps were taken out during the winter and some prospecting was done. Two hydraulic plants, one on "No. 18 above" and another on Discovery, were in operation throughout the summer. Both of these plants have been in operation for several years. A rock conveyer to be operated by a Pelton water wheel was shipped to the creek in the summer, but was not set up. Some work was also done on Dawson Creek, a tributary of IIunter Creek from the south, and values were reported. Favorable reports were also current from Miller Creek, a tributary from the north near the mouth.

Hoosier Creek.-On Hoosier Creek one hydraulic plant with an elevator was operated during most of the summer on claim "No. 14 above." The gold was reported to be irregularly distributed, and thorough prospecting was necessary to estimate with any accuracy the value of the ground. Some prospecting was done in the winter, but the results are reported to be not very encouraging.

Little Minook Junior Creek.-Little Minook Junior Creek is known to contain some very rich gravel, but the lack of water or of any economical method of obtaining it prohibits summer work, except 
such as may be done with a rocker. The melting of the winter accumulation of ice and snow permits the washing of winter dumps for a few days. The work of the last season was of about the same extent as in previous years.

Quail Creek.-Gold was first discovered on Quail Creek in 1898, and nearly every winter since then considerable prospecting has been done, but the gravels have, as a rule, been found to be of too low a tenor to pay to work by hand methods. The last season's work, however, has been exceptionally fruitful in demonstrating what can be done by hand methods. Claims "Nos. 8 and 9 below" and "No. 7 above" were worked by six men by shoveling into sluice boxes. The bench on the left bank opposite claim "No. 9 below" was crosscut and good prospects were reported. The creek promises to become an important producer if capital can be procured for development.

Other creeks. - Some mining was done on Ruby and Slate creeks during the summer. Chapman Creek also shows values sufficient to attract an occasional prospector, and one or two claims which were said to contain values were being developed during the summer. Seven or eight men were seen along the bars of Minook Creek shoveling into boxes or rocking where the bed rock was exposed at the rims. They are reported to have made good wages. Moose Creek and its small tributary, Buckeye Creek, have been generally staked, and while prospecting has shown gold, no values were reported.

\section{PRODUCTION.}

Lack of information prevents anything but a very rough estimate of the production of the district for 1909 , which is placed at $\$ 100,000$ and is somewhat in excess of that of 1908 , owing to the better water supply.

The estimated value of the gold production in this district previous to 1904 and the annual value since and including 1904 are given in the following table:

Value of production of gold from Rampart distriet.

\begin{tabular}{|c|c|c|c|}
\hline Previous to $1904 \ldots \ldots \ldots \ldots \ldots$ & $\$ 616,000$ & $1908 \ldots \ldots \ldots$ & $\$ 75,000$ \\
\hline & 90,000 & $1909 \ldots \ldots \ldots \ldots \ldots \ldots$ & 100,000 \\
\hline 1905 . & 80,000 & & \\
\hline $1906 \ldots$ & 120,000 & & $1,206,000$ \\
\hline $1907 \ldots \ldots \ldots \ldots \ldots \ldots$ & 125,000 & & \\
\hline
\end{tabular}

HOT SPRINGS DISTRICT.

MINING CONDITIONS.

General statement.-The value of the gold production from the Hot Springs district in 1909 is estimated at approximately $\$ 325,000$, which is more than double the estimated output in 1908. The $55695^{\circ}-$ Bull. $442-10-16$ 
water supply was slightly better, but the increase in production was due mainly to the development of the mines on Sullivan Creek. As there are large bodies of gravel in this district known to contain values, and as prospecting is continually developing new ground, the outlook for the future of the camp is good.

Thanksgiving Creek.-On Thanksgiving Creek the bed-rock flume which was excavated in 1908 was found to have too small a grade to remove the tailings with the small amount of water available and was abandoned this season in favor of an elevated flume. A pole incline to the flume was built opposite the cut and the dirt was hoisted up the incline by a steam scraper, operated by a doubledrum hoist. This system gave entire satisfaction when the water was sufficient and required less water than the bed-rock flume. Considerable gold was found in the muck overlying the gravel and a very vigorous washing was necessary to remove it.

Pioneer Creek.-The summer mining on Pioneer Creek was confined mainly to What Cheer Bar and open-cut methods were used. The muck was ground-sluiced off and the gravels were carried to the sluice boxes by a steam shovel supplemented by some pick-andshovel work. Several winter dumps were taken out by hand methods on the creek and its tributaries.

Eureka Creek.-Extensive open-cut work was in progress on Eureka Creek near the mouth of Boston Creek during the summer of 1909 , but the output was greatly curtailed by lack of water. A ditch was constructed in the early summer, which diverts water from Pioneer Creek above Boothby Creek, with the outlet on Eureka Creek a short distance above Boston Creek. The length is $2 \frac{1}{2}$ miles, the bottom width 5 feet, and the grade 5 feet to the mile. A few men were sluicing during a part of the summer near claim "No. 14 above." An attempt was made during the winter to obtain artesian water by a churn drill, but after a depth of about 200 feet was reached lack of casing necessitated the suspension of work for the season. It was planned to continue drilling during the winter of 1909-10.

Patterson Creek basin.-Values were located in the Patterson Creek basin on Sullivan Creek just below Tofty Gulch by Messrs. Snyder and Kempter January 1, 1907. Since then pay has been found at several different localities, and by the spring of 1909 a thriving camp was established. The business center, called Tofty, is situated about $1 \frac{1}{2}$ miles above Tofty Gulch on the east side of the valley, at the crossing of the Hot Springs-Tanana winter mail trail. Three road houses and several stores are located there and a postoffice has been recently established.

The open-cut work on Tofty Gulch was continued during the summer of 1909 and, although progress was frequently retarded by 
lack of water, about 75,000 square feet of bed rock has been uncovered. The 5 or 6 feet of muck which overlies the gravel was so thoroughly intermixed with small trees and driftwood that great difliculty was experienced in disintegrating the mixture of frozen muck and wood. Dynamite was used to break down the banks and to give a greater area for attack by the sun's rays and water. Steam points were used to pierce the banks for the insertion of dynamite.

Discovery claim and "No. 1 below" have been worked more or less continuously for nearly two years. Considerable excitement was occasioned by the finding of gold on the so-called left-limit bench during the winter of $1908-9$ and several steam hoisting plants were installed there. A large number of men were employed and work was actively carried on until the extreme low water of midsummer necessitated its suspension. The Midnight Sun, Abe Lincoln, and Dakota Bar were the principal producing claims. The depth to bed rock varies from 40 to 60 feet. In some places as much as 10 feet of the overlying gravel carries values. The gold, however, appears to be irregularly distributed and no very definite pay streak has yet been traced.

Cache Creek, which unites with Sullivan Creek to form Patterson Creek, has been prospected more or less for several years, but values were first discovered during the winter of 1908-9, near the winter trail crossing about 1 mile from Tofty post-office. Two or three self-dumping steam hoists were soon installed and active mining was at once commenced. The results are reported as satisfactory.

Quartz Creek, one of the headwater streams of Sullivan Creek, carries coarse gold, and open-cut mining has been carried on there for the last two summers. The ground is shallow and is cheaply worked when the water supply will permit.

\section{PRODUCTION.}

The estimated value of the gold production in this district previous to 1904 and the annual value since and including 1904 are given in the following table:

Value of production of gold from Hot Springs district.

\begin{tabular}{|c|c|c|c|}
\hline Previous to 1904 & $\$ 262,900$ & 1908 & $\$ 150,000$ \\
\hline 1904 . & 146,500 & $1909 \ldots \ldots \ldots \ldots \ldots$ & 325,000 \\
\hline $1905 \ldots$ & 120,000 & & \\
\hline$\ldots \ldots \ldots \ldots$ & 180,000 & & $1,359,400$ \\
\hline
\end{tabular}

\section{FORTYMILE AND EAGLE DISTRICTS.}

The Fortymile and Eagle districts were not visited by members of the Survey last year, but the reports from those sections indicate that the season of 1909 was exceptionally prosperous. 
Fortymile district.-The results of the work of two dredges on Walker Fork and one on the South Fork of Fortymile River that were successfully operated throughout the season have demonstrated that this form of mining is practicable, notwithstanding the remoteness of the placers, which renders the introduction of heavy machinery very expensive.

The following table, based on information furnished by $\mathrm{E}$. R. Brady, United States commissioner at Jackwade, shows the progress and distribution of work on the principal creeks of the district during 1909:

Mining operations in Fortymile district.

\begin{tabular}{|c|c|c|c|c|c|c|}
\hline \multirow[b]{2}{*}{ Stream. } & \multicolumn{3}{|c|}{ Winter, 1908-9. } & \multicolumn{3}{|c|}{ Summer, 1309.} \\
\hline & $\begin{array}{c}\text { Num- } \\
\text { ber of } \\
\text { claims. }\end{array}$ & $\begin{array}{l}\text { Num- } \\
\text { ber of } \\
\text { men. }\end{array}$ & $\begin{array}{l}\text { Produc- } \\
\text { tion. }\end{array}$ & $\begin{array}{l}\text { Num- } \\
\text { ber of } \\
\text { claims. }\end{array}$ & $\begin{array}{l}\text { Num- } \\
\text { ber of } \\
\text { men. }\end{array}$ & $\begin{array}{l}\text { Produc- } \\
\text { tion. }\end{array}$ \\
\hline 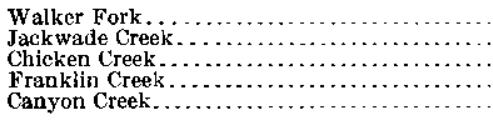 & $\begin{array}{r}10 \\
12 \\
12 \\
\cdots\end{array}$ & $\begin{array}{r}10 \\
40 \\
30 \\
\cdots\end{array}$ & $\begin{array}{r}\text { None. } \\
\$ 25,000 \\
10,000 \\
5,000 \\
\text { None. }\end{array}$ & $\begin{array}{r}3 \\
10 \\
12\end{array}$ & $\begin{array}{l}30 \\
35 \\
30\end{array}$ & $\begin{array}{r}\$ 130,000 \\
20,000 \\
6,000 \\
5,000 \\
5,000\end{array}$ \\
\hline
\end{tabular}

Incomplete reports from Ingle Creek show that substantial results were obtained by winter work. Lilling Gulch, a small tributary of Ingle Creek, was also mined by drifting and open-cut work. On Napoleon Creek the mines were worked by both open cuts and drifting and a relatively large output as compared with previous years was reported.

The value of the production for 1909 , estimated at $\$ 225,000$, indicates a gain of about $\$ 75,000$ over that of 1908 , and the increase is probably due chiefly to the improvement in mining methods.

The estimated value of the gold production in this district previous to 1904 and the annual value since and including 1904 are given in the following table:

Value of production of gold from. Fortymile district.

\begin{tabular}{|c|c|c|c|}
\hline Previous to $1904 \ldots \ldots \ldots \ldots$ & $\$ 4,000,000$ & $1908 \ldots \ldots \ldots \ldots \ldots$ & $\$ 150,000$ \\
\hline $1904 \ldots \ldots \ldots \ldots \ldots \ldots \ldots$ & 307,000 & $1909 \ldots \ldots \ldots$ & 225,000 \\
\hline $1905, \ldots \ldots \ldots \ldots \ldots \ldots$ & 256,000 & & \\
\hline 1906. & 204,000 & & $5,282,000$ \\
\hline $1907, \ldots \ldots \ldots \ldots \ldots \ldots$ & 140,000 & & \\
\hline
\end{tabular}

Eagle district.-In the Eagle district American Creek was probably the principal producer, but some mining was also done on Crooked and Barney creeks and Seventymile River. A total gold output of about $\$ 25,000$ was reported. 


\section{SALCHAKET-TENDERFOOT DISTRICT.}

\section{MINING CONDITIONS.}

Tenderfoot and Banner creeks.-Tenderfoot Creek, which probably leads the Salchaket-Tenderfoot district in point of output and has been the best producer in the past, is now conceded to be about worked out. Mining on this creek was actively carried on during the winter of $1908-9$, but in the early summer operations commenced to decline and by the middle of July only a few mines were in operation.

The above statement applies equally well to Banner (reek and its tributaries. After the winter dumps were, washed work was discontinued on all but one or two claims. Democrat (reek, a small tributary of Banner (reek, was an important producer.

Salchaket basin.--In the Salchaket basin prospecting has been carried on for several years with indifferent results. (aribou and Butte creeks have received the major portion of the work and have rather uniformly shown values sufficient to warrant further prospecting.

Juring 1909 Caribou ('reek has come to the front as a producer and considerable local enthusiasm has been aroused by the results. Values are reported on two or three claims, and although a welllefined pay streak has not been traced it is believed that further work will prove that one exists. Some machinery has been installed and it is understood that some minor ditch work has been accomplished. Jrifting is accompanied by difficulties because of the thawed ground. Although the depth to bed rock averages about 30 feet, open-cut methods have been adopted in part.

Several men were prospecting on Redmond (reek during the winter of $1908-9$, and during the last summer two of the men continued prospecting near the mouth of Mosquito Fork. There the depth to bed rock is said to be from 40 to 50 feet and sufficient prospects to indicate the proximity of a pay streak were reported.

\section{PRODUCTION.}

Very little information is available showing the progress of work in this section for 1909. From the few reports that have been received, the output is estimated at $\$ 150,000$, which is a decided decrease from that of 1908.

The estimated annual and total values of gold production in this district since its discovery in 1905 are given in the following table:

Value of production of gold from Salchaket-Tenderfoot district.

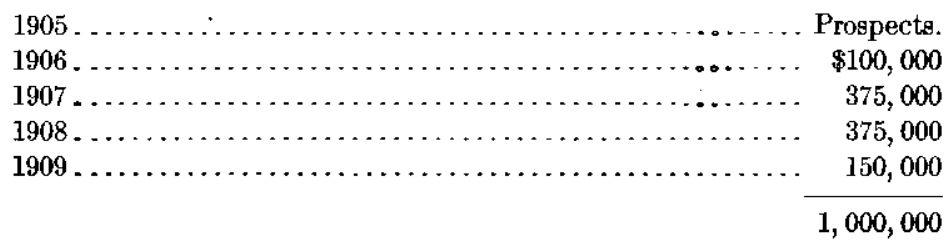




\title{
OCCURRENCE OF WOLFRAMITE AND CASSITERITE IN THE GOLD PLACERS OF DEADW0OD CREEK, BIRCH CREEK DISTRICT.
}

\author{
By Bertrand L. Johnson.
}

\section{INTRODUCTION.}

The known occurrences of tungsten and tin minerals in the YukonTanana region are restricted to the Fairbanks, Hot Springs, and Birch Creek districts. Wolframite ${ }^{\alpha}$ (a manganese-iron tungstate, $\left.(\mathrm{FeMn}) \mathrm{WO}_{4}\right)$ was first recognized in this region in 1908 in concentrates from the gold placers of Deadwood Creek, in the Birch Creek district, and later in the auriferous concentrates from the placers on Fairbanks and Little Eldorado creeks, in the Fairbanks district. Cassiterite (tin dioxide, $\mathrm{SnO}_{2}$ ) was found in concentrates from Cleary Creek, in the Fairbanks district, in 1904. It has since been found on Twin and Eldorado creeks, in the Fairbanks district, and also in the Hot Springs district. Recently it was identified in concentrates from Mastodon Creek, in the Birch Creek district, and also in association with the wolframite at the Deadwood Creek locality. In June, 1909, a Survey party visited Deadwood Creek, and the following description is based on the data obtained by the writer at that time.

\section{GEOGRAPHY.}

Deadwood Creek rises in the long line of hills culminating in Mastodon and Porcupine domes and flows northeastward to its junction with Crooked Creek, 30 miles southwest of Circle. It is 15 miles in length. The upper 10 miles of its course lies within the hills, where the narrow valley is bordered by long level-topped ridges 2,000 feet above the stream. The lower portion of the valley merges gradually with the low, level alluvial flats of Crooked Creek. Switch Creek is the most important tributary. Through most of its course Ieadwood Creek flows close to the steep east side of the valley. There is

\footnotetext{
a The tungsten minerals used as ores are hübnerite, a tungstate of manganese; wolframite, a tungstate of iron and manganese; ferberite, a tungstate of iron; and scheelite, calcium tungstate. The first three minerals grade into one anotler, and a chemical analysis is necessary for an exact determination of the mineral species. The $\mathrm{MnO}$ content of this group ranges from zero in pure ferberite to 23.4 per cent in pure hübnerite. The intermediate members of this series, with a MnO content of 3 to 15 per cent approximately, are usually considered as wolframite. A recent determination made in the chemical laboratory of the United States Geological Survey shows the tungsten mineral occurring in the Deadwood Creek placers to contain 7.3 per cent of $\mathrm{MnO}$, and it is therefore referred to in this report as wolframite.
} 
a well-defined, gravel-covered, rock-cut bench on the west side of the valley, approximately one-half mile in width, rising gradually toward the west from 75 to 200 feet above the stream. Poorly defined gravel benches occur at lower levels.

The supplies for this creek are brought from Circle. During the summer of 1909 the government wagon road from Circle was extended to the Central House, on Crooked Creek. From Central House the Deadwood Creek trail is passable for wagons as far as the mouth of Switch Creek. The rates for freighting are 10 to 15 cents a pound in the summer and 2 to 3 cents a pound in the winter.

\section{GEOLOGY.}

The bed rock consists of closely folded metamorphic rocks, principally of sedimentary origin and regarded as pre-Ordovician in age, and an intrusive granite. Quartzite schists and quartz-mica schists predominate, but carbonaceous, greenstone, and chloritic schists are present. Sulphides and magnetite occur, disseminated throughout the metamorphic rocks, and may have resulted from the metamorphism of the original sediments, or may have been subsequently introduced at the time of the granitic intrusion. The schists are garnetiferous in places. Exposures of the granite were observed at four localities

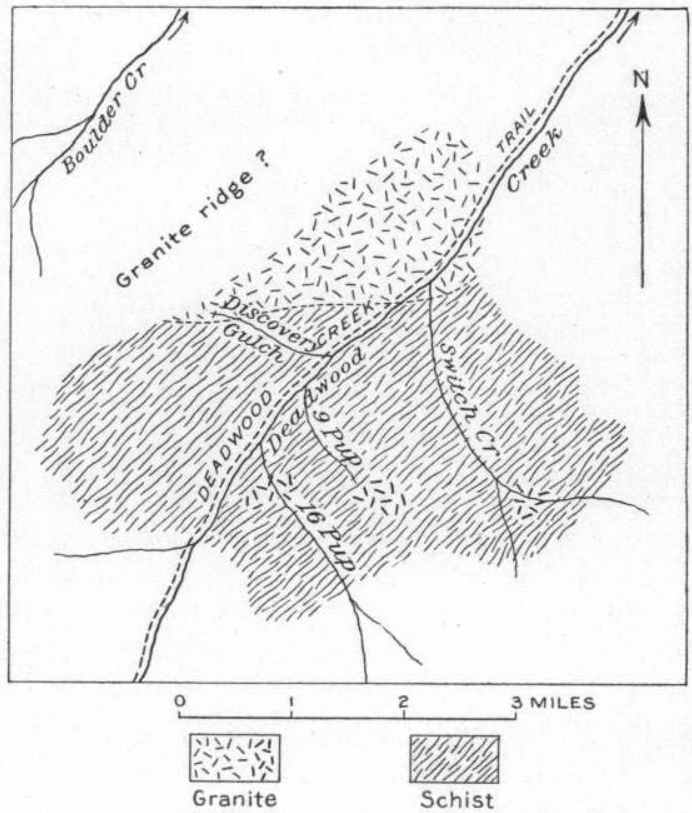

Figure 5.-Geologic sketch map of Deadwood Creek. in the vicinity of the tungsten placers. (See fig. 5.) The rock is a light-colored porphyritic biotite granite, with abundant feldspar phenocrysts. The age of the intrusion of the granite mass is not known. The nearest similar intrusive rocks whose age is rather definitely determined are those of the Rampart region, where Upper Cretaceous rocks have been intruded.

Numerous quartz veins are found in the metamorphic rocks. These veins vary considerably in size, ranging from a fraction of an inch to several feet in width, though most of them are but a few inches 
wide. A few small quartz veins were seen, which were closely folded with the inclosing schists. Most of the veins, however, cut across the foliation of the schists, are not folded, and are therefore younger than the regional metamorphism which produced the schists. They were probably formed during the final stages of the consolidation of the intrusive granite mass. The rusty appearance of a few of these later quartz veins indicates the former presence of sulphiles, but the greater number of the veins show no surface signs of mineralization. Numerous bowlders showing feldspar-bearing quartz veins cutting schist can be seen in the creek gravels. Arsenopyrite occurs in association with these quartz-feldspar veins, especially on Switch Creek. On Deadwood Creek wolframite pebbles with mica and quartz attached have been found in the placers. Fragments of schist containing gold-bearing quartz veins have been found in the Birch Creek region, and gold nuggets with attached vein quartz have been found on many of the claims on Deadwood and Switch creeks. Mineralized fracture zones permeated by quartz stringers carrying pyrite and galena have been found in the schists on the upper part of Deadwood Creek.

The unconsolidated deposits of the area are divisible into creek and bench gravels. The creek gravels are distributed over a stream flat several hundred feet wide. The depth to bed rock varies in the creek bed from 3 to 12 feet, and on the high bench to the west from 6 to 20 feet. The gravels in both localities are composed of the varieties of rocks outeropping within the drainage area of the creek. They consist of subangular fragments, mostly under a foot in diameter, irregularly arranged, and containing much fine material.

\section{OCCURRENCE OF THE WOLFRAMITE AND CASSITERITE.}

No exposures of the wolframite or cassiterite in place were seen. A small wolframite-bearing vein was reported to have been found in a prospect hole sunk while prospecting the high-bench gravels for gold, on the high bench west of Deadwood Creek, near the junction of Deadwood Creek and Discovery Gulch. ${ }^{a}$ At the time of the writer's visit this prospect hole had caved in and was filled with water. No wolframite could be found on the dump.

Wolframite and cassiterite occur most abundantly in the placer gravels of Deadwood Creek a short distance below the mouth of Discovery Gulch. Concentrates collected from the sluice boxes here are composed principally of these two minerals. Placer wolframite is also reported from Discovery Gulch. It is not known to occur in the stream gravels of Deadwood Creek above the mouth of this gulch, nor has any been detected in the examinations of the concentrates

\footnotetext{
a The name Discovery Gulch is used to designate the small gulch which enters Deadwood Creek from the west near "Discovery Deadwood," about 1 mile above the mouth of Switch Creek.
} 
collected above this point. It is not known whether these minerals are present in the high bench gravels. The placer wolframite is found on all the creek claims on Deadwood Creek for at least 4 miles below Discovery Gulch, but it is not as plentiful on the lower claims as above the mouth of Switch Creek. The coarsest and most abundant welframite and cassiterite are found on the west side of Deadwood Creek, a short distance below Discovery claim. The wolframite occurs in waterworn cleavage fragments, with slightly rounded edges. The color and streak are both dark brown. The largest piece seen measured 1.7 by 0.8 by 0.8 inches, but pieces three times as large as this are reported to have been found. The largest piece of cassiterite observed in the concentrates measured 1 by $\frac{3}{4}$ by $\frac{1}{2}$ inch. Most of the concentrates collected, however, passed through an 8-mesh sieve.

Concentrates from several claims on Deadwood and Switch creeks were examined. Associated with the gold in the concentrates were found wolframite, cassiterite, magnetite, ilmenite, arsenopyrite, pyrite, galena, limonite, garnet, tourmaline, and quartz. Wolframite was not detected in the Switch Creek concentrates. Cassiterite was found in all the concentrates examined, but most abundantly in those from Deadwood Creek between Discovery Gulch and Switch Creck. Magnetite was very abundant in the Deadwood Creek concentrates, but nearly absent from those collected on Switch Creek. The sulphides-arsenopyrite, pyrite, and galenn-were found principally on Switch Creek.

\section{VAIUE OF PLACER TIN AND TUNGSTEN OF DEADWOOD CREEK.}

The best data available at present indicate that where the wolframite and cassiterite are found most ahundantly in the stream gravels they will yield an average of 1 to 2 pounds of concentrates (principally wolframite and cassiterite with some magnetite and garnet) per cubic yard of gravel. I abor at present on this creek costs $\$ 8$ a day, provided the miner boards himself. The average amount of dirt moved per day per man during the open season is approximately 4 cubic yards. To meet expenses alone this would require that the gravel have a value of $\$ 2$ a cubic yard. Were the concentrates entirely of wolframite and cassiterite, without gold or impurities, their value under present conditions would probably not exceed 50 cents per cubic yard of gravel, so that the value of the concentrates obtained per day would be only about $\$ 2$. This would not cover the expense of working these gravels for wolframite and cassiterite alone by the methods now in use on the creek, but as the gold caught in the sluice boxes more than pays expenses, the wolframite and cassiterite in the concentrates, if saved and sold, would represent an additional profit. Tin, however, is treated as a very serious impurity in tungsten ores, 
and it is hard to say how such ores would be received, although the two minerals can readily be separated by electro-magnetic methods.

Tungsten ores are now selling at about $\$ 6.25$ a unit (the unit being 1 per cent, 20 pounds per ton of ore, of tungsten trioxide) for ore running 60 per cent or more of tungsten trioxide. A 60 per cent ore at this rate is worth about $\$ 375$ a ton, or, as a more convenient basis for figuring, about $18 \frac{3}{4}$ cents a pound.

Pure cassiterite $\left(\mathrm{SnO}_{2}\right)$ containing 78.6 per cent of tin would, at the present market price of tin, $32 \frac{7}{8}$ cents a pound, be worth approximately 26 cents a pound.

\section{CONCLUSIONS.}

Tungsten and tin minerals are generally confined to quartz veins and pegmatites associated with granitic rocks. As a rule, the veins cut the igneous rocks, but they are also found penetrating adjacent sedimentary or metamorphic rocks. Their common occurrence in regions where auriferous quartz veins are abundant is worthy of notice. These tungsten and tin bearing quartz veins are supposed to have been formed during the final stages of the cooling and consolidation of intrusive granitic magmas, the mineralized solutions and vapors given off at that time filling the cracks and fissures due to the contraction of the cooling mass.

The wolframite and cassiterite found in the placer gravels of Deadwood Creek are probably derived from the quartz veins which cut the granites and schists of the region. Veins carrying these minerals may occur anywhere within the area of influence of the granitic intrusives or within the granitic rocks themselves.

Regarding the prospective economic importance of the occurrences of these minerals in bed rock nothing definite can be said. The occurrence of cassiterite in the concentrates is more widespread than that of wolframite, and the cassiterite-bearing veins are probably the more numerous. A study of the concentrates collected on Deadwood and Switch creeks indicates a decided localization of cassiterite and wolframite in the Deadwood Creek placers in the vicinity of Discovery Gulch, and in this region the wolframite-bearing veins probably occur. It appears probable, also, that both cassiterite and wolframite will be found in the same veins. 


\title{
WATER SUPPLY OF THE YUKON-TANANA REGION, 1909.
}

\author{
By C. F. Ellsworth.
}

\section{INTRODUCTION.}

A systematic investigation of the water supply in the Fairbanks district was begun in 1907 by C. C. Covert, ${ }^{a}$ of the United States Geological Survey. Although daily records were kept on several streams in the Fairbanks district, the work was mainly of a reconnaissance nature, preliminary to a more detailed study of the available water supply from the drainage areas contiguous to the various mining sections in the Yukon-Tanana region.

In $1908^{b}$ the work was continued by C. C. Covert and the writer and extended to the Circle and Rampart districts. Daily records were kept on all streams where observers could be obtained, and estimates of daily flow have been made.

In 1909 similar work was done in this region by the writer, and the object of this report is to present the results of the season's work in as comprehensive a form as the space will permit. Those interested in the water supply of these districts should also consult the reports already referred to, which have been freely quoted in the preparation of this report.

The writer arrived at Fairbanks April 1, and until the early part of May spent the time chiefly in making preparations for the work of the summer. The object in view was to continue as many of the 1908 stations as possible. It was found necessary to discontinue several of the old stations, but a few new ones were established. Two trips were made up Tanana River as far as McCartys, in addition to the work in the Fairbanks, Rampart, and Circle districts. The records cover the period from April 20 to October 6 . Fstimates of daily discharge from an area of about 5,000 square miles have been made, and about 400 square miles of this area was studied in detail.

Acknowledgments are due to many residents of the region for courtesies extended and aid given to the work. Special acknowledgments for those supplying gage readings are due to the Bachelor

a Henshaw, F. F., and Covert, C. C., Water-supply investigations in Alaska, 1906-7: Water-Supply Paper U.S. Geol. Survey No. 218, 1908.

b Covert, C. C., and Ellsworth, C. E., Water-supply investigations in the Yukon-Tanana region, Alaska, 1907-8: Water-Supply Paper U. S. Geol. Survey No. 228, 1909. 
Creek Mining Company, the Mammoth Creek Mining Company, the Tofty Gulch Mining Company, and Messrs. W. II. Bayless, C. F. W. Cassidy, James Climie, Dave Currier, F. E. Diver, James Fitzsimmons, Alfred Johnson, J. F. Kelley, M. E. Koonce, J. A. Laird, J. W. MeCluskey, Wm. Mosiman, W. F. Munson, Charles Nelson, C. R. Rieger, Peter Ryden, Joseph Sanders, A. F. Stowe, and S. M. Wheeler.

\section{CONDITIONS AFFECTING WATER SUPPLY.}

Precipitation in the form of rain or snow is primarily the source of all water supply. In the Iukon-Tanana region the chief factor influencing the distribution of this supply is the imperviousness of the frozen ground, which prevents any considerable underground storage, and consequently makes impossible a uniform distribution of the total run-off. In warmer climates the main source of supply for most of the streams during the low-water periods is derived from that portion of the rainfall and melting snow which sceps into the ground and slowly percolates through until it finally joins the surface watercourses again at a lower elevation. That process, however, is relatively insignificant in this latitude for the reasons above set forth.

The accumulations of snow and ice of the winter are of great value in the sections where drift mining prevails. There the winter dumps are in a position to be handled rapidly, and the fow weeks of abundant spring flow are in most places sufficient to wash the gold-bearing gravels hoisted during the entire winter. In the open-cut works, however, where the progress is directly dependent on the water supply from day to day, the spring flow is of but little value, because the very fact that the ground is then covered with ice and snow prevents any work of this nature. Of course many of the mines lie in the lower valleys, where the ice disappears before the winter aceumulations in the upper valleys and hills are exhausted, but the spring floods are generally of such short duration that they are not usually considered a very valuable asset in this form of mining.

An additional supply of water is that derived from the thawing of frozen ground during the summer, but this source is of minor importance.

In this region, where artificial storage of any magnitude has been so far considered economically impossible, the water supply available for mining is the daily flow of the stream at the point of diversion, and the determining factors of this supply are summer rains and their distribution.

The local distribution of this supply is affected not only by the frozen condition of the soil but also to a large extent by the topography. The summer low-water flow of the streams that rise in high, rugged mountains is kept up by the melting of large bodies of ice and 
snow in the sun-protected gulches and rock crevices. The rainfall, however, is not so well conserved in these streams as in gently sloping valleys and pondage areas, where the run-off, in percentage of the rainfall, even though less than in higher regions, may be so distributed as to furnish the better supply.

The prevailing moss covering is the one great natural storage agent, and to its preservation should be given more thought than it evidently has received in the past. The writer has frequently observed while traveling over the country that those areas which were heavily covered with moss distributed the run-off from summer rains in a more uniform manner than those with a lighter moss covering.

\section{PRECIPITATION.}

The precipitation records during the mining season of 1909 show that at Circle and Kechumstuk the rainfall was considerably above the average. $\Lambda t$ Fairbanks there was a slight increase over the mean, and at Rampart and Fort Egbert there was a small decrease. At all the stations, however, with the exception of Fort Egbert, there was a marked increase over the rainfall of 1908.

Although there is a wide difference from month to month and from year to year in the rainfall at the various stations in the YukonTanana region, the mean yearly precipitation at each station for the period covered by the records is uniformly close to the average of the means of all the stations. In other words, the records show no uniform difference in precipitation throughout this area.

The following table gives the monthly precipitation at all points in the Yukon-Tanana region where records have been kept subsequent to 1903. Such scattered records as were kept previous to 1903 have been compiled by Abbe. ${ }^{a}$

Monthly precipitation, in inches, at stations in Yukon-Thanna region, 19013-1909.

[Rainlobl or me]ted sinow i.; given i: the first line; snowfall in tile sweond line.]

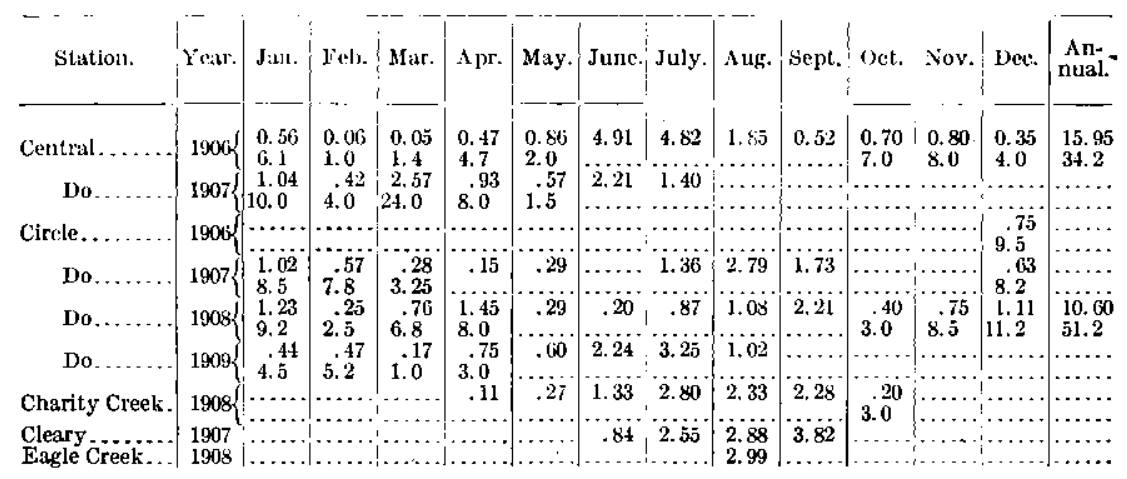

a Abbe, Cleveland, jr., Prof. Paper U. S. Geol. Survey No. 45, 1906, pp. 189-200. 
Manthly precipitation, in inches, at stations in Yukon-Tanana region, 1908-1909-Cont'd.

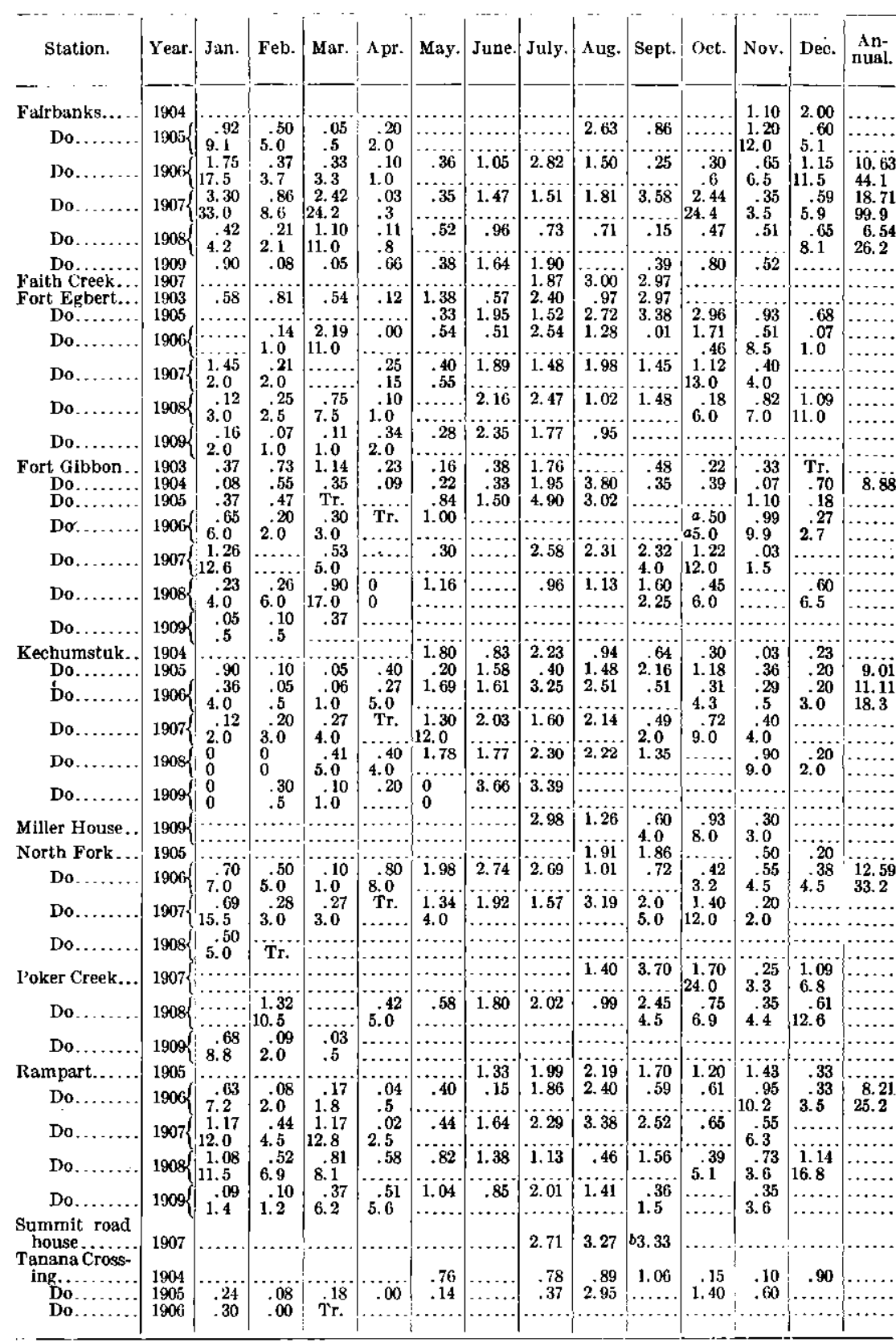


Precipitation records for May to August, inclusive, at various points in the Yukon-Tanana region may be summarized as follows:

Summary of precipitation in Yukon-Tanana region.

\begin{tabular}{|c|c|c|c|c|c|c|}
\hline \multirow{2}{*}{ Station. } & \multicolumn{2}{|c|}{ M:เximum. } & \multicolumn{2}{|c|}{ Mininutum. } & \multirow{2}{*}{$\begin{array}{l}\text { Mean, } \\
\text { inclos. }\end{array}$} & \multirow{2}{*}{$\begin{array}{l}\text { Duration of } \\
\text { records. }\end{array}$} \\
\hline & Inches. & Year. & Inches. & Year. & & \\
\hline 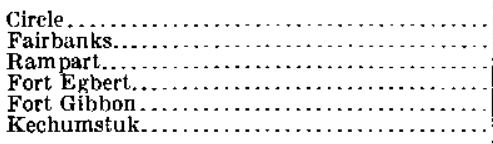 & $\begin{array}{r}7.11 \\
5.73 \\
7.75 \\
6.52 \\
10.26 \\
9.06\end{array}$ & $\begin{array}{l}1909 \\
1906 \\
1907 \\
1905 \\
1905 \\
1906\end{array}$ & $\begin{array}{l}2.44 \\
2.92 \\
3.79 \\
4.87 \\
3.30 \\
3.66\end{array}$ & $\begin{array}{l}1908 \\
190 k \\
1908 \\
1906 \\
1904 \\
1905\end{array}$ & $\begin{array}{l}\text { 5. } 07 \\
\text { 4. } 76 \\
5.57 \\
5.68 \\
5.76 \\
7.10\end{array}$ & $\begin{array}{r}1907-1909 \\
1906-1909 \\
19051909 \\
1903,19051909 \\
19031908 \\
1904-1909\end{array}$ \\
\hline
\end{tabular}

The table above shows that a total precipitation as high as 10.26 inches and as low as 2.44 inches has occurred during the mining season.

\section{HYDRAULYC DEVELOPMENT.}

During the season of 1909 several small ditches were completed and others were commenced, but no large development was undertaken. For the last three years the country has experienced sucli a drought that the outlook for a successful venture in water-power development or gravity system of supply by any new ditch construction was discouraging. Nearly all the areas that are now being worked by hydraulic methods or that will be worked by plants under construction are creek deposits with a shallow depth of gold-bearing gravel. Very few bench deposits are known and the gradients of the bed rock underlying the creek deposits are invariably too low to permit hydraulicking without elevating the gravel. It requires about twice as much water to operate the elevator as it does to deliver the material to it. $\Lambda$ s a result the demand frequently exceeds the supply during the low-water periods and operations have to cease until there is a rain. Natural reservoir sites at a suitable elevation with a sufficient drainage area are lacking and the expense of constructing large dams is prolibitive.

The method now being tried on Eagle and Mammoth creeks, in the Circle district (see p. 237), may prove to be better suited to the conditions prevailing in the interior of Alaska than elevators. In the vicinity of nearly all the camps an ample supply of water is available at a lower elevation than the mines and can be brought to them only by pumping. Experience has shown that in nearly every instance where pumping water for placer mining has been tried, unless unusually economical means of developing power were possible, the costs were prohibitive. The total value of the gold to be removed through the agency of a certain system of water supply or power must be balanced against the cost of installation as well as operating expenses, for as soon as the gold is worked out the plant is practically valueless. 
The development of electricity and its transmission to the mines in the Fairbanks district for pumping, operating dredges, and the various other uses to which it might be put has been under consideration for the last three years. Records were kept on Chatanika and Little Chena rivers during 1907 and 1908, and on Washington Creek during 1908, to determine the horsepower that might be developed from these streams. ${ }^{a}$ Stream flow is known to vary greatly from year to year and these records do not cover a period long enough to permit the extremes to be predicted, but they are of sufficient duration to enable the engineer to determine if more extensive investigations are warranted.

The Circle district has shown the greatest activity in hydraulic development (see pp. 234-239) of all the mining sections visited by the writer. It is too early to predict the success or failure of the ventures, but it is hoped that some method may be devised whereby the working of low-grade ground may be put on a paying basis. The days of the bonanzas are numbered unless new ones are discovered and the future of the camp must soon come to depend on working ground of low tenor on a large scale.

Very little was accomplished in liydraulic development in the Rampart district during the last season. Few if any of the mines have an adequate supply of water after the midlle of June except for a short time after a rain, and the problem of increasing that supply has been much discussed anong the mine owners and operators. The records of stream flow for the last two seasons show that the country has a low summer run-off, and this evidence, combined with the comparatively high eleration at which the mines are located, should be sufficient to check any hasty expenditure in new ditch construction.

On the north side of the Yukon-Tanana divide little Minook and Little Minook Junior creeks have drainage areas so small that it is with the utmost difficulty that anything is accomplished during the summer. Even the washing of winter dumps during the spring runoff has to be carried on as rapidly as possible in order to clean them up before the low-water season commences. Minook Creek has been and is still to some extent considered as a possible source of relief. However, an 'xamination of the discharge measurements that have been made during the last two years and a careful consideration of the elevation at which the water would have to be diverted in order to be carried to the mines by gravity indicate that this stream should no longer be considered in a favorable light. There is no doubt that an adequate supply of water is available for pumping, but it is very

a Water-supply investigations in the Yukon-lanına region, Alaska, 1907 and 1908; Water-Supply Paper U. S. Geol. Survey No. 228, 1909, p. 100. 
doubtful if such a method would prove profitable in view of the small quantity of gravel to be moved and the high cost of power.

On the south side of the divide, in the Hot Springs section of the Rampart district, the mines are more poorly supplied with water and the possibilities of increasing it are small. The developments in this section are described on pages 241-243.

Any remarks that seem unfavorable to hydraulic mining are not made with the intention of discouraging such methods but rather of encouraging a more careful investigation of the water supply and other factors necessary for the success of such a project.

\section{MISCELLANEOUS MEASUREMENTS.}

A great many miscellaneous measurements were made during the season of 1909 at points where it was impracticable to attempt to procure daily records.

A comparison of the run-off per square mile at the various points where daily records were obtained shows a general trend of similarity, but the daily variations and in some cases the monthly departures from the average are so great that extreme care should be used in making any estimates from these measurements.

The season was characterized by extreme fluctuations in the stage of the streams, a fact which renders these miscellaneous data far more uncertain than those obtained during 1907-8, when a more uniform flow was maintained during the summer.

\section{EXPLANATION OF DATA AND METHODS.}

The methods of earrying on the work and collecting the data were essentially the same as those previously used for similar work, ${ }^{a}$ but were adapted to the special conditions found in Alaska.

In the consideration of industrial or mining enterprises which use the water of streams, it is necessary to know the total amount of water flowing in the stream, the daily distribution of the flow, and facts in regard to the conditions affecting the flow. Several terms are used-such as second-foot, miner's inch, and gallons per minuteto describe the quantity of water flowing in a stream, the one selected depending on the use to be made of the data.

"Second-foot" is in most general use for all classes of work, and from it the quantity expressed in other terms may be obtained. It is an abbreviation of cubic foot per second, and may be defined as the quantity of water flowing per second in a stream 1 foot wide and 1 foot deep at the rate of 1 foot per second. It should be noted that it is a rate of flow, and to obtain the actual quantity of water it is necessary to multiply it by the time. 
"Second-feet per square mile" is the average number of cubic feet of water flowing per second from each square mile of area drained, on the assumption that the run-off is distributed uniformly, as regards both time and area.

"Run-off in inches" is the depth to which the drainage area would be covered if all the water flowing from it in a given period were conserved and uniformly distributed on the surface. It is used for comparing run-off with rainfall, which is expressed in depth in inches.

"Acre-foot" is equivalent to 43,560 cubic feet and is the quantity required to cover an acre to the depth of 1 foot. It is commonly used in connection with storage problems.

The "miner's inch," the unit used in connection with placer mining, also expresses a rate of flow and is applied to water flowing through an orifice of a given size with a given head. The head and size of the orifice used in different localities vary, thus making it a most indefinite and unsatisfactory unit. Owing to the confusion arising from its use it has been defined by law in several States. The California miner's inch is in most common use in the United States and was defined by an act approved March 23, 1901, as follows: "The standard miner's inch of water shall be equivalent or equal to $1 \frac{1}{2}$ cubic feet of water per minute, measured through any aperture or orifice." This miner's inch corresponds to the so-called " 6 -inch pressure," and is one-fortieth of a second-foot.

The determination of the quantity of water flowing past a certain section of a stream at a given time is termed a "discharge measurement." The quantity is the product of two factors-the mean velocity and the area of the cross section. The mean velocity is a function of surface slope, wetted perimeter, roughness of bed, and the channel conditions at, above, and below the gaging station. The area depends on the contour of the bed and the fluctuations of the surface. The two principal ways of measuring the velocity of a stream are by floats and current meters.

All measurements by the engineers of the Survey were made with the current meter, but as float measurements can readily be made by the prospector, the method is described below.

The floats in common use are the surface, subsurface, and tube or rod floats. A corked bottle with a flag in the top and weighted at the bottom makes one of the most satisfactory surface floats, as it is affected but little by wind. In flood measurements good results can be obtained by observing the velocity of floating cakes of ice or débris. In all surface-float measurements the observed velocity must be multiplied by 0.85 to $0.90^{\circ}$ to reduce it to the mean velocity. The subsurface and tube or rod floats are intended to give directly the mean velocity in the vertical. Tubes give excellent results when the channel conditions are good, as in canals. 
In measuring velocity by a float, observation is made of the time taken by the float to pass over the "run"-a selected stretch of river from 50 to 200 feet long. In each discharge measurement a large number of velocity determinations are made at different points across the stream, and from these observations the mean velocity for the whole section is determined.

The area used in float measurements is the mean of the areas at the two ends of the run and at several intermediate sections.

\section{FAIRBANKS DISTRICT.}

\section{DESCRIPTION.}

The area known as the Fairbanks district extends about 60 miles to the north of Fairbanks and is from 40 to 50 miles wide. The greater part of the region lies in the lower Tanana basin, but a portion to the northwest drains directly to the Yukon. Generally speaking, the district embraces three divisions - a low, broad alluvial plain, a moderately high plateau, and a mountain mass.

The low, broad plain forms the bottom lands of the lower Tanana Valley, which in this section is divided into several parts by the Tanana and its sloughlike channels. The main slough starts near the mouth of Salcha River, about 30 miles above Fairbanks, where it diverts a portion of the Tanana waters. Its course is along the foothills of the plateau to the north, and it receives Chena River about 7 miles above Fairbanks. The plain is swampy and is well covered with timber along the banks of the streams. In the vicinity of Fairbanks it has a general elevation of about 500 feet above sea level.

The plateau is drained by streams tributary to Tanana River, which flow through rather broad, unsymmetrical valleys and most of which extend in a northeast-southwest direction. Their bottom lands range in elevation from 500 to over 2,000 feet above sea level, and the dividing ridges are in general 2,000 to 3,000 feet above the stream beds. That portion of the plateau which comes under discussion in this report is drained principally by Iittle Chena and Chatanika rivers. The upper region of these drainage basins is crosscut by a zigzag range, which separates the Yukon from the Tanana drainage.

The mountain mass north of this plateau forms what might be termed the apex of the divide between the Tanana and the Yukon drainage basins, its highest points reach altitudes 4,000 to 5,000 feet above sea level, and its corrugated slopes are drained principally by tributaries to Yukon River.

All drainage areas tributary to the Tanana are similar in character. The streams have little slope except near their source and flow over 
wide gravelly beds in shifting and tortuous courses, keeping to one side of the valley. Most of the channels have rather steep banks that form approaches to broad, level bottom lands which extend 1,000 to 4,000 feet or more before they meet the abrupt slopes of the dividing ridges. The drainage basins are 4 to 15 miles wide and are cut up by small tributary streams that flow thrcugh deep and narrow ravines.

A large portion of the area is covered with a thick turf, known as tundra, which is wet, spongy, and mossy and ranges in thickness from 6 inches to 2 feet. In some localities this is meadow-like, producing a rank growth of grass and a variety of beautiful wild flowers. Ground ice is found beneath this tundra in many places, particularly on the northern slopes, where the scanty soil supports little timber or other vegetation. The soil of the southern slopes is, for the most part, gravelly clay, underlain by a mica schist which affords suitable ground for ditch construction. When stripped of its mossy covering and exposed to the sun it thaws rapidly, so that the plow and scraper can be used to advantage.

Above altitudes of 2,000 to 2,200 feet practically the only vegetation is a scrubby, bushy growth which attains a height of 2 to 4 feet. In general the country below this altitude is timbered by spruce and birch, with scattered patches of tamarack and willow along the banks of the smaller streams. The timber increases, in density and size toward the river bottoms, where the prevailing growth is spruce, much of which attains a diameter of 18 to 24 inches.

The Fairbanks mining district lies between Little Chena and Chatanika rivers. It embraces an area of about 500 square miles and extends 30 miles north of Fairbanks, which is situated on Chena Slough nearly 12 miles above its confluence with the Tanana. Most of the producing creeks rise in a high rocky ridge, of which Pedro Dome, with an elevation of about 2,500 feet, is the center. $\Lambda$ t least half of the mines are located at an elevation of over 800 feet, and 25 per cent are over 1,000 feet above sea level.

\section{GAGING STATIONS.}

The following list gives the points in the Fairbanks distriet at which gages were established or discharge measurements made in 1909:

Gaging stations in Fairbanks district, 1909.

Chatanika River drainage basin:

Chatanika River near Faith Creek.

Chatanika River below Poker Creek.

Homestake Creek at mouth.

Charity Creek below Homestake Creek.

Charity Creek at mouth

Hope Creek at mouth.

Faith Creek at mouth.

Smith Creek at mouth. 
Chatanika River drainage basin-Continued.

Pool Creek at mouth.

McManus Creek above Smith Creek.

Sourdough Creek at mouth.

Cassiar Creek at mouth.

Flat Creek below 3d Pup.

Flat Creek,below lst Pup.

Kokomo Creek above Rusty Gold Creek.

Cleary Creek above Wolf Creek.

Chatham Creek at mouth.

Wolf Creek at mouth.

Goldstream Creek drainage basin:

Fox Creek 1 mile above mouth.

Little Chena River drainage basin:

Fish Creek above Fairbanks Creek.

CHATANIKA RIVER DRAINAGE BASIN.

Chatanika River is formed by the junction of Faith and MeManus creeks, which drain the high ridge constituting the divide between the lower Tanana and Yukon basins. The river flows southwestward, in a winding course, through a long and rather narrow valley, and unites with the Tolovana from the cast about 30 miles above the confluence of that stream with the Tanana. Its course lies mostly to the west side of the valley, which is from half a mile to 7 miles wide and about 80 miles long. The drainage area of the river above its mouth is approximately 1,300 square miles.

From the junction of Faith and McManus creeks the stream has a shifting, gravelly bottom. In low and medium stages it flows in a series of pools and rapids in a channel 75 to 200 feet wide; during the high-water period it may spread through several channels covering a width of 100 to 400 feet. This high-water channel is usually well defined by steep, alluvial banks ranging from 8 to 10 feet in height.

Below Poker Creek, a tributary from the right about 40 miles downstream from the junction, the valley widens and the bottom lands become marshy and swampy. From the left the Chatanika receives Cleary, Eldorado, Dome, and Vault creeks and other less important streams from the mining district proper. Below these tributaries the valley narrows to a gorgelike channel, which it follows for about 10 miles; below this the dividing ridges disappear and the stream meanders through the low swampy grounds to the north of Tanana River. About 10 miles from its mouth Goldstream Creek, its largest tributary, joins it from the left.

The average elevation of the divides in the upper drainage area of the Chatanika is between 3,000 and 4,000 feet above sea level, and the altitude of the ridges bounding the valley on the east and west is about 2,000 feet. Below an altitude of 1,800 to 2,000 feet the slopes are heavily timbered. 
The tributary streams from the right are short and precipitous, flowing through $V$-shaped valleys; those from the left have less precipitous courses and broader valleys and gradually lose themselves in the rather broad expanse of swamplike bottom lands.

The altitude and drainage area of the upper Chatanika has attracted the attention of "outside" capital for some time. The general topography has seemed suitable for a possible water supply by ditch line to the mining district proper, and the favorable slope of portions of Faith and McManus creeks has made them attractive to the promoter for hydraulicking.

Daily discharge, in second-feet, of Chatanika River below Poker Creek, 1909.

[Drainage area, 456 square miles.]

\begin{tabular}{|c|c|c|c|c|c|c|c|c|c|c|c|c|c|}
\hline Day. & May. & June & July. & Aug. & Sept. & Oct. & Day. & May. & June. & July. & Aug. & Sept. & Oet. \\
\hline $\begin{array}{l}1 . \\
2 . \\
3 . \\
4 . \\
5 .\end{array}$ & & $\begin{array}{l}621 \\
588 \\
621 \\
474 \\
502\end{array}$ & $\begin{array}{l}319 \\
300 \\
359 \\
449 \\
359\end{array}$ & $\begin{array}{l}911 \\
872 \\
794 \\
588 \\
474\end{array}$ & $\begin{array}{l}168 \\
157 \\
146 \\
135 \\
130\end{array}$ & $\begin{array}{r}110 \\
110 \\
110 \\
92 \\
92\end{array}$ & $\begin{array}{l}21 \\
22 \\
23 \\
24 \\
25 \ldots\end{array}$ & $\begin{array}{r}502 \\
474 \\
833 \\
1,740 \\
1,520\end{array}$ & $\begin{array}{l}176 \\
164 \\
152 \\
266 \\
\mathbf{4 4 9}\end{array}$ & $\begin{array}{l}250 \\
219 \\
234 \\
402 \\
424\end{array}$ & $\begin{array}{l}289 \\
278 \\
267 \\
256 \\
245\end{array}$ & $\begin{array}{l}152 \\
164 \\
130 \\
130 \\
130\end{array}$ & $\cdots$ \\
\hline $\begin{array}{r}6 . \\
7 . \\
8 . \\
9 . \\
10 .\end{array}$ & 3,620 & $\begin{array}{r}359 \\
283 \\
338 \\
1,180 \\
1,220\end{array}$ & $\begin{array}{l}283 \\
359 \\
380 \\
402 \\
654\end{array}$ & $\begin{array}{r}449 \\
424 \\
654 \\
1,630 \\
1,740\end{array}$ & $\begin{array}{l}130 \\
130 \\
130 \\
176 \\
219\end{array}$ & & $\begin{array}{l}26 \ldots \ldots \ldots \\
27 \ldots \ldots \\
28 \ldots \ldots \\
29 \ldots \ldots \\
30 \ldots \ldots \\
31 \ldots \ldots \ldots \\
\end{array}$ & $\begin{array}{r}1,420 \\
1,220 \\
757 \\
757 \\
720 \\
757\end{array}$ & $\begin{array}{l}300 \\
559 \\
687 \\
\mathbf{4 2 4} \\
\mathbf{3 5 9}\end{array}$ & $\begin{array}{l}359 \\
300 \\
283 \\
266 \\
266 \\
338\end{array}$ & $\begin{array}{l}234 \\
223 \\
212 \\
201 \\
190 \\
179\end{array}$ & $\begin{array}{l}130 \\
130 \\
130 \\
152 \\
141\end{array}$ & …... \\
\hline & $\begin{array}{l}3,080 \\
3,080 \\
2,970 \\
1,320 \\
1,680\end{array}$ & $\begin{array}{l}474 \\
338 \\
300 \\
319 \\
260\end{array}$ & $\begin{array}{l}833 \\
530 \\
449 \\
720 \\
\mathbf{8 3 3}\end{array}$ & $\begin{array}{r}1,420 \\
872 \\
559 \\
424 \\
424\end{array}$ & $\begin{array}{l}204 \\
176 \\
152 \\
152 \\
130\end{array}$ & & $\begin{array}{l}\text { Mean } \\
\text { Mean per } \\
\text { squ are } \\
\text { mile...... }\end{array}$ & 1,870 & 416 & 414 & 530 & 151 & 103 \\
\hline 10 & $\begin{array}{l}3,260 \\
3,200 \\
3,380 \\
2,160 \\
1,080\end{array}$ & $\begin{array}{l}266 \\
234 \\
204 \\
190 \\
170\end{array}$ & $\begin{array}{l}588 \\
474 \\
474 \\
424 \\
319\end{array}$ & $\begin{array}{l}359 \\
338 \\
300 \\
311 \\
300\end{array}$ & $\begin{array}{l}130 \\
164 \\
219 \\
152 \\
152\end{array}$ & & $\begin{array}{l}\text { depth in } \\
\text { inches... }\end{array}$ & 3. 51 & 1.02 & 1.05 & 1.34 & .37 & .04 \\
\hline
\end{tabular}

The following table gives the horsepower ( 80 per cent efficiency) per foot of fall that may be developed at different rates of discharge and shows the number of days on which the discharge and the corresponding horsepower were respectively less than the amounts given in the columns for "discharge" and "horsepower."

Estimated discharge and horsepower for Chatanika River below Poker Creek, 1907-1909.

\begin{tabular}{|c|c|c|c|c|}
\hline \multirow{2}{*}{$\begin{array}{l}\text { Discharge } \\
\text { (second- } \\
\text { feet). }\end{array}$} & \multirow{2}{*}{$\begin{array}{c}\text { Horsepower } \\
\text { (80 per cent } \\
\text { efficiency) } \\
\text { per foot of } \\
\text { fall. }\end{array}$} & \multicolumn{3}{|c|}{$\begin{array}{l}\text { Days of deflcient dis- } \\
\text { charge. }\end{array}$} \\
\hline & & 1907. & 1908 & 1909. \\
\hline $\begin{array}{r}88 \\
110 \\
121 \\
132 \\
154 \\
176 \\
198 \\
220\end{array}$ & $\begin{array}{r}8 \\
10 \\
11 \\
12 \\
14 \\
16 \\
18 \\
20\end{array}$ & $\begin{array}{r}0 \\
5 \\
17 \\
27\end{array}$ & $\begin{array}{r} \\
0 \\
5 \\
27\end{array}$ & $\begin{array}{r}0 \\
2 \\
5 \\
17 \\
26 \\
27 \\
39 \\
46\end{array}$ \\
\hline
\end{tabular}

The above table shows entirely the reverse of what would be expected after an examination of the precipitation records at Fairbanks 
and Circle during the last three years, and furthermore it confirms the belief that a wide variation in precipitation, even in adjoining drainage basins, is to be expected in the Yukon-Tanana region.

Miscellaneous measurements in Chatanika River drainage basin, 1909.

\begin{tabular}{|c|c|c|c|c|}
\hline Date. & Stream and locality. & $\begin{array}{c}\text { Drainage } \\
\text { area. }\end{array}$ & $\begin{array}{c}\text { Dis- } \\
\text { charge. }\end{array}$ & $\begin{array}{c}\text { Discharge } \\
\text { per } \\
\text { square } \\
\text { mile. }\end{array}$ \\
\hline une & & Sq. miles. & Sec.,ft. & Sec. $f t$. \\
\hline & . do......... do & 132 & 239 & 1.81 \\
\hline A & ......do. & 132 & 134 & 1.02 \\
\hline Jun & Homestake Creek at mou & 5.6 & 16.4 & 2.93 \\
\hline A & .....do. & 5.6 & 7.7 & 1.38 \\
\hline Jun & Charity Creek below Homestake Cree & 6.5 & 30 & 4. 62 \\
\hline Aug & 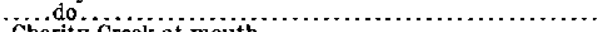 & 6.5 & 13.7 & 2.11 \\
\hline Jun & Charity Creek at mout & 8.0 & 37 & 4. 62 \\
\hline A & .....do. & 8.0 & 16.5 & 2.06 \\
\hline June & Hope Creek & 20.3 & 77 & 3.79 \\
\hline A & .....do. & 20.3 & 33 & 1.63 \\
\hline $\mathbf{J}$ & Faith Creek at mouth. & & 151 & 2.96 \\
\hline $\mathrm{J}$ & .....do.... & & 148 & 2.90 \\
\hline A & 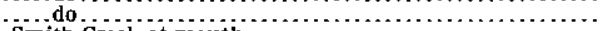 & 51 & 88 & 1.73 \\
\hline & Sinith Creek at mouth. & & & .76 \\
\hline & ....do... & 34 & & 1.59 \\
\hline Aug & $\ldots . .$. do $\ldots . . .$. & 34 & 25 & .73 \\
\hline June & Pool Creek at mouth.. & 14 & & 2.29 \\
\hline$\ldots$ & $\ldots \ldots \ldots \ldots \ldots$ & & 10. & \\
\hline June 6. & MeManus Creek above SmI & 42.8 & 67 & 1.57 \\
\hline & ....d & 42.8 & & 1.21 \\
\hline & $\ldots \mathrm{d}$ & 42.8 & & .68 \\
\hline Augu & Sour & 16.5 & 25 & 1.52 \\
\hline & Cassig & 7.3 & 2.6 & .36 \\
\hline & Flat & & 5.1 & .74 \\
\hline Allg & Flat & 16.9 & 10.0 & .59 \\
\hline & Koko & 26.1 & 12.7 & .49 \\
\hline Jul & Cleary Creel & 3.4 & 1.9 & \\
\hline Augi & .de & 3. & 3.7 & 1.09 \\
\hline July & Chatham Creek at mouth. & 3.0 & .55 & .18 \\
\hline Auge & , do...$\ldots \ldots \ldots$ & 3.0 & 1.4 & .47 \\
\hline July $17, \ldots \ldots \ldots$ & Wolf Creek at mouth. & 3. & .71 & .19 \\
\hline ist & .... do.... & 3.8 & 1.5 & .39 \\
\hline
\end{tabular}

The following measurements were made on streams outside of the Chatanika basin:

\section{OTHER STREAMS.}

Other miscellaneous measurements in Fairbanks district, 1909.

\begin{tabular}{|c|c|c|c|c|}
\hline Date. & Stream and locality. & $\begin{array}{c}\text { Drainage } \\
\text { area. }\end{array}$ & $\begin{array}{c}\text { Dis- } \\
\text { charge. }\end{array}$ & $\begin{array}{l}\text { Discharge } \\
\text { per } \\
\text { square } \\
\text { mile. }\end{array}$ \\
\hline $\begin{array}{l}\text { June } 16 \ldots \ldots \ldots \\
\text { June } 4 \ldots \ldots \ldots \ldots \\
\text { June } 28 \ldots \ldots \ldots\end{array}$ & $\begin{array}{l}\text { Fox Creek } 1 \text { mile above mouth...... } \\
\text { Fish Creek above Fairbanks Creek .. } \\
\ldots \ldots \text { do } \ldots \ldots \ldots \ldots \ldots \ldots \ldots \ldots \ldots \ldots \ldots \ldots\end{array}$ & $\begin{array}{r}\text { Sq. miles. } \\
4.1 \\
39 \\
39\end{array}$ & $\begin{array}{r}\text { Sec.fft. } \\
1.2 \\
22 \\
48\end{array}$ & $\begin{array}{r}\text { Sec.-ft. } \\
0.29 \\
.56 \\
1.23\end{array}$ \\
\hline
\end{tabular}

\section{CIRCLE DISTRICT.}

\section{DESCRIPTION.}

The area to the north of the Yukon-Tanana divide, between latitude $143^{\circ} 40^{\prime}$ and $146^{\circ} 50^{\prime}$, is known as the Birch Creek region of the Circle district. Generally speaking, it occupies two geographic divisions-a low, broad alluvial plain and a high plateau. 
The northwestern portion of the low, broad plain forms the bottom lands of the Yukon Flats north of Crazy Mountains; the southeastern portion occupies an irregular area surrounded by a low ridge along the Yukon, the Crazy Mountains, and the range of hills 20 to 40 miles farther south. This portion is cut by Birch and Crooked creeks; it is well timbered along these streams and contains large areas of meadow-like swamp land that furnish forage for both summer and winter use.

The plateau division, whose longer diameter trends east and west, occupies a position between two distinct ridges-the eastern extensions of the White Mountains. The ridge to the south is high and barren and forms the main Yukon-Tanana divide; that to the north is lower, irregular, and barren, separates the upper tributaries of the Birch Creek drainage from the lower, and is itself divided by the deep canyon-like gorge through which Birch Creek flows on its way to the Yukon.

At elevations of 2,000 feet or more above sea level the country is as a rule barren and rocky; below this altitude, especially in the flats where Birch and Crooked creeks join, considerable timber is found.

\section{GAGING STATIONS.}

The following is a list of points in the Circle district at which gages were established or measurements made in 1909:

Gaging stations in Circle distriet, 1909.

Birch Creek proper:

Birch Creek at Fourteenmile House.

Preacher Creek drainage basin:

Preacher Creek below Bachelor Creek.

Bachelor Creek below Costa Fork.

Bachelor Creek at mouth.

North Fork of Birch Creek drainage basin:

Mastodon Fork of Eagle Creek above ditch intake.

Miller Fork of Eagle Creek above ditch intake.

Eagle Creek at mouth.

Ptarmigan Creek at mouth.

Golddust Creek at mouth.

Fish Creek at mouth.

Butte Creek at mouth.

Bear Creek at mouth.

Twelvemile Creek 5 miles above mouth.

Twelvemile Creek above East Fork.

East Fork of Twelvemile Creek at mouth.

Harrison Creek above North Fork.

Harrison Creek below North Fork.

North Fork of Harrison Creek at claim "No. 10 above."

North Fork of Harrison Creek at claim "No. 5 above."

North Fork of Harrison Creek at mouth. 
Crooked Creek drainage basin:

Crooked Creek at Central House.

Mammoth Creek at Miller House.

Independence Creek at mouth.

Mastodon Creek at mouth.

Porcupine Creek above ditch intake.

Porcupine Creek above Bonanza Creek.

Bonanza Creek above ditch intake.

Mammoth Creek ditch at intake.

Mammoth Creek ditch at outlet.

Boulder Creek at mouth.

Deadwood Creek above Switch Creek.

Switch Creek at mouth.

Quartz Creek at trail crossing.

\section{BIRCH CREEK DRAINAGE BASIN.}

Birch Creek is tributary to the Yukon almost exactly on the Arctic Circle, about 25 miles directly west of Fort Yukon. Its mouth is about 5 miles west of the confluence of Chandalar River with the Yukon. The north and south forks join to form the main stream about 40 miles south of the town of Circle. Below this junction the general direction of flow is northwestward with a gradual increase in deviation from the north, and the stream roughly parallels the Yukon for 100 miles at a distance of about 10 miles. Its drainage is almost entirely from the west, and for most of the distance it flows through a low, broad valley, which gradually merges with the flats of the Yukon. The principal tributaries are Preacher and Crooked creeks. The headwaters of the South Fork interlock with those of Salchaket and Charley rivers.

Daily discharge, in second-feet, of Birch Creek at Fourteenmile House, 1909.

[Drainage area, 2,150 square miles.]

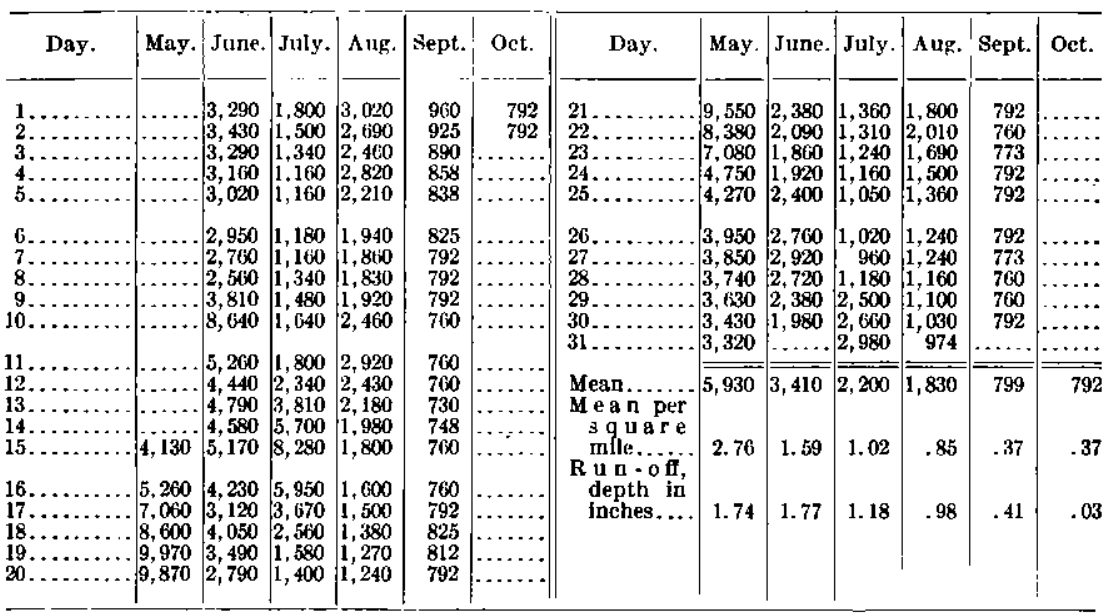




\section{PREACHER CREEK DRAINAGE BASIN.}

Preacher Creek rises near the headwaters of Chatanika River and Beaver Creek and flows in a general northeasterly direction for about 65 miles, entering Birch Creek about 50 miles from the Yukon. It drains an area of 1,090 square miles, ranging in elevation from over 5,000 feet at the head to about 700 feet at the Birch Creek flats.

The main tributaries are the North Fork from the north and Loper and Rock creeks from the south. Bachelor Creek is a small but economically important branch from the south near the head.

Daily discharge, in second-feet, of Bachelor Creek below Costa Fork, 1909.

[Drainage area, 11.4 square miles.]

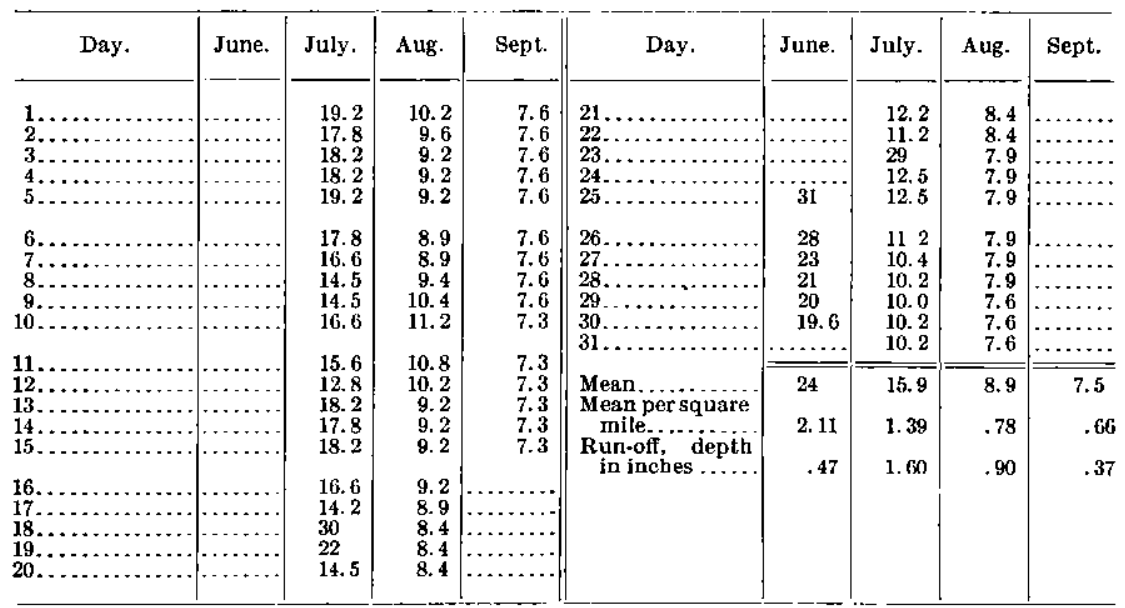

Miscellaneous measurements in Preacher Creek drainage basin, 1909.

\begin{tabular}{|c|c|c|c|c|}
\hline Date. & Stream and locality. & $\begin{array}{l}\text { Drainage } \\
\text { area. }\end{array}$ & $\begin{array}{l}\text { Dis- } \\
\text { charge. }\end{array}$ & $\begin{array}{c}\text { Dis- } \\
\text { charge } \\
\text { per } \\
\text { square } \\
\text { mile. }\end{array}$ \\
\hline $\begin{array}{r}\text { August } 15 \ldots \ldots \\
\text { Do } \ldots \ldots \ldots . . . .\end{array}$ & 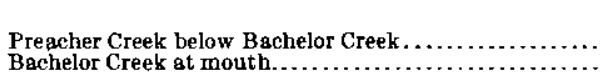 & $\begin{array}{c}S_{q}{ }_{121} \text {. } \\
26.4\end{array}$ & $\begin{array}{c}\text { Sec.-ft. } \\
115 \\
16.4\end{array}$ & $\begin{array}{r}\text { Sec.-ft. } \\
0.95 \\
.62\end{array}$ \\
\hline
\end{tabular}

\section{NORTH FORK OF BIRCH CREEK DRAINAGE BASIN.}

Eagle Creek, which is formed by the junction of Mastodon and Miller forks, unites with Ptarmigan Creek to form the North Fork of Birch Creek. The headwaters are opposite to those of Crooked Creek.

The North Fork takes a southwesterly course for about 7 miles, to the point where it receives Twelvemile Creek and turns abruptly to the south, following that direction for about 8 miles. It is then joined 
by a fair-sized unnamed tributary from the west and makes a rightangle turn to the east, roughly following that course to its confluence with the South Fork, a distance of approximately 45 miles. Harrison Creek is the principal tributary from the north and Clums Fork from the south.

Daily discharge, in second-feet, of Mastodon Fork of Eagle Creek above ditch intake, 1909.

[Drainage area, 4.1 square miles.]

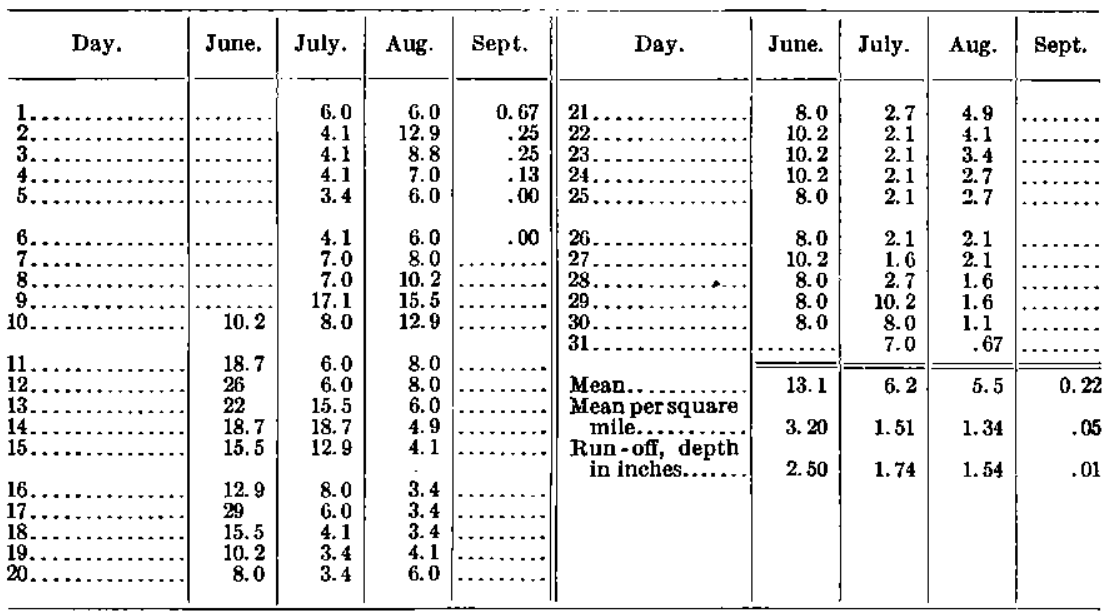

Miscellaneous measurements in North Fork of Birch Creek drainage basin, 1909.

\begin{tabular}{|c|c|c|c|c|}
\hline Date. & Stresm and locslity. & $\begin{array}{l}\text { Drainage } \\
\text { area. }\end{array}$ & $\begin{array}{l}\text { Dis- } \\
\text { charge. }\end{array}$ & $\begin{array}{l}\text { Dis- } \\
\text { charge } \\
\text { per } \\
\text { square } \\
\text { mile. }\end{array}$ \\
\hline 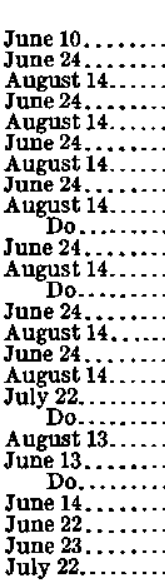 & 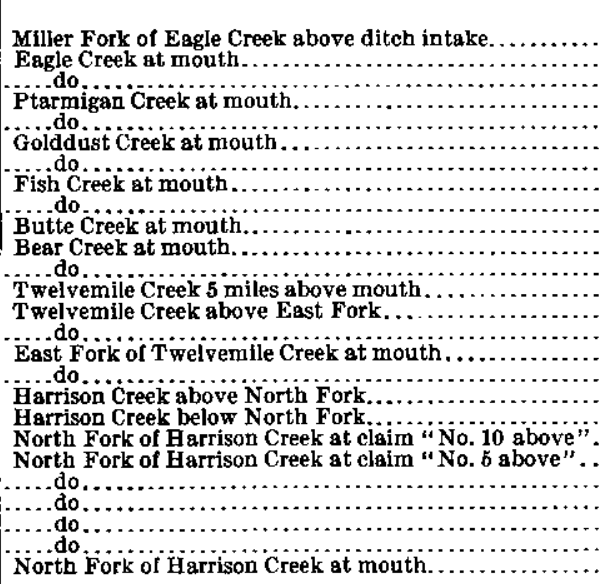 & $\begin{array}{r}\text { Sg. mi. } \\
2.6 \\
15.5 \\
15.5 \\
19.0 \\
19.0 \\
13.6 \\
13.6 \\
6.0 \\
6.0 \\
9.2 \\
12.4 \\
12.4 \\
10.4 \\
18.9 \\
18.9 \\
22.9 \\
22.9 \\
21.6 \\
47.3 \\
6.3 \\
11.4 \\
11.4 \\
11.4 \\
11.4 \\
11.4 \\
25.1\end{array}$ & $\begin{array}{c}\text { Sec.-ft. } \\
9.9 \\
19.4 \\
22 \\
34 \\
27 \\
15.9 \\
15.7 \\
6.6 \\
7.1 \\
5.6 \\
21 \\
12.9 \\
4.6 \\
17.6 \\
19.5 \\
51 \\
18.5 \\
19.1 \\
52 \\
15.7 \\
108 \\
96 \\
49 \\
28 \\
17.9 \\
36\end{array}$ & $\begin{array}{r}\text { Sec.-ft. } \\
3.81 \\
1.25 \\
1.42 \\
1.79 \\
1.42 \\
1.17 \\
1.15 \\
1.10 \\
1.18 \\
.61 \\
1.69 \\
1.04 \\
.44 \\
.93 \\
1.03 \\
2.23 \\
.81 \\
.88 \\
1.10 \\
2.49 \\
9.47 \\
8.42 \\
4.30 \\
2.46 \\
1.57 \\
1.43\end{array}$ \\
\hline
\end{tabular}




\section{CROOKED CREEK DRAINAGE BASIN.}

Crooked Creek, which is formed by the junction of Mammoth and Porcupine creeks, meanders through a rather broad valley for about 30 miles and discharges its waters into Birch Creek about 10 miles above the Fourteenmile House. Not far below the Central House the valley loses its identity in the flats of Birch Creek.

Mastodon and Independence creeks unite to form Mammoth Creek, which receives Miller Crcek about 2 miles below this junction from the west. The total length of that portion of the stream called Mammoth Creek is less than 4 miles.

Deadwood and Boulder creeks are tributaries from the south below and above the Central House, respectively. They follow parallel courses about 3 miles apart, with a length of about 18 miles.

Albert Creek, the principal tributary from the north, drains the southern slope of the Crazy Mountains.

Daily discharge, in second-feet, of Crooked, Mammoth, and Porcupine creeks, 1909.

\begin{tabular}{|c|c|c|c|c|c|c|c|c|c|c|c|c|}
\hline \multirow{2}{*}{ Day. } & \multicolumn{4}{|c|}{$\begin{array}{l}\text { Crooked Creek at Central } \\
\text { House (drainage area, } 161 \\
\text { square miles). }\end{array}$} & \multicolumn{4}{|c|}{$\begin{array}{l}\text { Marnmoth Creek at Miller } \\
\text { House } a \text { (drainage area, } \\
\text { 37.1 square mlles). }\end{array}$} & \multicolumn{4}{|c|}{$\begin{array}{l}\text { Porcupine Creek below Bo- } \\
\text { nanza Creek } b \text { (drainage } \\
\text { area, } 39.9 \text { square miles). }\end{array}$} \\
\hline & May. & June. & July. & Aug. & June. & July. & Aug. & Sept. & June. & July. & A ug. & Sept. \\
\hline & $\cdots$ & $\begin{array}{l}358 \\
377 \\
451 \\
604 \\
584\end{array}$ & $\begin{array}{l}60 \\
50 \\
32 \\
32 \\
32\end{array}$ & $\begin{array}{l}50 \\
50 \\
42 \\
50 \\
50\end{array}$ & $\because$ & $\begin{array}{l}138 \\
122 \\
113 \\
128 \\
128\end{array}$ & $\begin{array}{l}138 \\
126 \\
128 \\
149 \\
128 .\end{array}$ & $\begin{array}{l}63 \\
60 \\
58 \\
55 \\
50\end{array}$ & & $\begin{array}{l}20 \\
18.9 \\
28 \\
20 \\
18.9\end{array}$ & $\begin{array}{l}23 \\
23 \\
26 \\
23 \\
22\end{array}$ & $\begin{array}{r}7.2 \\
110.8 \\
16.2 \\
11.2 \\
15.6\end{array}$ \\
\hline 9. & $\begin{array}{l}28 \\
37\end{array}$ & & $\begin{array}{l}32 \\
60 \\
60 \\
60 \\
50\end{array}$ & $\begin{array}{l}46 \\
50 \\
60\end{array}$ & $\begin{array}{l}(-1 \\
\cdots \cdots \\
\cdots \cdots\end{array}$ & $\begin{array}{l}128 \\
134 \\
162 \\
228 \\
186\end{array}$ & $\begin{array}{l}115 \\
107 \\
113 \\
140 \\
162\end{array}$ & 45 & & $\begin{array}{l}16.8 \\
31 \\
43 \\
77 \\
45\end{array}$ & $\begin{array}{l}21 \\
21 \\
25 \\
38 \\
45\end{array}$ & $\begin{array}{l}15.3 \\
15.0 \\
15.0 \\
15.0 \\
15.0\end{array}$ \\
\hline & $\begin{array}{l}28 \\
37 \\
32 \\
28 \\
62\end{array}$ & & $\begin{array}{r}50 \\
55 \\
293 \\
196 \\
148\end{array}$ & $\begin{array}{l}29 \\
29\end{array}$ & & $\begin{array}{r}158 \\
144 \\
1,170 \\
635 \\
744\end{array}$ & & & $\begin{array}{l}246 \\
490 \\
246 \\
231 \\
329\end{array}$ & $\begin{array}{r}33 \\
29 \\
288 \\
150 \\
160\end{array}$ & $\begin{array}{l}31 \\
28 \\
28 \\
21\end{array}$ & $\begin{array}{l}14.4 \\
15.0 \\
15.0 \\
15.0 \\
15.0\end{array}$ \\
\hline & $\begin{array}{r}122 \\
190 \\
237 \\
122 \\
62\end{array}$ & $\begin{array}{r}190 \\
90 \\
82\end{array}$ & $\begin{array}{l}5 \\
5 \\
4 \\
4\end{array}$ & $\begin{array}{l}21 \\
21\end{array}$ & $\begin{array}{l}380 \\
180 \\
420 \\
342 \\
228\end{array}$ & $\begin{array}{l}294 \\
169 \\
140 \\
128 \\
113\end{array}$ & $\begin{array}{r}99 \\
93 \\
103\end{array}$ & & $\begin{array}{r}170 \\
170 \\
120 \\
85 \\
75\end{array}$ & $\begin{array}{l}33 \\
30 \\
24 \\
19.3\end{array}$ & & $\cdots \cdots$ \\
\hline & $\begin{array}{r}55 \\
48 \\
88 \\
190 \\
221\end{array}$ & $\begin{array}{l}73 \\
73 \\
66 \\
73 \\
66\end{array}$ & $\begin{array}{l}36 \\
32 \\
32 \\
32 \\
32\end{array}$ & $\begin{array}{l}30 \\
21 \\
21 \\
21 \\
21\end{array}$ & $\begin{array}{l}180 \\
169 \\
154 \\
216 \\
194\end{array}$ & $\begin{array}{r}109 \\
97 \\
93 \\
93 \\
84\end{array}$ & $\begin{array}{r}113 \\
99 \\
91 \\
84\end{array}$ & & $\begin{array}{l}68 \\
66 \\
64 \\
58 \\
54\end{array}$ & & & $\cdots$ \\
\hline$\therefore$ & $\begin{array}{l}221 \\
\mathbf{1 6 1} \\
161 \\
205 \\
305 \\
305\end{array}$ & $\begin{array}{l}90 \\
82 \\
82 \\
60 \\
60\end{array}$ & $\begin{array}{l}32 \\
32 \\
39 \\
73 \\
60 \\
50\end{array}$ & $\begin{array}{l}21 \\
21 \\
21 \\
21 \\
21 \\
21\end{array}$ & $\begin{array}{l}228 \\
202 \\
202 \\
169 \\
144\end{array}$ & $\begin{array}{r}82 \\
75 \\
82 \\
138 \\
126 \\
138\end{array}$ & 84 & & $\begin{array}{l}50 \\
46 \\
42 \\
38 \\
34\end{array}$ & $\begin{array}{l}15.0 \\
16.2 \\
17.9 \\
25 \\
25 \\
27\end{array}$ & $\begin{array}{l}15.6 \\
15.6 \\
15.0 \\
15.0 \\
15.0 \\
14.4\end{array}$ & $\begin{array}{c}\cdots \\
\cdots \\
\cdots\end{array}$ \\
\hline persquare & 128 & 229 & 62 & 6 & 232 & 202 & 111 & 55 & 134 & 43.5 & 22 & 15.4 \\
\hline $\begin{array}{l}\mathrm{m} \text { un-off, depth } \\
\text { in inches...... }\end{array}$ & $\begin{array}{l}3.45 \\
2.95\end{array}$ & $\begin{array}{l}6.17 \\
6.88\end{array}$ & $\begin{array}{l}1.67 \\
1.92\end{array}$ & $\begin{array}{r}.97 \\
1.12\end{array}$ & $\begin{array}{r}1.44 \\
.86\end{array}$ & $\begin{array}{l}1.25 \\
1.44\end{array}$ & $\begin{array}{r}0.69 \\
.80\end{array}$ & $\begin{array}{r}0.34 \\
.08\end{array}$ & & & & \\
\hline
\end{tabular}

a These values are only approximate owing to an uncertainty in the amount of water diverted above.

$b$ These values show the run-off from the area above the gage less the amount diverted by the Bonanza Creek diteh. 
Daily discharge, in second-feet, of Bonanza and Deadwood creeks, 1909.

\begin{tabular}{|c|c|c|c|c|c|c|c|c|}
\hline \multirow{2}{*}{ Day. } & \multicolumn{4}{|c|}{$\begin{array}{l}\text { Bonanza Creek above ditch in- } \\
\text { take (drainage area, } 7.9 \text { square } \\
\text { miles). }\end{array}$} & \multicolumn{4}{|c|}{$\begin{array}{l}\text { Deadwood Creek above Switch } \\
\text { Creek (drainage area, } 21.3 \\
\text { square miles). }\end{array}$} \\
\hline & June. & July. & Aug. & Sept. & June. & July. & Aug. & Sept. \\
\hline $\begin{array}{l}1 \ldots \\
2 . . \\
3 . \ldots \\
4 \ldots \\
5 \ldots\end{array}$ & & $\begin{array}{l}16.0 \\
15.7 \\
25 \\
17.9 \\
15.7\end{array}$ & $\begin{array}{l}16.8 \\
17.9 \\
17.9 \\
15.2 \\
17.9\end{array}$ & $\begin{array}{l}12.2 \\
11.1 \\
10.8 \\
10.8 \\
10.6\end{array}$ & $\cdots$ & $\begin{array}{r}12.5 \\
8.0 \\
8.0 \\
8.0 \\
5.0\end{array}$ & $\begin{array}{l}17.5 \\
17.5 \\
17.5 \\
12.5 \\
12.5\end{array}$ & $\begin{array}{l}8.0 \\
8.0 \\
8.0 \\
8.0 \\
8.0\end{array}$ \\
\hline $\begin{array}{r}6 \ldots \\
7 \ldots \\
8 \ldots \\
9 \ldots \\
10 \ldots\end{array}$ & (n...... & $\begin{array}{l}14.5 \\
15.2 \\
15.2 \\
18.5 \\
19.2\end{array}$ & $\begin{array}{l}17.9 \\
15.7 \\
17.1 \\
17.9 \\
17.9\end{array}$ & $\begin{array}{l}10.4 \\
10.1 \\
10.1 \\
10.0 \\
10.0\end{array}$ & & $\begin{array}{l}5.0 \\
25 \\
25 \\
17.5 \\
17.5\end{array}$ & $\begin{array}{l}12.5 \\
12.5 \\
17.5 \\
17.5 \\
17.5\end{array}$ & $\begin{array}{l}5.0 \\
5.0 \\
5.0 \\
5.0 \\
5.0\end{array}$ \\
\hline $\begin{array}{l}11 \ldots \\
12 \ldots \\
13 \ldots \\
14 \ldots \\
15 \ldots\end{array}$ & $\begin{array}{l}82 \\
40 \\
38 \\
32\end{array}$ & $\begin{array}{l}19.2 \\
19.2 \\
49 \\
18.2 \\
34\end{array}$ & $\begin{array}{l}15.5 \\
17.7 \\
16.8 \\
16.3 \\
15.7\end{array}$ & $\begin{array}{l}9.8 \\
9.8 \\
9.8 \\
9.8\end{array}$ & & $\begin{array}{l}17.5 \\
12.5 \\
77 \\
25 \\
17.5\end{array}$ & $\begin{array}{l}17.5 \\
17.5 \\
12.5 \\
12.5 \\
12.5\end{array}$ & $\begin{array}{l}5.0 \\
5.0 \\
5.0 \\
5.0 \\
5.0\end{array}$ \\
\hline 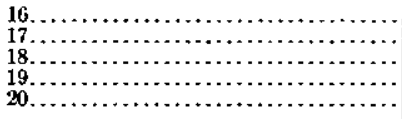 & $\begin{array}{l}32 \\
32 \\
30 \\
28 \\
27\end{array}$ & $\begin{array}{l}19.2 \\
16.8 \\
16.8 \\
16.3 \\
16.3\end{array}$ & $\begin{array}{l}15.2 \\
14.5 \\
14.0 \\
14.0 \\
13.5\end{array}$ & & $\begin{array}{r}25 \\
105 \\
53 \\
25 \\
25\end{array}$ & $\begin{array}{r}17.5 \\
12.5 \\
12.5 \\
12.5 \\
8.0\end{array}$ & $\begin{array}{l}12.5 \\
12.5 \\
12.5 \\
12.5 \\
12.5\end{array}$ & $\begin{array}{l}\text { 5. } 0 \\
5.0 \\
5.0 \\
5.0 \\
5.0\end{array}$ \\
\hline 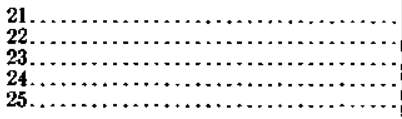 & $\begin{array}{l}26 \\
26 \\
26 \\
24 \\
22\end{array}$ & $\begin{array}{l}\text { 16. } 0 \\
16.0 \\
16.0 \\
15.7 \\
15.2\end{array}$ & $\begin{array}{l}13.3 \\
13.3 \\
12.9 \\
12.4 \\
15.0\end{array}$ & $\cdots$ & $\begin{array}{l}17.5 \\
17.5 \\
17.5 \\
17.5 \\
25\end{array}$ & $\begin{array}{l}\text { 8.0 } \\
8.0 \\
8.0 \\
5.0 \\
5.0\end{array}$ & $\begin{array}{r}12.5 \\
8.0 \\
8.0 \\
8.0 \\
12.5\end{array}$ & $\begin{array}{l}5.0 \\
\cdots \\
\cdots\end{array}$ \\
\hline 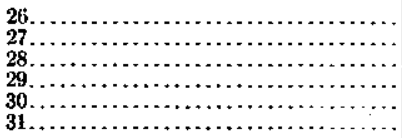 & $\begin{array}{l}20 \\
20 \\
20 \\
20 \\
19.2 \\
2.2 .\end{array}$ & $\begin{array}{l}14.7 \\
15.0 \\
15.5 \\
16.3 \\
16.3 \\
16.3\end{array}$ & $\begin{array}{l}14.8 \\
14.0 \\
13.8 \\
13.5 \\
13.3 \\
12.9\end{array}$ & & $\begin{array}{l}25 \\
17.5 \\
17.5 \\
12.5 \\
12.5 \\
\cdots+.\end{array}$ & $\begin{array}{l}5.0 \\
12.5 \\
17.5 \\
36 \\
36 \\
36\end{array}$ & $\begin{array}{l}8.0 \\
8.0 \\
8.0 \\
8.0 \\
8.0 \\
8.0\end{array}$ & (1). \\
\hline 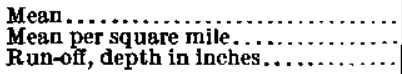 & $\begin{array}{r}30 \\
3.80 \\
2.68\end{array}$ & $\begin{array}{l}18.4 \\
2.33 \\
2.69\end{array}$ & $\begin{array}{l}15.3 \\
1.94 \\
2.24\end{array}$ & $\begin{array}{r}10.4 \\
1.32 \\
.68\end{array}$ & $\begin{array}{r}28 \\
1.31 \\
.73\end{array}$ & $\begin{array}{r}16.8 \\
.79 \\
.91\end{array}$ & $\begin{array}{r}12.5 \\
.59 \\
.68\end{array}$ & $\begin{array}{l}5.7 \\
.27 \\
.21\end{array}$ \\
\hline
\end{tabular}

Miscellaneous measurements in Crooked Creek drainage basin, 1909.

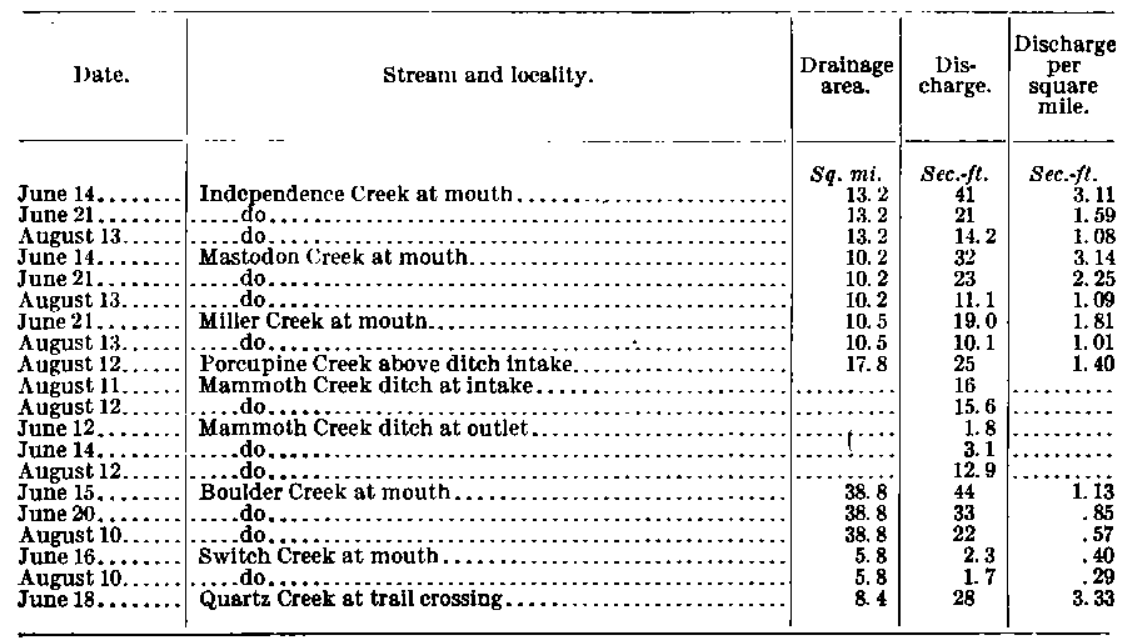




\section{RAMPART DISTRICT.}

\section{DESCRIPTION.}

The area originally known as the Rampart district embraces three main drainage areas, as follows: Minook and Troublesome creeks, tributary to Yukon River, and Baker Creek, tributary to the Tanana.

The town of Rampart, situated on the left bank of the Yukon just below the mouth of Minook Creek, was long the main supply point for the entire region, and from it all the mining outfits and provisions were hauled on sleds in winter and packed on horses in summer. Now, however, the Baker Creek area is by far the largest producer, and since several stores have been opened at Hot Springs, about 6 miles from Tanana River on Baker Slough, Rampart has ceased to be the main trading point and the term "Rampart district" is now understood by some to include only Minook and Troublesome creeks. In this report, however, the original meaning is retained.

The divide between the Minook Creek and Baker Creek drainage basins has a general but very irregular east-west direction, with a notable break to the north at the head of Hutlinana Creek. It varies in elevation from 1,000 to 4,000 feet, Wolverine Mountain being the highest point. The northern area is rugged and mountainous, with narrow valleys and precipitous slopes, even down to the mouths of the streams; the southern area, although rough at the headwaters, broadens out below into alluvial flats in which the streams are sluggish.

Timber sufficient for fuel is found in most of the valleys and lower slopes of the Rampart region. Spruce, birch, and poplar are abundant on the hillsides near Hot Springs and along the Tanana.

\section{GAGING STATIONS.}

The following list gives the points in the Rampart d1strict at which gages were established or measurements made in 1909:

Gaging stations in Rampart district, 1909.

Yukon River drainage basin:

Yukon River at Rampart.

Squaw Creek at mouth.

Minook Creek drainage basin-

Minook Creek below Granite Creek.

Minook Creek above Little Minook Creek.

Granite Creek at mouth.

Ruby Creek at mouth.

Hoosier Creek at claim "No. 11 above."

Little Minook Creek at claim "No. 9 above."

Hunter Creek at claim "No. I9 above." 
Yukon River drainage basin-Continued.

Troublesome Creek drainage basin-

Troublesome Creek above Quail Creek.

Troublesome Creek below Quail Creek.

Quail Creek at claim "No. 7 above."

Quail Creek at claim "No. 9 below."

Nugget Gulch at mouth.

Tanana River drainage basin:

Baker Creek drainage basin-

Baker Creek at road crossing.

Hutlinana Creek above Denver Creek.

Hutlinana Creek above Cairo Creek.

Eureka Creek above Boston Creek.

Pioneer Creek above What Cheer Bar ditch intake.

What Cheer Bar ditch at intake.

New York Creek at Thanksgiving ditch intake.

California Creek at Thanksgiving ditch intake.

Thanksgiving ditch one-quarter mile above outlet.

Patterson Creek drainage basin-

Sullivan Creek above Tofty ditch intake.

Quartz Creek at mouth.

Midnight Sun ditch near outlet.

Cache Creek at Baker Slough trail crossing.

YUKON RIVER AT RAMPART.

A cross section and a discharge measurement of the Yukon River were obtained on May 1, 1909, just above the mouth of Rampart Creek, which is a small tributary from the south at the lower end of the town of Rampart. The bed is thought to be of a semipermanent character and the channel is straight for at least 1,000 feet above and below the point of measurement. The banks on each side are high with long, gentle slopes. The left slope is of cemented gravel and bowlders; the right is of small gravel and is liable to slight changes. At the time the cross section was made, the ice varied in thickness from 4 to $4 \frac{1}{2}$ feet, which was probably the maximum for the winter. The width of the top of the ice was 1,560 feet, while the width of the water's surface was 1,300 feet, which shows that for 260 feet the ice was in contact with the bed of the river. This does not mean, however, that the water froze from the surface to the bed of the stream for that distance. The stage of the river at the time of the first ice cover in the fall was considerably higher than at the time of the measurement, and as the water surface lowered the width decreased and the ice sheet fell, coming into contact with that portion of the bank which was previously submerged and assuming a surface sloping on each side toward the center of the stream. The greatest depth of water below the bottom of the ice was found to be 15.9 feet, at a distance of 420 feet from the left edge of the ice. 
In the early part of May, when the discharge of the tributaries into the main stream commences to increase rapidly, the greater volume raises the ice sheet until it breaks away from the shore ice. This parting of shore and main ice indicates that the beginning of navigation is about to commence and is a momentous occasion for the people of the interior.

The river usually closes about the middle of October and opens about the middle of May. In the spring of 1909 the first movement of ice was noted on the night of May 17 and in a few hours the whole mass was broken up.

On May 19 and 21, after the flow of ice had been reduced from one solid mass to free-flowing cakes, two float measurements were made by timing the passage of ice cakes over a 500-foot range. No means were at hand to determine accurately the distance of the cakes from the shore, but the velocity and section were sufficiently uniform, so that no large errors were liable to be introduced through the uncertainty in the location of the floats. The measurements are, however, only approximate. The stage of the stream was considerably above the mean for the summer.

The average fall of the river from Fort Yukon to the mouth has been approximately estimated at 6 inches to the mile.

Discharge measurements of Yukon River at Rampart, 1909.

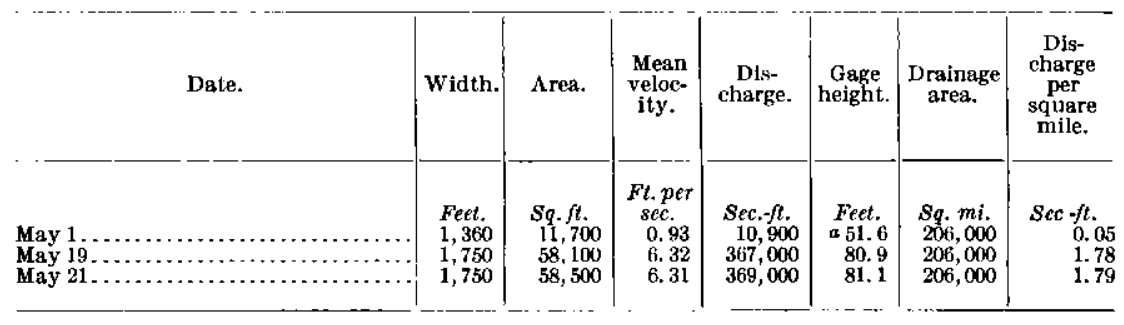

a Bottom of ice.

NotE.-The gage height is the distance of the water surface above an assumed datum.

SQUAW CREEK.

Squaw Creek enters the Yukon just above Rampart, directly opposite Minook Creek. A measurement made May 15, 1909, at the mouth gave a discharge of 484 second-feet. 


\section{MINOOK CREEK DRAINAGE BASIN.}

Minook Creek heads on the northern slope of Eureka Dome, flows northeastward for about 4 miles, and then takes a northerly course through a remarkably straight valley to Yukon River, which it joins just above Rampart. It is about 25 miles long and drains an area of 198 square miles, the major portion being on the east of the stream. The basin is covered with a light growth of timber which furnishes an ample supply for fuel but very little suitable for milling.

The chief tributaries are Chapman, Hoosier, Little Minook, and Hunter creeks from the east and Granite, Ruby, and Slate creeks from the west. Above Granite Creek the valley is narrow and V-shaped; below that point it broadens out and has perhaps a maximum width of one-half mile. The western slope is precipitous through the entire length; the eastern slope below Chapman Creek is more gradual, with prominent benches. In the upper course the stream is crooked, meandering from one side of the valley to the other; the lower part is comparatively straight.

Just below the mouth of Slate Creek the Minook spreads into a number of branches in a wide gravel flat. This flat, which is typical of many Alaskan streams, is probably due to a change in the grade of the creek. The stream here is unable to carry the gravels of the swifter water above and so spreads them upon the flat. Here are found the so-called winter glaciers, some of which last through the short summers. In 1904 a quarter or half acre of "winter glacier" still remained when the September frosts occurred. This ice owes its origin to the fact that, as the water freezes in the fall, the channel is greatly narrowed. The resulting hydrostatic pressure cracks the ice and the water overflows and freezes. This process is repeated until a considerable thickness of ice is accumulated. $a$

Discharge measurements of Minook Creek above Litlle Minook Creck, 1909.

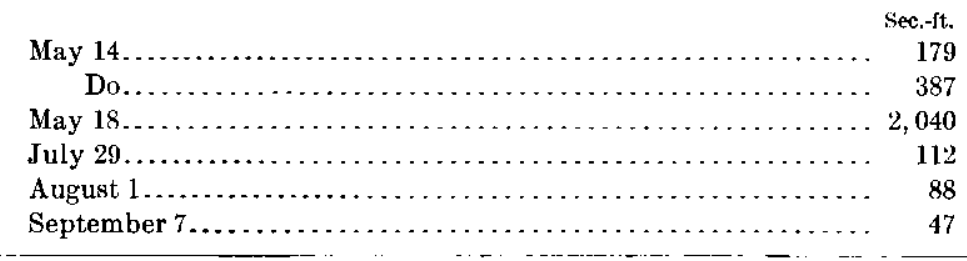

a Hess, F. L., The Rampart placers: Bull. U. S. Geol. Survey No. 337, 1908, pp. 67-68.

$55695^{\circ}-$ Bull. $442-10-18$ 
Daily discharge, in second-feet, of Minook Creek and tributaries, 1909.

\begin{tabular}{|c|c|c|c|c|c|c|c|c|c|c|c|c|}
\hline \multirow[t]{2}{*}{ Day. } & \multicolumn{2}{|c|}{$\begin{array}{l}\text { Minook Creek } \\
\text { above Little } \\
\text { Minook } \\
\text { Creek } a \\
\text { (drainage } \\
\text { area, 130 } \\
\text { square miles). }\end{array}$} & \multicolumn{5}{|c|}{$\begin{array}{l}\text { Hoosier Creek at claim “No. } 11 \\
\text { above"b (drainage srea, } 25.7 \\
\text { square miles). }\end{array}$} & \multicolumn{5}{|c|}{$\begin{array}{l}\text { Little Minrok Creek at claim } \\
\text { "No. } 9 \text { above" (drainage area, } \\
5.9 \text { square miles). }\end{array}$} \\
\hline & May. & June. & May. & June. & July. & Aug. & Sept. & May. & June. & July. & Aug & Sept. \\
\hline & & $\begin{array}{r}1,070 \\
1, \mathbf{1 2 0} \\
1,180 \\
\mathbf{1}, 070 \\
\mathbf{9 4 2}\end{array}$ & $\because$ & $\begin{array}{r}136 \\
126 \\
115 \\
115 \\
90\end{array}$ & $\begin{array}{r}18.7 \\
9.0 \\
9.0 \\
9.0 \\
6.8\end{array}$ & $\begin{array}{c}18.7 \\
23 \\
14.8 \\
35 \\
157\end{array}$ & $\begin{array}{l}6.8 \\
6.8 \\
6.8 \\
6.8 \\
6.8\end{array}$ & & $\begin{array}{l}32 \\
30 \\
27 \\
24 \\
22\end{array}$ & $\begin{array}{l}2.2 \\
2.1 \\
2.0 \\
1.9 \\
1.8\end{array}$ & $\begin{array}{r}2.4 \\
2.4 \\
2.4 \\
2.4 \\
28\end{array}$ & $\begin{array}{r}0.8 \\
.8 \\
.8 \\
.8 \\
1.0\end{array}$ \\
\hline $\begin{array}{l}6 . \\
7 . \\
8 . \\
9 .\end{array}$ & & $\begin{array}{l}814 \\
685 \\
475 \\
496 \\
518\end{array}$ & & $\begin{array}{l}66 \\
60 \\
53 \\
78 \\
66\end{array}$ & $\begin{array}{c}5.3 \\
5.3 \\
53 \\
23 \\
6.8\end{array}$ & $\begin{array}{r}35 \\
266 \\
497 \\
729 \\
586\end{array}$ & $\begin{array}{l}6.8 \\
6.8 \\
6.8\end{array}$ & & $\begin{array}{l}20 \\
18 \\
15.6 \\
18 \\
20\end{array}$ & $\begin{array}{c}1.8 \\
1.8 \\
28 \\
15 \\
5.0\end{array}$ & $\begin{array}{l}43 \\
47 \\
71\end{array}$ & $\begin{array}{l}1.2 \\
1.2 \\
1.3 \\
1.3 \\
1.4\end{array}$ \\
\hline 4. & $\begin{array}{l}\ldots \ldots \\
220 \\
268 \\
865\end{array}$ & $\begin{array}{r}540 \\
630 \\
1,070 \\
630 \\
630\end{array}$ & $\begin{array}{r}65 \\
130 \\
540\end{array}$ & $\begin{array}{l}53 \\
96 \\
80 \\
44 \\
35\end{array}$ & $\begin{array}{r}11.7 \\
9.0 \\
6.8 \\
5.3 \\
5.3\end{array}$ & $\begin{array}{c}443 \\
300 \\
157 \\
88 \\
18.7\end{array}$ & & & $\begin{array}{c}22 \\
25 \\
28 \\
15 \\
2.4\end{array}$ & $\begin{array}{l}.8 \\
.8 \\
.8 \\
.8 \\
.8\end{array}$ & 32 & $\begin{array}{l}1.4 \\
1.5 \\
1.6 \\
1.7 \\
1.8\end{array}$ \\
\hline 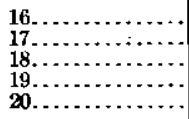 & $\begin{array}{r}1,460 \\
2,060 \\
2,240 \\
1,280 \\
810\end{array}$ & $\begin{array}{l}\cdots \\
\cdots \ldots \\
\cdots \ldots \\
\cdots\end{array}$ & $\begin{array}{r}490 \\
729 \\
499 \\
205 \\
78\end{array}$ & $\begin{array}{l}35 \\
23 \\
23 \\
18.7 \\
18.7\end{array}$ & $\begin{array}{l}5.3 \\
5.0 \\
4.7 \\
4.4 \\
4.1\end{array}$ & $\begin{array}{l}18.7 \\
18.7 \\
16.8 \\
14.8 \\
14.8\end{array}$ & & $\begin{array}{r}71 \\
167 \\
140 \\
110 \\
80\end{array}$ & $\begin{array}{l}2.4 \\
2.4 \\
2.5 \\
2.6 \\
2.7\end{array}$ & $\begin{array}{l}.7 \\
.7 \\
.7 \\
.7 \\
.6\end{array}$ & $\begin{array}{l}20 \\
12 \\
6.0 \\
1.8 \\
1.5\end{array}$ & \begin{tabular}{r}
1.5 \\
1.2 \\
.8 \\
\hdashline.. \\
..
\end{tabular} \\
\hline 25 & $\begin{array}{r}540 \\
494 \\
448 \\
2,320 \\
4,200\end{array}$ & & $\begin{array}{c}53 \\
14.8 \\
33 \\
346 \\
656\end{array}$ & $\begin{array}{l}18.7 \\
18.7 \\
14.8 \\
346 \\
315\end{array}$ & $\begin{array}{c}3.2 \\
2.2 \\
205 \\
136 \\
115\end{array}$ & $\begin{array}{r}13.8 \\
12.8 \\
11.7 \\
10.0 \\
8.4\end{array}$ & & $\begin{array}{l}52 \\
23 \\
36 \\
49 \\
62\end{array}$ & $\begin{array}{r}2.8 \\
2.8 \\
2.8 \\
2.8 \\
28\end{array}$ & $\begin{array}{r}.6 \\
.6 \\
2.4 \\
32 \\
20\end{array}$ & $\begin{array}{l}1.2 \\
1.2 \\
1.1 \\
1.1 \\
1.0\end{array}$ & 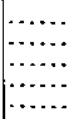 \\
\hline $\begin{array}{l}27 . \\
28 . \\
29 . \\
30 .\end{array}$ & $\begin{array}{r}2,600 \\
740 \\
740 \\
1,070 \\
975 \\
1,180 \\
\end{array}$ & ............... & $\begin{array}{l}115 \\
115 \\
115 \\
136 \\
258 \\
157 \\
\end{array}$ & $\begin{array}{r}115 \\
53 \\
35 \\
29 \\
23 \\
\cdots \\
\end{array}$ & $\begin{array}{l}23 \\
23 \\
23 \\
23 \\
23 \\
14.8 \\
\end{array}$ & $\begin{array}{l}6.8 \\
6.8 \\
6.8 \\
6.8 \\
6.8 \\
6.8 \\
\end{array}$ & & $\begin{array}{l}76 \\
63 \\
50 \\
37 \\
37 \\
37 \\
\end{array}$ & $\begin{array}{r}2.8 \\
28 \\
2.6 \\
2.5 \\
2.4 \\
2 . . . \\
\end{array}$ & $\begin{array}{c}10 \\
2.4 \\
8.3 \\
5.3 \\
2.4 \\
2.4 \\
\end{array}$ & $\begin{array}{r}1.0 \\
.9 \\
.8 \\
.8 \\
.8 \\
.8\end{array}$ & $\begin{array}{c}\ldots \ldots \\
\cdots \cdots \\
\cdots \cdots \\
\cdots \cdots \\
\ldots \ldots \\
\ldots \ldots\end{array}$ \\
\hline & 1,290 & 790 & 249 & 77 & 26 & $\overline{114}$ & 6.8 & 68 & 12.0 & 5.0 & 17.1 & 1.2 \\
\hline opth & 9.92 & 6.08 & 9. 69 & 3.00 & 1.01 & 4.44 & .26 & 11.53 & 2.03 & .85 & 2.90 & .20 \\
\hline & 7.01 & 3. 39 & 6. 85 & 3.35 & 1.16 & 5.12 & .09 & 6.86 & 2. 26 & .98 & 3. 34 & .13 \\
\hline
\end{tabular}

a Gage heights were kept until September 8 , but it was not thought advisable to make daily estimates after June 15 because of extreme shifting channel conditions.

$b$ These values are only approximate because of tnsufficent measurements and shifting channel.

Miscellaneous measurements in Minook Creek drainage basin, 1909.

\begin{tabular}{|c|c|c|c|c|}
\hline Date. & Stream and locality. & $\begin{array}{c}\text { Drainsge } \\
\text { area. }\end{array}$ & $\begin{array}{c}\text { Dis- } \\
\text { charge. }\end{array}$ & $\begin{array}{c}\text { Discharge } \\
\text { per } \\
\text { square } \\
\text { mile. }\end{array}$ \\
\hline September 9 & Minook Creek below Granite Creek & $S q . m i$ & Sec. ft. & Sec.-ft. \\
\hline Do...... & Granite Creek at mouth............ & 26.9 & 5.9 & .22 \\
\hline Do. & Ruby Creek at mouth. & 10.6 & & 25 \\
\hline May $16 . .$. & Hunter Creek at claim "No. ig above" & 34.4 & 1,000 & 29.07 \\
\hline May 19. & …do............................. & 34.4 & 326 & 9.48 \\
\hline July & ....do........... & 34.4 & 28 & .81 \\
\hline August & ....do............ & 34.4 & 21 & .61 \\
\hline Septem & $\ldots \ldots$ do........... & 34.4 & 5.8 & \\
\hline
\end{tabular}




\section{TROUBLESOME CREEK DRAINAGE BASIN.}

Troublesome (reek rises southeast of Wolverine Mountain, between the headwaters of Hutlinana Creek and the West Fork of Tolovana River, and flows northeastward for about 40 miles, entering Hess Creek 10 miles from the Yukon.

No study of this creek was made below the mouth of Quail Creek, but it is said to follow a winding course, meandering from one side of the valley to the other through soft mucky soil abounding with "niggerheads" and a thick growth of small trees which make travel slow and tedious. It also has steep, high slopes, which make it very difficult of approach.

The main and tributary valleys at the head are almost canyon-like in appearance, being shut in by rocky, barren ridges which are high and precipitous.

Troublesome Creek seems to be the only one near enough to the Rampart mines with sufficient run-off and gradient to be worthy of consideration as a possible water supply for the development of hydro-electric power to be transmitted to that region. The approximate grade of the stream below the mouth of Quail Creek averages 45 feet to the mile, ranging from 150 feet at the upper limit to 18 feet at the mouth.

About 7 miles from the head Troublesome Creek receives Quail Creek, its first important tributary. Quail Creek heads opposite Hoosier Creek and flows eastward, draining the north slope of Wolverine Mountain. It is about 5 miles long and drains an area of 20.6 square miles. The south slope of its basin is rocky and barren, rising precipitously to the summit of Wolverine Mountain. On the north the valley has a very gentle approach and is covered with a heavy growth of wild grass, which furnishes excellent forage for pack animals. The stream is lined with a dense growth of willows in the upper portion, and near the mouth is a growth of spruce suitable for cabin and fuel purposes.

The South Fork joins Quail Creek about a mile above Troublesome Creek and is its largest tributary. 
Daily discharge, in second-feet, of Troublesome Creek and tributaries, 1909.

\begin{tabular}{|c|c|c|c|c|c|c|c|c|c|c|c|c|}
\hline \multirow{2}{*}{ ay. } & \multicolumn{4}{|c|}{$\begin{array}{l}\text { Troublesome Creek below } \\
\text { Quail Creek (drainage area, } \\
\text { 43.2 square miles). }\end{array}$} & \multicolumn{4}{|c|}{$\begin{array}{l}\text { Quail Creek at claim "No. } 7 \\
\text { above"b (drainage area, } \\
8.5 \text { square miles). }\end{array}$} & \multicolumn{4}{|c|}{$\begin{array}{l}\text { Quail Creek at claim "No. } \\
\text { below" (drainage area } \\
20.2 \text { square miles). }\end{array}$} \\
\hline & June. & July. & Aug. & Sept. & Jume. & July. & Aug. & Sept. & June. & July. & Aug. & Sept. \\
\hline $\begin{array}{l}1 . \\
2 . \\
3 . \\
4 . \\
5 .\end{array}$ & $\begin{array}{l}\cdots \cdots \\
\cdots \cdots \\
252 \\
2 \ldots \\
\end{array}$ & $\begin{array}{l}32 \\
40 \\
58 \\
48 \\
34\end{array}$ & $\begin{array}{l}158 \\
153 \\
132 \\
191 . \\
600\end{array}$ & $\begin{array}{l}22 \\
20.0 \\
17.0 \\
15.0 \\
13.0\end{array}$ & 103 & $\begin{array}{l}16.0 \\
17.0 \\
24 \\
24 \\
18.0\end{array}$ & $\begin{array}{r}5.0 \\
13.5 \\
15.0 \\
50 \\
152\end{array}$ & $\begin{array}{l}3.5 \\
3.0 \\
2.0 \\
1.7 \\
1.6\end{array}$ & $\begin{array}{ll}\cdots \\
\cdots\end{array}$ & $\begin{array}{l}20 \\
21 \\
31 \\
32 \\
24\end{array}$ & $\begin{array}{r}37 \\
84 \\
88 \\
147 \\
323\end{array}$ & $\begin{array}{l}21 \\
18.3 \\
8.4 \\
7.8 \\
7.3\end{array}$ \\
\hline $\begin{array}{l}6 . \\
7 . \\
8 . \\
9 .\end{array}$ & $\begin{array}{l}250 \\
248 \\
276 \\
246 \\
115\end{array}$ & $\begin{array}{r}28 \\
100 \\
83 \\
83 \\
60\end{array}$ & $\begin{array}{l}271 \\
139 \\
167 \\
573 \\
325\end{array}$ & $\begin{array}{l}12.2 \\
11.8 \\
11.4 \\
11.4 \\
11.0\end{array}$ & $\begin{array}{l}9 \\
8 \\
8 \\
7 \\
6\end{array}$ & $\begin{array}{l}15.0 \\
28 \\
29 \\
24 \\
21\end{array}$ & $\begin{array}{r}74 \\
50 \\
40 \\
188 \\
43\end{array}$ & $\begin{array}{c}1.6 \\
\cdots \cdots \\
\cdots \cdots \\
\cdots\end{array}$ & $\begin{array}{r}128 \\
134 \\
120 \\
74\end{array}$ & $\begin{array}{l}2.0 \\
36 \\
38 \\
30 \\
26\end{array}$ & $\begin{array}{r}151 \\
94 \\
88 \\
394 \\
151\end{array}$ & $\begin{array}{l}7.1 \\
7.1 \\
6.8 \\
6.8 \\
6.5\end{array}$ \\
\hline$\cdots$ & $\begin{array}{l}110 \\
325 \\
276 \\
240 \\
276\end{array}$ & $\begin{array}{l}73 \\
58 \\
38 \\
28 \\
24\end{array}$ & $\begin{array}{r}225 \\
167 \\
97 \\
73 \\
63\end{array}$ & $\begin{array}{c}10.6 \\
10.6 \\
\cdots \cdots . .\end{array}$ & $\begin{array}{l}6 . \\
6 \\
5 \\
5\end{array}$ & $\begin{array}{l}11 . \\
8 . \\
6 . \\
6 .\end{array}$ & $\begin{array}{l}24 \\
25 \\
26 \\
27 \\
28\end{array}$ & & $\begin{array}{r}71 \\
118 \\
132 \\
104 \\
128\end{array}$ & $\begin{array}{l}36 \\
34 \\
25 \\
19.5 \\
18.3\end{array}$ & $\begin{array}{r}113 \\
80 \\
60 \\
44 \\
39\end{array}$ & $\begin{array}{r}6.2 \\
5.8 \\
\cdots . . \\
\cdots \cdots . \\
\cdots\end{array}$ \\
\hline & $\begin{array}{l}300 \\
305 \\
290 \\
270 \\
255\end{array}$ & $\begin{array}{l}20 \\
40 \\
60 \\
44 \\
28\end{array}$ & $\begin{array}{l}48 \\
60 \\
63 \\
56 \\
48\end{array}$ & & 5 & $\begin{array}{l}9 . \\
8 . \\
6 .\end{array}$ & $\begin{array}{l}28 \\
22 \\
16.0 \\
10.0 \\
5.9\end{array}$ & & $\begin{array}{r}94 \\
120 \\
116 \\
96 \\
116\end{array}$ & $\begin{array}{l}13.5 \\
12.7 \\
28 \\
28 \\
21\end{array}$ & 26 & $\cdots$ \\
\hline 2 & $\begin{array}{l}220 \\
218 \\
300 \\
524 \\
438\end{array}$ & $\begin{array}{c}22 \\
18.6 \\
394 \\
238 \\
63\end{array}$ & $\begin{array}{l}46 \\
44 \\
36 \\
28 \\
25\end{array}$ & & $\begin{array}{r}37 \\
40 \\
77 \\
188 \\
150\end{array}$ & $\begin{array}{c}4.0 \\
3.5 \\
161 \\
43 \\
10.0\end{array}$ & $\begin{array}{l}5 . \\
4 . \\
3 . \\
3 . \\
2 .\end{array}$ & & $\begin{array}{l}100 \\
109 \\
137 \\
238 \\
199\end{array}$ & $\begin{array}{c}13.1 \\
11.9 \\
179 \\
108 \\
37\end{array}$ & $\begin{array}{l}24 \\
18.9 \\
17.1 \\
15.3\end{array}$ & .... \\
\hline $\begin{array}{l}27 \\
28 \\
29 \\
30\end{array}$ & $\begin{array}{r}260 \\
250 \\
95 \\
68 \\
66\end{array}$ & $\begin{array}{r}63 \\
70 \\
97 \\
88 \\
80 \\
163\end{array}$ & $\begin{array}{l}23 \\
22 \\
20 \\
17.2 \\
16.5 \\
15.8\end{array}$ & & $\begin{array}{l}76 \\
72 \\
36 \\
33 \\
30\end{array}$ & $\begin{array}{r}10.0 \\
12.6 \\
20 \\
14.0 \\
9.0 \\
7.0\end{array}$ & $\begin{array}{l}2.1 \\
2.0 \\
1.8 \\
1.7 \\
1.7 \\
1.7\end{array}$ & & $\begin{array}{r}118 \\
113 \\
43 \\
31 \\
30\end{array}$ & $\begin{array}{l}37 \\
47 \\
69 \\
44 \\
74 \\
52\end{array}$ & $\begin{array}{r}12.7 \\
11.1 \\
9.5 \\
9.5 \\
9.5\end{array}$ &. \\
\hline Mean.. & 249 & 73 & 126 & 13.8 & 68 & 0 & 28 & 2.2 & 111 & 38 & $\overline{71}$ & $\overline{9.1}$ \\
\hline & 5 & 1.69 & 2.92 & .32 & 8.00 & 2.24 & 3. 29 & .26 & 5. 50 & 1.88 & 3. 51 & .45 \\
\hline II & 5. 57 & 1.95 & 3.37 & .14 & 7.74 & 2.58 & 3.79 & .06 & 4.91 & 2.17 & 4.05 & .21 \\
\hline
\end{tabular}

a These values are only approximate because of insufficient measurements and shifting channel.

$b$ These values are based on gage readings taken about every four days.

Miscellaneous measurements in Troublesome Creek drainage basin, 1909.

\begin{tabular}{|c|c|c|c|c|}
\hline Date. & Stream and locality. & $\begin{array}{c}\text { Drainsge } \\
\text { area. }\end{array}$ & $\begin{array}{c}\text { Dis- } \\
\text { charge. }\end{array}$ & $\begin{array}{l}\text { Discharge } \\
\text { per } \\
\text { square } \\
\text { mile. }\end{array}$ \\
\hline $\begin{array}{l}\text { September } 6 \ldots \\
\text { July } 27 \ldots \ldots \ldots \\
\text { Do.............. }\end{array}$ & 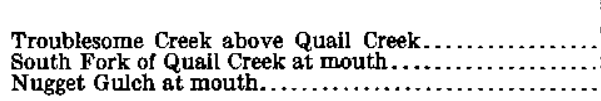 & $\begin{array}{r}S q . m i . \\
21.4 \\
3.7 \\
2.7\end{array}$ & $\begin{array}{r}\text { Sec. } f t . \\
6.8 \\
9.6 \\
2.7\end{array}$ & $\begin{array}{r}\text { sec. } f t . \\
0.32 \\
2.59 \\
1.00\end{array}$ \\
\hline
\end{tabular}




\section{BAKER CREEK DRAINAGE BASIN.}

Baker Creek and its tributaries drain a roughly fan-shaped area 542 square miles in extent. The greatest width of this basin from east to west is 37 miles, and its greatest width from north to south 21 miles.

The name Baker Creek is applied to the extreme western fork. It heads near Sullivan Creek on the south slope of Roughtop Mountain and flows eastward for about 17 miles; it then makes a right-angle turn to the south around the north end of Bean Ridge, which it follows closely for about 4 miles below the turn and then crosses the flat and receives its two largest tributaries, Hutlinana and Hutlitakwa creeks, which drain over half the entire area. It is about 28 miles long and enters the Tanana 70 miles from the Yukon.

The system of main and tributary streams is very unsymmetrical, about 88 per cent of the area lying on the left side. South of the creek the country rises abruptly to the summit of Bean Ridge and furnishes no tributaries of importance. On the north the valley spreads out into a broad alluvial flat with a very gradual slope to the area near the heads of the tributaries, where it rises abruptly to the summit of the divide.

The basin as a whole is favored with an abundant and diversified growth of timber. In the upper portion this growth is small but has furnished sufficient supply for fuel and cabins; on the flats, particularly in the lower valley of the Hutlinana, there is considerable spruce suitable for milling. On the slope near Hot Springs there is a heavy growth of birch and poplar.

Baker Creek has so low a gradient that its water can never be conveyed to any of the present mines by a gravity system, but as a supply for pumping it is ample, and it is so situated that it is worth consideration for that purpose.

Discharge measurements of Hutlinana Creek above Cairo Creek, 1909.

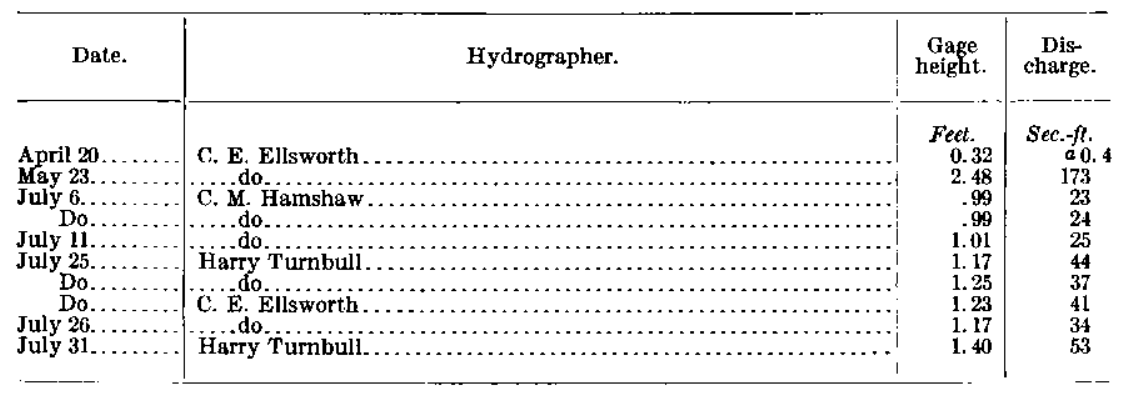

a This ineasurement shows the discharge of the hot springs. The creek was frozen solid above. 
Daily discharge, in second-feet, of Hutlinana Creek above Cairo Creek, 1908-9.

[Drainage area, 42.7 square miles.]

\begin{tabular}{|c|c|c|c|c|c|c|c|}
\hline \multirow{2}{*}{ Day. } & \multicolumn{2}{|c|}{1908.} & \multicolumn{5}{|c|}{1909.} \\
\hline & Sept. & Oet. & Apr. & May. & June. & July. & Aug. \\
\hline 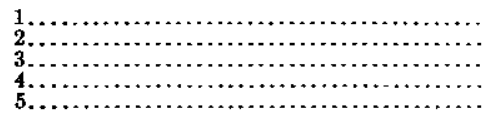 & $\begin{array}{l}15 \\
15 \\
16 \\
18 \\
19\end{array}$ & $\begin{array}{l}15 \\
15 \\
15 \\
15 \\
15\end{array}$ & $\mid \begin{array}{l}\cdots \ldots \\
\cdots \ldots \ldots \\
\cdots \cdots \\
\cdots \cdots\end{array}$ & $\begin{array}{l}15 \\
19 \\
4.5 \\
11 \\
7.5\end{array}$ & $\begin{array}{l}81 \\
81 \\
91 \\
91 \\
81\end{array}$ & $\begin{array}{l}24 \\
24 \\
24 \\
24 \\
24\end{array}$ & $\begin{array}{r}49 \\
45 \\
53 \\
91 \\
176\end{array}$ \\
\hline $\begin{array}{r}6 \\
7 \\
8 \\
9 \\
9 \\
10\end{array}$ & $\begin{array}{l}19 \\
19 \\
19 \\
19 \\
19\end{array}$ & $\begin{array}{l}15 \\
14 \\
13 \\
12 \\
11\end{array}$ & $\mid \begin{array}{l}\cdots \ldots \ldots \\
\cdots \ldots \ldots \\
\cdots \cdots\end{array}$ & $\begin{array}{l}15 \\
24 \\
43 \\
62 \\
71\end{array}$ & $\begin{array}{l}77 \\
72 \\
67 \\
62 \\
53\end{array}$ & $\begin{array}{l}24 \\
24 \\
30 \\
30 \\
23\end{array}$ & $\begin{array}{r}113 \\
81 \\
81 \\
315 \\
176\end{array}$ \\
\hline $\begin{array}{l}11 \\
12 \\
13 \\
14 \\
15 \\
15\end{array}$ & $\begin{array}{l}19 \\
19 \\
19 \\
19 \\
19\end{array}$ & $\begin{array}{l}11 \\
11 \\
11 \\
11 \\
11\end{array}$ & 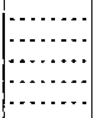 & $\begin{array}{r}71 \\
102 \\
62 \\
81 \\
138\end{array}$ & $\begin{array}{l}\mathbf{4 5} \\
\mathbf{4 5} \\
\mathbf{5 3} \\
62 \\
5 \mathbf{3}\end{array}$ & $\begin{array}{l}24 \\
25 \\
24 \\
24 \\
24\end{array}$ & $\begin{array}{r}113 \\
91 \\
71 \\
59 \\
53\end{array}$ \\
\hline $\begin{array}{l}16 \ldots \ldots \\
17 \\
18 \ldots \\
19 \\
20\end{array}$ & $\begin{array}{l}19 \\
19 \\
22 \\
24 \\
24\end{array}$ & $\begin{array}{l}11 \\
11 \\
11 \\
11 \\
11\end{array}$ & $\mid \begin{array}{c}\cdots \cdots \\
\cdots \cdots \\
\cdots \cdots\end{array}$ & $\begin{array}{l}102 \\
112 \\
122 \\
132 \\
142\end{array}$ & $\begin{array}{l}\mathbf{4 5} \\
\mathbf{4 5} \\
\mathbf{4 5} \\
\mathbf{3 7} \\
\mathbf{3 7}\end{array}$ & $\begin{array}{l}24 \\
19 \\
19 \\
19 \\
19\end{array}$ & $\begin{array}{r}45 \\
45 \\
\ldots \ldots \ldots \\
\cdots \ldots \ldots \\
\cdots \ldots\end{array}$ \\
\hline $\begin{array}{l}21 \\
22 \\
23 \\
24 \ldots \ldots \\
25 \\
25 \ldots \ldots\end{array}$ & $\begin{array}{l}24 \\
22 \\
21 \\
20 \\
19\end{array}$ & $\begin{array}{r}11 \\
11 \\
10 \\
9 \\
8\end{array}$ & $\begin{array}{l}1.0 \\
2.0 \\
1.5 \\
1.0 \\
2.0\end{array}$ & $\begin{array}{l}152 \\
162 \\
173 \\
190 \\
204\end{array}$ & $\begin{array}{l}34 \\
30 \\
30 \\
62 \\
45\end{array}$ & $\begin{array}{l}24 \\
37 \\
37 \\
53 \\
41\end{array}$ & $\mid \begin{array}{ll}\cdots \ldots \ldots \\
\cdots \ldots \ldots \\
\cdots \ldots \ldots\end{array}$ \\
\hline $\begin{array}{l}26, \ldots \ldots \\
27 \\
28 \\
29 \\
30 \\
31 \\
31\end{array}$ & $\begin{array}{r}19 \\
18 \\
17 \\
16 \\
15 \\
\ldots \ldots \\
\end{array}$ & \begin{tabular}{l}
$1_{11}^{1.5}$ \\
$\ldots \ldots \ldots$ \\
\hdashline$\ldots \ldots \ldots$ \\
\end{tabular} & $\begin{array}{r}1.0 \\
2.0 \\
1.0 \\
1.5 \\
2.0 \\
\ldots . . \\
\end{array}$ & $\begin{array}{r}163 \\
113 \\
91 \\
81 \\
81 \\
81\end{array}$ & $\begin{array}{r}37 \\
30 \\
24 \\
24 \\
24 \\
\end{array}$ & $\begin{array}{l}37 \\
37 \\
37 \\
37 \\
66 \\
53\end{array}$ & \begin{tabular}{|l|l}
$\ldots$ & $\ldots$ \\
\hdashline & $\ldots$
\end{tabular} \mid \\
\hline $\begin{array}{l}\text { Mean } \\
\text { Mean per square mile. } \\
\text { Run-off, depth in inehes........ }\end{array}$ & $\begin{array}{r}19.1 \\
.45 \\
.50\end{array}$ & $\begin{array}{r}11.7 \\
.27 \\
.28\end{array}$ & $\begin{array}{l}1.4 \\
.03 \\
.01\end{array}$ & $\begin{array}{l}91 \\
2.13 \\
2.46\end{array}$ & $\begin{array}{r}52 \\
1.22 \\
1.36\end{array}$ & $\begin{array}{r}30 \\
.70 \\
.81\end{array}$ & $\begin{array}{r}97 \\
2.27 \\
1.44\end{array}$ \\
\hline
\end{tabular}


Daily discharge, in second-feet, of New York and California creeks and Thanksgiving ditch, 1909.

\begin{tabular}{|c|c|c|c|c|c|c|c|c|c|c|c|c|c|c|}
\hline \multirow[t]{2}{*}{ Day. } & \multicolumn{5}{|c|}{$\begin{array}{l}\text { New York Creek at Thanks- } \\
\text { giving ditch intake (drain- } \\
\text { age area, } 4.7 \text { square miles). }\end{array}$} & \multicolumn{4}{|c|}{$\begin{array}{l}\text { Californis Creek at } \\
\text { Thanksgiving ditch } \\
\text { intake (drainage area, } \\
6.7 \text { square miles). }\end{array}$} & \multicolumn{5}{|c|}{$\begin{array}{l}\text { Thanksgiving ditch one-fourth } \\
\text { mile above outlet. }\end{array}$} \\
\hline & $y$. & June. & July. & Aug. & Sept. & June. & July. & Aug. & Sept. & May. & June. & July. & Aug. & Sept. \\
\hline 4. & & $\begin{array}{l}6.0 \\
6.0 \\
6.0 \\
6.0 \\
6.0\end{array}$ & $\begin{array}{l}1.0 \\
1.0 \\
1.0 \\
1.0 \\
1.0\end{array}$ & $\begin{array}{r}1.0 \\
1.0 \\
2.1 \\
4.2 \\
12.9\end{array}$ & $\begin{array}{l}1.4 \\
1.4 \\
1.4 \\
1.4 \\
1.4\end{array}$ & $\begin{array}{l}\cdots \\
\cdots \\
\cdots\end{array}$ & $\begin{array}{l}3.7 \\
3.6 \\
3.6 \\
3.6 \\
3.5\end{array}$ & $\begin{array}{l}3.2 \\
3.2 \\
3.5 \\
3.7 \\
5.1\end{array}$ & $\begin{array}{l}2.6 \\
2.6 \\
2.6 \\
2.6 \\
2.6\end{array}$ & & $\begin{array}{l}4.7 \\
4.7 \\
4.7 \\
5.6 \\
4.7\end{array}$ & & $\begin{array}{l}2.6 \\
3.0 \\
4.7 \\
6.4 \\
9.8\end{array}$ & $\begin{array}{l}3.4 \\
3.2 \\
3.2 \\
3.4 \\
3.4\end{array}$ \\
\hline $\begin{array}{l}6 . \\
7 . \\
8 .\end{array}$ & & $\begin{array}{l}3.7 \\
3.7 \\
3.7 \\
3.7 \\
2.1\end{array}$ & $\begin{array}{l}1.0 \\
1.0 \\
1.2 \\
1.8 \\
3.4\end{array}$ & $\begin{array}{r}9.0 \\
6.0 \\
6.0 \\
100 \\
81\end{array}$ & $\begin{array}{l}1.2 \\
1.2\end{array}$ & & $\begin{array}{l}3.5 \\
3.4 \\
4.3 \\
4.0 \\
4.3\end{array}$ & $\begin{array}{l}4.6 \\
3.8 \\
4.0 \\
8.3 \\
6.6\end{array}$ & $\begin{array}{l}2.6 \\
2.6\end{array}$ & & $\begin{array}{l}4.0 \\
3.4 \\
7.5 \\
5.6 \\
0.4\end{array}$ & $\begin{array}{l}4.0 \\
4.7\end{array}$ & $\begin{array}{r}6.8 \\
9.1 \\
9.1 \\
10.9 \\
6.4\end{array}$ & $\begin{array}{l}3.0 \\
3.0 \\
\cdots\end{array}$ \\
\hline & & $\begin{array}{l}2.1 \\
2.4 \\
2.9 \\
2.4 \\
2.1\end{array}$ & $\begin{array}{l}2.4 \\
2.1 \\
1.4 \\
1.8 \\
1.4\end{array}$ & $\begin{array}{l}23 \\
11 \\
7.9 \\
5.5 \\
3.7\end{array}$ & & 4.6 & $\begin{array}{l}4.2 \\
3.7 \\
3.5 \\
3.5 \\
3.5\end{array}$ & $\begin{array}{l}3.4 \\
3.5 \\
3.6 \\
3.5 \\
3.7\end{array}$ & & & & $\begin{array}{l}3.7 \\
3.7 \\
3.2\end{array}$ & $\begin{array}{r}6.4 \\
8.6 \\
9.1 \\
10.4 \\
8.6\end{array}$ & 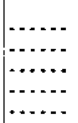 \\
\hline $\begin{array}{l}17 . \\
18 . \\
19 . \\
20 .\end{array}$ & & $\begin{array}{l}2.1 \\
2.1 \\
1.8 \\
1.2 \\
1.2\end{array}$ & $\begin{array}{l}1.0 \\
1.0 \\
.90 \\
.75 \\
.75\end{array}$ & $\begin{array}{l}3.7 \\
2.9 \\
2.9 \\
2.9 \\
2.4\end{array}$ & & $\begin{array}{l}4.8 \\
4.2 \\
4.3 \\
4.0 \\
4.0\end{array}$ & $\begin{array}{l}3.5 \\
3.5 \\
3.5 \\
3.5 \\
3.5\end{array}$ & $\begin{array}{l}3.4 \\
3.4 \\
3.4 \\
3.2 \\
3.2\end{array}$ & & & $\begin{array}{l}5.6 \\
4.4 \\
4.0 \\
3.7 \\
3.4\end{array}$ & $\begin{array}{l}2.8 \\
2.6 \\
2.5 \\
2.2 \\
2.1\end{array}$ & $\begin{array}{l}8.2 \\
6.4 \\
6.4 \\
6.4 \\
5.0\end{array}$ & - \\
\hline $\begin{array}{l}23 . . \\
24 .\end{array}$ & 49.0 & $\begin{array}{l}1.0 \\
1.0 \\
1.0 \\
2.1 \\
3.4\end{array}$ & $\begin{array}{l}.75 \\
.70 \\
1.4 \\
3.4 \\
2.1\end{array}$ & $\begin{array}{l}2.1 \\
2.1 \\
2.9 \\
2.4 \\
2.1\end{array}$ & & $\begin{array}{l}4.0 \\
4.0 \\
4.0 \\
4.8 \\
4.9\end{array}$ & $\begin{array}{l}3.4 \\
3.2 \\
3.6 \\
4.2 \\
3.5\end{array}$ & $\begin{array}{l}3.0 \\
2.9 \\
3.2 \\
2.9 \\
2.9\end{array}$ & & 7.1 & $\begin{array}{l}3.4 \\
3.2 \\
3.2 \\
6.1 \\
7.5\end{array}$ & $\begin{array}{l}2.1 \\
2.0 \\
3.2 \\
6.1 \\
4.0\end{array}$ & $\begin{array}{l}4.7 \\
4.7 \\
5.6 \\
4.7 \\
4.7\end{array}$ & $\cdots \cdot$ \\
\hline $\begin{array}{l}26 . . \\
27 . . \\
28 . . \\
29 . . \\
30 .\end{array}$ & $\begin{array}{r}31.0 \\
20.1 \\
12.9 \\
11.0 \\
9.8 \\
9.8\end{array}$ & $\begin{array}{l}2.1 \\
2.1 \\
1.4 \\
1.0 \\
1.0 \\
\cdots\end{array}$ & $\begin{array}{l}1.4 \\
1.4 \\
2.1 \\
1.8 \\
1.4 \\
1.2 \\
\end{array}$ & $\begin{array}{l}2.1 \\
2.1 \\
2.1 \\
1.8 \\
1.4 \\
1.4 \\
\end{array}$ & & $\begin{array}{l}4.3 \\
4.0 \\
3.8 \\
3.8 \\
3.8 \\
\cdots . . \\
\end{array}$ & $\begin{array}{l}3.5 \\
3.5 \\
3.5 \\
3.5 \\
3.4 \\
3.3 \\
\end{array}$ & $\begin{array}{l}2.8 \\
2.8 \\
2.8 \\
2.6 \\
2.6 \\
2.6 \\
\end{array}$ & $\mid \begin{array}{l}\cdots \\
\cdots \\
\cdots\end{array}$ & $\begin{array}{l}4.0 \\
6.1 \\
6.4 \\
6.8 \\
6.4 \\
6.1 \\
\end{array}$ & $\begin{array}{r}4.7 \\
4.0 \\
3.4 \\
3.2 \\
3.2 \\
\ldots \ldots . . \\
\end{array}$ & $\begin{array}{l}3.4 \\
3.4 \\
4.0 \\
3.4 \\
3.4 \\
3.0 \\
\end{array}$ & $\begin{array}{l}4.0 \\
3.7 \\
3.4 \\
3.4 \\
3.4 \\
3.4 \\
\end{array}$ & .. \\
\hline $\begin{array}{l}\text { Mean....... } \\
\text { Mesin per } \\
\text { square mile.. } \\
\text { Ru n-of f } \\
\text { depth in } \\
\text { inches....... }\end{array}$ & $\begin{array}{r}20 \\
4.26\end{array}$ & $\begin{array}{l}2.8 \\
.60\end{array}$ & $\begin{array}{r}1.4 \\
.30\end{array}$ & $\begin{array}{r}10 \\
2.13\end{array}$ & $\begin{array}{r}1.3 \\
.28\end{array}$ & $\begin{array}{r}4.2 \\
.63\end{array}$ & $\begin{array}{r}3.6 \\
.54\end{array}$ & $\begin{array}{r}3.6 \\
.54\end{array}$ & $\begin{array}{r}2.6 \\
.39\end{array}$ & 6.1 & 4.8 & 3.4 & 6.1 & 3.2 \\
\hline
\end{tabular}


Daily discharge, in second-feet, of Pioneer Creek and What Cheer Bar ditch, 1909.

\begin{tabular}{|c|c|c|c|c|c|c|c|}
\hline \multirow{2}{*}{ Day. } & \multicolumn{4}{|c|}{$\begin{array}{l}\text { Ploneer Creek above What } \\
\text { Cheer Bar ditch (drainage } \\
\text { area, 8.1 square miles). }\end{array}$} & \multicolumn{3}{|c|}{$\begin{array}{l}\text { What Cheer Bar ditch } \\
\text { st intake. }\end{array}$} \\
\hline & May. & June. & July. & Aug. & June. & July. & $\Lambda \mathbf{u g}$. \\
\hline $\begin{array}{l}1 \ldots \ldots \ldots \\
2 \ldots \ldots \\
3 \ldots \ldots \\
4 \ldots \ldots \\
5 \ldots \ldots \ldots\end{array}$ & & $\begin{array}{r}12.3 \\
9.4 \\
15.2 \\
12.3 \\
12.3\end{array}$ & $\begin{array}{l}3.0 \\
3.0 \\
3.0 \\
3.0 \\
3.0\end{array}$ & $\begin{array}{r}3.8 \\
3.0 \\
9.4 \\
15.2 \\
39\end{array}$ & $\begin{array}{r}4.2 \\
4.2 \\
13.3 \\
10.4 \\
10.4\end{array}$ & $\begin{array}{l}3.0 \\
3.0 \\
3.0 \\
2.9 \\
2.8\end{array}$ & $\begin{array}{r}3.6 \\
3.0 \\
6.8 \\
7.8 \\
25\end{array}$ \\
\hline $\begin{array}{r}6 \ldots \\
7 \ldots \\
8 \ldots \\
9 \ldots \\
10 \ldots\end{array}$ & & $\begin{array}{l}9.4 \\
9.4 \\
7.0 \\
7.0 \\
7.0\end{array}$ & $\begin{array}{l}\text { 3. } 0 \\
3.0 \\
4.7 \\
7.0 \\
4.7\end{array}$ & $\begin{array}{l}22 \\
15.2 \\
18.4 \\
22 \\
22\end{array}$ & $\begin{array}{l}7.8 \\
7.8 \\
5.8 \\
5.8 \\
5.8\end{array}$ & $\begin{array}{l}2.7 \\
2.6 \\
4.2 \\
5.8 \\
4.2\end{array}$ & $\begin{array}{l}16.7 \\
13.3 \\
16.7 \\
21 \\
21\end{array}$ \\
\hline $\begin{array}{l}11 \ldots \\
12 \ldots \\
13 \ldots \\
14 \ldots \\
15 \ldots\end{array}$ & & $\begin{array}{l}4.7 \\
4.7 \\
9.4 \\
7.0 \\
4.7\end{array}$ & $\begin{array}{l}4.7 \\
4.7 \\
3.0 \\
3.0 \\
3.0\end{array}$ & $\begin{array}{l}34 \\
83 \\
34 \\
26 \\
15.2\end{array}$ & $\begin{array}{l}4.2 \\
4.2 \\
7.8 \\
5.8 \\
4.2\end{array}$ & $\begin{array}{l}4.2 \\
4.2 \\
3.0 \\
3.0 \\
3.0\end{array}$ & $\begin{array}{l}21 \\
21 \\
21 \\
16.7 \\
13.3\end{array}$ \\
\hline $\begin{array}{l}16 \ldots \ldots \ldots \\
17 \ldots \ldots \ldots \\
18 \ldots \ldots \ldots \\
19 \\
20 \ldots \ldots\end{array}$ & $\ldots$ & $\begin{array}{l}4.7 \\
4.7 \\
4.7 \\
4.7 \\
4.7\end{array}$ & $\begin{array}{l}3.0 \\
3.0 \\
3.0 \\
3.0 \\
2.8\end{array}$ & \begin{tabular}{r|}
15.2 \\
12.3 \\
10.8 \\
10.8 \\
9.4
\end{tabular} & $\begin{array}{l}4.2 \\
4.2 \\
3.0 \\
3.0 \\
3.0\end{array}$ & $\begin{array}{l}2.6 \\
2.6 \\
2.6 \\
2.6 \\
2.5\end{array}$ & $\begin{array}{r}13.3 \\
10.4 \\
9.1 \\
9.1 \\
7.8\end{array}$ \\
\hline $\begin{array}{l}21 \ldots \\
22 \ldots \\
23 \ldots \\
24 \ldots \\
25 \ldots\end{array}$ & & $\begin{array}{l}4.7 \\
4.7 \\
3.0 \\
9.4 \\
7.0\end{array}$ & $\begin{array}{l}2.6 \\
2.4 \\
4.7 \\
7.0 \\
4.7\end{array}$ & \begin{tabular}{r}
8.2 \\
7.0 \\
15.2 \\
$\cdots . \cdots$. \\
\hdashline.$\cdots$. \\
\end{tabular} & $\begin{array}{l}\text { 3.0 } \\
3.0 \\
3.0 \\
5.8 \\
4.2\end{array}$ & $\begin{array}{l}2.3 \\
2.1 \\
4.7 \\
7.8 \\
4.2\end{array}$ & $\begin{array}{r}6.8 \\
5.8 \\
13.3\end{array}$ \\
\hline 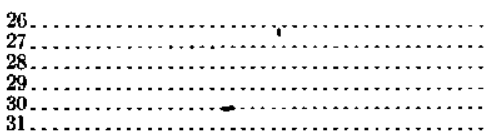 & $\begin{array}{l}80 \\
49 \\
30 \\
22 \\
22 \\
15.2\end{array}$ & $\begin{array}{l}4.7 \\
4.7 \\
3.0 \\
3.0 \\
3.0\end{array}$ & $\begin{array}{l}4.7 \\
4.7 \\
3.8 \\
3.8 \\
3.8 \\
3.8\end{array}$ & $\begin{array}{ll}\cdots \cdots \cdots \\
\cdots \cdots \cdots \\
\cdots \cdots \cdots\end{array}$ & $\begin{array}{l}\text { 4. } 2 \\
\text { 3. } \\
\text { 3. } 0 \\
\text { 3. } 0\end{array}$ & $\begin{array}{l}4.2 \\
4.2 \\
3.6 \\
3.6 \\
3.6 \\
3.6\end{array}$ & $\begin{array}{ll}\cdots \ldots \ldots \\
\cdots \cdots \cdots \\
\cdots \cdots \cdots\end{array}$ \\
\hline 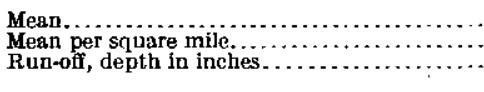 & $\begin{array}{r}36 \\
4.44 \\
.99\end{array}$ & $\begin{array}{l}6.8 \\
.84 \\
.94\end{array}$ & $\begin{array}{l}3.8 \\
.47 \\
.54\end{array}$ & $\begin{array}{l}19.6 \\
2.42 \\
2.07\end{array}$ & 5.2 & 3.5 & 13.2 \\
\hline
\end{tabular}

Miscellaneous measurements in Baker Creek drainage basin, 1909.

\begin{tabular}{|c|c|c|c|c|}
\hline Date. & Stream and locality. & $\begin{array}{c}\text { Drainage } \\
\text { area. }\end{array}$ & $\begin{array}{c}\text { Dis- } \\
\text { charge. }\end{array}$ & $\begin{array}{l}\text { Discharge } \\
\text { per square } \\
\text { mile. }\end{array}$ \\
\hline $\begin{array}{l}\text { May } 26 \ldots \\
\text { July } 21 \ldots \ldots \\
\text { July } 24 \ldots \ldots \\
\text { September } 3 . \ldots \\
\text { July } 7 \ldots \ldots \\
\text { July } 26 \ldots \ldots \\
\text { September } 5 \ldots \\
\text { July } 222 \ldots \\
\text { July } 23 \ldots \ldots \\
\text { September } 4 \ldots\end{array}$ & 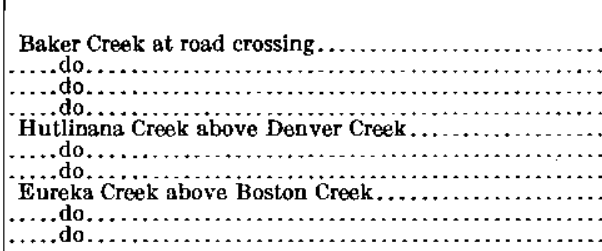 & $\begin{array}{r}S q . m i \\
232 \\
232 \\
232 \\
232 \\
23.7 \\
23.7 \\
23.7 \\
5.2 \\
5.2 \\
5.2\end{array}$ & $\begin{array}{r}\text { Sec. }-f t . \\
1,910 \\
27 \\
159 \\
54 \\
11.9 \\
24 \\
9.1 \\
1.2 \\
6.9 \\
2.4\end{array}$ & $\begin{array}{r}\text { Sec. }-f t . \\
8.23 \\
.12 \\
.69 \\
.23 \\
.50 \\
1.01 \\
.38 \\
.23 \\
1.33 \\
.46\end{array}$ \\
\hline
\end{tabular}

PATTERSON CREEK DRAINAGE BASIN.

Patterson Creek is formed by the junction of Sullivan and Cache creeks and is tributary to Tanana River about 40 miles below the mouth of Baker Creek. It drains an area of low relief, the most prominent feature being Bean Ridge, on the south, which furnishes 
several small tributaries. Woodchopper Creek is tributary to Patterson Creek about 6 miles from the Tanana.

Sullivan Creek, the right fork of Patterson Creek, rises on the south slope of Roughtop Mountain and for about 10 miles flows a little west of south through a wide valley with gentle slopes and high, broad benches. Birch and spruce timber suitable for cabins and fuel is abundant in the lower valley.

Daily discharge, in second-feet, of Sullivan Creek above Tofty ditch intake, 1909.

[Drainage area, 20.7 square miles.]

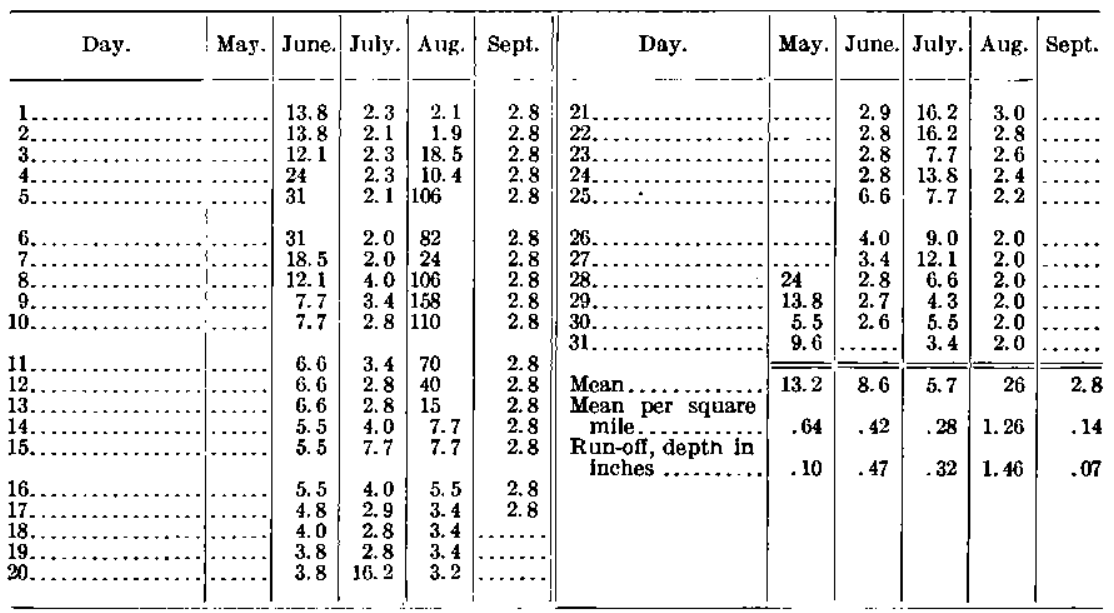

Note.-Some water was diverted by the Midnight Sun ditch during perfods of ample supply.

Miscellaneous measurements in Patterson Creek drainage basin, 1909.

\begin{tabular}{|c|c|c|c|c|}
\hline Date. & Stream and locality. & $\begin{array}{c}\text { Drainage } \\
\text { area. }\end{array}$ & $\begin{array}{c}\text { Dis- } \\
\text { charge. }\end{array}$ & $\begin{array}{l}\text { Discharge } \\
\text { per square } \\
\text { mile. }\end{array}$ \\
\hline $\begin{array}{l}\text { July } 20 \ldots \ldots \ldots \\
\text { July } 18 \ldots \ldots \ldots \\
\text { May } 28 \ldots \ldots \ldots\end{array}$ & $\begin{array}{l}\text { Quartz Creek at mouth..... ............... } \\
\text { Cache Creek at Baker Slough trail crossing ... } \\
\text { Midnight Sun ditch near outlet............... }\end{array}$ & $\begin{array}{r}S q . m i . \\
11.3 \\
22.7\end{array}$ & $\begin{array}{r}\text { Sec.ff. } \\
1.3 \\
2.5 \\
6.5\end{array}$ & $\begin{array}{r}\text { Sec.-fe. } \\
0.12 \\
.11\end{array}$ \\
\hline
\end{tabular}

\section{SALCHAKET DISTRICT.}

\section{DESCRIPTION OF AREA.}

The Tanana precinct, which includes the Salchaket district, embraces the area drained by the Tanana and its tributaries from and including Salchaket River to a point on Tanana River south of Lake Mansfield. The larger streams included in this area are Salchaket, Goodpaster, Volkmar, and Healy rivers from the north and Delta River from the south. Tenderfoot and Banner creeks, which have been the largest gold producers in this district, are tributary 
to the Tanana about 75 miles southeast of Fairbanks and about midway between Goodpaster and Salchaket rivers from the same side.

The Tanana in general follows the north side of the valley and is one maze of channels and islands. At McCartys, just above the mouth of Delta River, which is 95 miles from Fairbanks by the government road, the river flows in three channels except at extreme low water, when the middle one is dry. During the summer of 1909 the Alaska Road Commission installed ferries on the right and left channels and bridged the center one.

Salchaket River rises opposite the head of the South Fork of Birch Creek, about 25 miles from the Yukon. The average fall of the river from the Splits to the mouth is 10 feet to the mile, and from a point about 2 miles from the summit of the divide at the headwaters it averages 19 feet to the mile. At the mouth, which is 40 miles from Fairbanks, a ferry, post-office, store, and roadhouse are located and excellent accommodations are at hand for the traveler.

Redmond Creek joins the Salchaket from the south about 15 miles above the mouth.

Iittle Salchaket River is tributary to the Tanana from the east about midway between the town of Salchaket and the Salcha telegraph station.

\section{GAGING STATIONS.}

The following list gives the points in the Salchaket district at which gages were established or discharge measurements made in 1909:

Gaging stations in Salchaket district, 1909.

Tanana River at McCartys.

Banner Creek above Buckeye Creek.

Banner Creek near mouth.

Buckeye Creek near mouth.

Salchaket River at Salchaket.

Redmond Creek above Mosquito Creek.

Little Salchaket River at road crossing. 


\section{MEASUREMENTS.}

The following measurements were made during 1909 in the Salchaket district:

Daily discharge, in second-feet, of Banner Creek, Salchaket River, and Redmond Creek, 1909.

\begin{tabular}{|c|c|c|c|c|c|c|c|c|c|}
\hline \multirow[t]{2}{*}{ Day. } & \multicolumn{3}{|c|}{$\begin{array}{l}\text { Banner Creek near } \\
\text { mouth (drainage ares, } \\
21.5 \text { square miles). }\end{array}$} & \multicolumn{3}{|c|}{$\begin{array}{l}\text { Salchaket River at Sal- } \\
\text { chaket (drainage area, } \\
2,170 \text { square miles). }\end{array}$} & \multicolumn{3}{|c|}{$\begin{array}{l}\text { Redmond Creek above } \\
\text { Mos q uito Creek } \\
\text { (drainage area, } 24.7 \\
\text { square Imiles). }\end{array}$} \\
\hline & July. & Aug. & Sept. & July. & Aug. & Sept. & July. & Aug. & Sept. \\
\hline${ }^{\prime} \ldots \ldots \ldots \ldots \ldots \ldots \ldots \ldots$ & $\ldots$ & $\mid \begin{array}{c}\ldots \ldots \\
\ldots \ldots \\
\cdots \\
\cdots \\
\cdots\end{array}$ & $\begin{array}{l}7.8 \\
6.6 \\
6.6 \\
6.6 \\
6.6\end{array}$ & $\begin{array}{l}1,730 \\
1,710\end{array}$ & $\begin{array}{l}7,460 \\
5,700 \\
6,300 \\
5,590 \\
5,260\end{array}$ & $\begin{array}{l}1,730 \\
1,630 \\
1,530 \\
1,630 \\
1,630\end{array}$ & & $\begin{array}{r}28 \\
69 \\
145 \\
65 \\
38\end{array}$ & $\begin{array}{l}5.8 \\
5.3 \\
5.3 \\
5.3 \\
6.2\end{array}$ \\
\hline$\ldots \ldots \ldots \ldots \ldots \ldots \ldots$ & $\begin{array}{r}10.6 \\
6.6 \\
10.6 \\
5.4 \\
6.6\end{array}$ & $\begin{array}{l}\cdots \\
\cdots \\
\cdots \\
\cdots \\
\cdots \\
\cdots\end{array}$ & $\begin{array}{l}6.6 \\
6.6 \\
5.4 \\
5.4 \\
7.8\end{array}$ & $\begin{array}{l}1,630 \\
1,630 \\
1,800 \\
2,840 \\
2,840\end{array}$ & $\begin{array}{l}4,060 \\
4,250 \\
4,540 \\
5,480 \\
5,940\end{array}$ & $\begin{array}{l}1,630 \\
1,630 \\
1,630 \\
1,530 \\
1,530\end{array}$ & $\begin{array}{r}5.0 \\
6.7 \\
5.5 \\
8.3\end{array}$ & $\begin{array}{l}17.3 \\
12.2 \\
13.4 \\
22 \\
36\end{array}$ & $\begin{array}{r}7.5 \\
8.8 \\
10.2 \\
7.2 \\
6.7\end{array}$ \\
\hline$\ldots \ldots$ & $\begin{array}{r}5.4 \\
5.4 \\
10.6 \\
10.6 \\
9.2\end{array}$ & & $\begin{array}{l}6.6 \\
6.6 \\
5.4 \\
6.6 \\
6.6\end{array}$ & $\begin{array}{l}2,840 \\
3,380 \\
3,220 \\
4,640 \\
7,300\end{array}$ & $\begin{array}{l}4,940 \\
4,440 \\
4,160 \\
3,540 \\
3,060\end{array}$ & $\begin{array}{l}1,530 \\
1,480 \\
1,480 \\
1,480 \\
1,480\end{array}$ & $\begin{array}{c}10.2 \\
8.6 \\
27 \\
22 \\
36\end{array}$ & $\begin{array}{r}24 \\
28 \\
14.5 \\
10.2 \\
9.4\end{array}$ & $\begin{array}{r}7.2 \\
6.7 \\
6.2 \\
8.6 \\
12.2\end{array}$ \\
\hline $\begin{array}{l}\cdots \\
\ldots \ldots \ldots \\
\ldots \ldots \ldots\end{array}$ & $\begin{array}{l}7.8 \\
7.8 \\
7.8 \\
5.4 \\
4.3\end{array}$ & $\begin{array}{ll}\cdots \\
\cdots \\
\cdots \\
\cdots\end{array}$ & $\begin{array}{r}6.6 \\
12.2 \\
9.2 \\
7.8 \\
6.6\end{array}$ & $\begin{array}{l}9,130 \\
6,860 \\
3,960 \\
4,740 \\
4,440\end{array}$ & $\begin{array}{l}2,760 \\
2,410 \\
2,340 \\
2,340 \\
2,480\end{array}$ & $\begin{array}{l}1,480 \\
1,350 \\
1,350 \\
1,350 \\
1,350\end{array}$ & $\begin{array}{r}12.2 \\
6.7 \\
5.3 \\
5.2 \\
4.6\end{array}$ & $\begin{array}{c}9.4 \\
8.6 \\
7.2 \\
6.2 \\
73\end{array}$ & $\begin{array}{r}12.2 \\
11.2 \\
7.9 \\
8.7 \\
9.5\end{array}$ \\
\hline$\ldots \ldots \ldots \ldots \ldots \ldots \ldots$ & $\begin{array}{l}3.3 \\
3.3 \\
5.4 \\
5.4 \\
5.0\end{array}$ & $\begin{array}{l}\ldots \ldots \\
\cdots \\
\cdots \\
\cdots \ldots \\
\cdots \ldots \\
\cdots\end{array}$ & $\begin{array}{l}6.6 \\
6.6 \\
6.6 \\
7.8 \\
4.3\end{array}$ & $\begin{array}{l}4,160 \\
2,840 \\
2,690 \\
2,690 \\
3,220\end{array}$ & $\begin{array}{l}2,910 \\
3,060 \\
3,060 \\
2,910 \\
2,690\end{array}$ & $\begin{array}{l}1,350 \\
1,350 \\
1,350 \\
1,350 \\
1,350\end{array}$ & $\begin{array}{l}\mathbf{4 . 3} \\
\mathbf{4 . 0} \\
\mathbf{4 . 3} \\
\mathbf{7 . 2} \\
\mathbf{6 . 7}\end{array}$ & $\begin{array}{l}45 \\
32 \\
17.3 \\
12.2 \\
7.9\end{array}$ & $\begin{array}{r}10.2 \\
10.2 \\
10.2 \\
\ldots \ldots\end{array}$ \\
\hline 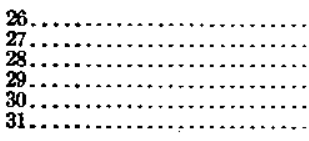 & $\begin{array}{r}4.3 \\
5.4 \\
10.6 \\
17.2 \\
29 \\
2\end{array}$ & $\begin{array}{l}9 . \overline{2} \\
9.2 \\
9.2 \\
7.8 \\
7.8\end{array}$ & \begin{tabular}{|l}
\multicolumn{2}{c}{4.3} \\
$\ldots \ldots \ldots$ \\
$\ldots \ldots \ldots$ \\
$\ldots \ldots \ldots$ \\
$\ldots \ldots \ldots$
\end{tabular} & $\begin{array}{l}2,910 \\
2,480 \\
2,410 \\
4,740 \\
6,580 \\
7,800\end{array}$ & $\begin{array}{l}2,480 \\
2,340 \\
2,200 \\
2,010 \\
1,780 \\
1,750\end{array}$ & $\begin{array}{r}1,350 \\
1,350 \\
1,350 \\
1,350 \\
1,350 \\
\cdots\end{array}$ & $\begin{array}{r}4.6 \\
4.5 \\
6.7 \\
40 \\
53 \\
47\end{array}$ & $\begin{array}{l}7.2 \\
6.7 \\
6.2 \\
6.2 \\
5.8 \\
5.8\end{array}$ & 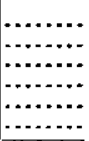 \\
\hline $\begin{array}{l}\text { Mean } \\
\text { Mean per square mile....... } \\
\text { Run-of, depth in inches.... }\end{array}$ & $\begin{array}{l}8.1 \\
.38 \\
.35\end{array}$ & $\begin{array}{l}8.6 \\
.40 \\
.07\end{array}$ & $\begin{array}{l}6.8 \\
.32 \\
.31\end{array}$ & $\begin{array}{r}3,830 \\
1.76 \\
1.83\end{array}$ & $\begin{array}{r}3,690 \\
1.70 \\
1.96\end{array}$ & $\begin{array}{r}1,460 \\
.67 \\
.75\end{array}$ & $\begin{array}{r}13.8 \\
.56 \\
.52\end{array}$ & $\begin{array}{r}25 \\
1.03 \\
1.19\end{array}$ & $\begin{array}{l}8.2 \\
.33 \\
.28\end{array}$ \\
\hline
\end{tabular}

Miscellaneous measurements in Salchaket district, 1909.

\begin{tabular}{|c|c|c|c|c|}
\hline Date. & Stream and locality. & $\begin{array}{c}\text { Drainage } \\
\text { area. }\end{array}$ & $\begin{array}{l}\text { Dis- } \\
\text { charge. }\end{array}$ & $\begin{array}{c}\text { Dis- } \\
\text { charge } \\
\text { per } \\
\text { square } \\
\text { mile. }\end{array}$ \\
\hline $\begin{array}{l}\text { July } 9 \ldots \\
\text { August } 28 \ldots \ldots \\
\text { July } 11 \ldots \\
\text { August } 27 \ldots \ldots \\
\text { July } 6 \ldots \ldots \ldots \\
\text { August } 27 \ldots \ldots \\
\text { July } 4 \ldots \ldots \\
\text { July } 13 \ldots \ldots \\
\text { August } 25 \ldots \ldots \ldots \\
\text { August } 30 \ldots \ldots\end{array}$ & 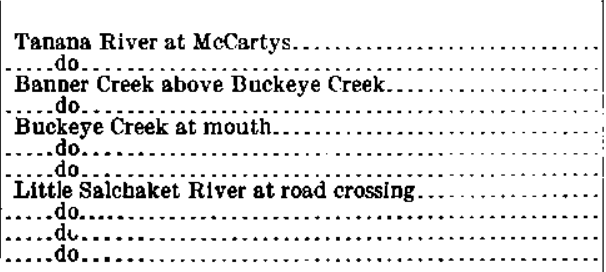 & \begin{tabular}{|c|} 
Sq. $m i$. \\
13,900 \\
13,900 \\
13.8 \\
13.8 \\
6.0 \\
6.0 \\
6.0 \\
70 \\
70 \\
70 \\
70
\end{tabular} & $\begin{array}{r}\text { sec.ft. } \\
27,600 \\
21,300 \\
3.3 \\
2.4 \\
5.2 \\
1.8 \\
4.3 \\
45 \\
62 \\
33 \\
27\end{array}$ & $\begin{array}{r}\text { Sec. }-f t . \\
1.99 \\
1.53 \\
.27 \\
.17 \\
.87 \\
.30 \\
.72 \\
.64 \\
.89 \\
.47 \\
.39\end{array}$ \\
\hline
\end{tabular}




\title{
THE KOYUKUK-CHANDALAR GOLD REGION.
}

\author{
By A. G. MADDRen.
}

\section{INTRODUCTION.}

\section{LOCATION AND EXTENT.}

The placer-gold districts of the Koyukuk and Chandalar valleys are situated toward the heads of those valleys, between $67^{\circ}$ and $68^{\circ}$ north latitude and $147^{\circ}$ and $152^{\circ}$ west longitude, from 50 to 75 miles north of the Arctic Circle. They lie well within the southern ranges of the mountain system that forms the Yukon-Arctic divide across northern Alaska, and are noteworthy as constituting one of the most northerly gold-mining regions in the world. (See Pl. VII.)

The same formations occur in both valleys in the sections where gold has been found. The kinds of rocks and their relations are similar in a general way throughout the region. Schrader ${ }^{a}$ noted this general geologic similarity in a report on an expedition he made through this region in 1899.

The writer visited this region during the summer of 1909 . He spent a month in gathering information about the occurrence, distribution, and general development of the gold placers of the Koyukuk district, and in the first week of September made a hasty examination of the Chandalar district.

\section{RELIEF AND DRAINAGE.}

The general features of relief are similar in every way throughout both these districts. The surface of the region is predominantly one of bold mountainous character, whose principal features are rugged ranges, with general strictural trends from northeast to southwest, and deep but comparatively narrow, steep-sided valleys cut through the mountains by the larger rivers from north to south. The bottoms of the larger valleys are from 1,500 to 2,000 feet above sea level and from one-fourth mile to 1 or 2 miles in width. The mountains rise boldly and in many places abruptly from the valley bottoms to rugged heights from 2,000 to 5,000 feet above the valleys, or from 3,000 to 6,000 feet above sea level; indeed, along the major divides some peaks rise to elevations of nearly 7,000 feet.

a Schrader, F. C., Preliminary report on a reconnaissance along Chandalar and Koyukuk rivers: Twenty-first Ann. Rept. U. S. Geol. Survey, pt. 2, 1900, pp. 441-486. 


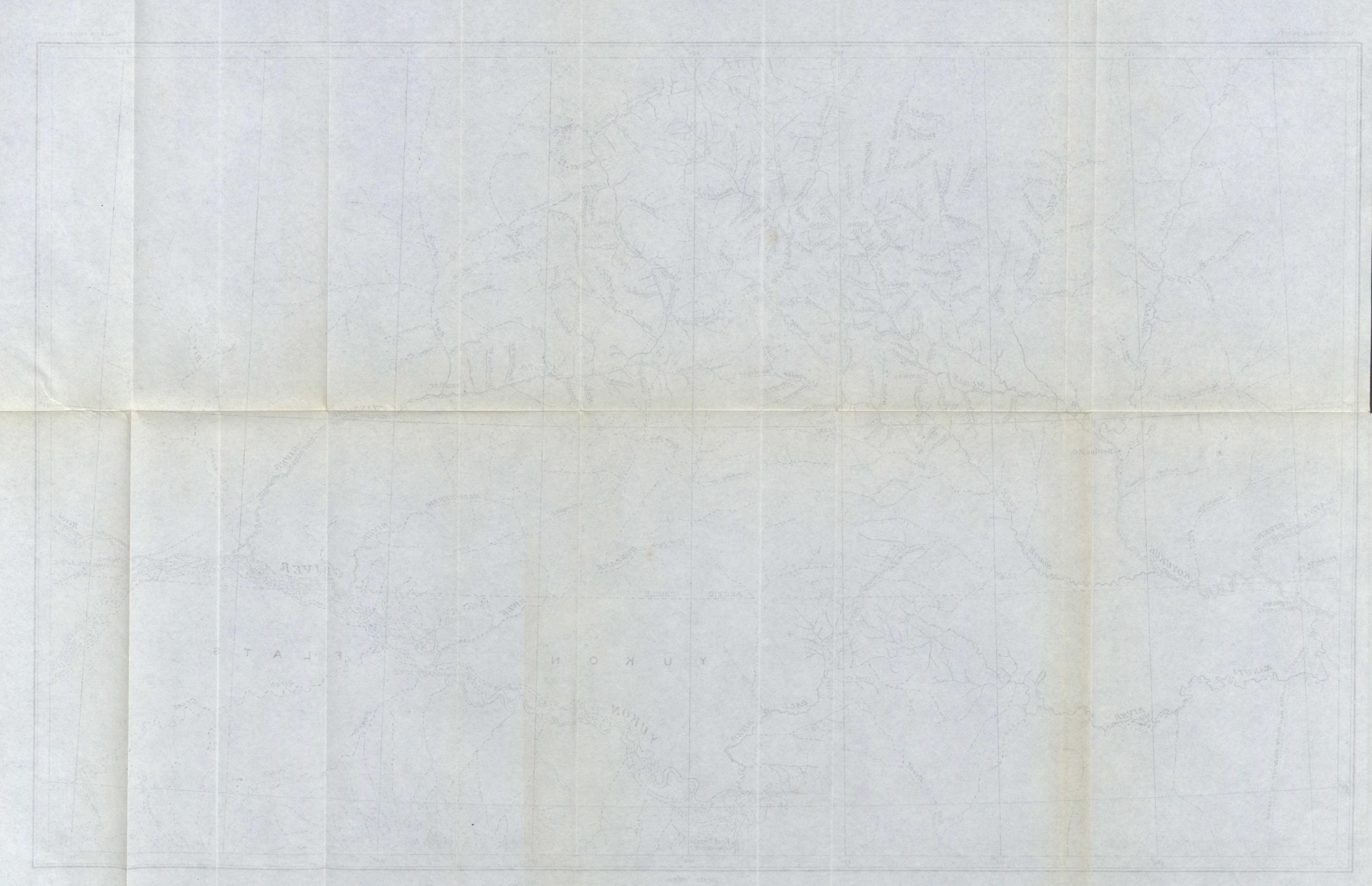


The most marked features of the drainage are a north-south system of narrow, parallel major valleys deeply incised into the mountainous land mass and an immaturely developed lateral drainage on the flanks of the mountain divides that separate the larger rivers. The downcutting along the larger valleys has been so rapid during the comparatively recent geologic history of this region that most of the drainage of secondary magnitude lateral to the rivers has not been able to extend the areas of the tributary valleys or wear them down to the lower level of the principal valleys, the result being that most of the creeks on which placer mining is done are rather swift in flow and consequently have steep gulch valleys and in many places box canyons along their courses, especially in their lower parts, just before they join the larger valleys. Much of the placer gold mined has been taken from the comparatively narrow and shallow gravel deposits along the bottoms of these gulch-shaped tributary valleys.

The general attitude of the Koyukuk-Chandalar drainage syst.m and the forms of the mountains appear to show that before the region was eroded into its present form it presented a very different kind of relief from that of to-day. Remnants of an older land surface of much more gentle character, with wide valleys and low ridges gently sloping up to moderate mountains, are indicated, but these older features have been largely obliterated by a profound regional glacial erosion that extended over a large part of the Endicott Mountains and deeply impressed an entirely new relief upon the region. A comprehensive description of these changes of land form can not be given at this time because most of the region is still unexplored. However, the development of the drainage system that has formed the dominant features of the present relief throughout the Koyukuk-Chandalar region and the widespread depcsits the streams of this system have laid down are so intimately associated with some of the gold placers that it seems necessary to give an introductory description of their principal characteristics in order to explain the relations of some of the placer deposits.

The main valleys appear to owe their present size and forms chiefly to the former presence of large, long glaciers that had their sources on the Arctic divide to the north and extended at least to the southern flanks of the Endicott Mountains. The large ice streams appear to have deepened the main valleys somewhat and steepened their side slopes considerably to the forms they have to-day, characterized by flat bottoms and abruptly rising sides, which are especially pronounced where formed by the truncated ends of the intertributary mountain spurs that are lateral to the main divides. In places these steeply truncated sides of the main valleys extend across the mouths of the tributary valleys, thus making them of the hanging-valley type. 
In most such places the streams in the discordant side valleys have partly cut their immediate channels down below the old floor levels of the hanging valleys and now enter the main valleys through gorges or canyons. Other side valleys, however, enter the main valleys by wide mouths at accordant levels.

When the large glaciers disappeared by melting, they left behind considerable quantities of unconsolidated material in the form of bowlders, cobbles, gravels, and silts, which now largely cover the floors of the valleys throughout their length and width. Very little of this material is now found in the form of unassorted drift. Most of it belongs to the class of glacial deposits that have been subjected to the vigorous wearing and assorting action of swiftly running water after the glaciers retreated. Along the flat lower parts of the valleys these deposits have been well graded and now occur in the form of partly sorted cobble beds, regularly arranged gravels, coarse crossbedded sands, and fine silts and clays. They occur not only along the floors of the large valleys, but also as terraces along their sides and back into the tributary valleys that open out from the mountains. In the middle part of the Tobin Creek valley and on lower Big Creek there are thick deposits of silt and clay which appear to have been deposited in small lakes that were formed along the borders of the glaciers in the lower parts of these side valleys at a time when the main valley glaciers dammed up their mouths with high barriers of ice. Most of the silts and clays of the dammed valley deposits appear to have been derived from muddy glacial waters, but no doubt some of the silts may have come from the upper parts of the side valleys above the areas formerly occupied by the lakes, and also from the slopes that were above the levels of the lakes along their sides. Wiseman Creek, on the Koyukuk, occupies one of the best examples of these glacier-dammed and silt-filled valleys, where the silts and clays have buried older gold-bearing stream gravels and where the later drainage has not been able to remove the glacial silt and clay filling. Tobin Creek is an example of a filled valley where the present drainage has been vigorous enough to remove a large part of the clays and is now rapidly carrying away what remains. This is shown by the turbid silt-laden water of this stream from the "mud banks" to its mouth. The lake that formerly occupied the basin of Wiseman Valley was apparently drained by several comparatively sudden drops to lower levels, with longer periods of rest between the different drops. During the stationary periods bench deposits, or narrow beaches, were formed on the valley slopes at the positions of the different shore lines of the lake and the gold now found in these benches along the valley sides was no doubt concentrated in them at the mouths of gulches. The gold appears to have come from the bed rock of the mountain slopes above the lakes, and no doubt much of the gold now 
found in the benches at the lower levels is from similar benches at higher levels where gold was concentrated previously.

On Tobin and Big creeks, in the Chandalar Valley, the old shore lines of the former lakes have not been traced or prospected and it is not known whether they occur at more than one level. On Wiseman Creek, in the Koyukuk Valley, the former glacial-lake shore lines are known to lie at several different levels. These have been prospected to a slight extent and the two lowest have been mined at several places along the east side of Nolan Creek. Placer gold is reported to occur on Tobin Creek, both below and above the locality where the stream is now washing away the clay deposits of the former glacial lake that occupied the lower half of its basin, but paying quantities have not yet been developed.

The foregoing examples show that the erosion and deposition accomplished during the period of glacial drainage that preceded the development of the present drainage system have exerted considerable influence on the distribution and character of the placer-gold deposits in the localities that have been mentioned. At other places, however, glacial drainage does not appear to have caused much change and the processes of erosion and concentration of the gold appear to be such as are normal to any mountain region. The influence of glacial drainage appears to be largely or wholly absent in the part of the Chandalar district where the most mining development has been carried on, and also on some of the streams in the Koyukuk district, such as the upper parts of Myrtle, Vermont, and Gold creeks.

\section{CLIMATE AND VEgetation.}

The winters in this region are long and severe, the temperature being below zero much of the time, and occasionally getting as low as $70^{\circ}$ below zero.

The short summers, because of the long days, are generally warm enough to allow hardy vegetables to be grown to a good state of maturity in properly prepared gardens in the bottoms of the larger valleys, but killing frosts may occasionally occur in midsummer, even in the most favorable situations.

Spruce is the only tree that grows here to a sufficient size for cabin logs, and this tree of suitable size for sluice-box lumber is found only in scattered localities in the larger valleys. Up the mountain slopes it becomes more scrubby and does not extend beyond an elevation of 3,000 feet above sea level.

At present the principal supply of water in this region is derived from snow, but a moderate rainfall during the summer also adds a variable and uncertain amount to the total stream flow. The snowfall over this region is not great in average amount, and it is only the great length of the winter season, from October to April, that enables an 
average depth of 3 to 4 feet of it to accumulate. Most of the snow melts and passes away during May, and then the streams are at their maximum flood stage. The larger streams continue to flow strongly during most of June, after which there is a subsidence with spasmodic increases until colder weather in September changes the precipitation into snow, freezes the higher mountain slopes, and lessens the flow. Early in October the rivers become frozen over and although there is still some flow of water in all the larger valleys, as is made manifest by frequent outbursts from under the ice, these rarely do more than form temporary local accumulations of ice, which disappear the following May. Sometimes, however, these overflows of water from beneath the ice continue throughout the winter and form considerable masses of flood-plain ice, called "glaciers" by the miners, which are not entirely removed during the following short summer, and become somewhat permanent features.

The rugged topography of this region presents many high, cold sheltered slopes and mountain-surrounded basins in which a considerable part of the snowfall does not melt rapidly, so there is generally a reserve flow of water in all the larger streams throughout the summer; but on the smaller creeks water sometimes becomes too scanty for the effective handling of the gold-bearing gravels, and the miners look forward to the uncertain rainfalls, especially during August.

\section{POPULATION AND SETTLEMENTS.}

The population of the Koyukuk region during the eleven years in which it has been occupied by whites has not been large. In the Klondike rush 1,000 or more inexperienced gold seekers entered the Koyukuk Valley in the fall of 1898 , but nearly all of them departed during the early summer of 1899 and only about 100 of the more hardy ones remained. Although a revival of interest was caused in 1900 by the discovery of gold on Myrtle Creek and the reports of rich finds on Hammond Creek, and the population again reached 1,000 or more, by $1901-2$ it had dwindled to about 200 . About 350 are reported to have been there in 1903-4, and since then the average population of the district has been about 200 persons.

Since mining was established in 1900 the principal settlement in the Koyukuk region has been the town of Coldfoot, located on Koyukuk River, about 586 miles from the Yukon, at the mouth of Slate Creek. Here the postal and recording offices are established; but within the last two years a new settlement has been formed about 16 miles farther up the Koyukuk at the mouth of Wiseman Creek, and this place is now the largest town in the district.

A small group of cabins on the north bank of Chandalar River near the mouth of Flat Creek is named Caro. This place is about 110 miles from Fort Yukon and 35 miles from the placer diggings about 
the head of Big Creek. During 1907-8 it had a small population of whites and the postal and recording offices for the district were located there. At present only a few natives live there, and the mining population of the district consists of some twenty white men who reside near their claims about the head of Big Creek.

TRANSPORTATION AND TRAILS.

There is only one natural highway for approaching this part of Alaska - that by way of Koyukuk River. From the middle of June until early in September the main Koyukuk may be ascended by medium-sized stern-wheel steamboats having a draft of about 2 feet. By this means all the supplies for the region are now transported up the river to the vicinity of a warehouse station named Bettles, a few miles below the mouth of John River and about 60 miles below Coldfoot. During some seasons of low water it has been found impracticable to reach Bettles, and at certain periods of high water it is possible for steamboats to ascend a short distance above that place. The general practice is to take all supplies from Bettles, or near by, upstream to Coldfoot or the mouth of Wiseman (reek during the summer by shallow-draft scows that carry from 8 to 12 tons, towed by horses, or by poling boats that carry about 1 ton, propelled by men. Both of these methods are tedious and expensive. From June 15 to September 15 may be considered the boating season on the Koyukuk.

The freight charges during the last three years have been from Seattle or San Francisco to Bettles by ocean and river steamboats, 4 to 6 cents a pound; from Bettles to the mouth of Wiseman Creek by horse-towed scows, 6 to 8 cents a pound. Thus it costs from 10 to 14 cents a pound, or from $\$ 200$ to $\$ 280$ a ton, for freight charges alone from Seattle or San Francisco to the mouth of Wiseman Creek.

Winter sledding of freight from Coldfoot to Nolan Creek is done for 4 cents a pound and horse packing in summer from the mouth of Wiseman Creek to Nolan Creek for 6 cents a pound.

To reach this district during the winter or closed season it is necessary to travel with dog-drawn sleds. A monthly winter mail service of this kind is maintained and a few persons occasionally travel in this manner.

\section{COSTS AND WAGES.}

It is impossible to give a detailed analysis of the commercial mining status of the Koyukuk district, because direct evidence in the form of actual figures from books is not available, but from general information the principal features may be outlined.

All the goods consumed by the population of this district, with the exception of a very small amount of game and fish procured locally, 
are brought from the United States, and the freight charges alone, for delivery at the mining localities, cost the consumer from 10 to 20 cents a pound.

Prices in 1909 were considerably below the average for the last ten years, as a result of recent competition in the commercial enterprise of the district. Likewise, the present scale of wages is considerably less than it has been during the past, and no doubt, if accurate figures could be obtained, they would show that the high retail prices of goods have directly controlked the scale of wages. The amount of supplies available has had considerable influence on prices. On a number of occasions during the last ten years a shortage of some articles has occurred, in spite of the high prices asked, and 1909 is the first year in the history of the district in which there has been a satisfactory amount of provisions in stock at the mining settlements at the close of summer transportation on Koyukuk River.

Very few miners in this district keep good records of operation costs and it is difficult to obtain accurate statements of the yield of gold, so both have to be approximately estimated in order to make comparisons.

The annual cost of proper food and clothing for the average prospector or miner is about $\$ 1,000$. Ordinary manual labor at present is paid from $\$ 4$ to $\$ 6$ a day, with food. The cost of food per man varies from $\$ 3$ to $\$ 5$ a day, according to the cost of transporting provisions from the settlements to the places where mining is being done. Before underground mining was developed on Nolan Creek, four years ago, there was little demand for day labor, and when men were employed for a period of time the usual wage was $\$ 1$ an hour, without board; but a large part of the mining, especially the shallow shoveling kind, and considerable of the deep mining, is done by groups of men who enter into partnerships and work on shares.

Under present commercial conditions only the richest placers of this district yield returns that are considered an adequate reward. A few of the most profitable operations are stated to have been conducted with a profit of 70 per cent of the gross yield of gold, or at a cost of 30 per cent of the production. These results, however, have been obtained only in a few localities of the richest deep ground on Nolan Creek and in the most easily worked shallow unfrozen ground, notably on Mascot Creek. Most of such opportunities have, been short lived, and a large part of the mining has been done with a relatively low percentage of profit, so low in many instances as to furnish no more than a bare living under the harsh conditions of climate and isolation that characterize this region, where only the optimism that is the predominant characteristic of the gold-seeker's temperament serves to stimulate many of these men to continued effort from year to year. 


\section{GENERAL PROGRESS OF MINING.}

Since placer gold was found in 1899 on Myrtle Creek, a tributary of Slate Creek, successive discoveries have been made on other tributaries of the Koyukuk, with the general result that the yearly production has steadily increased during the last ten years (see p. 292), the newer finds more than compensating for the decreasing yield of the older placers.

The production of placer gold in the Koyukuk, though not so large in amount as that of the Nome and Fairbanks districts, has been noteworthy when its difficulty of access and small population are considered, and has probably averaged higher per capita than that of any other district in Alaska. Since the discovery of the district its development has been practically accomplished with only its inherent mineral resources to aid mining enterprise, there having been, with one exception, no exploitation by capital from without the district. In other words, the Koyukuk stands as an entirely self-supporting mining community.

\section{PRODUCTION.}

Schrader ${ }^{a}$ has published a table of production of gold for the Koyukuk district for the period from 1900 to 1903, based on the most reliable information he could obtain. The writer has endeavored to extend this table to the close of 1909 (p. 292). Schrader's table gives a total of $\$ 667,500$. To this he added $\$ 40,000$ as the approximate output of sundry smaller diggings not given in the list for 1901; $\$ 6,000$ as the output in 1899 , derived mostly from Myrtle and Slate creeks and various places on South Fork; and $\$ 3,000$ to $\$ 4,000$ from Tramway Bar bench and river bars in previous years, all of which gave an aggregate yield for the district to that date of about $\$ 717,000$. The revised and enlarged table presented here gives an approximate total production of $\$ 2,200,600$ for the ten years 1900-1909. Up to 1909 the output of the year 1903 appears to have been the largest. This is easily accounted for by the facts that the shallow diggings were then at their best and that the very easily mined gravels on Mascot Creek yielded about $\$ 100,000$ during that summer. After 1903 there were several years of gradual decline in production, which appears to have reached its lowest point in 1906. The low yield for that year is partly explained by the rush to the new Chandalar placer district, about 75 miles east of Coldfoot, in August of that year, which took a number of men from productive work in the Koyukuk a month before the summer mining season had closed. From 1906 to the present time there has been an increase of produc-

a Schrader, F. C., Reconnaissanee in northern Alaska: Prol. Paper U.S. Geol. Survey No. 20, 1904, p. 102. 
tion each year which has been derived largely from the deep placers on Nolan Creek. There is some uncertainty in assigning the figures of production since 1906 to separate calendar years, because the underground mining operations extend from one year into the next and the figures given for a particular claim cover parts of two years. In the table the production of Nolan Creek for 1908 and 1909, which has been the largest factor during these two years, has been arbitrarily divided; but it is thought that if the statements obtained as to the yield are reliable the totals are good approximate estimates, and that the table as a whole is as fair a summary as it is possible to present from the information at hand.

Estimated production of placer gold in the Koyukuk district from 1900 to 1909, by localities and years.

\begin{tabular}{|c|c|c|c|c|c|c|c|c|c|c|c|}
\hline Localities. & 1900. & 1901. & 1902. & 1903. & 1904. & 1905. & 1906. & 1907. & 1908. & 1909. & Total. \\
\hline \multicolumn{5}{|l|}{ Middle Fork: } & & & & & $\$ 300$ & & $\$ 8,000$ \\
\hline $\begin{array}{l}\text { Creek......... } \\
\text { Porcupine Creek. } \\
\text { Slate Creek...... }\end{array}$ & & $\begin{array}{r}\$ 1,500 \\
1,000\end{array}$ & & & & & & & & & $\begin{array}{l}5,000 \\
2,000\end{array}$ \\
\hline Myrtle Creek.... & 40,000 & 7,000 & $\$ 50,000$ & 830,000 & $\$ 15,000$ & $\$ 15,000$ & $\$ 5,000$ & 85,000 & 5,000 & 810,000 & 182,000 \\
\hline Cla & 1,000 & 2,000 & & & & & & & ....... & & 3,000 \\
\hline & & 500 & & & & & & & & & 500 \\
\hline No & 27,000 & 40,000 & 13,000 & 15,000 & $\left|\begin{array}{l}10,000 \\
14,000\end{array}\right|$ & $\begin{array}{l}15,000 \\
40,000\end{array}$ & $\begin{array}{r}5,000 \\
90,000\end{array}$ & $\begin{array}{r}5,000 \\
125,000\end{array}$ & $\begin{array}{l}5,000 \\
208,000\end{array}$ & $\begin{array}{r}5,000 \\
288,000\end{array}$ & 160,000 \\
\hline $\mathrm{Bn}$ & & & $\cdots$ & 25,000 & 30,000 & 50,000 & 10,000 & 5,000 & 5,000 & 83 & 208,000 \\
\hline & & & & $\cdots$ & 2,000 & 2,000 & & & & & \\
\hline & & & & 3,000 & 20,000 & & $\begin{array}{r}3,000 \\
400\end{array}$ & & & & 200 \\
\hline & & 1,500 & $30,0 \oplus 0$ & & & & & & & 2,000 & $\begin{array}{r}1,000 \\
35,000\end{array}$ \\
\hline & 2,000 & 2,000 & 10,000 & 2,000 & 2,000 & 2,000 & & & & & 20,000 \\
\hline Go & & & 6,000 & 2,000 & 2,000 & & & & & & \\
\hline Swi & & & 3,000 & 2.000 & 1,000 & & & & & 1,200 & \\
\hline $\mathrm{Bu}_{\mathrm{e}}$ & & & & & 1,000 & 200 & & & & & \\
\hline $\begin{array}{l}\text { Ver } \\
\text { She }\end{array}$ & & 5,000 & 30,000 & 25,000 & 22,000 & 20,000 & 20,000 & 20,000 & 10,000 & 20,000 & 172,000 \\
\hline Go & 2,000 & 50,000 & 30,000 & 70,000 & 45,000 & 24,000 & $\dddot{3}, 000$ & 3,000 & 2,200 & 3.000 & $\begin{array}{r}2,000 \\
232,200\end{array}$ \\
\hline & & & 8,000 & 10,000 & & & & 400 & 300 & & 20,000 \\
\hline \multicolumn{12}{|l|}{ ettles } \\
\hline Ga & & & & & & & & & & 1,000 & \\
\hline \multirow{2}{*}{\multicolumn{12}{|c|}{ outh For }} \\
\hline & & & & & & & & & & & \\
\hline $\begin{array}{l}\text { Gold } \\
\text { Iron }\end{array}$ & 25,000 & 60,000 & 20,000 & 15,000 & 5,000 & & & & & & 125,000 \\
\hline$\stackrel{h}{G}$ & $\begin{array}{r}500 \\
1.500\end{array}$ & 1,500 & & & $\cdots$ & & & & & & $\begin{array}{l}2,000 \\
4,000\end{array}$ \\
\hline Es & $\begin{array}{r}1,500 \\
500\end{array}$ & & & & & & & & & & 1,000 \\
\hline & & & & & & & & & & & \\
\hline & & 1,000 & & & & & & & & & 3,00 \\
\hline \multirow{2}{*}{\multicolumn{12}{|c|}{ North For }} \\
\hline & & & & & & & & & & & \\
\hline \multirow{7}{*}{$\begin{array}{l}\text { Mascot Creek.... } \\
\text { W as h ing ton } \\
\text { Creek......... } \\
\text { Wild River: } \\
\text { Birch Creek...... } \\
\text { Lake Creek...... } \\
\text { Spring Creek.... } \\
\text { John River: Crevice } \\
\text { Creek.................. }\end{array}$} & & & & & & & & & & & \\
\hline & & & & 000 & & 000 & & & & & 5,000 \\
\hline & & & & & & 5,000 & 5,000 & & & & \\
\hline & & & & & 1,000 & 1,000 & & & & & \\
\hline & & & & & & & & 5,000 & 1,000 & 1,000 & 7,000 \\
\hline & & & & & $.2,500$ & & & & & & 2.500 \\
\hline & 107,000 & 173,500 & 200,00 & 301,000 & 200,000 & 195,200 & 141,700 & 168,900 & 238,800 & 41 & 600 \\
\hline
\end{tabular}

The results of mining as summarized in the table have been accomplished by an average of 100 men per year who have actually worked at mining. Some men have left the district each year, but others 
have come to replace them. If the average cost of production is placed at about 50 per cent of the total yield, about $\$ 1,000,000$ may be considered the amount of wealth that has been taken away from the Koyukuk district during the last ten years by those who have become satisfied witi their gains and have departed from Alaska for "the outside with a homestake," as it is called in that country.

The Koyukuk placer gold is of a high grade. Its refined value varies from $\$ 18$ to over $\$ 19$ an ounce. The unrefined gold has passed in commercial exchange at $\$ 17$ an ounce until 1909 , when it was allowed a value of $\$ 18$ an ounce.

\section{GEOLOGIC SKETCH.}

The country rock of the Koyukuk region is made up of many different kinds of metamorphic rocks, which are similar to and probably the same as the old formations that are known to form the bed rock over large areas through the interior of Alaska, both north and south of the Yukon and westward into the Kobuk Valley and Seward Peninsula. These old formations may be assembled into several indefinite groups that in general show similar characters, the most important of which is that the placer gold is associated with and largely derived from one or more of their members.

The oldest of these formations make up a diverse complex of more or less schistose sediments, in some places associated with igneous rocks of various types and relations. Many different phases of the schists have been recognized, but because of the changing character of the rocks from place to place enough evidence to warrant their definite subdivision, correlation, and classification has not yet been gathered, more particularly in the region north of the Yukon. South of the Yukon, between that river and the Tanana, the general sequence of the rocks, from the oldest upward, appears to comprise quartzite schists, carbonaceous and graphitic schists, quartz-mica schists, garnetiferous schists, crystalline limestones, and altered igneous rocks largely granitic and locally gneissoid intruded into the sediments. These rocks are called the Birch Creek schist and are considered to be of early Paleozoic age. North of the Yukon rocks that are considered to belong to the Birch Creek schist occupy a wide belt from the upper part of the Dall River basin northward to the headwaters of Jim River. In this area the rocks are similar in every particular to those of the Yukon-Tanana region and they contain a considerable amount of igneous intrusive rocks, mostly granite porphyries, both unaltered and metamorphosed. The Birch Creek schist appears to extend as a more or less continuous belt southwestward along the divide between Kanuti and Yukon rivers, and probably connects with the schists that occur in the Gold Hill district, on the north bank of the Yukon about 25 miles below the mouth of 
Tanana River. It is also reported to extend northeastward from upper Dall River to the upper basins of IIodzana and Hadweenzic rivers.

North of Jim River the Dall River belt of Birch Creek schist is interrupted by a belt of younger formations that extends from the South Fork of the Koyukuk to the West Fork of the Chandalar, but north of these younger rocks the Birch Creek schist reappears in the valley of Slate Creek and occurs throughout the gold-producing part of the Koyukuk Valley. On Slate Creek and generally throughout the Koyukuk placer district a carbonaceous schist, phyllite, and slate phase of the Birch Creek schist is commonly developed. To the northeast, in the vicinity of Chandalar Lake and along Chandalar River to Horse Creek, the rocks are more quartzose and micaceous, but also contain graphitic phases; to the southwest the lower part of the John River valley is crossed by a belt of schistose rocks, largely of sedimentary origin, which are locally graphitic and contain much secondary quartz like the carbonaceous schists of the Slate Creek valley. In the Koyukuk area these do not appear to contain the large amounts of igneous intrusive rocks that are characteristic of the areas between the Tanana and the Yukon or between Dall and Jim rivers.

In a general way this northernmost belt of Birch Creek schist may be considered to extend for a width of 10 to 20 miles from the Chandalar Lake region across the Koyukuk Valley between Slate and Gold creeks and southwestward across the lower John River valley. Its distribution eastward from the Chandalar Lake region is not known, but to the west and southwest it extends to the Kobuk Valley and Seward Peninsula, where part of it forms the gold-bearing rocks of the Nome, Candle, and other districts.

Northwest of the Chandalar-Koyukuk-John River belt of Birch Creek schist, throughout the southern part of the Endicott Mountains, there is a considerable thickness of massive, heavily bedded crystalline limestones with numerous layers that grade into micaceous schist. These limestones occupy a belt from 15 to 20 miles wide and form rugged mountains from 5,000 to 6,000 feet above sea level. They are much jointed and some of the fractures have been filled by veins and veinlets of calcite and some quartz, a few of which contain a little galena or iron and copper pyrites, but these limestones and associated schists are not believed to be gold bearing. Schrader named them the Bettles and Skagit formations and believed them to be of Silurian age.

In the vicinity of Tramway Bar, on the Middle Fork of the Koyukuk about 16 miles below Coldfoot, there is a formation which contains coal. The rocks with which this coal is associated are much younger than the rocks previously described. Eastward from the 
Middle Fork of the Koyukuk rocks believed to belong to this younger group were observed on the mountains just south of the mouth of Mosquito Fork, and they may extend still farther eastward to the Chandalar Valley but are not now definitely known to occur there. These rocks are probably of Cretaceous age.

\section{SOURCE OF THE PLACER GOLD.}

It has already been noted that the Birch Creek schist of the Koyukuk district contains a carbonaceous schist or phyllite that has been well silicified. The quartz is rather finely and uniformly disseminated throughout much of the rock, but in some places it occurs largely in the form of gashed and laced stringers, and is segregated as more or less lenticular or knotty bodies that have a general tendency to swell and wedge out and follow the curves and crenulations of the schistose structure. In other localities more intense metamorphism appears to have altered the carbonaceous rock with its quartz content into a micaceous quartz schist. That is, this rock apparently varies horizontally from a carbonaceous phyllite, locally having slaty cleavage, to a carbonaceous schist with more or less secondary quartz, at some places finely disseminated, at others more or less segregated; at other localities it has been further altered into a more typical schist of the micaceous quartz variety, some of which shows graphitic phases.

The form in which the secondary quartz occurs at different localities has undoubtedly been largely influenced by the physical character of the various phases of the rock. The more rigid quartzitic phases and the igneous rocks have been fractured or shattered into fragments and blocks, affording opportunity for quartz to be deposited in gashed and laced veinlets, while the members of finer-grained texture appear to have been kneaded like putty rather than broken, and as a consequence the quartz now contained in them is more finely and evenly disseminated throughout and is not so conspicuously segregated as in the harder rocks.

The disseminated and segregated quartz content of these rocks may be an original constituent or it may have been introduced by migrating solutions from other rocks during the progress of metamorphic changes, or it may very probably have been derived from both sources. Where the rock is fine textured and is a more typical phyllite the quartz is more finely disseminated, and locally, at least, this phase also contains a considerable amount of gold-bearing pyrite distributed through the rock as well-formed, sharp individual crystals. The rock at such localities might be called a pyritized phyllite or schist. A selected sample of fresh sharp crystals of this pyrite from Nolan Creek assays $\$ 1.24$ in gold to the ton. Where the quartz content of 
the rock occurs more in the form of knotty segregations and veinlets the pyrite is present in both the country rock and the quartz, though most of the quartz appears to be quite barren. But some weathered pieces of this quartz show oxidized pyrite, cubical cavities from which pyrite has evidently been removed, and occasionally small flakes and particles of free gold. Assays of samples from the quartz segregations and veinlets that occur in the micaceous quartz schist phase of these rocks show that gold occurs sparingly in it also.

The evidence outlined above appears to be sufficient to warrant the conclusion that the placer gold of the Koyukuk district has its chief source in the carbonaceous phyllite and micaceous quartz schist phases of the Birch Creek schist, because the pyrite it contains is known to be gold bearing and the quartz veinlets and lenses charac- teristic of parts of it are known to contain free gold. No doubt the form and condition of the gold as it now occurs in the bed rock is the result of one or more cycles of complicated changes and segregations, and no doubt the coarser placer gold as it now occurs in the gravels represents gradual accumulations from the erosion of a great amount of this mineralized country rock. Whether this gold-bearing pyrite mineralization is confined to any particular rocks, and if such is the case what its distribution within the rocks may be, can not now be definitely stated. Only a detailed study will show what the real relationships are and how they have come about.

\section{MINERAL RESOURCES.}

GENERAL STATEMENT.

The only mineral of present commercial value in the Koyukuk district is placer gold, so far as known to the writer. No gold lodes carrying values have been found. On the other hand, probably the most promise for the future in the Chandalar district lies in its quartzlode gold deposits, for the placers so far found appear to be rather local alluvial concentrations of gold derived from the quartz veins near by, some of which are now known and located. That these quartz lodes carry more or less free gold is indicated by the specimens that may be gathered near the surface of the outcrops, which give encouraging assays. None of the quartz veins in the Chandalar district have been prospected to a sufficient depth below the surface zone of weathering and probable zone of secondary enrichment to determine whether the veins extend in depth or if the values they show at the surface may hold good at deeper levels. Pieces of galena are occasionally found associated with placer gold, and this mineral is reported to occur in places at several localities in the limestone belt that lies northwest of the belt of gold-bearing schist. One of these localities is in the upper valley of Wild River and another on 
Bettles River. Native copper and silver are reported to have been found in small amounts on a northern tributary of Bettles River, associated with placer gold.

On the Middle Fork, just above Tramway Bar, in the southern part of the Koyukuk district, there is at least one coal bed of workable thickness. It is about 12 feet thick, of which the middle 9 or 10 feet is good fuel of a low-grade subbituminous quality, but no development of it has been undertaken up to the present time, though it should prove to be serviceable for local use.

Placer gold was first found in this region in the river bars of the Koyukuk sometime between 1885 and 1890, when it was visited by a few of the first prospectors who came to the lower Yukon Valley. John Bremner, who was killed by an Indian in 1888 on Hogatza River, was one of these pioneers.

Previous to 1898 Tramway Bar bench and two other localities, named Hughes and Florence bars, appear to have been the bestknown occurrences of placer gold in the Koyukuk Valley, and it is estimated that about $\$ 4,000$ worth of gold was mined from them.

Since 1898 prospectors have searched for gold within the valleys of all the headwater branches of Koyukuk River, with the result that placer gold has been found in greater or less amounts in the gravels of some of the tributaries of John and Wild rivers and the North, Middle, and South forks of the Koyukuk. This search has been best rewarded on the tributaries of the Middle Fork, so the deposits and operations within this drainage basin will be considered first. At present placer gold is known to occur in many of the creeks and gulches tributary to the Middle Fork, from Chapman Creek and Tramway Bar on the south to the head of Bettles River, but it is only from five or six of these streams that gold may be mined profitably under present conditions, and in many places work has been carried on from year to year with considerable uncertainty as to the result of the enterprise. This uncertainty is due in part to the nature of the gravel deposits, but largely to the high cost of all supplies and to the primitive methods of mining, which in turn may be attributed to the general remoteness of the region.

\section{PRINCIPAL PLACER-GOLD LOCALITIES ON MIDDLE FORK.}

The name Middle Fork is here used to designate that branch of the Koyukuk which, after being formed by the confluenee of Dietrich and Bettles rivers, flows southward and westward about 75 miles to the point where it is joined by the North Fork, 37 miles below Coldfoot. (See Pl. VII.) The most important creek, gulch, and bench gold-bearing deposits of the Middle Fork will be considered in upstream order from south to north. 
SLATE AND MYRTLE CREEKS.

Slate Creek is the largest eastern tributary of Middle Fork. The settlement of Coldfoot is situated on its south side at its mouth, approximately 1,450 feet above sea level. About 8 miles above its mouth its principal tributary, Myrtle Creek, enters from the mountains on the north, and its main branch heads in the same mountains about 12 miles farther northeast. Most of its valley floor is covered by deposits of washed gravels from 10 to 40 feet thick. The present drainage has intrenched itself in these gravels in the upper third of the valley, but has not reached bed rock, while along the lower two-thirds of the valley the main stream and the lower 2 miles of Myrtle Creek have cut through the gravels and further intrenched their channels into the underlying bed rock, so that rock bluffs from 10 to 20 feet high overlain by gravels from 15 to 30 feet thick are exposed along their banks. In several places these rock-walled cuts are narrow enough to be called canyons. Over the surface of the gravel benches, along the valley, are depressions, some of which are occupied by lakes and ponds, that have the position and arrangement of one or more old stream courses that apparently flowed on top of the gravels during a former period.

The bed rock of the Slate Creek valley is principally a carbonaceous phyllite that shows in places slaty cleavage and a micaceous quartz schist, both of which contain considerable segregated quartz in the form of veinlets, leaflets, and knotty lenses. There are also several dikes of altered dioritic intrusive rock, which has a speckled greenish-gray color and a medium grain. The gravels throughout the valley are the residual débris of the above-named kinds of rocks. The dike rock is the hardest and forms the largest bowlders, a few of which are as much as 6 feet in diameter. Most of the gravels are derived from the schistose rocks, and because of this they show a strong tendency to form flat, slabby shingle, the coarser pieces of which average 6 inches in longest dimension. The whole deposit of gravel is very cleanly washed, there being very little sand, silt, or sediment mixed with it. As a result of this, water seeps through it readily, and it does not pack closely, but lies loosely in the bars, which are consequently not easy to walk over.

Placer gold was discovered on Myrtle Creek in March, 1899, in the present stream-bed gravels, which are from 2 to 4 feet deep and from 100 to 300 feet wide. These gravels have been worked more or less from a point near the mouth of the creek up to claim No. 20, but have not proved profitable above claim No. 15. The seven creek claims from No. 9 to No. 15 have been the most productive. Considered in a general way, the gold has been found well scattered across the width 
of the present bed of the stream and mining has yielded an average of $\$ 5$ to $\$ 15$ a day to the man. All the work along the creek has been done with shovel, pick, and sluice box, the loose shingle gravels from 2 to 4 feet thick being favorable for this kind of mining. This work has been carried on more or less actively during each summer for the last ten years. Nearly all of this shallow ground is now worked out. The largest yield of gold has been mined from claim No. 11, and claims No. 12 and No. 9 have been the second and third best producers, respectively. These three claims are on that part of the creek from 2 to 3 miles above its present confluence with Slate Creek, just below the point where it leaves its mountain valley. Below these claims Myrtle Creek flows through the bench gravels of the Slate Creek valley, and these compose its banks. Above claim No. 12 the bed-rock slopes of the mountains that bound the real Myrtle Valley come down near the stream on both sides, and here and there it cuts rock bluffs at the bases of these slopes. Thus the richest concentration of gold appears to be just beyond the mountains, in that part of the creek that was its mouth when the main drainage along the Slate Valley may have occupied a more northerly position or when Myrtle Creek was at a higher level and dumped its gold-bearing gravels out upon the gravels of Slate Valley, to be mixed with the bench deposits. The gold of this locality is probably all derived from the wearing down of the bed rock of the mountains from which the valley of Myrtle Creek has been eroded.

The bench gravels along the sides of the lower 2 or 3 miles of Myrtle Creek carry some gold and are now being mined by a small hydraulic plant situated on the east side bench of claim No. 6. These bench gravels are largely of Slate Creek channel wash. As exposed by the cut of Myrtle Creek along its lower 2 miles they are from 10 to 30 feet thick and rest on a bench of bed rock from 10 to 15 feet above the present stream level. The gold in the gravel benches along lower Myrtle Creek has probably been largely introduced in to them by that stream. However, the bench gravels of Slate Valley have been found to contain gold at other localities, especially above Myrtle Creek, and it may be proved that these gravels are more generally gold bearing than the prospecting that has been done has disclosed.

The future of mining on Myrtle and Slate creeks apparently depends on the application of hydraulic methods. The only hydraulic plant in the Koyukuk district is now installed on the east side of Myrtle Creek about $1 \frac{1}{2}$ miles above its mouth.

The Myrtle Creek gold is of the size that the miners call shot and wheat gold. It is coarse, clean, and hammered flat to some extent. Some of it is of the size and shape of melon seeds, and nuggets up to $\$ 20$ in value are occasionally found. It rests principally near the 
bottom of the gravels and in the crevices of the slabby schistose bed rock, which stands on edge and is loosened with picks and shoveled into the sluice boxes after the upper part of the loose gravel has been moved aside.

\section{EMMA CREEK.}

Emma Creek is on the west side of the Middle Fork about 7 miles above Coldfoot. Its basin is bounded from south through west to north by a high semicircular divide that rises from 3,000 to 4,500 feet above the Middle Fork in the short distance of 5 to 7 miles, thus giving this basin very steep grades, the average fall being more than 500 feet to the mile, with the result that all the streams within the basin are swift.

At the mouth of its basin the main stream, the confined accumulation of a considerable drainage area, has cut a canyon about 100 feet deep and half a mile long through crystalline limestone and schist into the bottom of an older, wider valley, The Emma Creek valley appears to have been a hanging valley that has been partly dissected, but not enough to altogether obliterate its older configuration.

Some gold has been found in scattered patches of older stream gravels on top of the rock walls of this canyon, but most of the placer gold has been concentrated in the gravels that have choked into the wider funnel-like expansion of the valley at the upper end of the canyon, in the narrow gorge of the canyon, and in the upper part of the gravel fan at the lower end of the canyon, where the swift stream has dumped its gravel load into the valley of the Middle Fork. The funnel entrance at the upper end of the canyon and the bottom of the canyon also are clogged by numerous large bowlders from 3 to 10 feet in diameter. Thus the canyon is a great natural sluice box, with bowlder riffle blocks, through which a tremendous quantity of goldbearing gravels from the upper Emma Creek basin has been sluiced during a long period of rapid erosion. Without doubt this is the reason why the richest diggings have been found just above the canyon, in it, and just below it. The richest claim has been that at the mouth of the canyon, and the formation of the richest placer deposits in the gravels just above, through, and immediately below the canyon is a good example of natural hydraulic washing and concentration.

The rich placers of Emma Creek were first worked in 1900 and the largest production was attained in that and the two following years. Since then the locality has not been worked so extensively but has produced some gold each summer. The number and large size of the bowlders prevent it from being ideal ground for pick and shovel work.

\section{WISEMAN CREEK.}

Wiseman Creek is a west side tributary that flows into Middle Fork about 16 miles by the course of the river above Coldfoot. It is 
a comparatively small stream, occupying a large, broad valley, bounded by mountains that rise over 2,000 feet above it on both sides. The bottom of this valley is filled over a width of half a mile by deposits of gravel, sand, and silt from 200 to 300 feet thick. These unconsolidated deposits extend more than 6 miles from the mouth of the stream to a point near its head and also for more than 2 miles up Nolan Creek, its principal north side tributary.

Although Wiseman Valley has been located for placer-mining purposes throughout its length and width and even far up on the high sloping benches along its mountain sides, there has been no mining development of this ground. All the locations were made without any discovery of gold on the land. This was done on the assumption that because gold was known to occur in Nolan.Creek, one of its tributaries, it might be expected to be present in the deep deposits of the main valley. Only one prospect shaft has been put down to bed rock in Wiseman Valley. This work was done during the winter of 1908-9 about a mile below the mouth of Nolan Creek. The shaft is 260 feet deep. In going down it passes through 40 feet of vegetable muck, 180 feet of tough blue clay that had to be chopped with an ax, 30 feet of stream-washed gravels, and 10 feet of ground-up country rock mixed with some gravel. The bed rock is a black phyllite or slate. The shaft is dry. Colors of gold are found on bed rock and all through the 30 feet of washed gravels above bed rock, but are not considered to be present in large enough quantity to make the ground at present profitable for drift mining.

\section{NOLAN CREEK AND ITS TRIBUTARIES.}

Description.-Nolan Creek, a north-side tributary of Wiseman Creek, is about 4 miles long. Above Discovery claim its valley is of the mountain-gulch type, but for the most part cut to bed rock. This steep-sided $V$-shaped bed-rock valley continues down nearly to its mouth, but this would not be apparent if it were not for the information disclosed by mining operations. For 2 miles above its mouth the valley is deeply filled with unconsolidated glacial-silt deposits, the surface of which presents a gradually widening flood plain that slopes gently downstream to join the still wider flood plain of Wiseman Valley.

Nolan Creek and its east-side gulches - Smith, Archibald, and Fayare the important creeks of the district at present because it is along them that the rich gold-bearing gravels have been found and actively mined. The placers within the Nolan Creek basin are of three classes-bench gravels, shallow gulch gravels, and deeply buried frozen gravels.

Bench gravels.-The character of the bench deposits along Nolan Creek Valley suggests that they may be remnants of narrow, crudely 
washed beaches along the mountain sides that were formed when Nolan Valley was an arm of a glacier-dammed lake which occupied Wiseman Valley. They appear to mark periods of rest occupied by the lake at different stages. Those that have been found to contain gold in paying quantities are situated from 50 to 200 feet above the present valley floor between Smith and Fay gulches, through a distance of about $1 \frac{1}{2}$ miles. They have been prospected and mined to a moderate extent, but are difficult to work to advantage because of an inadequate supply of water for cheaply ground-sluicing away the frozen clay and vegetable muck containing accumulations of ice that cover the washed gravels.

Shallow gulch gravels.-There is not much shallow gold-bearing gravel in the valley of Nolan Creek. What there is appears to be confined to the tributary gulches. The discovery of gold in shallow gravels on Fay Gulch in 1901 a short distance above the point where it joins Nolan Creek first aroused interest in the search for gold within this drainage basin and caused its unconsolidated deposits to be located for placer ground, but actual mining was not actively begun until 1903, when the small amount of shallow ground on Fay, Archibald, and Smith gulches was worked. The lack of boilers and the necessary equipment for steam thawing delayed the investigation of the deep placers for several years. Some work of this kind was attempted with wood fires, however, that resulted in 1903 in the mining of ground from 15 to 25 feet deep on Smith Gulch and on Discovery claim on Nolan Creek at the mouth of Fay Gulch. Smith Gulch was a good producer from 1903 to 1905, Discovery claim on Nolan Creek yielded considerable gold during this period, and claims Nos. 1 and 2 on Fay Gulch were also productive; but not until 1905-6 were the deeper gravels in the bed of Nolan Valley itself demonstrated to be rich.

Deep frozen gravels.--By far the largest bodies of gold-bearing gravels in Nolan Valley are deeply buried beneath frozen silts and clays. By 1906 several boilers and some steam thawing equipment had been brought to Nolan Creek, and in this year the first successful prospect shaft was sunk 135 feet to bed rock in the valley on the lower end line of claim No. 3 below Discovery. Rich gold-bearing gravels were found at the bottom of this shaft, and since that time placer drift mining in the deep frozen deposits of this valley has been actively conducted by about 100 men.

$\mathrm{Up}$ to the present time the most productive ground on Nolan Creek has been found to extend from Discovery claim to claim "No. 6 below," a distance of about $1 \frac{3}{4}$ miles. The creek extends to claim "No. 8 below," one-half mile farther, where it joins Wiseman Creek. There are also six claims above Discovery, but little gold has been mined above Fay Gulch, which joins Nolan Creek on Discovery 
claim. The depth of the unconsolidated deposits increases downstream from 20 or 25 feet on Discovery to 180 feet at the mouth of the creek on claim "No. 8 below." This increase is gradual, the depth being from 40 to 70 feet on claims Nos. 1 and 2, 135 feet on No. 3, 155 feet on No. 5, 165 feet on No. 6, 170 feet on No. 7, and 180 feet on No. 8 below Discovery. However, the general configuration of the bed rock is not so regular as these figures indicate, for underground drifting shows that there are considerable irregularities, called "drop-offs" by the miners, especially across the bed of the valley. Besides these irregularities of the bed-rock surface of Nolan Valley, it carries numerous bowlders in many places, some of them of large size, between which the gold-bearing gravels have lodged. Here and there these bowlders separate the gravels into patches of greater or less extent and, together with the "drop-offs," make the work of drifting along the bed rock more uncertain than if the gravels were of uniform size and more evenly distributed, as they are in the Fairbanks district.

Source of the gold.-The country rock of Nolan Valley is largely carbonaceous phyllite schist strongly mineralized with gold-bearing pyrite. This formation extends northward through the mountains to Vermont Creek. The country rock is well jointed and quartz occurs in the form of veinlets along these joint cracks. Several of these veinlets are known to carry sulphides and some free gold. No doubt there are many more of these joint-crack veinlets that are concealed, and probably a great amount of country rock similarly mineralized has been worn away by erosion, and in this manner a large part of the placer gold has been concentrated from the stream gravels. The quartz mineralization along these joint cracks probably comes from the country rock, and as the sulphides in the country rock are known to be gold bearing, the gold in the quartz veinlets may be derived from the gold-bearing sulphides disseminated through the carbonaceous phyllites.

Character of gold.--The placer gold from Fay Gulch and the upper part of Smith Gulch, where it appears to be near its bed-rock source and probably has not been carried far, is mostly in the form of rough, angular grains. That in Fay Gulch has about as much quartz attached to it as there is gold, the proportion being about half gold and half attached quartz. On Smith Gulch the gold is in more rounded and heavier pieces the farther downstream it lies. Somc of the gold in Smith Gulch has a coating of white mineral matter, which the writer has not had opportunity to test, which is said to be lime but may be some other mineral substance. This coated gold is most common toward the head of the gulch. Either it does not occur on the gold farther downstream or the coating has been worn off of it by travel. The gold from Smith Gulch is of very high grade, 
its assay value being said to be more than $\$ 20$ an ounce, which would make it some of the highest-grade placer gold known.

The gold in the deep gravels along Nolan Creek is mostly in the form of rounded, smooth, heavy, chunky pieces. Large nuggets are rare; one of the largest, having a value of about $\$ 300$, was found on claim "No. 1 below," and another nugget with a value of about $\$ 120$ was taken from claim "No. 3 below."

\section{UNION GULCH.}

On the west side of Middle Fork, between Wiseman Creek and Hammond Creek, two gulch valleys drain the east side of the mineralized mountain mass that lies between Middle Fork and Nolan Creek. These gulches are named Union and Confederate. The gravels in both contain gold, but the southern, Union Gulch, which is situated about 2 miles above Wiseman Creek, is the more important. Although the deposits on Union Gulch are limited to about one claim in extent, about $\$ 30,000$ worth of coarse gold has been mined from them. Gold was discovered on Union Gulch in 1901. The largest production was attained in 1902, but work is still being carried on there. Prospects of coarse gold have been found on Confederate Gulch, but no mining has been attempted.

HAMMOND CREEK.

Hammond Creek flows into Middle Fork from the northwest about 20 miles, by the course of the main river, above Coldfoot. It is the largest tributary of Middle Fork, being at least 45 miles long and discharging a volume of water equal to about one-fourth of the flow of the main river above their confluence. The Hammond Valley shows strong evidences of having passed through the same stages of drainage development as the smaller tributaries to the south. In modified forms it has bench and deep gravel deposits and canyon features somewhat similar to those that have been already outlined for Emma and Wiseman valleys.

While the Hammond Valley has been prospected more or less throughout its lower 25 miles, gold has been mined only along its lower course, more particularly in several short gulch valleys tributary to it from the south within 5 miles of its mouth.

Little systematic or continuous mining has been done on the stream gravels of Hammond Creek, because the large flow of water and the presence of numerous cobbles and small bowlders make pick and shovel labor unprofitable. In 1902 a wing dam was built on claim "No. 6 above" early in the spring at a time of low water, to divert the river so that the gravels in its bed might be mined. 
Although the summer's work produced considerable gold, the expense of the operation is said to have made the venture unprofitable. Spasmodic work from year to year along the banks of the river, chiefly on Discovery claim, has yielded from $\$ 8,000$ to $\$ 10,000$ worth of gold. Most of this gold has been of the coarse nugget variety, some pieces being of large size. One nugget of a value of $\$ 849$ was found on claim "No. 6 above," another worth $\$ 842$ was found on Discovery claim, and one worth $\$ 1,000$ and another worth about $\$ 1,100$ have been mined in this valley.

\section{GOLD-BEARING STREAMS TRIBUTARY TO HAMMOND CREEK.}

Along the south side of Hammond Creek, between the Middle Fork and Vermont Creek, are several gulches that drain the north face of the mineralized mountain mass that has been already referred to in describing the placers of Nolan Valley and Union Gulch, and will be mentioned later in the discussion of Vermont Creek. The profitable ground on these gulches is near their mouths, where they have accumulated considerable washed waste from the mountain slopes to the south, more or less mixed with bench-gravel remnants of river deposits along the south side of Hammond Creek. The principal gulches are Goldbottom, Swift, and Buckeye. A small amount of mining has been done on them at different times.

\section{VERMONT CREEK.}

Vermont Creek is a small stream flowing into Hammond Creek from the south about 5 miles from the Middle Fork. It is formed by two branches, an east or left one, about 2 miles long, and a west or right one, about 3 miles long, which flow through deep gulch valleys that join about a mile from Hammond Creek. These gulch valleys head against similar gulches that are tributary to upper Nolan Creek and drain southward.

The bed rock in Vermont Creek is the same as that already described as occurring in Nolan Valley. This carbonaceous phyllite formation extends northward through the mountains from Nolan Creek to Hammond Creek and is well exposed on the east or left fork of Vermont Creek and to the east of it for some distance. It also outcrops along the south banks of Hammond Creek for some distance downstream from the mouth of Vermont Creek, where much of it shows slaty cleavage. On the upper part of the east fork of Vermont Creek, where unweathered exposures may be observed, it is found to be mineralized with pyrite in the same manner as on Nolan Creek, and it is here that quartz veinlets along joint cracks may be easily observed. One of these joint-crack veinlets about 1 inch thick was 
observed to be mineralized by sulphides and free gold in flakes and specks. No doubt there are other veinlets so mineralized.

Placer gold was discovered on Vermont Creek August 25, 1901, and has been profitably mined there ever since. Discovery claim is located on the main lower part of the creek just below the forks. Two claims, covering about half a mile, on the east fork have been good shallow mining ground, and Discovery claim and the two claims below Discovery contain good values. Thus the rich gravels extend over five claims for a distance of about $1 \frac{1}{4}$ miles, of which three-fourths of a mile is below the forks and half a mile along the east fork. On the west fork of Vermont Creek gold has not been found in paying qumntities. The gravels on the east fork average about 3 feet in depth and are not very wide, as the bottom of this gulch is narrow. On Discovery elaim the valley bottom broadens and the gravels are from 200 to 300 feet wide. On claim "No. 1 below" their width increases to about 400 feet. The gravels become somewhat deeper on the lower end of claim No. 1 below Discovery and decidedly deeper on claim No. 2 below Discovery. In fact, the lower half mile of Vermont Creek is flowing over deep frozen deposits that may be more properly considered, at least in large part, bench deposits of Hammond Valley, for these deposits are not in the form of shallow gravels, largely unfrozen, lying on the bed-rock floor of a narrow rock-cut valley such as extends above claim No. 2 below Discovery, but are deep frozen accumulations of gravel, sand, and clay that are directly related to similar extensive bench deposits which occur along the sides of Hammond Valley. Although the largest part of the unconsolidated stream deposit on this claim belongs to the sediments of Hammond Valley, there appears to be little doubt that most of the gold in this deep ground has been derived from Vermont Creek.

About the center of claim No. 2, below Discovery, on Vermont Creek, a sinking and drifting operation in these deep frozen deposits has proved very successful. This work was begun during the winter of 1908-9. The shaft is about 90 feet deep. At a depth of about 50 feet a bed of cemented sediment 11 feet thick was encountered which is termed a "false bed rock." Below this hard bed there is from 7 to 8 feet of washed gravel. In August, 1909, a drift about 200 feet long had been driven in a direction up Vermont Creek and another drift about 100 feet long across the direction of Vermont Creek. A report received in February, 1910, states that a rich pay streak 40 feet wide has been found on this claim and that the gravels panned in two days have yielded $\$ 2,400$ worth of gold.

The Vermont Creek gold is mostly coarse and rounded. Several nuggets worth more than $\$ 200$ have been found. 
GOLD CREEK.

The present form of the valley of Gold Creek apparently shows that it has passed through a series of drainage changes somewhat similar, but of modified form, to those that have taken place in the development of the basin of Emma Creek, but as it is impossible to describe these changes clearly without illustrating its features by a detailed topographic map, only an outline will be given here.

The most marked feature this valley now presents is a canyon section $1 \frac{1}{2}$ miles long in its lower part which is cut at right angles across a sloping bench of bed rock on the east side of the valley of Middle Fork. One mile above the mouth of Gold Creek this narrow canyon is 50 feet deep and its depth increases upstream for about half a mile, reaching 200 to 250 feet. In its upper part, where deepest, it appears to have cut down through a spur that slopes from the mountain mass which lies on the south between Gold Creek and Sheep Gulch. On the north wall of the canyon, in line with this mountain spur, there is a small but prominent bed-rock knoll that appears to be a remnant of the mountain spur on the south side of the canyon. Just above or northeast of this knoll, in the bed rock of the north wall, there is a depression about 50 feet deep and 300 feet wide, the bottom of which is about 200 feet above the present bottom of the canyon. This depression is filled with stream-washed channel gravels which in their present position are resting on top of the canyon wall. These washed gravels appear to occupy a part of a former channel of Gold Creek when it flowed at a level 200 feet higher than it does now. The significance and probable course of this old high channel will be discussed later in connection with the gold placers that occur on Linda Creck, with which it appears to be closely related.

The fall of Gold Creek from the head of its canyon to its mouth is about 200 feet in a distance of less than 2 miles. Above this canyon the valley widens out somewhat and has a deep V-shaped cross section whose slopes rise steeply to a height of about 1,000 feet above the creek. At this elevation, which is about 3,000 feet above sea level, the steep lower slopes form a shoulder, with more gently inclined slopes on the higher parts of the mountains; that is, the present valley of Gold Creek shows strong evidence of having been. rather abruptly cut down into an older land surface which had a moderately rolling mountain relief that was much less rugged than the topographic form of this region to-day.

This deep $V$-shaped portion of the valley extends upstream from the head of the canyon for about 3 miles, and in this distance the fall of the creek is about 400 feet. At about midway of this stretch and also at the upper end of it there are two more contractions in the 
valley, where the creek runs through short, low-walled, narrow gorges or small eanyons. The halfway gorge appears to be caused by the presence of a hard dike of intrusive diabase which outcrops on the north slope of the valley and whose greater resistance to erosion over that of the softer schists on both sides of it has offered a barrier to the cutting of the stream. The uppermost gorge, about a mile farther upstream, is cut through a low ridge of schists that are harder than the surrounding schists. This barrier rises about 60 feet above the present creek bed. Thus the lower half (4 or 5 miles) of Gold Creek valley has three contracted features, the first and deepest of which is a canyon, the second and third gorges. Between these three contracted features there are two wider $V$-shaped portions of the valley and it is in these portions that the richest goldbearing gravels have been found and mined.

Above the upper gorge the upper half of the Gold Creek valley is wider and has a form entirely different from its lower half, as there are no canyon-like contractions, and instead of a sharp deep $V$-shaped cross section it has more open and gradually sloping sides. This form continues throughout 3 or 4 miles to its headwater gulches.

The country rocks of the Gold Creek valley are practically all schists. The outcrops in the lower half of the creek are mostly of the carbonaceous phyllite schist that has been already noted in the basins of Wiseman Creek and Hammond Creek; in the upper half of the valley the bed rock is mostly of the micaceous quartz schist variety that occurs to the south in the Myrtle Creek basin.

Placer gold was discovered on Gold Creek in 1900 and has been mined more or less throughout 6 miles of its length, from claim No. 4 below Discovery, at the head of the canyon, to claim "No. 19 above," on its headwaters. The most profitable diggings have been the shallow stream gravels that occur in the two sections of the valley situated between the canyon and the middle gorge and between the middle and upper gorges.

Most of the gold placers on Gold Creek are shallow stream gravels without any large amount of overburden. For this reason it has been one of the best valleys for pick and shovel mining in the district. Some of the gold on claim "No. 19 above" and in the gulches near by is in rough, light pieces that appear not to have been trans- ported far from their bed-rock source, but most of the gold has the form of rounded shotlike pieces and small smooth nuggets.

\section{LINDA CREEK.}

Linda Creek is a small stream about 4 miles long that drains the southern half of a gravel-filled depression on the east side of the Middle Fork about a mile north of Gold Creek. The part of this wide depression occupied by Linda Creek is the southwesterly arm 
of a semicircular bend around or to the east of a mountain 3,000 feet high, which stands isolated from the main mountain ridges that bound the valley of Middle Fork. Linda Creek heads in a large pond in the elbow of this bend, where, with several other smaller ponds, it occupies a flat gravel and silt covered watershed between Linda Creek and another small creek of about the same length, which drains the northwesterly arm of this depression and flows into Middle Fork about 6 miles above the mouth of Linda Creek. A covering of waterworn gravels and silts is spread over the broad bottom of this depression throughout its extent, over which the creeks that drain its arms flow for the most of their lengths, but about the middle of their courses these creeks have washed through the unconsolidated deposits and cut shallow channels into the underlying bed rock. Linda Creek, however, has done practically no bed-rock cutting and does not occupy a valley of its own making, and it appears evident that any placer gold now occurring in the gravels of its channel must have been introduced there by some agency other than the present stream.

The most probable source for the placer gold that has been found on Linda 'Creek is Gold Creek. In the description of lower Gold Creek the significance of the stream-washed deposit of gravel that occupies an elevated position about 200 feet above that stream on the north wall of its canyon was referred to as having a possible intimate connection with the placer gold that has been found on Linda Creek. The gravels on top of the canyon wall occupy a depression in the bed rock about 300 feet wide and 50 feet deep, and as exposed have every appearance of being a cross section of an old high channel of Gold Creek before that stream was diverted down its present canyon. If the rock knoll that forms the west side of this depression in the north wall of the canyon is, as it appears to be, a remnant of a former continuation of the mountain spur opposite to it on the south wall of the canyon, then the most natural course for Gold Creek to have followed when at this higher level would have been to the north toward Linda Creek, across the sloping bench that now intervenes. The direct distance across this bench between the high gravels in Gold Creek canyon and the locality where placer gold occurs on Linda Creek is a little more than a mile and the fall of the surface is about 300 feet. The indications that a stream flowed between these two points are not particularly marked. There is no strong surface evidence of a former channel unless a slight depression or sag of the surface from 300 to 600 feet wide, which is indicated by a timberless strip overgrown with moss and willows, is considered to mark a frozen channel, that is too cold to foster a good stand of timber such as now grows along both sides of it. This barren strip of land seems to connect the high gravels on the canyon wall with the 
placer-gold locality on Linda Creek, but whether it is the course of an old channel can be proved only by prospecting, and even if this is proved it may not be found to contain gold, especially throughout its length.

Gold is said to have been first found on Linda Creek in 1901. The only ground that has been mined is on Discovery claim, situated about half a mile above its mouth, and only the lower half of this ground has proved very productive. The gold is similar to that of Gold Creek.

BETTLES RIVER.

Bettles River is the large eastern headwater branch of the Middle Fork of the Koyukuk. Its basin extends over 30 miles from east to west, and 25 miles from north to south, in a region of rugged mountains between the Middle Fork and upper Chandalar River. Its longest and largest tributaries flow from the north out of mountains largely composed of the crystalline limestone formation that overlies the gold-bearing schist formations. Its southern tributaries are shorter and flow almost wholly over the same schist formations that extend to the south from Gold to Slate creeks. This valley was not visited by the writer. The information given here is taken from notes gathered from prospectors who have worked on the creeks in this basin at various times during the last ten years.

Prospects of placer gold have been found on a number of creeks tributary to Bettles River, namely, Emory, Garnet, Mule, Eightmile, Phoebe, Spruce, Sheep, and branches of Robert Creek. The gold is found on the lower courses of these creeks where they have cut down into the schists beneath the massive limestones. Except on Emory Creek, which is said to have produced about $\$ 10,000$, only prospect work has been performed on the tributaries to Bettles River that have been mentioned and they have not yielded much gold.

\section{SOUTH FORK OF THE KOYUKUK.}

GENERAL DESCRIPTION.

The South Fork of the Koyukuk is one of the largest and longest branches of that river. It rises about 10 miles west of Chandalar Lake, just south of the headwaters of Bettles River, and flows southwestward for about 175 miles. Its general course is parallel to that of the Middle Fork throughout its length. At no place are the main channels of these two rivers more than 25 miles apart, and at one place a few miles below Tramway Bar their main channels approach within 7 miles of each other.

The three large tributaries to the South Fork, Fish Creek, Jim River, and Mosquito Fork, all flow from the east, where they have 
their sources in mountains from 4,000 to 5,000 feet above sea level. These mountains are made up of the schistose formations that compose the wide belt of metamorphic rocks between Dall and Jim rivers. These three streams head against the headwaters of Dall and Hodzana rivers and of West Fork and Crooked Creek, west-side tributaries of the Chandalar. Some prospecting for placer gold has been carried on within the valleys of these streams at different times during the last ten years, more particularly in the basin of the Hodzana, but though prospects of gold are reported to be widely distributed throughout this region no mining operations have been undertaken up to the present time.

In 1909 the Geological Survey party panned the gravels on the upper part of the south branch of Jim River and found colors of gold. The stream on which these colors were found has been named Prospect Creek. (See Pl. VII.)

The best known placer-gold locality in the valley of the South Fork is named Gold Bench. It is a deposit of high stream gravels situated on the northwest side of South Fork about 10 miles south of the Tramway Bar bench on Middle Fork, and apparently belongs to this same class of deposits. It is usually reached by a trail about 8 miles long that leaves the Middle Fork near the halfway road house, 28 miles below Coldfoot or 32 miles above Bettles.

The gold-bearing gravels lie on top of a sloping bench of thick unconsolidated wash deposits in a semicircular bend of the river. The surface deposits in which most of the gold has been found consists chiefly of fine washed stream gravels, largely composed of schist pebbles, a considerable amount of quartz pebbles, some of flint, and a few bowlders and cobbles of igneous rocks. The best gold-bearing gravels mined were from 18 to 24 inches thick, distributed over an area about three placer claims (60 acres) in extent. Most of the gold rested on a "false bed rock" of reddish sand from 2 to 12 inches thick and the richest yield was obtained from an area 150 to 200 feet wide and about a quarter of a mile long. Some of this shallow ground was so rich and so easily handled that from $\$ 80$ to $\$ 90$ a day to the man was mined with rockers, and in 1900-1901 an extensive shovel and sluice-box operation is reported to have yielded $\$ 85,000$ worth of gold. The gold is in the form of fine, flaky, light, and very much flattened pieces, the largest of which had a value of $\$ 3.50$.

The bed-rock source of the gold is not known. It may have been washed from the direction of Tramway Bar bench, as there is a low valley-like depression from that direction filled with channel-washed gravels, but it appears more probable that the gold may have come from the mountains that border the south side of the river opposite and for some distance above Gold Bench. These mountains are apparently formed of igneous rocks, largely diabases, which may 
have intruded the schist formations with which they are associated, and it may be that these igneous rocks have an intimate relation with the origin of the placer gold. On the south branch of Jim River, where colors of gold were found on Prospect Creek, the mountains that form the north side of the valley appear to be largely made up of the same diabasic rocks.

One of the best reasons for believing that the Gold Bench gold may be derived from the mountains that lie between the South Fork and Jim River is that placer gold is known to occur on some of the streams that drain from this group of mountains and also in other benchgravel deposits on the South Fork above Gold Bench. Three of these bench deposits are named Ironside and Grubstake bars and Eagle Cliff.

\section{DAVIS AND OTHER CREEKS.}

Davis Creek is a stream about 5 miles long flowing from the mountains about 4,000 feet high that lie to the southeast between South Fork and Jim rivers. It joins South Fork about 8 miles above Gold Bench and is one of the first known placer-gold streams in this valley. The bars at its mouth are usually dry, as the stream apparently sinks into unfrozen gravels, but there is a good flow of water above its mouth, where it has cut into thick washed-gravel deposits. A small amount of gold occurs in these gravels and they have been mined to a small extent at intervals for the last ten years. It is reported that above Davis Creek there are prospects but no good paying quantities of gold in several creeks flowing from the same mountains, and also on Wilson Creek, a north-side tributary to South Fork, about 21 miles above Gold Bench. It is also reported that loosely scattered colors of gold may be found in the gravels along South Fork as far up as Bowlder Creek, which rises opposite the upper basin of Slate Creek; but no mining has been done along this part of the river.

\section{HEADWATERS OF GLACIER CREEK.}

Glacier Creek is a large north-side tributary of the upper South Fork, about 10 miles long, that heads against Gold Creek and two south-side tributaries of Bettles River. Gold was discovered in 1901 on its principal headwater branch, California Creek, and two of its tributaries, Jim and Boer gulches. Shovel and sluice-box mining operations have been carried on in a small way by several men each summer since 1901, but this work has never yielded much more than the equivalent of the current wages of the district, and hence has not proved very attractive to the miners. 


\section{NORTH FORK OF THE KOYUKUK.}

GENERAL DESCRIPTION.

The North Fork of the Koyukuk is a large stream that rises on the south side of the Arctic divide west of the head of Hammond Creek and drains a north-south valley over 60 miles long and from 10 to 15 miles wide that lies west of and parallel to the Middle Fork Valley. The upper part of the North Fork valley is in mountains of the same limestone formation that occupies a wide belt north of Bettles River, extends westward across Dietrich River, and crosses Hammond Valley about 25 miles above its mouth. The southern half of the North Fork valley lies in the schist formations that underlie the massive limestones to the north. About halfway up the valley, some 35 miles above its mouth, are several small creeks that carry shallow gold-bearing gravels. The first discovery of gold in this valley was made on Washington Creek in August, 1902; in September of the same year gold was found on Mascot Creek, a short distance farther west.

Washington Creek, which heads against several of the lower westside tributaries of Hammond Creek, has not so far yielded enough gold to encourage serious mining operations, although some coarse smooth gold is found in its gravels.

\section{MASCOT CREEK.}

Mascot Creek is the only stream in the North Fork Basin that has been extensively mined. Its bed rock is a micaceous quartz schist and its gravels are shallow, being nowhere more than 3 feet and in some places but a few inches deep. While the gravels were not considered to be very rich by the miners, the ease with which they could be handled made the work very profitable, it being little more than equivalent to what is termed "cleaning bed rock" in an ordinary hydraulic operation. The gold rested mostly upon bed rock or in the lowest layers of gravel and to some extent in the soft decayed bed rock, which in places was removed to a depth of a foot. The gold mined was coarse, large nuggets, some worth $\$ 100$, being found. The ease with which these deposits could be handled made it possible to carry on mining with a profit of about 70 per cent of the yield, and when the extremely high costs of that time are considered the operations on Mascot Creek may be said to be the most profitable that have ever been performed in the Koyukuk district.

\section{WIID RIVER.}

Wild River enters the Koyukuk from the north about 13 miles below the mouth of North Fork. Its valley lies between that of North Fork on the east and that of John River on the west, but it 
is not so long or large as either of these streams and is probably not over 50 miles long in a direct north-south direction. The upper part of the valley crosses the gold-bearing schist belt from 30 to 40 miles north of Koyukuk River, and small amounts of gold have been mined from three creeks lying in this schist belt. To take these creeks in upstream order, the first one is Birch Creek, an east-side tributary, from which about $\$ 10,000$ worth of gold was mined during 1905-6.

About 10 miles above Birch Creek the river flows from a lake, and on two small creeks that flow into this lake from the east some gold has been mined. The southern of these streams is named Iake Creek. In 1903-4 gold to the amount of $\$ 2,000$ was mined from a claim on one of its headwater gulches. The gold was coarse, some of the nuggets ranging in value from $\$ 90$ to $\$ 150$.

Spring Creek is the next stream above on the same side of the lake. The claim that has been mined is located about a mile from the lake and made a good yield in 1907, but the summer of 1908 was so dry that there was not enough water available for advantageous work.

\section{JOFN RIVER.}

John River is one of the largest northern tributaries of the Koyukuk, which it joins about 2 miles above Bettles. It is about 120 miles long and occupies a deep valley across the Endicott Mountains that has its head in a pass across the arctic divide at an elevation of about 2,500 feet above sea level.

From 40 to 60 miles above its mouth this river crosses the southwesterly extension of the Koyukuk belt of gold-bearing schist. North of this belt is the same massive limestone formation that is found overlying the schists on North Fork, Hammond Creek, and Dietrich and Bettles rivers to the northeast. Schrader has noted a zone of sulphide mineralization in this belt of schistose rocks and the localities where prospects of gold have been found, and small amounts mined are located in this belt. No gold-bearing deposits have been found north of this schist belt.

Crevice Creek, which lies in these rocks on the east side of the river, and Fool Creek and its tributaries, on the west side, are the only localities where encouraging prospects have been found up to this time. About $\$ 1,800$ worth of gold was mined on Crevice Creek in 1904 and good prospects were found on Midas Creek, a tributary of Fool Creek, in 1905, but these discoveries have not led to further development.

\section{CHANDALAR RIVER.}

At present mining operations in the Chandalar Valley are confined to a rather small area whose central part is situated about 6 miles east of the upper end of Chandalar Lake. On the west this area 
is bounded by the north-south portion of the Chandalar Valley, on the north by a wide east-west valley feature now drained by I ake and Grave creeks, on the east by the headwaters of McClennan and Big creeks, and on the south by Tobin Creek. As thus limited the area is about 10 miles in extent from north to south and the same from east to west and embraces about 100 square miles. The mountains within it are from 5,000 to 6,000 feet above sea level and from them the placer streams flow in various directions. These streams are Big Creek and its tributary headwater gulch (St. Marys), Tobin Creek, Bowlder (reek, Big and Little Squaw creeks, and Big and Little McClennan creeks.

The largest production of placer gold to date in this district has been from the head of Big Creek and St. Marys Gulch. The gold so far mined appears to be rather local alluvial concentrations derived from quartz veins near by that are now known and located. It is estimated that about $\$ 50,000$ worth of placer gold has been produced since 1906.

Probably the most promise for the future of the area defined above is in its quartz lodes, but it requires a much larger initial investment of capital to develop lode deposits than placers, especially in a region so remote as this, where even rich shallow placers that require very little capital or machinery do not always yield adequate returns under present commercial conditions. A more detailed account of this district will be presented in a report now in preparation. 


\section{MINERAL RESOURCES OF THE NULATO-COUNCIL REGION.}

By Philip S. Smith and Henry M. Eakin.

\section{INTRODUCTION.}

West of Koyukuk and Yukon rivers a large area long remained geologically unexplored. During the season of 1909 a party from the Geological Survey worked in a portion of this area, and it is the results of the studies there carried on and extended as far as Council, on Seward Peninsula, that the following paper aims to set forth:

\section{GEOGRAPHY.}

\section{LOCATION OF AREA.}

From the itinerary of the expedition of 1909, as indicated by the different camps, the area in which new geographic and geologic information has been obtained may be inferred. It has seemed feasible, however, to extend the discussions of this paper beyond the area actually visited so as to include contiguous regions which throw light on parts of the region visited in 1909 or in which problems have been raised by other parties and are explained wholly or partly by the 1909 results. The area treated in this report, therefore, is in the main rectangular and may be roughly described as bounded by parallels $64^{\circ}$ and $65^{\circ} 30^{\prime}$ north and meridians $156^{\circ}$ and $164^{\circ}$ west. The southern margin is near the settlement of Unalaklik and the northern is a short distance north of the big bends of Koyukuk and Kateel rivers. . On the east the region is bounded by a northsouth line midway between the mouths of Melozi and Koyukuk rivers. On the west the best-known point to which to refer the margin is the town of Council, on Niukluk River. (See Pl. VIII.)

\section{GENERAI TOPOGRAPHY.}

Throughout the Nulato-Council region the relief is relatively low. There are few hills over 3,000 feet high, and the larger part of the upland area is only about 2,000 feet above sea level. Although there are no high ranges, steep slopes lead from the flat river bot- 


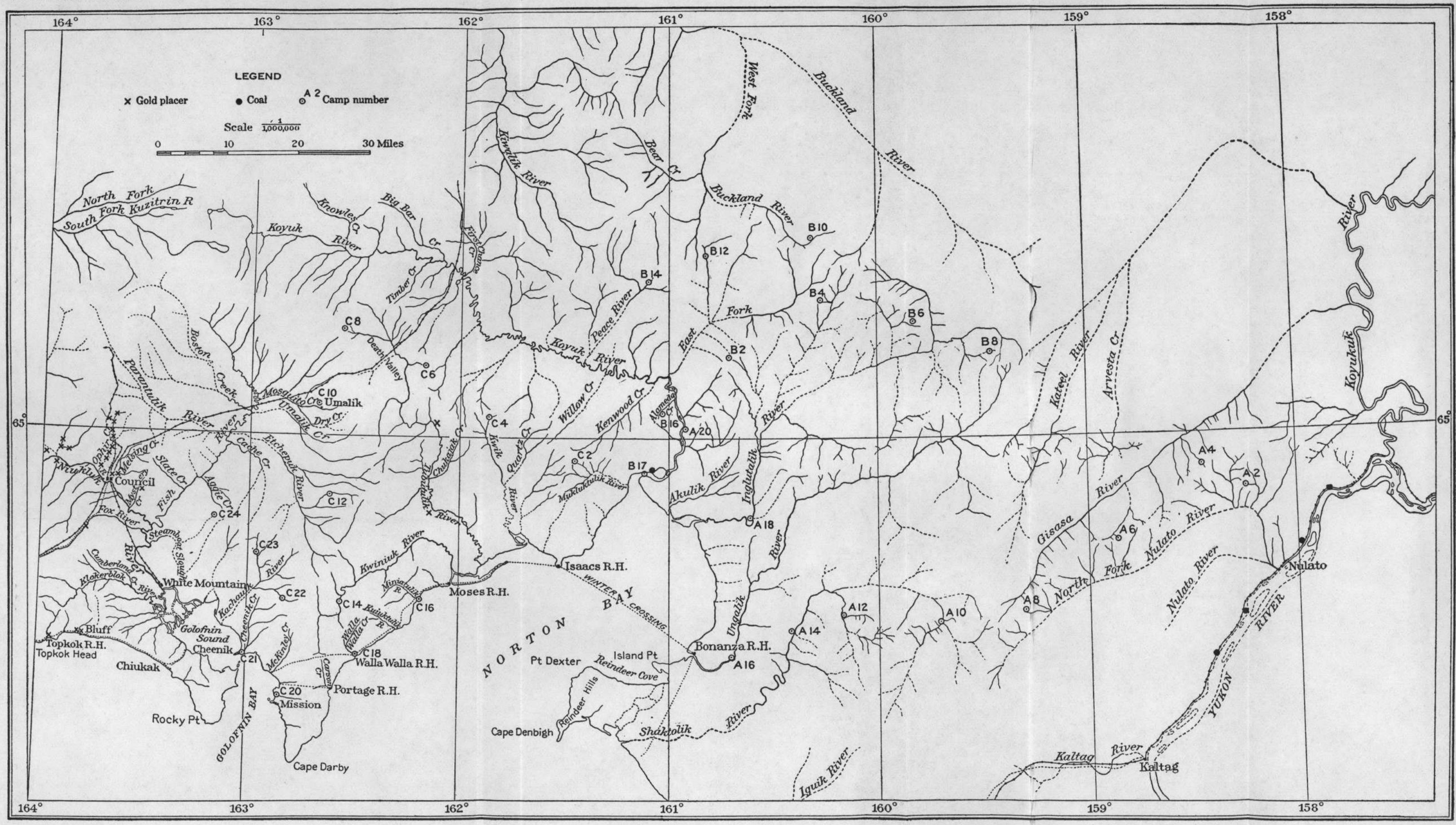

MAP OF NULATO-COUNCIL REGION. 


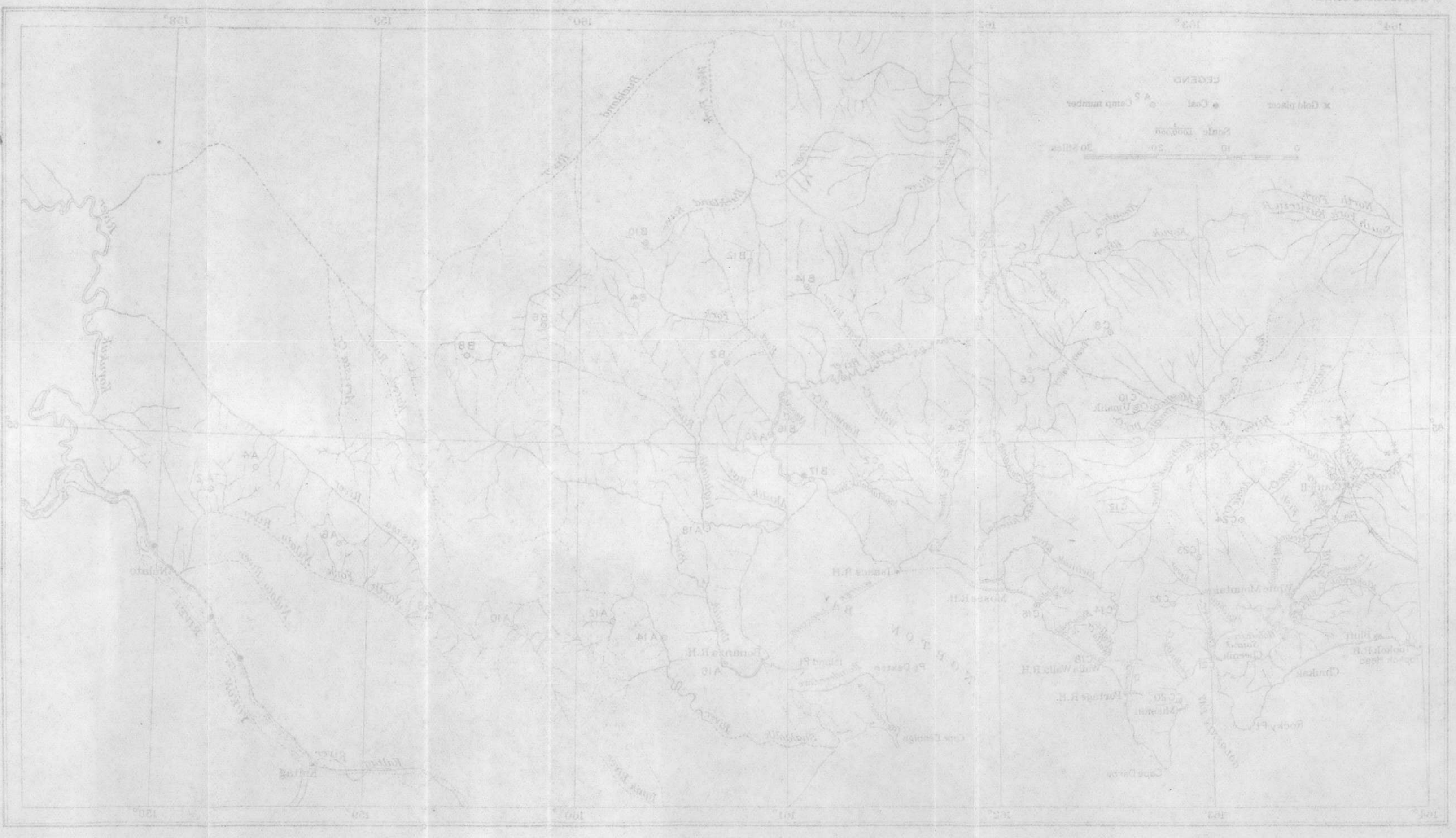


toms to the highlands. In the Nulato-Norton Bay region there are numerous parallel northeast-southwest ridges, the highest of which forms the divide between Inglutalik-Ungalik and Kateel-Gisasa rivers. The hills to the north of the East Fork of Koyuk River are low and rolling, without pronounced direction. To the west, in Seward Peninsula, three ranges form prominent landmarks. These are the hills between Buckland and Kiwalik rivers and the Darby and Bendeleben mountains. The higher points of the first range rise to elevations of about 2,500 feet. In the Bendeleben Mountains the highest point is a little over 3,700 feet and in the Darby Range the highest peak is 3,000 feet. In the two latter ranges precipitous slopes rising to 2,000 feet or more give wildness to the topography.

Outside of these three higher areas the uplands are usually rolling, with elevations of 1,000 to 2,000 feet above sea level, unforested, well drained, and covered with angular fragments of frost-riven waste. Pinnacles of the underlying rocks form fantastic knobs here and there.

The drainage of the region studied flows either into the Yukon, into Norton Bay, or into Kotzebue Sound. The streams belonging to the Yukon drainage area and the eastern part of the Norton Bay show pronounced parallelism with the geologic structure, the result being long, narrow valleys, as for instance that of the Gisasa. The gradients of the main valleys are low, but the small side streams rise rapidly headward. In some places the streams flow through narrow rock-walled canyons of slight depth, but in others there are flat flood plains and gravel deposits. In the headward portions of the basins the relations of the streams on opposite sides of the divide are complex, and it is by no means possible to foretell the direction of the drainage at long range. In Seward Peninsula, where the geologic structure is more complex, its effect on the streams is not well marked and irregular courses are the rule. In this part of the area the longer streams, such as the Koyuk, the Kiwalik, and the Tubutulik, flow more or less parallel with the mountains, but Fish River and its larger tributaries flow at right angles to the Bendeleben Range.

Almost all the valleys show signs of having been eroded entirely by stream action. In the headwaters of the rivers rising in the Bendeleben and Darby ranges, however, there are glacial cirques and valleys produced by ice erosion. Here the present streams form irregular threads on the broadly open floors of valleys that have very steep sides. Many of the streams flowing into Norton Bay, instead of showing erosion features at their mouths, have filled the former valleys, which have been depressed, with sand and gravel. Examples of topography of this kind are found at the mouths of Kwik, Tubutulik, and Kwiniuk rivers, where numerous lakes and sloughs form an untraversable network during the summer. 
The coast line presents numerous examples of different types of shore topography. From the Reindeer Hills to the Koyuk a coastal plain, recently emerged, affords a relatively straight shore with such slight depths of water off the coast that approach for large vessels is impossible. Of course, under such conditions, harbors do not exist. On the west side of Norton Bay the sinking of the land and the attack of the waves have resulted in harbors and a rugged clifflined coast. This part of the coast is formed by the Darby Range, which rises in abrupt slopes from the sea and forms a long southwardpointing peninsula. West of this range the deep reentrant of Golofnin Sound and Bay, which probably represents the submerged portion of an old valley similar to that of Fish River, affords a good harbor. Still farther west rocky headlands with intervening beaches produce a diversity of forms. In the depressed portions of the coast there are sand spits, such as the long point extending eastward from a point near the mouth of the Kwiniuk.

\section{GENERAL GEOLOGY.}

\section{GENERAL STATEMENT.}

In this paper no attempt will be made to discuss in detail the geology of the Nulato-Council region. There are, however, certain general features which it is important to set forth in order to understand the geology of the area and it will be the purpose of this section to describe these features.

The rocks of the region fall into four main divisions--the metamorphie rocks, the older igneous rocks, the nonmetamorphic sediments, and the late effusive rocks.

\section{METAMORPHIC ROCKS.}

West of the Koyuk the rocks belong predominantly to the metamorphic complex known in other parts of the peninsula as the Nome group, of Paleozoic age or older. They consist of a variety of lithologic types, many of which persist over large areas, whereas others are distinctly local. This group consists essentially of schists and limestones, all highly metamorphosed and in places showing structures due to more than one period of deformation.

Schists form the greater part of the metamorphic complex and may be described according to the mineral or minerals characteristic of them. The schists most commonly found are quartzose, graphitic or carbonaceous, biotitic, feldspathic, and calcareous. Gradations between different types are numerous and the differentiation is by no means certain. It appears, however, that the present lithologic differences are in considerable measure due to original characters, so 
that in a broad way identity of lithology may be taken as indicating deposits formed at essentially the same time. This is true of most of the feldspathic and graphitic schists and of some of the calcareous schists, but is in general not true of the biotitic schists.

Quartz is the most common mineral found in the schists and is of small diagnostic value, except where its proportion to other minerals is high. Quartzose schists are widely distributed through the entire area and are apparently not restricted to any single geologic relation with respect to the other rocks. Associated with the quartz is usually more or less chlorite or other mica-like minerals. As the amount of quartz decreases calcite or feldspar and chlorite increase and the schist may gradually merge into one of the other types. This usually takes place near the contact of the quartz schist with beds of limestone or with the sheared intrusive rocks.

The black quartzites and schists in the western part of Seward Peninsula, known as the Kuzitrin group, are also represented in this field. No accurate determination of the coloring matter has been made, but a part of it is certainly graphite, although some may be another form of carbon. The carbonaceous schists are more or less closely related geologically to some of the limestones which occur along the flanks of the Darby Mountains, but they are also found in many other parts of the region. Where not too thoroughly metamorphosed they are usually high in quartz and low in alumina and lime minerals. It is believed that this type is similar to the Hurrah slate of the Solomon region and to the quartzites and slates of the region around Lanes Landing. Where much sheared this type shows an increased amount of chlorite and merges into the quartz schists until separation of the two is impossible.

Biotite schists are found only in the Bendeleben and Darby mountains. The presence of biotite seems to be due in large measure to the effect of the igneous intrusions that have taken place in these ranges, and the biotite is therefore believed to be of no significance in determining the stratigraphy. This conclusion is not in accord with the work of the Survey in the Kigluaik Mountains to the west, but seems justified where the presence of biotite in the limestones as well as in the schists and igneous rocks is so pronounced as in the Darby Range. So far as observations go they point to the conclusion that the biotite is one of the later minerals and may either have been introduced subsequent to the other minerals or have been formed by the recrystallization, under dynamic processes, of some earlier minerals, such as chlorite.

Feldspathic schists such as are common in the eastern part of the Nome and Solomon areas are not abundantly developed in the area of metamorphic rocks studied in 1909. Snall areas of schist of this kind were noted at several places. No new facts bearing on the 
origin were ascertained, but nothing was seen to controvert the previously expressed idea that in the main the feldspathic schists are the sheared equivalents of intrusive rocks of diabasic character in the older schists. This of necessity is true only in a general way, for it is realized that marginal phases merge with the other types of schist, and sharply defined boundaries do not exist. The feldspathic schists are as a rule less quartzose and higher in alumina and soda than the other rocks. Although they are assumed to be of igneous origin it has not been feasible to indicate the position of these rocks on the geologic map (Pl. VIII), and they have been included with the metamorphic rocks.

Calcareous schists are probably the second most widespread type of schist. Some of these rocks undoubtedly represent original calcareous sediments subsequently metamorphosed, but a large part has beenderived from the metamorphism of the massive limestones through mountain building. Owing to the question as to their origin, therefore, the lithology of the schists is not of definite stratigraphic value and probably this type includes rocks of diverse ages. The distribution of these rocks in places affords a clue as to their relations, and the chemical character is also of considerable importance. The largest areas of calcareous schists are in the divide east of the canyon of Fish River and in the hills around the head of the Mukluktulik. In the former the calcareous schists seem to have been derived from the more massive limestones through shearing, but in the latter their origin is not clear.

In addition to the schists, bands of limestone, in places many hundred feet thick, are found, in some places continuous and elsewhere in isolated masses. A large area of limestone extends along the east side of the Darby Range from a point east of Death Valley of the Tubutulik to the coast near Mount Kwiniuk. Another series of massive limestones occurs on the west side of the Darby Range, stretching southward from the Omilak mine. Several other large areas where limestone forms the country rock are in the Fish River canyon near White Mountain, at the head of Fish River, near Bluff, north of Koyuk River near the head of Kiwalik River, and west of Council. Not all the limestones are lithologically similar. Some are dolomitic, but most are not. The dolomitic limestones are of two main types, one compact, slightly crystalline, and whitish gray, and the other nearly black and more crystalline. The nondolomitic limestones present a number of different types. Some are white, coarsely crystalline, and friable; others are bluish white, thinly laminated, and fine textured; and still others are nearly black and practically indistinguishable from the black dolomites except by chemical means. Abrupt transitions from one type to another are noted locally. All the limestones in places grade into calcareous schists through shear- 
ing, so that all stages from a nearly pure calcite rock to a rock containing large amounts of chlorite and mica are found. Apparently, however, the limestones have not been subjected to the same amount of deformation as the older schists.

The structure of the metamorphic rocks is complex and close folding, shearing, and faulting are the rule. It is impossible to determine the broader structural features until much more detailed surveys have been made. As has been noted, there is some evidence that the thicker limestones as a whole have not been subjected to as many periods of mountain building as some of the schists. If this conclusion is supported by closer investigation, it indicates an unconformity between part of the schists and the limestones.

Owing to the absence of precise structural data it is not possible to make any close estimate of the thickness of the metamorphic rocks. From the facts at hand it is certain that a thickness measured in terms of thousands of feet must be assumed. Limestone beds at least a thousand feet thick are known, and it is believed that these form the smaller part of the section. Reduplication through intense folding is so common that actual thickness and apparent thickness seldom coincide.

\section{OLDER IGNEOUS ROCKS.}

The group of older igneous rocks as described in this report contains members of different ages, composition, and method of formation which are treated as a unit only because they have all been produced by igneous activities. In composition these rocks range from acidic granites to basic lavas and in method of formation from surface flows to deep-seated intrusive rocks. Three main divisions-diorites, granites, and ancient lavas-merit further description.

The granites are confined, with few exceptions, to the mountainous regions of the Bendeleben and Darby ranges and the divide between the Kiwalik and the Buckland. Some of the granites are medium fine grained with pegmatitic phases containing relatively small amounts of dark-colored silicates. This type is particularly characteristic of the Bendeleben Range and of the hills west of the Buckland, forming areas 5 to 10 miles in diameter. In the Darby Range, particularly in the Kwiniuk basin, a porphyritic granite with feldspar phenocrysts averaging about $1 \frac{1}{2}$ inches in length, forms areas 15 to 20 miles long and 5 to 6 miles wide. The granite is usually unsheared, but here and there gneissic phases are found. Two small areas of fine-grained igneous rocks, apparently not associated with the intrusions noted, occur near Ungalik River.

Diorites and similar granular basic rocks form portions of the Darby Mountains and the divide between Buckland and Kiwalik rivers. These intrusive rocks have not been carefully separated from $55695^{\circ}-$ Bull. $442-10-21$ 
the granites in the field, and their areal extentecan not be closely estimated, but it seems probable that they are not so widespread as the granites. Some of these basic rocks are sheared and slightly schistose, but their cleavage is much less pronounced than that of the metamorphic rocks and they have been subjected to fewer periods of deformation. Some diorites preceded, but others followed the intrusion of the granites.

The third division of the ancient igneous rocks consists of those forming a large part of the hills of the Buckland-Kiwalik divide. In the northern part of the area these have been studied by Moffit and are reported to be andesites. "They are of a dark-gray or greenish color and on an exposed surface have a spotted appearance due to the alteration of the feldspar phenocrysts." a South of the Koyuk these rocks were recognized only in the hills near Alameda Creek. At this place the lavas are amygdaloidal. In places they show marked deformation, but this has not gone far enough to produce schistosity. These lavas can be most easily distinguished from the recent lavas by their geologic relations and by the absence in the former of fresh glass and unfilled gas cavities.

\section{CRETACEOUS ROCKS.}

The eastern part of the Nulato-Council region is occupied by unmetamorphosed sedimentary rocks, extending from Koyuk River on the west to and beyond the Yukon on the east. North and south they extend beyond the field investigated. Outlying areas of sedimentary rocks occur on Koyuk River at its mouth and at a point a few miles west of the mouth of East Fork and in the divide between Tubutulik and Kwik rivers. These unmetamorphosed sediments apparently comprise a single conformable series of great thickness. Though the structure and relations of the beds are not finally determined, three rather distinct types of deposits are recngnized; in their apparent order of occurrence these are a basal conglomerate, an intermediate group, and an upper group of sandstones and shales.

The lowest member of the series is a basal conglomerate. It is exposed over considerable areas on the Ungalik and on East Fork of Koyuk River and along the Kwik-Tubutulik divide. It is usually coarse, bowlders up to 1 foot in diameter being common. In the coarsest phases bowlders up to 3 feet in diameter were noted. In composition the conglomerate seems to agree in each loçality with the underlying terrane, suggesting local origin and slight transportation. On the Ungalik and East Fork the bowlders are of various igneous types, corresponding to the series of ancient lavas with intrusive granitic dikes from which it is derived. The granite was readily dis-

a Moffit, F. H., The Fairhaven gold placers, Seward Peninsula: Bull. U. S. Geol. Survey No. 247, 1905, p.31. 
integrated and is represented in the matrix of the conglomerate mainly by numerous angular feldspar crystals.

In the western part of the East Fork area the conglomerate is composed almost exclusively of granites corresponding to the massive rocks of that vicinity. Between the Kwik and the Tubutulik limestone conglomerate is found in a limestone area and schist conglomerate where the underlying formation is schist. Obviously the conglomerate rests unconformably upon the older rocks.

Overlying the conglomerate is a great thickness of beds, mainly sandstones. These beds are uniformly fine grained and massively bedded, composed chiefly of feldspar and quartz with varying amounts of calcite. Interbedded with them are varying amounts of black shales. Some of the shale beds are very carbonaceous, and at the mouth of the Koyuk the series contains lignite. The lower sandstone beds closely resemble the matrix of the underlying conglomerate, pointing to continued sedimentation from the same source.

In the eastern part of the area occurs a series of similar sandstones which have been described by Dall under the name Nulato sandstone. They are probably equivalent to a part of the sandstone series farther west. They comprise alternating sandstone, shales, and grits, as a rule rather thinly bedded, and include several thin lignitic layers. Cross-bedding, ripple marks, worm borings, and plant remains are common.

In the central part of the area, along the Nulato-Gisasa divide and westward to the head of the Shaktolik, the beds exposed are predominantly black shales. They probably represent a vertical gradation into finer sediments upward in the series, though lateral gradation is not impossible. The shales are usually indurated and on weathering break down into pencil-like fragments. Schistosity has been developed very locally near structural axes in some of the more carbonaceous members.

The main structural axes in the entire sedimentary area run generally in a northeast-southwest direction. Open folds with dips of $30^{\circ}$ or thereabouts are typical in the vicinity of the Yukon, but to the west, on Shaktolik River, the dip ranges within a few degrees on either side of $90^{\circ}$. In the most western exposures of the unmetamorphosed sediments in the area west of Kwik River the dip is vertical. Faulting evidently occurs generally throughout the area. Faults of small throw were actually observed and in several places considerable displacements are required to account for the attitude and relations of the beds.

Measurements of the unmetamorphosed sediments indicate an enormous thickness. Close estimates, however, were not obtained, as in the less deformed regions exposures are poor, and in the more deformed regions reduplication through faulting and folding is likely 
to vitiate the observations. A measurement of the basal conglomerate on the ridge between Tubutulik and Kwik rivers gave a thickness of about 1,800 feet for this member. Atwood and Eakin in 1907 measured a section of the intermediate member exposed along the Yukon, which showed a thickness of about 10,000 feet. A section of the upper member exposed to the west of Divide Peak, if no reduplication has affected the beds, would indicate a thickness of over 5 miles. Although none of these sections can be regarded as complete, it is believed that they overestimate rather than underestimate the actual thicknesses.

\section{POST-CRETACEOUS IAVAS.}

Lavas of such recent date that in places they still preserve the surficial characters of flows are found in the Koyuk and Buckland basins. The general distribution of these rocks is indicated on the geologic map (Pl. VIII). Little study of the flows was made during 1909, but the following quotation from Moffit's report ${ }^{a}$ gives a clear idea of these lavas as a whole:

In color the lavas are dark gray, green, or nearly black; they are usually very cellular or even spongy in appearance, but at times compact and without the amygdaloidal cavities. * * * That a succession of outbreaks of lava has taken place is shown in a number of places, but probably most plainly in the region about the head of Kuzitrin River, where positive evidence is afforded in the terraced condition of the different flows, three distinct benches occurring in one locality. $* * *$ On the upper part of Koyuk River a similar relation of basalts and gravels was observed by Mendenhall. He found on the truncated edges of the schists 5 feet of gravel made up of schist, vein quartz, and granite; this in turn was covered by an undisturbed horizontal sheet of olivine basalt, which had been but little affected by the erosive action of the stream since it came to rest.

As the low divide between the Buckland and the Koyuk is formed of these recent lavas, it is an interesting speculation to attempt to reconstruct the surface on which the lavas were poured out. No data, however, are available as to the thickness of the recent lavas. At certain places, as, for instance, in the Koyuk basin, near Knowles Creek, the lavas run out into lobes not over 20 feet thick, but in other places a much greater thickness is indicated. Taken as a whole, however, the recent lavas probably form a relatively thin veneer on the preexisting surface.

\section{VEINS.}

Veins of different mineralogical character, formed at different times and under different conditions, have been noted in many places. They are abundant in the areas of metamorphic rocks and are practically absent in the greater part of the area occupied by the nonmetamorphic sediments. In the schist area veins are numerous in 
the quartzose and graphitic schists and are fewer in the calcareous and feldspathic schists and limestones. Most of the veins in the limestone areas have calcite as the vein filling, but few of them are extensive either horizontally or vertically, and most of them appear to have been formed by shearing and the infiltration of calcite from the adjacent limestones. In veins of this class there are usually no other minerals than calcite.

Quartz veins of at least two distinct ages have been recognized in the schists. The veins of one age are much contorted and sheared; in those of the other crystalline quartz with characteristic comb structure is found. So far as can be determined, the mineral content of both of these classes is nearly identical. Sulphide mineralization is usually absent. Both classes of quartz veins in places carry small amounts of gold. Few of the contorted and sheared veins are more than a few inches in width, and most of the later veins are also narrow. The later veins, especially in the black carbonaceous schists and quartzites, are here and there so numerous the.t they form a stockwork through the rock. In selected specimens seven or eight of these veins may be recognized in a linear inch. Larger veins, however, occur in both types, and masses of quartz up to 2 or 3 feet in thickness, found in the float, show that veins of at least that size exist. All the veins are somewhat shattered, and few of them can be traced for any considerable distance on the surface.

\section{UNCONSOLIDATED DEPOSITS.}

No attempt will be made at this place to describe in detail the unconsolidated deposits of the Nulato-Council region. Later, in the section dealing with the placers, attention will be paid to those unconsolidated deposits in which minerals of economic importance have been found. It will be sufficient to state that many different types of unconsolidated deposits have been recognized. Coastalplain gravels occur along the eastern coast of Norton Bay; beach gravels, of course, are formed along the entire coast line; creek gravels are present in all the streams of the region; low-bench gravels occur on many of the streams; high-bench gravels are to be found in a few of the valleys, where they have been disclosed by prospecting; gravel-filled basins occur behind lava barriers and in those places where deformation has obstructed drainage. Rock waste unsorted by water action is abundant on the hillsides. Glacial deposits are found in the mountainous regions where valley glaciers formerly existed. Glacial deposits, however, have not been recognized more than a few miles from the Bendeleben and Darby mountains and do not occur elsewhere. 


\section{GEOLOGIC HISTORY.}

From the description of the different kinds of rocks and deposits found in the region an idea of the past conditions is afforded. As it has not been possible to set forth all the data, however, it is desirable to present the sequence of events as it has been made out. The earliest recorded event was the deposition of sandstones and limestones, now the metamorphic rocks, which were intruded by dikes and cut by veins. Interruptions of this deposition may have occurred, but this has not been definitely proved. Some of these sediments were laid down in the earlier and middle parts of the Paleozoic era. Subsequently mountain building took place, probably with vein formation and igneous intrusion. During this period the ancient igneous rocks were formed. Later, sediments were laid down in the region east of Norton Bay. To judge from the relation of the Nulato sandstone, in which fossils have been found, to the rest of the series, it is believed that the sediments in the region are in the main Cretaceous, though Eocene beds may be included in the upper part of the series. This group of rocks represents more or less gradual encroachment of the sea upon the land. Consolidation of these deposits took place and was followed by a period of pronounced deformation by which the Cretaceous rocks were thrown into a series of northeast-southwest folds. During the later stages of this mountain building some intrusions of granite, such as that at Bonanza. Creek, occurred, probably with some mineralization. Long-continued erosion of the mountains followed and has gone on down to the present time with only slight interruptions. The recent lavas record one of these breaks in the period of erosion, but these were distinctly local in distribution. Other interruptions that have occurred are shown by the warpings of the crust which have brought certain areas above the sea or depressed others. The incised character of some of the streams also affords evidence of the folding that certain parts of the region have recently experienced. The absence, however, of any widespread deposits of sediments over the region subsequent to the Cretaceous-Eocene points to the conclusion that since that time the region as a whole has been land, and therefore subjected to erosive processes, rather than that it has been under water, and therefore an area of deposition.

\section{ECONOMIC GEOLOGY.}

From the preceding description of the areal geology of the region it has been shown that east of Koyuk River the country is formed of late sedimentary rocks little if any metamorphosed, whereas the region to the west of this stream is predominantly one of schists, limestones, and igneous rocks. So far as has been indicated by mining in con- 
tiguous areas, the metamorphic rocks are those in which deposits of gold may be searched for with some promise of success, whereas the unmetamorphosed sedimentary rocks are but little mineralized.

\section{GOLD IN THE AREAS OF NONMETAMORPHOSED SEDIMENTS.}

\section{GENERAL DISCUSSION.}

In the unmetamorphosed sedimentary deposits the chances of finding economically important gold deposits are relatively slight except under rather local conditions. It is well known that the deposits of Cretaceous-Tertiary age, the unmetamorphosed sediments, were formed from the material eroded from the earlier rocks and deposited on the sea floor and in estuaries and marshes in essentially the same way that sediments are being deposited at the present day off the coast. However, it is known that some of the present-day sediments are auriferous, and it might be asked why similar placers should not be found in the older sedimentary deposits. Under conditions similar to those of the known coastal plain, gold placers should occur in the Nulato-Norton Bay region, but there are few places where such conditions prevailed.

In order to understand the different conditions at the two places it is necessary to point out the salient facts concerning the productive placers of the coastal plain, as, for instance, those at Nome. ${ }^{a}$ The known placers are not more than 3 or 4 miles from the old land from which the sediments were derived; the depth of gravel covering the bed rock is in few places more than 100 feet; the gravel is as a whole fairly coarse; the rich ground occurs in ancient beaches which mark areas of concentration; the country immediately adjacent to the rich placers is known to be heavily mineralized. Consider the physical and geographic conditions which these facts entail. First, the short distance from the ancient shore line suggests that the gold did not travel far seaward from the place where it might have been formed. This is, of course, a conclusion which would have been reached by anyone accustomed to the action of gold in a sluice box. It might be safely postulated that in general the farther from the source the less gold there would be, other conditions being equal. Evidence of the proximity of the placer deposits to the old land is shown by the second fact stated above, namely, that the depth of gravel is as a rule not more than 100 feet. This condition, like the preceding, is valuable in establishing the nearness of the gold to its source. The third fact also is of value in further establishing this conclusion, but it is also important as showing that the agencies by which this material was transported were of sufficient strength to permit con-

a Details as to the character of the surface of the bed rocks, etc., are omitted as they are not important in bringing out the point of the following paragraph. 
siderable sorting of the gravel and thus allow concentration of the particles of gold. The fact that the coastal-plain placers are found along old strand lines shows that in order to make a deposit of economic importance it is necessary to have a marked concentration of otherwise disseminated particles. It is of course unnecessary that this concentration should be effected by the sea, for streams would do it equally well, as is shown by the numerous creek placers. Perhaps the most important condition which must be fulfilled in order to make a rich placer is the presence of a highly mineralized area in the more or less immediate vicinity. Without this the other conditions are ineffective.

It has also been pointed out by others that certain physiographic conditions are essential for the production of placers, such as longcontinued subaerial erosion followed by rapid sweeping off of detritus by revived drainage. As the physiographic history of northwestern Alaska has not yet been worked out in sufficient detail to permit the application of this criterion, it can not be critically considered in this discussion.

On turning now to the Nulato-Norton Bay region and considering it in the light of the premises enumerated above, it at once becomes evident that few of the conditions in this region are analogous to those postulated. It is true that there are places where the Cretaceous basin is in immediate contact with the old land. This has been proved by the basal conglomerate extending from a point near the Tubutulik northward along the east side of the Buckland-Kiwalik divide and noted by Mendenhall ${ }^{a}$ on the Kobuk, from which it swings southeast and was recognized, although not correctly correlated, by Schrader on the Koyukuk and by Dall, Collier, and Spurr, and correctly correlated by Maddren on the Yukon near the Melozi.

In the belt occupied by the heavy conglomerate the deposits were certainly near enough to the shore to permit the formation of placers, but the physical conditions under which this conglomerate was deposited do not seem to have been well suited to the unlocking of gold from bed rock. Instead, the bowlders were riven from sea cliffs and were subjected to trituration rather than decomposition or disintegration, and whatever gold may have been in the rocks was so abraded before it was deposited that it undoubtedly formed flour gold, which would be much more widely disseminated than flake or shot gold. Furthermore, over a considerable part of the region where the basal conglomerate was seen by the Survey party the country rock forming the old shore line against which the sediments were deposited consisted of limestones and igneous rocks. So far as is known from a careful study of the known placer camps farther west,

a Mendenball, W. C., Reconnaissance from Fort Hamlin to Kotzebue Sound: Prof. Paper U. S. Geol. Survey No. 10, 1902, p. 39. 
practically no gold is found in the limestones, and little, if any, is known to be associated with the granites or other igneous rocks. It will be seen, therefore, that in the shoreward portion of the metamorphic area the important condition of near-by highly mineralized country rock from which the sediments were derived is lacking. For this reason it is believed that search for economic placers, while not entirely out of the question in the conglomerate area, is to be discouraged unless the field evidence is such as to show that conditions other than those in general encountered in the basal member exist.

It has been shown that over the greater part of the Nulato-Norton Bay area the lower member marking proximity to the old shore line is not exposed. It seems probable that through this part of the region the deposits are much higher geologically. From the physical character of the sediments and from the structures observed, such as cross-bedding, it seems certain that the higher geologic members were deposited in relatively shallow water. This fact, however, does not mean that the deposits were near the old land of metamorphic rocks. Figure 6 shows in diagrammatic manner the conditions

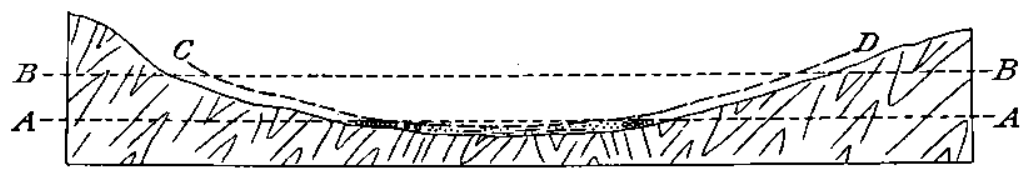

FIGURE 6.-Diagrammatic cross section of the Nulato.Norton Bay region during Cretaceous deposition.

believed to have prevailed in the Nulato-Norton Bay region during Cretaceous time. The metamorphic rocks to the left may be considered as representing the schists of Seward Peninsula and those to the right the rocks near the Melozi, the intervening area being the Nulato-Norton Bay region at the beginning of Cretaceous deposition, with sea level indicated by the line $A-A$. At this stage conglomerates were laid down close to the old land shore and sandstones and shales toward the center of the basin. Gradually depression took place, and continued at such a rate that the surface of the deposits was always within a short distance of sea level. It is evident, therefore, that if this depression continued until the surface of the deposits and sea level stood at the line $B-B$ no part east of $C$ as far as $D$ had ever been close enough to the metamorphic area, which is assumed to have been the source of mineralization, to have received any notable amount of gold. Consequently, in this part of the region, unless subsequent folding exposed rocks at the surface outside of the part included within the line $C-D$, the probability of finding auriferous deposits is slight, and that only if the old land area from which the sediments were derived was sufficiently mineralized to afford placer gold. 
It has been the object in the preceding paragraphs to point out that, on the whole, the chances of finding gold in the area of unmetamorphosed rocks are slight. From the fact that only under exceptional conditions are valuable deposits likely to be found, it seems that the ordinary prospector for gold should be warned against spending much time in the region east of Koyuk River. Not only does this conclusion seem sound from a theoretical standpoint, but it was learned from prospectors on the Inglutalik that they had been from that river eastward to and beyond the Gisasa and had not been able to raise a single color of gold.

It is not the purpose of this warning, however, to assert that no gold will be found in this region; for, as has been previously noted, there are three conditions under which deposits may be found. The first of these conditions, as has already been described, is that the unmetamorphosed sediments under discussion may have been those originally deposited at no great distance from the shore of a mineralized area of metamorphic rocks. Such deposits might be found at several places even in the middle parts of the basin if subsequent deformation brought up to the level of erosion the underlying rocks. As an example of this condition may be cited the area of metamorphic rocks which appear between Kwik and Koyuk rivers.

The second condition which might permit the formation of valuable gold placers in the Nulato-Norton Bay region is long-continued concentration of the material, either by streams or by the ocean. Concentration of this sort may have been effected either during the time when the sediments were being deposited or at a much later time. Throughout the period occupied by the deposition of the sands and gravels the region was apparently undergoing almost uninterrupted depression, so that although there was, of course, water sorting, it was nowhere so effective as it would have been if the region had been one of alternate erosion and deposition, like the coastal plain at Nome. In other words, the ancient placers at Nome seem to have been subjected to at least two periods of concentration, whereas the deposits of the other region seem to have undergone but one.

Since consolidation the sandstones and shales of the CretaceousTertiary have been eroded by the streams, and a present-day concentration is being effected. Some of the reported finds of gold in the Yukon basin are probably due to this sorting, although as yet too little is known about the occurrences, and they may have been formed by original sorting before the consolidation of the sediments. If, however, the Cretaceous rocks were relatively devoid of valuable minerals because of their distance from a mineralized area, it is evident that such concentration would not produce very rich deposits.

The third type of locality where search for gold placers or lodes in the area of nonmetamorphic rocks would be warranted is at those 
places where mineralization has occurred since Cretaceous time. Such places are, so far as known, closely associated with the areas of intrusive igneous rocks. The effusive rocks or lavas of TertiaryRecent age do not seem to have brought any valuable minerals, and therefore placers or lodes due to post-Cretaceous mineralization are not to be sought in those areas where only these rocks occur.

Intrusive rocks later than the Cretaceous have been noted at two places, and a more detailed investigation of the area would undoubtedly result in discovering others. The two places where these later granitic rocks have been examined by the Survey party are on Ungalik River south of camp A 16 and at Bonanza Creek. From reports of prospectors it seems that the placer-bearing gravels of Anvik River may have been derived from a similar area of intrusive granitic rock, although too little is known of the geology of the country to advance this interpretation more than tentatively. Spurr, ${ }^{a}$ in his summary of the occurrence of gold in southwestern Alaska, says:

The gold in this region is by no means so abundant as it is along the belt of the Yukon geanticline, where the ancient schists with their inclosed quartz veins are found. The mineralization of southwestern Alaska is of a later date and not so intense or widespread. Within the area examined by the writer's party last summer (1898), the Tordrillo Mountains are undoubtedly the chief seat of mineralization, and this appears to be directly dependent upon the fact that these mountains have also been the chief seat of intrusion of igneous rocks.

\section{BONANZA CREEK PLACERS.}

Bonanza Creek is the only stream between the Koyuk and the Yukon where placer mining has been successfully carried on. The creek is only about a mile long, but values have been found almost the entire length of its course, and from the character of the gold seem to be of distinctly local origin. Gold was originally discovered on this creek in 1899 by Thomas Moon and his partner, who staked claims. The absence of water and the boom that the Seward Peninsula placers were having prevented any considerable development in the first year or so. After the lower claims had changed hands several times they were at last bought by the Nelsons, who have since been the most industrious miners there. Other outfits have held ground on claims No. 2 and No. 3 above the Discovery claim, and some work has been done in the last two or three years.

At first the creek claims were the ones from which the values were obtained. On the lower claim the pay streak was 400 feet wide, but it narrowed upstream so that at the northern line of No. 1 above Discovery the width was only about 75 feet. The gravels were

a Spurr, J. E., Reconnafssance in southwestern Alaska In 1898: Twentieth Ann. Rept. U.S. Geol. Survey, pt. 7,1900, p. 261. 
typically river wash in form and consisted of material from near-by rocks, although some of the pebbles were undoubtedly derived from higher-level gravels which were not of local origin. The bed rock is a much shattered black slate or shale, on the whole rather thinly laminated and not so quartzose as the black quartzitic slates of the metamorphic group. The slates are cut by igneous rocks of the granite family. An exposure of one of the intrusive dikes occurs a short distance north of the cabins at the junction of Bonanza Creek and the Ungalik. Here the dike is apparently about 10 feet wide and shows by its undeformed character that it was injected subsequent to the period of folding and faulting of the slates. It trends obliquely to the slates, having a strike of N. $5^{\circ} \mathrm{E}$., and stands vertical. It is heavily iron stained in places. This iron is probably derived from the decomposition of sulphides, some of the unaltered material under the microscope showing pyrite.

Above the creek on the northeast side of the valley is a bench on which gravels have been found that are highly auriferous. After the exhaustion of the creek gravels attention was turned to this highlevel ground and satisfactory returns have been obtained. Aneroid readings give the elevation of the bench as about 80 feet above Bonanza Creek at the cabins, but some gravels have been found up to an elevation of 150 feet above the stream. The gold on the benches is medium coarse and of a dark-reddish color. None of it is black gold. Several nuggets were seen that had small pieces of quartz attached. From the owners it was learned that the largest nugget taken from this creek was worth about $\$ 21$. The value of the gold is high, that from the lower claim being reported to be worth about $\$ 19.25$ an ounce, and some obtained higher up on the creek and not from bench ground was reported to assay from $\$ 19.05$ to $\$ 19.15$ an ounce.

Concentrates from the bench ground show a good deal of magnetite or black sand. Some of the fragments of this mineral were as much as one-fourth inch in length. Together with the magnetite is also ilmenite, the oxide of titanium and iron, which is nonmagnetic. Garnet, or the so-called "ruby" sand, is practically absent in all parts of the creek. This was to be expected, for none of the rocks in the neighborhood show any such development of this mineral as can be seen in the Seward Peninsula placers. Some float pieces of antimony are occasionally found in the gravels of Bonanza Creek. Foreign material, not derived from the immediate Bonanza Creek basin, is abundant, notably felsite and fragments of other effusive rocks.

Bonanza Creek has so small a supply of water that the extraction of the gold from the gravels has been a serious problem. In the early days the separation was accomplished by the use of rockers, and even during the summer of 1909 this method was still in use on some of the creek gravels half a mile or so above the mouth of the stream. 
With the discovery of gold in the high benches the need of a supply at considerable elevation compelled further consideration of the water supply. Ditches, except of such length as to be prohibitive in cost, were not feasible and the experiment was tried of pumping water from Ungalik River. Wood cut in the neighborhood of the mines was used for fuel. Although no figures are available as to the cost of the water delivered on the ground, the fact that this method was pursued until the claims were worked out is sufficient proof that the owners were satisfied with the project.

The method of work was to make cuts at intervals at right angles to the trend of the old channel. In these trenches sluice boxes were placed in such manner that their lower end discharged toward Bonanza Creek. The abrupt cliff that occurs at the edge of the bench deposit offered particularly favorable topography for the discharge of tailings onto the lower ground so that the boxes would not become choked. The water pumped in two lifts was delivered to the nozzles on the bench ground and the gravels and overburden were washed through the sluice boxes. After the gravels had thus been sluiced off, the bed rock was taken up by hand and cleaned. In places 3 feet of the rather angular blocky slate had to be picked up to recover the pay values, but over much of the bench ground it was necessary to take up only from a foot to 18 inches.

During 1909 the last of the bench and creek ground nearest the mouth of the creek was exhausted and the boiler and pump were dismantled and put into condition to be shipped away, so that the lower claims may now be regarded as worked out. Good bench placer ground, however, continues from the north end line and the next claim upstream undoubtedly contains valuable deposits. . During the early part of 1909 the owner of this ground was engaged in building a small ditch from the upper part of Bonanza Creek to bring water to this bench. The small amount of water available, however, makes it probable that the operations will be much hampered. The bench ground is frozen, so that either a strong head of water will be required to break down the gravels or else the owners will be forced to resort to thawing.

On the fourth claim above the mouth of Bonanza Creek little work was accomplished during 1909 and that mainly of a prospecting character. The unusually dry season made this part of the stream practically dry by the middle of July, so that the only gold taken out was by means of rockers. At this place specimens of gold in a black graphitic slate were seen. This occurrence suggests that the carbon which is abundant in the slates may have been effective in causing the deposition of the gold.

At the mouth of Bonanza Creek some gold has been found in the gravels of Ungalik River. Several shallow holes have been put down 
in the river flats a few score yards north of the mouth of Bonanza Creek and good prospects have been reported. On the whole, however, the tenor of these gravels is low and although occasional 5-cent pans have been found the average indicated is so low that the ground could not be worked without labor-saving devices capable of handling large amounts of gravel at a small cost. The gold is reported to be irregularly distributed, so that rich pockets separated by intervals of barren ground are to be expected, and this condition is not one calculated to encourage the development of large undertakings.

Scores of lode claims have been staked on Christmas Mountain, which is about 5 miles east of Bonanza Creek, but with the exception of a little sulphide mineralization few indications of profitable veins have been disclosed. In spite of the apparent absence of lodes that would warrant extensive development, it is believed that there is a disseminated mineralization in the vicinity of this mountain that might justify a search for placers in the neighborhood. From the reports of prospectors it was learned that colors of gold had been found in the gravels of many of the streams heading in this mountain and draining into either the Ungalik or the Shaktolik. Several placer claims have been staked on Christmas Creek, which enters the Ungalik 3 or 4 miles north of camp A 16, but no mining has been done. It seems probable that owing to the inaccessibility of the region it would not be profitable to work any but a rather high-grade placer at the present time at this place.

It is further reported that stibnite (antimony sulphide) float has been found on the divide between the Shaktolik and the Ungalik, about 4 miles northeast of Bonanza Creek, on the slopes of Christmas Mountain. This mineral was not found at this place by the Survey party, but its presence would indicate that the sulphide mineralization already noted may have introduced many different minerals.

In the same general region but not definitely associated with intrusive igneous rocks are streams that are said to contain some auriferous gravels, but the geology of the places is too indeterminate at the present time to warrant even a suggestion of the origin of the valuable minerals. Garryowen Creek, a tributary of the Inglutalik heading in the Inglutalik-Ungalik divide, is reported to yield colors of gold. Negromoon Creek, which joins the Inglutalik from the west upstream from Garryowen, also shows gold-bearing gravels. The values, however, on both these streams are so low that they are of no economic significance at the present time and can not be worked under existing conditions. No adequate prospecting has been done on any of these streans, and it is therefore impossible to make even an approximation of the tenor of the gravels. 

ROCKS.

\section{GENERAL DISCUSSION.}

As the metamorphic rocks are older than the unmetamorphic rocks, broadly speaking, they have been subjected to at least the same number of periods of mineralization as the latter plus whatever number occurred before the laying down of the CretaceousTertiary sediments. It is of course realized that mineralization may be distinetly local and may affect one region and not another, so that it is not intended to assert that the richness of a region is necessarily dependent on the number of periods of minaralization it has undergone. The object of the above statement is, however, to suggest that according to the law of chances such a generalization is sound. From the field evidence this view receives corroborative support, for it is found that in most of the Seward Peninsula placer regions there were at least two periods of vein formation, during each of which gold lodes were made, whereas in the area of unmetamorphosed sediments only one has been recognized.

Valuable gold deposits have been mined most extensively in Seward Peninsula, where the metamorphic rocks are most abundant, and it is believed that regions underlain by them are the most promising areas in which to prospect for new placers. In general, the richest placer areas are near the contacts between the heavy overlying limestones and the underlying quartz-chlorite schists. So far as known the intrusive igneous rocks older than the Cretaceous are slightly if at all auriferous and the recent lava flows are entirely devoid of valuable minerals. Therefore areas deriving their surficial deposits from such rocks are not likely to afford valuable placers.

Several of the various placer camps located within the area covered by the map of southeastern Seward Peninsula were not visited during 1909 and will not be described in this report. In order, therefore, to gain a complete account of the economic geology of the eastern part of Seward Peninsula, the reader should also refer to the published reports of Brooks, Moffit, Collier, and others. ${ }^{a}$ In the treatment of the gold placers of the areas of metamorphic rocks a geographic order will be adopted. The placer deposits of a single river basin will be treated from the mouth toward the head of the stream. The various river basins tributary to Norton Sound will be described from east to west, starting with the Koyuk, and this will be followed by descriptions of the various basins emptying into Kotzebue Sound from the Buckland River westward.

a Collier, A. J., Hess, F. L., Smith, P. S., and Brooks, A. H., Gold placers of parts of Seward Peninsula: Bull. U. S. Geol. Survey No. 328, 1908. Moffit, F. H., The Falrhaven gold placers, Seward Peninsuls: Bull. U. S. Geol. Survey No. 247, 1904 , 


\section{KOYUK RIVER BASIN.}

At the present time no gold placers are being mined in the Koyuk basin, and there are few places where mining has been carried on in the past on an economic basis. Colors of gold have been found on many of the streams and a number of different outfits have been brought into the region, but so far without sufficiently encouraging returns to keep a permanent force on any of the streams.

About a mile west of camp B 17, at the mouth of the Koyuk, there is a black limy schist and limestone that occurs east of a lightercolored schist, the dip of both being practically vertical. On the beach at this place and extending for a considerable distance to the east and west are many lerge angular pieces of quartz float that

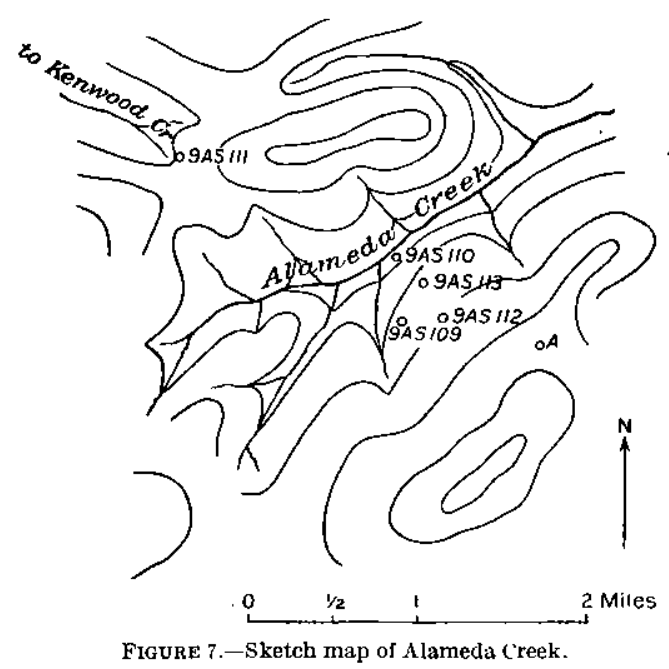
suggest vein material. Pans of broken-up material from the schists near this place show a number of very small colors of worn placer gold. From a prospector living near by it was learned that 1 per cent pans had been found, but the small returns were not sufficiently encouraging to warrant any considerable expenditures either of time or money.

Alameda Creek, a small tributary to the Koyuk from the west, joining the river a short distance below the mouth of East Fork, was visited in the early part of August. Although no active work was in progress, the problems that have been raised by earlier prospecting are such as to attract the attention of the geologist. Figure 7 shows the headward portion of this stream, with the location of the different prospect holes that have been sunk. The elevations given are only approximate, as the weather was so changeable that an aneroid was of no assistance.

At locality 9AS109, south of Alameda Creek, a shaft 192 feet deep was sunk, all the way through well-rounded, predominantly quartz gravel. The upper part of the gravel is whitish, with black quartzite pebbles and some glassy lava. Not many pebbles of the lava were found. Midway in the shaft the gravels are yellower and more ironstained than in the upper part. In the lower part of the hole the fine material is of a greenish-white color, but is otherwise similar to 
that above. On reaching a depth of 192 feet the miners were forced to abandon the shaft, as a great deal of water was encountered. This condition suggests that the bottom of the shaft was close to bed rock, a conclusion that receives some support from the fact that in the bottom of the shaft pieces of ancient lava, probably the country rock here, became more numerous.

It is reported that in the section cut by the shaft a few thin sedimentary layers were found that gave fairly good prospects. A pan of the gravel from the dump, which was said to have come from near the top of the shaft, gave two small colors. Samples from the gravels said to occur near the bottom of the shaft showed also minute specks of gold. In the concentrates from the same part of the section there was a good deal of black sand, but garnet was practically absent. A good many pieces of undecomposed sulphides were also recognized in the concentrates. Within a hundred feet of the shaft a pan from the surface gravels directly under the grass roots showed several bright colors of gold and some magnetite and ilmenite.

Nearly due east of the last locality and at an elevation about 100 feet higher another shaft had been sunk (locality 9AS112). The depth of the shaft was somewhat over 70 feet and it had not reached bed rock. The material on the dump consisted mainly of well-washed white quartz gravel, with some pebbles of black quartzite and red lava. About 25 feet east of this hole and at a slightly higher elevation was a shaft 45 feet deep that had been sunk without reaching bed rock. The material on the dump at this shaft was more sandy and the pebbles smaller than from the shaft at locality 9AS112.

Northward down the slope, at locality 9AS113, another shallow shaft had been put down. It was only about 15 to 20 feet deep and in it no gravel at all was reported.

On a low bench on the south side of Alameda Creek, at an elevation of less than 10 feet above the water, there is a caved shaft (locality 9AS110). This was originally 32 feet deep and reached bed rock, which belonged to the group of ancient igneous rocks. There was a great deal of well-rounded quartz gravel on the dump, but as a whole the material was much darker than at locality $9 \mathrm{AS} 109$, and there was a much greater proportion of lava fragments. The prospectors who sunk this shaft reported that the values were found entirely on bed rock and that the lower gravel went about 1 cent to the pan. The present gravels of Alameda Creek upstream from this shaft are reported to carry no gold, whereas to the northeast, or downstream, the creek gravels yield about 7 cents to the 10-pan bucket. A mile and a half downstream, however, even this amount of gold disappears and the gravels are barren. From these facts it would appear that the present creek may derive its gold from the earlier channel. It 
should be remembered, however, that if the values occur mainly on bed rock in this channel the bottom is still below the level of Alameda Creek, and therefore the reconcentration has not affected the richest portion of the old channel.

Directly across the creek and at the same elevation above the stream as locality $9 \mathrm{AS} 110$ a shaft 12 feet deep has been sunk to bed rock. The bed rock at this place also was dark, much-fractured, fine-grained old lava. A pan of gravel from the dump at this place showed an abundance of green lava sand with numerous hornblende crystals. Several well-rounded garnets twere also noted.

A mile and a half west of this shaft, on one of the small tributaries of Kenwood Creek, some further prospecting has been done to locate the northwest continuation of the old channel. At locality 9AS111 there is a shaft 24 feet deep, now badly caved. The material on the dump is nearly all angular, almost completely decomposed rock, which seems to contain some rounded black pebbles. The material is so badly changed that it is impossible to assert definitely whether it represents a recent slightly consolidated gravel or a more ancient sandstone or fine grit. It was claimed by the prospectors that bed rock was reached in this shaft and samples of the material supposed to be from the bottom of the hole showed thin quartz and calcite veins with decomposed material between. Some of the quartz was much slickensided.

At 45 and 65 paces west of locality $9 \mathrm{AS} 111$ were two other prospect pits at a slightly lower elevation than the one just described. The western one showed undoubted gravel on the dump, some of the pebbles being 3 to 4 inches in diameter. There were very few white quartz pebbles, the greater number being of black quartzite. There seems to be little room to doubt that this is a portion of the same deposit encountered in the deep shaft at locality 9AS109. It is unfortunate that the depth to bed rock has not been determined at the two places, for it might afford information as to either the direction of the old drainage or the amount of deformation since the cutting of the channel.

On the broadly open saddle $1 \frac{1}{2}$ miles southwest of locality $9 \mathrm{AS} 109$ quartz gravel is reported to be abundant and it is believed that this low pass may mark the southern continuation of this channel. On this assumption prospectors were engaged in examining the ground and a party of three or four men intended to winter at this place. It should be pointed out that even if this should be the old course of the valley it does not follow that the gravels will be auriferous, for, as has already been noted, so far as prospected the gravels in the deep hole on Alameda Creek are not sufficiently gold bearing to be mined at the present time. 
Not enough facts are as yet available for more than a tentative interpretation of the conditions under which the old channel was formed. It is evident from the presence of lava in the gravels of the channel filling that the channel was carved and occupied by a stream later than the effusion of the recent lava. It seems probable that a rearrangement of drainage may have resulted from the extrusion of the tongue of lava which occupied the low country between Koyuk and Buckland rivers and flowed down the present Koyuk Valley below East Fork. This may have resulted in turning the lower part of the Koyuk out of its former course and allowing it to cut the gorge here discussed. After the gorge had been eroded, either by change in the relation of the land with respect to sea level or by capturing, the old valley was filled and the stream was diverted, so that it took up a course parallel with the tongue of lava that flowed down the Koyuk Valley. It eroded the lava, thus etching out and uncovering its former valley, in which it now flows.

In regard to the origin of the gold found in the old valley gravels there is some question. Alameda Creek is near the area of metamorphic rocks and the presence of a great number of pebbles of vein quartz in the gravels suggests that they at least have been derived from the quartz stringers in this series. If this vein quartz has been derived from this source there is a strong presumption that the gold has also come from the same place. On the other hand, it should be noted that there are indications that some of the ancient lava is mineralized. A shallow prospect pit has been sunk on a ledge of amygdaloidal trap outcropping on the divide between the Koyuk and Alameda Creek shown at A, figure 7. Assays made at Nomo of material from this pit are reported to have given as high as $\$ 3.72$ in gold to the ton. The rock shows no macroscopic mineralization and considerable doubt is felt of the accuracy of this determination.

Kenwood Creek, which enters the Koyuk from the south above East Fork, has been prospected near the head, as already noted, and a little work has been done also on the lower part. Two prospectors, who were reported to have found good prospects at this place several years ago, went to the lower part of Kenwood Creek during the summer of 1909 . The low water prevented their getting upstream far enough with their boat and they returned. It is probable, how-. ever, that bed rock through the lower part of the creek is deep and difficulty with water will be experienced.

On Willow Creek, which enters the Koyuk from the south above Kenwood Creek, there are signs of former prospecting, but the stream is now deserted. J. L. McPherson, who visited this region in 1907, during the progress of a survey made for the Alaska road commission, has stated that at that time location notices were seen which showed that the prospecting had been done about five years before. 
Peace River is one of the northern tributaries of the Koyuk west of East Fork. About 12 miles above the mouth it forks, and near this place some prospecting was done during the winter of 1908 . Two shafts were put down on the east bank of the river, but they were so badly caved that only the upper 3 feet or so was visible. This part of the section shows brown irregularly bedded sands of even texture having in general a dip toward the west--that is, toward the stream. The material on the dump is fairly well rounded river wash consisting almost entirely of igneous rocks with some red ironstained gravel of the same nature. The eastern of the two holes was probably not more than 15 feet deep, but the other may have been 25 feet deep. Some material put aside as though it were the pay gravel was a greenish-brown sand.

About 100 yards east of this place and on a slightly higher bench there is another shaft now filled with water. This pit was probably not more than 5 to 10 feet deep. From the material on the dump it appeared that the gravel is not so well rounded and there is much more mud mixed with the sand. The upper 2 or 3 feet, which was the only part visible, instead of consisting of sands as in the western holes, was entirely formed of muck. From prospectors later in the season it was learned that some gold had been found in these holes, but not enough to warrant further exploitation. It was currently reported that one piece of gold found there was worth 4 cents, but this was the largest piece. The presence of gold at this place suggests the possibility that some of the ancient lavas have been more or less mineralized, but the evidence is not sufficiently definite to preclude other sources of origin.

Mendenhall ${ }^{a}$ notes that in 1900 Knowles Creek had been prospected and a mining district established there. He was unable to learn the success of the operations, but the fact that in 1903, when this region was visited by Moffit, no work was in progress and the creek was deserted shows that the gold tenor of the gravels must have been too low to make mining profitable.

A tributary creek farther upstream, heading in the hills near the low pass into Death Valley and the upper part of the Koyuk basin, is mentioned by Mendenhall ${ }^{a}$ as follows:

Just above the camp of September 5 another tributary enters from the south carrying only schistose pebbles. These, however, are very calcareous. Most of the streams which enter the upper course of the river from the north lie without the lava belt, but the schists here have not the aspect of the gold-bearing members. At Cheenik in the fall we met prospectors who had been up the river and reported finding colors all along its course.

Moffit, in 1903, reported no mining in this part of the river basin and no signs of recent work were seen by the party in 1909 .

a Mendenhall, W. C., A reconnaissance in the Norton Bay reglon, Alaska, in 1900; a special publication of the U. S. Geol. Survey, 1901, p. 213. 


\section{KWIK RIVER BASIN.}

No mining was in progress during 1909 on any of the streams in the Kwik River basin, and so far as could be learned little or no prospecting has been done in the past in this area. On the head of Quartz Creek, about 3 or 4 miles east of camp C 3, there were some old claim stakes and some sluicing had been done several years ago. J. L. McPherson noted that in 1907 he found location notices of about five years previous date on this creek.

\section{TUBUTULIK RIVER BASIN.}

During the time that the Survey party of 1909 was in the vicinity of the Tubutulik no prospectors were seen and no evidence of any recent mining was observed. Practically the only thing that is known about the mining in the basin is furnished by the report. of Mendenhall, ${ }^{a}$ in which the following statements are made:

This stream, while farther from the known productive districts than the Fish, was the object of considerable attention during the summer of 1900 . The surface gravels of the river bare gave colors quite as heavy as those on Fish River wherever a pan was washed out-at least as far up as the granite area. We had no reports from the head of this stream, and did not have an opportunity to examine it ourselves, but the area drained by it is not particularly promising.

Mr. C. C. Alexander and members of his party, who had been prospecting on Chukajak and Vulcan creeks during the fall of 1899 and the summer of 1900 , report the finding of coarse gold early in their work on the former stream, but more thorough development did not fulfill the promise of this first find. Reports of favorable prospects here, however, had reached Golofnin Bay and Nome, and a small stampede toward the Tubutulik resulted. When we left the river, late in August, many outfits were reaching the field. Reports toward the end of September did not tend to confirm the earlier accounts of rich strikes there.

It was reported that some mining was done several years ago on the next stream above Lost Creek. According to Mendenhall the name of this creek was Admiral, but the claims were described as on Camp Creek. It seems protable that the two names are applied to the same stream, but which is correct could not be determined. From the character of the bed rock near this stream it would appear that the geology is complex and that the older schists form the lower part of the valleys, so that it is presumed the gold was derived from them. Placer mining on Camp Creek was carried on by means of horse scrapers, but the absence of any recent work in the vicinity seemed to show that the returns were not satisfactory. From the strong evidence of glaciation of the valley type in many of the streams heading in the Darby Range and entering the Tubutulik from the west it seems unlikely that any rich placers will be found in that part of the basin. The eastern boundary of the basin in the southern part is formed of the Cretaceous conglomerate, so that strong mineraliza- 
tion is not to be expected in it. Farther north the eastern part of the Tubutulik divide is formed of the Paleozoic limestones, and these are not promising rocks from which to derive placers. It is felt, therefore, that a large part of this drainage basin is not particularly favorable for economically important placer deposits.

KWINIUK RIVER BASIN.

Practically the whole of Kwiniuk River and its tributaries flow in valleys carved in the igneous rocks that make up the Darby Range. So far as is known these rocks are but slightly mineralized. Consequently there is but little chance that the detritus worn from these rocks would form valuable placer deposits. In the lower part of the course, where the bed rock is heavily covered by unconsolidated deposits, the character of the country rock is not clear and the more mineralized schists may occur. If this is the case, there is some possibility that, where concentration has been effective, placers may be discovered. The depths of covering and the problem of handling water would make the development of such placers difficult.

\section{FISH RIVER BASIN.}

The main Fish River basin has not been important as a placer district, although the tributaries of the Niukluk, its longest western branch, have produced more gold than those of all the rest of the region. According to Mendenhall, ${ }^{a}$ Fish River carries gold from its mouth to the north end of the gorge. Throughout the lower part of the river the colors are very light, but they become heavier in the constricted part of the valley, where the stream crosses the belt of limestones and schists. Opposite the mouth of Anaconda Creek, as the lower part of Parantulik River is called, pans taken from the broken rim rock yielded from half a cent to 1 cent each. According to the same author prospectors found nothing in the upper flats of Fish River, and so far as reported the streams flowing out of the mountains to the north do not yield colors.

From the geologic description of the northern and eastern parts of the Fish River basin it is seen that the rocks are schists and limestones which appear to be the same as the rocks in some of the placer regions, except that the schists contain much greater quantities of biotite. Veins are equally abundant in both types, and it is believed that the absence of placers may be explained in part by the valley glaciation that has scoured out the water-sorted deposits from most of the valleys heading in the Bendeleben and Darby mountains. This process has scattered the deposits which may have existed in the valleys prior to this erosion. Information on the subject is still 
too meager to allow a final judgment as to the reason for the absence of placers in this part of the basin, but it is believed that the physical history rather than the lithologic character is responsible for the apparent absence of placers.

Placer gold has long been known in the region around Council, having been reported in 1865 by members of the Western Union Telegraph Company, and in 1892 John Dexter is said to have notified members of the Silver-Lead Mining Company that he had found gold. It was not until 1896-97, however, that the discovery of Ophir Creek, the richest stream in the Council district, was made by Mordant, Melsing, Libby, and Nelson. Although apparently gold was found at that time, it was not until the spring of 1898 that the district was organized and active placer mining begun. So valuable have the placers turned out that in 1903 Collier estimated that the gold output up to that year was between $\$ 5,000,000$ and $\$ 6,000,000 .^{a}$ Since that time $\$ 2,000,000$ to $\$ 3,000,000$ more has been taken out, so that this camp has been second in production to that of Nome.

The productive streams in this so-called Council region from southeast to west are Fox, Mystery, Melsing, Ophir, Goldbottom, Camp, and Elkhorn creeks. All except Fox Creek are tributaries of the Niukluk, and Fox Creek joins Fish River less than 4 miles below.

\section{BLUFF REGION.}

The region around Bluff has not been visited by Survey geologists since 1906. Gold is said to have been found at Daniels Creek in September, 1899, by William Hunter and Frank Walker. Beach placer ground was located soon afterward and within less than six months $\$ 600,000$ had been taken from a strip of land less than 1,000 feet long. Meanwhile the two lowest claims on Daniels Creek were opened and in 1900 yielded probably $\$ 200,000$ in gold. Most of the 1901-2 production came from Discovery claim, at the mouth of Daniels Creek. Meanwhile gold had been found on Eldorado and Ryan creeks and on Swede Gulch. In 1902 a strong company was organized and has been engaged in mining the important placer ground ever since. For further notes on the Bluff region reference should be made to the report by Brooks of his visit in $1906 .{ }^{b}$

\section{RIVERS TRIBUTARY TO KOTZEBUE SOUND.}

The only stream tributary to Buckland River on which gold placer has been found is Bear Creek, which heads in the ancient lava hills that form the western margin of the basin. The first

a Collier, A. J., Hess, F. L., Smith, P. S., and Brooks, A. H., Gold placers of parts of Seward Peninsula: Bull. U.S. Geol. Survey No. 328, 1908, p. 236.

b Brooks, A. H., The Bluff region: Bull. U. S. Geol. Survey No. 328, 1908, pp. 383-393. 
claims recorded on this stream were located by R. S. Hoxie, L. Tendness, and A. Barr in August, 1901. During 1903, according to Moffit, ${ }^{a}$ about 40 men were at work on Bear Creek and its tributaries, Sheridan and Cub creeks, but as only about $\$ 10,000$ in gold was won from this basin during that year it is evident that the work was not very profitable. Moffit says:

Mica schist is said not to be found in this creek, although mica does appear in the sands and gravels, which are composed largely of eruptive material and on some of the bench claims reach a thickness of 20 feet, with several feet of muck overlying. In places on the creek a considerable quantity of a heavy red cherty rock remains in the boxes with the gold and is a source of some annoyance to the miner. This is especially true on Cub Creek. On Sheridan and Bear creeks the gold is mostly on bed rock, differing in this respect from that on Cub Creek, where it is found throughout the whole thickness of the 2 feet of atream gravel; on the other hand, gold from Bear and Cub creeks is light and flaky while that from Sheridan is heavy. All the gold is bright yellow in color, assaying $\$ 19.20$ to the ounce. A little "white iron" pyrite is present and also an abundance of black sand which is entirely removed by the magnet.

From 1903 to 1907 a little desultory prospecting and mining was done, but during the latter year the building of a ditch along the west slope of the valley revived interest in the region. The small precipitation of 1908, however, prevented any extensive use of the new ditch and in 1909 there was little evidence that productive mining was in progress.

In spite of the small production of gold, this region is of interest as indicating that the placers have been derived from the ancient lavas that form the Buckland and Kiwalik divide. It will be remembered that this source was suggested as a possibility for the placers on Alameda Creek, in the Koyuk basin, on the southern extension of this lava series. It should be pointed out, however, that while a little local mineralization may have affected this group of rocks here and there, so far as can be foretold by present indications there is slight chance of finding any considerable extent of rich placer ground on those streams where the ancient lavas form the country rock. In other words, it is believed that only "one-man camps" will be established on streams deriving their gravels from areas of ancient lavas.

Although auriferous the larger part of Kiwalik River lies outside of the area represented on the map accompanying this report and as the region was not visited in 1909 by the geologists of the Survey party it is desirable to omit any detailed description of the placers. Complete descriptions, as the facts in hand warranted, have already been published by the Survey. ${ }^{b}$

a Moffit, F. H., The Fairhaven gold placers, Seward Peninsula, Alaska: Bull. U. S. Geol. Survey No. 247, 1904, p. 64.

b Moffit, F. H., The Fairhaven gold placers, Seward Peninsula, Alaska: Bull. U. S. Geol. Survey No. $247,1905,85$ pp. Henshaw, F. F., Mining in the Fairbaven precinct: Bull. U. S. Geol. Survey No. 379, 1909 , pp. $364-369$. 


\section{SILVER-LEAD DEPOSIT.}

Within the area of metamorphic rocks of southeastern Seward Peninsula one deposit of argentiferous galena has been of some economic value. This lode, staked in 1881 , was probably the second one discovered in the entire Territory of Alaska. Although the claims were not recorded until July, 1881, galena had been known for a year or more before and Petrof, in the census report for 1880, mentions the fact that silver-lead ore had been found in the vicinity of Golofnin Bay. The developments at this place have been carried on at a single group of claims located on a low limestone-schist hill on the western flanks of the Darby Range. As has already been

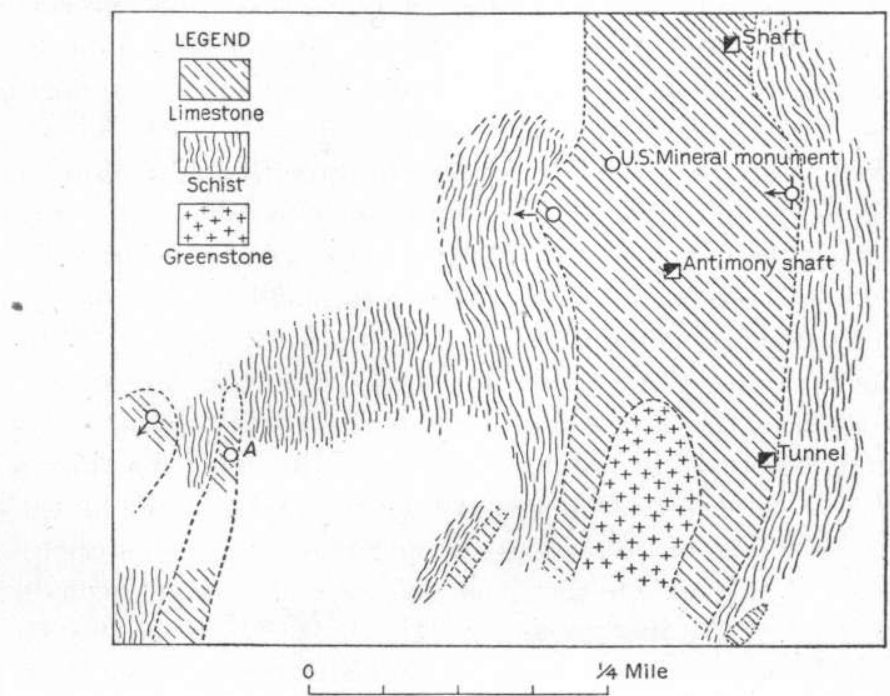

Figure 8.-Sketch map of Omilak mine.

stated, the claims were located in 1881 . In 1882 a company was formed and in 1883 was absorbed by the Omilak Gold and Silver Mining Company, which continued to hold the ground until 1898, when the Russian-American Mining Exploration Company took the properties. This transfer was one of name rather than of personnel. As the claims were patented in 1894 , there has been no recent controversy as to the ownership of the property.

The geology in the vicinity of the mine is so complex that without more detailed study than was made in 1909 the stratigraphy is not determinable. East of the mine, toward the head of Umalik Creek, is a large area of white crystalline limestone which in the main appears to dip westward at high angles. This is succeeded toward the west by schistose rocks containing much biotite and quartz and some graphite. Farther west, in the immediate neighborhood of the 
mine, the distribution of the various rocks is as shown in figure 8 . Although from this map it appears that the dip is in general westerly, the evidence on the ground shows that the rocks are much deformed, and tightly appressed folds have been recognized pitching steeply toward the west. With such an amount of folding the structure is by no means so simple as appears at first sight, and even the determination of bedding is in many places impossible. It is believed, though it has not been definitely proved, that the schists represent younger or overlying rocks.

In addition to the dark biotite schist and the limestones there is an area of slightly sheared igneous rock similar to the greenstones of the more western part of Seward Peninsula. Although the exposures were not sufficiently clear to preclude other interpretations, it seems probable that these greenstones intrude the limestones. Owing to the amount of deformation and consequent metamorphism it is possible that some of the greenstones may be included in the areas mapped as schist. The fact that the greenstone is more easily recognizable in the midst of the limestone may be due to the protection given to it by that rock, which is more easily deformed than the schist, whose resistance to dynamic metamorphism is more nearly equal to that of the igneous rocks.

According to Mendenhall ${ }^{a}$ the ore occurs near the contact of this intrusive rock and the limestone. From the study of the region in 1909 this conclusion could not be verified, as the shaft was inaccessible and the only mineralization seen was in the midst of the limestone. Owing to the absence of ore-bearing minerals in the greenstone, however, it seems doubtful whether the galena could have been introduced at the time of the intrusion. Furthermore, the well-crystallized character of the ore suggests that its deposition was later than the deformation of the region, whereas the greenstone was earlier.

Two kinds of ore minerals are found in this deposit-argentiferous galena and stibnite. So far no interrelation between the two has been shown, but it is believed that both were introduced at essentially the same time. It should be noted that the deposits containing the galena seem to be topographically above those with stibnite. This is not the condition that would be expected to result if the two ores had been deposited from the same solutions according to their relative fusibilities.

From the reports of others, as it was not possible to see the underground workings personally, it was learned that "no continuous vein of galena ore existed, the same being found only in irregular and disconnected pockets." ${ }_{b}$ None of the pockets were of large size and the

a Mendenhall, W. C., a reconnaissance in the Norton Bay region, Alaska, in 1900; a special publication of the U. S. Geol. Survey, 1901, p. 214.

b Idem, pp. 213-214. 
better ones occurred entirely within the limestone. Some of the ore was thickly covered with products of oxidation, mostly lead carbonate.

About 400 paces south of the galena shaft there are a shaft and incline which were used to explore the stibnite leads. The limestone is much fractured and the ore occurs in thin streaks in the shattered zone. None of the veins seen by the writers were of sufficient size to warrant mining. The stibnite is well crystallized, the thicker stringers apparently occupying fault planes and sending small offshoots into the limestone, which near the ore is abnormally granular and sugary.

Considering the number of years the ground has been held and the large expenditures that have been incurred, the amount of development work is astonishingly small. A shaft 180 feet deep has been sunk near the eastern margin of the limestone on top of the hill, and two short drifts have been turned off in the search for ore pockets. The upper part of the shaft is in limestone, but the lower is in schist, as the contact dips toward the west. The shaft is well timbered and is fairly dry. Hoisting is done by power, using a bucket not running on guides. Electric lights are used around the shaft house and underground. Two outfits for drilling have been used, one an air compressor and air drills, and the other an electric drill plant. Electricity for these uses is furnished by a coal-oil engine, located near the main bunk house on Umalik Creek.

At 200 to 300 feet vertically above Umalik Creek an adit has been started to intersect the shaft in depth and thus obviate the necessity of hoisting the rock to the top of the hill and then taking it down again for shipment. The length of the adit is 187 paces, or approximately 500 feet; this distance was in massive white limestone somewhat shattered but nowhere showing mineralization.

In addition to the equipment directly at the mine there are bunk and storehouses at Cheenik, on Fish River, half a mile or so below the mine on Umalik Creek. At the latter place is a repair shop, electric plant, assay laboratory, electric sawmill, stable, and the other things usually found only at large producing mines. The company also owns a large river steamer originally built for freighting the mine supplies up the river, but it has never been used.

The production of the mine is not definitely known, but it has probably not been more than 400 tons nor less than 300 tons. A part of this was obtained from the various pockets below ground, but a considerable amount is understood to have come from hand picking the float found on the hillside. The following tables show the returns from assays of the ore as shipped. It should be noted that owing to the high transportation charges the ore was carefully hand picked and some of it washed before shipping. 
Returns from assays of ore as shipped from Omilak mine.

\begin{tabular}{|c|c|c|c|c|c|c|}
\hline Number. & $\begin{array}{c}\text { Weight } \\
\text { (pounds). }\end{array}$ & $\begin{array}{c}\text { Gold } \\
\text { (value per } \\
\text { ton). }\end{array}$ & $\begin{array}{l}\text { Silver } \\
\text { (value per } \\
\text { ton). }\end{array}$ & $\begin{array}{l}\text { Lead } \\
\text { (pounds } \\
\text { per ton). }\end{array}$ & $\begin{array}{l}\text { Lead } \\
\text { (value per } \\
\text { ton). }\end{array}$ & $\begin{array}{l}\text { Total value } \\
\text { per ton. }\end{array}$ \\
\hline 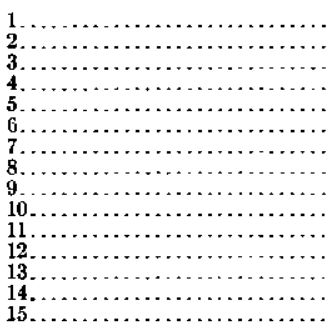 & $\begin{array}{r}4,230 \\
545 \\
130,000 \\
68,078 \\
12,167 \\
82,100 \\
86,885 \\
27,787 \\
13,606 \\
2,675 \\
6,569 \\
164 \\
595 \\
380 \\
26,175\end{array}$ & $\begin{array}{r}32.07 \\
3.09 \\
r 2.07 \\
\ldots 7.43 \\
7.53 \\
1.54 \\
1.54 \\
1.03 \\
2.07 \\
7.53 \\
2.07 \\
2.07 \\
2.07\end{array}$ & $\begin{array}{r}\mathbf{8 1 3 7 . 2 9} \\
106.62 \\
98.72 \\
104.00 \\
125.19 \\
132.95 \\
49.60 \\
41.40 \\
38.10 \\
54.93 \\
46.46 \\
65.54 \\
71.15 \\
86.86 \\
120.33\end{array}$ & $\begin{array}{r}1,538 \\
1,320 \\
1,128 \\
1,300 \\
1,440 \\
1,494 \\
502 \\
606 \\
566 \\
770 \\
890 \\
816 \\
980 \\
966 \\
1,222\end{array}$ & $\begin{array}{r}\$ 61.52 \\
52.80 \\
45.12 \\
52.00 \\
57.60 \\
59.76 \\
20.08 \\
24.24 \\
22.64 \\
30.80 \\
35.60 \\
32.64 \\
39.20 \\
38.64 \\
48.88\end{array}$ & $\begin{array}{r}8198.81 \\
161.49 \\
146.93 \\
156.00 \\
184.86 \\
192.71 \\
77.11 \\
67.18 \\
62.28 \\
86.76 \\
84.13 \\
105.71 \\
112.42 \\
127.57 \\
171.28\end{array}$ \\
\hline
\end{tabular}

1 to 6 , inclusive, solid ore from Omilak mine; 7 to 14 , inclusive, carbonate ores from Omilak mine; 15 , carbonate ore concentrated by washing in sluice boxes.

Unfortunately in the above assays the data are not sufficient to determine the percentage of any of the constituents except the lead, so the following assays, less complete in certain other ways, are given:

Silver and lead in ore from Omilak mine.

\begin{tabular}{|c|c|c|}
\hline Number. & $\begin{array}{c}\text { Silver } \\
\text { (ounces per } \\
\text { ton). }\end{array}$ & $\underset{\text { (per cent). }}{\text { Lead }}$ \\
\hline 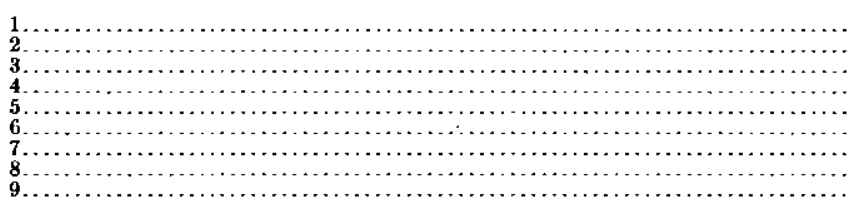 & $\begin{array}{r}173.00 \\
141.00 \\
158.00 \\
153.70 \\
162.97 \\
149.16 \\
142.20 \\
94.30 \\
60.00\end{array}$ & $\begin{array}{l}75.0 \\
80.7 \\
78.0 \\
82.0 \\
78.5 \\
73.0 \\
74.7 \\
55.9 \\
10.27\end{array}$ \\
\hline
\end{tabular}

Assays 1-2 by Herford Copper Works, Swansea, England; 3 by Pennsylvania Lead Company, Pittsburg, Pa.; $4-6$ by W. P. Miller, San Francisco; 7 by T. Price, San Francisco; $8-9$ reported by W. C. Mendenhall, op. cit., p. 214 (8, yellow carbonate; 9 , red carbonate ore).

Assays and relative weights of part of the different ores shipped by the Omilak mine in 1889 , with the price paid in the open market for the same, are given in the following table:

Assays and weights of ore shipped by Omilak mine in 1889.

\begin{tabular}{|c|c|c|c|c|c|}
\hline Commercial name. & $\begin{array}{c}\text { Weight } \\
\text { (pounds). }\end{array}$ & $\begin{array}{c}\text { Gold } \\
\text { (ounces per } \\
\text { ton). }\end{array}$ & $\begin{array}{c}\text { Silver } \\
\text { (ounces per } \\
\text { ton). }\end{array}$ & $\begin{array}{c}\text { Lead } \\
\text { (per cent). }\end{array}$ & $\begin{array}{l}\text { Price re- } \\
\text { ceived } \\
\text { per ton. }\end{array}$ \\
\hline $\begin{array}{l}\text { Red carbonates......... } \\
\text { Gray carbonates........ } \\
\text { Yellow carbonates..... } \\
\text { Argentiferous galena... }\end{array}$ & $\begin{array}{r}.380 \\
595 \\
6,569 \\
82,100\end{array}$ & $\begin{array}{r}0.1 \\
.1 \\
.1\end{array}$ & $\begin{array}{r}92.9 \\
76.1 \\
49.7 \\
142.2\end{array}$ & $\begin{array}{l}48.3 \\
49.0 \\
44.5 \\
74.7\end{array}$ & $\begin{array}{r}\$ 93.00 \\
81.00 \\
57.00 \\
154.00\end{array}$ \\
\hline
\end{tabular}

It is evident that the ore is high in silver and also usually carries a small amount of gold. Its metallurgical treatment is simple and 
the ore is especially valuable to mix with other more refractory ores. The absence of fuel at a reasonable price prevents treatment near the mine and the high charges for transportation restrict shipments to only the higher-grade ores.

From the foregoing descriptions certain facts are evident which may be summarized as follows. The claims have been inadequately prospected and large expenditures have been made without disclosing a workable vein; the ore found is of excellent quality, but the quantity seen by the writers was not sufficient to warrant extensive developments. The most promising area to prospect is in the limestone near its contact with the schists, but the deposits likely to be found will probably be pockets not easily adaptable to cheap mining methods and not capable of affording a large, constant amount of ore.

\section{GOLD LODE PROSPECTS.}

Although, as has been shown, placer gold has been found on many of the streams in the area of metamorphic rocks, no veins sufficiently rich to allow lode mining have been discovered. This is probably due in part to the diffused character of the mineralization, but is also due to the absence of adequate prospecting. Quartz veins containing gold have been found at many places, at a few of which pits have been sunk. In order to give an idea of the places where auriferous veins have been exploited to a greater or less extent the following notes may be of service.

A sample taken from the schists adjacent to some quartz strings near the mouth of Ophir Creek contained gold in such amounts that when crushed in a hand mortar and panned free gold was obtained. On Crooked Creek, a tributary of Ophir Creek, there "is a mineralized belt 12 feet wide which strikes northwest. In this impregnated zone vein quartz is associated with pyrite. It is reported to assay as high as $\$ 8$ to the ton." a Near this place, on the divide between Goldbottom and Crooked creeks, is a gold-bearing vein which seems to be a continuation of this lead. Mineralization on a small scale has been recognized at several places at Goldbottom and Warm creeks, and a short distance from the mouth a vein on which some development work had been done was found at the contact of schist and limestone. "Near the mouth of the creek are two quartz veins, one about 3 feet wide and the other about 1 foot wide, striking N. $30^{\circ} \mathrm{E}$." $b$

In the Bluff region, according to Brooks ${ }^{{ }^{-}}$-

So far as observed, the schists appear to be mineralized only near their contact with the limestones. At these places quartz veins cutting the foliation of the schists are not uncommon. The individual veins appear to be of small extent, but at some

$a$ Collier, A. J., Bull. U. S. Geol. Survey No. 328, 1908, p. 252

b Idem, p. 255.

c Brooks, A. H., Bull. U. S. Geol. Survey No. 328, 1908, pp. 286, 291-292. 
Localities a stockwork forms a coutsiderable mass of low-grade ore. The ores appear to be chiefly iron pyrite, with some chalcopyrite and arsenopyrite.

An impregnated zone is well exposed atong the sea cliff about three-fourth ${ }^{*}$ of a mile east of the mouth of Daniels Creek. * * At this locality a belt of mica schist about 60 feet wide is more or less impregnated by pyrite-bearing quartz stringers. The belt, including some irregular limestone masses, is bounded by graphitic limestone walls which dip away from the schists and form a small anticline much broken by faults. * * At the west contact a band of schist 20 feet in cross section lies between one of the included limestone masses and the country rock. In this band the mineralization is more intense than in the rest of the schist. Here a series of gash veins, the largest of which is 18 inches in width, cuts the foliation of the schist. A mass of crushed material or gouge forms the hanging wall of this deposit and along this zone, which has been a plane of movement, the quartz veins are cut off abruptly. Stringers of quartz do, however, occur in the limestone on both sides of the schist. The ore appears to be chiefly iron pyrite and mispickel, with some chalcopyrite; the gangue is mostly quartz, with some calcite.

Although this mineralized zone was known for several years, not much active exploitation was undertaken until 1907. At one claim a shaft 50 feet deep was sunk and a short drift about 15 feet in length was turned off. On the adjoining claim the zone of mineralization is so wide that two shafts, one on the hanging wall and one on the foot wall, have been sunk. One of these is reported to be 100 feet deep; the other is slightly less than half that depth. On the next claim also two shafts have been sunk to a depth of approximately 50 feet. Two shorter shafts have been put down on the next claim and one shaft about 75 feet deep has been sunk near the end line of the next claim beyond. In 1907 the ore from these properties was crushed in an arrastre which was operated by a horse and it was intended to erect a stamp mill later. The developments at this place have, however, not been ascertained for the last two years.

According to Brooks ${ }^{a}$ in 1906 a lode 3 miles east of Bluff had been developed to some extent. It was located near the shore and was said to be 14 feet wide and to yield up to $\$ 30$ in gold to the ton. The ore is reported to be iron pyrite and mispickel. A few tons have been sacked and prepared for shipment but practically nothing is known about the mode of occurrence.

\section{COAL RESOURCES.}

Wherever the Cretaceous-Tertiary sediments are extersively developed throughout Alaska there are indications of coal. Some of these croppings in the area under discussion have been prospected and claims staked, but there are no producing mines within the Nulato-Norton Bay region. Detailed field examinations of many of the Alaskan coal deposits along the Yukon have been 
recently completed by W. W. Atwood, but the results have not yet been made available. As the party of 1909 revisited none of the coal prospects along the Yukon no new data were procured and descriptions will therefore be omitted.

In addition to that in the Yukon basin coal has been reported at a number of places along the eastern shore of Norton Bay, but so far as known no beds of a sufficient size to allow profitable mining have been discovered. Dall mentions a 2 -foot bed of shale and lignite on Ulukuk River, a tributary of the Unalaklik from the north. ${ }^{a}$ It was reported to have no commercial value. Brooks ${ }^{b}$ states: "Capt. D. H. Jarvis informed the writer that some very good looking coal had been found near Unalaklik Cape, near the eastern shore of Norton Sound. These probably belong to the same series described by Dall."

Several openings have been made near the mouth of the Koyuk on the west side, close to camp B 17. Unfortunately the shafts were not in condition to be examined and the only information gained was from a study of the material on the dump, as there are no exposures of the coal-bearing rocks in the neighborhood. Although lignitic material was found at this place, several years of desultory prospecting have failed to disclose a workable bed. The shafts cut a series of sandstones and clays which have weathered badly on the dump and appear much less consolidated than the average sandstones near Nulato. It is understood that during the last year the company formerly interested in this claim has abandoned the enterprise.

In this same region coal float has been found on Coal Creek and claims have been reported, but none of them was being prospected. Probably little of value was found, as the series is without doubt similar to that near camp B 17 .

Mendenhall ${ }^{c}$ states concerning his work in southeastern Seward Peninsula: "The only rocks encountered in the reconnaissance likely to carry coul are the sediments supposed to be of Tertiary age outcropping on the Tubutulik and Koyuk rivers in narrow belts. No direct evidence of the presence of this mineral was secured on the Koyuk, but along the river bank associated with the sandstone outcrops on the Tubutulik are numbers of small pieces of bright, compact coal, seemingly of good quality." The presence of this coal float has long been known to prospectors, but so far no beds that would warrant investigation have been discovered. On the Rathlatulik, a tributary of Fish River, about 8 miles above the junction

a Dall, W. II., Correlation papers, Neocene: Bull. U. S. Geol. Survey No. 84, 1892, p. 246.

b Brooks, A. H., Coal resources of Alaska: Twenty-second Ann. Rept. U. S. Geol. Survey, pt. 3, 1902, p. 560 .

c Mendenhall, W. C., A reconnaissance in the Norton Bay region, Alaska, in 1900; a speclal publication of the U. S. Geol, Survey, 1901, p. 214, 
of the streams, there is a woody lignite of relatively recent age. A shallow pit has been sunk here and slightly carbonized fragments of wood have been found. Underneath this layer of woody material is a bed of blackish-green calcareous muck which is nearly flat but has a slight slope toward the east. A cross section of the valley at this point shows a low bench about 5 feet above the water succeeded toward the east by another bench 15 feet higher a hundred paces beyond the stream and separated from the lower bench by a steep cliff. All the material from the stream to the top of the 15 -foot cliff is well-rounded gravel. Several abandoned river beds are found on the lower bench.

The coal is not over 18 inches thick and is of poor quality, having advanced little beyond the wood stage. Resin is abundant in many of the samples of this material. No tests of the coal were made, but from its physical character it does not seem possible that it could be used for fuel except very locally. No accurate estimate of the amount of material available could be made without further exploitation, but it is believed to be of very slight extent and not of sufficient value to warrant further development.

There are certain conclusions that may save prospectors from spending their time unprofitably in the search for coal in the region between Nulato and Council. Coal will be found only in the areas of nonmetamorphic sediments. No economically important beds are to be expected in the unconsolidated alluvium, such as that in the Fish River basin on the Rathlatulik. From the fact that so far there is no productive mining of any of the coal-bearing rocks outcropping along the Yukon within the mapped area it seems improbable that workable beds in the same series of rocks will be developed in the more remote regions where transportation facilities and markets are wanting. While thicker beds may be found here and there, the additional cost of transportation for each mile that the deposit lies back from the river or from some other cheap avenue of communication increases much more rapidly than could be reasonably assumed for the thickness of the bed. It is improbable that workable coal will be found in the Nulato-Council area where it is not now known and the prospector is warned that on the whole search for such deposits is more likely to be followed by failure than by success. 


\title{
MINING IN SEWARD PENINSULA.
}

\author{
By Fred F. Henshaw.
}

\section{GENERAL CONDITIONS.}

The mining industry suffered a general state of depression all over Seward Peninsula during the season of 1909 . The value of the total gold production fell from about $\$ 7,000,000$ in 1907 and $\$ 5,000,000$ in 1908 to only a little over $\$ 4,000,000$ in 1909 . The output by years since 1897, as closely as can be determined, is given in the following table:

Value of gold production in Seward Peninsula, 1897 to 1909

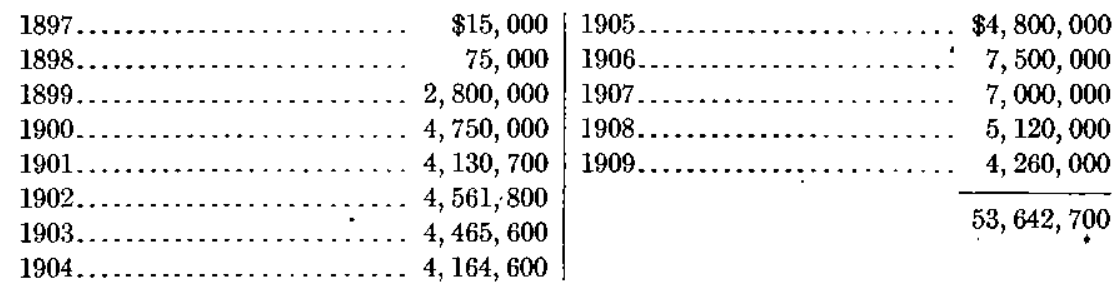

Foremost among the causes of this falling off in production was the extreme and widespread drought which affected practically every portion of the region and lasted from early July until the freeze-up in September. The previous summer had been marked by lowwater conditions that were said to have been more severe than in any other year since mining began, more than a decade earlier. A comparison of the two years shows that the low-water period of 1909 was more protracted, although the discharge of most of the streams was never so low as during the fourth week in July, 1908. The snowfall at Nome was 41 and 38.5 inches, respectively, for the winters of 1907-8 and 1908-9, and the water equivalent approximately 2.7 and 3 inches. The snow disappeared faster in the spring of 1908 than in 1909 , so that the shortage of water was felt earlier.

The rainfall at Nome during the summer months of June to September was 6.44 inches in 1908 and only 4.32 inches in 1909 . Another fact which tended to cause lower water in 1909 was that there were no fall rains to saturate the ground before the freeze-up in 1908, while 
the fall of 1907 was very stormy and the ground-water conditions were good. All these influences had their effect on the season's mining activities.

The richer parts of the beach placers were virtually exhausted in 1908 , as noted by Smith ${ }^{a}$ in a previous report, and the falling off in production in 1909 was not due in any great degree to this cause. The summer season was longer than the previous one; the first large steamers arrived June 13, or three days earlier than in 1908, and the freeze-up was delayed until September 27 or 28 , or about five days later than in 1908.

The mining developments at Nome and in the adjacent country have entered on practically the third stage in their history. The first was in the days when the present beach and the richer creeks were yielding their store of precious metal, from 1899 to 1904 ; the second, the years of the third-beach line, from about 1905 to 1908 . Coincident with this second stage came the expenditure of a large amount of capital in ditches, which created an active demand for labor and for mining machinery and supplies, gave a strong impetus to business, and produced what is popularly called a prosperous camp. The third stage has already begun, and will be marked by improved methods for the handling of large bodies of gravel economically and also by a willingness on the part of the individual miner to work many creeks that have hitherto been regarded as of too low grarle to yield adequate return for labor.

To the tendency just mentioned is believed to be due in no small degree the fact that the production for 1909 reached an aggregate of a little more than $\$ 4,000,000$, or about the same as for the average year prior to 1905 . On many creeks all over Seward Peninsula parties of two to half a dozen men were engaged in reworking old claims where the original operators had failed to extract all the values, in mining the less productive portions of the richer streams, or in opening new creeks which had not before been systematically prospected. The lack of water and consequent lack of work at most of the hydraulic mines left many old miners unemployed. Their number was augmented by a horde of foreign laborers brought in on the first run of steamers, without funds and almost wholly incapable of caring for themselves in a barren, unhospitable country, which could not even in a favorable season be expected to furnish all of them employment. The more resourceful and energetic of those thus thrown out of work resorted to working leases on such mining ground as was available, and it is believed that most of them made the equivalent of fair wages.

a Smith, P. S., Recent developments in southern Seward Peninsula: Bull.,U. S. Geol. Survey No. 379, 1909, pp. 267-301. 
The era of greatest activity in ditch building in Seward Peninsula is probably past, as nearly all the water supplies available for use on proved mining ground have already been diverted and capitalists have become more cautious in advancing money without a careful examination of mining properties and conditions.

The dredge has proved its adaptability to Alaskan conditions, and the success of a few well-managed ventures has led almost every owner of a few river or creek claims to consider the possibility of installing such a machine. This movement in a way resembles the activity in ditch building that followed the success of the earlier ditches on Nome River and Ophir Creek and at Bluff. It is to be feared that there will be the same tendency to install excavating machinery unsuited to local conditions as there was to build ditches in districts where the water supply has since proved insufficient for the needs of hydraulic plants. There will be smaller justification for failures in dredging enterprises than in projects involving the use of water. The features controlling the suitability of a mining claim for being worked by dredging, such as depth of gravel, character of bed rock, and existence of frozen ground or bowlders, can always be determined beforehand by drilling, whereas the water supply available in a stream can not be predicted from one year to the next with any legree of certainty unless a number of years' recorts of discharge are available.

The writer visited most of the important mining fields of Seward Peninsula at one time or another cluring the season of 1909 . As his examination of placer-mining operations was incidental to the carrying on of systematic stream measurements, all the mines could not be visited, and only the more salient features of the season's developments will be mentioned in the following notes. The operations of previous years have been covered in previous reports of the Geological Survey, ${ }^{a}$ and no especial mention will be made of them, except as they bear on the work done in 1909 .

a Brooks, A. HI., Placer mining in Alaska: Bull. U. S. Geol. Survey No. 259, 1905, pp. 19-24.

Moffit, F. H., Gold mining in Seward Peninsula: Bull. 284, 1906, pp. 132-141.

Moffit, F. H., The Nome region: Bull. 314, 1907, pp. 126-144.

Smith, P. S., Gold fields of the Solomon and Niukluk River basins: Idem, pp. 146-156.

Smith, P. S., Geology and mineral resources of Iron Creek: Idem, pp. 157-163.

Brooks, A. H., The Kougarok region: Idem, pp. 164-179.

Collier, A. J., Hess, F. L., Smith, P. S., and Brooks, A. H., Gold placers of parts of Seward Peninsula: Bull. 328, 1908.

Smith, P. S., Investigations of the mineral deposits of Seward Peninsula: Bull. 345, 1908, pp. 206-250.

Knopf, A., The Seward Peninsula tin depasits: Idem, pp. 251-267.

Knopf, $\Lambda$., Mineral deposits of the Lost River and Brooks Mountain region: Idem, pp. 268-271.

Knopf, $\Lambda$, Geology of the Seward Peninsula tin deposits: Bull. 358, 1908.

Smith, P. S., Recent developments in southern Seward Peninsula: Bull. 379, 1909, pp. 267-301.

Smith, P. S., The Iron Creek region: Idem, pp. 302-354.

Henshaw, F. F., Mining in the Fairhaven precinet: Idem, pp. 355-369. 


\section{NOME REGION.}

\section{BEACH PLACERS.}

As previously stated, the season of 1908 showed a marked decrease in the production of the beach placers, and in 1909 practically all the gold from this source came from the so-called "sloughover" and from the intermediate beach near Center Creek. Prospecting on the coastal plain was continued during the winter of $1908-9$, but it was rewarded with little that appeared worth developing, and the impetus to further search has been generally lost. The beach mines did not receive the writer's special attention and have been described in considerable detail in previous reports.

The most notable feature of the drift-mining operations in 1909 was the application of artificial freezing to check the flow of water from unfrozen ground into the drifts. The first experiment of this character was tried on the Cyrus Noble bench near Bourbon Creek for the purpose of shutting off an inflow of some 6 or 8 miner's inches of water. An ice machine from the Nome cold-storage plant was moved to the mine and a grillage of ammonia pipes was installed underground. This was applied to the unfrozen portion of the wall of the drift and the freezing mixture turned on. After the frost had penetrated a few inches the pipes were removed, a layer of thawed gravel placed against the face, and frozen against the other by the same method. This process was repeated until a wall was formed of sufficient thickness to withstand the water pressure. The small hole through which the water had been allowed to enter was then plugged up and the inflow stopped.

The Bessie mine presented a much more difficult problem. There was a misconception as to the extent of the flooded and abandoned workings of an adjoining claim, and late in May, 1909, a steam point was driven through the frozen wall into this subterranean reservoir. The rush of water filled the workings on the Bessie, and it seemed for a time that a considerable body of ground that had been blocked out was lost beyond recovery. A drill operator finally undertook to free the mine of water. Drill holes were sunk every few inches to form a line across the drift in which the water had been encountered. Small pipes were inserted inside the casings and the ammonia was pumped in. A solid wall of ice was thus formed across the drift and the inflow of water stopped. The mine was then pumped out and operations were resumed. It seems not unlikely that a similar method will be tried on other claims on the third-beach line where water has prevented work, and it may result in making possible the exploitation of much valuable ground.

Another plan that has been suggested for disposing of surplus water is the building of a drain tunnel, about 2 miles in length, to extend from 
the ancient beach to a point at sea level near Nome. Such a tunnel could be given a fall of 60 to 70 feet, which would be ample to carry off the water. The uncertainty as to whether such a tunnel could be kept open during the winter, together with the difficulty of organizing a large number of individul claim owners for such an expensive and questionable undertaking, has this far prevented any progress in the venture.

\section{DREDGING.}

Dredging bids fair to become an important factor in the working of the deposits of gold-bearing gravels in the coastal plain. Two large dredges were erected near Nome in 1908-one on Bourbon Creek near its junction with Dry Creek, the other on Wonder Creek just south of the third-beach line. The Bourbon dredge has a chain of 66 buckets, close connected, of 9 cubic feet capacity, and a nominal capacity of some 5,000 cubic yards a day. When first built, the bucket ladder was poorly balanced, and when digging near the water surface the heavy weight on the forward gantry sank the bow of the dredge so low that the deck was awash. When the machine was digging on bed rock, the bow was higher than the stern. This dredge was completed in August, 1908, and worked for a few days. An accident caused by the buckets coming into contact with the hull resulted in the sinking of the dredge, and it was not raised in time to start again that season. In 1909 the dredge was thoroughly overhauled, the bow gantry, the tackles for hoisting the ladder and spud, and the supports of the revolving trommel were strengthened, and the sluices were essentially modified. A 6-inch sand pump was installed, which is sufficient to handle the sluice water from one side only.

The gravel in the channel of Bourbon Creek is mostly fine, fully 70 or 80 per cent of the total passing through the screens. The sluices are ill adapted to handling so much fine material, and it has been found impracticable to fill the buckets more than half full. The ladder is arranged to dig to a depth of about 30 feet below the water level. Much of the ground is deeper than this and it may be found necessary to lower the water level in the pond by pumping. The strip of ground being worked was only about 180 feet wide, and it was sometimes found necessary to cut into tongues of frozen ground in order to keep a sufficient width of face, thus causing an excessive amount of wear of the buckets and machinery.

The second large dredge, on Wonder Creek, carries a chain of 40 buckets of 7 cubic feet capacity, open connected, on a ladder 100 feet in length, and is adapted to digging 40 to 45 feet below the water level. Wonder Creek is dry during a summer like 1909, and water to float the dredge had to be obtained from one of the ditches. The bed rock is about 50 feet deep, and the water surface was kept about 10 feet below the ground level in order to reach it. The water in the 
pool was used over and over and became very thick and muddy. The gravels are nearly as fine as those in Bourbon Creek, about 70 per cent passing through the screens. Considerable difficulty was experienced by the grounding of the stern in the deposits of fine tailings, and it was found necessary to make two settings of the spud in order to use the entire width of the cut, nearly 300 feet, for dumping the tailings. A number of large bowlders and slabs of rock were encountered near bed rock, some of them at least 4 or 5 feet in length. These seemed to be handled without difficulty, but the dredge had to be stopped while they were removed from the buckets with a hoist block.

Both the Bourbon and Wonder Creek dredges are electrically driven with current generated from a power station located near the former. It was not learned just why the plant was built at this point instead of on the beach, where fuel could have been landed direct from the lighters instead of having to be hauled from 1 to 2 miles.

A third large dredge was in process of erection in 1909 on Dry Creek near the mouth of Bourbon. It is a second-hand machine, having been originally built to mine black sand in Oregon. It has a 5 -cubic-foot open-connected bucket line and is operated by steam, crude oil being the fuel used. The dredge was not completed in time to test its adaptability to conditions in its present location.

It is reported that several new dredges will be built near Nome in 1910. The experience gained by both the successful and unsuccessful operations of the last few years, if wisely utilized, should assure the avoidance of the blunders of the past.

\section{DITCHES.}

Extensive operations were carried on near Little Creek by drifting and open-cut work in the summer of 1909 . Five large dumps, said to contain a total of nearly 100,000 cubic yards, were taken out between Little and Moonlight creeks during the winter. These were nearly all sluiced up with water from the Pioneer Nome River ditch, but when the water supply became short the last two were finished with pumped water. During the summer the work was carried on near Moonlight Creek, in what is probably an old channel of Anvil Creek, or of a stream that occupied approximately the location of the present Anvil above Discovery claim. The bed rock is very uneven, and the depth varies less than 10 to more than 20 feet in a few depressions. The gravels were entirely frozen and covered with frozen muck. This overburden was first ground-sluiced off; the gravels were then worked by shoveling into buckets which were trammed with a track system to derricks and hoisted to the dump box of the sluices. The Pioneer ditch furnished sufficient water at all times for 
one string of boxes, but two or three strings would probably have been used had the water been available. The pits were kept dry by small reciprocating steam pumps, similar to those used for underground work.

The ground in this locality lying between Anvil and Little creeks near the edge of the foothills is well adapted for hydraulicking with a hydraulic elevator. The depth is not more than 30 to 40 feet, including the overburden of muck, which is easily ground-sluiced off, and in many places there is not over 10 feet of gravel. Values are found through a considerable thickness of the section. The gravels are mostly fine, although they contain some good-sized bowlders. The cost of hydraulicking would probably be much less than that of the methods that have been used and the values would be more completely recovered. It is believed by the owners that there still remains a large body of rich ground and it is possible that arrangements may be made to work it with water under pressure.

Some work was done on Newton Gulch, a short distance above the third-beach line, by means of water from the Seward ditch. The gravels are shallow and the grade is sufficient to handle them through bed-rock flumes without elevating.

The Miocene ditch water was used mostly on Grass Gulch, which has been operated since 1906 and is now said to be nearly worked out. About 120 inches (2.4 second-feet) of water is pumped from the ditch to a reservoir near the Anvil-Dexter divide and used for hydraulicking. The pressure available on some parts of the claim has not exceeded 60 feet, but by careful handling a large duty has been obtained. The giants have been set close behind the gravel to be moved and steel flumes without riffles have been kept close to the face to carry the dirt to the sluices. From 300 to 400 inches of water was delivered at the head of the sluices, either by gravity from the ditch or through a centrifugal pump lifting about 12 feet. A hydraulic elevator was operated on Glacier Creek about a mile below Snow Gulch for a short time early in the season, but was obliged to close down early in July on account of shortage of water. Practically none of the other ditches in the vicinity were able to work for more than a few weeks in June and July.

Hardly any progress was made on the ditch and pipe line to Grand Central River, as only enough work was done to hold the water rights.

\section{SOLOMON AND CASADEPAGA REGIONS.}

On Solomon River practically the only mining in 1909 was carried on by the two dredges near the mouth of Shovel Creek. Hydraulicking was greatly hindered by the shortage of water, which began almost as soon as the ditches could be cleaned out and put into condition for carrying water. Of the ditches in the Solomon River drain- 
age basin only two were used at all-one from East Fork to Big Hurrah Creek and the other from California Creek to Mystery Creek, a tributary of Shovel Creek. The operation of the dredge is not affected by shortage of water and its season is limited only by the presence of the annual frost. It seems not unlikely that the total yardage handled by the two dredges on Solomon River in 1909 was equal to the total for the hydraulic mines in the whole peninsula. The Big Hurrah lode mine was shut down, except for a short time during the winter.

Mining in the Casadepaga region was carried on at several points on a small scale. A party of five men were at work on a bend of the river near Ruby Creek ground-sluicing and shoveling in, using water from Ruby Creek through a short ditch. Two parties were working on Lower Willow Creek above Wilson Creek, both hydraulicking, using Ruble elevators when suflicient water was available. The grizzly of one of the machines was too short and some of the gold was carried over it by the stream from the giant. It was stated that pors tions of the tailing pile contained enough values to pay to rework with a rocker. Of the two ditches on Canyon Creek neither was in use at the time of the writer's visit to this region in August. The lower or McKay ditch had not been opened at all, and the ditch of the Canyon Creek Gold Mining Company was short of water. On Goose Creek a small dredge was installed, having a hull 15 by 30 feet and buckets of 1 cubic foot capacity. It was assembled on a portion of the creek where the low-water flow sinks in the bed rock, and as there was no water to float it when completed it was unable even to start work. There were a few other outfits at work besides those mentioned, but they probably contributed little to the total production of the region. On the whole, the season in the Casadepaga basin was one of retrogression, but this was largely due to the shortage of water, and a favorable year might have seen much greater activity.

Bluff was not visited, but it was learned from operators that little mining was in progress. During most of the season the water supply of the Topkok ditch was small, even at the intake, and this was lost before it reached the outlet. Values were found on Daniels Creek in crevices and potholes in the limestone below what had previously been supposed to be the bed rock, and some of these deposits were being shoveled into buckets and hoisted with a derrick for sluicing when water became available.

\section{COUNCIL DISTRICT.}

The Council district, and particularly Ophir Creek, probably suffered less from the shortage of water in 1909 than any other portion of Seward Peninsula. The Canyon and Pargon ditches, from which the mines on Ophir Creek receive most of their water, head in the 
Bendeleben Mountains, where the rainfall is much heavier than in the areas of lower elevation. The records of discharge of these ditches (see pp. 377-380) show that the mean discharge for 1909 was not far below that of the average year. The amount diverted by the Canyon ditch for the last four seasons, as shown by records kept near the intake, is given below:

Mean yearly discharge of Canyon ditch near intake, 1906 to 1909.

\begin{tabular}{|c|c|c|c|c|c|}
\hline \multirow[b]{2}{*}{ Year. } & \multirow[b]{2}{*}{ Date of opening. } & \multirow[b]{2}{*}{$\begin{array}{l}\text { Date of } \\
\text { closing. }\end{array}$} & \multirow[b]{2}{*}{$\begin{array}{l}\text { Length of } \\
\text { season } \\
\text { (days). }\end{array}$} & \multicolumn{2}{|c|}{ Seasonal discharge. } \\
\hline & & & & $\begin{array}{c}\text { Minimum } a \\
\text { (second- } \\
\text { feet). }\end{array}$ & $\begin{array}{l}\text { Mean } b \\
\text { (second- } \\
\text { feet). }\end{array}$ \\
\hline $\begin{array}{l}1906 \ldots \ldots \ldots \ldots \ldots \\
1907 \ldots \ldots \ldots \ldots \ldots \ldots \\
1908 \ldots \ldots \ldots \ldots \ldots\end{array}$ & $\begin{array}{l}\text { About June } 15 . \ldots \\
\text { June } 20 \ldots \ldots \\
\text { About June } 10 \ldots \\
\text { June } 5 . \ldots \ldots \ldots \ldots\end{array}$ & $\begin{array}{l}\text { Oct. } 9 \\
\text { Sept. } 29 \\
\text { Sept. } 22 \\
\text { Sept. } 26\end{array}$ & $\begin{array}{l}117 \\
102 \\
105 \\
114\end{array}$ & $\begin{array}{r}38.6 \\
18.1 \\
21.0\end{array}$ & $\begin{array}{l}54 \\
57 \\
44 \\
40\end{array}$ \\
\hline Mean. & June $12 \ldots$ & Sept. 29 & 110 & & 49 \\
\hline
\end{tabular}

a The minimum does not represent low discharges occurring either before the Pargon ditch water was turned in or on days when the water was turned out for part of the time. Records for 1907 cover only a few weeks, and the minjmum for that year is not known, but it was stated by the diteh walker that there was nearly a full supply at all times, as it was a season of heavy rainfall.

$b$ The means Ior 1906,1907 , and 1908 are approximate, as the records are not complete.

In 1908 the Wild Goose Mining and Trading Company began the systematic development of its extensive properties on Ophir Creek. During the last two seasons the ground has been thoroughly prospected, mostly with the hand drill. The stream bed of Ophir Creek lends itself readily to the use of this machine. The gravels are of moderate depth, 8 to 15 feet as a rule, unfrozen, and contain no large rocks. A relatively light 5-inch drill was used, which could be operated by three men. It consisted primarily of a tripod, carrying a pulley, through which was passed a rope, to one end of which is attached the drilling tool and to the other the pump. The casing is driven by the impact of a rammer and not rotated except in pulling. It thus differs somewhat from the hand drill as described by Hutchins, ${ }^{a}$ being lighter and simpler. A steam-power drill was first used for this work, but was given up in favor of the hand machine. In some parts of Ophir Creek, where the flow sinks into the bed rock at low water, shafts were used instead of drill holes, as the lack of water is an advantage in sinking them, while it practically prevents the use of the drill.

Coincident with the prospecting the company began to work its claims in a systematic manner. In previous years it had been the practice to work only the richer spots. This plan necessitated the frequent removal of pipe, elevators, and flumes from one claim to another. The work is now carried on by beginning at the lowest claim and working upstream, dumping the tailings from one pit into

a Hutchins, J. P., Prospecting and mining gold placers in Alasks: Bull. U. S. Geol. Survey No. 345, 1908 , p. 61 . 
the next below, and handling all gravel that will pay a profit over operating expenses. The principal operations in 1908 were confined to Discovery claim at the mouth of Sweetcake Creek, which had been partly worked in 1905 and 1906 . When this claim was finished, the equipment was moved upstream to claims 4,5 , and 10 , and 4 hydraulic elevators were operated on these claims during the whole or part of the season of 1909 .

The Blue Goose dredge, which has been mining on claims 1, 2, and 3 below Discovery during the last four years, finished this part of the creek early in the season of 1909 and began to move upstream; during August and September it was at work on claim "No. 2 above." It is planned to dredge practically all the claims that will not be hydraulicked, including about six in the richer portion of the stream. Thus the entire pay streak of Ophir Creek will be thoroughly mined out. It is estimated by the operators that it will require some six or eight years to finish this work.

Only three claims aside from those already mentioned were being operated on any extensive scale in 1909. A combined steam scraper and derrick was installed on "No. $3 \frac{1}{2}$ above," and a force of 50 or 60 men was employed. This method of mining is more costly than either dredging or hydraulicking as they are practiced at present, and it will probably not be used as extensively in the future as in the past. The small dry-land dredge, which was built on No. 24 in 1908, was remodeled and a new revolving screen, belt stacker, and sluices were installed. It was operated for some six weeks at the end of the season, being delayed only by shortage of water for the sluices. The water was furnished by a small ditch, taking its supply from Ophir Creek above Crooked Creek, and the supply was small during most of the summer. This machine scemed well adapted to the favorable conditions found in this part of the creek, the fine gravel and decomposed schist bed rock being easily handled by its rather light machinery. A hydraulic elevator was installed on Albion Gulch, a tributary of Crooked Creek, and run by water conveyed in a small ditch from Portland Gulch, a tributary of Oxide Creek. The water supply was insufficient for continuous operation after the middle of July, but by storing it in a small reservoir at the lower end of the ditch the elevator was run intermittently.

On Ophir Creek, as in other portions of Seward Peninsula, the dredge apparently handles ground for which it is adapted at somewhat less cost than the hydraulic elevator, but where the bed rock is a very uneven, heavy, slabby limestone, as it is in the portion of Ophir Creek where the best values are found, the dredge is unable to recover nearly all the values and the greater efficiency of the hydraulic elevator in saving the gold more than offsets its greater cost of operation. On the whole, it appears that Ophir Creek will continue for 
several years to yield a production approximately equal to that of the last two seasons.

Of the other streams in the Council district, Goldbottom Creek deserves special mention. Two small dredges were built in 1909 at the mouth of Warm Creek, one being intended to work up Goldbottom and the other up Warm Creek. They are strongly-built machines, with hulls 26 by 60 feet and $2 \frac{3}{4}$ cubic-foot open-connected buckets, and are driven by two gasoline engines, one of 40 horsepower for driving the bucket chain and one 25 horsepower to run the pumps and lines. The steam scraper near the mouth of Melsing Creek operated successfully, but practically all other work in this district was hindered by the shortage of water.

\section{IRON CREEK REGION.}

Iron Creek and its tributaries presented signs of considerable activity in 1909. The tunnel for sluicing the gravels of lower Iron Creek into Kruzgamepa River was practically completed during the previous winter. A wooden flume 3 feet 8 inches wide and 2 feet high, lined on the bottom with steel plates, was built inside it. It had been planned to extend the tunnel under the bed of Iron Creek and to open up ground on the right of the stream, but this plan was found to be impracticable on account of the wet and unfrozen condition of the river bed. The upper end was accordingly given an increase in grade so as to come out above the water level. The water was then turned into the tunnel by means of a diversion dam. A shaft located about 80 feet from Iron Creek was enlarged with a view to converting the upper end of the tunnel into an open cut. Most of the material was frozen muck or clay which thawed very slowly, and steam thawing was undertaken in order to hasten the work. A small stream of water would have accomplished the same purpose, but it could not have been obtained without pumping. The amount of water used through the tunnel varied from 10 to 25 second-feet and averaged about 18 second-feet. This gave a depth of about 8 inches in the sluice, or not over half of what it would carry. Large stones up to 8 or 10 inches in diameter were put through without blocking and a large amount of fine material was carried, but the transporting capacity of the flume was not thoroughly tested. The current of the Kruzgamepa removed the small gravel from the outlet, but it was evident that the stream would require more than its own unaided force to handle the coarser material. The work of extending the flume on grade had been begun when, about August 12, an accident resulted in blocking it at the upper end. This would not have been serious earlier in the season, but as it was seen that the work could not be finished in time to do any sluicing that summer the work was suspended. 
On the upper portion of Iron Creek, locally known as Dome Creek, six parties of laymen, comprising about a dozen men altogether, were at work the greater part of the season, for the most part reworking portions of the creek that had been mined unsystematically in earlier years. The best values were found on a piece of virgin ground near the mouth of Hardluck Creek. It is probable that most of the men made at least fair wages. A steam scraper worked for a few weeks on the flat near the mouth of Discovery Creek, where an attempt was made to mine with hydraulic elevators in 1906 and 1907 . Conditions were favorable for the scraper, the gravels being 4 or 5 feet deep and the bed rock soft and easy to clean. Such equipment is better adapted to working bodies of shallow ground than expensive ditches and hydraulic machinery. Near the mouth of Easy Creek work was continued; water being conveyed through a small ditch from the spring that issues from the mountain to the right of Iron Creek. The ditch that was built from Iron Creek in 1907 is almost hopelessly out of repair, especially the flumes that were used for a considerable part of the distance.

\section{KOUGAROK REGION.}

The most notable feature of operations in the Kougarok region during the season of 1909 was the development of drift mining. Several dumps were taken out on lower Coffee Creek and on upper Kougarok River, mostly between Macklin Creek and Taylor. No definite information was obtained as to the gold tenor or production, but it is believed that the work was conducted at a fair profit. The great handicap to drifting has in the past been the excessive cost of fuel; coal taken into the upper Kougarok by way of Lanes Landing has cost $\$ 80$ to $\$ 100$ a ton, even in winter. In the fall of 1908 a shipment of coal was laid down at Davidsons Landing. Freight can be delivered at this point as cheaply as at Nome, as only one transshipment is necessary, this being made at Teller from ship to river steamer. The fuel was then hauled in over the snow to Taylor and was retailed there at about $\$ 60$ a ton.

The operations of the ditches probably added but little to the total production of the region. Though the snowfall in the upper Kougarok is not excessive, it drifts so badly that it is hard to get a ditch cleaned out and ready for work before the middle of June. The North Star ditch was opened about June 20 and the Ilomestake on July 9. The Arizona, Coarse Gold, and Windy Creek ditches lie at a little lower elevation and in a smoother country and were all opened in the latter part of May. All the ditches were short of water by July 15 and were able to do very little after that date. The water of all the ditches except the one on Windy Creek was used on what appears to be an old channel of the Kougarok lying on the 
right of the present stream, at an elevation above the river varying from 15 or 20 feet at the mouth of Taylor Creek to over 100 feet below Coarse Gold Creek. The channel has been opened at three points - opposite the mouth of Taylor Creek, below Arizona Creek, and above Twobit Gulch not far below Coarse Gold. It has been located by prospecting at several intermediate points and is probably fairly continuous.

Five outfits were at work on the main river above Taylor Creek. Most of the work was with pick and shovel, but on one claim below Macklin Creek from two to four pairs of horses were used for scraping into the boxes. A large pit 110 feet wide was being worked. Water for sluicing was conveyed from the river by a ditch about threefourths of a mile long.

About a mile above Macklin Creek, near Trinity, a cut has been made across a bend in the river. This was started in 1907 with water from a small ditch. The sod was removed from the surface and the water allowed to cut down the gravel. In 1908 a dam was built across the river below the head of the eut, and in the spring of 1909 the dam was closed and the entire river turned through. Thus the ground was rapidly stripped of its overburden and prepared for mining. Two teams were being used for scraping at the time the claim was visited in July. About a mile above this point good values are said to have been found on two adjoining claims. On the upper one five men were at work shoveling into boxes at the time of the writer's visit, but it was stated that the force had just been reduced on account of the drought. Water for sluicing and running a water lift was supplied by a ditch about 2 miles long, giving a head of about 40 feet. The pay streak was said to extend into both banks for a total width of over 100 feet. On the claim below values had been found just outside the river bed. Water for sluicing was pumped from the river with a gasoline engine. Several parties were at work on Macklin Creek while there was sufficient water, but they were forced to close down early in July.

Work on Windy Creek was confined to stripping and hydraulicking on a bench lying to the left of the creek near Anderson Gulch, water being obtained from the Windy Creek ditch. The water supply ran short early in July, and work was suspended while the ditch was enlarged to a bottom width of 5 feet.

In the Noxapaga basin work was mostly confined to Boulder Creek. A dam about 15 feet high was built of sod and earth during the early summer. It was intended to use this for booming, but the slight grade and the shortage of water rendered the attempt a failure. The dam was then used to store the water during the night to be used for a few hours in the daytime. Thus it was possible to accomplish some work with the small supply of water that the creek fur- 
nished, amounting to only 0.5 second-foot (20 inches) on August 28. The ditch from Turner Creek carried very little water during 1909.

The developments for the last two seasons seem to show that hydraulicking is not the method best adapted for developing the gold-bearing gravels on Kougarok River and its tributaries. The scanty water supply, the small amount of fall in the streams, and the uneven distribution of values militate against the success of a hydraulic-mining enterprise. The future of the district seems to lie rather in the working of the richest parts of the pay streak either by winter drifting or by shoveling or scraping into boxes in the summer.

\section{FAIRHAVEN PRECINCT.}

The mining operations in the Fairhaven district were examined in rather more detail than in the other parts of Seward Peninsula. The writer spent about two weeks in the region in the first part of the summer, but most of the matter in the following pages is based on notes taken by G. L. Parker, who spent about two months in the district, engaged primarily in stream-gaging work. Mining was in progress on all the streams mentioned in the writer's former report, ${ }^{a}$ except on Bear Creek, and was for the most part a continuation of the work of previous years.

\section{GOODHOPE RIVER.}

To consider the area from west to east, the first river on which there was any activity was the Goodhope. Mining was confined to Esperanza Creek, where workable placers were first found in the spring of 1908. Esperanza Creek is a small stream which drains an area of about 20 square miles. It has a flat grade, especially in the lower portion, where the fall is only 5 to 7 feet to the claim, or about 25 feet to the mile. The stream has a narrow channel winding between muck banks and its general appearance is similar to that of Candle Creek. The pay streak, so far as developed, lies in a narrow, shallow strip in the creek bed. When the creek was visited, on June 24, preparations had been made to mine on six claims near the lower end of the creek. Ditches had been dug to convey water for sluicing and diversion dams had been put in. These ditches were for the most part about a claim in length and were built with very light grade, but even then they gave hardly enough head to raise the water into the sluice boxes. The discharge of the creek was measured June 25 and found to be 2.8 second-feet (112 inches). It fell rapidly after that date, and on July 21 there was only 0.25 second-foot (10 inches) flowing. The shortage of water prevented any sluicing, but a. little gold was taken out by rocking.

a Henshaw, F. F., Mining in the Fairhaven preclact: Bull. U. S. Geol. Survey No. 379, 1908, pp. 355-360. 
Placer Creek, a tributary of Goodhope River below Esperanza Creek, was prospected by shafts during the winter, but no values were found. A hole was sunk about 6 miles above the mouth, through muck and angular material, to a depth of about 45 feet, where heavy lava bowlders were encountered.

Some prospecting was done on Humboldt Creek, which rises near the hot springs north of Taylor Creek and enters the Goodhope about 10 miles from its mouth. Values were found, but nothing rich enough to pay to shovel.

\section{INMACHUK RIVER.}

The basin of the Inmachuk was the scene of fully as great mining activity as during the previous year. Operations were continued on the Utica group of claims with one to three hydraulic elevators, using water from the Fairhaven ditch. An average flow of about 30 second-feet (1,200 inches) was used from June 14 to September 21. Some interruption was caused by breaks in the ditch. (See pp. 402-403 for discharge of Fairhaven ditch.) Work was started on the construction of a pipe line extending to claims above the mouth of Pinnell River. The Homestake group was worked to some extent by winter drifting. On claim No. 1 below Pinnell a large dump was taken out during the winter and work was continued during a part of the summer season. Chicago Creek coal was used for fuel.

Open-cut operations were continued on the lower river between Washington and Cue creeks, at the same point as in 1908, and it was stated that good values were being found. A little work was carried on in the bed of Hannum Creek near the mouth of Milroy, so far as the scanty water supply permitted.

In the fall of 1908 water rights were staked by two different parties at the springs of the upper Inmachuk. The first locator posted his notice late in September, and by an error in wording claimed 2,000 "cubic inches per second," the water to be used on claims on the Inmachuk above and below Hannum Creek. Before an anended notice could be posted the water had been staked by others, who proposed to divert it around to tributaries of Old Glory Creek. Both parties took steps to start construction work, but the first actual diversion of water was made by the second locator. During 1909 work was being prosecuted on two ditches, located less than 10 feet apart in elevation, so close that the lower bank of the upper ditch was sloughing into the lower ditch. In September steps were being taken by the owners of the lower ditch to procure an injunction against the continuation of work by their rivals. This is a rather unusual instance of the controversies arising over conflicting claims to water rights in the present unsatisfactory status of the law governing the appropriation of water for mining purposes. 
An old ditch for bringing water from springs on Old Glory Creek to Nelson Gulch, a tributary from the north, was reopened and a little hydraulicking was done, the small supply of water being stored in the lower end of the ditch and used during a portion of the time.

Some prospecting has been carried on for several years under the lava rims which are such noticeable features in the topography of the lower Pinnell and Inmachuk valleys, and many interesting facts have been brought to light. Two old channels have been located on both sides of Perry Creek near its junction with Pinnell River. The lower channel is at least 200 feet in elevation above the river, and the upper channel is 52 feet higher. In the lower channel there is 3 to 9 feet of gravel covered with about 20 feet of muck, and this is overlain with lava except where the lava has been eroded away. There is no muck overlying the upper channel, and the lava and gravel are mixed, a fact which seems to show that this channel was later than the lower one and was occupied by the stream at the time of the extrusion of the lava sheet. Pieces of wood were found on top of the gravels of the lower channel. A log 3 feet in diameter is said to have been encountered in one hole, but its relation to other deposits was not learned. The old channel can be traced down the Pinnell, following the left of its valley to its mouth. It then crosses the Inmachuk to its left or north side and extends for 3 or 4 miles to a point above the Homestake group of claims, where it crosses again to the right. It was not learned whether more than one channel had been located in this portion of the valley. Fair prospects were found under the lava at the mouth of Perry Creek and also just below the upper crossing of the Inmachuk and nearly opposite the mouth of Pinnell River. The fact that some of the richest portions of the present stream channel have been found on Claim No. 1 below Pinnell and on the Homestake group seems to indicate the possibility that its gold was derived largely from the older channel and this should lend encouragement to further prospecting.

\section{KUGRUK RIVER.}

In the Kugruk River basin the mining of coal commands more attention than the search for gold. The mine on Chicago Creek was again operated during the winter of $1908-9$, and the production was considerable. A second mine was also opened on the right bank of the Kugruk about 5 miles above Chicago Creek and just above Reindeer Creek. The coal bed outcrops on a bluff at the water's edge. It has a strike of about N. $4^{\circ} \mathrm{E}$. (or about N. $18^{\circ} \mathrm{W}$. magnetic), a westerly dip of about $78^{\circ}$, and a thickness between 50 and 60 feet. ${ }^{a}$

These data were determined on an exposure of the bed made by a prospect shaft and tunnel on the opposite side of the river, a few 
hundred feet from the mine, but they are believed to represent the general position of the bed. This strike agrees fairly well with that observed in the Chicago Creek mine (N. $8^{\circ}$ E.) and also with the direction of a line joining the outcrops, facts which seem to indicate that these are two outcrops of the same vein. The geology of the region is so complex, however, that the evidence can hardly be regarded as conclusive. The coal bed is somewhat thinner and lies steeper on the Kugruk than on Chicago Creek. At the upper mine a tunnel and inclined shaft had been driven parallel in a general way to the walls of the vein and extending about 250 feet in and 100 feet down from the adit. The general character of the coal seems to be much the same as in the mine on Chicago Creek.

Gold mining was carried on more extensively in the Kugruk basin than for several years past. Some prospecting was done in the winter on the flood plain of the river, about 3 miles above Chicago Creek, and a small dump was taken out. A party of men worked for a part of the season mining the surface gravels of a river bar near Reindeer Creek, but without much success. During the latter part of the summer workable prospects were found on Mina and Chicago creeks. The water supply in both streams is scanty, and with coal so near at hand drifting may prove to be the cheapest method of mining.

Contrary to the impression which the writer received in 1908 , it was learned that prospects have been found rather widely but irregularly distributed in the flood plain of the Kugruk below Reindeer Creek, but nothing has been encountered that would pay to handle by drifting, except on Discovery claim, about 1 mile above Chicago Creek. The section seems to consist in general of about 5 to 7 feet of overburden and 8 to 10 feet of gravel lying on a bed rock of schist or of a decomposed limestone which is cubical rather than slabby. In the river channel the gravel is shallow, being 4 to 8 feet in depth. It is not unlikely that it may be found profitable to mine portions of the flood plain by dredging. The gravels would have to be thawed, but coal is close at hand and easily mined. The feasibility of such a plan can be determined only after much more extensive and careful prospecting than has been done heretofore.

\section{KIWALIK RIVER.}

As in previous years, Candle Creek was the largest producer of gold in the Kiwalik basin, but it can no longer claim the distinction of being the only one, as considerable mining was done on Glacier Creek and Gold Run. Winter drifting was conducted on Candle Creek and its tributaries on about the same scale as in previous years, but the production was slightly less than for the winters of 1904 to 
1907 , as the richer ground is becoming exhausted. The claims worked include two on Candle Creek below Jump Creek, four between Jump and Patterson, five between Patterson and Blank, six bench claims between Jump and Patterson, and seven claims on Patterson, or about 24 in all. The total winter production was not far from a quarter of a million dollars. The value of the gold taken out in the summer amounted to hardly anything. Open-cut work was carried on in June on about five claims, but little sluicing was done after July 1 , as there was practically no water in Candle Creek. (See measurements on p. 406.) Most of the miners were forced to remain idle or to seek other creeks where water was available for sluicing.

The Candle ditch was opened early in the spring and water was first used from it on May 15. There was an ample supply from the melting snow for four or five days. The ditch was opened as far as Rock Creek, within two miles of the intake, by June 1. This creek and those lower down furnished at least 200 to 300 inches of water for a fortnight. Large banks of snow had drifted into the ditch along Glacier Creek between Rock Creek and the intake, and this section was not opened until June 16. From 300 to 600 inches was delivered at the mine from this time until June 30, when the water was shut off on account of legal difficulties. The water was used for stripping the overburden on the bench on John Bull Hill. A large cut was ground-sluiced off; the amount of material removed was not measured, but it must have been at least 100,000 cubic yards. The greater portion of this matcrial was thawed by the sun and the water from the giant was used mostly to wash the soft mud into the Kiwalik. This material formed a fairly firm deposit in the river, forcing the current toward the opposite bank. At the landing place in front of Candle the river was so filled with slickens that the depth of water at low stage was reduced from 5 or 6 feet to about 2 feet. This caused some inconvenience to the boats plying on the river and aroused a strong protest from their owners. There was no decrease in depth, however, on the bars and riffles below Candle, which determine the navigable depth of the river, and the difficulties encountered by the river men in 1909 were due rather to the low stage of water than to the deposits of sediment formed in the pools. (See p. 406 for discharge of Kiwalik River.) High water in the fall would probably have gone far toward restoring the river to its original condition.

Six parties of one to three men each were engaged in mining and prospecting on Glacier Creek for the whole or a part of the summer. Values were found from the Candle ditch intake up to the forks of the creek, about $1 \frac{1}{2}$ miles above, and mining was in progress at three points. The returns were not as good as had been indicated by 
reports received the previous fall, but were probably better than the equivalent of wages. Gold was found late in the fall of 1908 on the upper part of Gold Run and on Trio Creek, a tributary, and some development work was done in 1909. The ground is 6 to 12 feet deep, but the fall is considerable and the bed rock can be drained by cuts. Cuts aggregating about 250 feet in length had been worked when the creek was visited in August. Mining on Glacier Creek and Gold Run is very costly, as supplies have to be hauled from Candle. a distance of 30 to 40 miles, over poor roads. 


\section{WATER-SUPPLY INVESTIGATIONS IN SEWARD PENIN- SULA IN 1909.}

By Fred F. Henshaw.

\section{INTRODUCTION.}

\section{SCOPE OF WORK.}

It is the purpose of this paper to present briefly the results of the work carried on in 1909 in the further investigation of the water resources of Seward Peninsula. The work for the years 1906 to 1908 has been described and its results outlined in previous reports, ${ }^{a}$ and in the present paper it is proposed to present the new data in a preliminary form in advance of the publication of the full report, now in preparation.

The investigation in 1909 carried on by the writer, assisted by G. L. Parker, embraced the districts where records had previously been obtained and, in addition, a considerable body of information was collected in regard to the Council country. In southern Seward Peninsula most of the old stations were continued, especially those in the drainage basins of Nome and Grand Central rivers. In the Kougarok region the results obtained were fewer and somewhat less satisfactory than in previous years. In the Fairhaven precinct the work covered a larger area and extended over a longer period than the 1908 investigations. Only two field trips were made to the Council district, but, thanks to the cooperation of the engineers of the Wild Goose Mining and Trading Company, the discharges of their ditch were obtained, not only for the current year but also for some previous years.

The season of 1909 was one of long-continued drought over the whole of Seward Peninsula, and the results of the year's measurements are of special value, for they can probably be taken as indicating the low-water flow of the streams. This condition, while, of course, very detrimental to the mining interests, was favorable to the obtaining of accurate records of stream flow. The range of stage was relatively small on most of the streams and a correspondingly small

a Hoyt, J. C., and Henshaw, F. F., Water supply of the Nome region, Seward Peninsula, Alaska, 1906: Water-Supply Paper U. S. Geol. Survey No. 196, 1907. Henshaw, F. F., and Covert, C. C., Water-supply Investigations in A laska, 1906-7: Water-Supply Psper U. S. Geol. Survey No. 218, 1908. Henshaw, F. F., Water-supply Investigstions in Seward Peninsula, 1908: Bull. U. S. Geol. Survey No. 379, 1909, pp. $370-401$. 
number of measurements were required to rate the stations. A break of a few days in record at a station could be estimated with reasonable accuracy from the known behavior of neighboring streams, as they would usually be practically constant or falling uniformly. The tundra and trails were dry and easy to traverse, so that a longer distance could be covered in a day than in a wet season. Moreover, fewer days were lost on account of storms than in previous seasons.

\section{COOPERATION.}

As in earlier years, it was possible to cover this large area properly only through the assistance rendered by ditch and mining companies and others interested in the work. A considerable number of measurements were made by persons outside of the Geological Survey, and were of great value in defining the ratings for stations which could be visited only two or three times during the season by the engineers of the Survey.

Special acknowledgment for discharge measurements is due to C. H. Munro, W. H. Lanagan, A. B. Shutts, and R. G. Smith, of the Wild Goose Mining and Trading Company; to C. T. Law, of the Taylor Creek Ditch Company; to F. F. Miller and J. W. Warwick, of the Miocene Ditch Company; and to H. M. Long and R.S. Dimmock, of the Candle-Alaska Hydraulic Gold Mining Company.

The following persons or companies have furnished gage readings and rendered assistance in other ways: B. Deleray, manager, and employees of the Miocene Ditch Company; C. H. Munro, general manager, and employees of the Wild Goose Mining and Trading Company; Jafet Lindeberg, president, and employees of the Pioneer Mining Company; Andrew J. Stone, general manager, and employees of the Taylor Creek Ditch Company; employees of the Kougarok Mining and Ditch Company, Fairhaven Water Company, and Candle-Alaska Hydraulic Gold Mining Company; F. H. Waskey, C. F. Merritt, and George Wallin.

The numerous gage observers all rendered efficient services and special thanks are due to them, but lack of space forbids individual mention.

\section{METHODS OF WORK.}

The methods of carrying on the work were substantially the same as those described by C. E. Ellsworth elsewhere in this volume (pp. 257-259), in his report on the results of stream measurements in the Yukon-Tanana region.

\section{ARRANGEMENT OF DATA.}

For the purposes of description, Seward Peninsula may be divided in a general way into three portions: (1) A southern portion, from the seacoast near Nome back to and including the Kigluaik and 
Bendeleben mountains; (2) a central portion, extending from the lowland areas north of the mountains to the divide at the headwaters of streams draining into Kotzebue Sound and sometimes designated as the Kougarok region, from its most important river; (3) the Fairhaven precinct, embracing the area from which the waters drain into Kotzebue Sound.

Within these three portions the streams will be considered in order from the head of Norton Bay around the coast to the head of Kotzebue Sound. Under each basin the stations on the main stream will be taken up first, beginning with the upper point of measurement, then the stations on tributaries in the same manner, beginning with the highest. Miscellaneous measurements for the whole area are given after the discharges, near the end of the report (pp. 407-414), and are arranged in the same order as the data for regular stations.

\section{SOUTHERN SEWARD PENINSULA.}

\section{DESCRIPTION.}

Southern Seward Peninsula is here taken as embracing the area from the coast to and including the Kigluaik and Bendeleben mountains. The region shows three types of topography-a coastal plain, an upland, and a mountain mass.

Bordering the coast line is an area of low relief, absent at Point Rodney, Cape Nome, and Topkok Head, but more than 10 miles wide back of the lagoon at Port Safety. This lowland is made up of wet moss-covered ground, rising with a gentle slope to an elevation of 200 or 300 feet at the southern margin of the upland.

The upland consists of limestone and schist hills, ranging in elevation from a few hundred to over 2,000 feet. The general trend of the ridges is north and south, especially in the area back of Nome, and the streams flowing into Bering Sea are roughly parallel. This upland extends back about 30 miles from the coast and presents a steep escarpment toward a wide, gravel-filled valley that separates it from the mountain mass.

North of the depression the Kigluaik liountains, locally known as the Sawtooth Range, and the Bendeleben Mountains, farther east, rise abruptly, constituting a rugged east-west mass, sharply dissected, with serrated crest line. These mountains have been the center of local glaciation in recent times and their valleys are characterized by cirques.

Nome River is the only stream which crosses the depression and brings water from the mountains to the vicinity of the rich placer ground near Nome. Hence its waters have been the most sought after for mining purposes, and the three largest ditches in this region have been built to divert them. West of Nome River the Sinuk fol- 
lows this depression and collects the drainage from the south slope of the mountains. The valley to the east is occupied by Salmon Lake and Kruzgamepa River, which flows in a broad sweep around the east end of the mountains to Imuruk Basin. The divides between the Nome and Grand Central and the Nome and Sinuk valleys are low785 and 1,012 feet, respectively - a fact which makes it possible to divert water from the headwaters of these rivers to Nome River, where it can be carried in the existing ditches to the mines. Similarly in the more easterly mountain area Ophir Creek, rising near Mount Chauik, the dominant peak of the vicinity, extends into an area of placer deposits, and water has been diverted from Pargon River over a low, flat divide into the head of Ophir Creek.

The mountains have a heavy precipitation, reaching 50 to 60 inches a year for some small areas, as indicated by run-off records, and therefore constitute an excellent source of water for mining purposes. The area south of the mountains has a rainfall of 15 to 25 inches, or fully twice that of the country north of the steep mountain wall.

In this region the flow of the streams comes in the early summer from the melting snow and later from the rains. When the snowfall is heavy, as in 1907, it remains until some time in July, and if the rains come early the streams maintain a good flow all summer. In 1908 , on the other hand, the snowfall was light and disappeared early, the ground became dry, and the rains were late, so that the run-off for July was small. In the mountains the snow is protected in the steep gorges and cirques and remains well into the summer. The ground is generally frozen within a foot or two of the surface, a condition which prevents any water from being taken up as ground storage and causes the rain to run off immediately, producing rapid fluctuations of stage. The greatest regulating effect is produced by the limestone springs that occur on some streams, notably IIobson Creek, Moonlight Creek, Canyon Creek, and tributaries of Solomon and Grand Central rivers.

Investigations of flow have been made on the following streams and their tributaries, in 1909:

Fish River.

Solomon River.

Nome River.

Sinuk River.

Cobblestone River.

Kruzgamepa River.

Iron Creek.

FISH RIVER DRAINAGE BASIN.

Fish River rises in the Bendeleben Mountains about 50 miles north of Golofnin Bay. After emerging from the mountains it meanders for some 20 miles across the lowland basin known as the Fish River 
flats. It then traverses a narrow valley, locally known as the canyon, for about 15 miles, and after receiving the waters of Niukluk River enters the lowland at the head of Golofnin Sound, into which it empties. The total drainage area above tide water at White Mountain is 2,110 square miles.

Fish River receives many tributaries, some of the largest being Mosquito Creek, Rathlalulik and Etchepuk rivers, and Cache Creek from the east, Boston Creek and Pargon River from the northwest in the flats, and Niukluk and Fox rivers, which join the main stream below the canyon.

Niukluk River has nearly as large a drainage area as Fish River at their junction. It rises in the Bendeleben Mountains adjacent to the headwaters of Pargon River and flows southwestward into a lowland basin, thence southeastward to its junction with Fish River. Its principal tributaries are Shoestring, Goldbottom, Ophir, and Melsing creeks from the east and Libby River, American Creek, and Casadepaga and Bear rivers from the west. Council, the largest settlement in southern Seward Peninsula outside of Nome, and headquarters of the Council precinct, lies on the Niukluk at the mouth of Melsing Creek.

The upper Fish River basin above the Niukluk is of little economic importance, practically the only mining in this area having been at the Omalik silver mine. Ophir Creek and Casadepaga River, with their tributaries, have been the leading producers of gold, especially the former, which was the scene of the first discoveries in Seward Peninsula.

Several ditches have been built to convey water for working the placers on these two streams. The six in the Casadepaga basin are mostly short, ranging from 2 to 4 miles in length. There are seven on Ophir Creek. Four of them are relatively short and furnish water under heads of 20 to 90 feet for sluicing and running china pumps. Three are larger and give sufficient pressure for hydraulicking.

The Canyon ditch of the Wild Goose Mining and Trading Company is the only one on which continuous records were kept. It diverts its water from Ophir Creek, near the upper end of the canyon, and extends to Discovery claim, at the mouth of Sweetcake Creek, having a totai length of 17 miles. The Pargon ditch diverts water from Pargon River and its tributaries, Dillon, McKelvie, and Helen creeks, over a low divide into the head of Ophir Creek, where it is picked up by the Canyon ditch.

The investigations of water supply carried on in this basin have been largely confined to streams capable of furnishing water to the placers of these two mining districts. Some measurements were made in 1907 of Casadepaga River and American Creek.

No stream gaging was done on Ophir Creek and adjacent streams until 1909. Several gages had been installed on the ditch system of 
the Wild Goose Company in earlier years, and others were installed in the spring of 1909 .

A number of measurements, made by engineers of the company, were of great assistance in defining the ratings for the gages. The following stations have been maintained, and the discharges are now available for the first time:

Pargon River below Pargon ditch intake, 1909.

Pargon ditch at intake, 1909.

Pargon ditch below McKelvie Creek, 1908-9.

Pargon ditch below Helen Creek, 1906-1909.

Canyon ditch near intake, 1906-1909.

Canyon ditch above claim 10, 1909.

Discharges for Ophir Creek at Canyon ditch intake have also been computed for 1909. A list of miscellaneous measurements, made in the Fish River basin in 1909, is given near the end of this report (pp. 407-408).

Daily discharge, in second-feet, of Pargon River below Pargon ditch intake and of Pargon ditch at intake for 1909.

[Elevation, 730 feet; drainge area, 20 square miles.]

\begin{tabular}{|c|c|c|c|c|c|c|}
\hline \multirow{2}{*}{ Day. } & \multicolumn{2}{|c|}{ July. } & \multicolumn{2}{|c|}{ Aug. } & \multicolumn{2}{|c|}{ Sept. } \\
\hline & River. & Ditch. & River. & Ditch. & River. & Ditch. \\
\hline 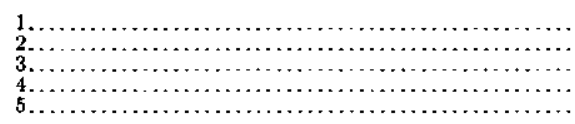 & $\begin{array}{l}48 \\
62 \\
48 \\
70 \\
48\end{array}$ & $\begin{array}{l}0 \\
0 \\
0 \\
0 \\
0\end{array}$ & $\begin{array}{l}1.0 \\
1.0 \\
1.0 \\
1.5 \\
2.0\end{array}$ & $\begin{array}{r}8.6 \\
10.7 \\
8.2 \\
18.0 \\
20.6\end{array}$ & $\begin{array}{l}1.0 \\
1.0 \\
1.0 \\
1.0 \\
1.0\end{array}$ & $\begin{array}{l}18.6 \\
18.0 \\
16.8 \\
16.8 \\
16.3\end{array}$ \\
\hline 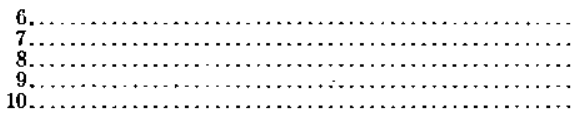 & $\begin{array}{l}89 \\
54 \\
29 \\
35 \\
29\end{array}$ & $\begin{array}{l}0 \\
0 \\
5.4 \\
5.4 \\
8.2\end{array}$ & $\begin{array}{l}1.0 \\
1.0 \\
1.5 \\
35 \\
24\end{array}$ & $\begin{array}{l}15.8 \\
13.7 \\
12.0 \\
20.6 \\
20.0\end{array}$ & $\begin{array}{l}1.0 \\
1.0 \\
1.0 \\
1.0 \\
1.0\end{array}$ & $\begin{array}{l}15.8 \\
15.2 \\
14.2 \\
13.7 \\
13.7\end{array}$ \\
\hline 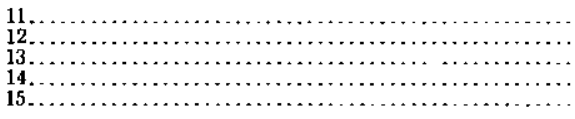 & $\begin{array}{l}48 \\
35 \\
29 \\
16 \\
16\end{array}$ & $\begin{array}{l}11.6 \\
11.6 \\
15.8 \\
20.6 \\
20.6\end{array}$ & $\begin{array}{l}16 \\
16 \\
29 \\
4.5 \\
9.0\end{array}$ & $\begin{array}{l}18.0 \\
20.6 \\
18.0 \\
18.0 \\
18.0\end{array}$ & $\begin{array}{l}1.0 \\
1.0 \\
1.0 \\
2.3 \\
1.5\end{array}$ & $\begin{array}{l}12.5 \\
12.5 \\
12.0 \\
17.4 \\
16.8\end{array}$ \\
\hline $\begin{array}{l}16 \ldots \ldots \ldots \ldots \ldots \ldots \\
17 \ldots \ldots \ldots \ldots \ldots \ldots \ldots \ldots \\
18, \ldots \ldots \ldots \ldots \ldots \ldots \ldots \\
19 \ldots \ldots \ldots \ldots \ldots \ldots\end{array}$ & $\begin{array}{l}9.0 \\
7.0 \\
4.5 \\
4.5 \\
2.0\end{array}$ & $\begin{array}{l}20.6 \\
21.7 \\
21.7 \\
24.1 \\
20.6\end{array}$ & $\begin{array}{l}29 \\
4.5 \\
4.5 \\
4.5 \\
4.5\end{array}$ & $\begin{array}{l}18.0 \\
20.6 \\
20.6 \\
20.6 \\
20.6\end{array}$ & $\begin{array}{l}2.3 \\
1.5 \\
1.5 \\
1.0 \\
1.0\end{array}$ & $\begin{array}{l}18.6 \\
15.2 \\
14.2 \\
12.5 \\
12.5\end{array}$ \\
\hline $\begin{array}{l}21 \\
22 \\
22 \\
23 \\
24 \ldots \ldots \\
25 \ldots \ldots \ldots\end{array}$ & $\begin{array}{l}2.0 \\
1.5 \\
1.5 \\
1.5 \\
1.5\end{array}$ & $\begin{array}{l}20.6 \\
19.1 \\
18.0 \\
17.4 \\
13.7\end{array}$ & $\begin{array}{l}2.8 \\
1.5 \\
1.0 \\
1.0 \\
.7\end{array}$ & $\begin{array}{l}20.6 \\
19.7 \\
18.6 \\
18.0 \\
17.4\end{array}$ & $\begin{array}{l}1.0 \\
1.0 \\
1.0 \\
1.0 \\
1.0\end{array}$ & $\begin{array}{l}13.7 \\
12.5 \\
12.0 \\
12.0 \\
11.6\end{array}$ \\
\hline 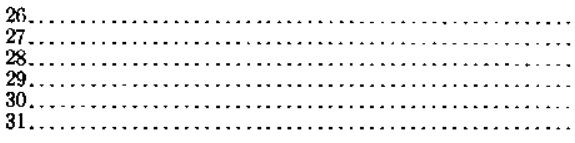 & $\begin{array}{l}1.0 \\
1.0 \\
1.0 \\
1.0 \\
.7 \\
.7\end{array}$ & $\begin{array}{r}12.5 \\
13.0 \\
11.6 \\
10.2 \\
9.4 \\
8.6\end{array}$ & $\begin{array}{r}.7 \\
.7 \\
.7 \\
.7 \\
1.5 \\
1.0\end{array}$ & $\begin{array}{l}17.4 \\
16.8 \\
18.0 \\
17.4 \\
19.7 \\
18.0\end{array}$ & $\begin{array}{l}\cdots \\
\cdots \\
\cdots \\
\cdots\end{array}$ & 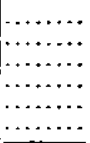 \\
\hline 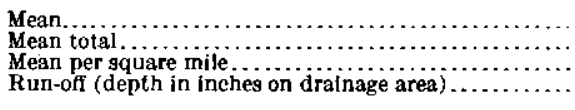 & $\begin{array}{l}22.5 \\
34.2 \\
1.71 \\
1.97\end{array}$ & $\begin{array}{c}11.7 \\
\cdots \cdots\end{array}$ & $\begin{array}{l}\text { 6. } 54 \\
24.0 \\
1.20 \\
\text { 1. } 38\end{array}$ & $\begin{array}{c}17.5 \\
\ldots \ldots \ldots\end{array}$ & $\begin{array}{r}1.16 \\
14.6 \\
.730 \\
.88\end{array}$ & $\begin{array}{l}13.4 \\
\ldots \ldots \ldots \\
\ldots \ldots \ldots\end{array}$ \\
\hline
\end{tabular}

NoTE. - The combined discharges for the river and diteh glve the total above the diversion dam. Values for the river are only approximate; they were obtalned from gage heights, which were not of the best, by means of a rating table which was extended from measurements at low stages. They were computed in order to give a general idea of the total flow of the river. Values for the ditch are based on a rating table well defined above 12 second-feet discharge. 
Daily discharge, in second-feet, of Pargon ditch below McKelvie Creek for 1908 and 1909.

\begin{tabular}{|c|c|c|c|c|c|c|c|}
\hline \multirow{2}{*}{ Day. } & \multicolumn{3}{|c|}{1908.} & \multicolumn{4}{|c|}{1909.} \\
\hline & July. & Aug. & Sept. & June. & July. & Aug. & Sept. \\
\hline 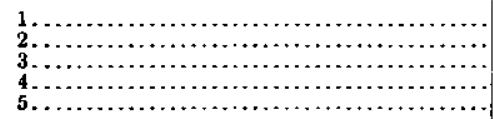 & $\begin{array}{l}17.7 \\
15.4 \\
20.4 \\
25.4 \\
22.8\end{array}$ & $\begin{array}{l}25.4 \\
25.4 \\
25.4 \\
22.8 \\
0\end{array}$ & $\begin{array}{l}22.8 \\
22.8 \\
22.8 \\
22.8 \\
22.8\end{array}$ & & $\begin{array}{l}24.7 \\
24.7 \\
24.7 \\
24.7 \\
25.4\end{array}$ & $\begin{array}{r}9.8 \\
10.9 \\
9.2 \\
22.8 \\
22.5\end{array}$ & $\begin{array}{l}21.0 \\
20.1 \\
18.6 \\
17.7 \\
18.6\end{array}$ \\
\hline $\begin{array}{r}6 \\
7 \\
8 \\
8 \\
9 \\
10 \ldots \ldots \ldots \ldots \ldots \ldots \ldots \ldots \ldots\end{array}$ & $\begin{array}{l}16.5 \\
16.5 \\
13.4 \\
11.2 \\
11.2\end{array}$ & $\begin{array}{r}5.0 \\
25.4 \\
25.4 \\
25.4 \\
25.4\end{array}$ & \begin{tabular}{l|}
25.4 \\
25.4 \\
25.4 \\
25.4 \\
25.4
\end{tabular} & & $\begin{array}{l}25.4 \\
25.0 \\
25.4 \\
24.7 \\
25.4\end{array}$ & $\begin{array}{r}18.6 \\
15.4 \\
14.4 \\
12.1 \\
3.3\end{array}$ & $\begin{array}{l}17.7 \\
16.5 \\
16.3 \\
14.6 \\
14.1\end{array}$ \\
\hline $\begin{array}{l}11 \\
12 \\
13 \\
14 \\
14 \\
15\end{array}$ & $\begin{array}{l}13.4 \\
13.4 \\
13.4 \\
10.3 \\
10.3\end{array}$ & $\begin{array}{l}25.4 \\
25.4 \\
25.4 \\
25.4 \\
25.4\end{array}$ & $\begin{array}{r}24.1 \\
24.1 \\
\cdots \\
\cdots\end{array}$ & & $\begin{array}{l}25.4 \\
25.0 \\
25.4 \\
24.7 \\
25.7\end{array}$ & $\begin{array}{l}25.4 \\
26.0 \\
25.4 \\
25.4 \\
25.4\end{array}$ & $\begin{array}{l}14.4 \\
14.4 \\
13.4 \\
18.6 \\
18.3\end{array}$ \\
\hline 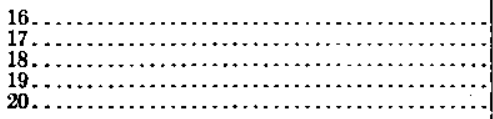 & $\begin{array}{r}10.3 \\
10.3 \\
11.2 \\
9.4 \\
11.2\end{array}$ & $\begin{array}{l}25.4 \\
25.4 \\
25.4 \\
25.4 \\
25.4\end{array}$ & $\mid \begin{array}{l}\cdots \\
\cdots \cdots \\
\cdots \cdots\end{array}$ & & $\begin{array}{l}25.0 \\
24.7 \\
26.0 \\
25.4 \\
24.1\end{array}$ & $\begin{array}{l}25.0 \\
25.4 \\
25.4 \\
25.4 \\
25.4\end{array}$ & $\begin{array}{l}18.3 \\
17.4 \\
15.4 \\
14.4 \\
12.8\end{array}$ \\
\hline $\begin{array}{l}21 \\
22 \\
23 \\
24 \\
24 \\
25\end{array}$ & $\begin{array}{r}10.3 \\
9.4 \\
9.4 \\
9.4 \\
7.8\end{array}$ & $\begin{array}{l}24.1 \\
24.1 \\
24.1 \\
24.1 \\
22.8\end{array}$ & $\begin{array}{ll}\cdots \\
\cdots\end{array} \ldots \ldots$ & $\begin{array}{l}19.2 \\
20.4 \\
25.4 \\
24.7\end{array}$ & $\begin{array}{l}23.1 \\
21.0 \\
20.4 \\
16.3 \\
14.9\end{array}$ & $\begin{array}{l}25.4 \\
24.7 \\
23.4 \\
22.8 \\
21.9\end{array}$ & $\begin{array}{l}13.4 \\
13.8 \\
13.8 \\
13.4 \\
12.4\end{array}$ \\
\hline $\begin{array}{l}26 \\
27 \\
28 \\
28 \\
29 \\
30 \\
31 \\
31\end{array}$ & $\begin{array}{r}7.8 \\
7.8 \\
7.8 \\
7.1 \\
25.4 \\
25.4\end{array}$ & $\begin{array}{l}22.8 \\
23.4 \\
22.8 \\
22.8 \\
22.8 \\
22.8\end{array}$ & $\mid \begin{array}{l}\cdots \cdots \\
\cdots \cdots \\
\cdots \cdots \\
\cdots \cdots \cdots \\
\cdots \cdots \\
\cdots \cdots \\
\cdots\end{array}$ & $\begin{array}{r}22.8 \\
23.8 \\
22.8 \\
17.7 \\
21.9 \\
2\end{array}$ & $\begin{array}{r}13.4 \\
12.8 \\
11.8 \\
11.2 \\
11.2 \\
9.8\end{array}$ & $\begin{array}{l}21.3 \\
20.4 \\
21.6 \\
21.6 \\
21.6 \\
20.4\end{array}$ & 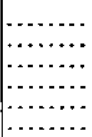 \\
\hline Mean..$\ldots \ldots \ldots \ldots \ldots \ldots \ldots \ldots \ldots \ldots \ldots \ldots \ldots \ldots \ldots \ldots$ & 13.3 & 23.1 & 24.1 & 22.1 & 21.5 & 20.6 & 16.0 \\
\hline
\end{tabular}

NotE.-These discharges are based on a rating table which is well defined above 6.0 second-feet discharge.

Daily discharge, in second-feet, of Pargon ditch below Itelen Creek for 1906 to 1909.

\begin{tabular}{|c|c|c|c|c|c|c|c|c|c|c|c|c|c|}
\hline \multirow{2}{*}{ Day. } & \multicolumn{3}{|c|}{1906.} & \multicolumn{3}{|c|}{1907.} & \multicolumn{3}{|c|}{1908.} & \multicolumn{4}{|c|}{1909.} \\
\hline & July. & Aug. & Sept. & July. & Aug. & Sept. & July. & Aug. & Sept. & June. & July. & Aug. & Sept. \\
\hline $\begin{array}{l}1 . \\
2 . \\
3 . \\
5 .\end{array}$ & & $\begin{array}{l}31.0 \\
28.8 \\
28.8 \\
31.0 \\
34.2\end{array}$ & $\begin{array}{l}36.4 \\
31.7 \\
31.7 \\
31.7 \\
33.1\end{array}$ & & $\begin{array}{l}34.6 \\
34.2 \\
34.6 \\
34.9 \\
34.2\end{array}$ & $\begin{array}{l}28.8 \\
28.8 \\
28.8 \\
28.8 \\
28.8\end{array}$ & $\begin{array}{l}31.7 \\
26.1 \\
26.1 \\
31.7 \\
28.8\end{array}$ & $\begin{array}{c}31.7 \\
31.7 \\
23.2 \\
18.1 \\
0\end{array}$ & $\begin{array}{l}36.4 \\
36.4 \\
31.7 \\
34.9 \\
34.9\end{array}$ & & $\begin{array}{l}31.7 \\
32.4 \\
34.2 \\
34.2 \\
35.6\end{array}$ & $\begin{array}{l}14.9 \\
15.4 \\
16.0 \\
24.8 \\
24.8\end{array}$ & $\begin{array}{l}25.7 \\
24.4 \\
23.8 \\
23.8 \\
23.2\end{array}$ \\
\hline $\begin{array}{r}6 . \\
7 . \\
8 . \\
9 . \\
10 .\end{array}$ & & $\begin{array}{l}37.1 \\
13.0 \\
35.6 \\
34.9 \\
18.2\end{array}$ & $\begin{array}{l}33.1 \\
33.1 \\
33.1 \\
33.1 \\
33.1\end{array}$ & & $\begin{array}{l}16.6 \\
34.2 \\
35.3 \\
34.6 \\
33.1\end{array}$ & $\begin{array}{r}28.1 \\
28.8 \\
28.8 \\
27.4 \\
9.0\end{array}$ & $\begin{array}{l}21.9 \\
19.3 \\
18.1 \\
18.1 \\
18.1\end{array}$ & $\begin{array}{l}11.1 \\
31.7 \\
33.1 \\
33.1 \\
33.1\end{array}$ & $\begin{array}{l}34.9 \\
34.9 \\
34.9 \\
34.9 \\
34.9\end{array}$ & & $\begin{array}{l}37.1 \\
35.6 \\
35.6 \\
34.2 \\
33.1\end{array}$ & $\begin{array}{l}21.6 \\
19.0 \\
18.1 \\
28.1 \\
15.2\end{array}$ & $\begin{array}{l}22.5 \\
21.9 \\
21.9 \\
20.9 \\
20.6\end{array}$ \\
\hline $\begin{array}{l}11 . \\
12 . \\
13 . \\
14 . \\
15 .\end{array}$ & & $\begin{array}{c}36.4 \\
18.2 \\
17.4 \\
34.2 \\
0\end{array}$ & $\begin{array}{l}33.1 \\
26.1 \\
26.1 \\
31.7 \\
31.7\end{array}$ & 32.4 & $\begin{array}{l}33.1 \\
34.9 \\
34.2 \\
34.9 \\
16.6\end{array}$ & $\begin{array}{l}0 \\
0 \\
0 \\
0 \\
0\end{array}$ & $\begin{array}{l}20.6 \\
20.6 \\
20.6 \\
13.2 \\
14.3\end{array}$ & $\begin{array}{l}33.1 \\
36.4 \\
36.4 \\
36.4 \\
36.4\end{array}$ & $\begin{array}{l}33.1 \\
33.1 \\
33.1 \\
33.1 \\
33.1\end{array}$ & & $\begin{array}{l}33.1 \\
30.6 \\
31.0 \\
31.0 \\
30.2\end{array}$ & $\begin{array}{l}29.9 \\
31.0 \\
32.4 \\
31.7 \\
31.0\end{array}$ & $\begin{array}{l}20.3 \\
19.6 \\
20.0 \\
23.2 \\
23.5\end{array}$ \\
\hline $\begin{array}{l}16 . \\
17 . \\
18 . \\
19 . \\
20 .\end{array}$ & & $\begin{array}{l}15.8 \\
31.7 \\
31.7 \\
31.7 \\
34.9\end{array}$ & $\begin{array}{c}31.7 \\
31.7 \\
31.7 \\
4.5 \\
0\end{array}$ & $\begin{array}{l}30.6 \\
21.9 \\
27.4 \\
30.2 \\
30.2\end{array}$ & $\begin{array}{r}33.1 \\
18.1 \\
4.5 \\
18.3 \\
18.1\end{array}$ & $\begin{array}{l}0 \\
0 \\
13.2 \\
15.4 \\
19.3\end{array}$ & $\begin{array}{l}11.1 \\
11.1 \\
13.2 \\
11.1 \\
11.1\end{array}$ & $\begin{array}{l}34.9 \\
34.9 \\
34.9 \\
34.9 \\
36.4\end{array}$ & $\begin{array}{l}33.1 \\
33.1 \\
33.1 \\
31.7 \\
30.2\end{array}$ & 31.7 & $\begin{array}{l}29.5 \\
29.5 \\
31.0 \\
31.0 \\
28.5\end{array}$ & $\begin{array}{l}32.4 \\
31.7 \\
31.3 \\
30.6 \\
30.2\end{array}$ & $\begin{array}{l}23.2 \\
21.6 \\
20.6 \\
19.3 \\
18.1\end{array}$ \\
\hline
\end{tabular}


Daily discharge, in second-feet, of Pargon ditch below Helen Creek for 1906 to 1909-Cont'd.

\begin{tabular}{|c|c|c|c|c|c|c|c|c|c|c|c|c|c|}
\hline \multirow{2}{*}{ Day. } & \multicolumn{3}{|c|}{1906.} & \multicolumn{3}{|c|}{1907.} & \multicolumn{3}{|c|}{1908.} & \multicolumn{4}{|c|}{1909.} \\
\hline & July. & Aug. & Sept. & July. & Aug. & Sept. & July. & Aug. & Bept. & June. & July. & Aug. & Sept. \\
\hline $\begin{array}{l}21 \ldots \\
22 . \\
23 . \\
24 . \\
25 .\end{array}$ & $\begin{array}{c}35.6 \\
0 \\
37.1 \\
34.9 \\
32.4\end{array}$ & $\begin{array}{l}34.2 \\
33.1 \\
31.7 \\
31.7 \\
31.7\end{array}$ & $\begin{array}{r}9.0 \\
13.2 \\
13.2 \\
13.2 \\
13.2\end{array}$ & $\begin{array}{l}26.1 \\
31.0 \\
31.0 \\
15.1 \\
15.1\end{array}$ & $\begin{array}{l}16.6 \\
15.4 \\
24.8 \\
26.1 \\
26.1\end{array}$ & $\begin{array}{l}21.2 \\
25.4 \\
24.8 \\
27.4 \\
27.4\end{array}$ & $\begin{array}{r}11.1 \\
11.1 \\
9.0 \\
9.0 \\
8.1\end{array}$ & $\begin{array}{l}34.9 \\
34.9 \\
34.9 \\
35.6 \\
35.6\end{array}$ & $\begin{array}{r}31.7 \\
31.7 \\
\cdots \cdots \cdots \\
\cdots \cdots\end{array}$ & $\begin{array}{l}28.8 \\
30.2 \\
31.7 \\
31.7 \\
26.8\end{array}$ & $\begin{array}{l}28.1 \\
25.4 \\
24.1 \\
20.6 \\
19.3\end{array}$ & $\begin{array}{l}30.6 \\
29.5 \\
28.1 \\
27.4 \\
27.1\end{array}$ & $\begin{array}{l}20.0 \\
19.3 \\
19.3 \\
19.0 \\
17.8\end{array}$ \\
\hline $\begin{array}{l}26 . \\
27 . \\
28 . \\
29 . \\
30 . \\
31 .\end{array}$ & $\begin{array}{l}36.4 \\
36.4 \\
35.6 \\
33.1 \\
34.2 \\
33.5 \\
\end{array}$ & $\begin{array}{c}15.8 \\
0 \\
0 \\
13.2 \\
21.9 \\
13.2\end{array}$ & 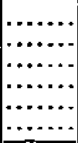 & $\begin{array}{l}29.5 \\
30.2 \\
33.1 \\
34.2 \\
34.9 \\
34.2\end{array}$ & $\begin{array}{l}26.1 \\
27.4 \\
27.4 \\
28.8 \\
28.8 \\
28.8\end{array}$ & $\begin{array}{l}27.4 \\
27.4 \\
27.4 \\
28.8 \\
28.5\end{array}$ & $\begin{array}{r}7.3 \\
6.5 \\
6.5 \\
6.5 \\
26.1 \\
13.2 \\
\end{array}$ & $\begin{array}{l}34.9 \\
34.9 \\
34.9 \\
34.9 \\
34.9 \\
34.9\end{array}$ & 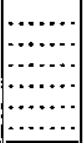 & $\begin{array}{r}31.7 \\
34.9 \\
33.1 \\
26.8 \\
1.0\end{array}$ & $\begin{array}{l}18.7 \\
19.6 \\
17.5 \\
16.6 \\
16.0 \\
15.4\end{array}$ & $\begin{array}{l}26.1 \\
26.1 \\
26.8 \\
26.1 \\
26.8 \\
25.4\end{array}$ & 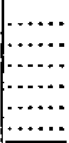 \\
\hline Mean. & 31.7 & 24.9 & 25.6 & 28.7 & 27.4 & 18.7 & 16.2 & 31.8 & 33.6 & 30.8 & 28.1 & 26.1 & $\overline{21.3}$ \\
\hline
\end{tabular}

NoTe.-These discharges are based on a rating table which is fairly well defined between 16 and 32 secondfeet discharge. The gage is located in the flume across Helen Creek above the Helen Creek lateral and is assumed to be an index of the discharge below the junction, but when a large portion of the water is coming from Helen Creek the discharge may be greater for the same gage height. Discharges from about July 14 to 29,1908 , are questionable; they are not consistent with those for the stations below and above and may be 5 or 6 second-feet too small.

Daily discharge, in second-feet, of Canyon ditch near intake for 1906 to 1908.

\begin{tabular}{|c|c|c|c|c|c|c|c|c|c|c|c|}
\hline \multirow{2}{*}{ Day. } & \multicolumn{5}{|c|}{1906.} & \multicolumn{3}{|c|}{1907.} & \multicolumn{3}{|c|}{1908.} \\
\hline & June. & July. & Aug. & Sept. & Oct. & June. & July. & Sept. & July. & Aug. & Sept. \\
\hline $\begin{array}{l}1 . . \\
3 . . \\
4 . \\
5 .\end{array}$ & & $\begin{array}{l}36.0 \\
36.0 \\
40.0 \\
47.9 \\
53.4\end{array}$ & $\begin{array}{l}54.9 \\
50.1 \\
50.1 \\
50.1 \\
57.9\end{array}$ & $\begin{array}{l}63.0 \\
63.0 \\
63.0 \\
63.8 \\
63.8\end{array}$ & $\begin{array}{l}50.1 \\
38.6 \\
38.6 \\
38.6 \\
38.6\end{array}$ & & $\begin{array}{l}38.6 \\
47.2\end{array}$ & & $\begin{array}{l}41.3 \\
28.4 \\
33.2 \\
30.7 \\
30.7\end{array}$ & $\begin{array}{l}44.4 \\
41.0 \\
40.0 \\
50.1 \\
47.2\end{array}$ & $\begin{array}{l}63.0 \\
63.0 \\
63.0 \\
63.0 \\
61.0\end{array}$ \\
\hline $\begin{array}{r}6 . . \\
7 \ldots \\
8 \ldots \\
9 \ldots \\
10 .-\end{array}$ & & $\begin{array}{l}54.1 \\
50.8 \\
58.7 \\
54.9 \\
63.0\end{array}$ & $\begin{array}{l}61.0 \\
50.1 \\
54.9 \\
63.0 \\
51.9\end{array}$ & $\begin{array}{l}63.8 \\
63.8 \\
63.8 \\
63.0 \\
63.0\end{array}$ & $\begin{array}{l}38.6 \\
38.6 \\
38.6 \\
38.6\end{array}$ & & $\begin{array}{l}56.4 \\
59.4 \\
59.4 \\
59.4 \\
61.0\end{array}$ & & $\begin{array}{l}33.2 \\
33.2 \\
28.4 \\
28.4 \\
25.9\end{array}$ & $\begin{array}{l}53.4 \\
56.4 \\
57.9 \\
59.4 \\
59.4\end{array}$ & $\begin{array}{l}57.9 \\
56.4 \\
56.4 \\
53.4 \\
53.4\end{array}$ \\
\hline $\begin{array}{l}11 . . \\
12 . \\
13 . \\
14 . \\
15 .\end{array}$ & $\begin{array}{l}\ldots . \\
\cdots \cdots \\
\cdots \\
\cdots \\
\cdots\end{array}$ & $\begin{array}{l}63.0 \\
63.0 \\
63.0 \\
63.0 \\
63.0\end{array}$ & $\begin{array}{l}63.0 \\
56.4 \\
50.1 \\
63.0 \\
41.3\end{array}$ & $\begin{array}{l}63.0 \\
63.0 \\
63.0 \\
63.0 \\
63.0\end{array}$ & & & & & $\begin{array}{l}28.4 \\
30.7 \\
25.9 \\
25.9 \\
22.8\end{array}$ & $\begin{array}{l}59.4 \\
59.4 \\
59.4 \\
59.4 \\
59.4\end{array}$ & $\begin{array}{l}53.4 \\
50.1 \\
50.1 \\
50.1 \\
59.4\end{array}$ \\
\hline $\begin{array}{l}16 . . \\
17 . \\
19 . \\
20 .\end{array}$ & & $\begin{array}{l}63.0 \\
44.4 \\
57.9 \\
57.9 \\
57.9\end{array}$ & $\begin{array}{r}38.6 \\
56.4 \\
56.4 \\
56.4 \\
.63 .0\end{array}$ & $\begin{array}{l}63.0 \\
63.0 \\
63.0 \\
63.0 \\
63.0\end{array}$ & & 33.2 & & & $\begin{array}{l}22.8 \\
22.8 \\
22.8 \\
19.9 \\
25.9\end{array}$ & $\begin{array}{l}50.1 \\
59.4 \\
59.4 \\
59.4 \\
57.9\end{array}$ & $\begin{array}{l}53.4 \\
51.5 \\
47.2 \\
48.6 \\
41.3\end{array}$ \\
\hline $\begin{array}{l}21 . \\
22 . \\
23 . \\
24 . \\
25 .\end{array}$ & & $\begin{array}{l}61.0 \\
53.4 \\
61.0 \\
59.4 \\
61.0\end{array}$ & $\begin{array}{l}63.0 \\
63.0 \\
63.0 \\
63.0 \\
53.4\end{array}$ & $\begin{array}{l}63.0 \\
63.0 \\
63.0 \\
63.0 \\
63.0\end{array}$ & & $\begin{array}{l}45.8 \\
50.1 \\
50.1 \\
53.4 \\
53.4\end{array}$ & & $\begin{array}{l}59.4 \\
59.4 \\
59.4 \\
59.4 \\
59.4\end{array}$ & $\begin{array}{l}23.8 \\
20.7 \\
20.7 \\
19.9 \\
19.9\end{array}$ & $\begin{array}{r}56.4 \\
.56 .4 \\
56.4 \\
63.0 \\
63.0\end{array}$ & 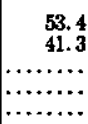 \\
\hline $\begin{array}{l}26 \ldots \ldots \ldots \\
27, \ldots \ldots \ldots \\
28 \ldots \ldots \ldots \\
29 \ldots \ldots \ldots \\
30 \ldots \ldots \\
31 \ldots \ldots \ldots\end{array}$ & $\begin{array}{r}33.2 \\
33.2 \\
33.2 \\
\ldots \ldots \ldots\end{array}$ & $\begin{array}{l}63.0 \\
59.4 \\
59.4 \\
59.4 \\
58.7 \\
57.9\end{array}$ & $\begin{array}{l}63.0 \\
63.0 \\
63.0 \\
26.7 \\
63.0 \\
63.0\end{array}$ & $\begin{array}{l}63.0 \\
63.0 \\
63.0 \\
63.0 \\
63.0\end{array}$ & & $\begin{array}{l}54.9 \\
50.1 \\
51.5 \\
56.4 \\
56.4 \\
\cdots \ldots . .\end{array}$ & & $\begin{array}{r}59.4 \\
59.4 \\
59.4 \\
59.4 \\
\ldots \ldots \ldots . \\
\ldots . . .\end{array}$ & $\begin{array}{l}19.9 \\
19.9 \\
18.1 \\
18.1 \\
28.4 \\
44.4\end{array}$ & $\begin{array}{l}63.0 \\
63.0 \\
69.4 \\
56.4 \\
54.9 \\
56.4\end{array}$ & 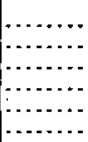 \\
\hline Mean & 33.2 & 56.3 & 56.0 & 63.1 & 39.8 & 50.5 & 54.5 & 59.4 & 26.3 & 56.1 & 54.1 \\
\hline
\end{tabular}

NorE.-These discharges are based on a rating curve which is well defined between 20 and 60 secondfeet discharge. The gage and channel conditions are believed to be permanent. No record was kept between July 10 and September 21,1907 , but the ditch was full practically all the time. The records do not cover the full perlod at the beginning of 1906 and 1908, water having been turned in early in June both years. 
Daily discharge, in second-feet, of Canyon ditch near intake and above claim 10 for 1909.

\begin{tabular}{|c|c|c|c|c|c|c|c|}
\hline \multirow{2}{*}{ Day. } & \multicolumn{4}{|c|}{ Near intake. } & \multicolumn{3}{|c|}{ A bove claim 10 . } \\
\hline & June. & July. & Aug. & Sept. & July. & Aug. & Sept. \\
\hline 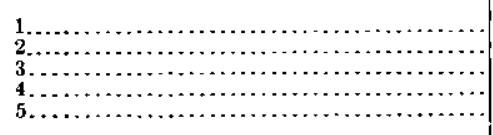 & 18.1 & $\begin{array}{l}56.4 \\
56.4 \\
56.4 \\
55.6 \\
55.6\end{array}$ & $\begin{array}{l}21.0 \\
21.0 \\
23.8 \\
40.0 \\
34.8\end{array}$ & $\begin{array}{l}38.0 \\
37.3 \\
36.0 \\
36.0 \\
36.0\end{array}$ & $\begin{array}{ll}\cdots \cdots \cdot \cdot \\
\cdots \cdots \cdot \\
\cdots \cdots \\
\cdots \cdots\end{array}$ & $\begin{array}{l}11.4 \\
10.8 \\
12.5 \\
30.1 \\
25.8\end{array}$ & $\begin{array}{l}35.4 \\
34.3 \\
33.9 \\
33.9 \\
34.3\end{array}$ \\
\hline $\begin{array}{r}0 \ldots \ldots \ldots \\
7 \ldots \ldots \ldots \\
9 \ldots \ldots \ldots \\
10 \ldots \ldots\end{array}$ & $\begin{array}{l}18.1 \\
18.1 \\
18.1 \\
38.6 \\
41.3\end{array}$ & $\begin{array}{l}57.2 \\
57.2 \\
53.4 \\
55.6 \\
56.4\end{array}$ & $\begin{array}{l}31.6 \\
28.4 \\
27.8 \\
49.7 \\
50.1\end{array}$ & $\begin{array}{l}34.8 \\
33.8 \\
32.5 \\
31.9 \\
31.9\end{array}$ & 39.6 & $\begin{array}{l}26.5 \\
22.5 \\
22.2 \\
31.6 \\
40.0\end{array}$ & $\begin{array}{l}31.6 \\
31.6 \\
30.1 \\
29.4 \\
29.4\end{array}$ \\
\hline 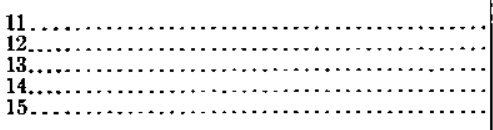 & $\begin{array}{l}45.8 \\
45.8 \\
47.2 \\
44.4 \\
41.3\end{array}$ & $\begin{array}{l}53.4 \\
53.4 \\
51.2 \\
47.2 \\
45.8\end{array}$ & $\begin{array}{l}47.9 \\
48.6 \\
53.4 \\
52.6 \\
48.3\end{array}$ & $\begin{array}{l}31.3 \\
30.7 \\
30.7 \\
39.3 \\
36.0\end{array}$ & $\begin{array}{l}37.3 \\
37.7 \\
33.9 \\
31.6 \\
30.1\end{array}$ & $\begin{array}{l}35.0 \\
39.3 \\
41.6 \\
44.4 \\
41.2\end{array}$ & $\begin{array}{l}29.4 \\
27.9 \\
27.9 \\
35.4 \\
33.5\end{array}$ \\
\hline 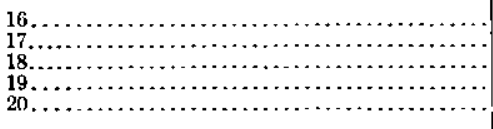 & \begin{tabular}{l|}
41.3 \\
41.3 \\
41.3 \\
41.3 \\
41.3
\end{tabular} & $\begin{array}{l}44.4 \\
43.4 \\
44.4 \\
43.4 \\
40.0\end{array}$ & $\begin{array}{l}51.9 \\
49.4 \\
47.2 \\
46.5 \\
45.8\end{array}$ & $\begin{array}{l}36.0 \\
37.6 \\
30.7 \\
31.3 \\
28.9\end{array}$ & $\begin{array}{l}30.1 \\
31.6 \\
30.5 \\
30.1 \\
27.9\end{array}$ & $\begin{array}{l}42.8 \\
42.0 \\
40.8 \\
40.8 \\
38.5\end{array}$ & $\begin{array}{l}32.8 \\
33.9 \\
27.5 \\
28.1 \\
25.7\end{array}$ \\
\hline 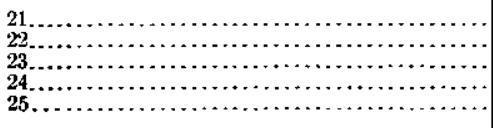 & $\begin{array}{l}45.8 \\
48.6 \\
51.9 \\
51.9 \\
44.4\end{array}$ & $\begin{array}{l}37.3 \\
37.3 \\
33.8 \\
29.5 \\
27.0\end{array}$ & $\begin{array}{l}45.1 \\
44.0 \\
42.7 \\
41.0 \\
40.0\end{array}$ & $\begin{array}{l}30.1 \\
35.7 \\
34.1 \\
34.8 \\
31.0\end{array}$ & \begin{tabular}{l|}
24.3 \\
22.5 \\
22.9 \\
19.3 \\
17.4
\end{tabular} & \begin{tabular}{l|}
38.9 \\
37.7 \\
36.9 \\
35.0 \\
35.0
\end{tabular} & $\begin{array}{l}26.9 \\
31.6 \\
30.9 \\
32.4 \\
29.7\end{array}$ \\
\hline 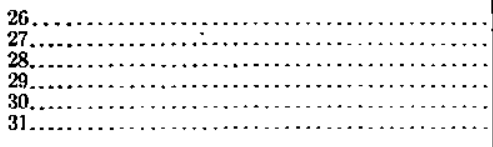 & $\begin{array}{l}44.4 \\
50.1 \\
56.4 \\
56.4 \\
56.4\end{array}$ & $\begin{array}{l}25.9 \\
27.0 \\
25.1 \\
22.6 \\
21.9 \\
21.6 \\
\end{array}$ & $\begin{array}{l}40.0 \\
39.3 \\
40.3 \\
39.3 \\
40.0 \\
38.0 \\
\end{array}$ & $\begin{array}{l}11.9 \\
\ldots \ldots \\
\cdots \cdots \\
\ldots \ldots \\
\cdots \cdots \\
\end{array}$ & $\begin{array}{l}16.1 \\
16.1 \\
15.5 \\
13.0 \\
12.5 \\
11.6 \\
\end{array}$ & $\begin{array}{l}35.0 \\
35.4 \\
37.3 \\
37.7 \\
36.9 \\
36.2 \\
\end{array}$ & $\begin{array}{r}22.9 \\
\ldots \ldots \\
\cdots \cdots \\
\cdots \cdots \\
\cdots \cdots \\
\end{array}$ \\
\hline Mean.. & 41.9 & 43.1 & 41.0 & 33.0 & 25.1 & $\overline{33.6}$ & 30.8 \\
\hline
\end{tabular}

Nore.-Discharges for the station above claim 10 sre based on a rating table whleh is fairly well defined between 15 and 40 second-feet discharge. September 18 to 21 interpolated; no record before July 10.

Daily discharge, in second-feet, of Ophir Creek at Canyon ditch intake for 1909.

[Drainage area, 24 square miles.]

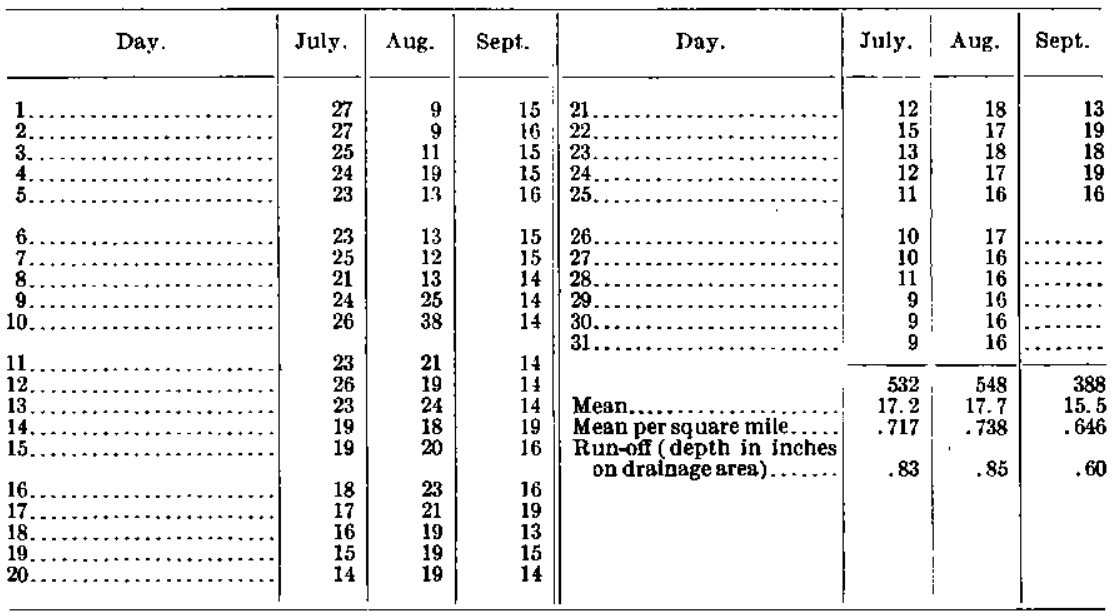

Nore.-These discharges were obtained by subtracting the discharge of the Pargon ditch below Helen Creek from that of Canyon ditch at the lntake, and adding 3 second-feet, the approximate amount of water lost by seepage from the Pargon ditch below Helen Creek. 
SOLOMON RIVER DRANAGE BASIN.

Solomon River empties into Bering Sea at Solomon, 40 miles east of Nome. This stream has been a good producer of gold, and several ditches have been built to utilize its water and that of its tributaries, including the East Fork ditch, the Midnight Sun ditch from Big Hurrah Creek, the Brogan ditch from the mouth of Johns Creek to East Fork, and a ditch about 7 miles long on Coal Creek.

One station has been maintained in this basin to obtain data for comparative purposes and for possible power development, that on Solomon River below East Fork, during July and August, 1908, and August and September, 1909.

A list of miscellaneous measurements macle in this basin is given on page 408 .

Daily discharge, in second-feet, of Solomon River below East Fork for 1908 and 1909.

[Elevation, 140 feet; drainage area, 66 square miles.]

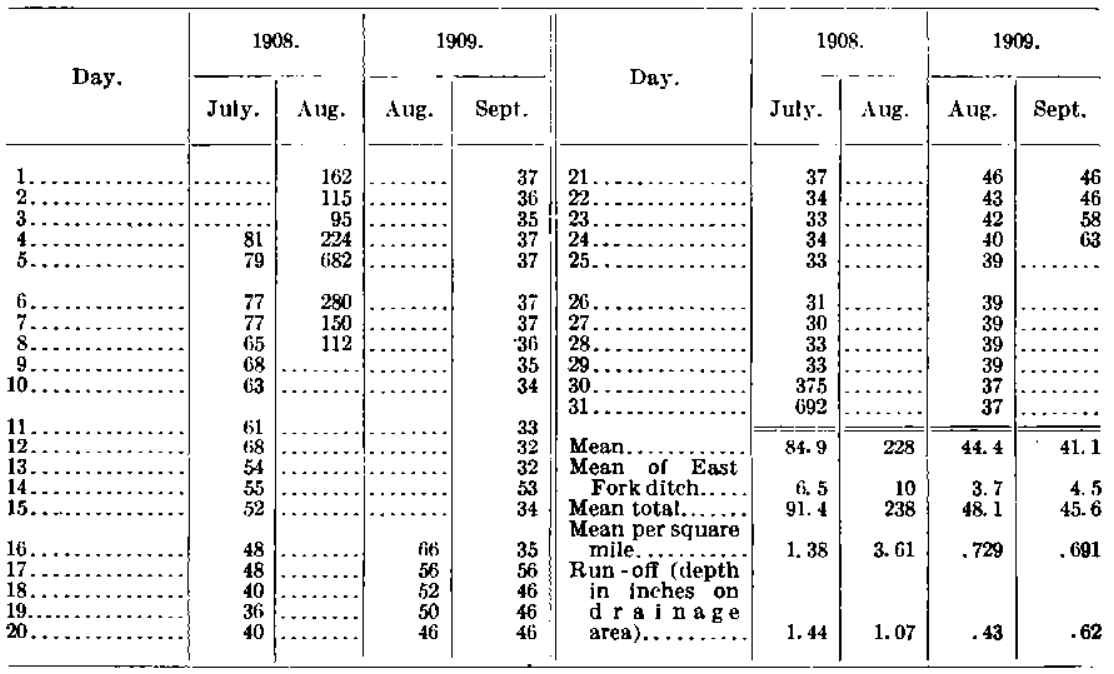

Nore.-The above dally discharges are based on rating curves which are applicable as follows: July 4 to 30,1908 (fairly well defined).

July 31 to August 8, 1908 (fairly well defined).

August 16 to September 24,1909 (well defined).

September 7 to 12 and 19 to 22 (estimated).
The values for 1908 are based on additional data and supersede those published in Bulletin 379 , p. 383. 


\section{NOME RIVER DRAINAGE BASIN.}

Nome River is formed by the junction of Buffalo and Deep Canyon creeks, which have their sources in the Kigluaik Range. The principal tributaries are David, Alfield, Christian, Darling, Buster, and Osborn creeks from the east and Divide, Dorothy, Clara, Hobson, and Banner creeks from the west. Hobson Creek, the most important of these tributaries, is a short stream but receives a large flow from limestone springs.

Four ditches have been built to divert water for mining purposes, and any additional water supply that may be obtained in other highlevel streams can best be brought to the mines by way of the valley of Nome River.

The Miocene ditch has its intake on Nome River just below the mouth of Buffalo Creek and extends along the right bank of Nome River to the Ex. Here it forks, one branch delivering water to Glacier and Anvil creeks, the other to Dexter Creek and its tributaries. The ditch crosses and diverts the flow of Hobson Creek and several other small creeks. The David Creek lateral delivers water to Nome River above the intake, the Grouse Creek branch comes in at the flume, and the Glacier Creek branch enters at the Ex.

The Campion ditch has its intake on Buffalo Creek, about half a mile above the mouth, and extends 4 miles to Dorothy Creek, into which its water is dropped. The Seward ditch has its intake just below the mouth of Dorothy Creek and receives much of its water supply from the Campion ditch. The Pioneer Nome River ditch takes its water about 3 miles below the Seward. Both of the latter ditches have laterals to Hobson Creek.

The total amount of water that can be made available for these ditches includes not only the discharge of Nome River itself, but also that of Grand Central River and some of its tributaries, which can be diverted over the Nugget divide. (See p. 383.) These discharges have been summarized by weekly periods in the accompanying table. The amount available for use at elevation 400 to 450 feet includes all above the level of the Miocene ditch; that for use at elevation 220 to 280 feet includes all additional water down to the level of the Pioneer ditch. Sinuk River and its tributaries, Windy and North Star creeks, could also be made to furnish some water, but only by a rather long ditch line and at considerable expense. Their discharge at elevation 800 feet may be estimated at one-half that of upper Grand Central River, Thompson Creek, and Gold Run.

The monthly discharge of Nome River above the Miocene intake, for 1906 to 1909 , is given in order to show the relation between the discharges of different years. 
Records of discharge have been kept on Nome River and the ditches since 1906, and the basin has been covered more thoroughly than any other in Seward Peninsula. The following stations have been maintained.

Nome River above Miocene intake, 1906-1908.

Nome River below Pioneer intake, August 21 to 31, 1907, 1908-9.

Hobson Creek below Manila Creek, 1907-1909.

Campion ditch at Black Point, 1906-1909.

Miocene ditch at Black Point, 1906-1909.

Miocene ditch at Clara Creek, 1907 and 1909.

Miocene ditch above Hobson Creek, 1907-1909.

Miocene ditch below Hobson Creek, 1907-1909.

Miocene ditch at the flume, 1906-1909.

David Creek ditch opposite Black Point, August, 1906, 1907-1909.

Seward ditch at intake, 1907-1909.

Seward ditch below Hobson Branch, 1909.

Seward ditch at Dexter Creek, 1909.

Seward ditch above Newton Gulch, 1909.

Hobson Branch above Seward ditch, 1909.

Pioneer ditch at intake, August 21 to $31,1907,1908-9$.

Mcan ueekly water supply, in second-feet, available for Nome River ditches in 1909.

\begin{tabular}{|c|c|c|c|c|c|}
\hline \multirow[b]{2}{*}{ Date. } & \multirow[b]{2}{*}{$\begin{array}{l}\text { For use st } \\
\text { elevation } \\
220 \text { to } 280 \\
\text { feet: Nome } \\
\text { River, Jow- } \\
\text { level flow. }\end{array}$} & \multicolumn{3}{|c|}{ For use at elevation 400 to 450 feet. } & \multirow[b]{2}{*}{ Total. } \\
\hline & & $\begin{array}{l}\text { Nome } \\
\text { Rlver, high- } \\
\text { level flow. } \\
\text {. }\end{array}$ & $\begin{array}{l}\text { Upper } \\
\text { Grsnd } \\
\text { Central } \\
\text { River, } \\
\text { Thompson } \\
\text { Creek, sud } \\
\text { Gold Run. }\end{array}$ & $\begin{array}{c}\text { Nugget, } \\
\text { Copper, } \\
\text { and Jett } \\
\text { creeks. }\end{array}$ & \\
\hline 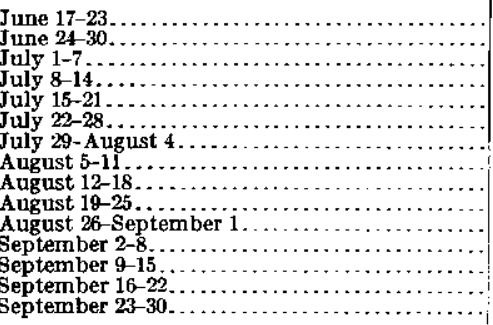 & \begin{tabular}{r|}
152 \\
117 \\
142 \\
68.7 \\
34.4 \\
26.8 \\
23.3 \\
25.8 \\
23.3 \\
20.1 \\
19.2 \\
15.6 \\
17.5 \\
16.9 \\
22.7
\end{tabular} & $\begin{array}{l}140 \\
119 \\
95.8 \\
62.1 \\
42.6 \\
28.8 \\
24.1 \\
32.1 \\
31.9 \\
25.8 \\
24.0 \\
22.1 \\
20.2 \\
22.2 \\
26.7\end{array}$ & \begin{tabular}{|c|}
258 \\
175 \\
105 \\
75.1 \\
72.8 \\
101 \\
92.5 \\
69.4 \\
559 \\
50.4 \\
42.6 \\
37.9 \\
$\ldots .7 .6$
\end{tabular} & $\begin{array}{l}9.7 \\
8.7 \\
4.4 \\
3.2 \\
1.9 \\
6.3 \\
6.0 \\
4.2 \\
3.1 \\
2.5 \\
1.8 \\
1.4\end{array}$ & $\begin{array}{l}292 \\
236 \\
506 \\
314 \\
186 \\
134 \\
122 \\
165 \\
154 \\
120 \\
102 \\
90.6 \\
82.1 \\
78.4 \\
49.4\end{array}$ \\
\hline 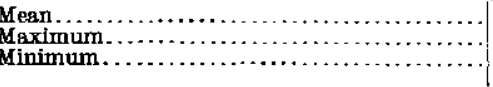 & $\begin{array}{r}48.4 \\
152 \\
16.9\end{array}$ & $\begin{array}{r}47.8 \\
140 \\
20.2\end{array}$ & $\begin{array}{r}94.6 \\
258 \\
37.9\end{array}$ & $\begin{array}{l}4.4 \\
9.7 \\
1.4\end{array}$ & $\begin{array}{r}175 \\
506 \\
49.4\end{array}$ \\
\hline
\end{tabular}

NoTE.-Discharges are those for the streams at the ditch intakes, except for Nugget, Copper, and Jett creeks, for which the values given are the approximate quantities of water delivered over the Nugget divide. Discharges for Grand Central River and for Nugget, Copper, and Jett creeks are omitted for June and the last week in September, as the records do not cover these periods, and no water could have been diverted from these streams on account of snow and ice conditions. 
Monthly discharge of Nome River above Miocene intake for 1906 to 1909.

[Drainage ares, 15 square miles.]

\begin{tabular}{|c|c|c|c|c|c|}
\hline \multirow[b]{2}{*}{ Month. } & \multicolumn{4}{|c|}{ Discharge in second-feet. } & \multirow{2}{*}{$\begin{array}{l}\text { Run off } \\
\text { (depth in } \\
\text { inches on } \\
\text { drainage } \\
\text { area). }\end{array}$} \\
\hline & Maximum. & Minimum. & Mean. & $\begin{array}{c}\text { Per } \\
\text { square } \\
\text { mile. }\end{array}$ & \\
\hline 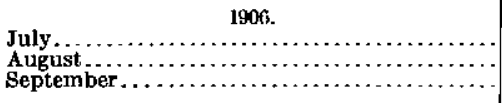 & $\begin{array}{l}314 \\
191 \\
230\end{array}$ & $\begin{array}{l}23 \\
20 \\
29\end{array}$ & $\begin{array}{l}57.8 \\
50.5 \\
65.6\end{array}$ & $\begin{array}{r}3.85 \\
3.37 \\
4.37\end{array}$ & $\begin{array}{l}4.44 \\
3.88 \\
4.88\end{array}$ \\
\hline The period, 92 days. & 314 & 20 & 57.9 & 3.86 & 13. 20 \\
\hline 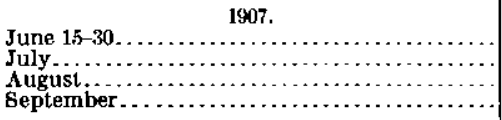 & $\begin{array}{r}460 \\
132 \\
71 \\
349\end{array}$ & $\begin{array}{l}125 \\
25 \\
19.2 \\
25\end{array}$ & $\begin{array}{r}212 \\
66.5 \\
33.8 \\
66.0\end{array}$ & $\begin{array}{r}14.1 \\
4.43 \\
2.25 \\
4.40\end{array}$ & $\begin{array}{l}8.39 \\
5.11 \\
2.59 \\
4.91\end{array}$ \\
\hline The period, 108 days. & 460 & 192 & 78.6 & 5. 24 & 21.00 \\
\hline 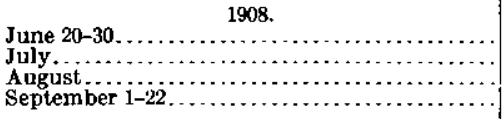 & $\begin{array}{r}86 \\
88 \\
146 \\
39\end{array}$ & $\begin{array}{l}26 \\
6.1 \\
22 \\
15.0\end{array}$ & $\begin{array}{l}59.5 \\
15.5 \\
43.6 \\
23.8\end{array}$ & $\begin{array}{l}3.97 \\
1.03 \\
2.91 \\
1.59\end{array}$ & $\begin{array}{l}1.62 \\
1.19 \\
3.36 \\
1.30\end{array}$ \\
\hline The perlod, 94 days. . & 146 & 6.1 & 32.0 & 2.13 & 7.64 \\
\hline 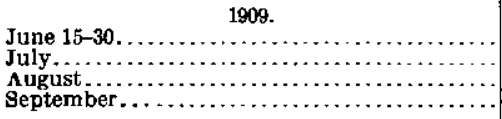 & $\begin{array}{r}271 \\
74 \\
39 \\
30\end{array}$ & $\begin{array}{l}26 \\
8.8 \\
7.4 \\
9.2\end{array}$ & $\begin{array}{l}99.2 \\
28.1 \\
15.5 \\
12.4\end{array}$ & $\begin{array}{l}6.61 \\
1.87 \\
1.03 \\
.827\end{array}$ & $\begin{array}{r}3.93 \\
2.16 \\
1.19 \\
.92\end{array}$ \\
\hline The period, 198 days.$\ldots \ldots \ldots \ldots \ldots \ldots$ & 271 & 7.4 & 30.8 & 205 & 8. 20 \\
\hline
\end{tabular}

Note. - Values for 1906, 1907, and 1908 have been recomputed and supersedo those published in previons reports. These discharges represent the natural tow of the river. 
Daily discharge, in second-feet, of Nome River and Hobson Creek for 1909.

\begin{tabular}{|c|c|c|c|c|c|c|c|c|c|c|c|c|c|}
\hline \multirow[t]{2}{*}{ Day. } & \multicolumn{4}{|c|}{$\begin{array}{l}\text { Nome River at Miocene } \\
\text { intake. E Elevation, } \\
572 \text { feet; drainage area, } \\
15 \text { square miles. }\end{array}$} & \multicolumn{4}{|c|}{ 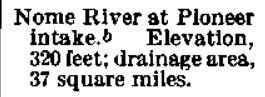 } & \multicolumn{5}{|c|}{$\begin{array}{l}\text { Hobson Creek at Milocene in- } \\
\text { take.c Elevation, } 500 \text { feet; } \\
\text { drainage area, } 2.6 \text { square } \\
\text { miles. }\end{array}$} \\
\hline & June. & July. & Aug. & Sept. & June. & July. & Aug. & Sept. & May. & June. & July. & Aug. & Sep \\
\hline 1. & & $\begin{array}{l}52 \\
50 \\
74 \\
58 \\
57\end{array}$ & $\begin{array}{r}7.4 \\
8.2 \\
13.0 \\
19.1 \\
12.6\end{array}$ & \begin{tabular}{l|}
10.9 \\
11.4 \\
11.1 \\
12.2 \\
13.3
\end{tabular} & & $\begin{array}{l}241 \\
211 \\
222 \\
228 \\
196\end{array}$ & $\begin{array}{l}27 \\
28 \\
41 \\
42 \\
33\end{array}$ & $\begin{array}{l}30 \\
28 \\
27 \\
26 \\
29\end{array}$ & & $\begin{array}{l}40 \\
35 \\
39 \\
31 \\
44\end{array}$ & $\begin{array}{l}21 \\
20 \\
22 \\
18.1 \\
17.7\end{array}$ & $\begin{array}{l}9.5 \\
9.0 \\
8.3 \\
6.2 \\
5.7\end{array}$ & $\begin{array}{l}6 . \\
6 \\
6\end{array}$ \\
\hline 6. & & $\begin{array}{l}51 \\
41 \\
45 \\
43 \\
33\end{array}$ & $\begin{array}{l}10.4 \\
10.1 \\
8.2 \\
39 \\
37\end{array}$ & $\begin{array}{l}13.8 \\
12.8 \\
10.4 \\
10.3 \\
10.4\end{array}$ & 430 & $\begin{array}{l}186 \\
169 \\
147 \\
130 \\
117\end{array}$ & $3=$ & $\begin{array}{l}29 \\
26 \\
26 \\
27 \\
26\end{array}$ & & & & $\begin{array}{l}8.2 \\
8.0 \\
8.3\end{array}$ & 6 \\
\hline & 238 & $\begin{array}{l}24 \\
27 \\
29 \\
25 \\
22\end{array}$ & $\begin{array}{l}16.3 \\
9.9 \\
24 \\
27 \\
23\end{array}$ & $\begin{array}{r}9.9 \\
9.2 \\
9.4 \\
13.3 \\
11.9\end{array}$ & $\begin{array}{l}424 \\
415 \\
364 \\
334 \\
310\end{array}$ & $\begin{array}{l}96 \\
99 \\
81 \\
67 \\
58\end{array}$ & 4 & 26 & $\begin{array}{l}0.12 \\
.12 \\
.12 \\
.12 \\
.19\end{array}$ & $\begin{array}{l}34 \\
27\end{array}$ & & $\begin{array}{l}7.2 \\
6.3\end{array}$ & 6 \\
\hline$\ldots \ldots \ldots$ & $\begin{array}{r}271 \\
111 \\
99 \\
93 \\
80\end{array}$ & $\begin{array}{l}24 \\
22 \\
23 \\
22 \\
20\end{array}$ & $\begin{array}{l}17.8 \\
14.8 \\
13.9 \\
14.5 \\
13.6\end{array}$ & \begin{tabular}{l|}
13.2 \\
12.8 \\
12.5 \\
11.7 \\
11.6
\end{tabular} & $\begin{array}{l}355 \\
316 \\
298 \\
316 \\
268\end{array}$ & $\begin{array}{l}60 \\
58 \\
52 \\
54 \\
52\end{array}$ & 4 & 29 & $\begin{array}{l}.26 \\
.26 \\
.54 \\
.1 .3 \\
5.8\end{array}$ & & & 8. & $\begin{array}{l}7 . \\
6 . \\
6 . \\
6 .\end{array}$ \\
\hline 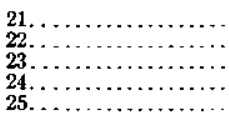 & $\begin{array}{l}73 \\
66 \\
72 \\
45 \\
26\end{array}$ & $\begin{array}{l}17.8 \\
16.0 \\
13.7 \\
11.0 \\
10.7\end{array}$ & $\begin{array}{l}14.1 \\
13.7 \\
13.1 \\
12.5 \\
11.7\end{array}$ & $\begin{array}{l}17.2 \\
30 \\
16.0\end{array}$ & $\begin{array}{l}236 \\
219 \\
162 \\
174 \\
138\end{array}$ & $\begin{array}{l}46 \\
43 \\
40 \\
38 \\
36\end{array}$ & $\begin{array}{l}3 \\
3 \\
3\end{array}$ & & $\begin{array}{l}7.1 \\
5.3 \\
6.7 \\
6.7 \\
6.1\end{array}$ & & & $\begin{array}{l}7.6 \\
7.4 \\
7.6\end{array}$ & $\begin{array}{l}5 . \\
5 . \\
6 . \\
5 .\end{array}$ \\
\hline 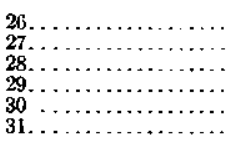 & $\begin{array}{r}27 \\
\\
27 \\
\vdots \\
89 \\
184 \\
86\end{array}$ & $\begin{array}{r}10.5 \\
10.4 \\
11.4 \\
10.0 \\
8.8 \\
9.5\end{array}$ & $\begin{array}{l}12.3 \\
13.1 \\
13.7 \\
13.1 \\
11.9 \\
12.1\end{array}$ & $\begin{array}{l}13.2 \\
13.2 \\
12.4 \\
12.0 \\
12.0\end{array}$ & $\begin{array}{l}120 \\
168 \\
192 \\
338 \\
303\end{array}$ & $\begin{array}{l}35 \\
34 \\
30 \\
29 \\
30 \\
32\end{array}$ & $\begin{array}{l}33 \\
33 \\
31 \\
30 \\
31 \\
29\end{array}$ & $\begin{array}{l}33 \\
33 \\
31 \\
30 \\
30\end{array}$ & $\begin{array}{r}5.0 \\
4.7 \\
5.8 \\
6.4 \\
9.7 \\
3 i\end{array}$ & $\begin{array}{l}15.1 \\
15.4 \\
18.8 \\
27 \\
24\end{array}$ & $\begin{array}{r}10.7 \\
11.3 \\
10.6 \\
11.0 \\
10.2 \\
9.9\end{array}$ & $\begin{array}{l}7.6 \\
7.7 \\
7.6 \\
8.0 \\
8.1 \\
7.0\end{array}$ & $\begin{array}{l}6 . \\
6 . \\
6 .\end{array}$ \\
\hline$\ldots \ldots$ s & 99.2 & 2 & 15.5 & 12.4 & 280 & $\overrightarrow{94.1}$ & 38.4 & 51.0 & 5.16 & 28.5 & 14.8 & 7.57 & 6.43 \\
\hline pth in & 6. 61 & 1.87 & 1.03 & .827 & $7.5 i$ & 2.54 & 1.04 & .838 & 1.98 & 11.0 & 5.69 & 2.91 & 2.47 \\
\hline $\begin{array}{l}\text { inches on drain- } \\
\text { age area) .......... }\end{array}$ & 3.93 & 2.16 & 1.19 & .92 & 5.91 & 2.93 & 1.20 & .94 & 1.55 & 12.27 & 6.56 & 3.36 & 2.76 \\
\hline
\end{tabular}

a These values were found by adding the discharges of Nome River below the Miocene intake and of Miocene and Campion ditches at Black Point, and subtracting the discharges of the David Creek Nugget Creek, and Jett Creek ditches. Values for September 20 to 30 were estimated as 40 per cent of the discharge at the Pioneer intake.

$b$ These values were found by adding the discharges of Name River below the Pioneer intake, Pioneer ditch at the intake, Seward ditch at the intake, and Miocene ditch at Clara Creek, and subtracting the discharges of the Nugget Creek and Jett Creek ditches.

$c$ These values up to June 17 were obtained from gage heights below the Miocene diversion dam, using a rating table which is well defined below 40 second-leet discharge. Those from June 18 to September 19 , while the Miocene diteh was diverting water, were obtained by subtracting the discharge of the diteh above the dam from that below the dam and adding the amount spilled over the wasteway, as computed from gage readings. September 20 to 28 the Hobson branch of Seward ditch diverted the totsl flow of the creek above its intake and the discharges were obtained by subtracting from the flow of the ditch the amount it had been carrying for the days just previous; for September 29 and 30 these figures are estimated.

$55695^{\circ}-$ Bull. $442-10-25$ 
Discharge measurements of Hobson Creek below Manila Creek in 1909.

[Drainage area, 5.1 square miles.]

\begin{tabular}{|c|c|c|c|c|c|}
\hline Point of measurement. & June 14. & July 15. & Aug. 1. & Aug. 10. & Sept. 12. \\
\hline 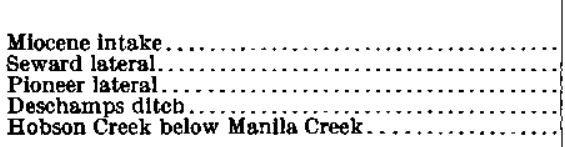 & $\begin{array}{c}\text { Sec. }-f t . \\
a 21.0 \\
0 \\
0 \\
0 \\
34.8\end{array}$ & $\begin{array}{r}\text { Sec. } \cdot f t . \\
15.9 \\
5.5 \\
4.3 \\
.2 \\
7.5\end{array}$ & $\begin{array}{r}\text { Sec. }-f t . \\
9.5 \\
3.2 \\
2.3 \\
3.3 \\
2.9\end{array}$ & $\begin{array}{r}\text { Sec. } f t . \\
8.3 \\
3.8 \\
1.7 \\
0 \\
4.2\end{array}$ & $\begin{array}{r}\text { Sec. ft. } \\
6.4 \\
2.5 \\
.85 \\
0 \\
4.9\end{array}$ \\
\hline $\begin{array}{l}\text { Per square mlle. } \\
\text { Ratlo of total to discharge at Miocene intake. }\end{array}$ & $\begin{array}{c}34.8 \\
6.82 \\
1.66\end{array}$ & $\begin{array}{c}33.4 \\
6.55 \\
2.10\end{array}$ & $\begin{array}{r}21.2 \\
4.16 \\
2.23\end{array}$ & $\begin{array}{c}18.0 \\
3.53 \\
2.17\end{array}$ & $\begin{array}{c}14.6 \\
2.86 \\
2.28\end{array}$ \\
\hline
\end{tabular}

a Discharge at $10 \mathrm{a} . \mathrm{m}$., when measurement was made below, no water diverted.

Daily discharge, in second-feet, of Miocene ditch for 1909.

\begin{tabular}{|c|c|c|c|c|c|c|c|c|c|c|c|c|}
\hline \multirow{2}{*}{ Day. } & \multicolumn{4}{|c|}{$\begin{array}{l}\text { Miocene ditch at Black } \\
\text { Point. }\end{array}$} & \multicolumn{4}{|c|}{$\begin{array}{l}\text { Miocene ditch above } \\
\text { Hobson Creek. }\end{array}$} & \multicolumn{4}{|c|}{$\begin{array}{l}\text { Miocene ditch at the } \\
\text { lume. }\end{array}$} \\
\hline & June. & July. & Aug. & Sept. & June. & July. & Aug. & Sept. & June. & July. & A ug. & Sept. \\
\hline 1. & & $\begin{array}{l}33.3 \\
33.3 \\
33.3 \\
33.3 \\
33.3\end{array}$ & $\begin{array}{r}7.5 \\
7.2 \\
11.6 \\
18.2 \\
11.4\end{array}$ & $\begin{array}{l}8.2 \\
8.2 \\
7.9 \\
7.9 \\
9.3\end{array}$ & & 27.2 & $\begin{array}{r}3.2 \\
2.8 \\
2.8 \\
16.8 \\
9.5\end{array}$ & $\begin{array}{l}2.4 \\
2.4 \\
1.8 \\
1.8 \\
3.0\end{array}$ & & $\begin{array}{l}43.6 \\
42.8 \\
43.9 \\
44.3 \\
43.2\end{array}$ & $\begin{array}{r}10.7 \\
9.5 \\
11.3 \\
20.8 \\
15.3\end{array}$ & $\begin{array}{l}8.9 \\
8.9 \\
8.3 \\
8.0 \\
9.2\end{array}$ \\
\hline $\begin{array}{l}8 . \\
9 .\end{array}$ & & $\begin{array}{l}40.4 \\
40.4 \\
42.2 \\
44.0 \\
44.0\end{array}$ & $\begin{array}{r}9.5 \\
9.3 \\
8.6 \\
40.8 \\
44.0\end{array}$ & $\begin{array}{r}10.0 \\
8.9 \\
7.4 \\
7.2 \\
7.2\end{array}$ & & & $\begin{array}{c}6.2 \\
1.8 \\
0 \\
17.4 \\
33.8\end{array}$ & $\begin{array}{l}2.0 \\
1.8 \\
1.8 \\
1.5 \\
1.8\end{array}$ & & $\begin{array}{l}45.8 \\
45.1 \\
44.7 \\
44.7 \\
44.7\end{array}$ & $\begin{array}{r}12.5 \\
9.5 \\
6.4 \\
21.7 \\
36.1\end{array}$ & $\begin{array}{l}7.8 \\
7.8 \\
7.7 \\
7.6 \\
7.1\end{array}$ \\
\hline : & & $\begin{array}{l}44.0 \\
44.0 \\
42.2 \\
36.1 \\
31.6\end{array}$ & $\begin{array}{l}28.4 \\
21.1 \\
28.4 \\
29.5 \\
25.0\end{array}$ & $\begin{array}{l}7.0 \\
6.5 \\
6.5 \\
7.9 \\
7.0\end{array}$ & & & & $\begin{array}{r}1.5 \\
1.2 \\
.8 \\
.8 \\
.8\end{array}$ & & $\begin{array}{l}4 . .4 \\
40.5 \\
37.6\end{array}$ & & $\begin{array}{l}6.6 \\
6.4 \\
6.2 \\
7.6 \\
6.2\end{array}$ \\
\hline$\cdots$ & & $\begin{array}{l}34.0 \\
31.2 \\
34.0 \\
29.8 \\
25.7\end{array}$ & $\begin{array}{l}18 \\
15 \\
14 \\
13 \\
12\end{array}$ & $\begin{array}{l}7.4 \\
7.4 \\
7.4 \\
6.5\end{array}$ & & 21 & $\begin{array}{r}10 . \\
9.0 \\
9 . \\
8 .\end{array}$ & $\begin{array}{l}.8 \\
.8 \\
.8 \\
.8\end{array}$ & $\begin{array}{r}6.2 \\
16.9\end{array}$ & $\begin{array}{l}34.3 \\
31.8\end{array}$ & & $\begin{array}{r}9.0 \\
11.3 \\
7.5 \\
7.2 \\
\ldots . .\end{array}$ \\
\hline$\cdots \cdots$ & $\begin{array}{l}12.0 \\
18.4 \\
26.4\end{array}$ & $\begin{array}{l}23.7 \\
21.8 \\
19.3 \\
16.5 \\
15.9\end{array}$ & $\begin{array}{l}12.5 \\
12.2 \\
11.8 \\
11.0 \\
10.0\end{array}$ & & $\begin{array}{l}12.7 \\
19.6 \\
21.0\end{array}$ & & $\begin{array}{l}7.8 \\
7.6 \\
6.6 \\
5.0 \\
4.6\end{array}$ & & $\begin{array}{l}21.1 \\
21.1 \\
27.5 \\
31.4 \\
35.4\end{array}$ & $\begin{array}{l}28.6 \\
26.2 \\
25.1 \\
22.4 \\
20.8\end{array}$ & $\begin{array}{l}14.1 \\
13.4 \\
12.8 \\
11.6 \\
11.6\end{array}$ & $\cdots$ \\
\hline$\cdots$ & $\begin{array}{l}29.8 \\
29.8 \\
29.8 \\
15.6 \\
33.3\end{array}$ & $\begin{array}{r}15.6 \\
15.1 \\
12.7 \\
11.0 \\
8.6 \\
7.9\end{array}$ & $\begin{array}{r}10.4 \\
10.8 \\
11.0 \\
9.6 \\
9.1 \\
9.5\end{array}$ & $\cdots$ & $\begin{array}{l}23.9 \\
23.9 \\
23.9 \\
22.4 \\
22.1\end{array}$ & $\begin{array}{r}10.9 \\
9.5 \\
9.0 \\
6.4 \\
5.8 \\
4.3\end{array}$ & $\begin{array}{l}4.6 \\
4.3 \\
4.6 \\
3.8 \\
3.0 \\
3.0\end{array}$ & $\begin{array}{c}\ldots \ldots \ldots \\
\cdots \ldots \ldots \\
\cdots \ldots \ldots \\
\cdots \ldots \ldots \\
\ldots \ldots \ldots\end{array}$ & $\begin{array}{c}39.0 \\
40.5 \\
41.7 \\
41.7 \\
37.9 \\
\ldots \ldots . .\end{array}$ & $\begin{array}{l}20.1 \\
19.2 \\
18.5 \\
15.6 \\
13.1 \\
11.9\end{array}$ & $\begin{array}{r}10.7 \\
11.6 \\
11.0 \\
9.5 \\
9.2\end{array}$ & $\begin{array}{c}\ldots \ldots \\
\ldots \ldots \\
\ldots \ldots \\
\ldots \ldots \\
\ldots \ldots\end{array}$ \\
\hline 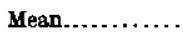 & 24.4 & 9. & 15.9 & 7.66 & 20.6 & 21.0 & 9.84 & 1.51 & 30.0 & 33.8 & 15.8 & 7.86 \\
\hline
\end{tabular}

NoTE-Discharges for all three stations are based on well-defined rating curves. Records at Black Point show the amount of water diverted from Nome River; those above Hobson show the amount delivered 12 miles below. The discharge below Hobson can be obtained by adding the flow of the creek to that of the ditch above, except for June 18 to 20 and June 28 to July 3 , when there was some waste from the spillway. The records at the flume show the amount delivered sbout 4 miles below Hobson Creek. 
Daily discharge, in second-feet, of Campion, Seward, and Pioneer ditches near their intakes for 1909 .

\begin{tabular}{|c|c|c|c|c|c|c|c|c|c|c|c|}
\hline \multirow{2}{*}{ Day. } & \multicolumn{3}{|c|}{$\begin{array}{l}\text { Campion ditch at } \\
\text { Black Point. }\end{array}$} & \multicolumn{4}{|c|}{ Seward ditch at intake. } & \multicolumn{4}{|c|}{ Pioneer ditch at intake. } \\
\hline & uly. & Aug. & Sept. & June. & July. & Aug. & Sept. & June. & July. & Aug. & Sept. \\
\hline $\begin{array}{l}1 . \\
2 . \\
3 . \\
4 . \\
5 .\end{array}$ & & $\begin{array}{l}2.8 \\
3.4 \\
4.2 \\
4.9 \\
4.9\end{array}$ & $\begin{array}{l}6.7 \\
7.1 \\
7.1 \\
8.0 \\
7.5\end{array}$ & & $\begin{array}{l}20.2 \\
20.2 \\
23.2 \\
28.0 \\
22.9\end{array}$ & $\begin{array}{r}9.5 \\
11.7 \\
17.0 \\
12.8 \\
13.4\end{array}$ & $\begin{array}{l}16.3 \\
15.7 \\
15.3 \\
15.0 \\
15.7\end{array}$ & & $\begin{array}{l}20.2 \\
23.2 \\
27.0 \\
26.2 \\
25.1\end{array}$ & $\begin{array}{l}12.7 \\
12.7 \\
14.7 \\
16.4 \\
12.7\end{array}$ & $\begin{array}{r}10.3 \\
9.7 \\
9.7 \\
9.7 \\
10.0\end{array}$ \\
\hline $\begin{array}{l}6 . \\
7 . \\
8 . \\
9 .\end{array}$ & & $\begin{array}{l}4.5 \\
4.5 \\
4.9 \\
4.9 \\
5.2\end{array}$ & $\begin{array}{l}7.1 \\
7.1 \\
6.0 \\
6.0 \\
6.0\end{array}$ & & $\begin{array}{l}26.8 \\
32.8 \\
32.8 \\
32.0 \\
28.0\end{array}$ & $\begin{array}{l}17.6 \\
18.3 \\
16.6 \\
27.8 \\
25.8\end{array}$ & $\begin{array}{l}16.6 \\
15.0 \\
15.0 \\
15.7 \\
15.0\end{array}$ & & $\begin{array}{l}26.6 \\
27.0 \\
27.0 \\
27.0 \\
26.2\end{array}$ & $\begin{array}{l}12.4 \\
11.5 \\
12.7 \\
23.2 \\
24.0\end{array}$ & $\begin{array}{r}10.0 \\
9.7 \\
9.7 \\
9.7 \\
9.7\end{array}$ \\
\hline - & & $\begin{array}{l}2.2 \\
2.2 \\
7.1 \\
\mathcal{\varepsilon} .0 \\
7.5\end{array}$ & $\begin{array}{l}5.6 \\
5.2 \\
5.2 \\
7.5 \\
7.1\end{array}$ & & $\begin{array}{l}29.2 \\
28.0 \\
19.5 \\
14.4 \\
13.1\end{array}$ & $\begin{array}{l}15 . \\
18 . \\
17 . \\
15 . \\
16 .\end{array}$ & $\begin{array}{l}15.0 \\
15.0 \\
16.6 \\
16.6 \\
17.0\end{array}$ & & $\begin{array}{l}27.0 \\
25.1 \\
26.6 \\
24.0 \\
21.7\end{array}$ & $\begin{array}{l}15.3 \\
15.0 \\
16.7 \\
16.0 \\
16.0\end{array}$ & $\begin{array}{r}9.7 \\
9.4 \\
9.7 \\
11.5 \\
9.7\end{array}$ \\
\hline$\ldots$ & & $\begin{array}{l}7.1 \\
7.1 \\
7.1 \\
8.0 \\
7.5\end{array}$ & $\begin{array}{l}8.0 \\
7.5 \\
7.1 \\
7.1\end{array}$ & & $\begin{array}{l}12.2 \\
12.2 \\
11.1 \\
10.5 \\
10.5\end{array}$ & $\begin{array}{l}16 . \\
16 . \\
17 . \\
15 . \\
17 .\end{array}$ & $\begin{array}{l}15.0 \\
15.0 \\
15.0 \\
14.4 \\
18.3\end{array}$ & & $\begin{array}{l}22.1 \\
20.2 \\
19.5 \\
19.5 \\
18.8\end{array}$ & $\begin{array}{l}15.3 \\
15.0 \\
14.0 \\
14.0 \\
13.4\end{array}$ & $\begin{array}{r}11.8 \\
9.7 \\
9.7 \\
9.7 \\
9.4\end{array}$ \\
\hline 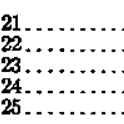 & & $\begin{array}{l}8.0 \\
7.5 \\
7.1 \\
7.1 \\
7.1\end{array}$ & & $\begin{array}{r}16.7 \\
15.0\end{array}$ & $\begin{array}{r}10.5 \\
10.5 \\
9.5 \\
9.5 \\
9.5\end{array}$ & $\begin{array}{l}16.6 \\
15.7 \\
15.3 \\
15.7 \\
15.3\end{array}$ & $\begin{array}{l}19.7 \\
18.3 \\
29.8 \\
25.8 \\
23.8\end{array}$ & $\begin{array}{l}10.9 \\
14.0 \\
12.7 \\
25.9 \\
22.1\end{array}$ & $\begin{array}{l}18.1 \\
17.4 \\
16.4 \\
15.7 \\
14.4\end{array}$ & $\begin{array}{l}13.4 \\
13.4 \\
12.7 \\
12.7 \\
12.7\end{array}$ & $\begin{array}{l}11.2 \\
12.7 \\
12.1 \\
24.0 \\
15.7\end{array}$ \\
\hline 8. & $\begin{array}{l}3.2 \\
3.2 \\
4.0 \\
4.9\end{array}$ & $\begin{array}{l}7.1 \\
7.3 \\
7.5 \\
8.0 \\
7.1 \\
6.7\end{array}$ & $\begin{array}{l}\ldots \ldots \ldots \\
\ldots \ldots \ldots \\
\cdots \ldots \ldots \\
\ldots \ldots \ldots \\
\ldots \ldots \ldots\end{array}$ & $\begin{array}{l}16.7 \\
16.7 \\
16.7 \\
16.7 \\
19.2\end{array}$ & $\begin{array}{r}9.5 \\
10.0 \\
10.0 \\
10.0 \\
10.8 \\
10.8\end{array}$ & $\begin{array}{l}17.0 \\
16.6 \\
15.7 \\
15.0 \\
16.6 \\
15.0\end{array}$ & $\begin{array}{r}19.0 \\
17.6 \\
17.2 \\
\cdots \cdots\end{array}$ & $\begin{array}{l}\mathbf{1 6 . 7} \\
18.1 \\
25.1 \\
25.1 \\
25.5\end{array}$ & $\begin{array}{l}14.4 \\
14.0 \\
14.0 \\
13.4 \\
13.4 \\
17.4\end{array}$ & $\begin{array}{l}12.4 \\
12.7 \\
11.5 \\
11.5 \\
10.9 \\
10.3\end{array}$ & $\begin{array}{r}13.4 \\
14.4 \\
12.7 \\
\ldots \ldots . \\
\ldots \ldots . \\
\ldots \ldots\end{array}$ \\
\hline Mean... & 3.82 & 6.08 & 6.78 & 16.8 & 17.4 & 16.5 & 17.3 & 19.6 & 20.9 & 14.1 & $\overline{11.2}$ \\
\hline
\end{tabular}

Note.-Discharges for all three stations are based on well-defined rating curves, Two were used for the Seward ditch station, covering the periods June 24 to August 5 and $A$ ugust 6 to Beptember 28 . T'hese records show the amount of water diverted by the ditches.

Daily discharge, in second-feet, of Seward ditch for 1909.

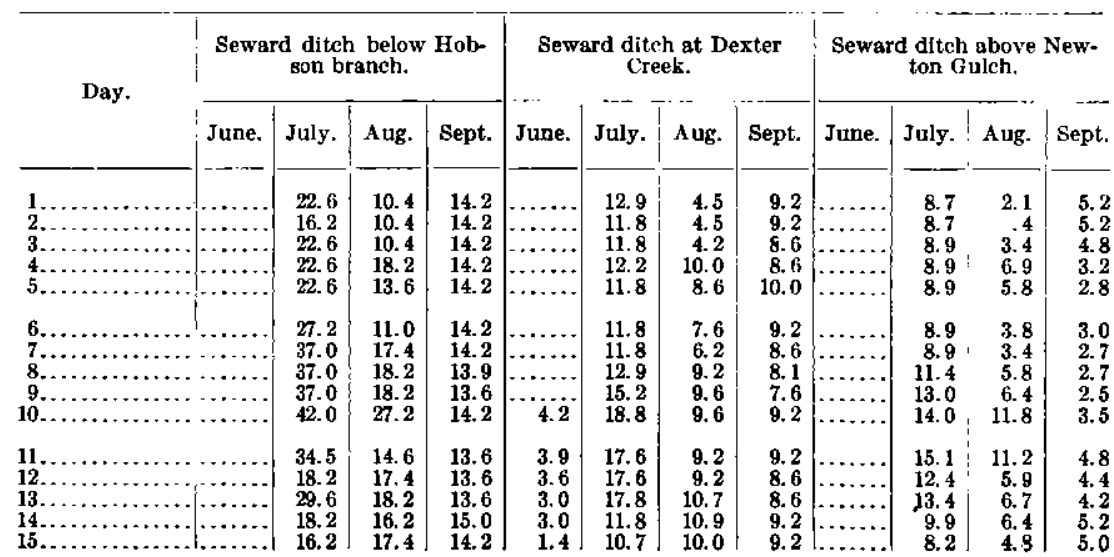


Daily discharge, in second-feet, of Seward ditch for 1909-Continued.

\begin{tabular}{|c|c|c|c|c|c|c|c|c|c|c|c|c|}
\hline \multirow{3}{*}{$a y$. } & \multicolumn{4}{|c|}{$\begin{array}{l}\text { Seward ditch below Holt } \\
\text { son tranch. }\end{array}$} & \multicolumn{4}{|c|}{$\begin{array}{l}\text { Seward diteh at Dexter } \\
\text { Creek. }\end{array}$} & \multicolumn{4}{|c|}{$\begin{array}{l}\text { Seward ditch aloove New- } \\
\text { ton Gulch. }\end{array}$} \\
\hline & & & & & & & & & & & & \\
\hline & June. & July. & Aug. & Sept. & J une. & July. & Aug. & Sept. & June. & July. & $\Lambda \mathrm{ug}$. & Sept. \\
\hline $\begin{array}{l}\text { fi... } \\
7 . .\end{array}$ & & $\begin{array}{l}18.2 \\
16.2 \\
16.2 \\
12.6 \\
12.6\end{array}$ & & $\begin{array}{l}14.2 \\
14.2 \\
14.2 \\
14.2 \\
24.9\end{array}$ & $\begin{array}{l}\text { 1. } 0 \\
\text { 6. } 7 \\
6.7 \\
\text { (i. } 7 \\
\text { i. } 7\end{array}$ & $\begin{array}{l}9.2 \\
8.8 \\
7.6 \\
7.8 \\
6.7\end{array}$ & $\begin{array}{l}8.4 \\
8.0 \\
8.0 \\
8.6 \\
8.6\end{array}$ & $\begin{array}{r}9.6 \\
11.8 \\
10.7 \\
12.2 \\
11.4\end{array}$ & & $\begin{array}{l}6.9 \\
6.6 \\
5.7 \\
4.4 \\
3.2\end{array}$ & $\begin{array}{l}4.7 \\
4.4 \\
3.6 \\
3.8 \\
3.5\end{array}$ & $\begin{array}{l}4.8 \\
\text { ti. } 6 \\
5.3 \\
4.7 \\
7.1\end{array}$ \\
\hline$\cdots$ & $\begin{array}{l}11.2 \\
18.2\end{array}$ & $\begin{array}{l}12.6 \\
12.6 \\
11.6 \\
11.6 \\
11.6\end{array}$ & $\begin{array}{l}15.0 \\
14.2 \\
14.2 \\
14.2 \\
14.2\end{array}$ & $\begin{array}{l}27.2 \\
27.2 \\
27.2 \\
27.2 \\
32.0\end{array}$ & $\begin{array}{r}9.6 \\
12.9 \\
11.8 \\
9.6 \\
11.8\end{array}$ & $\begin{array}{l}7.2 \\
6.2 \\
6.0 \\
5.5 \\
5.5\end{array}$ & $\begin{array}{l}8.6 \\
8.6 . \\
9.2 \\
9.2 \\
8.6\end{array}$ & $\begin{array}{l}16.4 \\
18.8 \\
19.3 \\
20.8 \\
20.8\end{array}$ & $\begin{array}{l}8.5 \\
8.5\end{array}$ & & 4. 2 & $\begin{array}{l}13.0 \\
13.4 \\
15.0 \\
15.2\end{array}$ \\
\hline $\begin{array}{l}\ldots \\
\cdots \\
\cdots \\
\cdots\end{array}$ & $\begin{array}{l}18.2 \\
27.2 \\
18.2 \\
24.9 \\
18.2\end{array}$ & $\begin{array}{l}10.4 \\
11.0 \\
11.0 \\
11.0\end{array}$ & $\begin{array}{l}14.2 \\
14.2 \\
14.2 \\
14.2 \\
14.2 \\
14,2\end{array}$ & $\begin{array}{l}27.2 \\
24.9 \\
29.10 \\
\cdots \cdots\end{array}$ & $\begin{array}{r}11.8 \\
10.7 \\
23.8 \\
9.6 \\
9.6\end{array}$ & $\begin{array}{l}4.8 \\
4.5 \\
4.5 \\
4.8 \\
4.9 \\
5.0\end{array}$ & $\begin{array}{r}8.0 \\
9.6 \\
10.0 \\
10.0 \\
9.6 \\
9.6\end{array}$ & $\begin{array}{l}16.4 \\
16.4\end{array}$ & $\begin{array}{r}8.7 \\
9.2 \\
10.7 \\
12.4 \\
8.7\end{array}$ & $\begin{array}{r}1.2 \\
1.1 \\
1.4 \\
.6 \\
.1 \\
.1\end{array}$ & $\begin{array}{l}3.8 \\
4.7 \\
5.0 \\
\text { i. } 4 \\
5.8 \\
5.2\end{array}$ & $\begin{array}{c}10.7 \\
13.0 \\
\ldots . \\
\cdots \\
\cdots\end{array}$ \\
\hline$\ldots$. & 20.2 & 19.5 & 15.2 & 18.4 & 8. 00 & 9.80 & 8.60 & 11.8 & 9.53 & 6.56 & 4.91 & 6. 60 \\
\hline
\end{tabular}

NOTE.-Discharges for all three siations are based on fairly well defined rating curves. There is practically no inflow between these stations, and the dilterences between upper and lower points show the loss by seepage from the ditch. The Hobson branch enters just above the first station, and its mean discharge was as follows: June 24 to $30,5.77$ second-feet; July, 5.00 second-feet; A ugust, 3.18 second-feet; September 1 to $28,4.58$ second-feet. The discharge at Dexter Creek prior to June 24 came from melting snow, and no record was kept of the amount delivered to Newton Gulch.

\section{GRAND CENTRAL RIVER DRAINAGE BASIN.}

Grand Central River rises in the heart of the Kigluaik Mountains, where the peaks reach an elevation of 3,000 to 4,500 feet. The river and its tributaries head in glacial cirques and flow through $U$-shaped valleys over broad gravel beds. North Fork rises on the east side of Mount Osborn, the highest peak of the range; West Fork rises to the south of the same mountain, and the two forks join at elevation 690 feet. West Fork receives the waters of Crater Lake, a glacial lake having an area of 43 acres, through a short tributary from the south. About 3 miles below the junction of the forks the river is joined by the two principal tributaries, Thompson Creek from the west and Gold Run from the east. From this point the river flows southeastward into Salmon Lake.

In order to make the waters of Grand Central River available for use near Nome, they must be carried over the Nugget divide, which has an elevation of 785 feet. The diversion must be made about a mile above the forks, and 8 or 9 miles of ditch will be required. There are two waterways being built to divert this water-a 42-inch woodpipe line, starting at Crater Lake, with laterals taking water from North Fork at about elevation 1,030 feet and from West Fork at elevation 1,010 feet, and a ditch 8 feet wide on the bottom with a 5 -foot bank, having its intake on the forks at an elevation of about 850 feet. 
The following stations have been maintained on Grand Central River and its tributaries:

West Fork at pipe intake, 1906, 1907, and 1909.

West Fork at ditch intake, 1906-7.

West Fork at the forks, 1907-1909.

Grand Central River below the forks, 1906-1908 and 1909.

Crater Lake outlet, 1906-1909.

North Fork at pipe intake, 1906-1909.

North Fork at ditch intake, 1906.

North Fork at the forks, 1907.

Gold Run below ditch intake, 1906- 7 .

Thompson Creek below ditch intake, 1906-1909.

Grand Central branch of Miocene ditch, 1907 and 1909.

Jett Creek branch of Miocene ditch, 1907 and 1909.

The daily discharge of four of the most important stations is given below, and a list of miscellaneous measurements made in the basin may be found on page 409. A table of monthly discharge of Grand Central River below the forks for 1906 to 1909 is given for comparative purposes.

Monthly discharge of Grand Central River below the forks for 1906 to 1909.

[Drainage area, 14.6 sqitare miles.]

\begin{tabular}{|c|c|c|c|c|c|}
\hline \multirow[b]{2}{*}{ Month. } & \multicolumn{4}{|c|}{ Discharge in second-feet. } & \multirow{2}{*}{$\begin{array}{l}\text { Kun-off } \\
\text { (depth in } \\
\text { inches on } \\
\text { drainage } \\
\text { area). }\end{array}$} \\
\hline & Maxinum. & Minimim. & Mean. & $\begin{array}{l}\text { Per } \\
\text { square } \\
\text { mile. }\end{array}$ & \\
\hline 1906. & & & & & \\
\hline June $24-30 \ldots$ & 150 & 75 & 112 & 7. 67 & 2.00 \\
\hline July .......... & 1.160 & 56 & 185 & 12.7 & 14.64 \\
\hline August..... & 210 & 53 & 85.2 & 5.84 & 6.73 \\
\hline September. & 510 & 47 & $12 \mathrm{I}$ & 8.29 & 9.25 \\
\hline The perlod, 99 days. & 1,160 & 47 & 129 & 8.84 & 32.62 \\
\hline 1907. & & & & & \\
\hline July $8-31 \ldots \ldots$ & 220 & 74 & 133 & 9.11 & 8.13 \\
\hline August $\ldots \ldots \ldots$ & 463 & 72 & 142 & 9.73 & 11.22 \\
\hline September 1-23.. & 770 & 55 & 174 & 11.9 & 10.18 \\
\hline The period, 78 days... & 770 & 55 & 149 & 10.2 & 29.53 \\
\hline 1908. & & & & & \\
\hline July. & 180 & 29 & 62.7 & 4. 29 & 4.95 \\
\hline Augu & 225 & 71 & 123 & 8.42 & 9.71 \\
\hline Septeml & 146 & 33 & 52.6 & 3. 60 & 4.02 \\
\hline The period, 92 days.. & 225 & 33 & 79.6 & 5.46 & 18. 68 \\
\hline 1909. & & & & & \\
\hline July............. & 200 & 37 & 101 & 6.92 & 7.98 \\
\hline August. ...... & 122 & 36 & 53 & 3.63 & 4.18 \\
\hline September $1-21$. & 36 & 28 & 31.9 & 2.18 & 1.70 \\
\hline The period, 83 days.... & 200 & 28 & 65.8 & 4.51 & 13.80 \\
\hline
\end{tabular}

NOTE.-Discharges for 1906 have been revised and missing periods estimated; for 1907 they are the combined dicharges at the stations on West and North forks. 
Daily discharge, in second-feet, of Grand Central River and tributaries for 1909.

\begin{tabular}{|c|c|c|c|c|c|c|c|c|c|c|c|c|}
\hline \multirow[t]{2}{*}{ Day. } & \multicolumn{3}{|c|}{$\begin{array}{l}\text { Grand Central River } \\
\text { below the forks. } \\
\text { Elevation, } 680 \text { feet; } \\
\text { drainage area, 14.6 } \\
\text { square miles. }\end{array}$} & \multicolumn{3}{|c|}{$\begin{array}{l}\text { West Fork of Grand } \\
\text { Central River at } \\
\text { the forks. Ele- } \\
\text { vation, 690 feet; } \\
\text { drainage area, } 7.7 \\
\text { square miles. }\end{array}$} & \multicolumn{3}{|c|}{$\begin{array}{l}\text { Crater Lake outlet. } \\
\text { Elevation, 925 feet; } \\
\text { drainage area, } 1.8 \\
\text { square miles. }\end{array}$} & \multicolumn{3}{|c|}{$\begin{array}{l}\text { Thompson Cre e k } \\
\text { below ditch in- } \\
\text { take. Elevation, } \\
720 \text { feet; drainage } \\
\text { area, 2.5 square } \\
\text { miles. }\end{array}$} \\
\hline & July. & Aug. & Sept. & July. & Aug. & Sept. & July. & Aug. & Sept. & July. & Aug. & Sept. \\
\hline & $\begin{array}{l}200 \\
195 \\
195 \\
185 \\
175\end{array}$ & $\begin{array}{l}41 \\
44 \\
55 \\
65 \\
58\end{array}$ & $\begin{array}{l}34 \\
33 \\
32 \\
33 \\
36\end{array}$ & $\begin{array}{l}122 \\
118 \\
118 \\
112 \\
106\end{array}$ & $\begin{array}{l}25 \\
28 \\
36 \\
39 \\
33\end{array}$ & $\begin{array}{l}19.0 \\
19.0 \\
18.1 \\
19.0 \\
20\end{array}$ & $\begin{array}{l}24 \\
23 \\
23 \\
22 \\
22\end{array}$ & $\begin{array}{l}4.6 \\
5.2 \\
7.5 \\
6.5 \\
5.5\end{array}$ & $\begin{array}{l}2.7 \\
2.4 \\
2.3 \\
2.2 \\
2.8\end{array}$ & $\begin{array}{l}36 \\
36 \\
36 \\
34 \\
32\end{array}$ & $\begin{array}{r}5.5 \\
7.6 \\
9.9 \\
14.5 \\
8.5\end{array}$ & $\begin{array}{l}4.0 \\
3.7 \\
3.6 \\
3.5 \\
4.0\end{array}$ \\
\hline $\begin{array}{l}6 . \\
7 . \\
8 . \\
9\end{array}$ & $\begin{array}{l}180 \\
170 \\
160 \\
145 \\
134\end{array}$ & $\begin{array}{r}46 \\
42 \\
40 \\
122 \\
97\end{array}$ & $\begin{array}{l}35 \\
35 \\
34 \\
32 \\
31\end{array}$ & $\begin{array}{l}110 \\
107 \\
104 \\
101 \\
98\end{array}$ & $\begin{array}{l}31 \\
28 \\
25 \\
50 \\
60\end{array}$ & $\begin{array}{l}19.0 \\
19.0 \\
18.1 \\
18.1 \\
18.1\end{array}$ & $\begin{array}{l}22 \\
22 \\
21 \\
21 \\
20.9\end{array}$ & $\begin{array}{r}7.5 \\
5.7 \\
4.6 \\
10.4 \\
10.2\end{array}$ & $\begin{array}{l}3.0 \\
2.7 \\
2.5 \\
2.4 \\
2.3\end{array}$ & $\begin{array}{l}34 \\
32 \\
30 \\
28 \\
27\end{array}$ & $\begin{array}{l}7.4 \\
6.2 \\
6.2 \\
21 \\
16\end{array}$ & $\begin{array}{l}3.5 \\
3.2 \\
2.8 \\
2.8 \\
2.8\end{array}$ \\
\hline$\cdots+\cdots$ & $\begin{array}{r}123 \\
116 \\
110 \\
88 \\
75\end{array}$ & $\begin{array}{l}70 \\
57 \\
63 \\
71 \\
64\end{array}$ & $\begin{array}{l}31 \\
30 \\
32 \\
32 \\
32\end{array}$ & $\begin{array}{l}94 \\
90 \\
81 \\
72 \\
60\end{array}$ & $\begin{array}{l}39 \\
31 \\
37 \\
34 \\
33\end{array}$ & $\begin{array}{l}17.2 \\
17.2 \\
18.1 \\
17.2 \\
17\end{array}$ & $\begin{array}{l}20.0 \\
19.2 \\
17.0 \\
12.2 \\
11.1\end{array}$ & $\begin{array}{r}10.0 \\
9.0 \\
10.4 \\
10.6 \\
9.3\end{array}$ & $\begin{array}{l}2.3 \\
2.2 \\
2.3 \\
2.2 \\
2.2\end{array}$ & $\begin{array}{c}57 \\
21 \\
15 \\
7.1 \\
14\end{array}$ & $\begin{array}{r}10.8 \\
8.5 \\
9.9 \\
13.0 \\
12.2\end{array}$ & $\begin{array}{l}2.8 \\
2.9 \\
3.0 \\
3.0 \\
2.8\end{array}$ \\
\hline$\ldots \ldots \ldots$ & $\begin{array}{l}64 \\
62 \\
71 \\
74 \\
72\end{array}$ & $\begin{array}{l}57 \\
54 \\
52 \\
50 \\
48\end{array}$ & $\begin{array}{l}31 \\
31 \\
30 \\
29 \\
29\end{array}$ & $\begin{array}{l}52 \\
50 \\
50 \\
50 \\
50\end{array}$ & $\begin{array}{l}31 \\
30 \\
29 \\
28 \\
28\end{array}$ & $\begin{array}{l}16 \\
16 \\
16 \\
15 \\
15\end{array}$ & $\begin{array}{l}10.0 \\
10.0 \\
10.4 \\
11.6 \\
10.8\end{array}$ & & $\begin{array}{l}2.1 \\
2.0 \\
2.0 \\
1.9 \\
1.8\end{array}$ & $\begin{array}{l}15 \\
15.8 \\
25 \\
21 \\
15.8\end{array}$ & $\begin{array}{r}10.0 \\
9.3 \\
8.5\end{array}$ & $\begin{array}{l}2.7 \\
2.6 \\
2.5 \\
2.4 \\
2.3\end{array}$ \\
\hline …... & $\begin{array}{l}62 \\
60 \\
60 \\
51 \\
50\end{array}$ & $\begin{array}{l}47 \\
45 \\
43 \\
42 \\
40\end{array}$ & 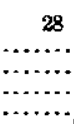 & $\begin{array}{l}\mathbf{4 6} \\
\mathbf{4 1} \\
36 \\
\mathbf{3 1} \\
\mathbf{3 3}\end{array}$ & $\begin{array}{l}27 \\
26 \\
26 \\
25 \\
24\end{array}$ & $\begin{array}{r}14.5 \\
\cdots \cdots\end{array}$ & $\begin{array}{l}\text { 8.3 } \\
8.3 \\
\text { 8.2 } \\
6.2 \\
\text { 5. }\end{array}$ & $\begin{array}{l}5.6 \\
5.3 \\
5.0 \\
4.7 \\
4.5\end{array}$ & 1.6 & $\begin{array}{r}13.3 \\
12.0 \\
11.4 \\
7.1 \\
10.8\end{array}$ & $\begin{array}{l}7.8 \\
7.0 \\
6.2 \\
5.5 \\
4.8\end{array}$ & $\begin{array}{l}2.3 \\
\cdots \cdots \\
\cdots \cdots \\
\cdots \cdots\end{array}$ \\
\hline 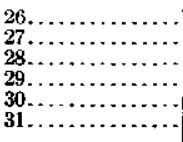 & $\begin{array}{l}49 \\
48 \\
50 \\
43 \\
41 \\
37 \\
\end{array}$ & $\begin{array}{l}40 \\
36 \\
36 \\
38 \\
42 \\
39 \\
\end{array}$ & 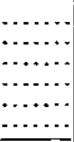 & $\begin{array}{l}31 \\
31 \\
28 \\
30 \\
28 \\
27 \\
\end{array}$ & $\begin{array}{l}24 \\
21 \\
20 \\
20 \\
22 \\
20\end{array}$ & & $\begin{array}{l}\mathbf{5 . 0} \\
5.0 \\
5.0 \\
5.5 \\
5.0 \\
\mathbf{4 . 2}\end{array}$ & $\begin{array}{l}4.5 \\
3.5 \\
3.0 \\
3.0 \\
3.5 \\
3.0 \\
\end{array}$ & $\begin{array}{l}\because . \\
. \\
.\end{array}$ & $\begin{array}{r}10.0 \\
8.5 \\
7.1 \\
7.6 \\
7.0 \\
6.2\end{array}$ & $\begin{array}{l}4.0 \\
3.8 \\
3.5 \\
3.5 \\
4.5 \\
4.2 \\
\end{array}$ & $\begin{array}{l}\cdots \cdots \\
\cdots \cdots \\
\cdots \cdots \\
\cdots \cdots \\
\cdots \cdots \\
\cdots\end{array}$ \\
\hline Mean -oif per & 101 & 0 & $\overline{31.9}$ & 68.0 & 0 & 17.5 & 13.5 & 6.29 & 2.28 & 20.4 & .45 & $\overline{3.01}$ \\
\hline 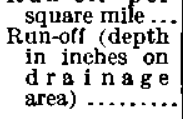 & 7.98 & 4.18 & 1.70 & 10.18 & 4.50 & 1.77 & 8. 65 & 4.02 & 1.27 & 8.16 & 3. 38 & 1.20 \\
\hline
\end{tabular}

Nore.-The rating tables used in cornputing these daily discharges are all well defined. There were no gage readings before July 10, from August 18 to 31 , and from September 15 to 20 , and discharges for these periods have been estimated, largely on the basis of the rate of rise and fall of Kruzgamepa River at Salmon Lake. Records for the low-water periods are belleved to be very reliable, but for the first half of July they are only approximate on account of diurnal fluctuations. 


\section{KRUZGAMTPA RIVER DRAINAGE BASIN.}

Kruzgamepa or Pilgrim River rises in Salmon Lake and, after traversing a valley filled with glacial débris, flows around the east end of the Kigluaik Mountains and through broad flats to Imuruk Basin. Its principal tributaries are Iron and Sherrette creeks from the south; Crater, Big, and Homestake creeks from the southern slope of the Kigluaik Mountains; and Goldengate, Pass, Smith, Grand Union, Osborn, Westend, and several unnamed creeks from the northern slope of the mountains. The Kruzgamepa and its tributaries offer excellent opportunities for power development. Salmon Lake has an area of 1,865 acres and a good dam site at its outlet and offers good facilities for storing the spring flood waters for use later in the season. The streams on the north side of the mountains have a prodigious fall, amounting in places to over 1,000 feet in 2 or 3 miles, and the amount of power which they can be made to furnish is very great. Records of stream discharge in the basin have been kept largely to obtain data on power available, as mining is confined almost wholly to Iron Creek and its tributaries.

The following gaging stations have been maintained on Kruzgamepa River and its tributaries:

Kruzgamepa River at Salmon Lake, 1906-1909.

Kruzgamepa River above Iron Creek, 1908.

Dome Creek below Telegram Creek, August 1 to 17, 1907.

Iron Creek below Canyon Creek, August 1 to 17, 1907.

Iron Creek near mouth, 1908-1909.

Pass Creek below lower lake, parts of 1908 and 1909.

Smith Creek below Swift Creek, parts of 1908 and 1909.

For Kruzgamepa River at Salmon Lake the total run-off is sought as the spring flood water can be stored and held until later in the season. The discharge at the station for the periods not covered by observation has been estimated on the basis of the best available data and the yearly values are given below. They are believed to be sufficiently accurate for general comparative purposes. 
Monthly discharge of Kruzgamepa River at Salmon Lake for 1906 to 1909.

[Drainage area, 84 square miles.]

\begin{tabular}{|c|c|c|c|c|c|c|}
\hline \multirow[b]{2}{*}{ Month. } & \multicolumn{4}{|c|}{ Discharge in second-feet. } & \multicolumn{2}{|c|}{ Run-off. } \\
\hline & Maximum. & Minimum. & Mean. & $\begin{array}{c}\text { Per } \\
\text { square } \\
\text { mile. }\end{array}$ & $\begin{array}{l}\text { Depth in } \\
\text { inches on } \\
\text { drainage } \\
\text { area. }\end{array}$ & $\begin{array}{l}\text { Total in } \\
\text { acre-feet. }\end{array}$ \\
\hline 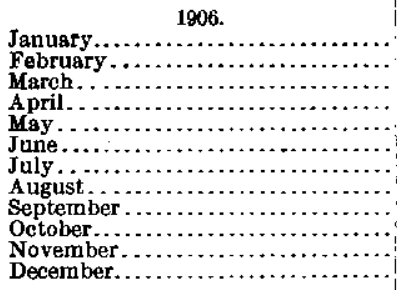 & $\begin{array}{r}3,450 \\
3,360 \\
2,130 \\
475 \\
1,460 \\
390 \\
.2 . \\
.2 .\end{array}$ & $\begin{array}{r}50 \\
308 \\
235 \\
175 \\
175 \\
\cdots \cdots \\
\cdots \\
\cdots\end{array}$ & $\begin{array}{r}80 \\
60 \\
50 \\
50 \\
888 \\
1,110 \\
575 \\
260 \\
466 \\
210 \\
110 \\
90\end{array}$ & $\begin{array}{c}0.95 \\
.71 \\
.60 \\
.60 \\
10.6 \\
13.2 \\
6.85 \\
3.17 \\
5.55 \\
2.50 \\
1.31 \\
1.07\end{array}$ & $\begin{array}{r}1.10 \\
.74 \\
.69 \\
.67 \\
12.22 \\
14.73 \\
7.90 \\
3.66 \\
6.19 \\
2.88 \\
1.46 \\
1.23\end{array}$ & $\begin{array}{r}4,920 \\
3,330 \\
3,070 \\
2,980 \\
54,600 \\
66,000 \\
35,400 \\
16,400 \\
27,700 \\
12,900 \\
6,540 \\
5,530\end{array}$ \\
\hline The year. & 3,360 & $\cdots$ & 330 & 3.92 & 53.47 & 239,000 \\
\hline 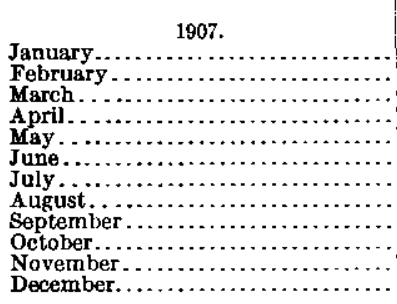 & $\begin{array}{r}2,500 \\
2,600 \\
875 \\
555 \\
1,560 \\
205\end{array}$ & 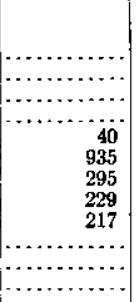 & $\begin{array}{r}70 \\
60 \\
50 \\
40 \\
507 \\
1,870 \\
555 \\
347 \\
489 \\
150 \\
90 \\
70\end{array}$ & $\begin{array}{r}.83 \\
.71 \\
.60 \\
.48 \\
6.04 \\
22.3 \\
6.61 \\
4.13 \\
5.82 \\
1.79 \\
1.07 \\
.83\end{array}$ & $\begin{array}{r}.96 \\
.74 \\
.69 \\
.54 \\
6.96 \\
24.88 \\
7.62 \\
4.76 \\
6.49 \\
2.06 \\
1.19 \\
.96\end{array}$ & $\begin{array}{r}4,300 \\
3,330 \\
3,070 \\
2,380 \\
31,200 \\
111,000 \\
34,100 \\
21,300 \\
29,100 \\
9,220 \\
5,360 \\
. \quad 4,300\end{array}$ \\
\hline The year.. & 2,600 & $\cdots$ & 358 & 4.27 & 57.85 & 259,000 \\
\hline 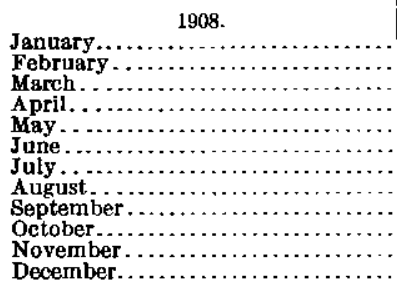 & $\begin{array}{r}1,100 \\
1,100 \\
375 \\
465 \\
210 \\
103 \\
70 \\
67\end{array}$ & $\begin{array}{r}40 \\
395 \\
92 \\
210 \\
92 \\
72 \\
67 \\
\end{array}$ & $\begin{array}{l}60 \\
50 \\
50 \\
40 \\
413 \\
732 \\
188 \\
299 \\
161 \\
80.0 \\
68.1 \\
65\end{array}$ & $\begin{array}{r}.71 \\
.60 \\
.60 \\
.48 \\
4.92 \\
8.71 \\
2.24 \\
3.50 \\
1.92 \\
.95 \\
.81 \\
.77\end{array}$ & $\begin{array}{r}.82 \\
.65 \\
.69 \\
.54 \\
5.67 \\
9.72 \\
2.58 \\
4.10 \\
2.14 \\
1.10 \\
.90 \\
.89\end{array}$ & $\begin{array}{r}3,690 \\
2,880 \\
3,070 \\
2,380 \\
25,400 \\
43,600 \\
11,600 \\
18,400 \\
9,580 \\
4,920 \\
4,050 \\
4,000\end{array}$ \\
\hline The year... & 1.100 & ……․ & 184 & 2.19 & 29.80 & 134,000 \\
\hline 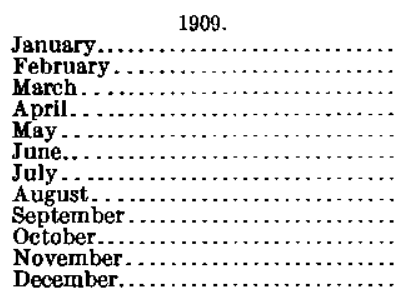 & $\begin{array}{r}1,100 \\
1,000 \\
674 \\
184 \\
123 \\
87 \\
71 \\
53\end{array}$ & $\begin{array}{r}40 \\
40 \\
590 \\
125 \\
113 \\
91 \\
52 \\
53 \\
5 \ldots \ldots\end{array}$ & $\begin{array}{l}60 \\
50 \\
40 \\
40 \\
348 \\
874 \\
349 \\
149 \\
108 \\
70.0 \\
60.6 \\
50\end{array}$ & $\begin{array}{r}.71 \\
.60 \\
.48 \\
.48 \\
4.14 \\
10.4 \\
4.15 \\
1.77 \\
1.29 \\
.83 \\
.72 \\
.60\end{array}$ & $\begin{array}{r}.82 \\
.62 \\
.55 \\
.54 \\
4.77 \\
11.60 \\
4.78 \\
2.04 \\
1.44 \\
.96 \\
.80 \\
.69\end{array}$ & $\begin{array}{r}3,690 \\
2,780 \\
2,460 \\
2,380 \\
21,400 \\
52,000 \\
21,500 \\
9,160 \\
6,430 \\
4,300 \\
3,610 \\
3,070\end{array}$ \\
\hline The yoar. & 1,190 & & 183 & 2.18 & 29.61 & 133,000 \\
\hline
\end{tabular}

Note,-Yearly values for 1906 and 1909 are believed to be within 10 or 15 per cent of the true values as only 30 and 25 per cent respectively of the totals have been estimated. Yearly values for 1907 and 1908 are liable to greater error, as over 50 per cent of the totais had to be estimated. The time when the river broke each year is known within a few days, and the maximum flood can be approximated. Values for February to April are uncertain, but they have little bearing on the yearly totals. 
Daily discharge, in second-feet, of Kruzgamepa River and Iron Creek for 1909.

\begin{tabular}{|c|c|c|c|c|c|c|c|c|c|c|c|c|}
\hline \multirow{2}{*}{ Day. } & \multicolumn{8}{|c|}{$\begin{array}{c}\text { Kruzgamepa River at Salmon Lake.a Elevation, } 442 \text { feet; } \\
\text { drainage area, } 84 \text { square miles. }\end{array}$} & \multicolumn{4}{|c|}{$\begin{array}{l}\text { Iron Creek above tunnel. } \\
\text { Elevation, } 280 \text { feet; drain- } \\
\text { age area, } 50 \text { square miles. }\end{array}$} \\
\hline & May. & June. & July. & Aug. & Sept. & Oet. & Nov. & Dec. & June. & July. & Aug. & Sept. \\
\hline $\begin{array}{l}1 . \\
2 . \\
3 . \\
4 . \\
5 .\end{array}$ & & $\begin{array}{r}1,000 \\
980 \\
980 \\
917 \\
938\end{array}$ & $\begin{array}{l}674 \\
656 \\
650 \\
614 \\
579\end{array}$ & $\begin{array}{l}127 \\
125 \\
117 \\
130 \\
134\end{array}$ & $\begin{array}{l}123 \\
117 \\
115 \\
113 \\
119\end{array}$ & $\begin{array}{l}87 \\
87 \\
84 \\
82 \\
81\end{array}$ & $\begin{array}{l}71 \\
68 \\
67 \\
65 \\
64\end{array}$ & $\begin{array}{l}\mathbf{5 3} \\
\mathbf{5 2} \\
\mathbf{5 2} \\
\mathbf{5 2} \\
\mathbf{5 2}\end{array}$ & & $\begin{array}{l}194 \\
129 \\
149 \\
138 \\
123\end{array}$ & $\begin{array}{l}19 \\
19 \\
24 \\
30 \\
24\end{array}$ & $\begin{array}{l}19 \\
17 \\
18 \\
17 \\
17\end{array}$ \\
\hline $\begin{array}{r}6 . \\
7 . \\
8 . \\
9 . \\
10 .\end{array}$ & & $\begin{array}{l}910 \\
966 \\
924 \\
896 \\
903\end{array}$ & $\begin{array}{l}590 \\
568 \\
530 \\
491 \\
475\end{array}$ & $\begin{array}{l}139 \\
127 \\
113 \\
121 \\
184\end{array}$ & $\begin{array}{l}119 \\
117 \\
115 \\
111 \\
111\end{array}$ & $\begin{array}{l}79 \\
77 \\
77 \\
79 \\
65\end{array}$ & $\begin{array}{l}64 \\
63 \\
63 \\
61 \\
63\end{array}$ & $\begin{array}{l}52 \\
51 \\
51 \\
51 \\
51\end{array}$ & & $\begin{array}{r}122 \\
121 \\
94 \\
89 \\
83\end{array}$ & $\begin{array}{l}23 \\
25 \\
22 \\
50 \\
50\end{array}$ & $\begin{array}{l}16 \\
17 \\
17 \\
17 \\
17\end{array}$ \\
\hline $\begin{array}{l}13 . . \\
14 . \\
15 .\end{array}$ & & $\begin{array}{l}910 \\
917 \\
924 \\
931 \\
917\end{array}$ & $\begin{array}{l}430 \\
412 \\
385 \\
340 \\
296\end{array}$ & $\begin{array}{l}179 \\
173 \\
173 \\
170 \\
173\end{array}$ & $\begin{array}{l}111 \\
111 \\
111 \\
111 \\
107\end{array}$ & $\begin{array}{l}64 \\
64 \\
64 \\
63 \\
64\end{array}$ & $\begin{array}{l}63 \\
64 \\
64 \\
63 \\
61\end{array}$ & $\begin{array}{l}51 \\
51 \\
51 \\
51 \\
51\end{array}$ & & $\begin{array}{l}84 \\
66 \\
63 \\
50 \\
45\end{array}$ & $\begin{array}{l}36 \\
34 \\
42 \\
37 \\
29\end{array}$ & $\begin{array}{l}17 \\
18 \\
25 \\
23 \\
23\end{array}$ \\
\hline $\begin{array}{l}18 . \\
19 . \\
20 .\end{array}$ & Ino & $\begin{array}{l}924 \\
931 \\
966 \\
938 \\
924\end{array}$ & $\begin{array}{l}272 \\
255 \\
235 \\
226 \\
226\end{array}$ & $\begin{array}{l}153 \\
156 \\
160 \\
158 \\
160\end{array}$ & $\begin{array}{r}107 \\
101 \\
96 \\
94 \\
96\end{array}$ & $\begin{array}{l}64 \\
57 \\
60 \\
57 \\
57\end{array}$ & $\begin{array}{l}61 \\
60 \\
60 \\
60 \\
60\end{array}$ & 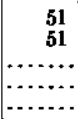 & $\begin{array}{r}1,160 \\
516 \\
509 \\
514 \\
418\end{array}$ & $\begin{array}{l}40 \\
35 \\
32 \\
28 \\
24\end{array}$ & $\begin{array}{l}29 \\
28 \\
27 \\
26 \\
26\end{array}$ & $\begin{array}{l}23 \\
28 \\
25 \\
20 \\
21\end{array}$ \\
\hline $\begin{array}{l}21 \ldots \\
22 \ldots \\
23 \ldots \\
24 \ldots \\
25 \ldots\end{array}$ & $\begin{array}{r}300 \\
500 \\
700 \\
900 \\
1,100\end{array}$ & $\begin{array}{l}875 \\
840 \\
833 \\
875 \\
784\end{array}$ & $\begin{array}{l}198 \\
187 \\
168 \\
160 \\
163\end{array}$ & $\begin{array}{l}156 \\
150 \\
143 \\
139 \\
134\end{array}$ & $\begin{array}{l}101 \\
105 \\
113 \\
105 \\
103\end{array}$ & $\begin{array}{l}57 \\
55 \\
52 \\
55 \\
64\end{array}$ & $\begin{array}{l}57 \\
57 \\
56 \\
\mathbf{5 6} \\
\mathbf{5 5}\end{array}$ & ......... & $\begin{array}{l}283 \\
347 \\
240 \\
162 \\
153\end{array}$ & $\begin{array}{l}24 \\
23 \\
26 \\
24 \\
23\end{array}$ & $\begin{array}{l}27 \\
26 \\
25 \\
27 \\
26\end{array}$ & \begin{tabular}{r} 
\\
19 \\
18 \\
$\ldots \ldots$ \\
\hdashline$\quad \%$ \\
$\cdots$
\end{tabular} \\
\hline 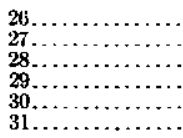 & $\begin{array}{l}1,100 \\
1,100 \\
1,100 \\
1,000 \\
1,000 \\
1,000\end{array}$ & $\begin{array}{l}650 \\
590 \\
590 \\
758 \\
710\end{array}$ & $\begin{array}{l}160 \\
160 \\
150 \\
136 \\
127 \\
125\end{array}$ & $\begin{array}{l}132 \\
121 \\
121 \\
127 \\
139 \\
130\end{array}$ & $\begin{array}{r}100 \\
98 \\
96 \\
9 \\
92 \\
91 \\
9 .\end{array}$ & $\begin{array}{l}71 \\
79 \\
87 \\
87 \\
79 \\
71\end{array}$ & $\begin{array}{r}\mathbf{5 5} \\
\mathbf{5 5} \\
\mathbf{5 4} \\
\mathbf{5 4} \\
\mathbf{5 3} \\
.\end{array}$ & $\begin{array}{l}\ldots \\
\cdots \\
\cdots\end{array}$ & $\begin{array}{l}181 \\
223 \\
311 \\
641 \\
180\end{array}$ & $\begin{array}{l}23 \\
27 \\
26 \\
24 \\
20 \\
22\end{array}$ & $\begin{array}{l}22 \\
23 \\
20 \\
23 \\
19 \\
19\end{array}$ & $\mid \begin{array}{l}\ldots \ldots \\
\cdots \ldots \\
\cdots \ldots \\
\cdots \cdots \\
\cdots \cdots \\
\cdots \cdots\end{array}$ \\
\hline & $8 \overline{25}$ & 873 & 343 & 144 & 107 & 70.0 & 60.6 & $51 . \overline{4}$ & 389 & 63.6 & 27.6 & 19.6 \\
\hline $\begin{array}{l}\text { square mile } \\
\text { in inches on } \\
\text { drainage area). }\end{array}$ & 9. 82 & 11.60 & 4. 08 & 1.71 & 1.27 & .833 & .721 & .612 & 4. 34 & 1.27 & .552 & . 392 \\
\hline
\end{tabular}

a Discharges are based on a defined rating curve; those up to June 2 are uncertain, as the gage was covered with snow and the moximum was estimated from $\mathbf{a}$ high-water mark. The river began to break up about May 20; the water had been flowing over the ice for a few days previous. The rfver became blocked with ice December 18 , and the discharge probably continued to diminish gradually.

$b$ Discharges for June 16 to July 14 were found by adding the discharge of Iron Creek at the railroad bridge near its mouth and that of the Iron Creek tunnel flume; from July 15 to 19 they are interpolated. Beginning July 20 records were obtained above the tunnel. Discharges for the latter station were obtained by the indirect method for shifting channels. For the other two stations a well-defined rating curve was obtained. 
Daily discharge, in second-feet, of Smith and Pass creeks for 1908 and 1909.

\begin{tabular}{|c|c|c|c|c|c|c|c|c|c|c|}
\hline \multirow{3}{*}{ Day. } & \multicolumn{5}{|c|}{$\begin{array}{l}\text { Smith Creek below Swift Creek. Eleva- } \\
\text { tion, about } 960 \text { feet. }\end{array}$} & \multicolumn{5}{|c|}{$\begin{array}{c}\text { Pass Creek below lower lake. Elevation, } \\
1,010 \text { feet. }\end{array}$} \\
\hline & \multicolumn{2}{|c|}{1908.} & \multicolumn{3}{|c|}{1909.} & \multicolumn{2}{|c|}{1908.} & \multicolumn{3}{|c|}{1909.} \\
\hline & July. & Aug. & July. & Aug. & Sept. & July. & Aug. & July. & Aug. & Sept. \\
\hline $\begin{array}{l}1 . . \\
2 . . \\
3 . . \\
4 . . \\
5 . .\end{array}$ & & $\begin{array}{r}77 \\
64 \\
64 \\
77 \\
124\end{array}$ & 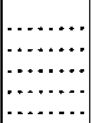 & $\begin{array}{l}20 \\
24 \\
32 \\
48 \\
42\end{array}$ & $\begin{array}{l}28 \\
24 \\
20 \\
20 \\
37\end{array}$ & & $\begin{array}{r}60 \\
39 \\
22 \\
33 \\
101\end{array}$ & & $\begin{array}{l}10 \\
15 \\
20 \\
32 \\
29\end{array}$ & $\begin{array}{l}17 \\
15 \\
13 \\
13 \\
15\end{array}$ \\
\hline $\begin{array}{r}6 \ldots \ldots \ldots \\
7 \ldots \ldots \ldots \\
8 \ldots \ldots \\
10 \ldots \ldots\end{array}$ & $\ddot{27}$ & $\begin{array}{r}108 \\
64 \\
51 \\
48 \\
48\end{array}$ & 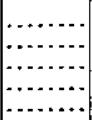 & $\begin{array}{r}37 \\
32 \\
28 \\
231 \\
140\end{array}$ & $\begin{array}{l}32 \\
32 \\
24 \\
23 \\
22\end{array}$ & … & $\begin{array}{l}53 \\
39 \\
33 \\
31 \\
31\end{array}$ & & $\begin{array}{l}26 \\
21 \\
17 \\
41 \\
38\end{array}$ & $\begin{array}{l}15 \\
15 \\
15 \\
15 \\
14\end{array}$ \\
\hline $\begin{array}{l}11 \ldots \ldots \ldots \\
12 \ldots \ldots \ldots \\
13 \ldots \ldots \ldots \\
14 \ldots \ldots \ldots \\
15 \ldots \ldots \ldots\end{array}$ & $\begin{array}{l}58 \\
80 \\
36 \\
36 \\
36\end{array}$ & $\begin{array}{r}48 \\
140 \\
92 \\
64 \\
77\end{array}$ & 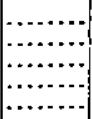 & $\begin{array}{r}120 \\
104 \\
88 \\
56 \\
48\end{array}$ & $\begin{array}{l}22 \\
20 \\
19 \\
18 \\
18\end{array}$ & $\begin{array}{l}30 \\
38 \\
28 \\
26 \\
26\end{array}$ & $\begin{array}{l}31 \\
76 \\
46 \\
28 \\
39\end{array}$ & $\cdots$ & $\begin{array}{l}34 \\
30 \\
32 \\
34 \\
30\end{array}$ & $\begin{array}{l}14 \\
13 \\
13 \\
12 \\
12\end{array}$ \\
\hline $\begin{array}{l}16 \ldots \\
17 \ldots \\
18 \ldots \\
19 \ldots \\
20 \ldots\end{array}$ & $\begin{array}{l}\mathbf{3 4} \\
\mathbf{3 5} \\
36 \\
38 \\
\mathbf{4 7}\end{array}$ & $\begin{array}{r}64 \\
51 \\
40 \\
\ldots \ldots\end{array}$ & 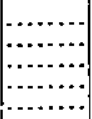 & $\begin{array}{l}37 \\
32 \\
34 \\
34 \\
32\end{array}$ & \begin{tabular}{|c}
16 \\
14 \\
9.4 \\
$9 \ldots \ldots$.
\end{tabular} & $\begin{array}{l}25 \\
25 \\
22 \\
22 \\
22\end{array}$ & $\begin{array}{c}33 \\
28 \\
30 \\
\cdots\end{array}$ & 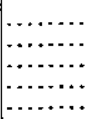 & $\begin{array}{l}26 \\
22 \\
21 \\
20 \\
20\end{array}$ & $\begin{array}{c}11 \\
10 \\
8 \\
7.7 \\
\cdots . .\end{array}$ \\
\hline $\begin{array}{l}21 \ldots \ldots \\
22 \ldots \ldots \\
24 \ldots \ldots \\
25 \ldots \ldots \\
25 . \ldots\end{array}$ & $\begin{array}{l}36 \\
27 \\
27 \\
19 \\
19\end{array}$ & $\begin{array}{l}\cdots \\
\cdots \\
\cdots\end{array}$ & $\begin{array}{l}28 \\
26 \\
25\end{array}$ & $\begin{array}{l}32 \\
34 \\
28 \\
24 \\
20\end{array}$ & (n) & $\begin{array}{l}20 \\
18 \\
18 \\
12 \\
14\end{array}$ & (l) & $\begin{array}{r}\cdots \\
17 \\
16\end{array}$ & $\begin{array}{l}20 \\
20 \\
19 \\
18 \\
15\end{array}$ & 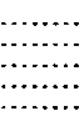 \\
\hline $\begin{array}{l}26 \ldots \ldots \ldots \\
27 \ldots \ldots \ldots \ldots \\
28 \ldots \ldots \ldots \ldots \\
29 \ldots \ldots \ldots \ldots \\
30 \ldots \ldots \ldots \ldots \\
31 \ldots \ldots \ldots \ldots\end{array}$ & $\begin{array}{r}23 \\
16 \\
16 \\
16 \\
171 \\
137\end{array}$ & $\begin{array}{l}\cdots \\
\cdots \\
\cdots \\
\cdots\end{array}$ & $\begin{array}{l}25 \\
24 \\
23 \\
22 \\
21 \\
20\end{array}$ & $\begin{array}{l}18 \\
18 \\
28 \\
48 \\
48 \\
32\end{array}$ & 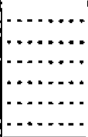 & $\begin{array}{r}13 \\
13 \\
13 \\
13 \\
101 \\
101 \\
\end{array}$ & 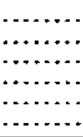 & $\begin{array}{l}15 \\
14 \\
13 \\
12 \\
11 \\
10\end{array}$ & $\begin{array}{l}15 \\
16 \\
16 \\
22 \\
28 \\
25\end{array}$ & 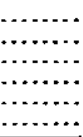 \\
\hline Mean...... & 44.1 & 72.3 & 23.8 & 50.0 & 22.1 & 28.3 & 41.8 & 10.8 & 23.6 & 13.0 \\
\hline
\end{tabular}

Nore-Discharges for both stations are somewhat uncertain, owing to poor measuring conditions and lack of measurements except at low stages. Those for July 11 to 19 , 1908, July 24 to 30, 1909, and shorter periods at other times have been esijmated with the aid of a hydrograph. 


\section{CENTRAL SEWARD PENINSULA}

\section{DESCRIPTION.}

The central portion of Seward Peninsula, lying north of the Kigluaik and Bendeleben mountains, shows two types of topography-(1) a lowland area 10 to 15 miles wide, lying at the foot of the mountains, and (2) an upland, with flat-topped ridges rising to an elevation of 1,000 to 1,600 feet, representing a former level of erosion. Several mountain masses rise above the level of the plateau, notably Kougarok, Midnight, and Baldy mountains. The streams have cut their channels deep into this plateau, and one or more levels of benches can usually be traced above the present streams. The principal streams are Kuzitrin River and its tributaries Kougarok and Noxapaga rivers.

This region is an area of low precipitation, especially in the early summer, and as there is 1.0 unfrozen ground the discharge is very small at low water.

Investigations of flow were made of the following streams and their tributaries in central Seward Peninsula in 1909

Kuzıtrin River.

Kougarok River.

Noxapaga River (miscellaneous measurements only).

KUZITRIN RIVER DRAINAGE BASIN.

Kuzitrin River is formed by the junction of North and South forks, which rise in the lava beds in the central portion of Seward Peninsula. Below their junction the river crosses the Kuzitrin Flats, a lowland area 20 miles long and averaging over 10 miles in width, lying north of the Bendeleben Mountains. The valley narrows to less than half a mile just above Lanes Landing, but widens as the river enters the lowland lying around Imuruk Basin. In the lower 10 miles of its course the Kuzitrin mingles its waters with those of the Kruzgamepa in an intricate network of channels and sloughs. The principal tributaries are Minnie, Ella, Bonanza, Birch, and Belt creeks from the Bendeleben Mountains on the south and Noxapaga River, Garfield Creek, and Kougarok River from the plateau region to the north.

One gaging station has been maintained on Kuzitrin River for comparative purposes, that at Lanes Landing, 1908 and 1909. 
Daily discharge, in second-feet, of Kuzitrin River at Lanes Landing for 1908 and 1909.

[Elevation, 40 feet; drainage area, 1,750 square miles.]

\begin{tabular}{|c|c|c|c|c|c|c|c|c|c|}
\hline \multirow{2}{*}{ Day. } & \multicolumn{4}{|c|}{1908.} & \multicolumn{5}{|c|}{1909.} \\
\hline & June. & July. & Aug. & Sept. & May. & June. & July. & Aug. & Sept. \\
\hline $\begin{array}{l}1 \ldots \ldots \ldots \\
2 \ldots \ldots \\
3 \ldots \ldots \\
4 \ldots \ldots \\
5 \ldots\end{array}$ & $\begin{array}{l}6,000 \\
6,000 \\
6,020 \\
6,620 \\
6,280\end{array}$ & $\begin{array}{l}830 \\
745 \\
628 \\
590 \\
665\end{array}$ & $\begin{array}{r}1,040 \\
802 \\
722 \\
425 \\
722\end{array}$ & $\begin{array}{l}448 \\
474 \\
448 \\
474 \\
500\end{array}$ & $\cdots$ & $\begin{array}{l}6,120 \\
7,200 \\
6,660 \\
6,300 \\
5,490\end{array}$ & $\begin{array}{l}1,930 \\
1,460 \\
1,400 \\
1,200 \\
1,200\end{array}$ & $\begin{array}{l}235 \\
235 \\
235 \\
257 \\
325\end{array}$ & $\begin{array}{l}285 \\
285 \\
285 \\
285 \\
317\end{array}$ \\
\hline $\begin{array}{r}6 \ldots \ldots \\
7 \ldots \ldots \\
8 \ldots \ldots \\
9 . \ldots \ldots \\
10 \ldots \ldots\end{array}$ & $\begin{array}{l}6,960 \\
6,440 \\
5,000 \\
4,490 \\
3,980\end{array}$ & $\begin{array}{l}465 \\
440 \\
365 \\
365 \\
365\end{array}$ & $\begin{array}{r}1,140 \\
1,240 \\
1,190 \\
895 \\
850\end{array}$ & $\begin{array}{l}448 \\
474 \\
474 \\
424 \\
424\end{array}$ & $\ldots$ & $\begin{array}{l}5,700 \\
5,220 \\
4,260 \\
3,920 \\
4,180\end{array}$ & $\begin{array}{r}1,240 \\
1,430 \\
976 \\
905 \\
855\end{array}$ & $\begin{array}{l}325 \\
305 \\
305 \\
334 \\
505\end{array}$ & $\begin{array}{l}325 \\
305 \\
293 \\
293 \\
285\end{array}$ \\
\hline $\begin{array}{l}11 \ldots \\
12 \ldots \\
13 \ldots \\
14 \ldots \\
15 \ldots\end{array}$ & $\begin{array}{l}3,810 \\
3,900 \\
3,900 \\
3,810 \\
3,810\end{array}$ & $\begin{array}{l}360 \\
380 \\
420 \\
410 \\
400\end{array}$ & $\begin{array}{l}590 \\
560 \\
560 \\
560 \\
500\end{array}$ & $\begin{array}{l}400 \\
378 \\
357 \\
378 \\
357\end{array}$ & & $\begin{array}{l}4,780 \\
5,490 \\
5,310 \\
4,950 \\
5,080\end{array}$ & $\begin{array}{l}718 \\
692 \\
587 \\
535 \\
487\end{array}$ & $\begin{array}{l}955 \\
830 \\
675 \\
535 \\
475\end{array}$ & $\begin{array}{l}278 \\
285 \\
285 \\
293 \\
348\end{array}$ \\
\hline 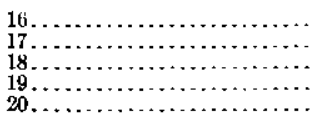 & $\begin{array}{l}3,900 \\
3,230 \\
3,150 \\
2,910 \\
2,670\end{array}$ & $\begin{array}{l}357 \\
357 \\
357 \\
357 \\
336\end{array}$ & $\begin{array}{l}474 \\
448 \\
448 \\
357 \\
424\end{array}$ & $\begin{array}{l}357 \\
424 \\
530 \\
560 \\
530\end{array}$ & $\begin{array}{l}4,000 \\
5,000\end{array}$ & $\begin{array}{l}5,220 \\
5,440 \\
5,150 \\
4,520 \\
3,760\end{array}$ & $\begin{array}{l}464 \\
431 \\
410 \\
380 \\
370\end{array}$ & $\begin{array}{l}410 \\
361 \\
334 \\
317 \\
293\end{array}$ & $\begin{array}{l}361 \\
380 \\
395 \\
380 \\
361\end{array}$ \\
\hline $\begin{array}{l}21 \ldots \ldots \ldots \ldots \\
22 \ldots \ldots \ldots \ldots \\
23 \ldots \ldots \ldots \ldots \\
24 \ldots \ldots \ldots \ldots\end{array}$ & $\begin{array}{l}1,640 \\
1,510 \\
1,280 \\
1,450 \\
1,510\end{array}$ & $\begin{array}{l}315 \\
330 \\
315 \\
336 \\
296\end{array}$ & $\begin{array}{l}400 \\
400 \\
400 \\
448 \\
474\end{array}$ & $\begin{array}{l}500 \\
448 \\
448 \\
378 \\
337\end{array}$ & $\begin{array}{l}6,000 \\
7,000 \\
8,000 \\
8,100 \\
7,200\end{array}$ & $\begin{array}{l}3,760 \\
3,420 \\
2,670 \\
2,320 \\
1,930\end{array}$ & $\begin{array}{l}348 \\
325 \\
317 \\
305 \\
293\end{array}$ & $\begin{array}{l}285 \\
285 \\
285 \\
268 \\
268\end{array}$ & $\begin{array}{l}334 \\
325 \\
305 \\
305 \\
305\end{array}$ \\
\hline 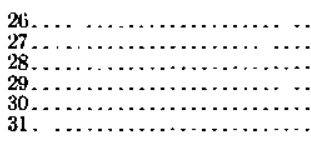 & $\begin{array}{r}1,570 \\
1,450 \\
1,280 \\
1,060 \\
875\end{array}$ & $\begin{array}{l}296 \\
278 \\
278 \\
262 \\
278 \\
722\end{array}$ & $\begin{array}{l}474 \\
449 \\
424 \\
400 \\
400 \\
400\end{array}$ & $\begin{array}{c}280 \\
\cdots \cdots \\
\cdots\end{array}$ & $\begin{array}{l}6,480 \\
5,940 \\
5,670 \\
5,490 \\
5,670 \\
\mathbf{6 ,}, 120\end{array}$ & $\begin{array}{l}1.500 \\
1,430 \\
1,720 \\
1,990 \\
2,320 \\
\cdots\end{array}$ & $\begin{array}{l}268 \\
268 \\
257 \\
250 \\
250 \\
250\end{array}$ & $\begin{array}{l}268 \\
268 \\
268 \\
268 \\
268 \\
268\end{array}$ & $\begin{array}{l}305 \\
285 \\
285 \\
278 \\
257\end{array}$ \\
\hline 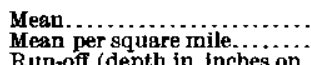 & $\begin{array}{r}3,550 \\
2.03\end{array}$ & $\begin{array}{r}416 \\
.238\end{array}$ & $\begin{array}{r}600 \\
.343\end{array}$ & $\begin{array}{r}433 \\
.247\end{array}$ & $\begin{array}{r}6,210 \\
3.55\end{array}$ & $\begin{array}{r}4,260 \\
2.43\end{array}$ & $\begin{array}{r}671 \\
.383\end{array}$ & $\begin{array}{r}363 \\
.207\end{array}$ & $\begin{array}{r}310 \\
.177\end{array}$ \\
\hline drainage are & 2. 26 & .27 & .40 & .24 & 1.72 & 2.71 & .44 & .24 & .20 \\
\hline
\end{tabular}

NorE.-Discharges for both years are based on well-defined rating curves Those for June 1 to 2,1908 . and May 19 to 23, 1909, are estimated on account of backwater. Somedays after this may have been slightly affected. Values for 1908 are based on additional data and supersede those published in Bulletin 379 , page 386.

\section{KOUGAROK RIVER DRAINAGE BASIN.}

Kougarok River drains a large area lying in the central portion of Seward Peninsula and empties into the Kuzitrin about 8 miles above Lanes Landing. It rises southeast of Kougarok Mountain and flows northward, then eastward, and, after making a sharp bend to the right, a little east of south to its mouth. The largest tributaries are Taylor Creek and North Fork from the east and Henry, Coarse Gold, and Windy creeks from the west. Of less importance are Washington, Columbia, Macklin, Homestake, Goose, California, Arctic, Arizona, Louisa, Galvin, and Dan creeks and Left Fork. Quartz Creek, which empties into the river below those named, and its tributaries, Coffee, Dahl, Checkers, Carrie, and Independence creeks, have been among the most important gold producers of the region, but have a very small run-off except at times of heavy rain. 
Several ditches have been built to divert the water of the river and its tributaries for hydraulicking. The largest are the Homestake ditch, on the upper Kougarok; the North Star and Cascade ditches, on Taylor Creek; and the Henry Creek and Coarse Gold Creek ditches. There are smaller ditches on Arizona Creek, North Fork, and Windy Creek.

The following gaging stations have been maintained on Kougarok River and the tributaries:

Kougarok River at Homestake intake and Homestake ditch at intake, 1907-1909.

Kougarok River below Henry (reek, 1909.

Kougarok River above Coarse Gold Creek, 1907-8 and June and July, 1909.

Taylor Creek at Cascade intake, 1907.

Henry Creek at mouth, 1908-9.

North Fork above Eureka (reek, 1908-9.

Homestake ditch above penstock, August and September, 1907.

North Star ditch above siphon, August and September, 1907.

The monthly discharge of Kougarok River above the Homestake intake for 1907 to 1909 is given for purposes of comparison:

Monthly discharge of Kougarok River above Ilomestake intake for 1907 to 1909.

[Dralnage area, 44 square miles.]

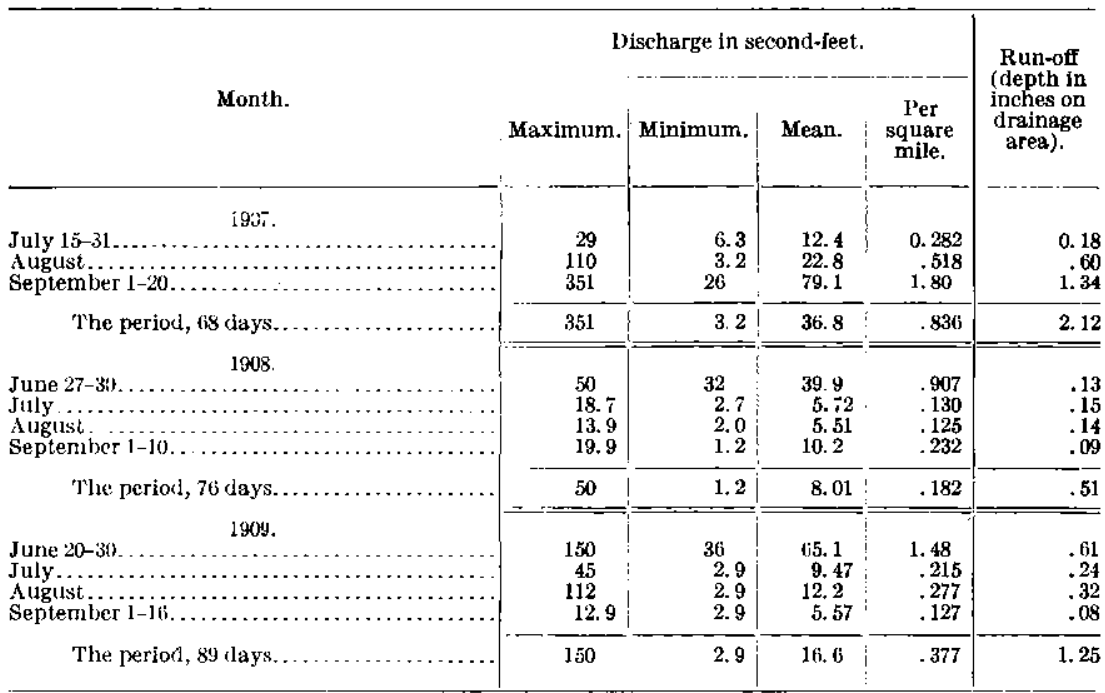

Note.-Diseharges for June 20 to July 8, 1909, have been estimated from the records at other stations in order to complete ihe season. 
Daily discharge, in second-feet, of Kougarok River and tributaries for 1909.

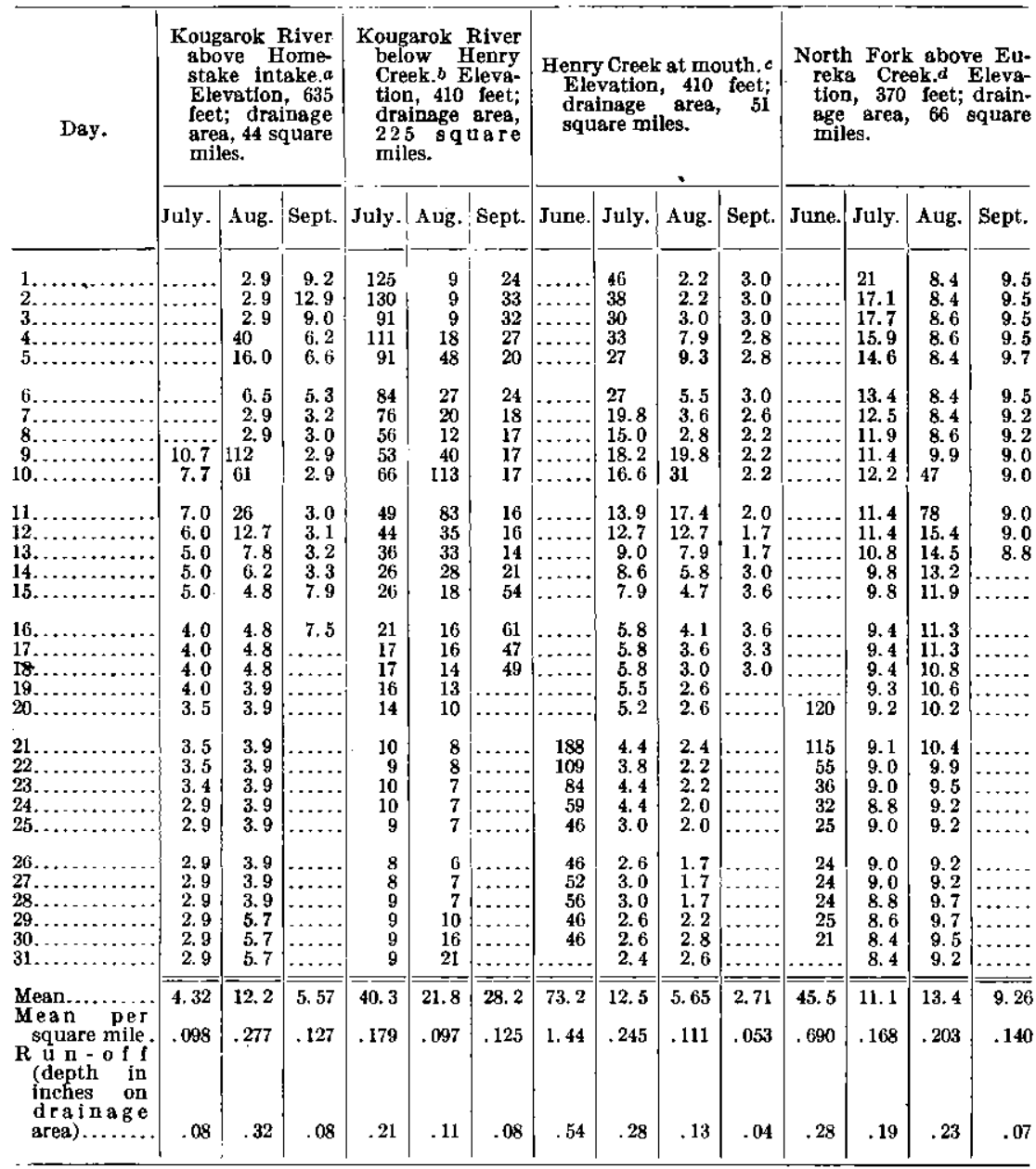

$a$ These discharges are the sums of those at the stations on Kougarok River below the intake and of the ditch. On account of changes in channel and lack of measurements they are liable to error, especially during the latter part of August. The water was turned into the ditch for only nineteen days.

$b$ These discharges are not of the best; the rating curve used up to July 28 is based on foat measurements at the higher stages. From July 29 to August 13 the gage was affected by backwater from a small mining dam. The gage was reset August 14; the curve used after that date is well defined above 15 secondfeet, but uncertain below.

$c$ Discharges for Henry Creek are based on a well-defined rating curve and are believed to be thoroughly reliable.

$d$ Discharges for North Fork are from gage readings at two points; the first gage was affected by backwater alter July 18 and was moved upstream July 22; the values for July 19 to 21 are estimated. The rating curves are fairly well defined.

\section{FAIRHAVEN PRECINCT.}

\section{DESCRIPTION.}

The Fairhaven precinct comprises all of Seward Peninsula that drains northward into Kotzebue Sound, except the flat area near Devil Mountain, west of Goodhope Bay. It is an area of relatively low relief, none of the mountains having an elevation of more than half a mile. There is no dominant mountain range like the Kigluaik 
and Bendeleben mountains to the south. The principal rivers, in order from west to east, are the Goodhope, Immachuk, Kugruk, Kiwalik, and Buckland. The southwestern portion of the precinct, together with parts of the adjacent Kougarok and Koyuk precincts, is covered with a recent lava flow, which has caused a considerable readjustment of drainage. The most notable effect of this flow is the formation of Imuruk Lake, the largest body of fresh water in Seward Peninsula. An area of older eruptive rocks east of Kiwalik River forms a rugged, dissected mass which reaches an altitude of 2,000 to 2,500 feet. In general the country is underlain by frozen muck and ground ice, in some places to a depth of 30 or 40 feet or more.

The climatic and other conditions affecting the run-off from the Fairhaven precinct are very similar to those prevailing in the Kougarok region. The run-off during the summer comes mostly from the rain, aided somewhat by melting snow and ice, ground water, and springs. The rainfall is relatively small, even in a rainy season, and runs off quickly. Most of the streams have a large drainage area, however, and in a wet season yield a good volume of water.

There are springs in limestone on Glacier Creek, in the Kiwalik River basin, and on the upper Inmachuk, and in the lava on Kugruk, Pinnell, and Goodhope rivers. These springs give the streams a steady flow during the summer, and the melting of the ice banks formed by their overflows during the winter yields a large amount of water during the early part of the open season.

Investigations of flow were made of the following streams and their tributaries in 1909:

Goodhope River.

Inmachuk River.

Kugruk River.

Kiwalik River.

GOODHOPE RIVER DRAINAGE BASIN.

Goodhope River is formed by the junction of Right Fork and Cottonwood Creek and flows in a general northwesterly course to Goodhope Bay. Right Fork, the true source of the river, rises in the lava near Imuruk Lake, the source of Kugtuk River, and flows through most of its course in a rather narrow canyon, in places 600 feet deep. There are springs in the lava which contribute a large portion of the low-water flow of the river. Cottonwood and Eagle creeks enter from the east and Esperanza, Placer, and Humboldt creeks from the west and south. The larger portions of the basins of these tributaries lie outside the area of lava.

Esperanza Creek is the only tributary on which any systematic mining has been done. Gold in paying quantity was discovered in 
1908 and the creek was worked in 1909 as far as the scanty supply of water permitted.

A gaging station was maintained during the season of 1909 below the mouth of Esperanza Creek, to determine the discharge available for diversion at points above for use on Esperanza Creek.

Daily discharge, in second-feet, of Goodhope River below Esperanza Creek for 1909.

[Drainage area, 194 square miles.]

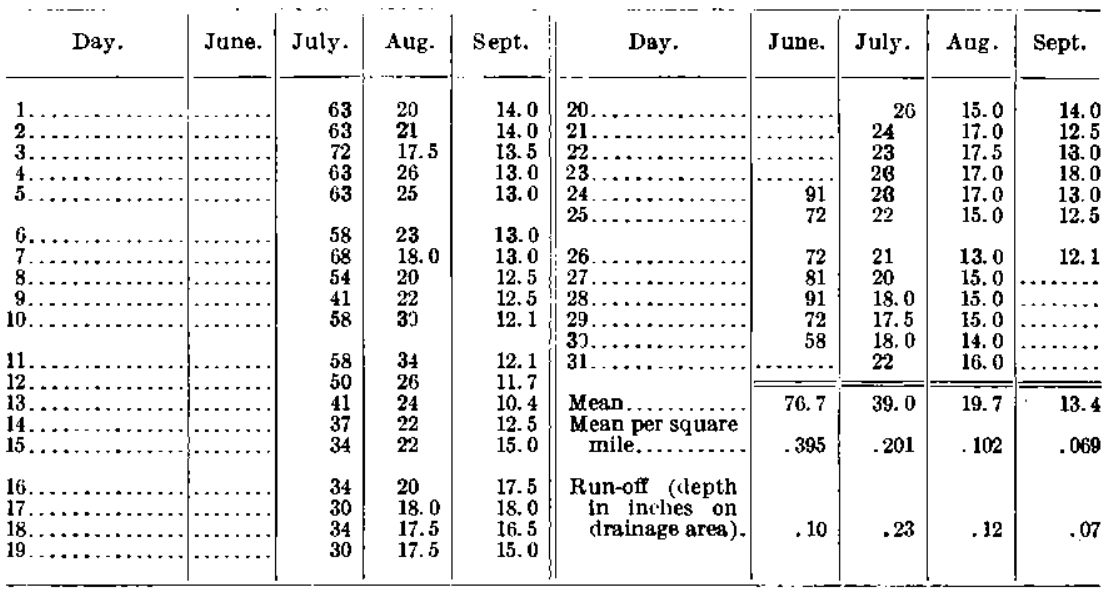

NOTE.-These discharges are based on a well-defined rating curve. There may be some seepage through the gravel, but the amount is probably not large.

\section{INMACHUK RIVER DRAINAGE BASIN.}

Inmachuk River rises against the head of Trail Creek, a tributary of the Goodhope, flows northwestward, and empties into Kotzebue Sound at Deering. Its principal tributaries are Hannum Creek, from the northwest, and Pinnell River, from the south, each of which has a larger drainage area than the main stream above the junction. Arizona, Fink, Washington, West, Cue, and Mystic creeks are small tributaries below the mouth of Pinnell River.

Hannum Creek occupies a deep and rather narrow valley. Its principal tributaries are Cunningham, Milroy, and Collins creeks. Pinnell River rises in a broad, flat swamp, or "goose pasture," formed by the lava flow. About 6 or 8 miles from its source the river has cut down through the lava, forming a deep, narrow canyon, in which it drops 250 to 300 feet in about half a mile. Its principal tributaries are Magnet, June, Perry, and Old Glory creeks and Snow Gulch.

A striking feature of the Inmachuk Valley is the lava rim which extends down the Pinnell from the canyon, following the left side of the valley for several miles, then crossing to the right side aind extending down the Inmachuk to the coastal plain and up Hannum 
Creek nearly to its head. Its elevation is generally 300 to 400 feet above the stream.

A limestone spring issuing from the hillside about 3 miles above Hannum Creek furnishes the only well-sustained water supply available for hydraulicking to be found in the basin. A ditch to divert this water for mining was begun in 1909 . Two other short ditches receive their supply from tributaries of the Inmachuk, one from Hannum Creek below Cunningham Creek and one from a spring near the head of Old Glory Creek. The Fairhaven ditch brings water from Imuruk Lake at the head of Kugruk River for use on mining claims on the Inmachuk.

A gaging station was maintained on Inmachuk River below Logan Gulch during the summer of 1909.

Daily discharge, in second-feet, of Inmachuk River below Logan Gulch for 1909.

[Elevation, 130 feet; drainage area, 145 square miles.]

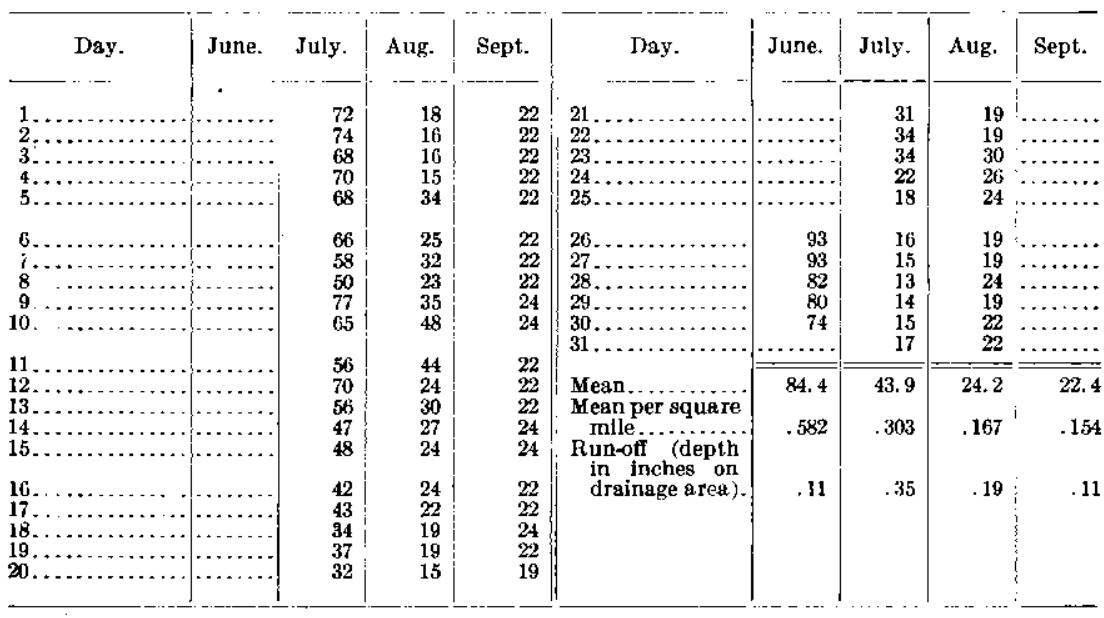

Notr-Water was wasted into Logan Gulch from the Fairhaven ditch in amounts varying from 0.5 to 6 or 8 seeond-feet and averaging, roughly, 2 second-feet; this water is included in the discharges given above. This water carried a large amount of sediment, which flller up the channel near the gage to such an extent that discharges up to August 10 were obtained by the indirect method for shffting channels and are only approximate. The gage used after August 12 was not materially affected and the results obtained are good.

\section{FAIRHA VEN DITCH.}

The Fairhaven ditch takes water from Imuruk Lake, which lies at an elevation of about 960 feet above sea level and is the source of Kugruk River. A dam 500 feet long and 5 feet high has been built to form a storage reservoir, and this will hold the total inflow at the lake for two years if necessary. The ditch is in three sections. The upper section, 17 miles long, lies on top of the lava and extends from the lake around the head of Wade Creek to a point near the Pinnell River divide, where the water is dropped into a channel emptying into Wade Creek. It is diverted from this channel into 
Pinnell River by the middle section of the ditch, which is 850 yards long. The water runs about $6 \frac{1}{2}$ miles between the upper and lower ditches and the drop is estimated at 150 feet. The lower section of the ditch extends from the intake on Pinnell River along the left side of the valley to a point a few hundred feet below Logan Gulch, a small tributary of the Inmachuk above Arizona Creek, and has a length of about 19 miles, making a total of $36 \frac{1}{2}$ miles of ditch.

Practically the whole of the upper ditch and at least three-fourths of the lower ditch, including all the upper 6 or 8 miles, is built in frozen muck with only a small percentage of solid matter. Along the upper ditch lava bowlders are present in the muck from the surface to bed rock. At some places the material encountered was composed of angular fragments of lava with little soil between them. Above and below Snow Gulch, the lowest tributary of Pinnell River which the ditch crosses, there are short pieces of rock work.

The ditch was built under contract; construction was begun early in 1906 and was completed in July, 1907. Water was run through the ditch for a short time in September, 1907, from July 1 to September 21, 1908, and from June 14 to September 21, 1909, except when it was turned out on account of breaks. The ultimate capacity of the ditch when some low parts of the bank are raised will be about 100 second-feet. The pressure-pipe leading from the penstock below Logan Gulch to the mine has a total length of 10,600 feet, and gives a total head on bed rock of 530 feet.

Measurements were made of the ditch in 1908 to determine its discharge and the loss by seepage, which was shown to be very small. In 1909 three regular gaging stations were maintained on the ditch for the whole or part of the season, located at the intake and Camp 2, of the upper section, and at Snow Gulch, about 5 miles above the outlet.

Daily discharge, in second-feet, of Fairhaven ditch for 1909.

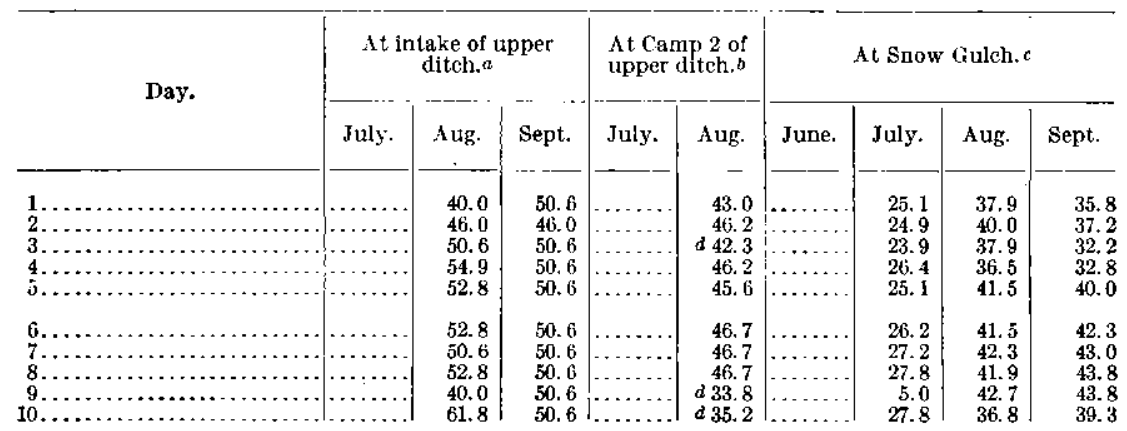

$a$ These discharges are based on a rating curve which is well defined above 20 second-feet diseharge.

$\Delta$ These discharges are based on several rating curves, as the ditch bed is constantly changing. (Gage heights observed in September are of no value, as no measurements were made during the month.

$c$ These discharges are based on a rating curve which is well defined above 18 second-feet discharge.

Records at this point show practically the amount delivered at the penstocks, about 5 miles below, by ditch.

$d$ Water turned out part of the day to make repairs on ditch. 
Daily discharge, in second-feet, of Fairhaven ditch for 1909-Continued.

\begin{tabular}{|c|c|c|c|c|c|c|c|c|c|}
\hline \multirow{2}{*}{ Day. } & \multicolumn{3}{|c|}{$\begin{array}{l}\text { At intake of upper } \\
\text { ditch. }\end{array}$} & \multicolumn{2}{|c|}{$\begin{array}{l}\text { At Camp } 2 \text { of } \\
\text { upper ditch. }\end{array}$} & \multicolumn{4}{|c|}{ At Snow Guleh. } \\
\hline & July. & Aug. & Sept. & July. & Aug. & June. & July. & Aug. & Sept. \\
\hline $4 \ldots$ & $\begin{array}{l}31.9 \\
28.3\end{array}$ & $\begin{array}{l}52.8 \\
48.6 \\
57.0 \\
57.0 \\
44.0\end{array}$ & $\begin{array}{l}48.6 \\
48.6 \\
54.9 \\
50.6 \\
61.8\end{array}$ & $\begin{array}{r}30.8 \\
30.3 \\
a 23.3\end{array}$ & $\begin{array}{r}45.6 \\
46.7 \\
41.5 \\
a 38.0 \\
a 29.2\end{array}$ & $\begin{array}{c}22.8 \\
0\end{array}$ & $\begin{array}{l}27.2 \\
29.2 \\
29.2 \\
29.7 \\
30.3\end{array}$ & $\begin{array}{l}36.2 \\
41.9 \\
42.3 \\
41.1 \\
31.6\end{array}$ & $\begin{array}{l}32.2 \\
44.6 \\
43.0 \\
45.7 \\
42.3\end{array}$ \\
\hline $\begin{array}{l}18 \ldots \ldots \ldots \\
20 \ldots \ldots\end{array}$ & $\begin{array}{l}30.1 \\
36.1 \\
40.0 \\
44.0 \\
40.0\end{array}$ & $\begin{array}{l}44.0 \\
46.0 \\
52.8 \\
52.8 \\
48.6\end{array}$ & $\begin{array}{l}57.0 \\
50.6 \\
50.6 \\
54.9 \\
54.9\end{array}$ & $\begin{array}{l}33.2 \\
33.2 \\
34.2 \\
39.2 \\
42.3\end{array}$ & $\begin{array}{c}0 \\
0 \\
\mathbf{a} 32.6 \\
21.8 \\
27.3\end{array}$ & \begin{tabular}{l|}
22.8 \\
18.8 \\
17.7 \\
18.4 \\
21.0
\end{tabular} & $\begin{array}{l}26.7 \\
30.3 \\
30.9 \\
34.5 \\
37.2\end{array}$ & $\begin{array}{c}23.2 \\
14.4 \\
11.6 \\
19.5 \\
0\end{array}$ & $\begin{array}{l}33.4 \\
38.6 \\
43.0 \\
42.3 \\
41.5\end{array}$ \\
\hline (3....... & $\begin{array}{r}46.0 \\
46.0 \\
44.0 \\
9.7 \\
9.7\end{array}$ & $\begin{array}{l}44.0 \\
44.0 \\
50.6 \\
50.6 \\
50.6\end{array}$ & 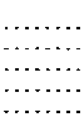 & $\begin{array}{c}43.3 \\
43.3 \\
a 24.8 \\
7.2 \\
0\end{array}$ & $\begin{array}{r}29.7 \\
\times 30.3 \\
42.3 \\
a 37.0 \\
44.4\end{array}$ & $\begin{array}{l}18.8 \\
16.4 \\
15.0 \\
13.1 \\
12.0\end{array}$ & $\begin{array}{l}39.3 \\
39.0 \\
40.0 \\
17.2 \\
13.7\end{array}$ & $\begin{array}{l}25.1 \\
27.8 \\
32.2 \\
40.8 \\
41.5\end{array}$ & 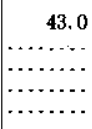 \\
\hline $\begin{array}{l}20, \ldots \ldots \\
27 \\
28 \\
29 \\
29 \\
30 \\
31\end{array}$ & $\begin{array}{l}0 \\
13.3 \\
30.1 \\
40.0 \\
30.1 \\
38.0 \\
\end{array}$ & $\begin{array}{l}48.6 \\
48.6 \\
48.6 \\
50.6 \\
50.6 \\
50.6\end{array}$ & $\begin{array}{l}\cdots \\
\cdots\end{array}$ & $\begin{array}{l}0 \\
11.8 \\
26.9 \\
38.0 \\
35.0 \\
39.0 \\
\end{array}$ & $\begin{array}{r}45.5 \\
a 41.6 \\
a 41.6 \\
a 46.5 \\
46.5 \\
a 42.5 \\
\end{array}$ & $\begin{array}{l}14.5 \\
18.2 \\
20.2 \\
21.4 \\
23.7\end{array}$ & $\begin{array}{r}10.0 \\
3.0 \\
0 \\
24.7 \\
248 \\
\because .5 \\
\end{array}$ & $\begin{array}{l}40.0 \\
41.5 \\
37.2 \\
37.2 \\
41.5 \\
42.3 \\
\end{array}$ & $\begin{array}{l}\cdots \cdots \\
\cdots \cdots \\
\cdots \cdots \\
\cdots \cdots \\
\cdots \cdots\end{array}$ \\
\hline Mean. & 31.6 & 49.8 & 51.7 & 28.2 & 37.4 & 17.9 & 26.0 & $\overline{34.4}$ & 40.0 \\
\hline
\end{tabular}

a Water turned out part of the day to make repairs on ditch.

\section{KUGRUK RIVER DRAINAGE BASIN.}

Kugruk River rises in Imuruk Lake and flows northwestward for about 20 miles and thence northward for the remainder of its 60 miles of length, emptying into Kotzebue Sound near Deering. Imuruk Lake, with an area of 31 square miles and a drainage basin of 102 square miles, lies on top of the lava plateau in the central part of Seward Peninsula. About 4 miles below the lake the river has cut into the edge of the lava, forming a canyon about 300 feet deep and 1,000 feet wide at its deepest point. At the mouth of the canyon the river is about 500 feet below the level of the lake and is probably at about the elevation it had before the invasion of the lava flow. This canyon affords a favorable location for a plant to develop electric power. Water from the lake can be diverted through a ditch for about $4 \frac{1}{2}$ miles and then through a pipe line to the bottom of the canyon, developing a pressure of nearly 500 feet. Below the canyon the grade of the river is relatively flat. The principal tributaries in this section are Holtz, Mina, Montana, Reindeer, and Chicago ereeks from the east and Ruby and Gold Bug creeks and Wade Creek, locally known as Burnt River, from the west. The Kugruk basin is relatively unimportant economically, as its gold production has been small. Chicago Creek is of interest on account of the coal mine which lies near its mouth. 
The following gaging stations have been maintained in this basin:

Kugruk River below Fairhaven ditch intake, 1909.

Kugruk River below Reindeer Creek, 1909.

Chicago Creek at coal mine, August and September, 1908.

Daily discharge, in second-feet, of Kugruk River for 1909.

\begin{tabular}{|c|c|c|c|c|c|c|c|}
\hline \multirow[t]{2}{*}{ Day. } & \multicolumn{3}{|c|}{$\begin{array}{l}\text { Below Fairhaven ditch } \\
\text { intake. E Elevation, } \\
\text { 940feet; drainage area, } \\
102 \text { square miles. }\end{array}$} & \multicolumn{4}{|c|}{$\begin{array}{l}\text { Above Reindeer Creek. } b \text { Drain- } \\
\text { age area, } 556 \text { square miles. }\end{array}$} \\
\hline & July. & Aug. & Sept. & June. & July. & Aug. & Sept. \\
\hline $\begin{array}{l}1 \ldots \\
2 \ldots \\
3 \ldots \\
4 \ldots \\
5 \ldots\end{array}$ & $\begin{array}{l}\cdots \\
\cdots \\
\cdots \\
\cdots\end{array}$ & $\begin{array}{l}3.7 \\
4.7 \\
4.7 \\
5.7 \\
5.7\end{array}$ & $\begin{array}{l}1.0 \\
1.0 \\
1.0 \\
1.0 \\
1.4\end{array}$ & $\cdots$ & $\begin{array}{l}158 \\
114 \\
114 \\
114 \\
114\end{array}$ & $\begin{array}{l}38 \\
34 \\
53 \\
56 \\
59\end{array}$ & $\begin{array}{l}46 \\
46 \\
46 \\
65 \\
46\end{array}$ \\
\hline $\begin{array}{r}6 \ldots \\
7 \ldots \\
8 \ldots \\
9 \ldots \\
10 \ldots\end{array}$ & $\begin{array}{l}\cdots \\
\cdots \\
\cdots\end{array}$ & $\begin{array}{l}5.7 \\
5.7 \\
5.7 \\
1.0 \\
1.0\end{array}$ & $\begin{array}{l}1.4 \\
1.0 \\
1.0 \\
1.0 \\
1.0\end{array}$ & $\cdots$ & $\begin{array}{r}93 \\
114 \\
114 \\
93 \\
116\end{array}$ & $\begin{array}{l}62 \\
65 \\
46 \\
46 \\
65\end{array}$ & $\begin{array}{l}29 \\
29 \\
29 \\
29 \\
29\end{array}$ \\
\hline 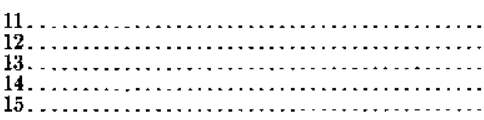 & $\begin{array}{l}1.0 \\
1.0\end{array}$ & $\begin{array}{l}1.0 \\
1.0 \\
1.0 \\
1.0 \\
1.0\end{array}$ & $\begin{array}{l}1.0 \\
1.0 \\
1.0 \\
1.0 \\
1.0\end{array}$ & $\begin{array}{l}\cdots \\
\cdots \\
\cdots\end{array}$ & $\begin{array}{r}114 \\
114 \\
114 \\
93 \\
93\end{array}$ & $\begin{array}{l}50 \\
50 \\
46 \\
46 \\
46\end{array}$ & $\begin{array}{l}29 \\
29 \\
29 \\
29 \\
46\end{array}$ \\
\hline 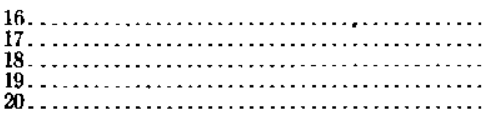 & $\begin{array}{l}1.0 \\
1.0 \\
1.4 \\
1.4 \\
1.4\end{array}$ & $\begin{array}{l}1.0 \\
1.0 \\
1.0 \\
1.0 \\
1.0\end{array}$ & $\begin{array}{l}1.0 \\
1.0 \\
1.0 \\
1.0 \\
1.0\end{array}$ & & $\begin{array}{l}93 \\
93 \\
73 \\
73 \\
53\end{array}$ & $\begin{array}{r}46 \\
46 \\
85 \\
105 \\
105\end{array}$ & $\begin{array}{l}46 \\
29 \\
29 \\
29 \\
29\end{array}$ \\
\hline $\begin{array}{r}21 \\
22 \\
22 \\
23 \\
24 \\
24 \\
25\end{array}$ & $\begin{array}{l}2.0 \\
2.0 \\
1.0 \\
1.0 \\
1.4\end{array}$ & $\begin{array}{l}1.0 \\
1.0 \\
1.4 \\
1.4 \\
1.4\end{array}$ & $\begin{array}{l}\cdots \\
\cdots \cdots \\
\cdots\end{array}$ & $\begin{array}{l}\cdots \\
\cdots \\
\cdots \\
\cdots\end{array}$ & $\begin{array}{l}53 \\
34 \\
40 \\
45 \\
73\end{array}$ & $\begin{array}{l}85 \\
75 \\
57 \\
46 \\
46\end{array}$ & $\begin{array}{l}29 \\
29 \\
29 \\
29 \\
29\end{array}$ \\
\hline 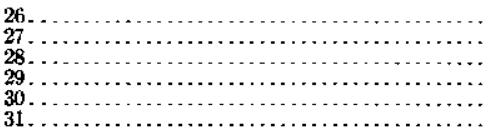 & $\begin{array}{l}1.4 \\
2.0 \\
2.0 \\
2.0 \\
3.7 \\
3.7\end{array}$ & $\begin{array}{l}1.8 \\
1.4 \\
1.4 \\
1.4 \\
1.4 \\
1.4\end{array}$ & $\begin{array}{l}\ldots \ldots \\
\cdots \cdots \\
\cdots \cdots\end{array}$ & $\begin{array}{l}180 \\
158 \\
180\end{array}$ & $\begin{array}{l}53 \\
53 \\
34 \\
34 \\
34 \\
34\end{array}$ & $\begin{array}{l}46 \\
29 \\
29 \\
29 \\
46 \\
46\end{array}$ & $\begin{array}{l}19 \\
19 \\
23 \\
17 \\
16\end{array}$ \\
\hline $\begin{array}{l}\text { Mean } \ldots \ldots \ldots \ldots \ldots \ldots \ldots \\
\text { Mean per square mile. } \ldots \ldots \ldots\end{array}$ & $\overline{1.69}$ & 2.21 & 1.04 & $\begin{aligned} 173 \\
.311\end{aligned}$ & $\begin{array}{l}82.1 \\
.148\end{array}$ & $\begin{aligned} 543 \\
.098\end{aligned}$ & .31 .9 \\
\hline Run-off (depth in inches on drainage area). & & & & .03 & .17 & .11 & .06 \\
\hline
\end{tabular}

$a$ These discharges represent merely the quantity of water wasted from the lake. They are only approximate, on account of the poor measuring conditions in the rocky stream bed.

$b$ These discharges are based on two well-defined rating curves used up to and after Aurust 4 . The drainage area has been taken as including the Imuruk Lake basin. To obtain the natural flow from the area below the lake, deduct the discharge below the ditch intake and the water spilled from the ditch from the measured discharge at this station.

\section{KIWAIIK RIVER DRAINAGE BASIN.}

Kiwalik River, the longest river on the north side of Seward Peninsula, rises in a low ridge which separates its drainage basin from that of the Koyuk and flows northward for nearly 70 miles to Kotzebue Sound, at Kiwalik. The river traverses a flat lowland area, several miles wide in places, which narrows a few miles above Candle to less than half a mile. Near its mouth the river widens into a lagoon.

The tributaries from the west drain rather narrow basins, roughly parallel and separated by long, low ridges. The principal streams from this side are Canoe Creek, Gald Run, and Glacier, Dome, Bo- 
nanza, Eldorado, Candle, and Minnehaha creeks. The largest tributaries from the east are Quartz and Hunter creeks, which rise in the mountainous mass separating the Kiwalik basin from that of Buckland River.

The Candle ditch, built in 1907, has its intake on Glacier Creek and extends for $33 \frac{1}{2}$ milas along the left side of Kiwalik River to John Bull Hill, opposite the mouth of Candle Creek. Of this length nearly 3 miles is made up of three siphons-2,250 feet of 28-inch pipe across Dome Creek, 912 feet of 30 -inch pipe across Bonanza Creek, and the big 12,300-foot siphon across Eldorado and Burnside creeks, composed of equal lengths of $35 \frac{1}{2}, 37 \frac{1}{2}$, and $39 \frac{1}{2}$ inch pipes. The lateral to Dome Creek consists of $3 \frac{1}{2}$ miles of 4 -foot ditch, making a total of 37 miles. The ditch is 6 feet wide at the intake, increasing to 9 feet at the lower end. It has a capacity of 20 to 30 second-feet and an elevation at the penstock of 249 feet above Kiwalik River. An extension of the ditch to Gold Run will require about 8 miles of ditch and a siphon. The mining operations in 1908 and 1909 were confined to stripping the overburden from the bench on John Bull Hill. A line has been surveyed for a second ditch to Candle Creek which will take its water from Quartz and Hunter creeks. It will have its intakes on the forks of Quartz Creek about 2 miles above the junction, and the flow of Hunter Creek will be diverted by a lateral. The proposed system will require a total of about 65 miles of ditch and 14,000 feet of pipe and will give a pressure of 303 feet above the mouth of Candle Creek.

Mining in the basin has been mostly confined to Candle Creek and its tributaries, but in 1909 a little work was done on Glacier Creek and Gold Run.

The following gaging stations have been maintained in this basin:

Kiwalik River below Candle Creek, 1909.

Quartz Creek below the forks, 1909.

Glacier Creek above Candle ditch intake, 1908-9.

Dome ('reek at siphon crossing, July, 1909.

Hunter Creek near proposed intake, 1908-9.

Monthly discharge of Glacier Creek above Candle ditch intake for 1908 and 1909.

[Drainage area, 10 squaro miles.]

\begin{tabular}{|c|c|c|c|c|c|}
\hline \multirow{2}{*}{ Month. } & \multicolumn{4}{|c|}{ Discharge in second-feet. } & \multirow{2}{*}{$\begin{array}{l}\text { Run-off } \\
\text { (depth in } \\
\text { inches on } \\
\text { drainage } \\
\text { area). }\end{array}$} \\
\hline & Maximum. & & Mean. & $\begin{array}{l}\text { square } \\
\text { mile. }\end{array}$ & \\
\hline 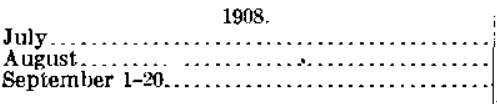 & $\begin{array}{r}14.0 \\
4.0 \\
8.2\end{array}$ & $\begin{array}{r}2.0 \\
-1.7 \\
-1.9\end{array}$ & $\begin{array}{l}4.67 \\
2.15 \\
3.35\end{array}$ & $\begin{array}{r}0.467 \\
.215 \\
.335\end{array}$ & $\begin{array}{r}0.54 \\
.25 \\
.25\end{array}$ \\
\hline The period, 82 days.. & 14.0 & 1.7 & 3. 40 & .330 & 1.03 \\
\hline 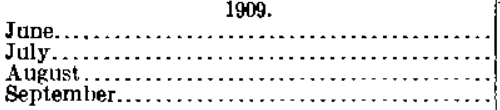 & $\begin{array}{rl}76 & \\
7 & 0 \\
5.0 \\
1.8\end{array}$ & $\begin{array}{l}6 \\
2.3 \\
1.5 \\
1.3\end{array}$ & $\begin{array}{l}\text { 35. } 3 \\
\text { 3. } 01 \\
2.13 \\
1.43\end{array}$ & $\begin{array}{l}3.53 \\
.301 \\
.213 \\
.143\end{array}$ & $\begin{array}{l}3.94 \\
.35 \\
.25 \\
.16\end{array}$ \\
\hline The period, 122 days.. & 76 & 1.3 & 10.6 & 1.06 & 4.70 \\
\hline
\end{tabular}


Daily discharge, in second-feet, of Kiwalik River and tributaries for 1909.

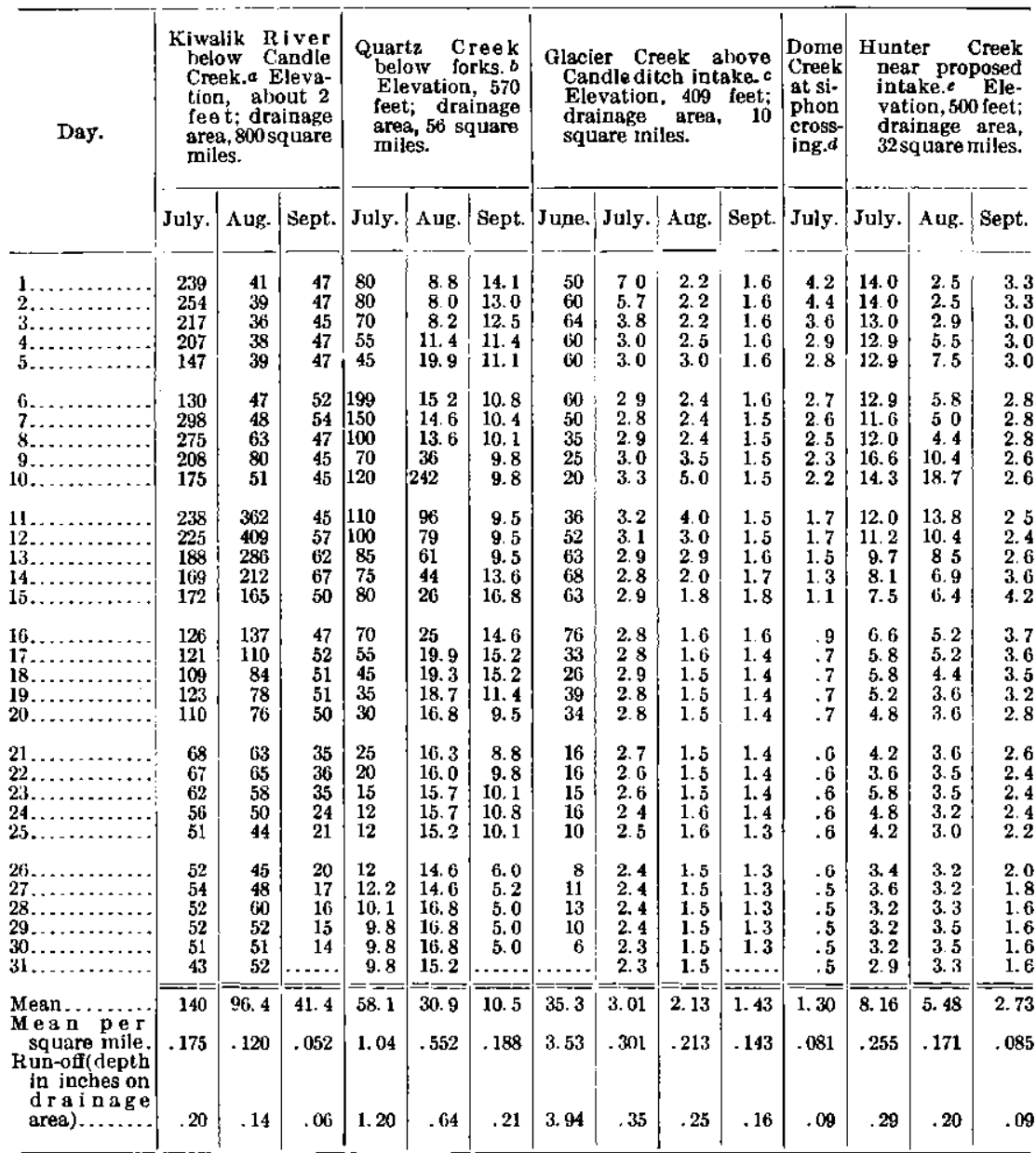

a Discharges for July 1 to 24 were ohtained by the indirect method for shifting channels, on account of the large amount of fine material washed into the river from the cut on John Bull Hill. The mining had practically ceased by July 25 , and after that date one rating curve was used, which is well defined between * 40 and 300 second-feet discharge.

b. Discharges for July 27 to September 27 were obtained from a rating curve which is well defined between 10 and 200 second-feet discharge. Those for July 1 to 26 have been estimated with the gid of a hydrograph, following the rate of rise and fall of Kiwalik River below Candle Creek. Most of the increase in the Kiwslik the second week in July came from Quartz Creek. $\Lambda$ measurement was made July 6 near the crest of the flood.

$c$ Discharges for June are based on float measurements by H. M. Long and R. S. Dimmock. These measurements were made in the afternoon, when the water was highest, and have been reduced by 20 to 40 per cent to give an approximate mean for the day. The values for July, August, and September are based on readings from three gages at difierent locations and are fairly good except those for August 1 to 15 and September 13 to 30 , which are estimated.

d Elevation, 230 feet; drainage area, about 16 square miles. These discharges are based on a fairly welldefined rating curve and for about half the days have been interpolated.

$e$ Discharges for July 5 to August 21 are based on a rating curve which is well defined between 3 and 15 second-foet discharge; those for July 1 to 4 and after August 22 are estimated on the basis of a hydrograph. 


\section{BEAR CREEK DRAINAGE BASIN.}

Bear Creek rises opposite the headwaters of Quartz and Hunter creeks and flows southeastward for about 20 miles into West Fork of Buckland River. Its principal tributaries are Eagle, Polar, Split, Bob, and Cub creeks from the west and May, Camp, and Sheridan creeks from the east. The Bear Creek ditch has its intake just below the mouth of May Creek and extends along the right bank nearly to Split Creek, diverting water from Eagle and Polar creeks. This ditch was not used in 1909 and no measurements were made in this drainage basin.

\section{MISCELLANEOUS MEASUREMENTS.}

Discharge measurements made at other points than regular gaging stations or at stations for which daily discharges are not given have been listed in the following table. For streams, the elevation of point of measurements, discharge, drainage area, and discharge per square mile are given; for ditches, the gage reading, if any, and discharge.

Miscellaneous measurements of streams in Seward Peninsula in 1909.

Fish River dralnage basin.

\begin{tabular}{|c|c|c|c|c|c|c|c|}
\hline Date. & Stream. & Tributary to- & Locality. & $\begin{array}{l}\text { Eleva- } \\
\text { tion. }\end{array}$ & $\begin{array}{l}\text { Dis- } \\
\text { charge. }\end{array}$ & $\begin{array}{l}\text { Draln- } \\
\text { age } \\
\text { area. }\end{array}$ & $\begin{array}{l}\text { Dis- } \\
\text { charge } \\
\text { per } \\
\text { square } \\
\text { mile. }\end{array}$ \\
\hline August 21. & Boston Creek.... & Fish River.... & 1 mile above edge & $\begin{array}{l}\text { Feet. } \\
\text { a } 350\end{array}$ & $\begin{array}{l}S e c .-f t . \\
102\end{array}$ & $S q, m i$ & Sec.fft. \\
\hline Do. & Baker Creek..... & Boston Creek.. & $\frac{1}{2}$ mile above edge & $a 450$ & 27 & & \\
\hline $\begin{array}{r}\text { Do...... } \\
\text { August } 19 . .\end{array}$ & $\begin{array}{l}\text { Oregon Creek.... } \\
\text { P'argon River... }\end{array}$ & Fish River..... & $\begin{array}{l}\text { of mountains. } \\
\text { Edge of mountains. } \\
\text { Below Miocene in- }\end{array}$ & $\begin{array}{r}a 700 \\
610\end{array}$ & $\begin{array}{l}11.1 \\
b 26\end{array}$ & 30 & \\
\hline epte & $\ldots$...do & 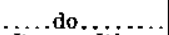 & $\begin{array}{l}\text { take. } \\
\ldots \text {...do.. }\end{array}$ & 610 & I4. 0 & 36 & \\
\hline Do.. & $\begin{array}{l}\text { Dillow Creek... } \\
\text { McKelvie Creek. }\end{array}$ & 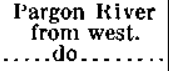 & $\begin{array}{l}\text { A bove Parg on } \\
\text { ditch crossing. } \\
A \text { bove parg on }\end{array}$ & $\begin{array}{l}720 \\
710\end{array}$ & $\begin{array}{r}4.0 \\
8.9\end{array}$ & & \\
\hline $\begin{array}{l}\text { epter } \\
\text { ugten } \\
\text { ugus }\end{array}$ & $\begin{array}{l}\ldots \ldots \text { do } \ldots \ldots \ldots \ldots \\
\text { Cawlfield Creek }\end{array}$ & $\begin{array}{l}\ldots . d \mathrm{~d} \\
\cdots \text { Pargo } \\
\text { Parg }\end{array}$ & $\begin{array}{c}\text { ditch intake. } \\
\ldots . \text { do } \\
\text { Miocene ditch jove }\end{array}$ & $\begin{array}{l}710 \\
710 \\
600\end{array}$ & $\begin{array}{l}6.4 \\
\text { 4. } 5\end{array}$ & & \\
\hline August 2 & Lanagan Creek.. & $\begin{array}{l}\text { Pargon Kiver } \\
\text { from east. } \\
\ldots \text { do ........... }\end{array}$ & Above Miocene & $\begin{array}{l}600 \\
650\end{array}$ & $\begin{array}{l}2.3 \\
9.0\end{array}$ & & \\
\hline September $18 .$. & ....do. & ...do. & Below M iocene & 550 & 4.5 & & \\
\hline August 19 . & Helen Creek... & Pargon River & In fume, at Par- & 700 & 6.1 & & \\
\hline $\begin{array}{l}\text { Septer } \\
\text { Septer } \\
\text { Augus }\end{array}$ & $\ldots . d$ & $\begin{array}{l}\ldots . . d \\
\cdots . . . d d\end{array}$ & e. ditch & $\begin{array}{l}700 \\
700 \\
580\end{array}$ & $\begin{array}{c}5.8 \\
5.6 \\
\text { c } 1.24\end{array}$ & & \\
\hline $\begin{array}{l}\text { September } 15 \ldots \\
\text { August } 29 . \ldots \ldots\end{array}$ & $\begin{array}{l}\text { Niukluk River. } \\
\text { Casadepag a }\end{array}$ & $\begin{array}{l}\text { Fish River .... } \\
\text { Niukluk River }\end{array}$ & A bove Ophir Creek & $\begin{array}{r}a 100 \\
500\end{array}$ & 296 & 644 & 0.46 \\
\hline Do............. & $\begin{array}{l}\text { River. } \\
\text {...do...... }\end{array}$ & ....do....... & $\begin{array}{l}\text { key Creek. } \\
\text { Below Moonlight } \\
\text { Creek, including } \\
\text { ditch. }\end{array}$ & 400 & 20 & $4 \pi$ & .43 \\
\hline Do & Moonlight Creek & Casadepaga & Ditch intake...... & 485 & 6.7 & .81 & (d) \\
\hline Do & do do h to & & $\begin{array}{l}\text { At mouth, includ. } \\
\text { ing ditch. }\end{array}$ & 400 & 8.9 & 1.0 & (d) \\
\hline
\end{tabular}

a Approximate.

o Not including Pargon ditch.

Inflow below Pargon ditch intake.

d The discharge of Moonlight Creek comes from large limestone springs, which probably receive much of their water from outside of the surface drainage area of Moonlight Creek. 
Miscellaneous measurements of streams in Seward Peninsula in 1909-Continued.

Flsh River dralnage basin-Continued.

\begin{tabular}{|c|c|c|c|c|c|c|c|}
\hline Date. & Stream. & Tributary to- & Locality. & $\begin{array}{l}\text { Eleva- } \\
\text { tion. }\end{array}$ & $\begin{array}{l}\text { Dis- } \\
\text { charge. }\end{array}$ & $\begin{array}{l}\text { Drain- } \\
\text { age } \\
\text { area. }\end{array}$ & $\begin{array}{l}\text { Dis- } \\
\text { charge } \\
\text { per } \\
\text { square } \\
\text { mile. }\end{array}$ \\
\hline August 28 . . & Ruby Creek.. & Casadepaga & At mouth, includ- & $\begin{array}{l}\text { Feet. } \\
\quad 310\end{array}$ & $\begin{array}{c}\text { sec.ft. } \\
1.8\end{array}$ & $\begin{array}{l}\text { Sq. } m i . \\
\text { 6. } 0\end{array}$ & $\begin{array}{r}S e c .-f t . \\
0.30\end{array}$ \\
\hline Do.. & Lower Willow & $\begin{array}{l}\text { Rlver. } \\
\text {....do. }\end{array}$ & $\begin{array}{l}\text { 1ng diteh. } \\
\text { A bove Ridgeway }\end{array}$ & 400 & 5.8 & 15.4 & .38 \\
\hline Do.... & Canyon Creek... & .....do. do. & $\begin{array}{l}\text { Above C a n y on } \\
\text { Creek Gold Min- } \\
\text { ing Company's } \\
\text { ditch intake. }\end{array}$ & 510 & 1.2 & 4.6 & .26 \\
\hline Do.. & .....do. & .....do do ......... & $\begin{array}{l}\text { Below B o u ld e I } \\
\text { Creek. }\end{array}$ & 355 & 9.4 & 22 & .43 \\
\hline Do. & Spring. . & Canyon Creek. & $\begin{array}{l}\text { At intake of Mc- } \\
\text { Kay ditch. }\end{array}$ & 395 & 6.4 & & \\
\hline $\begin{array}{r}\text { Do.......... } \\
\text { September } 20 .\end{array}$ & $\begin{array}{l}\text { Boulder Creek... } \\
\text { Ophir Creek.... }\end{array}$ & Niukluk River & At mouth. & $\begin{array}{l}355 \\
220\end{array}$ & 7.53 & 5.0 & .11 \\
\hline $\begin{array}{r}\text { September } 14 . \\
\text { Do.......... }\end{array}$ & $\begin{array}{l}\text { Melsing Creek. } \\
\text { Fox River.... }\end{array}$ & Fish River.......... & $\begin{array}{l}\text { At mouth. } \\
\text { Dam site at Fox } \\
\text { River road house. }\end{array}$ & 80 & $\begin{array}{r}9.6 \\
11.7\end{array}$ & $\begin{array}{l}30 \\
15.2\end{array}$ & .32 \\
\hline
\end{tabular}

Solomon River drainage basin.

\begin{tabular}{|c|c|c|c|c|c|c|c|}
\hline $\begin{array}{l}\text { August } 27 \ldots \ldots \\
\quad \text { Do } \ldots \ldots \ldots \\
\text { August } 16 \ldots . . \\
\text { August } 26 . \ldots \\
\text { September } 13 . \\
\text { August } 27 \ldots \ldots \\
\text { August } 16 \ldots . .\end{array}$ & 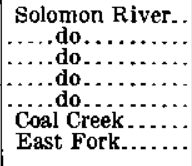 & 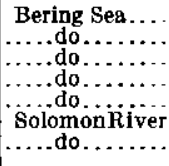 & 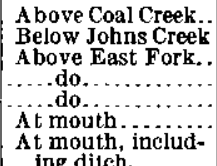 & $\begin{array}{l}250 \\
245 \\
146 \\
146 \\
146 \\
250 \\
146\end{array}$ & $\begin{array}{l}2.1 \\
22 \\
52 \\
26 \\
23 \\
16.3 \\
18.4\end{array}$ & $\begin{array}{l}10 \\
40 \\
49 \\
49 \\
49 \\
27 \\
17.2\end{array}$ & $\begin{array}{r}0.21 \\
.55 \\
1.06 \\
.53 \\
.47 \\
.60 \\
1.07\end{array}$ \\
\hline $\begin{array}{l}\text { August } 17 \ldots . . . \\
\text { September } 13 . . \\
\text { August } 16 \ldots . .\end{array}$ & Big ${ }_{\text {Creek. }}^{H}$ ur a h & $\begin{array}{l}\ldots \text { do } \\
\ldots \ldots \text { do } \\
\ldots \ldots \text { do } \\
\ldots \ldots \text { d }\end{array}$ & 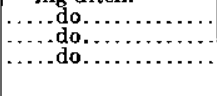 & $\begin{array}{r}146 \\
146 \\
. \quad 85\end{array}$ & $\begin{array}{l}16.2 \\
13.5 \\
19.3\end{array}$ & $\begin{array}{l}17.2 \\
17.2 \\
17.4\end{array}$ & $\begin{array}{r}.94 \\
.78 \\
1.11\end{array}$ \\
\hline
\end{tabular}

Nome River dralnage basin.

\begin{tabular}{|c|c|c|c|c|c|c|c|}
\hline July 16. & Nome Rlver. & Bering Sea. & Above Miocene in- & 575 & 36 & 15 & \\
\hline igust: & g & do & ..do. & 575 & 9.4 & 15 & \\
\hline & . & ....do. & $\begin{array}{c}\text { Below Seward in- } \\
\text { ta ke; seepage } \\
\text { through dam } \\
\text { onjy. }\end{array}$ & 408 & 3.3 & & \\
\hline $\begin{array}{r}\text { Do......... } \\
\text { eptember } 14 .\end{array}$ & \begin{tabular}{|} 
Alfield Creek.... \\
$\ldots$ do $\ldots$
\end{tabular} & $\begin{array}{c}\text { Nome River. } \\
\ldots \ldots . \text { do......... }\end{array}$ & $\begin{array}{l}1 \text { mile above mouth } \\
\text { mile above mouth }\end{array}$ & $\begin{array}{l}410 \\
500\end{array}$ & $\begin{array}{l}4.5 \\
3.3\end{array}$ & $\begin{array}{l}4.4 \\
4.4\end{array}$ & $\begin{array}{r}1.02 \\
.75\end{array}$ \\
\hline August & Christian Creek. & ......do & A bove railroad.... & 380 & 2. & 2. & 1.00 \\
\hline Se & $\ldots . . d \mathrm{dc}$ & 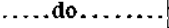 & ......do. & 410 & 1.4 & 2.1 & .67 \\
\hline
\end{tabular}

Sinuk River drainage basin.

\begin{tabular}{|c|c|c|c|c|c|c|c|}
\hline $\begin{array}{r}\text { September 5... } \\
\text { Do.......... }\end{array}$ & $\begin{array}{l}\text { Sinuk River.... } \\
\text { Wind y Creek... }\end{array}$ & $\begin{array}{l}\text { Bering Sea.... } \\
\text { Sinuk River.. }\end{array}$ & $\begin{array}{l}\text { Below upper lake.. } \\
\text { Bet w e n lower }\end{array}$ & $\begin{array}{l}770 \\
670\end{array}$ & $\begin{array}{l}12.4 \\
20\end{array}$ & $\begin{array}{r}6.2^{\circ} \\
12.0\end{array}$ & $\begin{array}{l}2.00 \\
1.67\end{array}$ \\
\hline $\begin{array}{l}\text { September } 15 . . \\
\text { September } 5 . .\end{array}$ & North Star Creek & Windy Creek. & 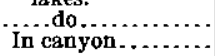 & $\begin{array}{l}670 \\
900\end{array}$ & $\begin{array}{l}a 18 \\
1.93\end{array}$ & $\begin{array}{r}12.0 \\
2.3\end{array}$ & $\begin{array}{r}1.50 \\
.84\end{array}$ \\
\hline
\end{tabular}

Cobblestone Rlver drainage basin.

\begin{tabular}{|c|c|c|c|c|c|c|c|}
\hline September $16 .$. & $\begin{array}{l}\text { Cobblestone } \\
\text { River. }\end{array}$ & Imuruk Basin. & $\begin{array}{l}\text { Below Oro Grande } \\
\text { Creek. }\end{array}$ & 500 & 126 & 58 & 217 \\
\hline
\end{tabular}

a Computed from gage reading. 
WATER-SUPPLY INVESTIGATIONS IN SEWARD PENINSULA. 409

Miscellaneous measurements of streams in Seward Peninsula in 1909-Continued.

Grand Central River dralnage bastn.

\begin{tabular}{|c|c|c|c|c|c|c|c|}
\hline Date. & Stream. & Tributary to- & Locality. & $\begin{array}{l}\text { Eleva- } \\
\text { tion. }\end{array}$ & $\begin{array}{c}\text { Dis- } \\
\text { charge. }\end{array}$ & $\begin{array}{l}\text { Drain- } \\
\text { age } \\
\text { area. }\end{array}$ & $\begin{array}{l}\text { Dis- } \\
\text { charge } \\
\text { per } \\
\text { square } \\
\text { mile. }\end{array}$ \\
\hline July $10 \ldots . . . .$. & West Fork ...... & Grand Central & Pipe intake........ & $\begin{array}{l}\text { Feet. } \\
1,010\end{array}$ & Sec.-ft. & $\underset{2.8}{S q . m i}$ & $\begin{array}{l}\text { Sec.-ft. } \\
11.4\end{array}$ \\
\hline $\begin{array}{l}\text { August } 5 \ldots \ldots \ldots \\
\text { August } 8 \ldots \ldots \ldots \\
\text { September } 21 \ldots \\
\text { July } 11 \ldots \ldots \ldots \\
\text { July } 18 . \ldots \ldots \ldots \\
\text { August } 5 \ldots \ldots \ldots \\
\text { August } 8 \ldots \ldots \ldots \\
\text { September } 4 \ldots .\end{array}$ & 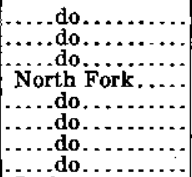 & 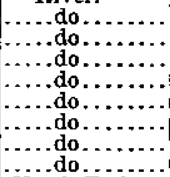 & 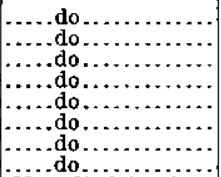 & $\begin{array}{l}1,010 \\
1,010 \\
1,010 \\
1,030 \\
1,030 \\
1,030 \\
1,030 \\
1,030\end{array}$ & $\begin{array}{l}7.3 \\
5.1 \\
1.56 \\
36 \\
27 \\
14.3 \\
13.0 \\
11.6\end{array}$ & $\begin{array}{l}2.8 \\
2.8 \\
2.8 \\
2.3 \\
2.3 \\
2.3 \\
2.3 \\
2.3\end{array}$ & $\begin{array}{c}2.61 \\
1.82 \\
.56 \\
15.7 \\
11.7 \\
6.22 \\
5.65 \\
5.04\end{array}$ \\
\hline $\begin{array}{r}\text { Do................ } \\
\text { July } 19 \ldots \ldots\end{array}$ & 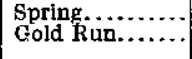 & North Fork... & $\begin{array}{l}\text { Near ditch intake.- } \\
\text { Below ditch intake. }\end{array}$ & $\begin{array}{l}850 \\
820\end{array}$ & $21^{4.6}$ & . & $\cdots \cdots$ \\
\hline $\begin{array}{l}\text { August } 4 \ldots \ldots . . \\
\text { August } 7 \ldots \ldots \ldots \\
\text { September } 21 . \\
\text { June } 28 \ldots \ldots \ldots \\
\text { July } 15 \ldots \ldots \ldots\end{array}$ & 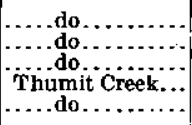 & 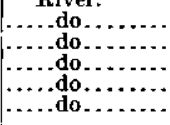 & 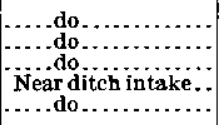 & $\begin{array}{l}820 \\
820 \\
820 \\
800 \\
800\end{array}$ & $\begin{array}{r}47 \\
15.2 \\
5.4 \\
8.0 \\
3.1\end{array}$ & $\begin{array}{r}.73 \\
.73\end{array}$ & $\begin{array}{c}11.0 \\
4.25\end{array}$ \\
\hline
\end{tabular}

Kruzgamepa Fiver dralnage basin.

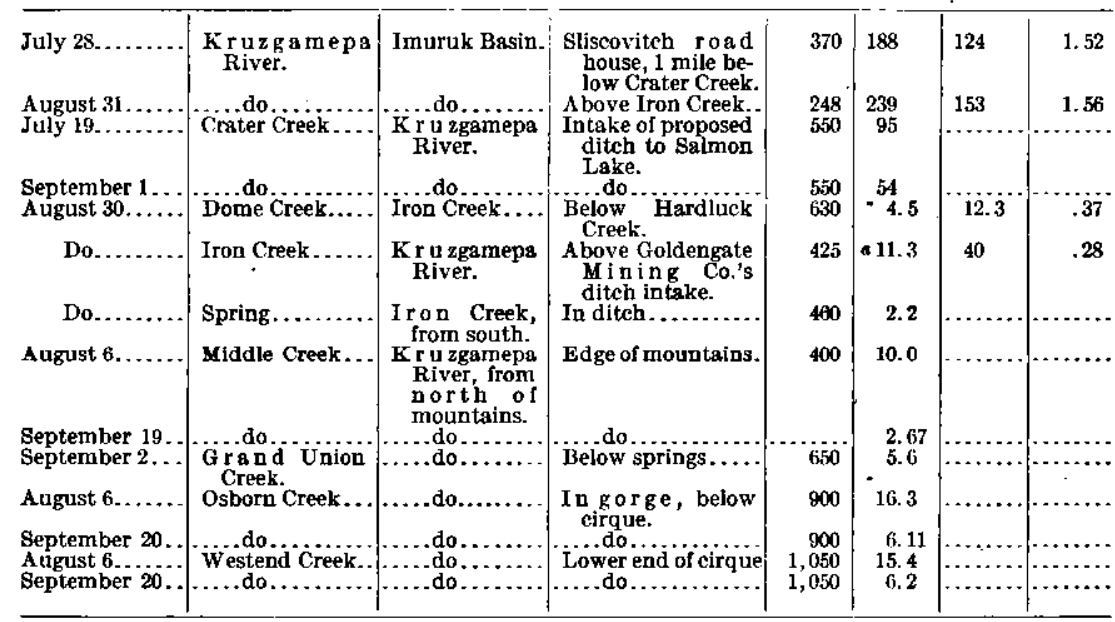

\section{Norapaga River dralnage basin.}

\begin{tabular}{|c|c|c|c|c|c|c|c|}
\hline $\begin{array}{l}\text { August } 29 \ldots \ldots \\
\text { August } 27 \ldots \ldots\end{array}$ & $\begin{array}{l}\text { Noxapaga River } \\
\text { Eldorado Creek. }\end{array}$ & $\begin{array}{c}\text { Kuzitrin River } \\
\text { Noxa p a a } \\
\text { River }\end{array}$ & $\begin{array}{l}\text { Above Goose Creek } \\
\text { Trail crossing...... }\end{array}$ & 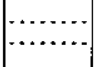 & $\stackrel{31}{2.1}$ & $\begin{array}{r}340 \\
30\end{array}$ & $\begin{array}{r}0.091 \\
.070\end{array}$ \\
\hline $\begin{array}{l}\text { August } 29 \ldots \ldots \\
\text { A ugust } 30 \ldots \ldots \\
\text { August } 28 \ldots \ldots\end{array}$ & $\begin{array}{l}\text { Aurora Creek... } \\
\text { Turner Creek.... } \\
\text { Boulder Creek.. }\end{array}$ & $\mid \begin{array}{c}\ldots . \text { do } \\
\ldots . . . . . . . \\
\text { Turner Creek. }\end{array}$ & $\begin{array}{l}\text { Near mouth.. } \\
\text { Diteh intake.. } \\
\text { Claim No. } 5 . .\end{array}$ & & $\begin{array}{r}2.0 \\
.5 \\
.5\end{array}$ & $\begin{array}{l}28 \\
13 \\
6.5\end{array}$ & $\begin{array}{l}.071 \\
.038 \\
.077\end{array}$ \\
\hline
\end{tabular}

$a$ Poor measuring section; results probably too small. 
Miscellaneous measurements of streams in Seward Peninsula in 1909-Continued.

Kougarok River dralnage basin.

\begin{tabular}{|c|c|c|c|c|c|c|c|}
\hline Date. & Stream. & Tributary to- & Locality. & $\begin{array}{l}\text { Eleva- } \\
\text { tion. }\end{array}$ & $\begin{array}{c}\text { Dis- } \\
\text { eharge. }\end{array}$ & $\begin{array}{l}\text { Drain- } \\
\text { age } \\
\text { area. }\end{array}$ & $\begin{array}{l}\text { Dis- } \\
\text { charge } \\
\text { per } \\
\text { square } \\
\text { mile. }\end{array}$ \\
\hline July $24 \ldots . .$. & Kougarok River & Kuzitrin River & Above Taylor & $\begin{array}{r}\text { Feet. } \\
433\end{array}$ & $\begin{array}{l}\text { Sec.-ft. } \\
4.0\end{array}$ & Sq. $m i$ & $\left\{\begin{array}{r}\text { Sec. } f t \\
0.049\end{array}\right.$ \\
\hline August $30 . \ldots$. & Taylor Creek... & $\begin{array}{l}\text { Kouga r o } \mathbf{k} \\
\text { River. }\end{array}$ & At North Star & 480 & 8. 5 & 83 & .10 \\
\hline July $24 \ldots .$. & .....do... & .... do ......... & At mouth, includ- & 433 & 2.8 & 90 & .031 \\
\hline $\begin{array}{l}\text { August } 9 \ldots \ldots . \\
\text { August } 10 \ldots \ldots \\
\text { June } 20 \ldots \ldots .\end{array}$ & Coarse Gold & 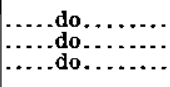 & 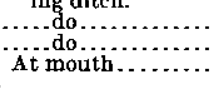 & $\begin{array}{l}433 \\
433 \\
341\end{array}$ & $\begin{array}{c}6.6 \\
103 \\
50\end{array}$ & $\begin{array}{l}90 \\
90 \\
34\end{array}$ & $\begin{array}{l}.073 \\
1.14 \\
1.47\end{array}$ \\
\hline $\begin{array}{l}\quad \text { Do.......... } \\
\text { July } 21 . \ldots . . . \\
\text { August } 31 . . . \\
\text { A ugust } 30 . \ldots .\end{array}$ & 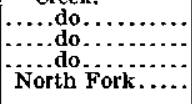 & $\ldots$.... do... & 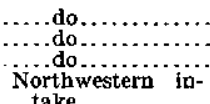 & $\begin{array}{l}341 \\
341 \\
341 \\
540\end{array}$ & $\begin{array}{r}76 \\
.9 \\
.8 \\
.7\end{array}$ & $\begin{array}{l}34 \\
34 \\
.34 \\
19.8\end{array}$ & $\begin{array}{l}2.24 \\
.026 \\
.024 \\
.035\end{array}$ \\
\hline June 20. & Eureka Creek... & North Fork... & Near mouth, in- & 370 & 5.4 & 3.1 & 1.74 \\
\hline June 19.. & Windy Creek.... & $\begin{array}{l}\text { Kougarok } \\
\text { River. }\end{array}$ & $\begin{array}{l}\text { A bove Anderson } \\
\text { Gulch, including } \\
\text { ditch. }\end{array}$ & & 20 & 27 & .74 \\
\hline $\begin{array}{l}\text { July } 20 . . . . . . \\
\text { September } 2 . .\end{array}$ & .... do... & .... do & .... do .............. & & $\begin{array}{l}1.2 \\
1.9\end{array}$ & $\begin{array}{l}27 \\
27\end{array}$ & $\begin{array}{l}.044 \\
.070\end{array}$ \\
\hline
\end{tabular}

Goodhope Rlver drainege basin.

\begin{tabular}{|c|c|c|c|c|c|c|c|}
\hline June $25 \ldots \ldots$ & Right Fork..... & Goodhope & At mouth . . . . . . & 260 & 38 & 80 & 0.48 \\
\hline $\begin{array}{l}\text { July } 21 . \ldots \ldots \\
\text { August } 26 \ldots \ldots \\
\text { June } 25 \ldots \ldots \ldots\end{array}$ & .... do... & do. & A bove $\mathbf{D}$ ivide & $\begin{array}{l}260 \\
260 \\
330\end{array}$ & $\begin{array}{r}18.1 \\
12.4 \\
a 10.4\end{array}$ & $\begin{array}{l}80 \\
80 \\
38\end{array}$ & $\begin{array}{l}.23 \\
.16 \\
.27\end{array}$ \\
\hline $\begin{array}{l}\text { July } 21 . . . . \\
\text { August } 26 . . \\
\text { June } 25 . . .\end{array}$ & Divide Creek.... & Cotton $w$ o o d & 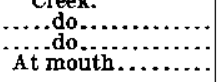 & $\begin{array}{l}330 \\
330 \\
330\end{array}$ & $\begin{array}{c}\text { a. } 2.3 \\
a .78 \\
4.9\end{array}$ & $\begin{array}{l}38 \\
38 \\
10.6\end{array}$ & $\begin{array}{l}.061 \\
.021 \\
.46\end{array}$ \\
\hline $\begin{array}{l}\text { July } 21 \ldots \ldots \ldots \\
\text { August } 26 \ldots \ldots \\
\text { June } 24 \ldots \ldots \ldots\end{array}$ & $\begin{array}{l}\ldots \text {. do .......... } \\
\text { Esperanza Creek }\end{array}$ & 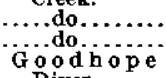 & $\begin{array}{l} \\
\cdots \\
\cdots\end{array}$ & $\begin{array}{l}330 \\
330 \\
100\end{array}$ & $\begin{array}{r}1.74 \\
.27 \\
2.8\end{array}$ & $\begin{array}{l}10.6 \\
10.6 \\
20\end{array}$ & $\begin{array}{l}.16 \\
.025 \\
.14\end{array}$ \\
\hline July 21 & do. & & do. & 100 & b. 25 & .20 & .012 \\
\hline
\end{tabular}

Inmachuk Rlver drainage basln.

\begin{tabular}{|c|c|c|c|c|c|c|c|}
\hline July $19 . . . . . .$. & Inmachuk River & $\begin{array}{l}\text { Ko t z e bue } \\
\text { Sound. }\end{array}$ & $\begin{array}{l}\text { A bove Eureka } \\
\text { Creek. }\end{array}$ & 210 & 10.9 & 8.6 & 1.27 \\
\hline August 7 . & .....do... & ....do....... & ....do........ & 210 & 9.4 & 8. 6 & 1.09 \\
\hline August 26..... & .... do............. & ..... do. . & 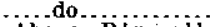 & 210 & 8.3 & 8.6 & .97 \\
\hline August 8. . .... & .....do.. & .....do. & $\begin{array}{l}\text { Above Pinnell } \\
\text { River. }\end{array}$ & 140 & 9.8 & 46 & .21 \\
\hline Do. & .....do.. & ....do. . . . . & Above Cue Creek. & 60 & $c 56$ & 177 & \\
\hline July 19. & Hannum Creek - & $\underset{\text { River. }}{\text { In mach }}$ k & At mouth $\ldots . .$. & 175 & 3.5 & 34 & 10 \\
\hline $\begin{array}{l}\text { August } 8 \text {. } \\
\text { August 25 }\end{array}$ & .... do & .....do. & .... do & 175 & 1.77 & 34 & .052 \\
\hline July $19 . .$. & Pinnell River... & -do & ..... do & 140 & 6.6 & 96 & .069 \\
\hline August $7 \ldots . .$. & ....do.......... & do & .....do. & 140 & 3.1 & 96 & .032 \\
\hline Anlgust 25..... & $\ldots . . d o$ & & do & 140 & 3.2 & 96 & .033 \\
\hline
\end{tabular}

a Probably much underflow through gravel.

$b$ Estimated.

c Includes about 42 second-feet from Fairhaven ditch. 
Miscellaneous measurements of streams in Seward Peninsula in 1909-Continued.

Kngruk River drainage basln.

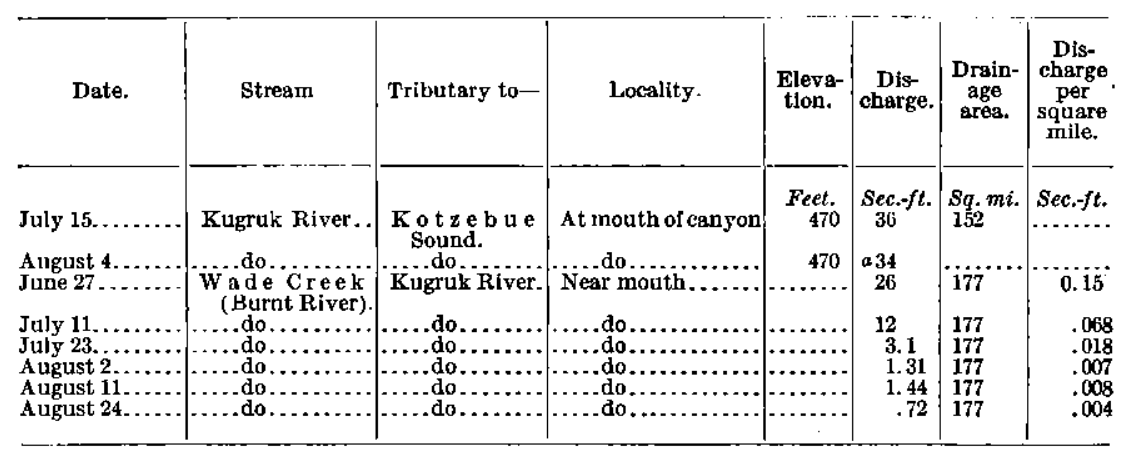

Kuwallk River dratnage basin.

\begin{tabular}{|c|c|c|c|c|c|c|c|}
\hline July $2 \ldots . . . .$. & Gold Run. & Kiwalik River & $\begin{array}{l}\text { Proposed ditch in- } \\
\text { take. }\end{array}$ & $\cdots$ & 3.2 & 9.0 & 0.36 \\
\hline $\begin{array}{l}\text { July } 28 . \ldots . . . . . \\
\text { August } 16 . . . . .\end{array}$ & ... do.. & $\begin{array}{l}\text {....do.. } \\
\text {..... do.. }\end{array}$ & 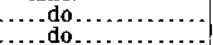 & & $\begin{array}{l}1.04 \\
1.20\end{array}$ & $\begin{array}{l}9.0 \\
9.0\end{array}$ & $\begin{array}{l}.12 \\
.13\end{array}$ \\
\hline 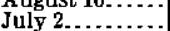 & Boulder Creek. & Gold Run...... & do. & & $\begin{array}{r}1.20 \\
.47\end{array}$ & $\begin{array}{l}9.0 \\
4.0\end{array}$ & .12 \\
\hline July 29. & Dome Creek.... & Kiwalik River & Candle ditch intake & 383 & 39 & 9.0 & .043 \\
\hline June 30 . . & Eldorado Creek. & .... do ........ & Siphon crossing... & & 2.4 & & \\
\hline June 29 . & Candle Creek... & .... do. & At mouth . .......... & & 6.3 & 60 & .105 \\
\hline July 6 . & ....do......... & ....do. & .....do............. & 2 & .72 & 60 & 012 \\
\hline July 8. & $\ldots$. do.... & .....do. & .....do.............. & 2 & .86 & 60 & .014 \\
\hline July $10 \ldots \ldots \ldots$ & .... do. & .....do........ & $\ldots .$. do do............. & 2 & 7.2 & & .12 \\
\hline July $30 \ldots \ldots$ & ..... do. & .....do... & ....do............... & 2 & 0 & 60 & .00 \\
\hline August $4 \ldots \ldots$ & & & .....do... & 2 & .30 & 60 & .005 \\
\hline
\end{tabular}

a Ineludes 14 second-feet from Fairhaven ditch and Imuruk Lake. 
Miscellaneous measurements of ditches in Seward Peninsula in 1909.

Fish River drainage basin.

\begin{tabular}{|c|c|c|c|c|c|}
\hline Date. & Ditch. & Diverts from- & Locality. & $\begin{array}{c}\text { Gage } \\
\text { height. }\end{array}$ & $\begin{array}{c}\text { Dis- } \\
\text { charge. }\end{array}$ \\
\hline & & & & Feet. & Sec.-fi. \\
\hline Ssptember 5... & Pargon............ & Pargon River...... & Above Dillon Creek........ & $\ldots \ldots$ & 14.2 \\
\hline Do.......... & ....do............ & ....do............. & Below Dillon Creek......... & & 15.3 \\
\hline August $19 \ldots \ldots$ & .....do... & .....do. & $1 \frac{1}{2}$ miles below Helen Creek. & a 1.56 & 29.2 \\
\hline July $17 \ldots \ldots$ & do. & .... do. & 2 miles below Helen Creek. & $a 1.50$ & 27.5 \\
\hline September 5... & $\ldots$ do... & ...do. & Outlet into Ophir Creek.... & a 1.33 & 19.7 \\
\hline August $19 . \ldots$. & $\begin{array}{l}\text { MeKelvie Creek } \\
\text { lateral. }\end{array}$ & McKelvi & 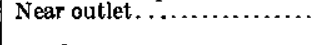 & . & 7.4 \\
\hline September $5 . .$. & ...do............. & do. & do. & & 3.9 \\
\hline September 18 . - & 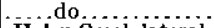 & do $\ldots$.... & .... do... & & 3.0 \\
\hline August $19 \ldots \ldots$ & Helen Creek lateral. & Helen Creek ....... & .... do... & a 1.56 & 6. 1 \\
\hline $\begin{array}{l}\text { September } 17 . \\
\text { September } 19 .\end{array}$ & .... do............. & 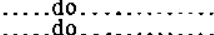 & $\ldots \ldots$ do $\ldots . . . . . . . .$. & $\begin{array}{l}a \\
a\end{array}$ & . $\quad 5.8$ \\
\hline $\begin{array}{l}\text { September } 18 . \\
\text { August } 23 . \ldots \ldots\end{array}$ & Canyon $\ldots . . . .$. & Ophir Creek ........ & Below Crooked Creek Hume. & 01.19 & $\begin{array}{r}5.6 \\
40.6\end{array}$ \\
\hline July $10 \ldots \ldots$. & ... do ............ & ....do............ & Below claim $10 \ldots \ldots \ldots$ & 1.80 & 29.7 \\
\hline July 14 & .....do... & .....do. & $\ldots$. do $\ldots \ldots \ldots \ldots \ldots \ldots \ldots$ & 1.50 & 21.5 \\
\hline August $18 \ldots \ldots$ & .....do... & .....do... & $\ldots$. do $\ldots \ldots \ldots \ldots \ldots \ldots \ldots$ & 1.74 & 33.4 \\
\hline $\begin{array}{l}\text { August } 24 . \ldots \\
\text { September } 15 .\end{array}$ & do. do. & $\ldots$ do... & 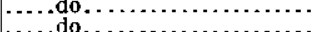 & 1.64 & 28.7 \\
\hline July $14 \ldots . . . .$. & ..do. & .....do. & 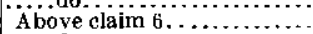 & $\begin{array}{l}1.58 \\
1.83\end{array}$ & $\begin{array}{l}25.1 \\
20.9\end{array}$ \\
\hline August 1 . & do. & -do. & $\ldots \ldots$ do $\ldots \ldots \ldots \ldots \ldots \ldots \ldots$ & 1.54 & 10.3 \\
\hline August 18. & do. & do. & $\ldots$. do......... & 2.03 & 30.4 \\
\hline September 15. - & ..do.. & do. & ..do... & 1.90 & 26.7 \\
\hline September 16. & do. & do. & $\ldots$ do... & 1.84 & 24.6 \\
\hline July $10 \ldots \ldots \ldots$ & . do. & . do. & Below claim 6... & 1.80 & 25.5 \\
\hline September 15. & ..do. & - do. & ....do. . . . . & $\cdots$ & 14.0 \\
\hline July 10 & do & . do. & Below claim 4... & .96 & 6.8 \\
\hline July 14 . & .do. & . do. & $\ldots .$. do................ & .71 & 2.19 \\
\hline August 13 & $\ldots$...... do. & .... do do.......... & .... do ... & .37 & 0 \\
\hline August 18..... & Twenty-two. & $\begin{array}{l}\text { Opbir Creek, on } \\
\text { claim } 22 \text {. }\end{array}$ & At intake. & & 3.3 \\
\hline $\begin{array}{l}\text { August } 24 . \\
\text { September }\end{array}$ & . do & -do.. & do & & 3.3 \\
\hline August $18 \ldots . .$. & Nineteen. & Ophir Creek, on & & & $\begin{array}{l}2.3 \\
5.7\end{array}$ \\
\hline August & do. & 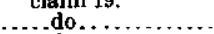 & .... do & & 5.8 \\
\hline SEPLEM & & do........ & & & 4. 3 \\
\hline August & Bot Air & Ophir Creek, on & On clain & & 11.3 \\
\hline August 23 & Stiteh. & $\begin{array}{l}\text { Portland Gulch, } \\
\text { tributary of Ox- } \\
\text { ide Creek. }\end{array}$ & At outlet & & 1.38 \\
\hline
\end{tabular}

Solomon River dralnage basin.

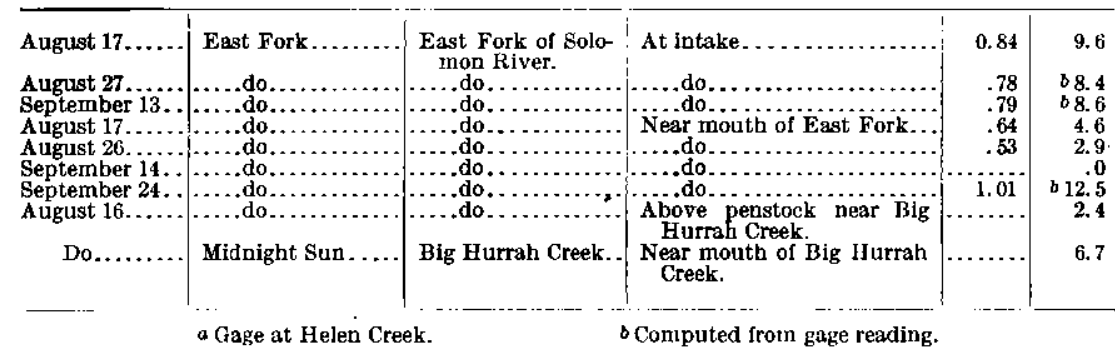


Miscellaneous measurements of ditches in Seward Peninsula in 1909-Continued.

Nome Rlver drainage besin.

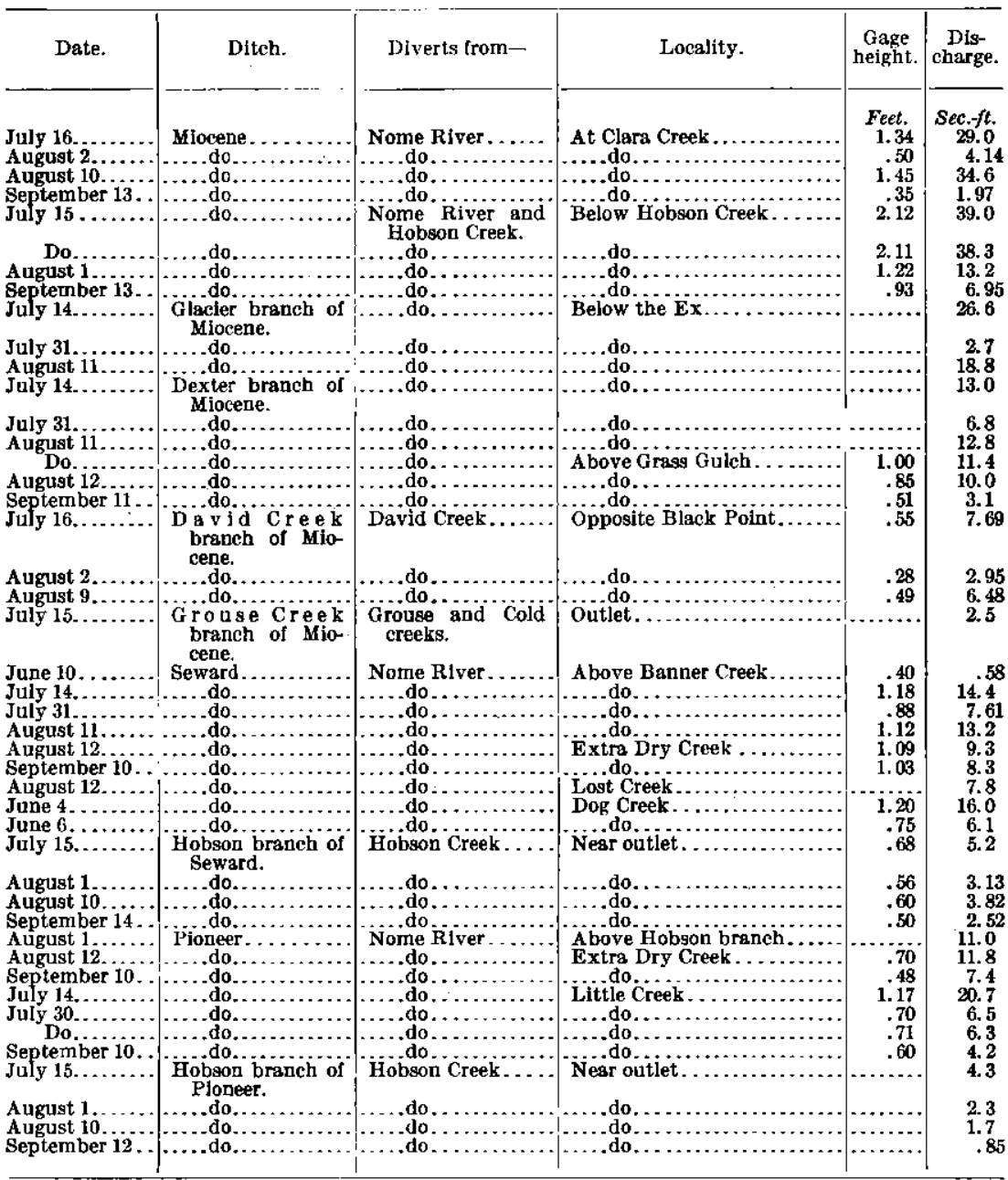

Grand Central Rlver draluage basln.

\begin{tabular}{|c|c|c|c|c|c|}
\hline July $17 . . . .$. & $\begin{array}{l}\text { G rand Central } \\
\text { branch of Mio- } \\
\text { cene. }\end{array}$ & Nugget Creek. & Below Nugget Creek.... & 0.80 & 1.85 \\
\hline August 3 & ....do............... & do. & do. & .73 & 1.05 \\
\hline July 17 . & $\begin{array}{l}\text { Jett Creek branch } \\
\text { of Miocene. }\end{array}$ & Jett Creek. & Above Copper Creek siphon. & & 1.3 \\
\hline $\begin{array}{r}\text { Do. } \\
\text { August } 3\end{array}$ & …do......... & $\begin{array}{l}\text { (.... do } \\
\text {..... }\end{array}$ & $\begin{array}{l}\text { Below siphon .... } \\
\text {....do.......... }\end{array}$ & $\begin{array}{r}1.00 \\
.75\end{array}$ & $\begin{array}{r}2.72 \\
.52\end{array}$ \\
\hline July 17 . & $\begin{array}{l}\text { C o p p e r Creek } \\
\text { branch of Mio- } \\
\text { cene. }\end{array}$ & Copper Creek. & $\begin{array}{l}\text { Above junction with Jett } \\
\text { Creek branch. }\end{array}$ & & 1.2 \\
\hline
\end{tabular}


Miscellaneous measurements of ditches in Seward Penninsula in 1909-Continued.

Kruzgamepa River drainage basin.

\begin{tabular}{|c|c|c|c|c|c|}
\hline Date. & Ditch. & Diverts from- & Locality. & $\begin{array}{c}\text { Gage } \\
\text { height. }\end{array}$ & $\begin{array}{c}\text { Dis- } \\
\text { charge. }\end{array}$ \\
\hline June $17, \ldots \ldots$ & Iron Creek tunnel & Iron Creek . & Intake... & $\begin{array}{c}\text { Fect. } \\
0.45\end{array}$ & $\begin{array}{r}\text { Sec. } f t . \\
9.7\end{array}$ \\
\hline $\begin{array}{l}\text { July } 20 \ldots \ldots \ldots \\
\text { July } 27 \ldots \ldots \ldots\end{array}$ & & (....do. & 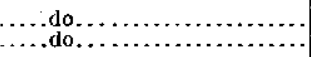 & $\begin{array}{r}1.05 \\
.80\end{array}$ & $\begin{array}{l}22.6 \\
17.2\end{array}$ \\
\hline
\end{tabular}

Kougarok River dralnage basin.

\begin{tabular}{|c|c|c|c|c|c|}
\hline September 1... & Homestake ........ & Kougarok River.... & Intske. & 0.29 & 5.3 \\
\hline August $30 \ldots \ldots$ & North Star. . . . . . . & Taylor Creek. & Below siphon . . . . . . . & $\ldots . . .$. & 7 \\
\hline September $3 . .$. & ... do......... & ... do..... & .... do........ & . & , \\
\hline September 15. & ....do.. & ...do...... & $\ldots$ do................... & $\ldots$ & 8. 7 \\
\hline June $20 \ldots$ & Galvin. & Coarse Gold Creek.. & Above penstock............ & $\ldots$ & 5.8 \\
\hline Do.. & wido........... & *y.do...... & ...do. . . & & 7.6 \\
\hline September $2 \ldots$ & 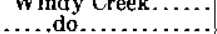 & $\begin{array}{l}\text { windy Creek } \\
\ldots . . . \text { do . . . . . }\end{array}$ & 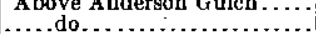 & & $\begin{array}{r}1.0 \\
.4\end{array}$ \\
\hline
\end{tabular}

Inmachuk RIver dralnage basin.

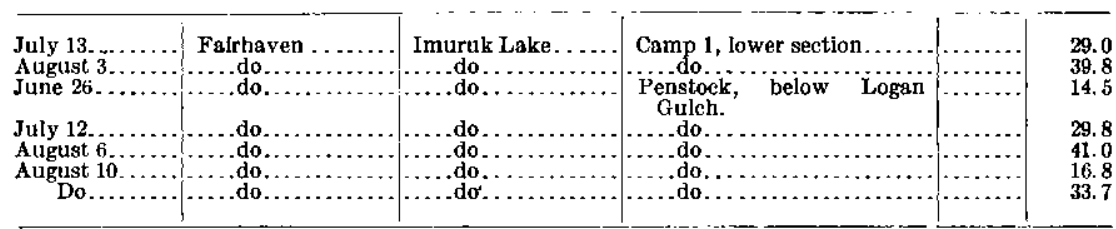

RAINFALL RECORDS.

Records of precipitation were obtained at six stations in Seward Peninsula for a part or the whole of the season of 1909 . It has been the object, as far as possible, to obtain the records near the drainage basin on which records of discharge were kept. The stations have therefore been placed in the interior, at mining and ditch camps, where it is hard to obtain records for an entire season. The Iocation, elevation, etc., of these stations are given in the following table.

Rainfall stations in Seward Peninsula, 1909.

\begin{tabular}{|c|c|c|c|c|c|c|}
\hline \multirow{2}{*}{ Station. } & \multirow{2}{*}{ Latitude. } & \multirow{2}{*}{ Longitude. } & \multicolumn{2}{|c|}{ Elevation- } & \multirow{2}{*}{ Observer. } & \multirow{2}{*}{$\begin{array}{l}\text { Date estab- } \\
\text { lished. }\end{array}$} \\
\hline & & & $\begin{array}{c}\text { Above } \\
\text { sea level. }\end{array}$ & $\begin{array}{c}\text { Above } \\
\text { ground. }\end{array}$ & & \\
\hline $\begin{array}{l}\text { Nome } \\
\text { Black Point................. } \\
\text { Grand Central........ }\end{array}$ & $\begin{array}{lc}\circ & , \\
64 & 30 \\
64 & 51 \\
64 & 58\end{array}$ & $\begin{array}{cc}\circ & 1 \\
165 & 24 \\
165 & 16 \\
165 & 14\end{array}$ & $\begin{array}{r}\text { Feet. } \\
40 \\
575 \\
690\end{array}$ & $\begin{array}{r}\text { Feet. } \\
20 \\
2 \\
2\end{array}$ & $\begin{array}{l}\text { Arthur Gibson ...... } \\
\text { F. F. Miller........ } \\
\text { P. B. Chapman and }\end{array}$ & $\begin{array}{l}\text { June } 14,1906 \\
\text { June } 23,1906 \\
\text { July } 10,1907\end{array}$ \\
\hline 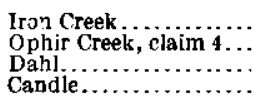 & $\begin{array}{ll}64 & 58 \\
64 & 56 \\
65 & 22 \\
65 & 55\end{array}$ & $\begin{array}{ll}164 & 38 \\
163 & 42 \\
164 & 41 \\
161 & 56\end{array}$ & $\begin{array}{r}350 \\
160 \\
230 \\
25\end{array}$ & $\begin{array}{r}2 \\
2 \\
2 \\
15\end{array}$ & $\begin{array}{l}\text { otners. } \\
\text { George Lorimer.... } \\
\text { H. Leland. } \\
\text { John A. White...... } \\
\text { Ward Estey ........ }\end{array}$ & $\begin{array}{lr}\text { June } & 22,1907 \\
\text { July } & 1,1908 \\
\text { Aug. } & 1,1909 \\
\text { Aug. } & 11,1909\end{array}$ \\
\hline
\end{tabular}


The records obtained show, as in previous years, that the precipitation is high in the Kigluaik Mountains, moderate in the area south of them, and very low in the northern half of the peninsula. The daily rainfall for 1909 at all stations and the monthly total for the years 1906 to 1909 at Nome are given below.

Monthly precipitation, in inches, at Nome, Alaska, for 1906 to 1909.

\begin{tabular}{c|c|c|c|c|c|c|c|c|c|c|c|c|c}
\hline Year. & Oct. & Nov. & Dec. & Jan. & Feb. & Mar. & Apr. & May. & June. July. & A ug. & Sept. & Pe- \\
riod.
\end{tabular}

Daily rainfall and snowfall, in inches, at Nome for 1908-9.

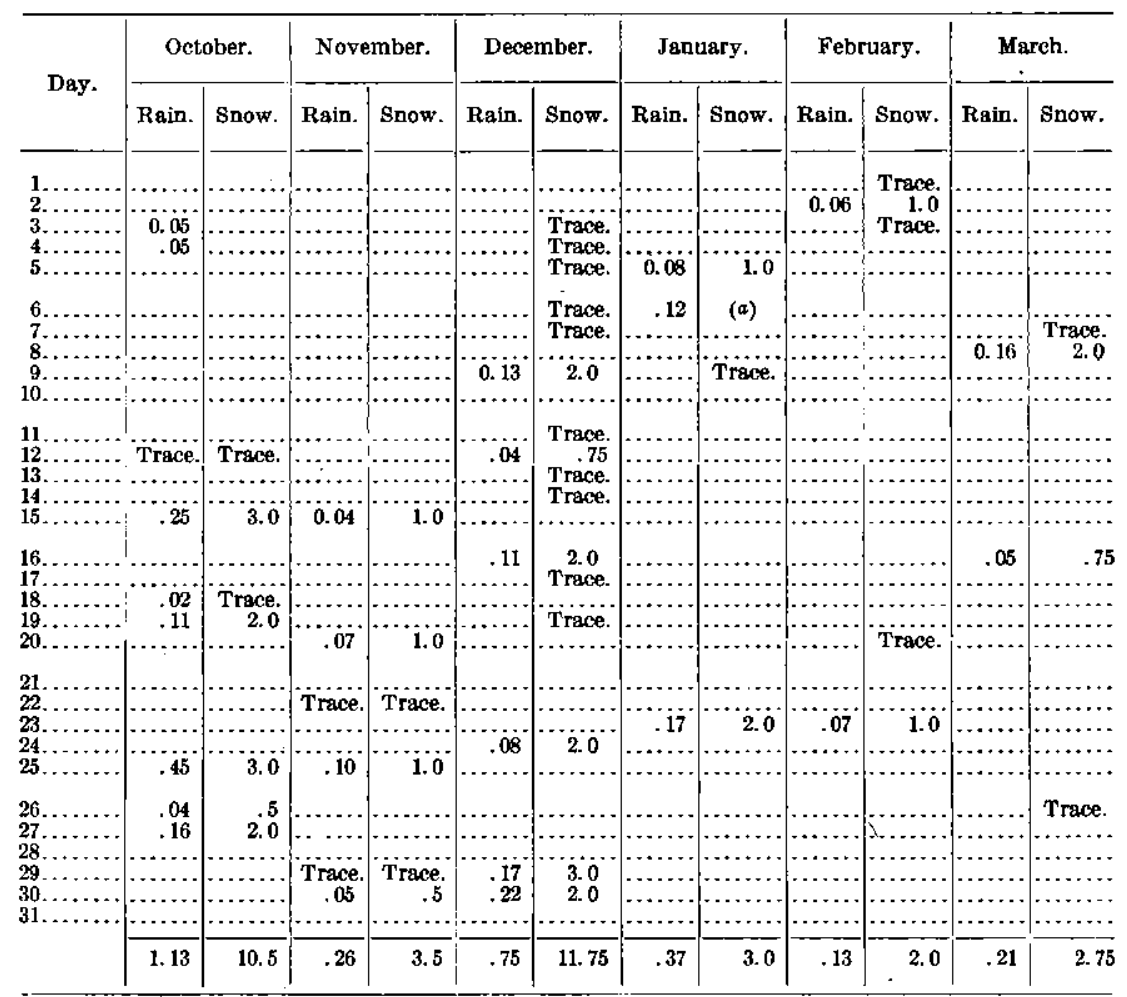

a Snow and sleet. 
Daily rainfall and snowfall, in inches, at stations in Seward Y'eninsula in 1909.

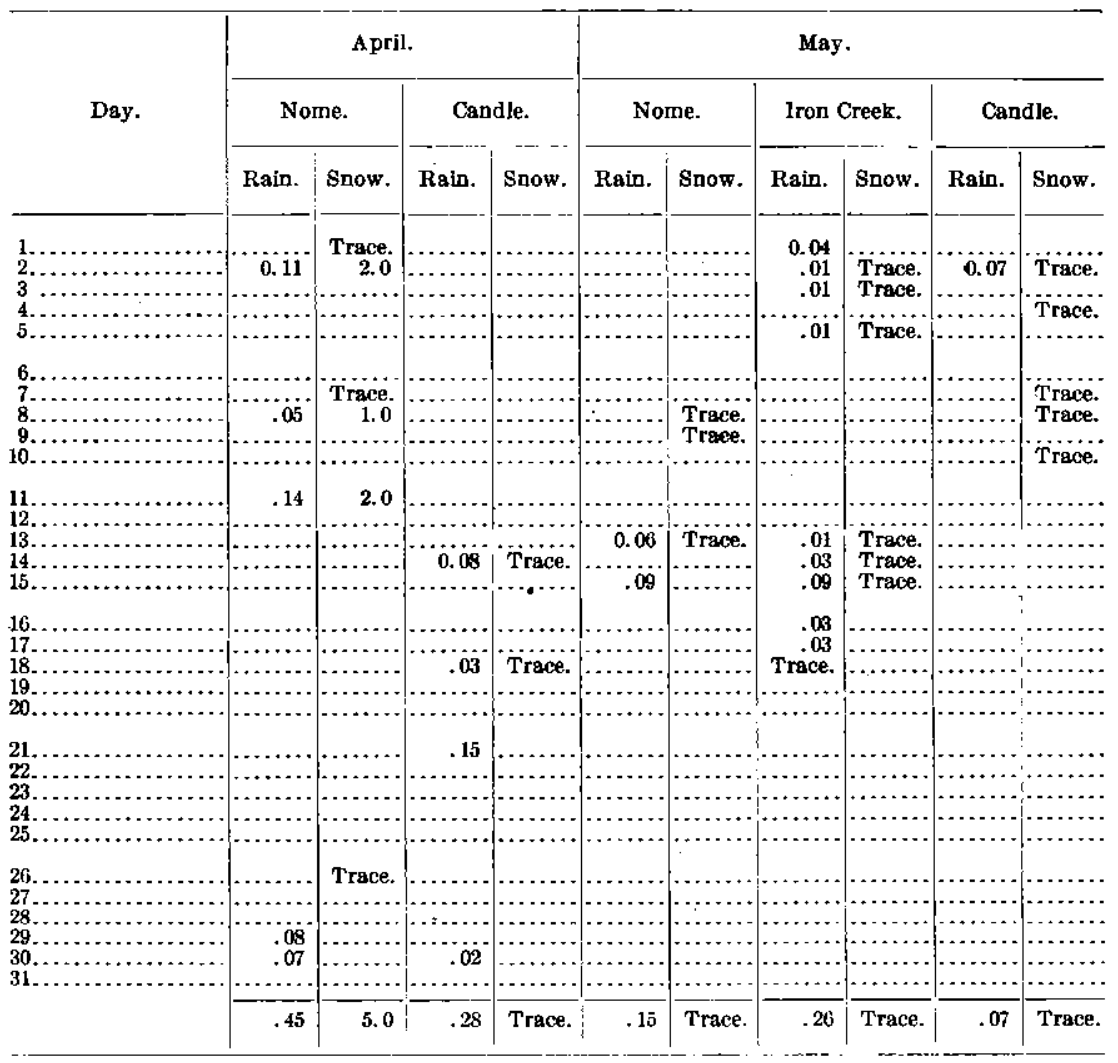


Daily rainfall and snowfall, in inches, at stations in Seward Peninsula for 1909-Cont'd.

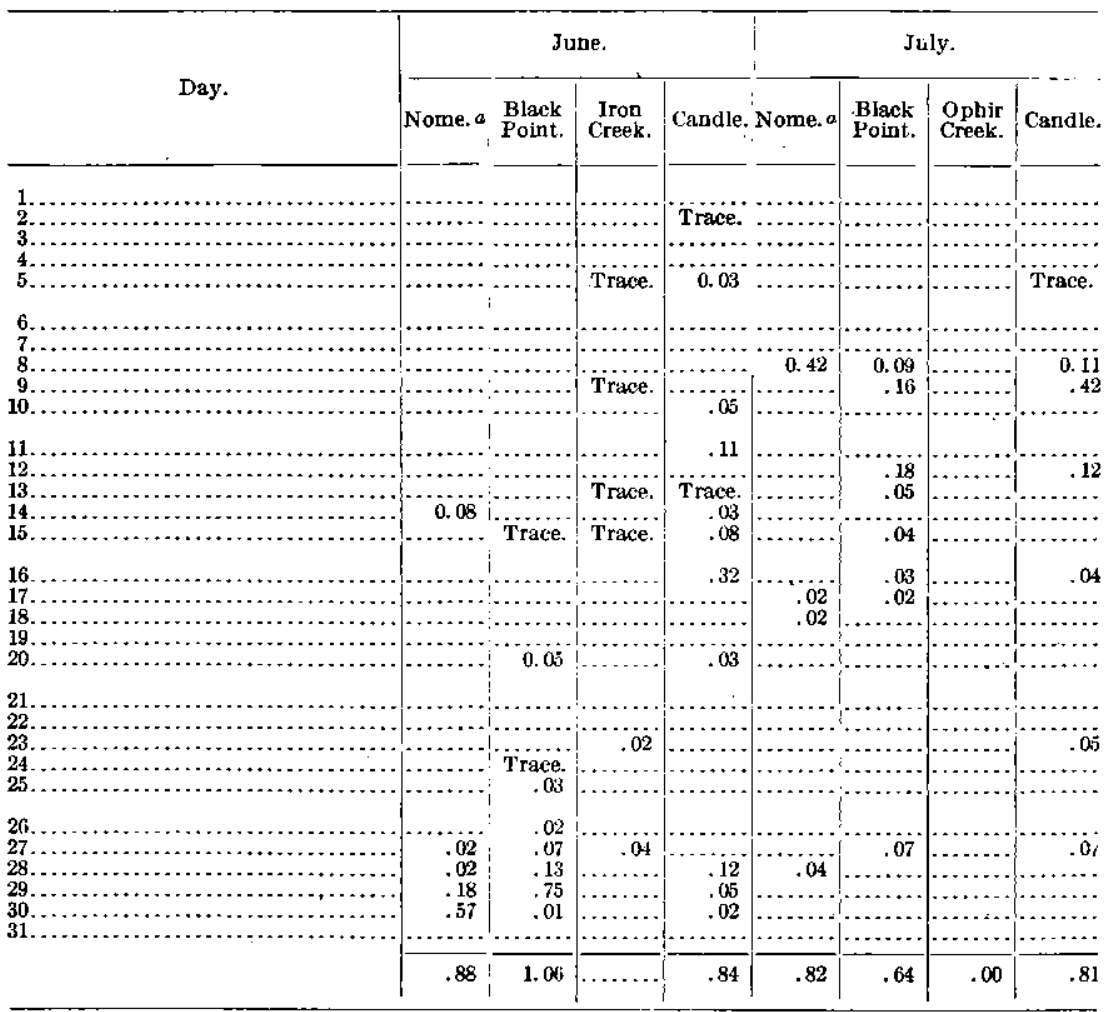

a The daily values for June and July at Nome are incomplete, but the monthly totals are correct. $55695^{\circ}-$ Bull. $442-10-27$ 
Daily rainfall and snowfall, in inches, at stations in Seward Peninsula for 1909-Cont'd.

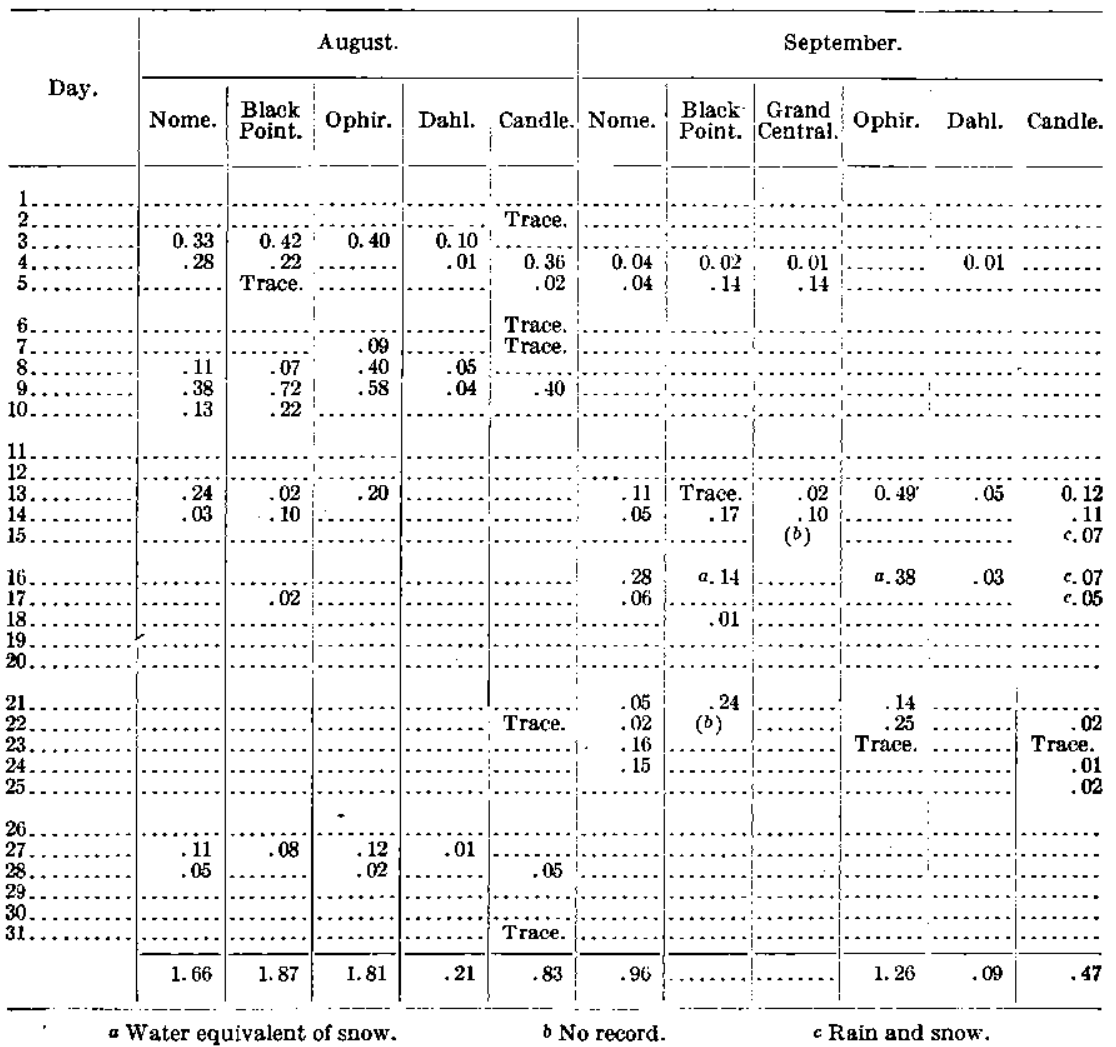




\section{IṆDEX.}

A.

Page.

Acknowledgments to those aiding . . 6, 251-252,373 Administration, report on ............... 5-19 Admiral Creek. See Camp Creek.

Alameda Creek, gold on. $336-338,339$ map of ........................... 336

Mlaska. See Northern Alaska; Northwestern Alaska; and Southeastern Alaska.

Alaska Northern Railway, construction of .. 29-30 Alaska Peninsula, coal fields on........... 59,68 Albion Gulch, hydraulic lift in ............ 362 Alfield Creek, flow of ..................... 408 Alder Creek, gold on.................... $2: 7$

Anchor Point, gold at .................. 1;1

Anthracite, consumption of, on Pacific coast. 89-90 price of, on Pacific coast................ 88

Antimony, mining of ................... 38 occurrence of ....................... 334

Appalachian coals, competition of . ........ 91-92 A ppropriations, allotment of ............ 8.9-10 A rchibald Gulch, gold in . . . . . . . . . . . . 301-303 Arctic slope, coal on ....................

Arsenopyrite, occurrence of.............. 221

Asia, coal of ............................. 93

Aten, E. M., work of................ 12,16-17

Attorney, coal locating by ................ 65

Atwood, W. W., cited.................... 171

work of ......................... 12,351

Auk Bay, mining on . .................. 138

Aukney claim, description of . ............ 198

Aurora Creek, flow of.................. 409

Australian coal, competition of............ $92-93$

\section{B.}

Bachelor Creek, flow of .................. 266 gold mining on ............. 208-209, 238-239

Bagley, J. W., work of

Baker Creek, basin of, stream flow in . ..... 277-280 flow of............................ 280,407

Banner Creek, flow of ..................... 283 gold on......................... 245

Beach mining, progress of ............... 41

Bear Bay, rocks on .................... 188, 192

Bear Creek, basin of, gold in............ 343-344 description of....................... 407 flow of.......................... 267

Bedrock Creek; gold on and near. . ... 225-226, 227

Beluga River, prospecting on............... 42

Bendeleben Mountains, rocks of. ......... 319-321

Bering River region, climate in ............ 70 cosl fields in................. 56-57,63,68 mining and marketing costs in......... $71-76$ rajlways in ....................... 28, 29, 30

Bering Ses coast, coal fields on.
Berners Bay region, geology of . .......... 136-137

investigations in.................. 12-13

mining in........................ 138-139

ores of ......................... 137-138

Bessie mine, artificial freezing at............ 356

Bettles River, gold on................. $\quad 310$

Big Creek, gold on..................... 315

Big Eldorado Creek, gold on.............. 227

Big IJurrah Creek, flow of ................. 408

Birch Creek, flow or.................... 265 gold on .......................... 314

Birch Creek (North Fork) basin, stream flow

in...................... $266-267$

Birch Creek (listrict, description of........ 203-204 See also Deadwood Creek.

Birch Creek schist, oceurrence and character of....................... 293-294

Bismuth, wecurrence of . . ................. 222

Black I'oint, rainfall at........... $414,417,418$

Bluff region, golt in ..................... 343 lodes in ...................... 38, 349-350

Bonanza Creek, flow of .............. 269, 332-333 gold lode on ......................... $37-38$ gold placers on ...................... 331-334

Bonanza mine, description of ............. 160

Bonnifield district, gold in ............ 36-37,44

Boston Creek, flow of .................... 407

Boulder Creek, flow of............ 269, 408, 409, 411 mining on ........................ 365-366

Bourbon Creek, dredging on............... 357

Broke, George, cited...................... $\quad 56$

Brooks, A. H., adminjstrative report by.... 5-19 cited ......................... 359 on Alaska coal and its utilization. . . . . 47-100 on Bluff region.................. $349-350$ on mining industry in $1909 \ldots \ldots \ldots \ldots .20-46$ work of........................... 11-12,210

Brooks Mountain, tin on ................. 39

Buck Creek, tin on...................... 39

Buckeye Creek, flow of .................. 283

Buckland River basin, gold in . .......... 343-344

Burnt River, flow of.................... 411

Butte Creek, flow of .................... 267

C.

Cache Creek, flow of ................... 281

gold on ............................. 243

California, coal of...................... $\quad 91$ coal consumption in ................... 85

California Creek, flow of ................. $\quad 279$ gold on .............................. 312

California oil, competition of, with coal..... 64,81

Camp Creek, gold on...................... 341 
Page.

Campion ditch, How of.

382,386

Candle Creek, llow of

mining on . .............

rainfall on ..... 414,416,417,418

Canyon Creek, ditches on ................ 360 flow of ........................ 408 mining on..................... 138

Canyon ditch, flow in........... 361,379-380, 412 Cape Lisburne, coal on . . . .......... 61-62, 64,67

Cape Mountain, tin mining on........... $\quad 39$

Capps, S, R., work of................... 15

Carboniferous system, coal of.... 47-48,59-60,61,62

Cariluou Creek, gold on ..... . . . . . . . . . . . . 200, 245

Casadepaga region. Sce Solomon-Casadepaga region.

Casadepaga River, flow of ............... 407

Cassiar Creek, flow of ................... 263

Cassiterite, oncurrence of. ........ 222, 246, 248-251

Cassiterite Creek, tin on .................. 39

Cawlfield Creek, flow of............... 407

Central, rainfall at . . . . . . . . . . . . . . . . . . . $\quad 353$

Central Seward Peninsula, description of.... 395 stream flow in . . . . . . . . . . . . . . 395-398

Chandalar region, gold mining in .......... 36 investigations in .................. 10 Sec also Koyukuk-Chandalar region.

Chandalar River, gold on ............ 314-315

Chapman Creek, gold on................ 241

Charity Creek, low of . . . . . . . . . . . . . . 263 rainfall on . ........................

Chatanika River, basin of, gold in . . . . . . 232-233 basin of, stream fow in............ 261-2ti3 flow of........................... 263 horsepower on................... 262

Chatham Creek, flow of .................. 263 gold on ......................... 226-227

Chicago Creek, coal on . ............ 01,64,368-369

Chichagof Island, mining on . . . . .......... 139

Chignik, coal at....................... 59

Chilkoot Inlet, iron at. . . . . . . . . . . . . . . . 144

Chinitna Bay, rocks near . . . ........ 189, 190, 192

Chisik Island, rocks of . . . . . . . . . . . . . . . . . 191

Chisna River, placer mining on........... $\quad 42$

Chistochina region, coal in............. placer mining in . . . . . . . . . . . . . . . 41-42

Chitina district, coal in ................. 57 copper in . . . . . . . . . . . . . . . . . . . . 159-161

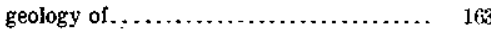
gold in ......................... 162 mining in . . . .................. 158

Chititu Creek, mining on ............... 162

Christian Creek, flow of . . .............. 408

Christmas Mountain, gold lodes on . ........ 334

Chrome iron, analysis of ................ 169 occurrence of . ...................... 169

Chukajak Creek, gold on ................ 341

Chute Creek, gold lode on . . . . . . . . . . . . . 36-37

Circle district, gold mining in.......... 234-239 production of. ....................... 239 hydraulic development in . . . 255-256 rainfall in . . . . . . . . . . . . . . . . . . . 253, 255 stream flow in. . . . . . . . . . . . . . . 263-269 water investigations in.

Claim Point, iron on .................... 169

Clark Lake region, investigations in See also Hiamna and Clark lakes region.
Page.

Cleary Creek, flow of..................... 263 gold in . ...................... 227, 232-233 rainfall on .......................... 253

Coal, Alaska, age of ..................... 47

analyses of . . . . . . . . .

bibliography of..................... $95-100$

competition with................... 88-93

composition of...................... 49-50

consumption of, in Alaska............. 83

on Pacific coast.................. 81-86

geologie distribution of . . . . . . . . . . . . . 47-48

marketing of . . . . ................ $99-76,80-95$

markets for................. 69,80-86,94-95

oceurrence and availability of ......... 47-100 See also particular localities.

price of, on Pacifie coast............... 86-88 production of .................. 20,22- $23,62-63$ tonnage of, estimates of. ............. $52-55$

value of $\ldots \ldots \ldots \ldots \ldots \ldots \ldots \ldots \ldots \ldots, 79-80$

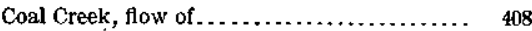

Coal fields, area of . . . . . . . . . . . . . . . . . . . 50-52

descriptions of........................ $55-62$

development of . ..................... 62-66 geographic control of ............... $66-68$

distribution of....................... of 68 map showing..................... 52

Coal lands, laws on .................... $64-66$

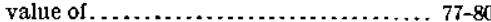

Coal mining, cost of . . . . . . . . . . . . . . . . . $69-76$ developments in ................ 22,62-66 profit in ............................. 21 wages in .......................... 70

Coarse Gold Creek, flow of ................ 410

Cobblestone River, flow of............... 408

Coftee Crcek, mining on .................. 364

Coke, competition with.................. 89 consumption of, on Pacific coast. ........ $85-86$

Commerce, statistics of .................... 23

Cone Mountain, gold near............... 176

Cook Inlet, coal on ............... 57-58, $63,68,178$ petroleum on ....................... 200 placer mining on . . . . . . . . . . . . . . . . . 42 rocks on........................ 188-189,192

Copper, occurrence of. See particular localities.

production of. ............... 20,22-23,31,32 sources of ............................. 31

Copper Creek, mining on ................ 162

Copper mining, progress of . . . . . . . . ...... 34, 38-39

Copper Mountain, mining on.............. 164

Copper River and Northwestern Railway, construction of ........... 29,158-159

Copper River region, coal in.............. 57 investigations in ..................... 14-15 placer mining in..................... 41-42 railways in . ....................... 28-29,30

Cordova, mining near................... 16:5

Cottonwood Bay, gold on................. 194

rocks near.......................... 185-188

Cottonwood Creek, flow of . . . . ............ 410

Cragie Creek, gold mining on ............... 35

Crater Creek, flow of..................... 40

Crater Lake outlet, flow of.................. 390

Corwin district, coal in .................... 62

Corwin formation, coal in.................. 48

Council district, mining in.............. 360-36e 
Councll region. See Nulato-Councll region.

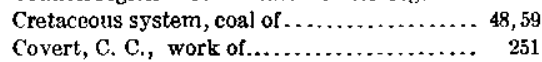

Crevice Creek, gold on.................... 314

Cripple Creek, gold on.................. 233-234

Crooked Creek, basin of, stream flow in.... 268-269 gold on.

\section{D.}

Dahl, rainfall at

414,418

Dall, w. H., cited...................... 351

Dall Island, mining on .................... 143

Dan Creck, mining on ..................... 162

Daniels Creek, gold on................... 343,360

Darby Mountains, rocks in .............. 319-325

Davis, C. A., on the preparation and use of peat as fuel................. 101-132 work of............................. 12

Davis Creek, gold on ................... $\quad 312$

Day Harbor, copper at and near.......... 170

Deadwood Creek, deseription of .......... 246-247 flow of........................ 235-236, 269 gold on .............................. 235 map of ........................... 247 rocks on ........................... 247-248 tin in...................... 39,246,248-251 wolframite in................... 246,248-251

Diamond Point, gold on................. 194

Dillon Creek, flow of..................... 407

Discovery Creek, mining on .............. 364

Ditches, flow of...................... 412-414

Divide Creek, flow of ..................... 410

Dome Creek, flow of.............. 406, 409,411 gold on $\ldots \ldots \ldots \ldots \ldots \ldots \ldots \ldots \ldots \ldots .232,364$

Douglas Island, mining on................. 134

Dredging, cost of ......................... 40 progress of...................... 40,357-358

Dry Creek, dredging on................. 358

Dummy entrymen, coal loeating by ......... 65

Durand prospect, description of . .......... 197

Duryea prospects, description of.......... 190-197

Dutton prospects, description of ........... 194 section at, figure showing ............ 195-196

E.

Eagle Creek, flow of . ................... 267 gold on .......................... 237-238 rainfall on ............................ 253

Eagle district, gold mining in.............. $\quad 244$

Eagle River, mine on, work at.............. 138

Eakin, H. M., work of.................. 16

Eakin, H. M., and Smith, P. S., on mineral resources of Nulato-Council region ..................... $316-352$

Easy Creek, gold on . ..................... 364

Eldorado Creek, flow of................ 409, 411 Ellamar, mining at....................... 164

Ellsworth, C. E., on placer mining in the Yukon-T'snana region......... 230-245 on water supply of Yukon-Tanana region $. . . \ldots \ldots \ldots \ldots \ldots \ldots \ldots .251-283$ work of............................ 15,251

Emma Creek, gold on ................... 300

Engineer Creek, placers on............... 230,232

Eocene series, coal of .............. 47, 48,55-62

Esperanza Creek, flow of.................. 410 mining on ........................ 366,399
Page.

Esther Creek, gold on................... 233-234

Eureka Creek, flow of................. 280,410 gold on $\ldots \ldots \ldots \ldots \ldots \ldots \ldots \ldots \ldots \ldots, 242$

Exports, value or..................... 23

\section{F.}

Fairbanks, rainfall at.................. 254,255

Fairbanks Creek, gold on............... 233,234

Fairbanks district, auriferous quartz veins in, paper on..................... 210-229

description of..................... 210-214

geography of....................... 211-214

geology of ........................ 214-218

gold mining in....... 36, 43-44, 223-228, 231-234

hydraulic development in . . ........... $\quad 256$

map of ........................... 212

prospecting in...................... 228

quartz veins in . . . . . . . . . . . . . . 218-220

production of..................... 230,234

rocks of, metallization of............ 220-223

stream flow in ..................... 259-263

water investigations in.............. 15

Fairbanks quadrangle, description of. .... 203-205 gcologic map of...................... 204 geology of . . . . . . . . . . . . . . . . . $205-209$ mining in . . . . . . . . . . . . . . . . . . . . 208-209

Fairhaven ditch, flow of ............ 401-403,414

Fairhaven precinet, description of . ........ 398-399 mining in . . . . . . . . . . . . . . . . . . . . stream flow in................... 399-407

Faith Creek, flow of ..................... 263 rainfall on......................... 254

False Creek district, gold on............. 173 map of ............................ 172

Fay Gulch, gold in ................ 301-303

Fish Creek, flow of . . . . . . . . . . . gold on ........................... 233

Fishhook Creck, gold mining on. . . . . . . $35-36$

Fish River basin, gold in .............. 342-343 stream flow in ........... 375-380, 407-408,412

Flat Creek, how of....................... 263

Flat Islets, gold near................ 176

Fort Egbert, rainfall at............... 254,255

Fort Gibbon, rainfall at . . . . . . . . . . . 254,255

Fort Seward, iron near................... 145

Fort Tongass, freezing records at............ 151 rainfall at. . . .................... 150

Fort Wrangell, freezing rocords at......... 151 rainfall at. . . . . . . . . . . $150 \ldots \ldots \ldots \ldots . \ldots$

Fortymile district, gold mining in......... 244 production of........................ 244

Fox Creek, tow of.................... 263

Fox River, how of ...................... 408

Freezing, dates of.................... 150-151

Freezing, artificial, use of ................ 356

Freighting, cost of. ................. 23-26, 73-76

Freighting, inland, cost of. ............. 25-26

G.

Galena, occurrence of........... 221-222,340-349

Garryowen Creek, gold on................ 334 Geography, relation of, to coal..............66-68 Geologic work, extent of................. 7,11 Giflin, C. E., work of ................. 14

Gilpatrick claims, description of.......... 171-172

Glacier Creek, flow of................ 405-406 gold on ......................... 312,370-371 
Gage.

ald deposition of production of................. 20,22-23,31-33 solurces of 31

Gold Bench, gold of . ................. 311-312

Goldbottom Creek, gold on.............. 349,363

Gold Creek, gold on . . . . . . . . . . . . . . . 307-308 lode mining on ...................... 135 placer mining on .................... $4 \mathbf{1}$

Golddust Creek, flow of.................. 267

Gold Hill district, placer mining in....... 44-45

Gold King Creek, placer mining on1......... 44

Gold lodes, production from . . . . . . . . . . . . 33-34 progress of .......................... 33-39 See also Southeastem Alaska.

Gold placers, conditions controlling ....... 327-331 mining of, status of .................. 39-46 production of ......................... 39

Gold Run, flow of. . .................. 409,411 gold on ......................... 371

Goldstream Creek, gold on................ 232

Goodhope River, basin of, mining in...... $360-367$ basin of, stream flow in. . . . . . . . 399-400,410 flow of ............................. 400

Goose Creek, dredge on................ 360

Grand Central River, basin of, stream flow in ................. $388-390,409,413$ flow of........................ $389-390$ rainfall on ....................... 414,418

Grand Union Creek, llow of ............... 409 Granite Creek, flow of . . . . . . . . . . . . . . . 274

Grant, U. S., on mining and prospecting on Prince Williern Sound......... 104-165 work of............................. 13

Grant, U. S., and Miggins, D. F., on mineral resources of Kenai Peninsula.. 160-178

Grant Creek, placer mining on........... 44-45 Grass Gulch, ditches on................... $\quad 359$

Gravina Island, mining on................. 143

Greenstone, occurrence and character of . . . 187-188

Grulsstake Gulch, placer mining in ......... 42 $\mathrm{H}$.

Haines, iron near..................... 144-146 Haiditarod River basin, placer mining in . . . 44, 45 Inammond Creek hasin, gold in . . . . . . . . . 304-305 Hannum Creck, flow of .......... 410

Hardenberg prospect, description of....... 198-199 Hardluck Creek, gold on .................... 364

Harrison Creek, flow of . . . . . . . . . . . . . . 267 gold on.......................... 238

Helen Creck, low of.................. 407

Henshaw, F. F., on mining in Seward l'eninsula. on water supply in Seward Peninsula... 372-418 work of ........................... 16

Henry Creek, flow of .................... 398

Herendeen Bay, coal on ................. 59

Hetta Inlet, copper mining on ............. 142 investigations at.................... 13

Higgins, D. F., work of................. 13

Higgins, D.F., and Grant, U. S., on mineral resources of Kenai Peninsula. . 160-178

Hill Creek, gold on ................... 220-221

Hobson Creek, antimony on .............. 38 flow of

$385-386$
Page.

Homestake Creek, flow of................. 263 sold on................................ 209

Hoosier Creek, flow of.................. 274 gold on .............................. 240

חope Creck, flow of...................... 263

Hot Springs district, gold mining in....... 241-243 hydraulic development in ............ 257 production of ...................... 241,243 Hoyt, J. C., on a water-power reconnaissance

in southeastcrn $A$ laska........ 147-157

Humboldt Creek, mining on............... 367

Hunter Creek, basin of, gold in ............. 240 now of......................... 274, 406

Hurrah mine, data on................. 38

Hutalina Creek, fow of........... 277-278,280

\section{I.}

Iliamna, description of.................. 181-182 Iliamna and Clark lakes region, advantages

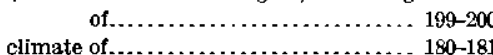
copper in. . . . . . . . . . . . . . . . description of ..................... 179-183 geology of . . . . . . . . . . . . . . . . . . . . 183 gold lodes in ...................... 194-200 investigations in.................... 14 map of .......................... 184 mineral resources of................. 193-200 petroleum in ....................... 200 placers in.......................... $\quad 200$ transportation to and in ............. 182-183 vegetation in........................ 181 Tliamna Bay, geology near.............. 185-186 marble near....................... 185 Imports, value of ...................... 23 Independence Creek, flow of ................. $\quad 269$ gold on ........................... 238

Iniskin Bay, rocks near............... 189,190,191 Inmachuk River, basin of, mining in ...... 367 368,414 basin of, stream flow in ..........400-401,410 water rights in.................... 367 flow of .......................... 401,410

Innoko district, placer mining in . . . . . . . 44,45

Intricate Bay, rocks on .................. 192

Iron Creck region, flow of . . . . . . . . . . . . . . 393, 409 mining in........................... $363-364$ rainfall in.................... 414,416,417 Iron ore, analysis of........................ 169 occurrence and character of......... 168-169 Iron pyrites, occurrence of . .............. 220-221

\section{J.}

Jerome ledge, deseription of.............. 36-37 Jim River, gold on . . . . . . . . . . . . . . . . 310-312 John River, gold on . . . . . . . . . . . . . . 314 Joknson, B. L., on wolframite and cassiter-

ite on Deadwood Creek........ 246-250 work of ............................ 15,210 Johnson, R. E., work of................. 13

Juneau district, freezing in. ................ 151 mining in . . . . . . . . . . . . . . . rainfall in . . . . . . . . . . . . . . . . . . . . Jurassic system, coals of .............. 48,58,62 
$\mathbf{K}$.

Page.

Kachemak Bay, coal on................5 57,178

Kakonak Bay, rocks on .............. 189, 192-193

Kantishna distriet, placer mining in....... 44

Kasaan Peninsula, copper mining on...... 141-142 investigations on ..................... 13

Katz, F. J., on gold placers of the Mulchatna. 201-202 work of.

Katz, F. J., and Martin, G. C., on Iliamna and Clark lakes region. . . . . . . . . 179-200

Kechumstuk, rainfall at . ............... 254,255

Kenai formation, character and distribution of.......................... 168

coal in........................... 47,48

Kenai Lake, antimony near............... 178 gold on ...................... 173,177

Kenai Peninsula, antimony on............ 178 coal on ............................. 57,178

copper on......................... 170 geology of ........................ 1006-108 gold-bearing veins of, analyses of...... 177-178 gold on ........................ 170-178 investigations in.................... 13 iron on........................... 168-169 map of ............................ 168 mineral resources of................. 166-178 railways in . . . . . . . . . . . . . . . . silver on ........................... 178

Kennicott formation, gold in............. 163

Kennicott Glacier, mining near ............. 160

Kenwood Creek, gold on................ 338-339

Ketchikan district, copper mining in..... 141-142 gold mining in...................... 139

Keyes prospects, description of........... 194

Kljik River, gold on...................... 200

Killisnoo, freezing records at............... 151 rainfall at....................... 150

Kiwalik River, basin of, mining in ....... 369-371 basin of, stream flow in .......... 404-406, 411 flow of........................ 406,411

Klondike district, gold lodes in ............ 37-38

Knight Island, mining on ................ 165

Knopl, Adolph, on iron ore near IIaines... 144-146 on mining in southeastern Alaska..... 133-143 work of......................... 12-13

Knowles Creek, gold on................. $\quad 340$

Knution prospect, description of............ 197

Kobuk Valley, placer mining in............ $4 \mathrm{di}$

Kokomo Creek, flow of ................. 2t

Kontrashibuna I.ake, rocks near......... 184,187

Kotsina River, mining on ................ 161

Kotzebue Sound basin, gold in .......... 343-344

Kougarok region, mining in............. 364-366

Kougarok River, basin of, stream flow in . . 396-398, flow of...................... 397-398,410

Koyuk River, basin of, gold in . . . . . . . $330-340$ coal on . ........................... 351

Koyukuk-Chandalar region, climate of..... 287-288 coal in .......................... 294-295, 297 description of...................... 284-291 geology of . . . . . . . . . . . . . . . . . $293-295$ glaciation in ....................... 285-287 gold of, source of.................... 295-296 Investigations in..................... 16 map of ............................ 284 mineral resources of $. . \ldots \ldots \ldots \ldots \ldots \ldots .290-315$
Koyukuk - Chandalar region, mining in..... 291 placers of .......................... 296-315 population and settlement in ......... 288-289 prices in.......................... 290 production of ..................... 291-293 transportation in..................... 289 wages in....................... 289-291

Koyukuk River, gold on . ............... $\quad \mathbf{2 9 7}$ Koyukuk River (Middle Fork) basin, gold in . . ....................... 297-310

Koyukuk River (North Fork) basin, gold in ....................... 313-314 Koyukuk River (South Fork) basin, gold in ......................... 310-312

Kruzgamepa River, basin of, stream flow in ................. 391-394, 409, 414 flow of........................ 392,393, 109 Kugruk River, basin of, stream flow in. $403-404,411$ coal on ...., . . . . . . . . . . . . . . . . . 368-369 flow of........................ 403-404,411 gold on........................... 369

Kuskokwim basin, coal flelds in ........... 61 placer mining in.................... 46

Kuzitrin group, occurrence and character of. . $\quad 319$ Kuzitrin River, flow of . ................. 395-396 Kvichak River, description of.............. 180 Kwik River basin, gold in................ $\quad 341$ Kwiniuk River basin, gold in.............. 342

L.

Lake Creek, gold in..................... 314

Lanegan Creek, flow of ................... 407

Land laws, application of, to coal. ............ $64-66$

Landlocked Bay, mining on .............. 165 Latouche Island, mining on ............ 164,165 Lava, gold under....................... 368 Leavitt, J. B., work of.................. 14 Lewington, G. A. R., on mining in Klondike district...................... 37-38

Linda Creek, gold on .................. $308-309$ Little Creek, ditches on.................. 358 Little Eldorado Creek, gold on.............. 233

Little Minook Creek, flow of............. 274 gold on .......................... 239-240

Little Minook Junior Creek, gold on..... 240-241 Little Salchaket River, flow of ........... 283 Lodes. See Gold lodes; Tin; Copper.

Lone Star mine, description of............. 37

Loper Creek, gold on....................... 239

Lost River, galena on....................... 38

Lower Willow Creek, flow of ............... 408 mining on ....................... 360

M.

McKelvie Creek, flow of ................. 407

McKinley Lake, mining near ................ If5

MeManus Creek, flow of ................. 263

Maddren, A. G., on Koyukuk-Chandalar gold region................ 284-315 work of ............................. 16

Mallard Bay, mining on.................. 143

Mammoth Creek, ditch on............... 236-237 flow of........................... 268, 269

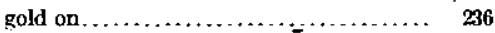

Maps; character of..................... 9

Marble, occurrence and character of......... 185 
Martin, G. C., work of Page.

Martin, G. C., and Katz, F. J., on Iliamna and Clark lakes region............. 179-200

Mascot Creek, gold on . .................. 313

Mason, F. H., on peat.................. 119

Mastodon Creek, flow of ................ 267,269 gold on ...................... 235

Matanuska Valley, climate in............ 70

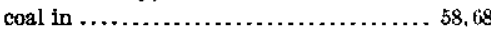

Investigations in $\ldots \ldots \ldots \ldots \ldots \ldots \ldots \ldots .14$

mining costs in ................ $71,75-76$

railways in ........................... 28 28

Meadow Lake, rocks near... . . . . . . . . . . . 186-187

Melsing Creek, flow of................. 408

Mendenhall, W. C., on Nulato-Council region $3 \pm 0$, $341,346,351$

Metal Creek, gold mining on. ........... 42

Metals, mining of. ...................... . $31-46$

Metamorphosed and unmetamorphosed rocks, gold in. . . . ............ $327-344$

Midas Creek, gold on .................. 314

Middle Creek, flow of. . . . . . . . . . . . . . . . . . . 409

Miller Creek, flow of ...................... 269

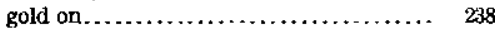

Middle Fork, flow of.................... $26 i$

Miller House, rainfall at. . . . . . . . . . . . . . . . 254

Millet prospect, description of . . . . . . . 197-198

Mineral resources, production of . . . . . . . . . 20-23 value of......................... 21

Mining industry, status of . ............. 20-16

Minook Creek basin, stream flow in. $25 i j-257,273-274$

Miocene ditch, flow of . . . . . . . . . . . 38. 38. 386, 413

Mollit, F. II., cited ............... 322,324,34t on mining in the Chitina district...... 158-165 work of. ........................... 15

Moonlight Creek, ditches on .......... 358-359 flow of........................... $40 \pi$

Moose Pass district, gold in .......... 171-172, 17 map of

Mount St. Elias, coal on.............. 56-57

Mulchatna River region, access to . . . . . . . 183, 201 description of . . . . . . . . . . . . . . . . . . 201-202 gold placers of ....................... 202

Myrtle Creek, gold on .................. 298-300

N.

Naknek jormation, cceurrence and character of

Nation River formation, coal in . .........

Negromoon Creek, gold on . . . . . . . . . . . . .

Nenana region, coal in. . . . . . . . . . . . . .

Nevads Creek, mining on . ..............

Newhalen River, description of............

New ton Gulch, mining on...............

New York Creek, flow of.

New Zealand coal, competition of. .........

Nikolai greenstone, copper and silver in . . . . .

Niukluk IRiver, flow of . . . . . . . . . . . . . . . .

Nizina district, investigations in........... map of, preparation of.............. 10.3 mining in . . . . . . . . . . . . . . . . . . . 16 $10-161$

Nolan Creek basin, gold in . . . . . . . . . . . 301-304

Nome region, besch placers in . . . . . . . . 35 4,$35 ;-357$ ditches in ....................... $358-359$ dredging in . . . . . . . . . . . . . . . . $357-358$ freight rates from. gold placers in. $327-328.354-355$
Page.

Nome region, rainfall in . . . . . . . 353-354,414-415

Nome group, occurrence and character of ... 318 Nome River, basin of, strearn flow in.... 382-388

408,413

ditehes on, flow of ............ 383

flow of ...................... $384-385,408$

lode mining on ..................... 38

Northern Alaska, coal fields of . . . . . . . . . . . 61-62

North Star Creek, flow of............... 408

Northwestern Alaska, placer mining in..... 40 See also Seward Peninsula.

Norton Bay region, investigations in . . . . . . . 16

Noxapaga River, basin of, mining in . . . . . 365-366 basin of, stream flow in............ 409 flow of ........................... 409

Nugget Gulch, flow of . ................... 276

Nuka Bay, gold on .................. 174

Nulato-Couneil region, cosl in ....... $60,350-352$ description of . . . . . . . . . . . . . . $310-318$ geography of .................... 316-318 geologic history of . . ................. 326 geology of . . . . . . . . . . . . . . . . . $318-326$ gold lodes in................. 335-344,349-350 gold placers in . . . . . . . . . . . . . . . . . 326,344 msp of ........................ 316 mineral resources of . . . . . . . . . . . . . . . . $326-352$ prospecting in . . . . . . . . . . . . . . . 330-331 veins in $\ldots \ldots \ldots \ldots \ldots \ldots \ldots \ldots \ldots \ldots . . \ldots \ldots 24-325$

Nulato-Norton Bay area, section across, figure showing ...................

Nulato sandstone, occurrence and character

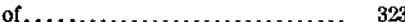

O.

Omilak mine, description of . .......... 345-348 map of ..................... 345 ores of, assays of .................... 348

Ophir Creek, dredging on................ 362 flow of . . . . . . . . . . . . . . . . . . . . . . 380,408 gold mining on ............ 343,349,360-363 rainfall at . . . . . . . . . . . . $414,417,418$ Orca, mining at........................ 165 Oregon, coal of . . . . . . . . . . . . . coal consumption in .................. 84 Oregon Creek, flow of................. 407 Osborn Creek, flow of . . . . . . . . . . . . . . . . ... 409 Otter Creek, placer mining on........... 45 P.

Pacific cogst, consumption of conl on . . . . . . 81-82 Pacific coast province, cool in ............66 68 placer mining in................... 41-43 Palmer, Chase, on iron ore............. 146 Pargon Creek, flow of .................. 407 Pargon ditch, flow of . ............ 378-379,412 Pargon River, flow of . . . . . . . . . . . . . . . . 377 Parker, E. W., cited................... 81 Parker, G. L., work of . . . . . . ........ 16, 356, 372 Pass Creek, flow of . . ..................... 394

Passenger rates, amount of . . . .............. 24

Patterson Creek basin, flow in . . . . . . . . . . . 280-281 gold in . . . . . .................... 242-243

Peace Creek, gold on . . . . . . ............. 340

Peat, analysis of. .................... 128-129 bibliography of . .................. 131-132 briquettes from . . . . . . . . . . . . . . . . 117-120 coke from . . . . . . . . . . . . . . . . . . . 121-129 
Page.

Peat, compasition of cost of. description of. distribution of formation of... fuel from, manufacture of ..... 106-108, 109-123 gas from.......................... 123-128 heat value of . ..................... 129-130 powder from...................... 120-121 preparation and use of, paper on...... 101-132 use of, for fuel..................... 108-131

Pest beds, volume of, estimation of......... 105 working of . . . . . . .

Perry Creek, mining on................. 368

Peterson Creek, mining on ............... 138

Petroleum, consumption of, in Alaska....... 84

Pile Bay, rocks on ............... 184, 188-189, 192

Pinnell River, flow of .................... 410

Pioneer Creek, flow of .................... 280

gold on............................. 242

Ploneer ditch, flow of.............. 382,386, 413

Placer Creek, mining on ................... 367

Placer mining, legal status of . . ............ 20-21 production from .....................

Placers, gold, formation of, conditions controlting................... $327-331$

Poker Creek, rainfall on ................... 254

Pool Creek, flow of ...................... 263

Porcupine Creek, flow of . . . .............. 268,269 hydrograph of ...................... 154

Poreupine district, placer mining in ........ 41

Portage Creek, gold on .................. 200

Port Chatham, gold on.................. 176 iron on ............................ 169

Port Dick, gold on .................. 174-175

Port Graham, cosl on................... 178 gold on ............................ 176-177

Port Snettisham, mining at............... 139

Port Valdez, mining at.................... $\quad 165$

Potter, O., aid of ..................... $\quad 11$

Preacher Creek, basin of, stream flow in.... 266 gold on .............................. 239

Priestley, w. E., eited ................. 61

Prince of Wales Island, copper mining on.. 143, 144 iron on............. 144

Prince William Sound, copper mining at.... 39

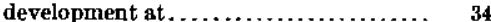
mining on, paper on................ 164-165

Prindle, L. M., on auriferous veins in Fairbanks district............. 210-229 on geology of Fairbanks quadrangle.. . 203-209 work of . . . . . ................... 15,210

Ptarmigan Creek, flow of ................ 207

Publications, list of . . . . . . . . . . . . . . . . 17-19

\section{Q.}

Quail Creek, flow of

276 gold on

Quartz Creek, flow of. gold on..................... 171-172,243

Quaternary system, coal of .............. 48

\section{$\mathrm{R}$.}

Railroads, construction of..... 26-31, 73-74, 158-159 See also Transportation.

Rampart distriet, gold mining in ........ 239-241

hydraulic development in . ........... 256

production of......................... 241

rainfall in
Page.

in $\ldots \ldots \ldots 270-281$

Redmond Creek, flow of................. 283

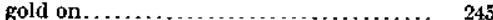

Red Mountain, iron on . . . . . . . . . . . . . . 168-169

Resurtection Bay, copper on.............. 170 gold near.......................... 170

Road commission, work of .............. 31

Ruby Creek, flow of . ................... 274,408 mining on $\ldots \ldots \ldots \ldots \ldots \ldots \ldots \ldots \ldots \ldots, 360$

8.

St. Marys Gulch, gold on................ 315

Salchaket River, flow of .................. 283

Salchaket-Tenderfoot district, gold mining in. $\quad 245$

production of....................... 245

stream flow in.................... $281-283$

Salt Chuck, mining on ................. 141

Sargent, R. II., work of . . . . . . . . . . . . . 11-12,14

Schrader, F. C., eited................... 291

Scope of report....................... $\quad 5-6$

Seal Bay, mining on .................... 143

Sea Otter Island, mining on. . ............ 143

Seldovia, iron near................... ](18-169

Seward, copper and gold near........... 170

Seward ditch, flow of........... 382,386-387,413

Seward Peninsula, coal fields of........... 61,64 ditches in, flow of . . . . . . . . . . . . $412-414$ dredging in......................... 40 drought in . . . . . . . . . . . . . . . . . . 353,372 gold lodes on ................... 38, 335-344 gold placers on . . . . . . . . . . . . . $335-344$ mining in, paper on. . . . . . . . . . . . $353-371$ placer mining in................. 46,353-371

See also Nome region; Solomon-Casadepaga region; Council district; Iron Creek region; Kougarok region; Fairhaven precinct.

production of ...................... 353

railways in ......................... $30-31$

rainfall in .................... 353-354,414-418

stream flow in. ..................... $374-414$

miscellaneous measurements of. ... $407-414$

See also Southern Seward Peninsula; Central Seward Peninsula: Fairhaven precinct.

water investigations in............... 16

Shovel Creek, dredging on............... 359-360

Silver, production of . . . . . . . . . . . . . $22,31,32$ sources of . . . . . . . . . . . . . . . . . . . 31

Silver-lead deposit, description of........ 345-349 Sinuk River, basin of, stream flow in ....... 408 flow of ............................ 408

Sitka district, freezing in. . . . . . . . . . . . 151 mining in .......................... 139 rainfall in ........................... 151

Skagway, freezing records at............ 151 rainfall at......................... 151

Skoogy Gulch, gold in............. 221, 223-224

Slate Creek, gold on . . . . . . . . . . . . . 172,298-299

Smith, P. S., work of.................... 16

Smith, P. S., and Lakin, H. M., on mineral resources of Nulato-Council region...................... $316-352$

Smith Creek, flow of . .................. 393,394 Smith Gulch, gold in..................... 301-303 Solomon-Casadepaga region, mining in ....359-360 Solomon River, basin of, stream flow in. $381,408,412$ flow of . . . . . . . . . . . . . . Sourdough Creek, flow of .................. 263 
Page.

South America, coal of ................ 93

Southeastern Alaska, climate of......... 149-151

coal fields of. ........................ 55

copper mining in............ 38-39.140-143

industrial conditions in ............. 155

investigation in ..................... 12-13

lode mining in . . . . . . . . . . . . .

map of . . ......................... 148

placer mining in..................... 41

railways in ........................ 30

raintalt in . . . . . . . . . . . . . . . . . . . 150-151

stream flow in, conditions of........... 153

topography of................... 147 -149

vegetation in ...................... 152

water powers in, paper on. .......... 147-157

possibilities of .................. 156-15i

Southern Seward Peninsula, description of. 374-375 drainage of . . . . . . . . . . . . . . . . . . 374-375 stream fow in.................... 375-395

Spring Creek, gold on................... 314

Spurr, J. E., cited .......................... 331

Squaw Creek, flow of ................... 272

Statistics; collection of . . . ................. 17

Stibnite, occurrénce of. . ............ 221,334,340

Storrs, A. II., on Alaska coal............. 70.72

Stream flow, investigation of.............. $7-8$

Sullivan Creek, flow of . .................. 281

gold on ........................... 242

tin in ............................... 39

Summit Ilouse, rainfall at............... $\quad 254$

Sunrise district, placer mining in .......... 42

Sunrise series, character and distribution of. 160-167

Surveys, classes of ....................... $8-9$ progress of . ........................ 10-11

Susitna basin, coal in. . . . . . . . . . . . . . 58-59 placer mining in .................... 42- 63 railways in

Switch Creek, flow of ................... $2 t ; 9$ gold on ...........................

minerals on . ..................... 249

T.

Tamarack Creek, gold near...............

Tanana Crossing, rainfall at............... 254

Tanana region. Sce Y ukon-Tanana region.

Tanana River, flow of.

placer mining on.

Taylor Creek, flow of .................... 410

Tazimina Lake, rocks near. . ........... 189-190

Tenderfoot district. See Salchaket-Tenderfoot district.

Tertiary system, coal of . . . . . . . . . 47, 48, ij

Thanksgiving Creek, gold on.............. 242

Thanksgiving ditch, flow of . ............. 279

Thompson Creek, flow of ................ $\quad 390$

Thumit Creek, flow of ................... 409

Tin, mining of . . . . . . . . . . . . . . . . . . .

Tofty Gulch, gold on .................. 242-243

Transportation, cost and means of. ... 23-31,73-76 routes for, relation of, to coal.......... $74-76$

map showing ..................... 52

Treadwell mines, deseription of . . . ...... 134-135

Troublesome Creek, basin of, stream flow in $275-276$

flow of. ........................... 276

Tubutulik River basin, gold in.......... 341-342

Tuluksak River, placer mining on.......... 46

Tungsten, ores of ...................... 240 See also Wolframite.
Page.

Turner Creek, flow of . .................. 409

Turner River, hydrograph of ........... 154

Tuxedin Bay, rocks on ........... 188, 189, 190, 192

T welvemile Arm, mining on ............. 139

Twelyemile Creek, flow of ................. 267

Two Arm Bay, gold on ............... 173-174

U.

Umalik Creek, silver-lead deposit near, description of .................. 345-349

Unga Island, coal on ...................... 59

Ungalik River, gold on ................ 333-334

Union Gulch, gold in .................... 304

V.

Valdez, freight rates from................ $\quad 25$

Valde Creek, placer mining on ............. 42

Vancouver Island, coal of ................ 92

Vermont Creek, gold on .................. 305-306

Victoria Creek, gold on .................... 209

Victory Creek, gold on .................. 173

W.

Wade Creek, flow of ................... 411

Wainwright Inlet, coal on ............ 61,62,67

Worm Creek, dredge on ................ $\quad 363$

Washington, coal of . . ................ 91

coal consumption In .................. 84

Washington Creek, gold on ............. 234,313

Water powers, description of ........... 147-157

list of ............................... $\quad 157$

possibilities of .................... 156

Water resources, investigation of ........... 7-8

Water supply, source of . . . .............. 252-253

Westend Creek, flow of ................. 409

White Molntuins, rocks of and near ... 204,206-207

Whiting River, mining on ............... 139

Wild River, gold on .................... 313,314

Wiljow Creck, gold on ............... 227,340

Wilsow Creck region, gold mining ....... 35-36, 42

Wilson Creek, gold on .................. 312

Windy Bay, gold on ................... 175-176

Windy Creek, flow of ...............4 408,410 mining on ............................. 365

Wiseman Creek, golà on................. 300-301

Witherspoon, D. C., work of........... 14,15,163

Wolf Creck, flow of ....................... 263 gold on.......................... 227

Wolframite, occurrence of ........... 246,248-251

Wonder Crcek, dredging on . . . . . . . . . . . 357-358

Woodchopper Creek, gold on .............. 239

Wright, C. W., work of .................... 13

Y.

Yakataga, beach mining near ............. 41

Yentra basin, placer mining in............

Yakon basin, coal in ............ 59-60,63-64,67 dredging in ...................... 40 freight rates in .......................... 26

placer mining in . ...................... $43-45$

Yukon River, flow of . . . . . . . . . . . . . ... 271-272

Yukon-Tanana region, hydraulic development in ..................... 255-257 Investigations in . . . . . . . . . . . . . . . . . placer mining in, paper on .......... 230-245 railways in .......................... 28,30 precipitation in ..................... 253-255 stream measurements in............... 257-283

making of, method of............ 257-259 water supply of ................... $251-253$ 


\section{RECENT SURVEY PUBLICATIONS ON ALASKA.}

[Arranged geographically. A complete list can be had on application.]

All these publications can be obtained or consulted in the following ways:

1. A limited number are delivered to the Director of the Survey, from whom they can be obtained free of charge (except certain maps) on application.

2. A certain number are delivered to Senators and Representatives in Congress for distribution.

3. Other copies are depasited with the Superintendent of Documents, Washington, D. C., from whom they can be had at prices slightly above cost. The publications marked with an asterisk $\left(^{*}\right)$ in this list are out of stock at the Survey, but can be purchased from the Superintendent of Documents at the prices stated.

4. Copies of all government publications are furnished to the principal public libraries throughout the United States, where they can be consulted by those interested.

\section{GENERAL.}

*The geography and geology of Alaska, a summary of existing knowledge, by A. H. Brooks, with a section on climate, by Cleveland Abbe, jr., and a topographic map and description thereof, by R. U. Goode. Professional Paper 45, 1906, $327 \mathrm{pp}$. \$1.

Placer mining in Alaska in 1904, by A. H. Brooks. In Bulletin 259, 1905, pp. 18-31.

The mining industry in 1905, by A. H. Brooks. In Bulletin 284, 1906, pp. 4-9.

The mining industry in 1906, by A. H. Brooks. In Bulletin 314, 1907, pp. 19-39.

Notes on the petroleum fields of Alaska, by G. C. Martin. In Bulletin 259, 1905, pp. $128-139$.

*The mining industry in 1907 , by A. H. Brooks. In Bulletin 345, pp. 30-53. 45 cents.

The mining industry in 1908, by A. H. Brooks. In Bulletin 379, 1909, pp. 21-62.

Railway routes, by A. H. Brooks. In Bulletin 284, 1906, pp. 10-17.

Administrative report, by $\Lambda$. H. Brooks. In Bulletin 259, 1905, pp. 13-17.

Administrative report, by A. H. Brooks. In Bulletin 284, 1906, pp. 1-3.

Administrative report, by A. H. Brooks. In Bulletin 314, 1907, pp. 11-18.

*Administrative report, by A. H. Brooks. In Bulletin 345, 1908, pp. 5-17. 45 cents.

Administrative report, by A. H. Brooks. In Bulletin 379, 1909, pp. 5-20.

The petroleum fields of the Pacific Coast of Alaska, with an account of the Bering River coal deposits, by G. C. Martin. Bulletin 250, 1905, 64 pp.

Markets for Alaska coal, by G. G. Martin. In Bulletin 284, 1906, pp. 18-29.

The Alaska coal fields, by G. C. Martin. In Bulletin 314,1907 , pp. $40-46$.

The possible use of peat fuel in Alaska, by C. A. Davis. In Bulletin 379, 1909, pp. 63-66.

*The distribution of mineral resources in Alaska, by $\Lambda$. H. Brooks. In Bulletin 345 , pp. 18-29. 45 cents.

Mineral resources of Alaska, by A. H. Brooks. In Bulletin 394, 1909, pp. 172-207.

* Methods and costs of gravel and placer mining in Alaska, by C. W. Purington. Bulletin 263, 1905, 362 pp. 35 cents. Abstract in Bulletin 259, 1905, pp. $32-46$.

*Prospecting and mining gold placers in Alaska, by J. P. Hutchins. In Bulletin 345,1908 , pp. $54-77$. 45 cents.

Geographic dictionary of Alaska, by Marcus Baker; second edition by James McCormick. Bulletin 299, 1906, 690 pp.

*Water-supply investigations in Alaska in 1906-7, by F. F. Henshaw and C. C. Covert. Water-Supply Paper 218, 1908, 156 pp. 25 cents.

\section{Topographic maps.}

Alaska, topographic map of; scale, $1: 2,500,000$; preliminary edition; by R. U. Goode. Contained in Professional Paper 45. Not published separately.

Map of Alaska showing distribution of mineral resources; scale, 1:5,000,000; by A. H. Brooks. Contained in Bulletin 345 (in pocket).

Map of Alaska; scale, l : 5,000,000; by Alfred H. Brooks. For sale at 10 cents each, or $\$ 6$ per hundred. 


\section{SOUTHEASTERN ALASKA.}

*Preliminary report on the Ketchikan mining district, Alaska, with an introductory sketch of the geology of southeastern Mlaska, by Alfred H. Brooks. Professional Paper 1, 1902, $120 \mathrm{pp}$. 25 cents.

*The Porcupine placer district, Alaska, by C. W. Wright. Bulletin 236, 1904, 35 pp. 15 cents.

The Treadwell ore deposits, by A. C. Spencer. In Bulletin 259, 1905, pp. 69-87.

Economic developments in southeastern Alaska, by F. E. and C. W. Wright. In Bulletin 259, 1905, pp. 47-68.

The Juneau gold belt, Alaska, by A. C. Spencer, pp. 1-137, and A reconnaissance of Admiralty Island, Alaska, by C. W. Wright, pp. 138-154. Bulletin 287, 1906, $161 \mathrm{pp}$.

Lode mining in eoutheastern Alaska, by F. E. and C. W. Wright. In Bulletin 284, 1906, pp. 30-53.

Nonmetallic deposits of southeastern Alaska, by C. W. Wright. In Bulletin 284, 1906, pp. 54-60.

The Yakutat Bay region, by R. S. Tarr. In Bulletin 284, 1906, pp. 6I-64.

Lode mining in southeastern Alaska, by C. W. Wright. In Bulletin 314, 1907, pp. $47-72$.

Nonmetalliferous mineral resources of southeastern Alaska, by $\mathrm{C}$. W. Wright. In Bulletin 314, 1907, pp. 73-81.

Reconnaissance on the Pacific coast from Yakutat to Alsek River, by Eliot Blackwelder. In Bulletin 314, 1907, pp. 82-88.

*Lode mining in southeastern Alaska in 1907, by C. W. Wright. In Bulletin 345, 1908, pp. 78-97. 45 cents.

*The building stones and materials of southeastern Alaska, by C. W. Wright. In Bulletin 345, 1908, pp. 116-126. 45 cents.

* Copper deposits on Kasaan Peninsula, Prince of Wales Island, by C. W. Wright and Sidney Paige. In Bulletin 345, 1908, pp. 98-115. 45 cents.

The Ketchikan and Wrangell mining districts, Alaska, by F. E. and C. W. Wright. Bulletin 347, 1908, 210 pp.

The Yakutat Bay region, Alaska: Physiography and glacial geology, by R. S. Tarr; Areal geology, by R. S. Tarr and B. S. Butler. Professional Paper 64, 1909, $186 \mathrm{pp}$.

Mining in southeastern Alaska, by C. W. Wright. In Bulletin 379, 1909, pp. 67-86.

\section{Topographic maps.}

Juneau special quadrangle; scale, 1:62,500; by W. J. Peters. For sale at 5 cents each, or $\$ 3$ per bundred.

Berners Bay epecial map; scale, I : 62,500; by R. B. Oliver. For sale at 5 cents each, or $\$ 3$ per hundred.

'Topographic map of the Juneau gold belt, Alaska. Contained in Bulletin 287, Plate XXXVI, 1906. Not issued separately.

\section{In preparation.}

The Yakutat Bay earthquake of September, 1899, by R. S. Tarr and Lawrence Martin. Professional Paper 69.

The geology and ore deposits of Kasaan Peninsula and of Copper Mountain, Prince of Wales Island, by C. W. Wright.

The geology and mineral resources of the Berners Bay region, by Adolph Knopf.

Kasaan Peninsula special map; scale, 1:62,500; by D. C. Witherspoon, J. IV. Bagley, and R. H. Sargent.

Copper Mountain special map; scale, $1: 62,500$; by R. II. Sargent.

\section{CONTROLLER BAY, PRINCE WILLIAM SOUND, AND COPPER RIVER REGIONS.}

* The mineral resources of the Mount Wrangell district, Alaska, by W. C. Mendenhall. Professional Paper 15, 1903, $71 \mathrm{pp}$. Contains general map of Prince William Sound and Copper River region; scale, 12 miles $=1$ inch. 30 cents.

Bering River coal field, by G. C. Martin. In Bulletin 259, 1905, pp. 140-150.

Cape Yaktag placers, by G. C. Martin. In Bulletin 259, 1905, pp. 88-89.

Notes on the petroleum fields of Alaska, by G. C. Martin. In Bulletin 259, 1905, pp. 128-139. Abstract from Bulletin 250. The petroleum fields of the Pacific coast of Alaska, with an account of the Bering River coal deposits, by G. C. Martin. Bulletin 250, 1905, 64 pp.

Geology of the central Copper River region, Alaska, by W. C. Mendenhall. Professional Paper 41, 1905, 133 pp. 
Copper and other mineral resources of Prince William Sound, by U. S. Grant. In Bulletin 284, 1906, pp. 78-87.

Distribution and character of the Bering River coal, by G. C. Martin. In Bulletin 284,1906 , pp. 65-76.

Petroleum at Controller Bay, by G. C. Martin. In Bulletin 314, 1907, pp. 89-103.

Geology and mineral resources of Controller Bay region, by G. G. Martin. Bulletin $335,1908,141$ pp.

* Notes on copper prospects of Prince William Sound, by F. H. Moffit. In Bulletin 345,1908 , pp. 176-178. 45 cents.

* Mineral resources of the Kotsina and Chitina valleys, Copper River region, by F. H. Moffit and A. G. Maddren. In Bulletin 345, 1908, pp. 127-175. 45 cents.

Mineral resources of the Kotsina-Chitina region, by F. H. Moffit and A. G. Maddren. Bulletin 374, 1909, $103 \mathrm{pp}$.

Copper mining and prospecting on Prince William Sound, by U. S. Grant and D. F. Higgins, jr. In Bulletin 379, 1909, pp. 87-96.

Gold on Prince William Sound, by U. S. Grant. In Bulletin 379, 1909, p. 97.

Mining in the Kotsina-Chitina, Chistochina, and Valdez Creek regions, by F. H. Moffit. In Bulletin 379, 1909, pp. 153-160.

Mineral resources of the Nabesna-White River district, by F. II. Moffit and Adolph Knopf. In Bulletin 379, 1909, pp. 161-180.

Mineral resources of the Nabesna-White River district, by F. H. Moffit and Adolph Knopf; with a section on the Quaternary, by S. R. Capps. Bulletin 417, 1910, $64 \mathrm{pp}$.

\section{Topographic maps.}

Map of Mount Wrangell; scale, 12 miles $=1$ inch. Cọntained in Professional Paper 15. Not issued separately.

Copper and upper Chistochina rivers; scale, 1:250,000; by T. G. Gerdine. Contained in Professional Paper 4l. Not issued separately.

Copper. Nabesna, and Chisana rivers, headwaters of; scale, 1:250,000; by D. C. Witherspoon. Contained in Professional Paper 41. Not issued separately.

Controller Bay region special map; scale, 1:62,500; by E. G. Hamilton. For sale at 35 cents a copy or $\$ 21$ per hundred.

General map of Alaska coast region from Yakutat Bay to Prince William Sound; scale, 1:1,200,000; compiled by G. C. Martin. Contained in Bulletin 335 .

\section{In preparation.}

Geology and mineral resources of the Nizina district, by F. H. Moffit and S. R. Capps.

Reconnaissance of the geology and mineral resources of Prince William Sound, Alaska, by U. S. Grant and D. F. Higgins. Bulletin 443 .

Geology and mineral resources of the southern part of Kenai Peninsula, by U. S. Grant and D. F. Higging.

Chitina quadrangle map; scale, 1:250,000; by T. G. Gerdine and D. C. Witherspoon.

\section{COOK INLET AND SUSITNA REGION.}

The petroleum fields of the Pacific coast of Alaska, with an account of the Bering River coal deposits, by G. C. Martin. Bulletin 250, 1905, 64 pp.

Coal resources of southwestern Alaska, by $R$. W. Stone. In Bulletin 259, 1905, pp. 151-171.

Gold placers of Turnagain Arm, Cook Inlet, by F. H. Moffit. In Bulletin 259, 1905, pp. $90-99$.

Mineral resources of the Kenai Peninsula; Gold fields of the Turnagain Arm region, by F. H. Moffit, pp. 1-52; coal fields of the Kachemak Bay region, by $R$. W' Stone, pp. 53-73. Bulletin 277, 1906, $80 \mathrm{pp}$.

Preliminary statement on the Matanuska coal field, by G. C. Martin. In Bulletin 284,1906 , pp. 88-100.

A reconnaissance of the Matarruska coal field. Alaska, in 1905, by G. C. Martin. Bulletin 289, 1906, $36 \mathrm{pp}$.

Reconnaissance in the Matanuska and Talkeetna basins, by Sidney Paige and Adolph Knopf. In Bulletin 314, 1907, pp. 104-125.

Geologic reconnaissance in the Matanuska and Talkeetna basins, Alaska, by Sidney Paige and Adolph Knopf. Bulletin 327, 1907, 71 pp.

Notes on geology and mineral prospects in the vicinity of Seward, Kenai Peninsula, by U. S. Grant. In Bulletin 379, 1909, pp. 98-107. 
Topographic maps.

Kenai Peninsula, northern portion; scale, 1:250,000; by E. G. Hamilton. Contained in Bulletin 277. Not published separately.

Reconnaissance map of Matanuska and Talkeetna region; scale, 1:250,000; by $T$. G. Gerdine and R. H. Sargent. Contained in Bulletin 327. Not published separately.

Mount McKinley region; scale, $1: 625,000$; by D. I. Reaburn. Contained in Professional Paper 45. Not published separately.

\section{In preparation.}

The Mount McKinley region, by A. H. Brooks, with descriptions of the igneous rocks and of the Bonnifield and Kantishna districts, by L. M. Prindle. Profissional Paper 70 .

\section{SOUTHWESTERN ALASKA.}

Gold mine on Unalaska Island, by A. J. Collier. In Bulletin 259, 1905, pp. 102-103. Gold deposits of the Shumagin Islands, by G. C. Martin. In Bulletin $2 \overline{5} 9$, 1905, pp. 100-101.

Notes on the petroleum fields of Alaska, by G. C. Martin. In Bulletin 259, 1905, pp. 128-139. Abstract from Bulletin 250 .

The petroleum fields of the Pacific coast of Alaska, with an account of the Bering River coal deposits, by G. C. Martin. In Bulletin 250, 1905, 64 pp.

Coal resources of southwestern Alaska, by R. W. Stone. In Bulletin 259, 1905, pp. $151-171$.

The Herendeen Bay coal fields, by Sidney Paige. In Bulletin 284, 1906, pp. $101-108$.

Mineral resources of southwestern Alaska, by W. W. Atwood. In bulletin 379 1909, pp. 108-152.

\section{In preparation.}

Geology and mineral resources of parts of Alaska Peninsula, by W. W. Atwood. Geology and mineral resources of the Iliamna and Clark lakes region, by $G$. $C$. Martin and F. J. Katz.

\section{YUKON BASIN.}

*The coal resources of the Yukon, Alaska, by A. J. Collier. Bulletin 218, 1903, 71 pp. 15 cents.

*The gold placers of the Fortymile, Birch Creek, and Fairbanks regions, by L. M. Prindle. Bulletin 251, 1905, 89 pp. 35 cents.

Yukon placer fields, by I. M. Prindle. In Bulletin 284, 1906, pp. 109-131.

Reconnaissance from Circle to Fort Hamlin, by R. W. Stone. In Bulletin 284, 1906, pp. 128-131.

The Yukon-Tanana region, Alaska; description of the Circle quadrangle, by L. M. Prindle. Bulletin 295, 1906, $27 \mathrm{pp}$.

The Bonnifield and Kantishna regions, by L. M. Prindle. In Bulletin 314, 1907, pp. $205-226$.

The Circle precinct, Alaska, by Alfred H. Brooks. In Bulletin 314, 1907, pp. 187204.

The Yukon-Tanana region, Alaska; description of the Fairbanks and Rampart quadrangles, by L. M. Prindle, F. L. Hess, and C. C. Covert. Bulletin 337, 1908, $102 \mathrm{pp}$.

* Occurrence of gold in the Yukon-Tanana region, by L. M. Prindle. In Bulletin 345,1908 , pp. 179-186. 45 cents.

*The Fortymile gold-placer district, by L. M. Prindle. In Bulletin 345, 1908, pp. $187-197.45$ cents.

Water-supply investigations in Alaska, 1906 and 1907, by F. F. Henshaw and C. C. Covert. Water-Supply Paper 218, 1908, $156 \mathrm{pp}$.

* Water supply of the Fairbanks district in 1907, by C. C. Covert. In Bulletin 345, 1908 , pp. $198-205.45$ cents.

The Fortymile quadrangle, by L. M. Prindle. Bulletin 375, 1909, 52 pp.

Water-supply investigations in Yukon-Tanana region, 1906-1908, by C. C. Covert and C. E. Ellsworth. Water-Supply Paper 228, 1909, 108 pp.

The Fairbanks gold-placer region, by L. M. Prindle and F. J. Katz. In Bulletin 379,1909 , pp. 181-200. 
Water supply of the Yukon-Tanana region, 1907-8, by C. C. Covert and C. E. Ellsworth. In Bulletin 379,1909 , pp. 201-228.

Gold placers of the Ruby Creek district, by $A$. G. Maddren. In Bulletin 379, 1909, pp. 229-233.

Placers of the Gold Hill district, by A. G. Maddren. In Bulletin 379, 1909, pp. $234-237$.

Gold placers of the Innoko district, by A. G. Maddren. In Bulletin 379, 1509, pp. $238-266$.

The Innoko gold-placer district, with accounts of the central Kuskokwim Valley and the Ruby Creek and Gold Hill placers, by A. G. Maddren. Bulletin 410, 1910, $87 \mathrm{pp}$.

Topographic maps.

Fortymile quadrangle; scale, 1:250,000; by E. C. Barnard. For sale at 5 cents a copy or $\$ 3$ per hundred.

The Fairbanks quadrangle; scale, 1:250,000; by T. G. Gerdine, D. C. Witherspoon, and $R . B$. Oliver. For sale at 10 cents a copy or $\$ 6$ per hundred.

Rampart quadrangle; scale, $1: 250,000$; by D. C. Witherspoon and R. B. Oliver. For sale at 10 cents a copy or $\$ 6$ per hundred.

Fairbanks special map; scale, 1: 32,500 ; by T. G. Gerdine and R. H. Sargent. For Eale at 10 cents a copy or $\$ 6$ per hundred.

Yukon-Tanana region, reconnaissance map of; scale, $1: 625,000$; by T. G. Gerdine. Contained in Bulletin 251, 1905. Not published separately.

Fairbanks and Birch Creek districts, rcconnaissance maps of; 8cale, 1:250,000; by T. G. Gerdine. Contained in Bulletin 251, 1905. Not issued separately.

Circle quadrangle, Yukon-Tanana region; scale, $1: 250,000$; by D. C. Witherspoon. Contained in Bulletin 295. In print as separate publication.

\section{In prepraration.}

Geology and mineral resources of Fairbanks quadrangle, by L. M. Prindle.

Map of Circle quadrangle; scale 1:250 000: by D. (. Witherspoon.

The Koyukuk and Chandalar placer districts, by $\mathbf{A}$. G. Maddren.

\section{SEWARD PENINSULA.}

A reconnaissance of the Cape Nome and adjacent gold fields of Seward Peninsula, Alaska, in 1900 , by A. H. Brooks, G. B. Richardson, and A. J. Collier. In a special publication entitled "Reconnaissances in the Cape Nome and Norton Bay regions, Alaska, in 1900," 1901, $180 \mathrm{pp}$.

A reconnaissance in the Norton Bay region, Alaska, in 1900, by $1 \mathrm{~W}$. C. Mendenhall. In a special publication entitled "Reconnaissances in the Cape Nome and Norton Bay regions, Alaska, in 1900," 1901,38 pp.

A reconnaissance of the northwestern portion of Seward Peninsula, Alaska, by A. J. Collier. Professional Paper 2, 1902, 70 pp.

The tin deposits of the York region, Alaska, by A. J. Collier. Bulletin 22:, 1904, CI pp.

Recent developments of Alaskan tin deposits, by A. J. Collier. In Bulletin 259, 1905 , pp. 120-127.

The Fairhaven gold placers of Seward Peninsula, by F. H. Moffit. Bulletin 247, $1905 ; 85 \mathrm{pp}$.

The York tin region, by F. L. Hess. In Bulletin 284, 1906, pp. 145-157.

Gold mining on Seward Peninsula, by F. H. Moffit. In Bulletin 284, 1906, pp. $132-141$.

The Kougarok region, by A. H. Brooks. In Bulletin 314, 1907, pp. 164-181.

*Water supply of Nome region, Seward Peninsula, Alaska, 1906, by J. C. Hoyt and F. F. Henshaw, Water-Supply Paper 196, 1907, 52 pp. 15 cents.

Water supply of the Nome region, Seward Peninsula, 1906, by J. C. Hoyt and F. IS. Henshaw. In Bulletin 314, 1907, pp. 1S2-186.

The Nome region, by F. H. Moffit. In Bulletin 314,1907 , pp. 126-145.

Gold fields of the Solomon and Niukluk river basins, by P. S. Smith. In Bulletin 314,1907 , pp. 146-156.

Geology and mineral resources of Iron Creek, by P. S. Smith. In Bulletin 314, 1907, pp. 157-163.

The gold placers of parts of Seward Peninsula, Alaska, including the Nome, Council, Kougarok, Port Clarence, and Goodhope precincts, by A. J. Collier. F. L. Hess, P. S. Smith, and A. H. Brooks. Bulletin $328,1908,343$ pp. 
*Investigation of the mineral deposits of Seward Peninsula, by P. S. Smith. In Bulletin 345, 1908, pp. 20b-250. 45 cents.

*The Seward Peninsula tin deposits, by Adolph Knopf. In Bulletin 345, 1908, pp. 251-267. 45 cents.

* Mineral deposits of the Lost River and Brooks Mountain regions, Seward Peninsula, by Adolph Knopf. In Bulletin 345, 1908, pp. 268-271. "45 cents.

*Water supply of the Nome and Kougarok regions, Seward Peninsula, in 1906-7, by F. F. Henshaw. In Bulletin 345, 1908, pp. 272-885. 45 cents.

Water-supply investigations in Alaska, 1906 and 1907, by F. F. Henshaw and C. C. Covert. Water-Supply Paper $218,1908,156 \mathrm{pp}$.

Geology of the Seward Peninsula tin deposits, by Adolph Knopf. Bulletin 358, $1908,72 \mathrm{pp}$.

Recent developments in southern Seward Peninsula, by P. S. Smith. In Bulletin 379,1909 , pp. $267-301$.

The Iron Creek region, by P. S. Smith. In Bulletin-379, 1909, pp. 302-354.

Mining in the Fairhaven precinct, by F. F. Henshaw. In Bulletin 379, 1909, pp. $355-369$.

Water-supply investigations in Seward Peninsula in 1908, by F. F. Henshaw. In Bulletin 379, 1909, pp. 370-401.

Geology and mineral resources of the Solomon and Casadepaga quadrangles, Seward Peninsula, by P. S. Smith. Bulletin 433, 1910, 227 pp.

\section{Topographic maps.}

The following maps are for sale at 5 cents a copy, or $\$ 3$ per hundred:

Casadepaga quadrangle, Seward Peninsula; scale, 1:62,500; by T. G. Gerdine.

Grand Central special, Seward Peninsula; scale, 1:62,500; by ' 1 ' G. Gerdine.

Nome special, Seward Peninsula; scale, 1:62, 500; by T. G. Gerdine.

Solomon quadrangle. Seward Peninsula; scale, 1:62,500; by T. G. Gerdine.

The following maps are for sale at 25 cents a copy, or $\$ 15$ per hundred:

Seward Peninsula, northeastern portion of, topographic reconnaissance of; scale, $1: 250,000$; by T. G. Gerdine.

Seward Peninsula, northwestern portion of, topographic reconnaissance of; scale, 1: 250,$000 ;$ by $T$. G. Gerdine.

Seward Peninsula, southern portion of, topographic reconnaissance of ; scale, 1:250,000 ; by T. G. Gerdine.

\section{In prepuration.}

Geology of the area represented on the Nome and Grand Central special maps, by F. H. Moffit, F. L. Hess, and P. S. Smith.

The water resources of the Seward Peninsula, by F. F. Henshaw.

\section{NORTERRN ALASKA.}

A reconnaissance from Fort Hamlin to Kotzebue Sound, Alaska, by way of Dall, Kanuti, Allen, and Kowak rivers, by W. C. Mendenhall. Professional Paper 10, 1902, 68 pp.

*A reconnaissance in northern Alaska across the Rocky Mountains, along the Koyukuk, John, Anaktuvuk, and Colville rivers, and the arctic coast to Cape Lisburne, in 1901, by F. C. Schrader and W.J. Peters. Professional Paper 20, 1904, 139 pp.

Coal fields of the Cape Lisburne region, by A. J. Collier. In Bulletin 259, 1905, pp. $172-185$.

Geology and coal resources of Cape Lisburne region, Alaska, by A. J. Collier. Bulletin $278,1906,54 \mathrm{pp}$.

Topographic maps.

Fort Yukon to Kotzebue Sound, reconnaissance map of; scale, 1:1,200,000; by D. L. Reaburn. Contained in Professional Paper 10. Not published separately.

*Koyukuk River to mouth of Colville River, including John River; scale, 1: 1,200,000; by W. J. Peters. Contained in Professional Paper 20. Not published separately.

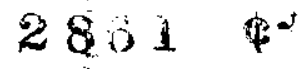

\section{From \\ The Library of WAYNE LOEL}

